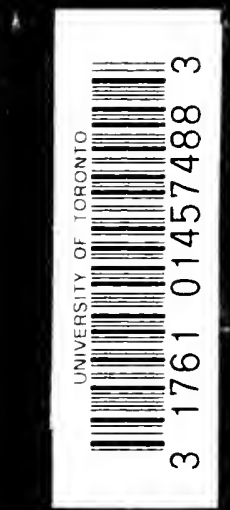



Digitized by the Internet Archive in 2007 with funding from Microsoft Corporation 


) 
(98)<smiles>[13CH]C1CC1</smiles>

5010 


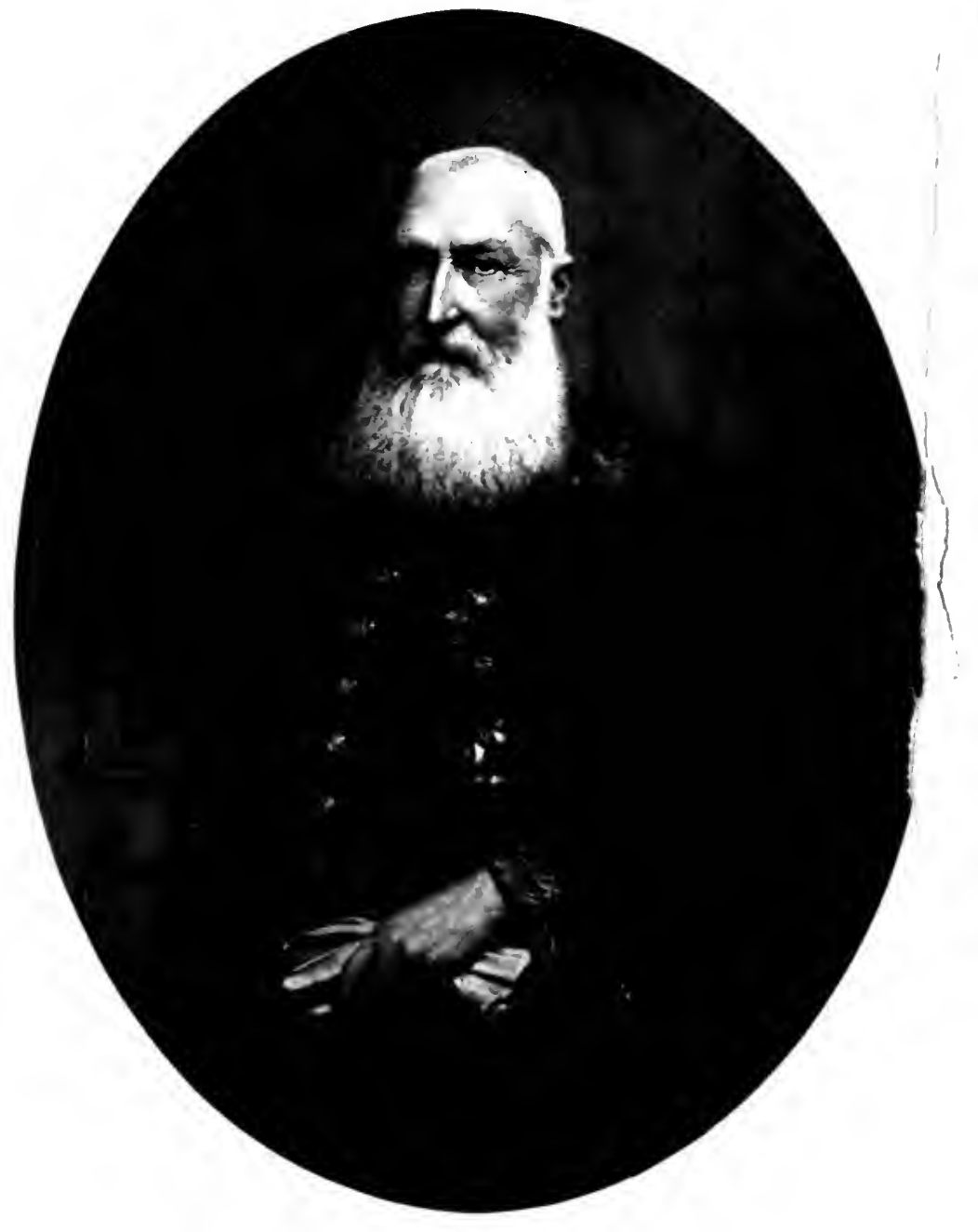




\section{The Story of the}

\section{Congo Free State}

Social, Political, and Economic Aspects of the Belgian System of Government in Central Africa

By

Henry Wellington Wack, F.R.G.S. (Member of the New York Bar)

With 125 Illustrations and Maps

G. P. Putnam's Sons

New York and London

đbe Knickerbocker Dresg

1905 
Copyright, rgos

BY

HENRY WELLINGTON WACK

$$
\begin{aligned}
& \text { DT } \\
& 652 \\
& \text { W2 } \\
& \operatorname{cop} 2
\end{aligned}
$$

Tbe tentcherbocker press, Pew purk

$$
42 / 2690
$$




\section{PREFACE}

$\Lambda \mathrm{S}$ a student of Mid-African affairs for the past seven years, and a close observer of the rapid progress toward complete civilisation now being made in that part of the world, I have felt it my duty to lay before my countrymen the true and complete story of the conception, formation, and development of the Congo Free State.

At a period of such bitter controversy concerning the government of the Congo Free State as the present, it is necessary that I should explain the circumstances under which I add this volume to the literature of that subject.

During a residence of several years in the United Kingdom, I could not fail to observe the growth there of an organised campaign against the Congo Free State. That a small section of the British public, interested in the rubber trade, should by subtle means seek to delude or should even succeed in deluding, the great British nation so completely as to obtain general credence for its stories of cruelty and oppression alleged against King Leopold's government failed to move me. It was not my concern, while enjoying the hospitality of England, to criticise the way in which her religious organisations were being used to further the selfish aims of a 
small clique of Liverpool merchants. But when, within the past year, I perceived that the campaign of calumny against the Congo Free State was being extended to the United States, I could not longer regard the phenomenon with a merely passive interest. It occurred to me that my knowledge of Mid-African affairs might enable me to place before the American people a complete statement of the actual facts of the Congo Free State, and that my self-imposed task could not fail to be of value at a time when interested partisans were endeavouring to deceive them.

Having obtained an introduction to the King of the Belgians, I informed his Majesty that I believed the American people would much esteem the true history of the affairs of the Congo written by an American, and that if his Majesty would grant me access to the archives of the Administration of the Congo Free State in Brussels, and leave me free to write the story of his enterprise in my own way, absolutely without interference or suggestion from any of his ministers or himself, I would undertake the task on my own account.

His Majesty, having considered my credentials and the nature of my introduction, in due course informed me that all the documents in the Congo Administration Office were open to my inspection. His Majesty added that he had no fear but that the American people, when informed of the truth about the Congo, would appreciate, as he did, that the Congolese civilisation movement is the greatest colonising success in the history of the world. I 
was admitted into the offices of the Congo Administration and spent many weeks there searching for, translating, and copying documents. Those which had already been translated into English, I adopted in the form in which I found them. When I left Brussels, I again indicated to his Majesty's ministers, and to his Majesty himself, that I should write the story in my awn way. I brought away many boxes of memoranda and documents and at once began to work upon The Story of the Congo Free State. I have not submitted the manuscript or proofs to any person connected, either directly or indirectly, with his Majesty, with the Congo Free State, or with the Belgian Government, neither have I in any way communicated with his Majesty in reference to what I have written. For all I know, his Majesty may entirely disapprove of this history. I should, of course, regret exceedingly to learn that I had displeased the royal host who had extended to me the hospitality of his country during a long and interesting visit. But as I am under no obligation whatever to the Congo officials, nor to his Majesty, and as my original intention of writing an independent history of the Congo was made quite clear to both, I regard myself as absolved from blame should the King of the Belgians disapprove of the straightforward story here presented.

That this story is true, I have satisfied myself in every particular. It is the story of a great colonising undertaking founded upon modern social science. It can hardly fail to interest the reader who admires the courage and daring which small countries. 
sometimes display in extending their borders and establishing new markets.

Should this book in any way assist my countrymen in thinking out the underlying motives in the campaign against the Congo, and bring them to a knowledge of the real issues at stake, my labour will be sufficiently rewarded.

I take this opportunity to acknowledge my obligation to the works of Messrs. Stanley, Descamps, Boulger, Johnston, Cattier, and Wauters, and to all who have kindly assisted me with information.

NEW YORK, January 2, I905.

H. W. W. 


\section{CONTENTS}

CHAPTER

PAGE

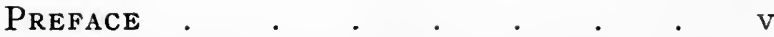

I.-Genesis of Mid-African Civilisation . I

- II.-Stanley and King Leopold II.'s Conception of the Congo Free State.

- III.-Founding of the Congo Free State

V.THE WATERWAYS OF THE CONGO

VI.-The State and International Law . • 64

VII.-Hórrors of the Arab Slave Trade . . 83

- VIII.-The Beriln Conference . . . . . . 92

- IX.-The Economic RÉgime of the Berlin ACT . . . . . . . $\mathrm{IO4}$

X.-An Appeal to Belgium to Suppress the Slave Trade . . . . . . . . 126

- XI.-The Second Brussels Conference . . 134 XII.-The Congo Bequeatha Belgium - I 45 XIII.-Tribes of the CongeState_- I5I

XIV.-The Congo PUBLIC Force . . . . . I64

XV.-Belgian Campaigns against the Arabs . 177

XVI.-Belgian Campaigns against the Arabs -(Concluded $) \quad$. $\quad . \quad$. $\quad . \quad$. $\quad$ I89

XVII.-The Suppression of Slavery . . . 197 -

XVIII.-Frontiers and Diplomatic Settlements . 206

XIX.-The Bahr-el-Ghazal and the Nile . . 2 II

XX.-Mutinies of the Batetela Tribe . . 2 I 6

XXI.-Displacement of the Population . . 223

-XXII.-The State's Administration: • . . 228

Department of Justice . . . 231

Native Chieftaincies . . 239

XXIII.-The Postal, Telegraph, and Telephone

SERVICE . . . . . . . 243 
- XXV.-Science, Agriculture, Civilising Meas-

\section{APPENDIX}

The Treaty of Vivi, I $3^{\text {th }}$ June, 1880 . . . . 487

The Treaty of Manyanga, i 2 th August, i 882 . $\quad 488$

The Treaty of Leopoldville, 29th April, 1883 . $\quad ~ 489$

The Treaty of Stephanieville, undated . . . 490

Table of other Treaties, Districts ceded, and Stations established by the International Association of the

Congo

Report from the Committee on Foreign Relations to the

Senate of the United States, March 26, i $88_{4}$ (Senator John T. MLrgan, of Alabama), recommending the recognition of the International African Association as a friendly Government, with citations from the history of the American colonies . .

An essay on "The Free Navigation of the Congo," by

Sir Travers Twiss, taken from the Revue de Droit International, 1883 


\section{Contents}

An argument by Professor Arntz, citing numerous authorities, on the question, Can Savage Tribes cede their territory to Private Persons with the Sovereign Rights appertaining thereto . . .

For Treaty between the International Association of the Congo and the United States, see Chapter IV.

The General Act of the Berlin Conference

Declaration of the General Act of the Brussels Conference, July 2, 1890

Treaty of Amity, Commerce, and Navigation between the United States and the Congo Free State, January 24, I 89 I

Protocol in which the United States ratifies the General Act of the Brussels Conference, February 2, 1892 .

Dispatch from his Britannic Majesty's Minister at Brussels enclosing:

A Decree by the Sovereign of the Congo Free State providing Settlements for native children orphaned or abandoned, July I 2, I 890

A Decree instituting a local Commission of Europeans for the Protection of Natives, September I 8, I 896

Official letter of instruction thereon from the Secretary of State to the Governor-General at Boma, in the Congo Free State, October I, I896 . . .

Letter of Governor-General Wahis to the Reverend George Grenfell (British), of the Baptist Missionary Society at Bolobo, transmitting Decree, December 26, 1896

Circular to all District Commissioners, Heads of Zones and of Posts with regard to barbarous customs prevailing among the native tribes, February 27, 1897

Letter from the Reverend George Grenfell to the Governor-General, July r 3, 1897 •. • . .

Co-ordinated text of various instructions respecting relations between state officials and natives . .

Report of first meeting of Commission for Protection of Natives, May I 7, I 897 
A Decree appointing additional members upon the Commission for the Protection of Natives, March 23, I9OI

The British Dispatch to European Powers calling attention to charges alleged against the Congo Free State, and inviting consideration thereof. August 8,1903

Letter from Sir Constantine Phipps, his Britannic Majesty's Minister at Brussels, transmitting text of the Note and its enclosures addressed by the Congo Government to the Powers parties to the Act of Berlin, replying to the British Dispatch of August 8,1903

Rejoinder of the Congo Government to the Report, dated December I I, I903, of Mr. Roger Casement, his Britannic Majesty's Consul at Boma, wherein, amongst others, charges of maltreatment of natives are made. March I 2, I904 . . . . .

Memorandum on the part of the Congo Government regretting that the British Foreign Office did not deem it necessary to communicate to it previous Consular Reports, the names of persons accused and generally such specific information as would enable the Congo Government to prosecute offenders, etc., together with the remarks of the Secretary-General of the Congo Free State upon the debates in the British Parliament as to partitioning that State between the Powers whose possessions surround it. May I4, I904 .

Features of the Land System in the African Colonies of

Germany, Great Britain, France, and Portugal .

Concessionaires, Firms, and Trading Companies in the Congo Free State . . . . . . . 6I6 Officials of the Congo Free State . . . . . 6I 7

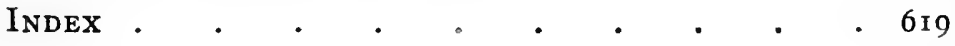




\section{LIST OF ILLUSTRATIONS}

FACING PAGE

His Majesty Leopold II., King of the Belgians . Frontispiece

(From a painting by Jef Leempoels.)

Native Huts Built of Leaves (Aruwimi) . . $\quad$. 4

Elephant Farm on the Bomokandi . . $\quad$. 8

Basongolo Chiefs (Lokandu) . . . . . . . 12

House of Governor-General, Boma . . . . 14

The Congo at Lokandu . . . . . . $\quad$ I8

View of the Port of Leopoldville (Stanley Pool) . . 26

Making a Road (I75 kilometres) for Automobiles

(Kwango)

A Saddle Ox, Kassai

European Travelling in the Uelle District

Native Employees of the State Waiting for Rations at

Boma . . . . . . . . . 40

SS. Leopoldville Bound for Boma . . . . . 42

Departure of Commissioner-General Halfeyt, on Board

SS. Stanley, Stanleyville, I899 • . . . . . 46

Departure of SS. Goodwill from Upoto . . . . 50

Bridge, 80 Metres (Kwilu) . . . . . . $\quad 5^{8}$

State Pilot Barge, Banana . . . . . . $\quad . \quad 5^{8}$

Taking Merchandise to the SS. Leopoldville . . . 66

State Post at Yankomi, near Basoko, Surrounded by

Palisade (Aruwimi) . . . . . . $\quad 7_{2}^{2}$

Europeans at Stanleyville, 1902 . . . . . $\quad$. 78

Post-Office, Boma $\quad$. $\quad$. $\quad$. . . . 80

Native Boys, Boma $\quad . \quad$. $\quad . \quad$. $\quad . \quad$. 82 
Group of Yie-Yie Women (Uelle) . . . . . $\quad 84$

Types of Bearers (North Bank of Cataracts) . $\quad .84$

Native Potters at Work (Aruwimi) . . . . $\quad .88$

Making Manioc Flour, Baneko (Aruwimi) . . . 92

Native Musicians at Lusambo (Lualaba-Kassai) . $\quad .98$

Market, near Boma $\quad . \quad$. $\quad . \quad$. . . . 104

Government Park, Boma, I904 . . . . . . I Io

Students of the State Technical School, New Antwerp

(Bangala) . . . . . . . . . I 8

Hospital, Boma . . . . . . . . . . . II8

Bridge Made of Cement, Boma . . . . . . 126

Types of Barumbus (Stanley Falls) . . . . . I30

Government Wagons . . . . . . . . 132

House of Vice-Governor-General, Stanleyville . . . I34

Postmaster's House, Suruango, 1904 . . . . . I 34

A Street in Coquilhatville, 1896 (Equateur) . . . . 138

Camp on Line of Cataracts Railroad, Songololo . . . 142

Return from the Hunt at Bumba (Bangala) . . . I 144

Baluba Chiefs . . . . . . . . . 144

The Governor's House, Ponthierville (Upper Congo) . 146

European Houses at Coquilhatville (Equateur) . . ${ }_{148}$

Specimens of Hair-dressing among Women of the Sango

Tribe, Banzyville (Ubanghi) . . . . . 150

Cicatrised Batetela Woman (Lualaba-Kassai) . . I 50

Funeral at Bumba (Bangala) . . . . . . 152

Women Beating Rice, Uelle . . . . . . I 54

Tribunal at Boma. Sentencing a Native to Death for

Cannibalism Committed in the Upper Congo . . ${ }_{1} 5^{6}$

Batetela Women (Lualaba-Kassai) . . . . ${ }_{1} 8$

Kassai Women Returning from Market . . . ${ }_{1} 58$

African Belles. Hair-dressing of Sango Women at Banzy-

ville, 1894 (Ubanghi) . . . . . . I60 


\section{List of Illustrations}

Bangala Women

Bakusu Chiefs, Stanleyville . . . . . . . 162

Group of Warriors, Djabbir . . . . . . . . 164

Coffins for Native Chiefs, Wangata, I897 (Equateur) . 164

Native Making Butter at his Home in Botandana (Kivu)

A Bangala Chief, with his Harem

. 166

Native Canoes, Lower Congo

166

Fishermen, Uvvia

Uelle Chief and his Wives, Van Kerckhovenville . . I72

Port of Leopoldville. Natives at Work . . . 172

Tailors' School, New Antwerp (Bangala) . . . . I74

Steam Saw-Mill, Boma . . . . . . . 176

Camp of Bangalas, Stanleyville . . . . . . 178

Types of Lokélés, Jafungas (Oriental Province) . . I80

Review of Troops by Governor-General at New Antwerp i 84

Soldiers' Mess, Suruango, 1903 (Uelle) . . . . . 189

Soldiers' Wives, Bumba . . . . . . . $\quad$ I 86

The White Man's Cemetery, Stanleyville . . . . I 88

Hospital, New Antwerp . . . . . . 188

An Avenue at Boma $\quad . \quad$. $\quad . \quad$. $\quad . \quad$. $\quad$. rgo

Office of Secretary-General, Boma $\quad$. . . . . 192

Post-Office on River Bank, Boma . . . . . 192

Bishop's Palace, Mission of Our Lady of M'Pala (Tan-

ganyika) . . . . . . . . 196

Office of Director of Transport, Boma . . . . . 196

Cattle, Luvungy (Kivu) . . . . . . . 200

Various Mounts, Lusambo (Lualaba-Kassai) . . . 200

Grand Hotel, Boma . . . . . . . 203

Native Ploughing in Botanical Garden at Ealer (Equateur) . . . . . . . . . 206

The Old Covered Market at Boma . . . . 2 Io 
Commissariat of the District of Banana, 1893

King Nekuku and his Suite at Boma . . . . 2 I4

Regiment of Commissioner-General Halfeyt, Stanleyville 2 I 6

State Officials at Ponthierville . . . . . 220

Saddle Ox, Lusambo (Lualaba-Kassai) . . . 220

Bird's-eye View of the Station at Basoko, 1893 . 222

Dutch Mission, Banana . . . . . 226

Bishop's Palace at Baudouinville (Oriental Province) . 228

Children of the Settlement School, Boma . . . 234

In the State Printing Office at Boma. Natives Laying-on

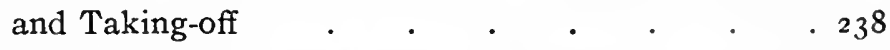

Natives Working Sewing Machines at Kisantu . . 242

Children of the Settlement Drilling at New Antwerp,

r 896 (Bangala) . . . . . . . . 246

Zappo-Zapp Musicians, Luluabourg . . . . 250

Band of Government Technical School, Boma . . ${ }_{25} 6$

Coffee Plantation at Yalicombe (Oriental Province) $\quad{ }_{25} 8$

Shelling Coffee, Stanleyville . . . . . . 270

Making Baskets for Transportation of Rubber (Kassai) . 272

Collecting Rubber in Forest of Lusambo (Lualaba-

Kassai) . $\quad . \quad . \quad . \quad . \quad . \quad . \quad . \quad .280$

Church and Rectory, Matadi . . . . 286

Native Carpenters at Work, Mission of New Antwerp, I897 294

Orphans Praying at St. Truden (Kassai) . . . 302

Children of the Settlement School at Boma Praying . 308

Mission of the White Fathers, Tanganyika . . . 314

The Mission, Moanda . . . . . . . 320

Missionary Necropolis, Luluabourg . . . . $\quad 328$

Franciscan Sisters at the Mission of St. Gabriel of the

Falls (Oriental Province) . . . . . 336

Native Christians of the Village of Our Lady of Lourdes, near the Mission of Luluabourg, I897 • . $\quad$ • 344 
Drying Rubber in the Forest (Kassai) PACING PAGs Mission Children at New Antwerp . . . . 358

A Beautiful Spot in Mayumbe . . . . . $\quad .366$

Interior of Cathedral, Baudouinville (Tanganyika) $\quad .374$

Sisters of New Antwerp Teaching Natives to Weave . 374

Building a Bridge for the Cataracts Railroad, $1897 \quad .382$

Christian Child, New Antwerp (Bangala) . . . 390

Fetich-Idol, Lower Congo . . . . . . 390

Coffee-Drying Grounds, Coquilhatville (Equateur) $\quad .398$

Bakusu Woman (Lualaba-Kassai) . . . $\quad . \quad 398$

Village near Coquilhatville. A Native Attempt to Copy the European Style . . . . . . 406

Melting Latex of Rubber in Forest of Lusambo (Lusambo-

Kassai) . . . . . . . . . . . . 412

Soldiers' Mess at Coquilhatville (Equateur) . . 420

Public Library, Matadi . . . . . . 420

The Station at Bumba . . . . . . . 426

Convent of Franciscans of St. Gabriel of the Falls (Oriental Province) . . . . . . . 434

Prison, with Carpenter's Shop, at New Antwerp (Ban-

gala) . . . . . . . . . . . 446

Native Planter's House, near Stanley Falls . . $\quad .446$

Mission of New Antwerp (Bangala) . . . . 460

The Sultan Djabbir . . . . . . $\quad 482$

Father Kisouru of the New Antwerp Mission (Bangala) $\quad 482$

MAPS.

Outline Map of Africa . . . . . . . .

Map of Central Africa $\quad . \quad$. $\quad . \quad$. $\quad . \quad$. At end 




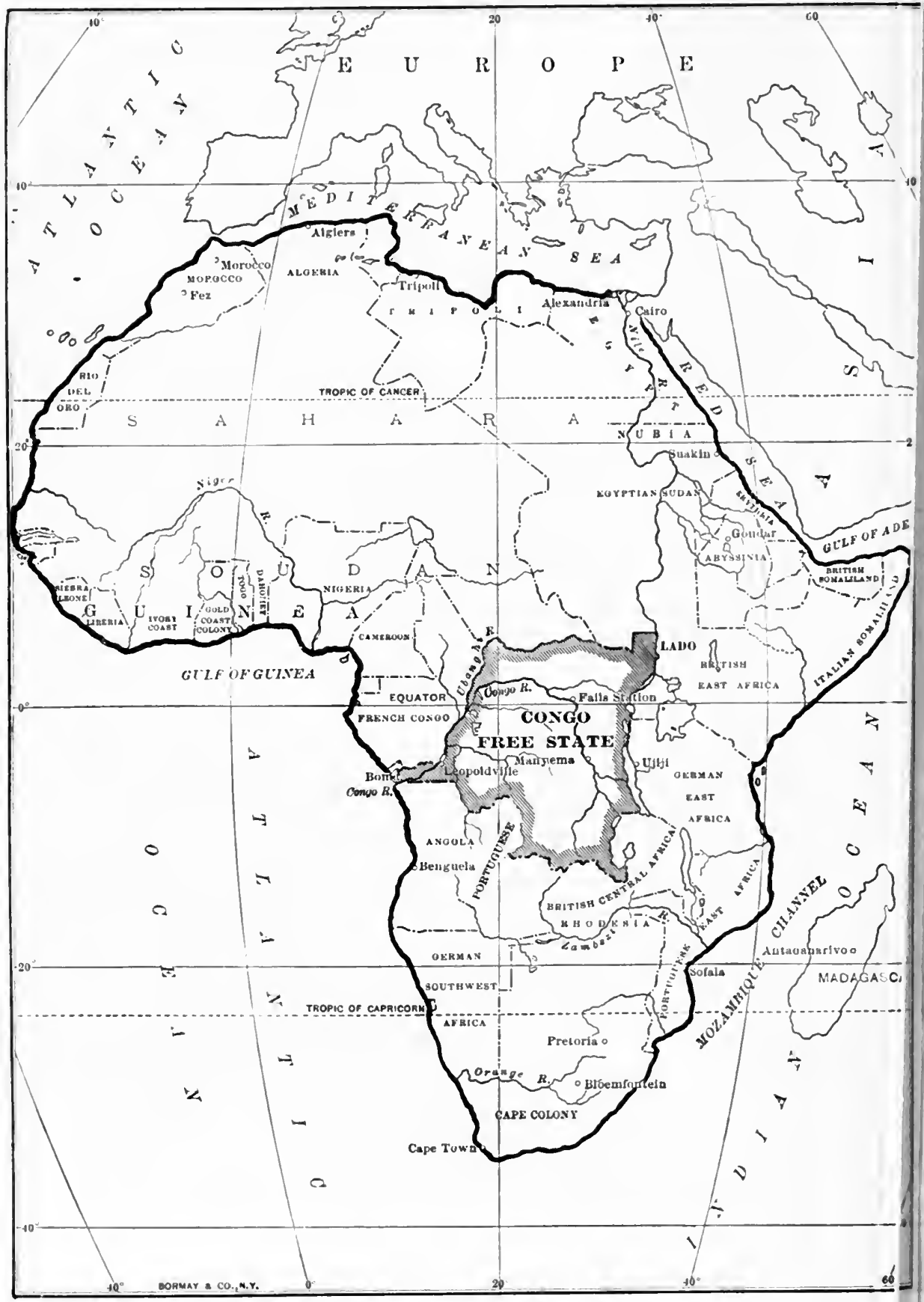

Outline Map of Africa 


\section{THE STORY OF \\ THE CONGO FREE STATE}

\section{CHAPTER I}

\section{GENESIS OF MID-AFRICAN CIVILISATION}

THE decline and fall of great empires has ever been a fascinating subject of study, congenial alike to students of widely diverse opinions and pursuits; yet it must be clear to all that in human interest the breaking up of an empire is as nothing when compared with its in Embryo. founding. The reason is, probably, that so little is known of the origin of great national communities. The United States is almost alone among nations in respect that its growth, from its inception to its mature ultimate triumph, has been watched by keenly observant eyes, and every particular of its perilous progress carefully recorded. But when the future historian, with comprehensive appreciation impossible in a contemporary, reviews the events of the last quarter of the nineteenth century, one fact will stand well out before him, a unique and very potent fact, fraught with vast possibilities for the 
future-none other than the founding, by the wisdom of a kingly philanthropist, of a humanitarian, civilising, free political state in the very heart of savage and cannibalistic Africa.

Consider for a moment how the great Congo Free State has been evolved out of a group of warring tribes (in part cannibal), and inquire what manner of man is Leopold II., King of the Belgians, alone responsible for this wondrous transformation; and who even now, when weight of years and record of achievement might well entitle him to repose, works on bravely, through good and through ill report, for the prosperity and happiness of the twenty-odd million Africans who acknowledge him for their Sovereign.

Thirty-six years ago, when the present Sovereign of the Congo Free State succeeded his father as King of the Belgians, and became known to the world as Leopold II., Africa was generally referred to as the "Dark Continent." At that period, and for long after, even the most optimistic of statesmen failed to perceive in those vast regions any promising outlet for the congested populations of the Old World, or possible markets for their manufactures. Diamonds, small in quantity and of indifferent quality, had, it is true, been discovered in the southernmost part of that continent, in a region already appropriated by the British. Gold, also, was thought to exist there, but not in paying quantities; while the deadliness of the African climate to Europeans, in all save a few favoured sections, was an universally accepted article of faith.

Foremost among the small band of thinkers who 
totally dissented from this view was Leopold II., King of the Belgians. A young man of extraordinarily fine physique, an accomplished linguist, widely read and travelled, and holding advanced liberal views in all matters pertaining to statecraft and social science, King Leopold had early the prescience to perceive in Africa the means to uplift some twenty or more millions of the Negro race from debased savagery to peaceful civilisation, and at the same time and by the same means-the latter a necessarily accompanying incident of the former-found a colony for the surplus population of the small State of which he is King; Belgium being then, as now, the most densely populated of European countries, its people almost entirely dependent on the sale abroad of the products of their industry.

Bold and original ideas rarely find much favour when first presented to the world. The bulk of mankind is conservative; it thinks of yesterday, is oppressed by the troubles of to-day, and lets to-morrow take care of itself. At first, where King Leopold's ideas for the regeneration of Africa attracted any attention at all, they were regarded with bland smiles as utopian visions, more creditable to the heart than to the head of the princely visionary. But true genius, though it may be hampered and delayed in its onward march, is not to be extinguished either by active opposition or cold indifference. Of such calibre is King Leopold, or there would to-day be no Congo Free State, nor what some past-masters in the obscuration of the obvious are sometimes pleased to call "the Congo Question." 

fields of France; but I prefer to regard those almost impenetrable African wilds where a small band of men, whose numbers may be counted on the fingers of one hand, add year by year to our knowledge of those little-known regions, carrying with them the blessings of civilisation and of truth, heralding the extinction of what for so many ages has been the world's curse-slavery."

Gladstone was right. To all civilised peoples, but specially to men of Anglo-Saxon speech-Englishmen, who had given lavishly of their millions to free the slaves held in their colonies; Americans, who had poured out their blood like water in a similar cause - the accounts given by explorers and missionaries of the horrors of the slave trade, rampant in Central Africa, were as the smell of powder to the war-horse. Only a few people are interested in geography as a science. A vastly greater number are affected by a widening of the area for trade. But the effectual suppression of slavery is a question that comes home to everybody. No one can stand aside, indifferent to it. The ghastly horrors of the murderous raids made by the remorseless Arab slave-traders upon defenceless Central African villages, so graphically described by travellers, thrilled the civilised world. No effort was needed now to direct public attention to Africa. Africa loomed large in men's minds; and the question of slavery, fondly thought to be for ever laid at rest by the tremendous conflict in America in the early sixties, again became a vital problem.

Of the numerous activities which distinguish the character of Leopold II., philanthropy has the 
greater force. Much that is quite incontrovertible might be urged in support of this statement; but King this is neither the place nor time to arKing
Leopold's gue that matter. Suffice it to say here Main that upon no one did the revelations as to object. the methods of capture and subsequent treatment of Central African slaves make a deeper impression than upon King Leopold. As a lifelong student of Africa, and a geographer of rare attainments, in personal touch with all the authorities on the subject, his information was as accurate and complete as it was possible for it to be. Though the great European governments had compelled the Khedive of Egypt to exert himself to the utmost to repress slave-trading on the Upper Nile, and the complaisant Egyptian ruler had appointed first one Englishman and then another (Sir Samuel Baker and Charles Gordon, the latter being the ill-fated General of that name) to administer the government of the Soudan, and some good resulted, it was well known to King Leopold that south of the Equator to the Zambesi the slave trade continued to be prosecuted as vigorously as it had ever been in the remote past. How might the evil be stamped out? Or, if such a consummation were too much to hope for within the immediate future, how best might the evil be checked? In considering these questions, King Leopold very rightly concluded that the more thorough the knowledge of Central Africa possessed by Europeans the greater the possibility of success in their efforts to ameliorate the awful misery of its people. 
Imbued with these views, King Leopold in 1876 called the attention of the principal geographical societies throughout the world to the conditions then prevailing in Central Africa, and invited all expert geographers of international reputation to confer in Brussels. The circular letter of King Leopold convening this Conference, though perfectly explicit in its terms, has, in light of subsequent events, been so distorted to serve personal interests, that no excuse is necessary for reproducing its exact words:

In almost every country [wrote King Leopold], a lively interest is taken in the geographical discoveries recently made in Central Africa. The English, the Americans, the Germans, the Italians, and the French have taken part in their different degrees in this generous movement. These expeditions are the response to an idea eminently civilising and Christian: to abolish slavery in Africa, to pierce the darkness that still envelops that part of the world, while recognising the resources which appear immense-in a word, to pour into it the treasures of civilisation: such is the object of this modern crusade. Hitherto the efforts made have been without accord, and this has given rise to the opinion, held especially in England, that those who pursue a common object should confer together to regulate their march, to establish some landmarks, to delimit the regions to be explored, so that no enterprise may be done twice over. I have recently ascertained in England that the principal members of the Geographical Society of London are very willing to meet at Brussels the Presidents of the Geographical Societies of the Continent, and those other persons who, by their travels, studies, philanthropic tastes, and charitable instincts, are the most closely identified with the efforts to introduce civilisation into Africa. This reunion will give rise to a sort of conference, the object of which would be to discuss in common 
the actual situation in Africa, to establish the results attained, to define those which have to be attained.

In cordially accepting King Leopold's invitation, the six great nations of Europe selected their most An Historic distinguished geographers and travellers to Conference. represent them. Great Britain sent five delegates, all men of distinction in African affairs, Germany sent four, France three, Austria two, Russia one, and Italy one. Belgium had eleven representatives, among them the accomplished Baron Lambermont. The Conference, which lasted three days, was convened in the royal palace at Brussels on September I 2, I876. It was opened by King Leopold in person. The speech made by his Majesty on that occasion follows so naturally his invitation to the assembled gentlemen that it might almost be mistaken for a continuation of that document. The reason for quoting the former now applies to the following exact translation of the King's speech:

"Gentlemen," said his Majesty, "permit me to thank you warmly for the amiable promptness with which you have been kind enough to come here at my invitation. Besides the satisfaction that I shall have in hearing you discuss here the problems in the solution of which we are interested, I experience the liveliest sense of pleasure in meeting the distinguished men whose works and valorous efforts on behalf of civilisation I have followed for many years.

"The subject which brings us together to-day is one that deserves in the highest degree to engage 


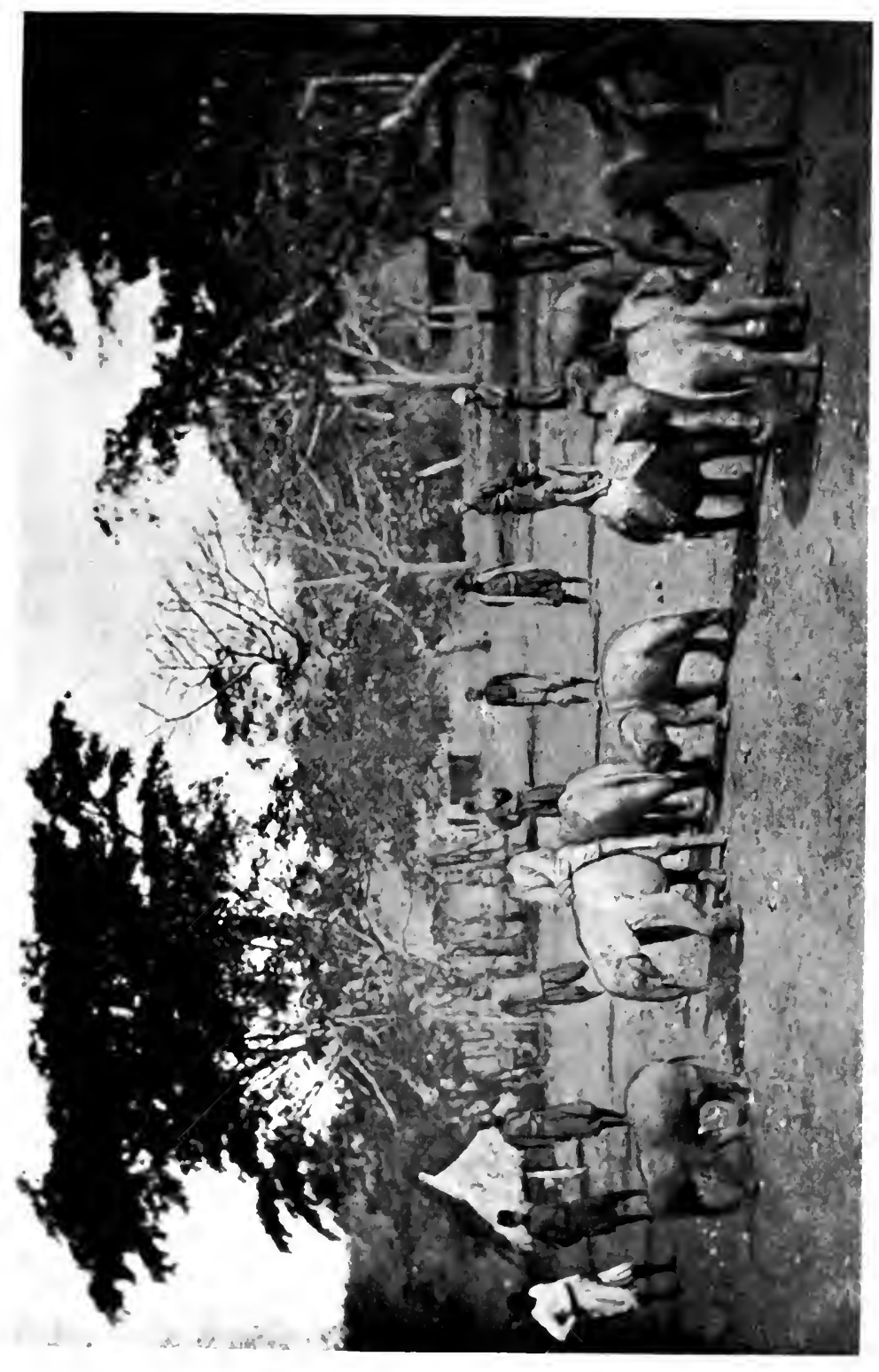

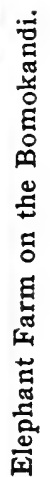



the attention of the friends of humanity. To open to civilisation the only part of the globe where it has not yet penetrated, to pierce the darkness enshrouding entire populations, that is, if I may venture to say so, a crusade worthy of this century of progress; and I am happy to discover how much public sentiment is in favour of its accomplishment. The current is with us.

"Gentlemen, among those who have most closely studied Africa, a good many have been led to think that there would be advantage to the common object they pursue if they could be brought together for the purpose of conference with the object of regulating the march, combining the efforts, deriving some profit from all circumstances, and from all resources, and finally, in order to avoid doing the same work twice over.

"It has appeared to me that Belgium, a central and a neutral state, would be a spot well chosen for such a reunion, and it is this view which has emboldened me to call you all here, to my home, for the little Conference that I have the great satisfaction of opening to-day. Is it necessary for me to say to you that in inviting you I have not been guided by egotistic views? No, gentlemen; if Belgium is small, she is happy and satisfied with her lot. I have no other ambition but to serve her well. But I will not go so far as to declare that I should be insensible to the honour which would result for my country if an important forward movement in a question which will mark our epoch should be dated from Brussels. I should be happy that Brussels 
should become in some way the headquarters of this civilising movement.

"I have, then, allowed myself to believe that it would be convenient to you to come together to discuss and to specify, with the authority belonging to you, the means to be employed in order to plant definitely the standard of civilisation on the soil of Central Africa, to agree as to what should be done to interest the public in your noble enterprise, and to induce it to support you with its money. For, gentlemen, in works of this kind it is the concurrence of the greater number that makes success; it is the sympathy of the masses which it is necessary to solicit, and to know how to obtain.

"With what resources should we not, in fact, be endowed if every one for whom a franc is little or nothing consented to throw it into the coffers destined for the suppression of the slave trade in the interior of Africa!

"Great progress has been already accomplished; the unknown has been attacked from many sides; and if those here present, who have enriched science with such important discoveries, would describe for us the principal points, their exposition would afford us all a powerful encouragement.

"Among the questions which have still to be examined have been cited:

" I. The precise designation. of the basis of operation to be acquired on the coast of Zanzibar, and near the mouth of the Congo, either by conventions with the chiefs, or by purchase or leases from private persons. 
"2. Designation of the routes to be opened in their order towards the interior, and of the stations -hospitable, scientific, and pacifying - to be organised, as the means of abolishing slavery, of establishing concord among the chiefs, of procuring for them just and distinguished judges, etc.

" 3 . The creation - the work being well definedof an International and Central Committee, and of National Committees to prosecute the execution, each in what will directly concern it, by placing the object before the public of all countries, and by making an appeal to the charitable that no good cause has ever addressed in vain.

"Such are, gentlemen, the different points which seem to merit your attention. If there are others, they will appear in the course of your discussions, and you will not fail to throw light on them.

"My desire is to serve, as you shall point out to me, the great cause for which you have already done so much. I place myself at your disposal for this purpose, and offer you a cordial welcome."

The object of the Conference, thus clearly outlined by the King, was loyally adhered to by the delegates, their discussions being strictly confined to geography and philanthropy, nothing political or personal obtruding itself upon their deliberations. At the close of its three days' session the Conference submitted to King Leopold the following declaration upon its labours:

In order to attain the object of the International Conference of Brussels-that is to say, to explore scientifically 
the unknown parts of Africa, to facilitate the opening of the routes which shall enable civilisation to penetrate into the interior of the African Continent, to discover the means for the suppression of the slave trade among the Negro race in Africa-it is necessary:

(I) To organise on a common international plan the exploration of the unknown parts of Africa, by limiting the regions to be explored-on the east and on the west by the two oceans, the Indian and the Atlantic, on the south by the basin of the Zambesi, on the north by the frontiers of the new Egyptian territory and the independent Soudan. The most appropriate mode of effecting this exploration will be the employment of a sufficient number of detached travellers, starting from different bases of operation.

(2) To establish, as bases for these operations, a certain number of scientific and hospitable stations both on the coasts and in the interior of Africa-for example, at Bagamoyo and Loanda, as well as at Ujiji, Nyangwe, and other points already known, which it would be necessary to connect by intermediate stations.

In accordance with the recommendation contained in this declaration of the Brussels Geographical ConThe Out- ference, "The International Association for come of the the Exploration and Civilisation of Central Conference. Africa" was formed, consisting of an International Commission sitting in Brussels, assisted by dependent National Committees in each country. The executive power of the International Association was vested in an Executive Committee, of which King Leopold was appointed President. When the British Government selected Sir Bartle Frere for the Governorship of the Cape, it became necessary for him to resign his position as a member of the Executive Committee, the vacancy thus created being filled 


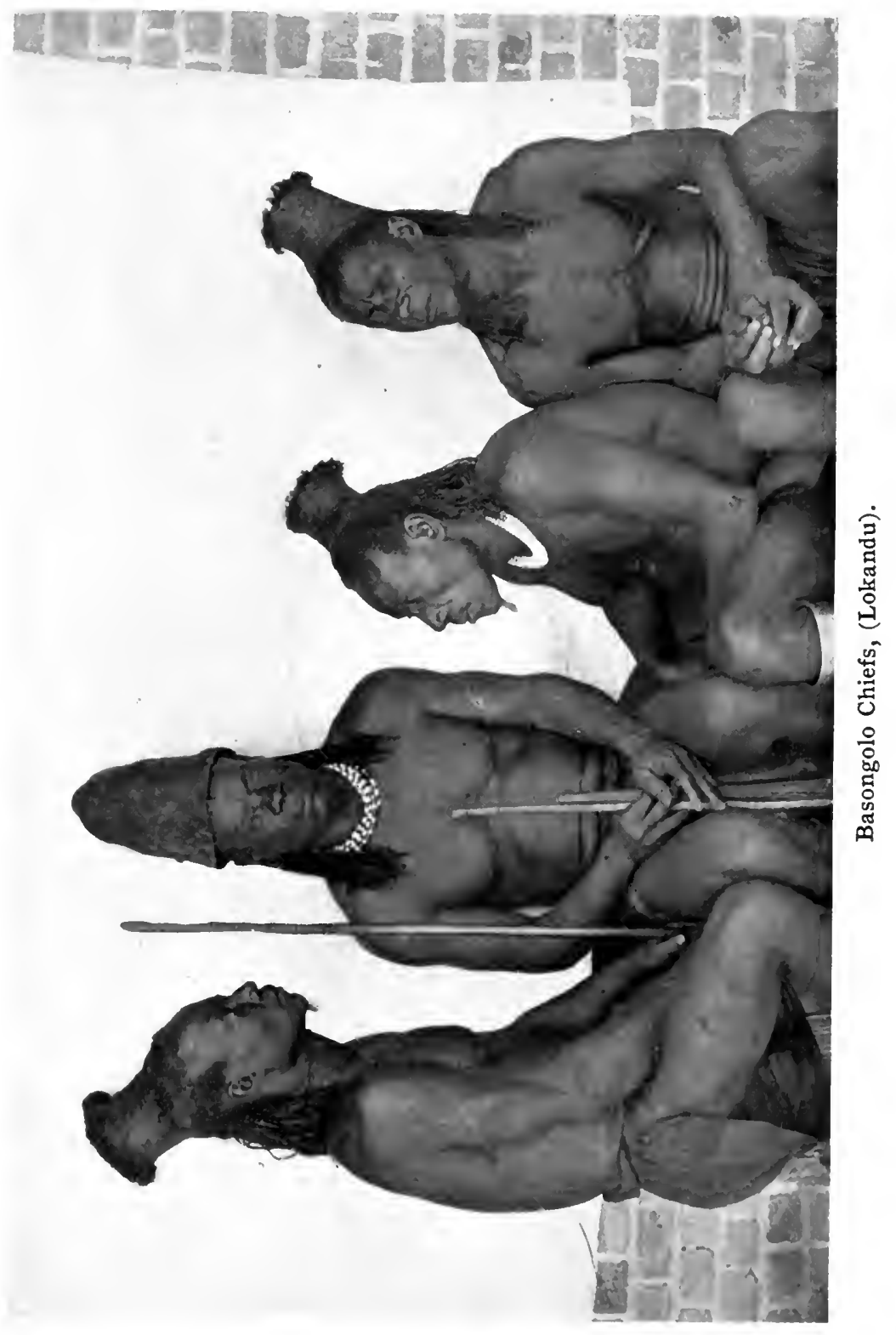



by an American. General Sanford, for many years United States Minister at Brussels.

The idea of an International Association for the Exploration and Civilisation of Central Africa, to which the Brussels Geographical Conference had given birth, at once began to grow, and flourished amazingly. Not only were influential committees formed in those countries which had sent delegates to the Conference, but in other countries as well, the United States among them.

To show how keen general interest in the civilisation of Central Africa had now become, it is only necessary to cite a few instances of the powerful support given to the National Committees. In Spain, the King; in Austria, the Archduke Rudolph, heir to the Austrian throne; in Holland, Prince Henry of the Netherlands; in Belgium, the Count of Flanders, brother of the King; all became Presidents of their respective National Committees. Philanthropists, men of science, all who were in any way interested in the world's progress towards better things, accorded ungrudging support to the work set in motion by King Leopold.

The civilisation of Central Africa had now begun in earnest. 


\section{CHAPTER II}

STANLEY, AND KING LEOPOLD II.'S CONCEPTION OF THE CONGO FREE STATE

$\prod$

$\mathrm{N}$ every case the National Committees of the International Association for the Exploration and Civilisation of Central Africa displayed extraordinary activity; but, as was to be expected, their rate of progress was measured by the Belgian Belgian Committee, which met, for the first time, on the 6th of November, 1876 , in Brussels, just six weeks after the close of the Brussels Geographical Conference which had decreed its existence. As was fitting in the circumstances, King Leopold was present at the meeting, and delivered upon that occasion a speech which may be regarded as an amplification of his Majesty's previous pronouncements on the situation, now in some measure become political, in Central Africa.

"'Gentlemen," said King Leopold, " the slave trade, which still exists over a large part of the African Continent, is a plague-spot that every friend of civilisation would desire to see disappear.

"The horrors of that traffic, the thousands of victims massacred each year through the slave trade, the still greater number of perfectly innocent beings who, brutally reduced to captivity, are condemned en 


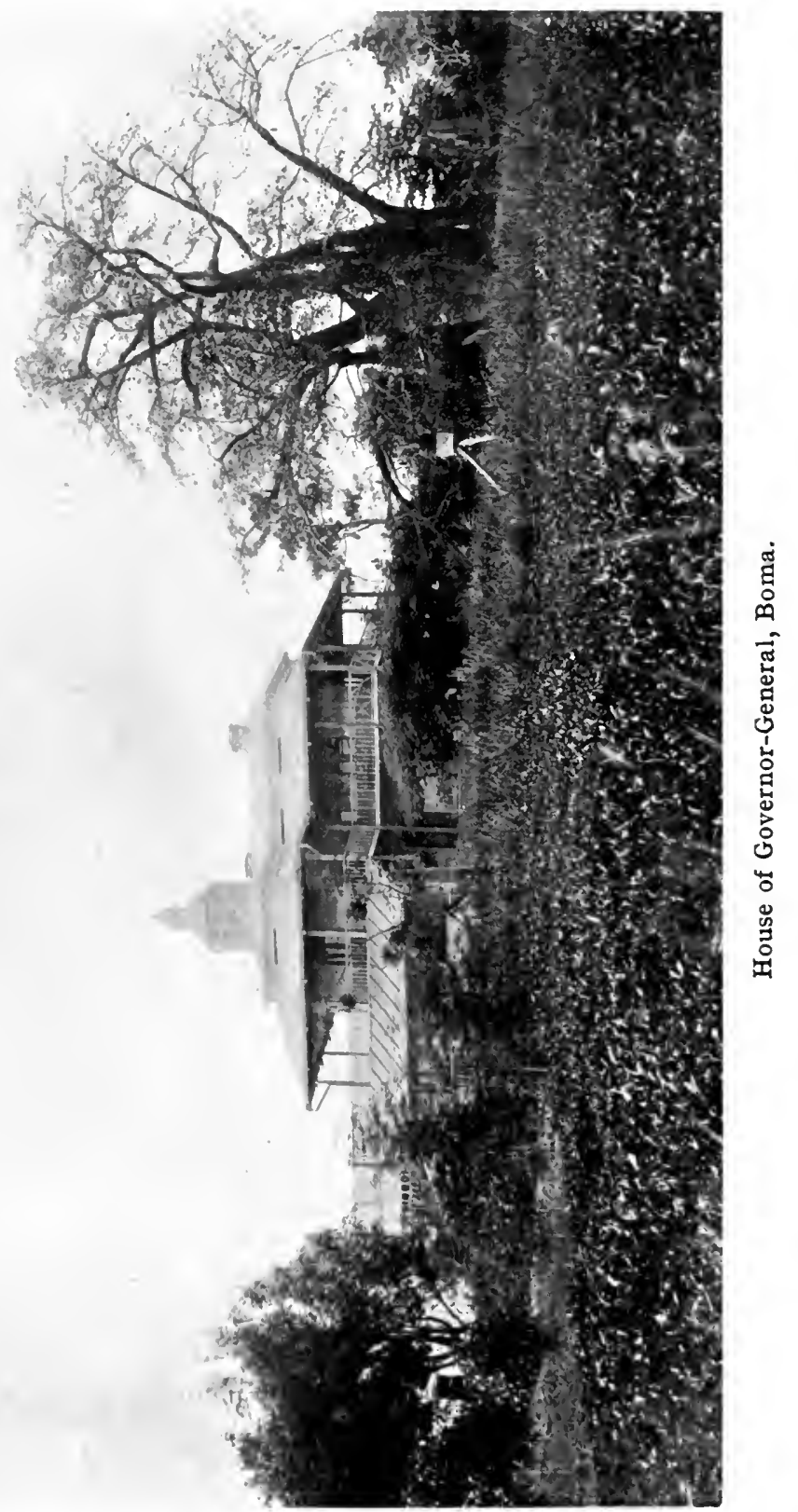



masse to forced labour in perpetuity, have deeply moved all those who have even partially studied this deplorable situation, and concerting, in a word, for the founding of an International Association to put an end to an odious traffic which makes our epoch blush, and to tear aside the veil of darkness which still enshrouds Central Africa. The discoveries due to daring explorers permit us to say from this day that it is one of the most beautiful and the richest countries created by God.

"The Conference of Brussels has nominated an Executive Committee to carry into execution its declaration and resolutions.

"The Conference has wished, in order to place itself in closer relationship with the public, whose sympathy will constitute our force, to found, in each State, National. Committees. These Committees, after delegating two members from each of them to form part of the International Committee, will popularise in their respective countries the adopted programme.

"The work has already obtained in France and Belgium important subscriptions, which make us indebted to the donors. These acts of charity, so honourable to those who have rendered them, stimulate our zeal in the mission we have undertaken. Our first task should be to touch the hearts of the masses, and, while increasing our numbers, to gather in a fraternal union, little onerous for each member but powerful and fruitful by the accumulation of individual efforts and their results.

"The International Association does not pretend 
to reserve for itself all the good that could or ought to be done in Africa. It ought, especially at the commencement, to forbid itself a too extensive programme. Sustained by public sympathy, we hold the conviction that, if we accomplish the opening of the routes, if we succeed in establishing stations along the routes followed by the slave merchants, this odious traffic will be wiped out, and that these routes and these stations, while serving as fulcrums for travellers, will powerfully contribute towards the evangelisation of the blacks, and towards the introduction among them of commerce and modern industry.

"We boldly affirm that all those who desire the enfranchisement of the black races are interested in our success.

"The Belgian Committee, emanating from the International Committee, and its representative in Belgium, will exert every means to procure for the work the greatest number of adherents. It will assist my countrymen to prove once more that Belgium is not only a hospitable soil, but that she is also a generous nation, among whom the cause of humanity finds as many champions as she has citizens.

"I discharge a very agreeable duty in thanking this assembly, and in warmly congratulating it for having imposed on itself a task the accomplishment of which will gain for our country another brilliant page in the annals of charity and progress."

We have here, in his Majesty's own words, a very lucid and reiterated exposition of King Leopold's main object in concerning himself with Central African 
affairs-the suppression of the slave trade, with consequent moral and material advancement of its peoples. But let it not be lost sight of that, subsidiary to this lofty mission, King Leopold has never disavowed-nay, his Majesty had more than once expressly declared it-his desire to find in Africa new markets for Belgian manufactures, and a wide field for the surplus population of overcrowded little Belgium, where his people might live and where their peculiar genius in the arts and sciences might flourish unfettered by alien laws.

The experience of recent travellers, and particularly of Livingstone and Stanley, had demonstrated the truth of what had hitherto always been disbelieved, viz., that it was possible for the white man to live and maintain his health

Old Beliefs Disproved. in Central Africa. This fact alone was of vast importance; but when was added to it proof that the country was fertile, with immense natural sources of wealth, needing only the brain and hand of civilised man to tap them, a prosperous future for the country was assured. England, France, and Portugal, but notably England, had already claimed large sections of Africa for their own, and Italy and Germanyespecially Germany-were feverishly anxious to follow suit. But it is doubtful if among all the students of the African problem-and they numbered among them the ablest of every nation - there was at this period another man with prescience to foresee, as we now know King Leopold must have foreseen, the illimitable possibilities of Central Africa. Indeed it is tolerably certain that had the great nations realised 
the potential value of this region, their cupidity would never have permitted them to allow its sovereignty to become vested in any single individual with claim to it based upon anything except irresistible material force. King Leopold's claim, as we have already partly seen, and as will presently be fully demonstrated, had for its foundation a long-cherished and active philanthropic interest in the welfare of its natives, chiefly in the form of the suppression of slavery; the expenditure, out of his Majesty's private purse, of large sums of money for exploration, establishment of route stations, etc.; and generally for calling the attention of the civilised world to a lictleknown and less-cared-for region commonly thought to be worthless.

Bacon asserts, in his Advancement of Learning, that "States are great engines moving slowly," and from the beginning of the world until long past the English philosopher's time, the axiom was true; but we of the twentieth century inhabit a world as unlike the world that Bacon lived in as modern New York is unlike the city that Washington Irving described under that name. The teeming millions of Europe are ever more and more perplexed by the problem of how to live, and not a day passes but the cruel competition of life waxes fiercer and hotter. New lands, new markets, must be found-the social pressure in the older nations demands it as a prime necessity. Therefore comes it that States are no longer "engines moving slowly." On the contrary, they move very rapidly; and as all the fat lands of the earth have already been appropriated, future 


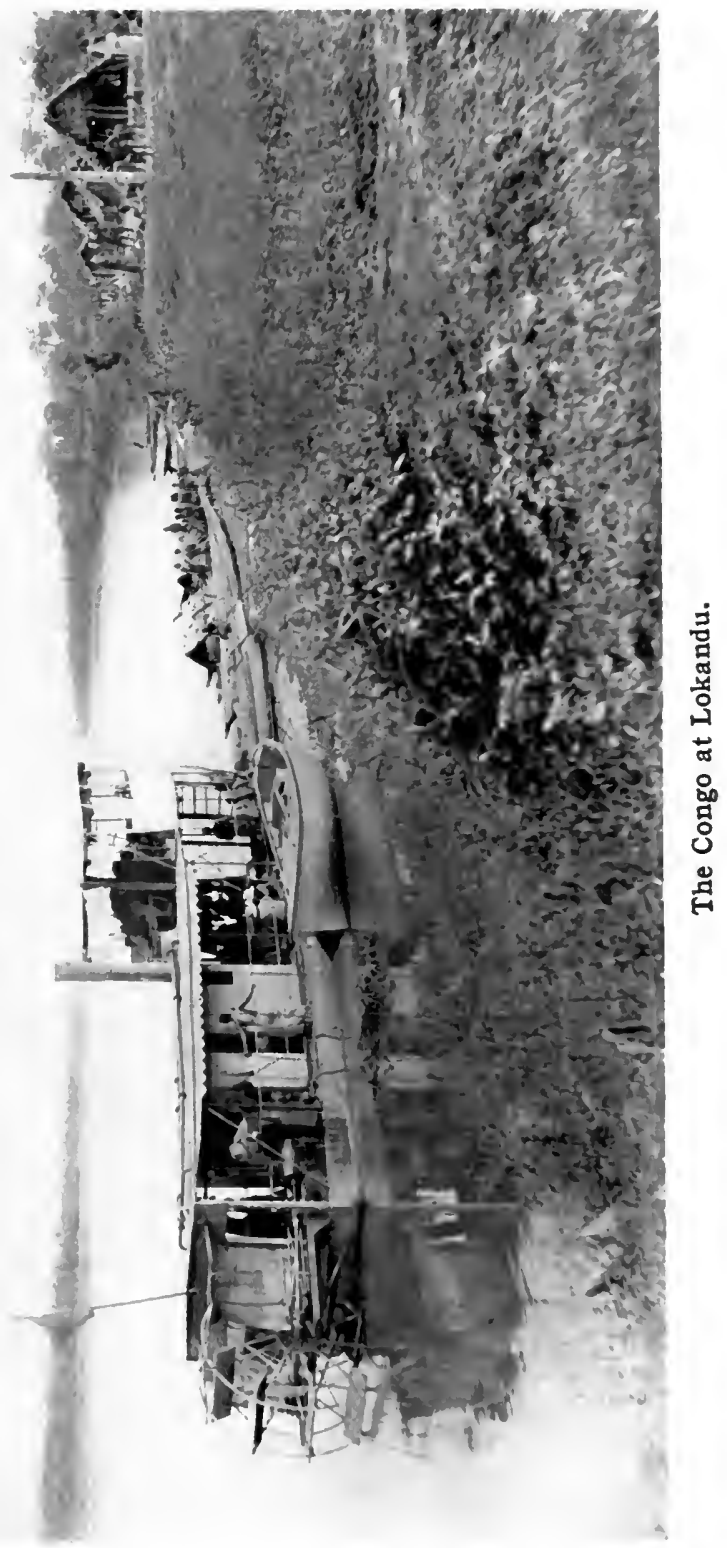



trouble seems not improbable. John Bull, early in the field, worked hard painting the map red, and now it is not possible to get far away from one or other of his frontiers. The British colossus has many imitators; but these started in the game late, when most of the prizes had been won.

No sooner was it perceived that the Congo region of Central Africa is a valuable possession, than France set up her flag on the Congo, at Universal Brazzaville. The Portuguese, rummaging Land in their musty archives for traces of their Hunger. past glory, set up a claim to the Congo River because one of her navigators had discovered the mouth of it five hundred years ago. Germany, too, now exhibited her desire for huge territorities in East Africa, and did not betray any marked scrupulousness as to whose rights were invaded in obtaining them. With such neighbours pressing closely upon him, it was no more than natural that King Leopold should cast about him how best he might preserve inviolate the great country to which he had so lavishly devoted his time and money; and he finally conceived the idea of a Congo Free State, with himself as its Sovereign ruler. Without some such clear recognition of Congo territory, and of his own personal rights in respect of it, it was abundantly clear that the first would be filched and the second ignored. For King Leopold to proclaim himself Sovereign ruler of the Congo region was, of course, not sufficient. It would be necessary to secure the assent to that course of all the great Powers interested. 
It was a momentous time. While the French were establishing themselves on Stanley Pool, Stanley the man was working in the interests of King Leopold, travelling through the Congo country, buying land here and there, establishing stations, and making treaties in the King's name with native chiefs.

The French regarded Stanley's proceedings with jealous distrust, and in France the question was raised whether the International Association for the Exploration and Civilisation of Central Africa ought to be permitted to exercise sovereign rights. That history furnished examples of corporate bodies exercising sovereign authority was acknowledged, but there was a large party in France which insistently asserted that no such right pertained to the International Association.

The situation was very complicated. If King Leopold recognised the preposterous claim of Portugal over the mouth of the Congo River, the entire region in which he was interested would be without a free way to the sea, a fatal bar to its proper development.

To deal with Portugal in this matter, even supposing her alleged right to be well founded, would have presented no insuperable difficulty; poor nations like poor individuals being ever open to sell their commodities at something more than their market value. But just at this juncture an unexpected act on the part of Great Britain added enormously to the difficulty. Lord Granville, at that time British Secretary of State for Foreign Affairs, after having refused to recognise any right by 
Portugal over the mouth of the Congo, in return for concessions granted by Portugal to Britain elsewhere, now recognised those claims in an extended form.

This Anglo-Portuguese Convention, made on the 26th of February, 1884, had it been carried out, would have killed at one blow the International Association for the Exploration and Civilisation of Central Africa, and all King Leopold's cherished dreams would have evaporated like mists before the sun.

But the good work done by King Leopold was not fated to be so ignominiously extinguished. France and Germany combined to denounce the John Bull Convention; and even with the British pub- Complaislic it was very unpopular, as hard things ant. being said of it in the British Parliament and press as any uttered in Belgium. King Leopold appealed to the British Government to suspend the ratification of the Convention, urging the despatch of a British mission to the West Coast to examine the validity of the treaties made between his Majesty's representatives and native chiefs in that part of the Congo country which the Convention proposed to acknowledge as Portuguese territory. The British Government granted the King's request, and despatched General Sir Frederic Goldsmid to the Congo. The result was a complete triumph for King Leopold, General Goldsmid reporting to his Government that the treaties were in perfect order and that the allegations of the Portuguese were baseless. That was the end of the Anglo-Portuguese Convention. 
Though the Anglo-Portuguese Convention was dead, and nothing remained to fear from it, the incident served to emphasise the great and growing necessity for endowing the Congo region with a clearer and more definite political status than it yet possessed. There were not wanting other, and happier, incidents pointing the same moral. On April 22, I 884, the United States officially recognised the flag of the International Association as that of a friendly Government, in which course it was soon after followed by France, though the latter country made it a condition of its acknowledgment that the Association would never alienate any of its territory without France having the right of pre-emption. Germany, entering upon joint action with France for the first time since the war of 1870 , concurred in recognising the International Association as an independent and friendly State; and on the very day that she gave her adherence to it, she invited, through Prince Bismarck, all the Powers interested in the future of Africa to confer in Berlin with the object of regulating African affairs. The invitation was accepted by fourteen nations, whose representatives met under circumstances to be presently described, and gave reality to the grand idea, conceived long before by Henry Morton Stanley and Leopold II., King of the Belgians, of a Congo Free State. 


\section{CHAPTER III}

FOUNDING OF THE CONGO FREE STATE

$\mathrm{O}^{\mathrm{N}}$

$\mathrm{N}$ the 15 th day of November, I884, the International Conference, convened by Prince Bismarck to regulate what that statesman termed "the African question," held its first meeting. It took place in Berlin, Prince Bismarck presiding. In briefly outlining the object of the Conference, the distinguished presi-

The Great Nations Agree. dent exhibited in no small degree that condensation and lucidity for which his utterances were remarkable.

The Imperial Government [said Prince Bismarck] has been guided by the conviction that all the Governments invited here share the desire to associate the natives of Africa with civilisation, by opening up the interior of that continent to commerce, by furnishing the natives with the means of instruction, by encouraging missions and enterprises so that useful knowledge may be disseminated, and by paving the way to the suppression of slavery, and especially of the slave trade among the blacks, the gradual abolition of which was declared to be, as far back as the Vienna Congress in 1814 , the sacred duty of all the Powers. The interest which all the civilised nations take in the material development of Africa assures their co-operation in the task of regulating the commercial relations with that part of the world. The course followed for a number of years in the relations of the Western Powers with the countries of Eastern Asia having up to this 
moment given the best results by restraining commercial rivalry within the limits of legitimate competition, the Government of His Majesty the German Emperor has considered it possible to recommend to the Powers to apply to Africa, in the form appropriate to that continent, the same regimen, founded on the equality of the rights and the solidarity of the interests of all the commercial nations."

Proceeding, Prince. Bismarck declared that the main object of the Conference was the opening up to all the world of Central Africa. He rejoiced that France was in perfect accord with Germany in this matter. The first thing to be considered in this matter was, he thought, how best to establish freedom of trade at the mouth and in the basin of the Congo. On that subject the German Government had formulated a plan, drawn as a declaration, designed to assure freedom of trade in that region, with equal rights for all nations,-monopolies and preferential duties for none.

Prince Bismarck was followed by the British representative, Sir Edward Malet. No other Power in the world, said Sir Edward, had done so much on behalf of the objects that the German Government affected to have at heart as Great Britain; and he went on to point out that the warm support of his country and Government might be relied upon for proposals which had always formed part of their policy. He hoped that the attention of the Conference would not be devoted entirely to commerce, and that the welfare of native races would receive attention. Freedom of trade should be restricted to legitimate articles of trade, or the natives would lose more than they gained. He apprehended that the 
chief difficulty of the Conference would be, not to secure its unanimous adherence to general principles, but to provide means for carrying those principles into effect. It was certainly desirable to establish the validity of effective new occupations on the coasts of Africa.

The Portuguese representative claimed for his country the honour of having introduced the elements of civilisation into Africa, and saw in an increase of commerce in that part of the world the assurance of peace and respect for the rights of humanity. The American representative contented himself by calling attention to the part his country had taken in the opening of Central Africa, and referred with pride to the achievements of Stanley, congratulating his countrymen on being first to recognise the good work accomplished by that great philanthropist, the King of the Belgians. The practical business, however, of the sitting, was the question, "What territories constitute the basin of the Congo and its affluents?" This being a matter less easily disposed of, it was referred to a Commission of eight experts selected by the eight Powers chiefly interested in its solution.

The Commission of eight reported to the Conference at its third sitting as follows:

The Basin of the Congo is delimited by the crests of the contiguous basins, to wit, the basins in particular of the Niari, the Ogowe, the Schari, and the Nile, on the north; by the Lake Tanganyika, on the east; by the crests of the basins of the Zambesi and the Loge, on the south. It comprises consequently all the territories drained by the Congo and its 
affluents, including Lake Tanganyika and its eastern tributaries.

This report seems as explicit as it well could be, and after much discussion and some slight modifications it was adopted. Baron Lambermont (Belgium) presented a report upon the best means of safeguarding the welfare of the native races, treating with remarkable ability of slavery, the importation of alcohol into the Congo country, and other dangers that threaten uncivilised races at their first contact with civilisation. Count Van der Straeten Ponthoz (Belgium) spoke even more vigorously to the same effect, and between them these two Belgian subjects of King Leopold showed themselves more solicitous for the welfare of the Congo native than the representative of any other nationality present.

The International Conference held its tenth and last sitting on the 26 th of February, I885. As on the occasion of its first sitting, Prince Bismarck presided. The drafting of the final act of the Conference was ably performed by Baron Lambermont. The representatives of the Powers assembled at Berlin signed conventions with the International Association, acknowledging it as a friendly and sovereign State whose flag-a golden five-pointed star on a blue banner-they agreed henceforth to recognise.

I am sure I am the interpreter [said the President in announcing the existence of these treaties to the Conference] of the unanimous sentiment of the Conference in saluting as a happy event the communication made to us on the subject of the almost completely unanimous recognition of the International Association of the Congo. All of us here render justice 


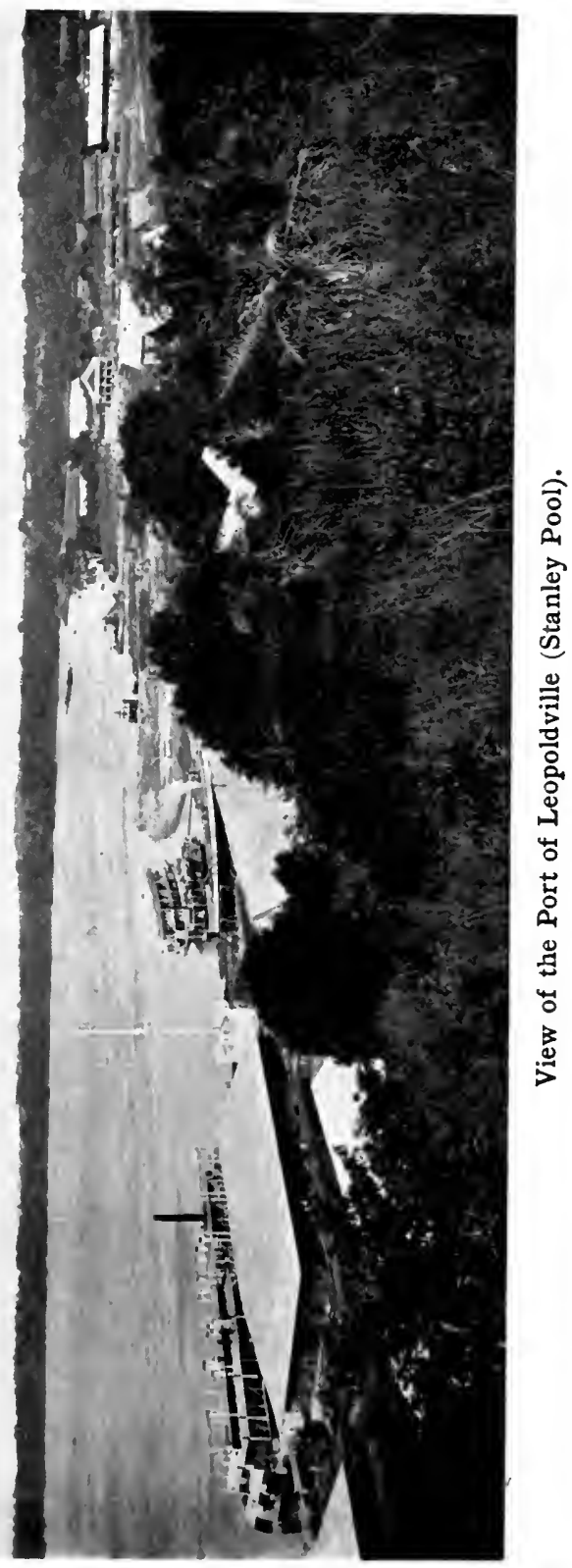



to the lofty object of the work to which His Majesty the King of the Belgians has attached his name; we all know the efforts and the sacrifices by means of which he has brought it to the point where it is to-day; we all entertain the wish that the most complete success may crown an enterprise that must so usefully promote the views which have directed the Conference."

Thus the great Bismarck. Sir Edward Malet (Great Britain) said:

The part which Queen Victoria's Government has taken in the recognition of the flag of the Association as that of a friendly Government warrants me in expressing the satisfaction with which we regard the constitution of this new State, due to the initiative of His Majesty the King of the Belgians. During long years the King, dominated by a purely philanthropic idea, has spared nothing, neither personal effort nor pecuniary sacrifice, which could contribute to the realisation of his object. Yet the world at large regarded these efforts with an eye of almost complete indifference. Here and there his Majesty attracted some sympathy, but it was somehow rather the sympathy of condolence than that of encouragement. People said that the enterprise was beyond his resources, that it was too great for him to achieve success. We now see that the King was right, and that the idea he pursued was not utopian. He has brought it to a happy conclusion, not without difficulties, but the very difficulties have made the success all the more striking. While rendering to his Majesty this homage by recognising all the difficulties that he has surmounted, we salute the new-born State with the greatest cordiality, and we express the sincere desire to see it flourish and grow under his ægis.

Baron de Courcel (France) said: "The new State owes its origin to the generous aspirations and the enlightened initiation of a prince surrounded by the 
respect of Europe." Other members of the Conference were as warm as the representatives of Great Britain and France in their eulogy of the great work achieved by King Leopold, and their opinions of his Majesty's life-work were admirably summed up by Prince Bismarck in his speech closing the Conference, in the course of which he referred to the consolidation of the Congo Free State as a "precious service to the cause of humanity."

Central Africa had now become in all essential respects a State. It had been recognised as such by the United States on April 22, 1884, seven months before the opening, and ten months before the close, of the Berlin Conference, but now its geographical limits were defined, its political status fixed, its neutrality assured. The large part played by Leopold, King of the Belgians, in its creation had received full and complete acknowledgment from the foremost geographers and statesmen of the world, who had united in lauding the King, not only for his wonderful achievement, but for the high humanitarian motive stimulating his Majesty through all the years of its difficult accomplishment.

But let no one suppose that it followed, as a necessary consequence of all this, that the future government of Central Africa was to be as plain Hard Work
Ahead been created, it is true, and it had had as its sponsors the great Powers of the world, who had recognised Leopold II., King of the Belgians, as its Sovereign ruler. But it is beyond the ability of States, just as it is beyond the ability of indivi- 
duals, to exist without money, and to be entrusted with the government of a territory nearly a million square miles in extent - about a fifth the size of Europe, or a third of the United States - inhabited by twenty millions or so of semi-barbarous tribes, was no light task. The "African Exploration Fund" of the Geographical Society of London contributed $£ 250$, and the Belgian Committee collected among their countrymen 500,000 francs-a generous gift, but utterly inadequate for such a colossal task as the civilisation of Central Africa. Belgians, as a people, were in no degree liable for the expense of the philanthropic colonial enterprise entered upon by Leopold, their King, as an individual. The magnitude of that expense will be apparent to anybody who gives the subject a moment's thought. The payment of explorers, - men of the first rank in intellectual attainment, such as Stanley,- -the cost of their equipment (stores, carriers, lake steamers, etc.), the carving out of routes, establishment of stations, purchases of land from native chiefs, conciliatory gifts, and so forth, had seriously depleted the large private fortune of King Leopold.

Though all civilised countries were more or less interested in the opening up of Central Africa, less than twenty thousand dollars was subscribed outside Belgium for that object. It had, therefore, some years before the Berlin Conference, become necessary to raise money for the continuation of the work. On November 25, 1878, the Comité d'Etudes du Haut-Congo was formed in Brussels, with King Leopold as honorary president and Colonel Strauch 
as president. The Comité was really a company, and it had a capital of a million francs. Thanks no less to its wise dircction than to its sufficient capital, the operations of the Comite were attended with so much success that it soon usurped the place of the International African Association as principal agent of the civilising crusade undertaken by King Leopold. The work of the Comité was consolidated and greatly accelerated by the General Act of the Berlin Conference, assuring the Sovereignty of the Congo State to King Leopold, it being no more than natural that Belgians should have increased confidence in a State secure under the rule of their own King, and be disposed to invest their money therein more freely than when the form of its government was matter of doubt. Though much still remained to be done, the Congo Free State had now been founded, and that fact of itself was sufficient to inspire confidence everywhere, but particularly among the Belgian people, whose King was its founder. 


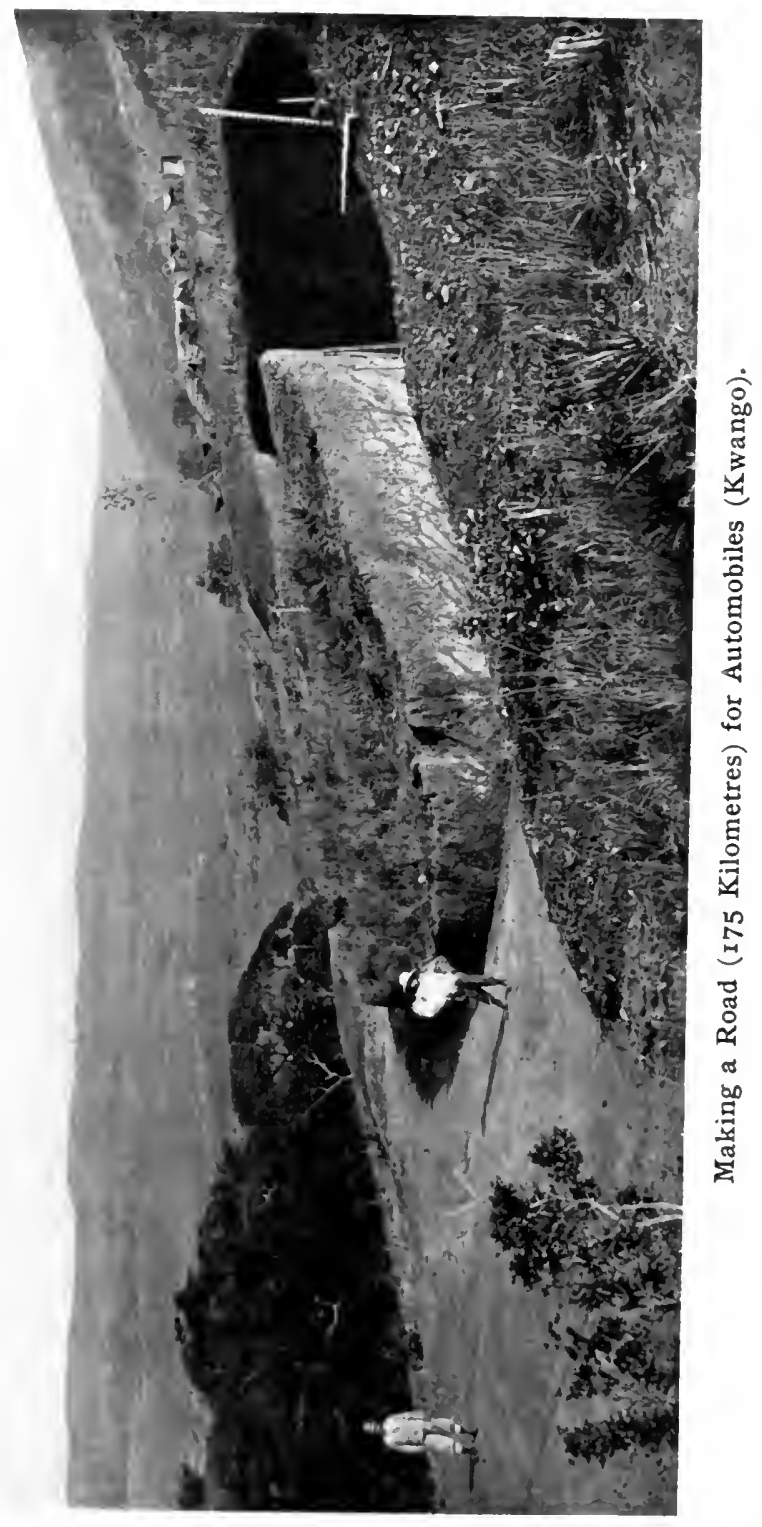





\section{CHAPTER IV}

\section{EARLY BELGIAN EXPEDITIONS}

$\mathrm{H}^{\prime \prime 2}$

AVING narrated the principal political circumstances which eventuated in the founding of the Congo Free State, it now becomes necessary to revert to an earlier period, and sketch briefly the various Belgian expeditions to whose Cartography labours are so largely owing our knowledge and of the geography of Central Africa, the Civilisation. suppression of the slave trade there, and the establishment of civilising and humanitarian government by Belgians.

It is hardly necessary to say that so great an enterprise was not possible of achievement without loss of life, and much personal sacrifice and suffering; that many men of high intellectual power and indomitable courage fell by the way, martyrs to disease, treachery, and the innumerable accidents by flood and field which ever dog the footsteps of pioneer explorers. The official records of the expeditions, for the most part vouched for by independent testimony (chiefly English), establish beyond possibility of dispute the patient forbearance and humanity of the explorers in their dealings with the natives. The dignity of truth is lost with too much protesting, and that some few mistakes were committed here 
and there, the result of over-zealousness on the part of particular individuals, is frankly admitted, such admission in no way detracting from the confident assertion that no exploration of unknown lands had ever before been made which occasioned so small an amount of friction with their indigenous occupiers. A sound discretion is not so much indicated by never making a mistake as by never repeating it. Mistake, error, is the discipline through which we all advance, and the greatest of faults is to be conscious of none.

The first Belgian expedition arrived at Zanzibar in December, I877, having been three months on its A Bad Start. voyage from Ostend. It was commanded by Captain Crespel, an officer of the Belgian Army, and included, besides Lieutenant Cambier, also of the Belgian Army, Dr. Maes, and M. Marno, an Austrian. Some time was spent by these explorers in Zanzibar, purchasing supplies and engaging an escort, before starting for the interior; a task in which they were assisted by the Sultan, Seyyid Burghash, an enlightened ruler, opposed to slavery and sympathetic with the expedition and its objects. Unfortunately, these favourable auspices were not followed by correspondingly happy events. In less than a month after the arrival of the expedition in Zanzibar, Dr. Maes was dead of fever; and Captain Crespel, who was ill from the first moment that he set foot on African soil, survived Dr. Maes only a few days.

Shortly before these two sad events, Cambier and Marno had started on their journey into the interior, 
and at once became the victims of every sort of misfortune. Their cattle were tormented and destroyed by the tsetse fly, which in that year assumed the proportions of a plague, and, their route lying through a marshy region, progress was rendered impossible. Two months later they returned to Zanzibar worn out and dispirited, having achieved nothing, only to be greeted by the melancholy news of the death of Captain Crespel and Dr. Maes. Command of the expedition now devolved upon Lieutenant Cambier, who resolved to await reinforcements from Belgium.

It was not until September of the following year that Lieutenant Cambier, accompanied by Lieutenant Wautier and Dr. Dutrieux, ventured to move forward. On the occasion of his second attempt he started from Bagamoyo. His difficulties, if not so great as on his previous journey, would have daunted any ordinary mortal. His native carriers gave great trouble, continually deserting or threatening to desert him, while crossing the Mgonda-Mkali desert. However, after passing through infinite danger and difficulty, Cambier succeeded in reaching the territory of Mirambo, and prospered so well in his efforts to secure the friendship and assistance of that powerful chief that the two entered into a treaty of alliance, and went through the strangely barbarous ceremony of taking the oath of blood; after which, according to African superstition and custom, they became brothers. This was the first example of a Belgian officer and a native chief taking the oath of blood. It was entered into by Cambier only after 
he had informed himself that it was a ceremony the sanctity of which the Negro race held to be inviolable, and was therefore exactly suited to his purpose.

The object of the expedition was to found a station on the shores of Lake Tanganyika. Having been provided with some necessary supplies by his newly made "blood brother," M. Cambier was about to resume his journey, of which another hundred and fifty miles remained, when he learned with consternation of the death of M. Wautier, the able lieutenant to whom he had entrusted the difficult task of keeping open his communications with the coast, who had succumbed to the climate after prolonged exposure to torrential rain. M. Wautier was the third Belgian who had lost his life in the cause of African exploration. His place was taken by M. Bryon, a Swiss traveller of much experience, who rendered good and faithful service. But though so near to his destination, M. Cambier's difficulties were by no means ended. As before, it was his carriers who made the trouble. They were insubordinate, quarrelled among themselves, and deserted in great numbers, on the slightest provocation, and often for none at all. Finally, however, on August r 2, I 879, Karema, on Lake Tanganyika, was reached in safety, and the first station of the International Association for the Exploration and Civilisation of Central Africa established by the Belgian Committee. The site chosen for the station was about five thousand acres of land, very healthfully situated, which Cambier obtained by treaty with a local chief. Thus 


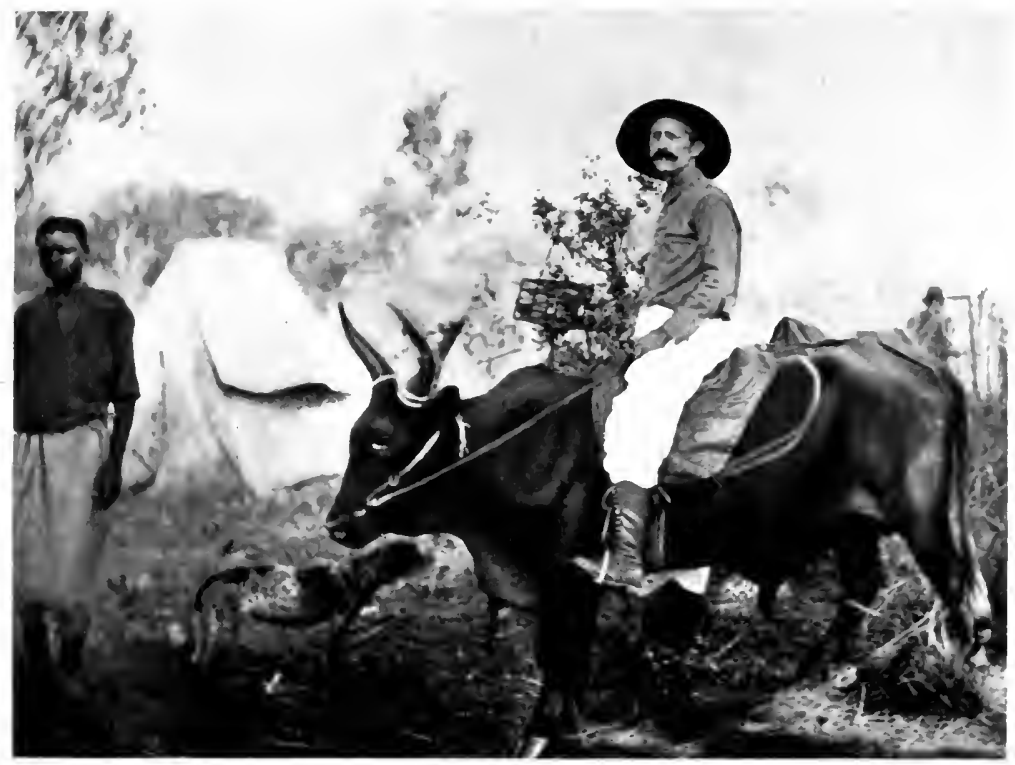

A Saddle Ox, Kassai.

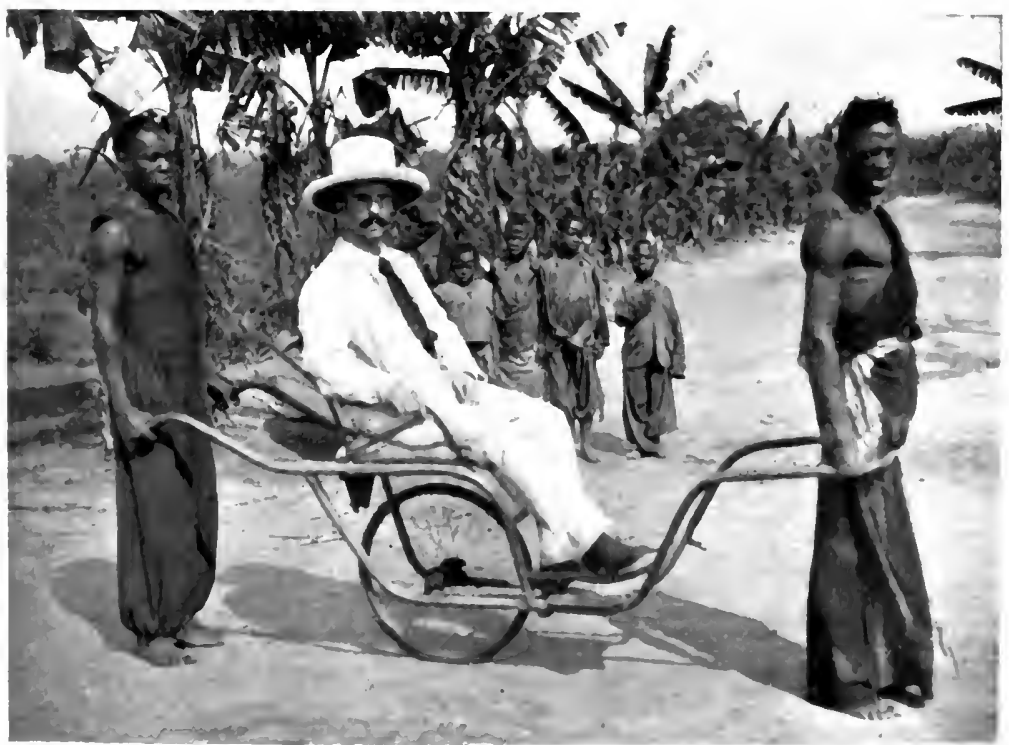

European Travelling in the Uelle District. 

through difficulty and danger, by the expenditure of energy, money, and of life itself, was the object of the first Belgian expedition successfully accomplished, and M. Cambier set out to return to Belgium. When he reached the coast he was surprised to meet a second expedition, of whose existence he knew nothing, which had just arrived from Belgium. In consequence, M. Cambier decided not to return to Europe, but to remain in Africa for a while to assist, so far as he was able, in this second enterprise. The period was May, I879. The new expedition, under command of Captain Popelin, of the Headquarters Staff, assisted by Dr. Van den Heuval and Lieutenant Dutalis, had not completed their arrangements for their inland journey when the latter fell ill and was obliged to return at once to Belgium. The expedition had brought with it four Indian elephants, attended by two English keepers accustomed to the management of those animals, it having been suggested to King Leopold that elephants were better adapted for transport purposes in Central Africa than oxen. The experiment proved a costly failure. All four of the elephants died before any use could be made of them, and their English keepers were waylaid by brigands and murdered on their way back to Zanzibar. Notwithstanding these misfortunes, MM. Cambier and Popelin persevered bravely with their task, stocked the station at Karema with provisions, and organised a native guard for its protection.

The third expedition, judged by results, hardly deserves to be called such. It consisted of only two 
Belgians (MM. Burdo and Roger), and the health of the former breaking down immediately on his arrival at Zanzibar, he was obliged to return home at once. War was now being waged between the chiefs Mirambo and Simba; but though each of the contestants was friendly to the Belgians, the conflict rendered their position very precarious. In the circumstances, MM. Cambier and Popelin judged it expedient to divide their forces, so as to ensure efficient protection for the newly founded station at Karema, and the route thence to the coast.

While matters were standing thus, a fourth expedition arrived, the strongest and best equipped yet sent out by Belgium, commanded by Captain Ramaeckers, an experienced African traveller, skilled in native wiles, who had been more successful in his dealing with the black man than any other Belgian. Captain Ramaeckers was ably seconded by MM. Becker and De Leu, lieutenants in the Belgian Artillery, and an expert photographer. The moment of the arrival of this expedition was opportune, for the difficulties of MM. Cambier and Popelin, due to the war between the natives, increased daily, and they were in a bad way. Captain Ramaeckers made all possible haste to succour them, and after a perilous journey succeeded in joining his colleagues on the banks of Lake Tanganyika; but he lost by death on the way his brave lieutenant, De Leu, a victim of malarial fever, and the health of the photographer failed so completely that it was found necessary to send him home. Captain Ramaeckers now took over the command from Lieutenant Cambier, who 
had carried on the work in Central Africa for three years, and was now desirous of returning to Europe. In that period Cambier had contrived to achieve much valuable work, of which the worth is more apparent to-day than it was in December, 1880 , when he resigned his command. But in estimating its value, then or now, the enormous difficulties under which he laboured should never for a moment be lost sight of. These difficulties were so great as hardly to admit of exaggeration. Language is inadequate to convey any just conception of the trackless deserts, impenetrable forests, and malarial swamps, through which the explorers' route lay, complicated by two friendly but warring tribes, each suspicious of the strangers' relations with the other.

Popelin and Ramaeckers, unlike Cambier, were not destined to see their native land again. Eighteen months after the departure of Cambier, Popelin died of malarial fever, and a short while after Ramaeckers also, from a like cause. In spite of these terrible losses, the Belgian station continued to exist, and even prospered in its work. The command now devolved upon Lieutenant Storms, then on his way to Central Africa to establish a new station on the western shore of Lake Tanganyika. When Storms arrived and took command he chose as the site of the new station a spot called Mpala, immediately opposite Karema. The chief of the district, who himself bore the name of Mpala, proved friendly to the expedition, and the new station soon became as important as Karema itself. So great was the influence exerted by Storms over Mpala that that chief, 
when dying, left the appointment of his successor to be determined by the Belgian officer. Storms showed himself a clever diplomatist, and during his twoand-a-half-years' control did much to consolidate the work of his predecessors.

So far, we have seen, these expeditions were exclusively Belgian. They owed their inception to King Leopold, by far the larger part of the heavy expense they entailed was met out of his Majesty's private purse, and the personnel was Belgian almost to a man. Humanitarian in their object, the expeditions had been conducted so humanely that no injury had resulted to any one for which the expeditions could be blamed. With the exception of the two English elephant-keepers, murdered by Arab brigands, the loss of life was wholly Belgian, resulting in every case from the trying climate of Equatorial Africa.

But before any Belgian expedition had started, Henry M. Stanley, the great Anglo-American travelAn Intrepid ler, had penetrated Africa as far as the Journalist. mouth of the Congo, and had startled the world by the information contained in his letters addressed thence to the New York Herald and the London Daily Telegraph. In glowing and incisive language Stanley demonstrated the future commercial importance of the superb Congo River, and significantly pointed out that, so far, no European power, except Portugal, had put forth any claim to its control-a claim which England, France, and the United States had refused to recognise.

This pregnant statement excited widespread re- 
mark, but the King of the Belgians was alone in acting upon the startling information. His Majesty invited Mr. Stanley to Brussels to confer with some distinguished geographers, merchants, and financiers; and out of that meeting grew the Comité d'Études $d u$ Haut-Congo, to which reference has been made in an earlier chapter. Soon after, however, the name of this body was changed to that of the International Association of the Congo. Mr. Stanley was invited to enter its service, and to establish along the Congo a series of stations, designed as bases for future operations, humanitarian and commercial, i.e., suppression of the slave trade and securing the commerce of the Congo country.

How Stanley accepted that invitation, and carried out the mission which the King of the Belgians entrusted to him, is almost as well known as the story of the same intrepid traveller's discovery of Dr. Livingstone a few years before. With only ten companions (five Belgian, two English, two Danish, and one French), Stanley left Europe in January, 1879. At Zanzibar he hoped to be reinforced by at least some of those who had been associated with him on his previous journey. Meanwhile the steamboats En Avant and Royal, the twin-screw steamer La Belgique, one-screw barge Young Africa, and two steel lighters, were sent direct from Belgium to the mouth of the Congo, there to await Stanley's coming. Stanley recruited a hundred and forty blacks (Askaris and Kabindas), to say nothing of carriers, whom he obtained as he required them during his progress along the Congo. 
The first station to be founded was Vivi, and six months were spent in fortifying it. Then came the Difficult construction of a road from Vivi to Isang-
Pioneering. hila - fifty miles higher up the river - required for the conveyance of the steamers in section, stores, merchandise, etc. This proved a formidable task and took a whole year to accomplish. But Stanley and his men proved equal to it, and another station was founded at Isanghila. At that station, fortunately, the Congo was again found to be navigable, and Stanley pushed on to Manyanga by boat, where he founded a third station. It was while at Manyanga that Stanley first learned of $M$. de Brazza's having set up the French flag on the northern shore of Stanley Pool, and calling it Brazzaville, a fact previously referred to.

Stanley countered this act by founding, on the plain of Kintamo, near the lake, a station out of which has grown the modern Leopoldville, named in honour of the King of the Belgians, and now recognised as the capital of Central Africa.

The spread of French influence so far as Brazzaville was significant and ominous. Clearly the nations of Europe were waking up to the importance and value of Central Africa. Leaving the expedition in charge of Captain Hanssens, Stanley hurriedly returned to Brussels to report the circumstance in person. That was in April, I882; and by February, 1883 , he was back again with the expedition in Africa, recharged, as it were, with energy, and busied himself in establishing numerous stations.

In all, Stanley served five years with this expedi- 


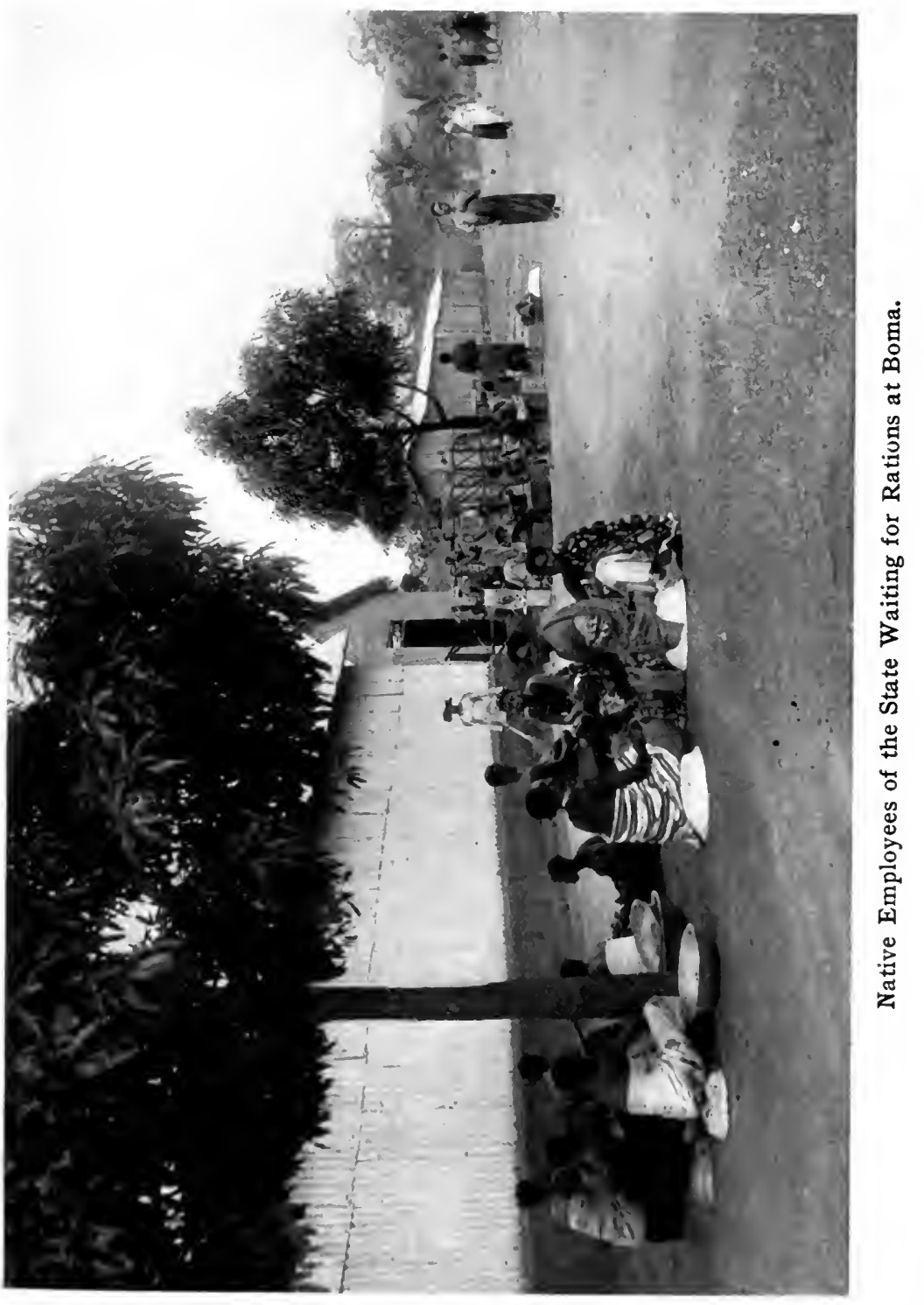





\section{Early Belgian Expeditions}

tion, which, notwithstanding his nationality, must in all fairness be accounted a Belgian expedition.

Such, then, were the early expeditions in Central Africa undertaken by Leopold, King of the Belgians. There were other contemporaneous expeditions in the same region undertaken by France, Germany, and Russia, or rather by natives of those countries presumably working in the interest of their respective nations, but their results will not stand comparison with those achieved by Belgians. At one time it was the intention of King Leopold to appoint General Gordon to the chief command on the Congo, and that extraordinary man had agreed to accept his Majesty's offer; but the British Government had a prior claim on Gordon's services, who went to Khartoum and lost his life there in tragic circumstances so well known that they need not be recounted here. 


\section{CHAPTER V}

\section{THE WATERWAYS OF THE CONGO}

$\mathrm{I}^{\mathrm{T}}$

$T$ was Diego Cam, an intrepid Portuguese navigator, who, in $\mathrm{I}_{4} 84$, voyaging towards the mythical East Indies, discovered the Congo. In the name of his sovereign, King Juan II., he took posDiscovery session of the country, though it does not of the appear that he proceeded far into the inCongo. terior. From n'zadi, the native name for river, the Portuguese formed the word Zaire, and it is by this name that the river was long called. It so appears in the map of Martin of Bohemia, who accompanied the expedition. The globe prepared by this German cosmographer is still to be seen in the museum of Nuremberg. It was not until two centuries later that the river was called Rio de Congo.

On the south promontory of the Delta the Portuguese erected a pillar to commemorate their discovery. This promontory is still known as the Padrão Foreland. It is certain that these Portuguese, who were missionaries before they were explorers, remained a considerable time in the Delta; for they converted the King of Ekongo, as the country was then called, to Christianity. It was to this king that the sovereigns of Angolo traced descent, and it 


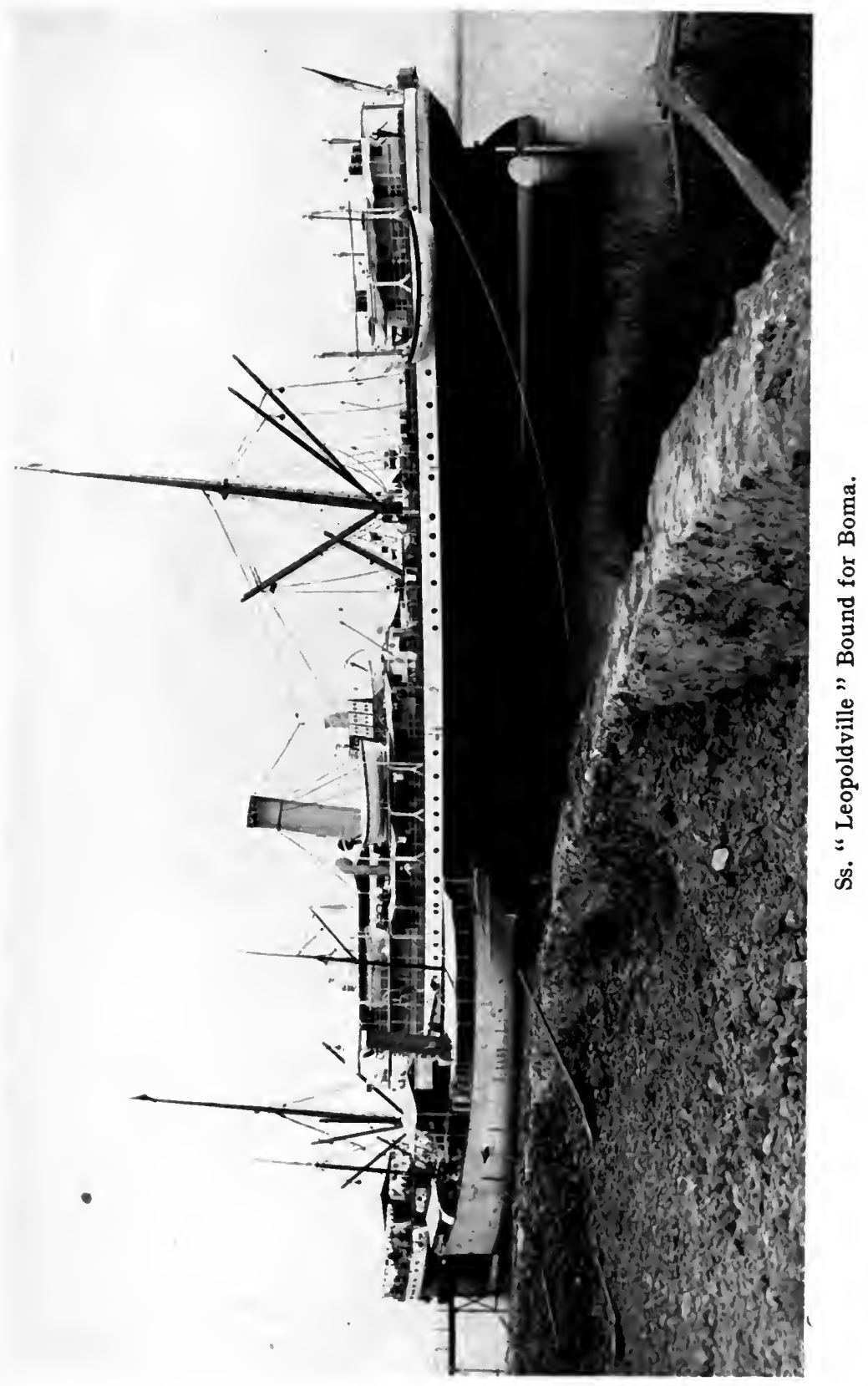



is significant that their blue banner with the golden star is to-day the flag of the Congo Free State.

About seven years after the first expedition a second was sent out from Portugal, and the ruins of the trading posts then established, called San Antonio and Salvador, are still to be seen. The old Kingdom of Ekongo continued a hundred miles into the interior. It was bounded on the north by N'zadi, the modern Congo, and on the south by the river Coanza. The accounts of the early traders, some of which are still preserved in the State archives of Portugal, abound in fanciful descriptions. To the mediæval mind the forest was peopled with mythical monsters. It was probably for this reason that the superstitious Portuguese kept so near the coast.

In I534 San Salvador, which until the arrival of the Portuguese was known as Ambassa, became the seat of a bishopric. Here a cathedral was erected, but later the see was transferred to St. Paul de Loanda, which thus became the capital of the Portuguese authority.

In 1784 , to maintain their occupation of the Congo, the Portuguese built a fort at Kabinda, about thirty miles north of the mouth of the river. Several slave stations also were established in the interior. From this position they were soon driven by the French, though the latter made no attempt to found a colony.

In I8I6 the British Government despatched an expedition to the Congo. James Kingston Tuckey, the leader, explored the river from its mouth to a distance of 170 miles into the interior. In his 
description of the country Tuckey speaks of the numerous slave stations along the banks. At this period two thousand slaves were exported annually. Fifty years later this number had increased to over one hundred thousand!

The Congo with its multitudinous branches forms a river-basin unequalled even by that of the Mississippi. This great territory, over fourteen hundred miles in breadth, covers an area of nearly a million square miles. Though mere size is not always a measure of importance, yet this region is unsurpassed, in respect to natural resources, by any part of the world. Second only to the Amazon in volume, the Congo precipitates about $2,000,000$ cubic feet of water each second into the Atlantic.

This immense basin has been divided by geographers into three gradual terraces: the first and lowest is near the coast; the second, in the region of the Upper Congo; and the highest in the vicinity of the great lakes. According to the official Act the basin is bounded by the watersheds of the neighbouring basins of the Niari, the Ogowe, the Shari, and the Nile on the north; by the eastern watershed line of the affluents of Lake Tanganyika on the east; and by the watersheds of the basins of the Zambesi and the Loge on the south. Congoland is about I,500,000 square miles in extent. From its western frontage of 400 miles it broadens eastward until at Lake Tanganyika it has a frontier of about 1500 miles.

The numerous ramifications of the Congo open rapid and economic channels of communication to 
the interior. To this magnificent system of waters the country also owes its unequalled fertility. Many of the rivers now practically useless can in time be rendered navigable by the skill of the engineer. Where blasting out channels is not feasible canals can be built to connect the navigable parts of the stream. It is obvious, too, that the effects on that torrid climate of these great rivers, from one to twenty miles in breadth, must be considerable. Without them the country would be an arid desert, another Sahara, deadly to life, both animal and vegetable.

We shall first follow the successive stages of the Congo, as the Chambesi, the Luapula, and the Lualaba, in the huge watershed on the eastern border between Lakes Nyassa and Tanganyika.

The source of the Congo is in the Chingampo Mountains, in British territory, and about 50 miles from the western confines of German East Africa, whence it issues as the Chambesi. Source of It was Livingstone who, in 1867 , discovered the Congo. the Chambesi. Mistaking it for the undiscovered source of the Nile, he explored it towards the south-west-250 miles-as far as Lake Bangweolo. Thence he followed its gradual curve to the north, first as the Luapula, through Lake Moero, as far as Ankorro; and then as the Lualaba, in a northwesterly direction to Nyangwe, I 300 miles from its source. The river assumes the distinctive name of the Congo first at Nyangwe. It was from this place that Stanley, in 1876 , made his famous descent of the river. The journey, which covered 1660 miles 
by water and 140 miles by land, was accomplished in $28 \mathrm{I}$ days.

From Nyangwe the river flows due north 400 miles as far as Stanley Falls. The country between these two places is peopled by the cannibal Bakumu. With "these insensate furies of savageland" Stanley had many bloody encounters. "At every curve of this fearful river," he writes in his now famous book, "the yells of the savages broke loud on our ears, the snake-like canoes dashed forward impetuously to the attack, while the drums and horns and shouts raised fierce and deafening uproar."

From Stanley Falls the river, flowing west and north-west, makes a huge curve, in the form of a horse-shoe, to Equateurville, where the junction of the Congo with the Ruki takes place. Throughout this immense curve, called the Middle Congo, and as far south as Leopoldville, a distance of ro68 miles, the river is navigable. In the contiguous territory live the Balolo, or "men of iron," forgers of metal instruments. Famous as warriors, they are also noted as clever craftsmen, and are valuable allies of the Statc.

From the junction of Lake Matumba with the Congo, the river, flowing south-west about $45^{\circ}$ miles to Manyanga, forms the boundary between the French and the Belgian possessions. Thence down to Matadi it pursues a southerly course of about 100 miles through the territory of the State. From Matadi, whence it flows westward to the sea, it forms for 30 miles the northern boundary of the Portuguese Congo.

At Stanley Pool the Congo is no longer navigable. 


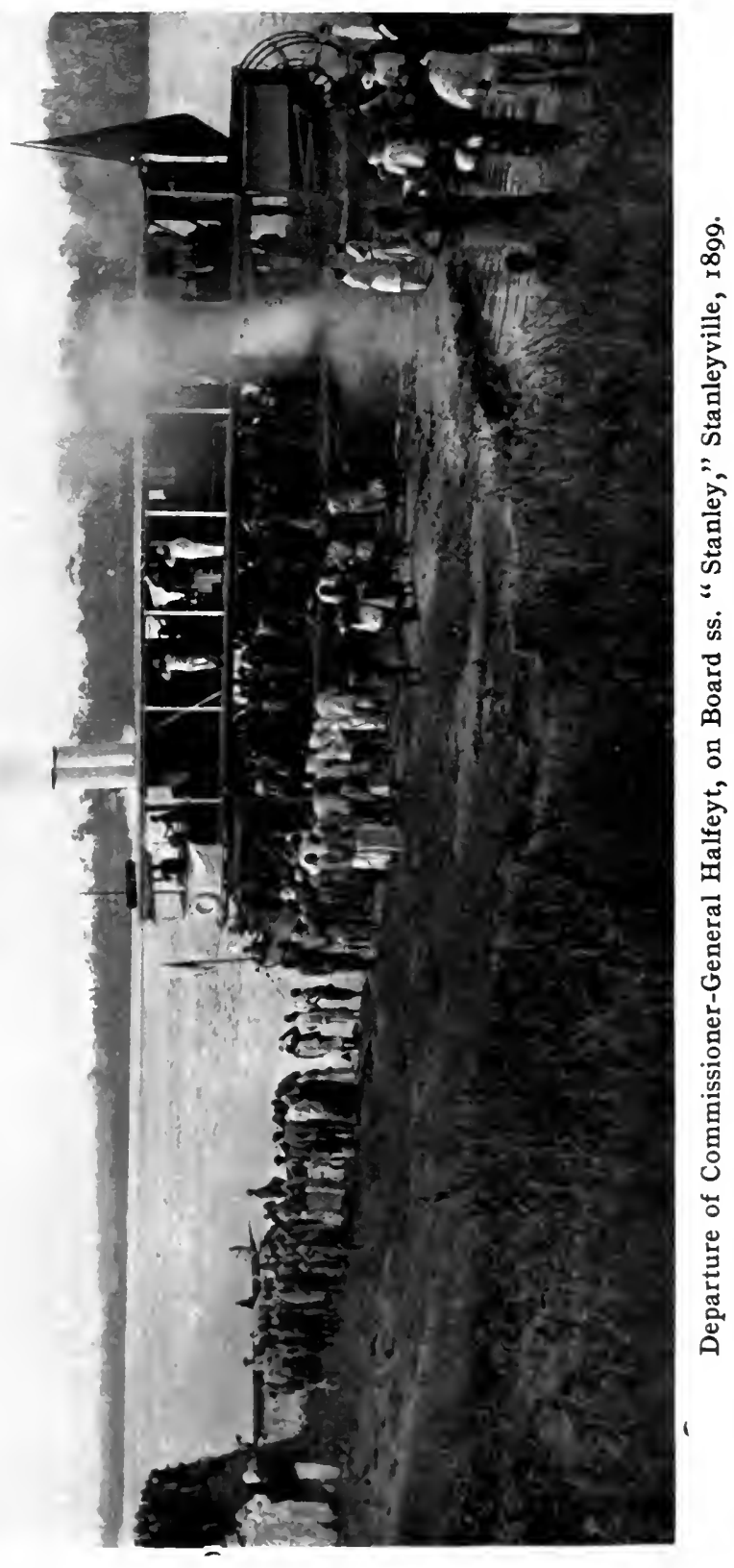



Here, gathering the full force of its waters, the now immense river ploughs its passage for over 200 miles through the Crystal Mountains, whence by a succession of plunges it bounds down to Matadi, I 800 feet below.

From Matadi, unobstructed and triumphant, it hurls the overwhelming volume of its current far into the Atlantic. At its meeting with the sea, the Congo, now over 3000 miles in length, is fully twenty miles wide.

Until a few years ago there was considerable controversy as to the true upper course of the Congo. This has been at last established by the explorations of Delcommune, Bia, and Brasseur; and it is now agreed that the upper course is that continuation of the Chambesi called the Luapula, and not the Lualaba, as was formerly believed.

The Luapula, the boundary between the Congo State and North-Eastern Rhodesia, and navigable for 340 miles above Kassongo, is longer than the Lualaba. It is, however, inferior to the latter in size and in the number and importance of its affluents. The Lualaba rises in the southern part of the Congo territory, about fifty miles west of North-Western Rhodesia. The source of this river was discovered by Lieutenants Derscheid and Francqui.

Along the important tributaries of the Luapula is the Lufupa, which joins it not far below Nzilo. It is at the Nzilo gorge that the first cataracts on the Luapula are encountered. They continue almost uninterruptedly for forty-three miles. Another affluent of the Luapula is the Lubudi, a considerable 
river on the left, which, because of its breadth and volume, was at first mistaken for the main stream. The next important tributary-the Lufila-empties into the Luapula at Lake Kassali. It flows through the fertile country of the Katanga.

This region, noted for its mineral resources, is described by travellers as "a land flowing with milk and honey." It was first explored by that indefatigable pioneer, Delcommune. Until a few years ago the Katanga was ruled by the truculent tyrant, Msiri. Now that this despot is dead, the country is developing rapidly. The climate is far more healthful than in the regions around the Lower or Middle Congo. The fertility of the soil and the advantageous climate augur a brilliant future for this section of the State. The conditions are, in fact, well adapted to the needs of the white race, and here, no doubt, eventually will be established cities no less important and flourishing than those of Java. Already a railway to the Katanga is being constructed. Great deposits of copper are known to exist here, and it is expected that the development of these resources will begin a new era in the history of Central Africa. By the railway, Katanga will be brought within six weeks of the European centres.

In this vicinity also are the Kibala Mountains, An African which will, no doubt, soon attract tourists Switzer- from all parts of the world. The beauties land. of this section are thus described by their discoverer, Delcommune:

Seated on a rock of sandstone, eagerly scanning all around us, glancing in every quarter, we were astonished by this 
picture, which no pencil could render. None of the loudly vaunted beauties of Switzerland and the Pyrenees, where charming scenery nevertheless exists, could rival these lost corners of the Kibala Mountains, of which the whole effect, in its turn picturesque and savage, imposing and on a grand scale, seemed softened and rendered pleasant by the brilliant equatorial vegetation.

We shall now briefly refer to the more important tributaries of the Congo proper, first taking up those that join the river from the south.

Of these the Lomami is navigable for nearly $65^{\circ}$ miles. Rising in the Usamba Plateau, 600 miles east of Lake Moero, it runs almost parallel to the Congo till it joins that stream I50 miles west of Stanley Falls. The Lomami varies in breadth from 60 to 400 yards. In places it has a depth of twenty feet, and it is destined to play an important part in the development of this part of the continent. It was on the Lomami that one of those entrenched camps was established which proved so effective in the expulsion of the Arabs and suppression of the slave trade. The many tributaries of the Lomami, some of which are navigable, make that river the natural base also of commercial operations.

The next southern affluent of the Congo is the Lulongo. Rising not far from the valley of the Lomami it flows for several hundred miles in a south-westerly direction and empties into the Congo at Uranga. A northern tributary of the Lulongo is the Lopori. Both of these streams are rendered more important by the fact that, being free from obstruction, they are navigable. They water a 
beautiful and exceedingly fertile country, some of which is yet unexplored.

South of the Lulongo and almost parallel to it is the Ruki. It has two upper courses and rises near the great valley of the Lomami. The Ruki is a wide, open river, nearly six hundred miles in length. It empties into the Congo at Equateurville, and because of its several tributaries it renders a large territory easily accessible.

But the largest of all the southern affluents is the Kassai, which ranks in importance next to the Congo itself. The exact course of the Kassai was until recently a matter of considerable speculation. This has now been definitely determined, and the Sankuru, formerly thought by some geographers to be the main course of that river, is now known to be its largest affluent. The Kassai rises nearly one thousand miles south of where it joins the Congo, near the Portuguese possessions in the south-western corner of the Congo State. Its course is north, north-east, and north-west. Navigable from Wissmann Falls, which is situated about midway its length, it forms its junction with the Congo not far above Stanley Pool. Joining the Kassai, near Bokala, is the river Kwango, which, rising in the Portuguese possessions, flows directly northward for several hundred miles. The Sankuru, like so many other of the Congo rivers, rises in the Sambas Plateau. Its course is first due north, then west, and, at its junction with the Kassai, is an imposing stream, almost as deep and broad as the Kassai itself. The Lubefu, a northern tributary of 


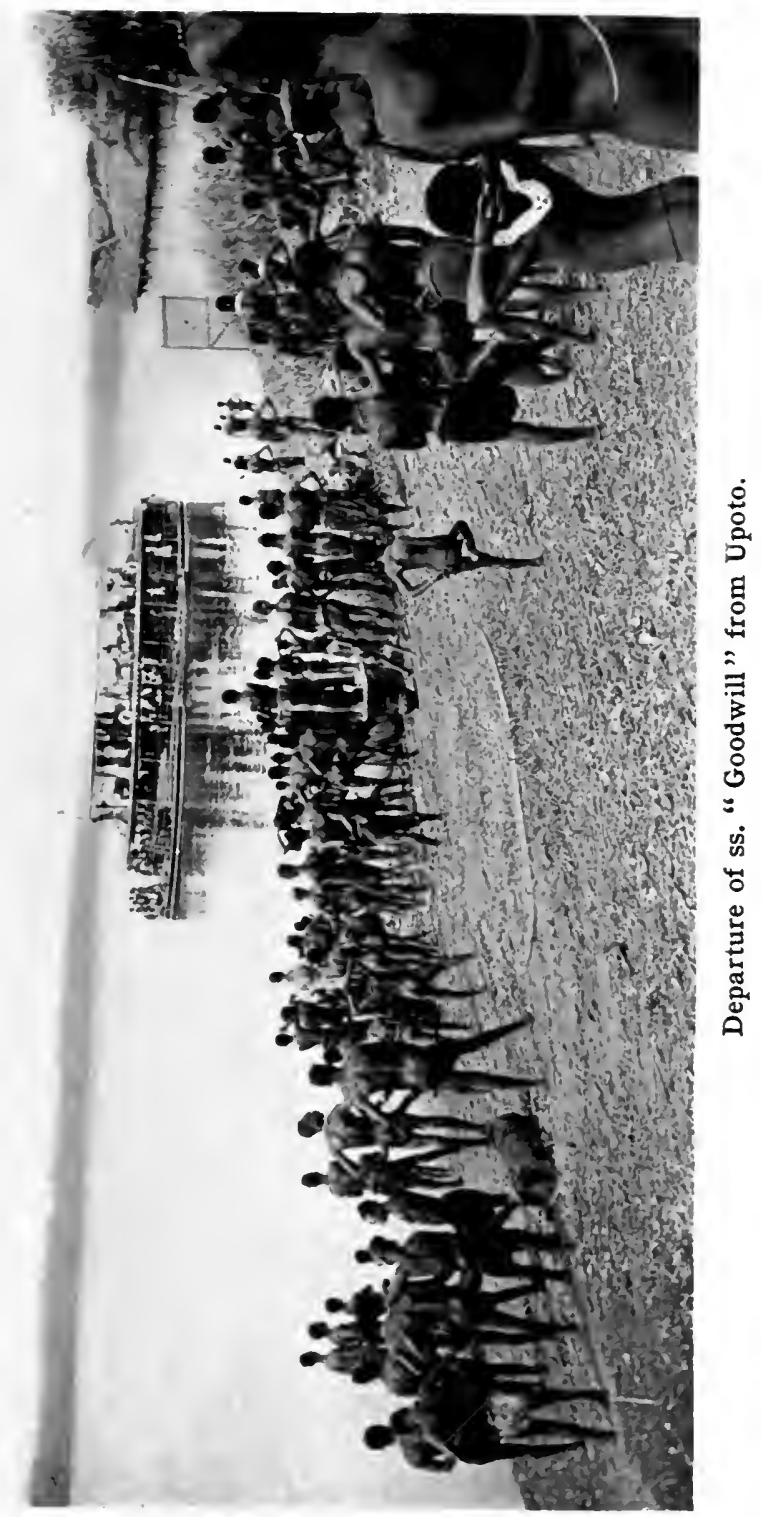



the Sankuru, reaches almost to the valley of the Lomami.

It is intended soon to build a railroad connecting these rivers, and when this is accomplished a large area not now accessible will be open to commerce. Necessarily such trading stations will, for a while at least, need governmental protection. Hence each station will be in the nature of a military establishment, and will form also the nucleus for a future city. The Caucasian, observing, of course, certain necessary precautions, will find the climate of a large part of this section quite congenial. It is not unlike that of the tablelands of Java or of the highlands of Ceylon. Moreover, the soil no less than the forests and the mineral resources of this vicinity will offer splendid opportunities to the investor.

Necessarily the future of this part of the Congo, as well as that of all regions distant from the navigable rivers, is dependent upon the construction of a railway system which will bring them into touch with the rest of the world. That such railways cannot be built without a great expenditure of money is obvious, but the success of the lines already established and the enormous profits sure in the end to repay the investors are calculated to attract sooner or later the necessary capital. All who have visited this part of the Congo country are agreed that its natural resources are incomparably greater than those of any part of Europe. When developed they will excite the wonder of the world. But this result, so devoutly to be wished, involving as it does the betterment of millions of lives lately 
enveloped in densest ignorance, is not to be attained without some sacrifices. Capital, time, and labour must co-operate to bring about this result.

On the right or northern bank of the Congo are to be found several large affluents. Of these, one of the The most important is the Aruwimi, which joins Congo's the Congo just below Nyangwe. The AruAffluents. wimi rises in the Blue Mountains, not far from Lake Albert Nyanza. Thence flowing westward about seven hundred miles, and gathering on its way the waters of its numerous tributaries, it is, when it reaches the Congo, a copious stream over a mile wide. Above Yambuya the navigation of the Aruwimi is rendered impossible by a succession of cataracts, that bane of the African navigator. However, the beauty and the resources of the surrounding country somewhat compensate for these hindering conditions. Here is the famous forest of Ituri, the home of a vast population and the haunt of many species of game. In and around the Ituri occurred some noted skirmishes with the mutinous Batetelas.

About I 50 miles west of the Aruwimi the Rubi reaches the Congo at Itembo. Rising in the Mabode about 500 miles north of Stanley Falls, it flows west and south-west for a distance of 600 miles.

Three hundred miles west of the Rubi is the Mongalla. It rises at the northern boundary of the State and, flowing south-south-west, reaches the Congo at Molieka. The Mongalla is a fine, open stream, and on its banks the Government has established a line of important stations. By these the State maintains control of the surrounding territory 
and renders possible commerce with a large population. Similar stations have been and are being erected along the smaller navigable streams, and these, when connected with the centres by railroad and by telegraph, as eventually they will be, will make the whole interior equally accessible.

Probably no tributary of the Congo is of more importance than the Ubanghi. It was Van Gele who, in I886, first explored the Ubanghi country and demonstrated the strategic value and commercial possibilities of this mighty river. The Uelle, which flows in a north-westerly direction, rises in the Blue Mountains. It was discovered by Dr. Junker, the German explorer, and may be considered the upper course of the Ubanghi. Above the Panga Falls, the Uelle is navigable for large vessels as far as Niangara.

After receiving the waters of the Uelle the Ubanghi forms for a long distance the boundary between the Free State and the French territory. Beyond Banzyville the river makes a wide curve towards the north to Waddas, whence it flows almost directly south, joining the Congo a little above Lake Matumba. The rich valley through which this splendid stream, over a thousand miles in length, takes its winding course, comprises an area of 160,000 square miles. Emin Pasha described it as possessing wonderful productivity - "The Granary of Equatoria" he called it. Here the natives, who are instinctively agricultural, raise tobacco, coffee, and sugar-cane in large quantities. The highways now being constructed will give to the industry of this region an 
immediate impetus, and the natives, who are skilful in the making of brick, will greatly contribute to the development. It is also proposed to continue the Uelle Railway to the left bank of the Nile. Such a continuous route, amply justified by the resources of this section and by commercial considerations, will be a most desirable consummation.

The Lua, an eastern branch of the Ubanghi, will prove of great commercial importance. Captain Heymans, who first navigated the Lua, explored it as far as Bowara. The Dekere, which also has been partly explored, is probably the upper course of the Lua, and this continuous stream will prove a convenient route to the Uelle.

In this way the great detour of the Ubanghi, in which are the impassable cataracts of Zongo and Mokoangi, can be successfully avoided.

The importance of the Mbomu, a northern ramification of the Ubanghi, is increased by the fact that it forms for a considerable distance a natural boundary between the Congo Free State and the French possessions. Its position, therefore, renders it of considerable political consequence. The Mbomu, although not yet entirely explored, is destined therefore to play, with its numerous branches, a large part in the history of the Congo. The country around is not only of great fertility, but also very beautiful. Here is to be found one of the finest forests.in the territory.

By means of the Congo and its tributaries an admirable system of communication is being established, the ramifications of which, supplemented by 
the telegraph and the railway, will within a few years render every part of this vast territory accessible. In proportion thereto will increase the authority of the State and its civilising influence. The growth of commerce, and the security and advancement of the native population, are, in fact, coexpansive with the extension of the facilities of intercommunication. The larger rivers-the Kassai, the Kwango, the Lualaba and the Ubanghi-are all patrolled by government steamers.

Of hardly less importance than the rivers of the Congo are the lakes. Besides the larger and navigable lakes are hundreds of smaller ones.

There are thousands of shallow pools along The Congo
Lakes. the courses of the rivers, as those along the upper Luapula. It was that keen observer, M. Delcommune, who foretold that many of these lakes will eventually disappear. $\mathrm{He}$ contended that a combination of causes, chief among which being the dryness of the equatorial climate and the consequent evaporation of the water, will gradually bring about this result. By a succession of experiments, covering a period of more than two years, he discovered a diminution of the water of the Lualaba. This process of evaporation, incessantly continued for centuries, will completely absorb the water in the marshes and pools, and decrease the volume of the great rivers themselves. However, this need occasion no alarm. On the contrary, it is believed that it will aid materially the development of the country. Not only will it dry the pestiferous marshes, but it will also define the beds of the rivers, 
whose courses, because of the contraction of their channels, will thus be rendered simpler and more definite.

By the disappearance of the pools and lagoons, now to be found in the vicinity of the rivers, hundreds of thousands of acres of valuable arable lands will be reclaimed. And as this soil, formed of alluvial deposits, is exceedingly fertile, the benefits that will accrue therefrom are incalculable. The famous polders of Holland, and the lowlands of Egypt near the mouth of the Nile, demonstrate the possibilities of such a soil.

But it will not be necessary to wait for the slow processes of nature. Vast areas can be drained by artificial means, and this, since the sun is for ever assisting, can be done without great cost. The lands so drained will possess, besides their extraordinary fertility, other advantages, not the least of which is their accessibility.

The most important lake in the western part of the State is Lake Leopold II., discovered by Stanley in I882. It is broad but shallow, and is joined to the Congo by the Mfini and the Kassai. On its banks are several flourishing stations. North-west of Lake Leopold is Lake Matumba, from which the navigable river, Irebu, flows upwards into the Congo.

On the north-eastern boundary is Lake Albert Edward, the western part of which belongs to the State. This lake, the haunt of numerous hippopotami, is joined to Lake Albert Nyanza, which is about I 50 miles north, by the Semlika, the boundary between the Belgian and British possessions. 
Directly south of Lake Albert Edward is Lake Kivu. From this lake, part of which is yet unexplored, flows the river Rusisi. This torrential stream dashes through a rocky country, descending 2380 feet in 68 miles. It empties into Lake Tanganyika. On the eastern shore of the lake are Lubuga and Luahilimta, trading stations, established by the State. Lake Kivu is dotted with hundreds of islets, and is situated in the centre of a lofty plateau. Towering from this plateau rises a range of enormous snow-clad volcanic cones, from eight to over fourteen thousand feet above the level of the sea. Of these the highest is Kirunga-cha-gongo, which is said to be the largest inland volcano in the world. It was first ascended by its discoverer, Count von Gotzen, and later by the English naturalist, Moore. All around Kivu are inaccessible crags, calcined gorges, and arid deserts, showing that the whole region is of volcanic origin. Such is the wonderful clarity of the atmosphere that the outline of every crag and spur of the mountains is visible sixty miles away. The forests of Kivu abound in elephants. Travellers report seeing here as many as a thousand in one day.

Of Lake Kivu Count von Gotzen, its discoverer, has given an excellent account. I quote the following from his work, Durf Afrika von Ost nach West:

The bed of Lake Kivu, according to my measurement with the hypsometer, is at an altitude of 4800 feet. Its extent should be considerable, for on my crossing it I saw the immense sheet of blue water disappear far off into the clouds. Its general direction is from North to South. . . . The 
appearance of the isles of Lake Kivu is most picturesque. Their rocky and snow-white banks rise in peaks and are frequented by herons and cranes. A fresh breeze ever rustles across the lake and cools the air agreeably. . . . When one turns one's gaze to the north a sort of immense barrier formed by the Kirunga-cha-gongo and the four other Virunga Mountains is to be seen. . . . The neighbourhood of Kivu is extremely fertile in provisions of every kind.

Directly south of $\mathrm{Kivu}$, and connected with it by the river Rusisi, is Lake Tanganyika, partitioned equally between the Congo Free State and German East Africa. It is about four hundred miles in length and nearly fifty in breadth. It was Stanley who first circumnavigated Lake Tanganyika, though it had been discovered in 1858 , about twenty years before, by Burton and Speke. It was, in fact, the latter who first called the attention of the world to the Congo Region. On the shores of this lake Lieutenant Cambier, in I879, established, at Karema, the first station of the International Association of the Congo. Cambier was so impressed with the possibilities of this region that, by purchase and treaty, he obtained from its native ruler about five thousand acres of land, and this tract may be regarded as the nucleus of King Leopold's colony. It was this station on Tanganyika also that afterwards became the basis of operations against the Arab slavetrade.

From Albertville, Baudouinville, and other stations on its western shore a flotilla of small vessels and several steam-yachts now navigate this lake, and to these other and larger craft will soon be added. 



\section{The Waterways of the Congo}

A telegraph and telephone line, connecting Kassongo on the Lualaba with Baraka on Lake Tanganyika, was opened in the latter part of 1903 . This line will soon be extended to Lake Kivu.

The region around Tanganyika is noted for its beautiful scenery, and a large part of it is said to be unusually healthful. Like Kivu, this lake is situated in an immense plateau, six thousand feet above the sea. The angular inclination and general configuration of all these lakes in the eastern part of the Congo is, in fact, very similar; each lake, however, has its individual scenery, climate, and peculiar flora. Moore found Tanganyika floored with the shells of millions of molluscs, the zoölogical remains of a dead sea. He discovered here also three kinds of sponges. On the eastern shores abound huge swamps and immense tracts of mimosa. The dark red cliffs on the West Coast form a brilliant contrast to the blue African sky and the white clouds. Between Tanganyika and Nyangwe, the old slave-capital of Tippo Tip, the country is tenanted by the Manyema, famous as collectors of ivory. Surveys are now being made for a railway from Beni to Tanganyika. This it is proposed to continue to Stanleyville on the Middle Congo.

Lake Moero, one hundred miles south-west of Tanganyika and the south-eastern boundary between British territory and the State, was discovered by Livingstone. It was first explored, however, by the Belgian officers, Bia and Francqui. This lake, which is one hundred miles long and about half as broad, is now patrolled by a steam-yacht. 
Only a few years ago the immense basin of the Congo was an untamed wilderness, "a slave-park" Stanley called it, bare to raids of murderLooking
Backward. Ous marauders. Bands of predatory Arabs Backward. swooping down upon the defenceless natives decimated whole tribes, and carried away men, women, and children by the thousand. The slavetrader stalked like a pestilence through the land, leaving in his wake the smoking ruins of a hundred villages and the charred skeletons of his black victims.

It was not only the natives who suffered from the raids of merciless ravagers; but the Europeans, explorer, merchant, and missionary, were also subject to their tyrannical impositions. And when, as in the case of Emin Pasha, they opposed the designs of these despoilers, they were ruthlessly murdered. Flame and sword, robbery and massacre,- such, until ten years ago, were the chief episodes in the epic of the Congo.

To-day this vast region is not only geographically determined, occupied, and effectually protected, but the power of the Arab raider has been for ever annihilated. Regions which for ages were the scene of carnage and holocaust have now been pacified. Where all was insecurity and turbulence a reign of law and order has been substituted.

Nature has here been so prodigal of her gifts that her very extravagance renders in some respects the task of colonisation less easy. Before roads could be built it was necessary to hew down huge forests; before stations could be established it was needful 
to explore and to conquer the wilderness. The paths that plunged into the jungle ended in trackless solitudes. The vastnesses bristled with unknown terrors. There was call for the explorer and the pioneer, but it seemed as if ages must elapse before there was need of the carriers of commerce.

To conduct broad highways from the coast to the centre, through a territory so vast in extent, so dangerous, and so impenetrable, would seem indeed a task for centuries. Such, too, it is safe to assume, would still be the situation had it not been for the magnificent water-system of the region and the great colonising genius who turned its natural destiny to the civilising course of an onward industry. Without these splendid flowing highways of commerce, pulsing from the heart of the continent to the sea, the wonderful progress of the last quarter of a century would not have been possible. Following the lead of the Congo and its tributaries, Belgian pioneers have moved through the great wilderness, planting the plough and the cross, until to-day Central Africa, so long curtained from the eyes of civilised man, lies bare to the world.

It was by this instrument that the siege of the great unknown was prosecuted. It was thus that that citadel of despair, the stronghold of Darkest Africa, was subjugated. And as we look at the magnificent results, and at the still more magnificent future which those results foreshadow, we cannot but conclude that this natural aid to the efforts of a heroic band of explorers was more than the mere manifestation of blind chance. 
The campaign of exploration planned by King Leopold, and executed by his courageous subjects King and and his able ally, Stanley, was the first of Journalist. those remarkable achievements of practical utility that have no parallel in the history of modern colonisation. In the Congo and its affluents these State-builders found a providential and generous auxiliary. These wide rivers, the veins of the civilisation of the Congo, are the key to a situation of which triumphant Belgian sacrifice and valour in Central Africa will yet perfect the sequel.

To the existence of these natural allies, then, is largely due the speedy extirpation of the slave trade, the suppression of cannibalism, the control of the country, the gradual conversion of its populations to the saving influences of civilisation, the effective system of communication between port and port, and the beginnings of the development of those vast resources which already excite the cupidity of nations less successful. Indeed, without such advantage it is doubtful whether the King of the Belgians would have been equal to the onerous responsibilities he so cheerfully assumed.

But now with more than nine thousand miles of waterways open to navigation, few sections of this "Change immense domain are to-day inaccessible. in all Great areas which but a few years ago were Around." virgin forests are now under successful cultivation. The jungle, once the lair of the cannibal, is safe and peaceful. Where the raider ravished his shrieking victims, the State and the Mission instruct in the attributes of a useful life. Chaos has at last 


\section{The Waterways of the Congo}

yielded to order, and another triumph has been added to civilisation in the short term of twenty years. It is a great story, and the Prince who wrote it on the face of Africa need not deign to hear the hiss of envy straining at the gorge. Let Leopold II. find consolation in that rugged philosophy of Carlyle which mocked at the timid temper of his own time: "To subdue mutiny, discord, widespread despair by manfulness, justice, mercy and wisdom, to let light on chaos and make it instead a green flowery world, is great beyond all other greatness, work for a God." 


\section{CHAPTER VI}

\section{THE STATE AND INTERNATIONAL LAW}

I view of the confused controversy that has prevailed between the friends and the enemies of the Congo Free State, concerning its legal foundation and its existence de facto before the Conference of the Powers which recognised its statehood at Berlin (November I5, I884-February 26, I885), it seems pertinent at this point to examine the issue at some length.

For unknown centuries Central Africa had been peopled with many millions of savage, semi-savage, Central and barbarian black men, hidden from all Africa civilising influence. Their social condition Reviewed. varied. Many were cannibals, some were living in a rude state of primitive tribal order, others were at incessant war with hostile tribes, all were living in the gloom of an interminable night of barbaric existence. Their only touch with the human family had been through the slave trade, of which they were the object and the victims. The white man knew of their lot in this respect many years before he listened attentively to an appeal for deliverance from the Arab marauders who enslaved them. The natural law of human solidarity had not as yet inspired civilised nations 
with an energetic movement to ameliorate the condition of the savage black in Mid-Africa. Indeed, Stanley's explorations had not gone to completion save for the enlightened and philanthropic moral and material support of Leopold II. When Great Britain declined to provide Stanley with the means to further his brave work, the King of the Belgians, having several years before openly associated himself with sentiments seeking the organisation of a consistent civilising movement in Central Africa, sent for this intrepid explorer and fortified his hopes and plans from his private purse. It was with the highest motives, from an elevated point of view, that his Majesty considered the situation of these cannibal tribes. His solicitude for the Belgians, their economic needs, their legitimate and necessary expansion, gave point to his consideration of a distant land, where great natural wealth lay unrevealed and unused, for the good of the native and his benefactor. A wild life abounded in those parts which by civilisation might be regenerated and brought into the sphere of human usefulness. Here opportunity seemed to throw wide her arms for the Prince with the courage to dare an undertaking which the great Powers and the small had so far deftly avoided. "I will pierce barbaric darkness; I will secure to Central Africa the blessing of civilised government. And I will, if necessary, undertake this great task alone." So spake his Majesty, when, as Duke of Brabant, he electrified Europe with what Europe, in her narrowed conservatism, regarded as the utopian utterances of an impractical and effervescing 
youth. Europe smiled and shrugged her shoulders at the temerity of him who essayed to analyse the heart of Africa and prescribe its panacea.

If this great task had fallen upon a man of ordinary natural powers and acquired means, that part of Darkest Africa which now defies the organised conspiracy of the despoiler would interest nobody save the slave-trader who terrorised the land and polluted the sea with the black man's blood. To his Majesty's great initiative in 1876 , and to his prescience of mind, his generous hand, and astonishing industry in the cause which inspired him are due those two decades of progress which some regard as a triumph of Colonial civilisation; while others, from motives which need not be examined with a lens, stigmatise it as the curse of Central Africa.

Point of view and interest are important elements in all controversy. Where so much has been charged and refuted, a judicial attitude is sometimes maintained with difficulty. But against the assertion that the Congo Free State is a creation of the General Act of the Berlin Conference, may be arrayed a body of well-settled law which only an unreasoning enemy or a paid advocate would have the hardihood to dispute.

Long before the Berlin Conference had been conceived, acts of government had been effecting orSimple ganisation and order in the territory now Facts known as the "Independent State of the Briefly Told. Congo." Legislation, one of the later signs of established government, had occurred in the territory acquired by the Comité d'Études du Haut-Congo, 


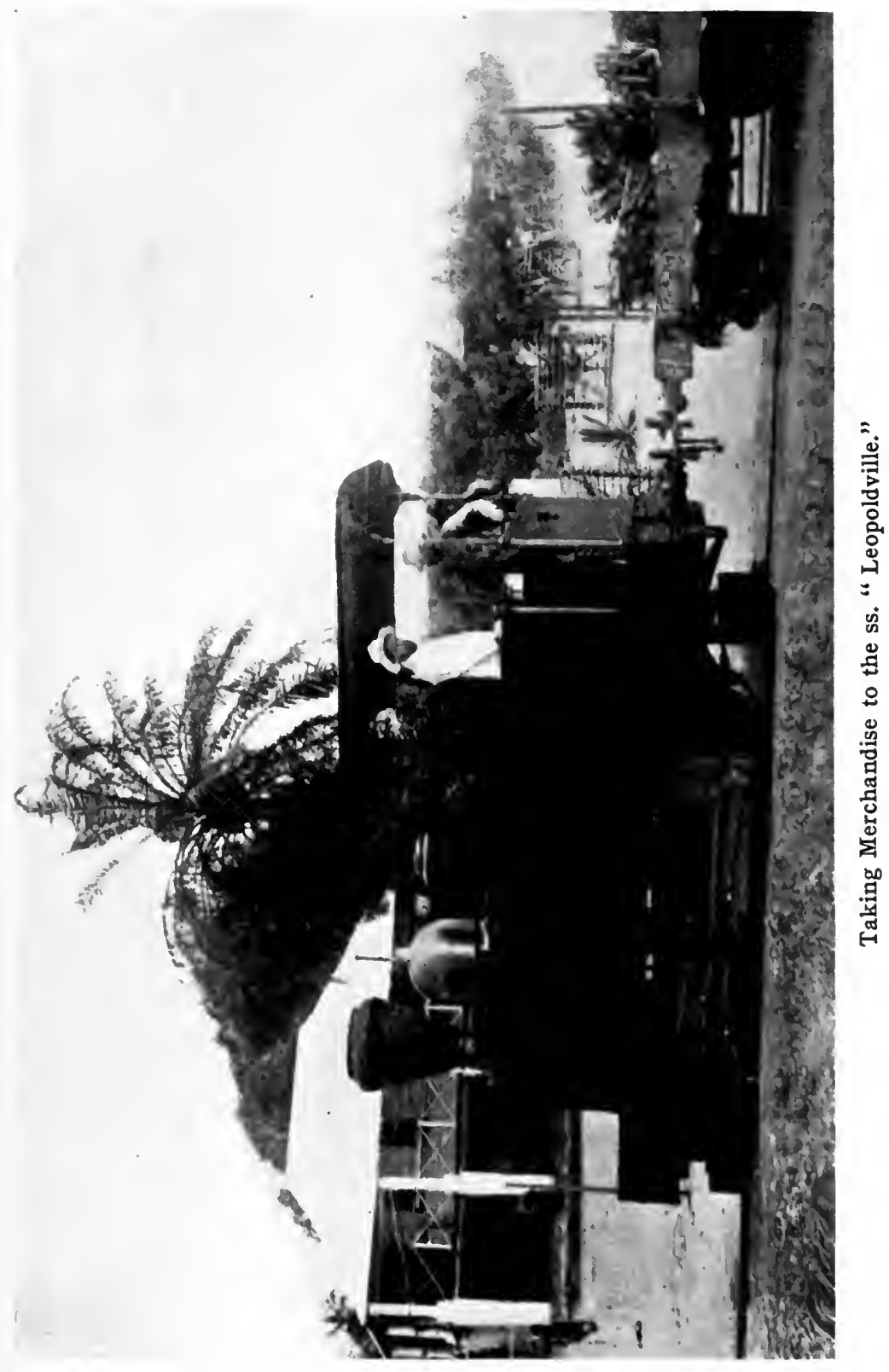



of which King Leopold was honorary president and Colonel Strauch president.

The conception of the State was that of the King personally; the character of its governmental manifestations was surcharged with his personality; its being was crystallised by his own touch and modelling. It is error to confound the recognition of the State by the Berlin Conference as the act which created the State. Recognition presupposes existence, and in the case of the Congo Free State there had been, for a considerable time before the adoption of the General Act of the Berlin Conference, a government de facto in the territories under the dominion of the Comité d'Études du Haut-Congo. Indeed, before the Berlin Conference had adopted the General Act, the State was qualified to announce, and did notify the Conference, that it had been recognised by all the Powers except one, which, however, soon thereafter followed the example of the other signatories. It was as a State, standing on an equality with the other Powers, that the Congo Free State attended the Berlin Conference and, under Article 37, adhered to an Act which did not deal with the sovereignty of States at all, but confined itself to a consideration of an economic régime applicable throughout the Congo Basin, including the territories therein of Great Britain, France, Germany, Portugal, and the Congo Free State. Events anterior to its introduction to the Conference as a friendly State by Prince Bismarck do not depend for their quality upon the form of that introduction. They are not destroyed by the peculiarity of phrase or the 
spontaneous honour which accompanied its entrance into the society of nations. That which does not exist cannot be the object of recognition. Even without the facts of the recognition by the United States of the State's flag (April 22, I 884) as that of a friendly Government seven months before the Berlin Conference convened, and its recognition by Germany seven days before the opening of the Conference (November 8, I884), the State contends that it was a State in esse, a Government de facto, fully organised and qualified to maintain itself as such within the territory it had acquired by cession from the native tribal chiefs and by prior occupation.

An examination of competent authorities on this important phase of Congolese civilisation convinces us that the idle contention which questions the State's independence of the Powers signatory of the General Act of Berlin has been brought forth merely for its cumulative effect, not for its inherent power to sustain itself.

The subject may be approached by two questions: What is a State? What is a Government?

"A State . . . implies the union of a number of individuals in a fixed territory, and under one central authority. Austria-Hungary is a State, but, as Prince Gortchakoff once sarcastically remarked, 'It is a Government, and not a nation.'

The Constitution of the United States defines the term State as combining the idea of people, territory, and government. Defining the difference between a government in law and a government in fact, Montague Bernard says, in Neutrality of Great Britain 


\section{The State and International Law}

during American Civil War: "A de jure government is one which, in the opinion of the person using the phrase, ought to possess the powers of sovereignty, though at the time it may be deprived of them. A de facto government is one which is really in possession of them, although the possession may be wrongful or precarious."

In Tharington $v$. Smith, 8 Wallace, 8-II, the Court said:

There are several degrees of what is called de facto government. Such a government in its highest degree assumes a character very closely resembling that of a lawful government. . . There is another species of de facto government, and it is one which may be perhaps aptly called a government of paramount force. Its distinguishing characteristics are: That its existence is maintained by active military power, within the territories . . . etc."

In Wheaton's Elements of International Law, the latest edition of the leading authority on the subject, the author maintains that:

The recognition of any State by other States, and its admission into the general society of nations, may depend, or may be made to depend, at the will of those other States, upon its internal constitution or form of government, or the choice it may make of its rulers. But whatever be its internal constitution, or form of government, or whoever may be its rulers, or even if it be distracted with anarchy, through a violent contest for the government between different parties among the people, the State still subsists in contemplation of law, until its sovereignty is extinguished by the final dissolution of the social tie, or by some other cause which puts an end to the being of the State.

The internal sovereignty of a State does not, in 
any degree, depend upon its recognition by other States. A new State, springing into existence, does not require the recognition of other States to confirm its internal sovereignty. The existence of the State de facto is sufficient, in this respect, to establish its sovereignty de jure. It is a State because it exists.

Thus the internal sovereignty of the United States of America was complete from the time they declared themselves "free, sovereign and independent States," on the 4 th of July, 1776 . . . . The treaty of peace of 1782 contained a recognition of their independence, not a grant of it.

The external sovereignty of any State, on the other hand, may require recognition by other States in order to render it perfect and complete. So long, indeed, as the new State confines its action to its own citizens, and to the limits of its own territory, it may well dispense with such recognition.

The principles thus indicated would appear to distinguish with marked certitude the vast difference between the State's existence and its recognition. The latter was a political consequence of the former. At the Berlin Conference no question was raised concerning a fact so patent, nor did the signatories distinguish between the five Powers in possession of the Congo Basin in framing the clauses of the Berlin Act imposing the same obligations on all these Governments. Those obligations related only to their economic régime in Central Africa. The articles of the Act concerning the Congo Basin, which applied to the Independent State of the Congo, were also binding upon Great Britain, France, Germany, and Portugal. This sign of equality is inconsistent with the notion that the Congo Free State is the vassal territory of the Powers signatory of the General Act of Berlin. 
It has been contended by technicians of the law of nations who are in the service of those who seek to disrupt the Congo Free State, that a State cannot accrue out of a private association, such, for instance, as the International African Association or the Comité d'Études du Haut-Congo. But just as events are constantly spoiling theories, so had the flag of the Belgians confounded that contention by demonstrating in a practical manner that a State did exist, and that all the elements of a State government were present in the neighbourhood of Stanley Pool long before the Berlin Conference.

The identity of a State consists in its having the same origin or commencement of existence; and its difference from all other States consists in its having a different origin or commencement of existence. . . . The habitual obedience of the members of any political society to a superior authority must have once existed in order to constitute a sovereign State. ${ }^{\mathrm{I}}$

American writers on the subject are of opinion that the North American Indian in his aboriginal state was not a political unit of the United States at the time when the Union declared its independence. In Johnson $v$. McIntosh, 8 Wheaton, p. 543, ChiefJustice Marshall described their status in the following language:

The Indian inhabitants of the United States are to be considered merely as occupants, to be protected, indeed, while in peace, in the possession of their lands, but to be deemed incapable of transferring the absolute title to others independent of territorial sovereignty.

Wheaton's International Law. 
To this may be added the apposite declaration of Mr. Fish, Secretary of State, to Mr. Hackett, Junc I 2, I 873 :

Aboriginal inhabitants in a savage state have not such a title to the land where they dwell or roam as entitle them to confer it upon persons from another country.

The Congo State law to which the foregoing declaration applies will be discussed in the chapter on the State Lands and Concessions. The citation A Strange is offered here merely for its general bear-
Fallacy. ing upon the doctrine put forth by certain writers who contend that barbarous races living in primitive conditions upon lands over which civilised government has not been established, attain to the organic level of political units or citizenship upon the recognition of the government which dominates them with either its civil or its military power. That doctrine, it seems to us, is untenable. There is, on the other hand, no doubt that savage races can, by the symbols and the operating functions of government, humanely enforced according to the conditions with which it must cope, be brought to the knowledge of, and obedience to, an orderly civil community. The instruments of civilisation must vary with the various character of the life upon which they are to operate effectively. Yet there are strabismic monitors of African civilisation who, representing no high moral standard in themselves, have laid down a rule of conduct for the Congo Free State which disregards that principle. It has been this narrow view of a liberal civilising scheme 


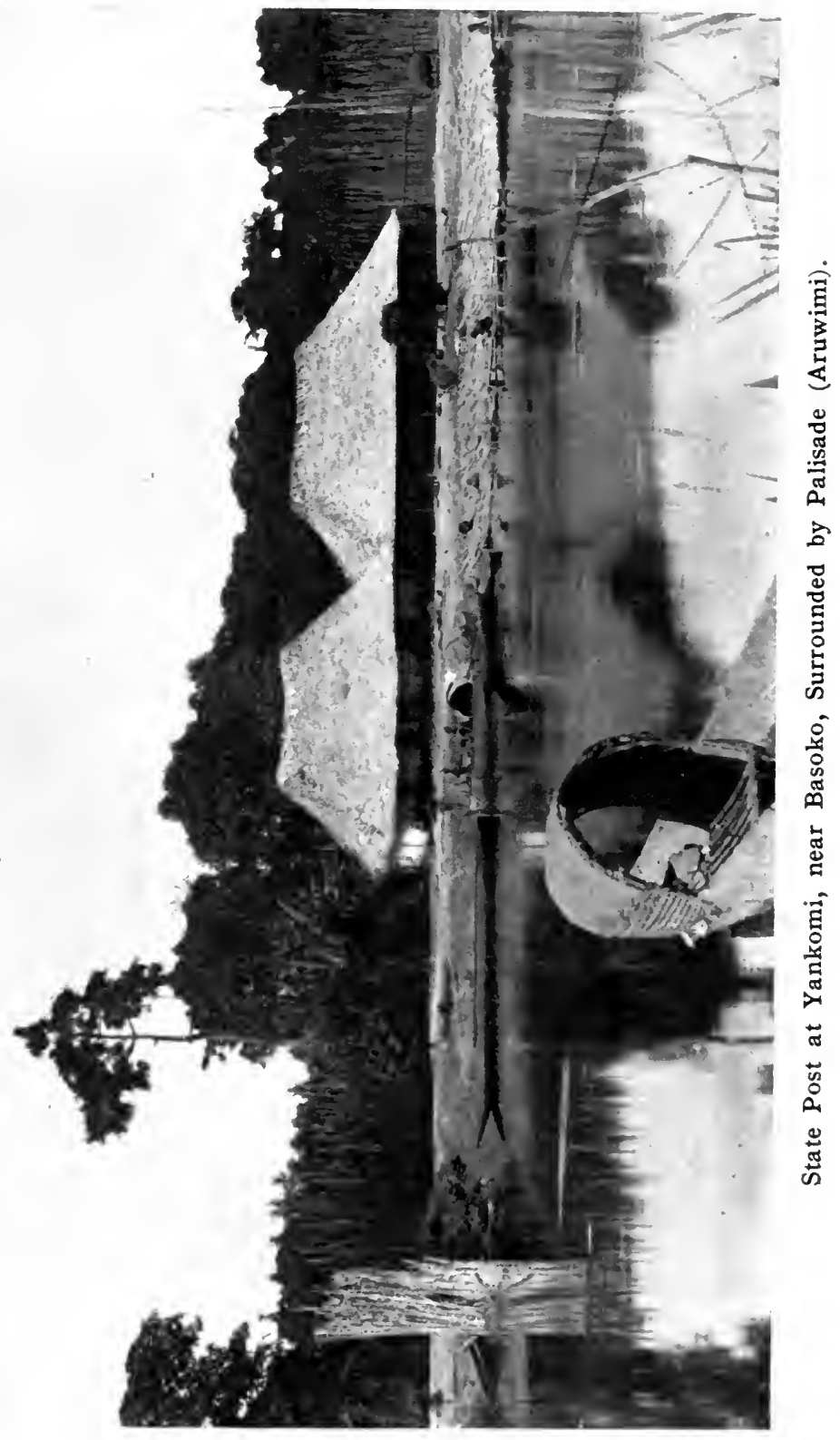



that has caused so much mischievous mewling in Great Britain concerning alleged misrule in Central Africa.

The foundation of the Congo Free State really began with the organised movement and structures of the Comite d'Etudes du Haut-Congo on November 25, 1878. The expedition of Stanley on August I4, 1879, was an earnest of the Committee's intention to establish the institutions of a permanent local government with all practicable speed.

The Belgian post of Vivi was the first monument fixed in the wake of Stanley. On February 2 I, I880, Isanghila was established, and on May I, I88I, Manyanga was occupied. In the following December the expedition arrived at Stanley Pool, and reconstructed the steamboat En Avant, which, having been dismantled, had been carried in small sections through the forest to this point above the cataracts. In a short time this pioneer craft bore Stanley up the Congo River to accomplish the dream of Leopold II.

Many stations were established, steamers began running between them, treaties were concluded with the chiefs of independent native tribes to protect the territory so occupied against the claims of subsequent explorers; administrative and police services were required, and all the effective essentials of a central authority and an actual government were then and there established.

At this juncture the Committee changed its name to the International Congo Association and redoubled its activities. The Niadi Kwilu Basin was explored; that important factor in late Congo 
prosperity, the Upper Kassai, was brought under the influence of Belgian regeneration, and the Lunda country and districts beyond were taken within the Government's sphere.

In five years discoveries of great value had been made in Darkest Africa, hundreds of tribes had been peacefully visited, over five hundred treaties of suzerainty had been made with the ruling chiefs, forty stations had been erected and their complement of officers put to the work of administering a definite system of local government, and five steamers on the Upper Congo were regularly communicating the affairs of a Government which now effectively controlled all the territory between the East Coast and Stanley Falls, between Bangala and Luluabourg. ${ }^{x}$

This, then, was the position of the Government in the Congo Basin in 1883 , long before the Berlin Conference. The status that Government acquired as a consequence of its administrative acts in, and dominion over, the territory it occupied, has been briefly indicated from the point of view of American authorities on the subject of international law. Before examining the leading European authorities, whose approaches to the subject are peculiar to European experience and learning, it is interesting to observe how consistently the action of the Government of the United States followed the American view of the law on the subject.

Baron A. Descamps' New Africa, an excellent essay on government civilisation in new countries, I L'État Indépendant du Congo, M. Wauters, p. 27. 
embodies a concise statement of what occurred in the fortunes of the infant State early in 1884 , when its progressive work had extended a civilising influence to those regions of the Congo Basin where the Arab slave trade had not retained

A Learned Belgian. its devastating sway. The writer says:

The practical sympathy speedily accorded to the International Congo Association by the greatest Power of the New World, the United States of America, full of life and vigour and ever inclined to progress, proved that King Leopold's enterprise had secured public support and official suffrage far beyond the limits of Europe. On April Io, I884, the American Senate, on Mr. Morgan's remarkable report, $\mathbf{x}$ passed a resolution asking the President of the United States to recognise the Association "as the governing power of the Congo." A few days later, on April 22, 1884, that recognition was an accomplished fact. In officially recalling, at the opening of the Berlin Conference, the nature and cause of this great Act, Mr. Kasson, Chief Plenipotentiary of the United States, pointed out that, following upon Stanley's explorations, the newly discovered regions "would be exposed to the dangerous rivalries of conflicting nationalities. It was the earnest desire of the Government of the United States that these discoveries should be utilised for the civilisation of the native races, and for the abolition of the slave-trade; and that early action should be taken to avoid international conflicts likely to arise from national rivalry in the acquisition of special privileges in the vast region so suddenly exposed to commercial enterprises." Referring to the work so effectively performed by the International Congo Association "under high and philanthropic European patronage," he said

I See Compilation of Reports of Committee on Foreign Relations. United States Senate. Recognition of Congo Free State. March 26, 1884, Washington, Government Printing Office, 1902. Vol. vi., p. 22 r. The appendices include, among other documents, the notes of Sir Travers Twiss and Mr. Arntz. 
that those gallant pioneers of civilisation had "obtained concessions and jurisdiction throughout the basin of the Congo from the native sovereignties which were the sole authorities existing there and exercising dominion over the soil or the people. They immediately proceeded," added he, "to establish a Government de facto." Declaring next that the legality of the acts of that Government should be recognised, under penalty of recognising "neither law, order, nor justice in all that region," he concluded as follows: "The President of the United States, on being duly informed of this organisation, and of their peacefully acquired rights, of their means of protecting persons and property, and of their just purposes towards all foreign nations, recognised the actual government established, and the flag adopted by this Association. Their rights were grounded on the consent of the native inhabitants, in a country actually occupied by them, and whose routes of commerce and travel were under their actual control and administration. He believed that in thus recognising the only dominant flag found in that country he acted in the common interest of civilised nations."

"In so far," said the American Plenipotentiary, "as this neutral and peaceful zone shall be expanded, so far he foresees the strengthening of the guarantees of peace, of African civilisation, and of profitable commerce with the whole family of nations." I

Such was the position taken up by the United States of America in regard to the recognition of the newly installed government in Equatorial Africa. Germany was the first European Power to consider this subject of recognition, and to accord to the new enterprise marks of its sympathy and the support of its authority. In acknowledging, by the Convention of November 8,1884 , concluded before the Berlin Conference opened, the flag of the International Congo Association " as that of a friendly State," the German Government clearly indicated that, so far as it was concerned, the new State

I Protocoles et Acte Général de la Conférence de Berlin (1884-85), p. 23 ss. 


\section{The State and International Law}

ought to take its place from the first among the Powers called to the Conference.

M. Ernest Nys, Professor of International Law of the University of Brussels, Associate Justice of the Court of Appeal (Conseiller à la Cour d'Appel de Bruxelles); member of the Institute of International Law, a distinguished

Another Learned Belgian Belgian, and writer on several branches of the law, sets forth with greater detail the precise form of the recognition of the Congo Free State by the Senate of the United States. M. Nys relates:

In his annual message to Congress the President of the United States raised the question of the relations which were henceforth to be established between the Republic and "the inhabitants of the Congo Valley in Africa." On 26th May, I884, Mr. Morgan (Alabama) reported to the Senate in the name of the Committee on Foreign Relations.

On 18 th January, I884, a communication from Mr. Frelinghuysen, Secretary of the State Department, explained to Mr. Morgan how along the Congo the African International Association had created important establishments. On I $3^{\text {th }}$ March of the same year a further communication from $\mathrm{Mr}$. Frelinghuysen set forth the opportuneness and the usefulness of recognising the flag of the Association, and added that no principle of international law was opposed to the creation of a State by a philanthropical society.

In his report of 26 th March Mr. Morgan recalled the fact that Stanley had concluded at Vivi on $13^{\text {th }}$ June, 1880 , the first convention with a native chief, and that since that date nearly a hundred other treaties between tribal chiefs and the agents of the Association had been concluded, in which important commercial arrangements and stipulations relative to law, the maintenance of order, and the delegation of power figured among the provisions. Consequently two hypotheses presented themselves. "If the local rulers," said Mr. Morgan, 
"were qualified to make the cession they did, the sovereign power that they conferred on the African International Association might obtain recognition on the part of other nations precisely because that Association thus proves its existence as a Government by law. If," he added, "there exists any doubt concerning the sovereignty or the territory or the subjects, the understanding among the native tribes who conclude treaties with the Association offers a sufficient guarantee to other peoples for recognising the Association as a Government in fact."

The Committee on Foreign Relations made a motion in favour of the recognition of the Association. It is permissible to affirm that at this moment a juridical person already existed, which could claim the principal rights of a State, and which found itself prepared to fulfil the duties of one. The first direction of the efforts of the Committee for studying the Upper Congo had been indicated in July, 1879 , in the instructions given to Stanley. "It would be wise," wrote Colonel Strauch, "to extend the influence of the stations over the chiefs and tribes inhabiting the neighbourhood. There might be made out of them a republican confederation of free Negroes, an independent confederation under this reservation, that the King, to whom its conception and creation would be due, should nominate its President who was to reside in Europe. . . . A confederacy thus formed might of its own authority grant concessions to companies for the construction of works of public utility, or issue loans, as Liberia and Sarawak do, and also itself execute public works. Our enterprise does not tend to the creation of a Belgian Colony but to the establishment of a powerful Negro State." I But the political idea was not slow in taking a precise form. If in Mr. Morgan's report there is still question of the Free States of the Congo the conclusion did not the less relate, as we have just seen, to the African International Association.

It was it which was [sic], according to the Committee on

'F. Cattier, Droit et Administration de l'État Indépendant du Congo, 1898, p. I7. 


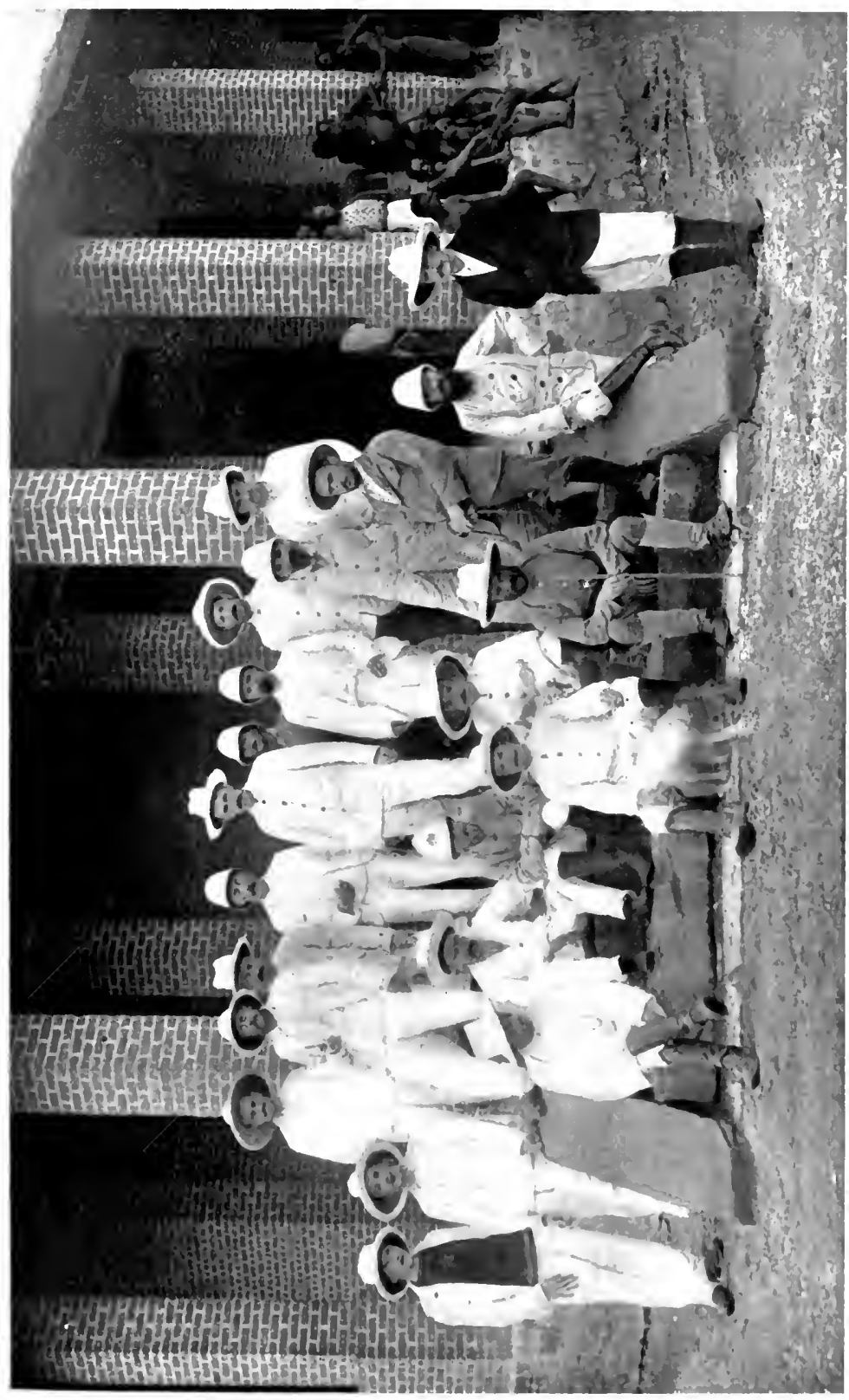

 



\section{The State and International Law}

Foreign Relations of the Senate, in law or in fact a "Government" qualified to claim international recognition.

Besides, the solution was very soon effected. The Government of the United States recorded the existence of The International Association of the Congo, managing the interests of the Free States established in that region, and gave orders to all United States officials on sea and on land to recognise the flag of the International Association as the equal of that of a friendly Government.

The following is the text of the declarations which were exchanged on 22d April, r884:

The International Association of the Congo hereby declares that by Treaties with the legitimate Sovereigns in the basins of the Congo and of the Niadi Kwilu and in adjacent territories upon the Atlantic there has been ceded to it territory for the use and benefit of Free States established and being established under the care and supervision of the said Association in the said basins and adjacent territories to which cession the said Free States of right succeed.

That the said International Association had adopted for itself and for the said Free States, as their standard, the flag of the International African Association, being a blue flag with a golden star in the centre.

That the said Association and the said States have resolved to levy no custom-house duties upon goods or articles of merchandise imported into their territories or brought by the route which has been constructed around the Congo cataracts; this they have done with a view of enabling commerce to penetrate into Equatorial Africa.

That they guarantee to foreigners settling in their territories the right to purchase, sell, or lease lands and buildings situated therein; to establish commercial houses, and to carry on trade upon the sole condition that they shall obey the laws. They pledge themselves, moreover, never to grant to the citizens of one nation any advantages without imme- 
diately extending the same to the citizens of all other nations, and to do all in their power to prevent the slave trade.

In testimony whereof, Henry S. Sanford, duly empowered therefor by the said Association, acting for itself and for the said Free States, has hereunto set his hand and affixed his seal this 22nd day of April, I884, in the City of Washington.
(L. S.)
(Signed)
H. S. SANFORD.

Frederick T. Frelinghuysen, Secretary of State, duly empowered therefor by the President of the United States 'of America, and pursuant to the advice and consent of the Senate, heretofore given, acknowledges the receipt of the foregoing notification from the International Association of the Congo, and declares that, in harmony with the traditional policy of the United States, which enjoins a proper regard for the commercial interests of their citizens, while at the same time avoiding interference with controversies between other Powers as well as alliances with foreign nations, the Government of the United States announces its sympathy with, and approval of, the humane and benevolent purposes of the International Association of the Congo, administering, as it does, the interests of the Free States there established, and will order the officers of the United States, both on land and sea, to recognise the flag of the International African Association as the flag of a friendly Government.

In testimony whereof, he has hereunto set his hand and affixed his seal this 22nd day of April, A. D. I884, in the City of W ashington.

(L. S.) (Signed) Frederick T. Frelinghuysen.

We observe in the spontaneous recognition accorded the youthful State-whatever its form of United government may have been-prompt adStates mission of its qualification as a member of Leads the the society of nations. This was before Way. the signatory Powers to the General Act of Berlin had opportunity of indicating that sympathy 


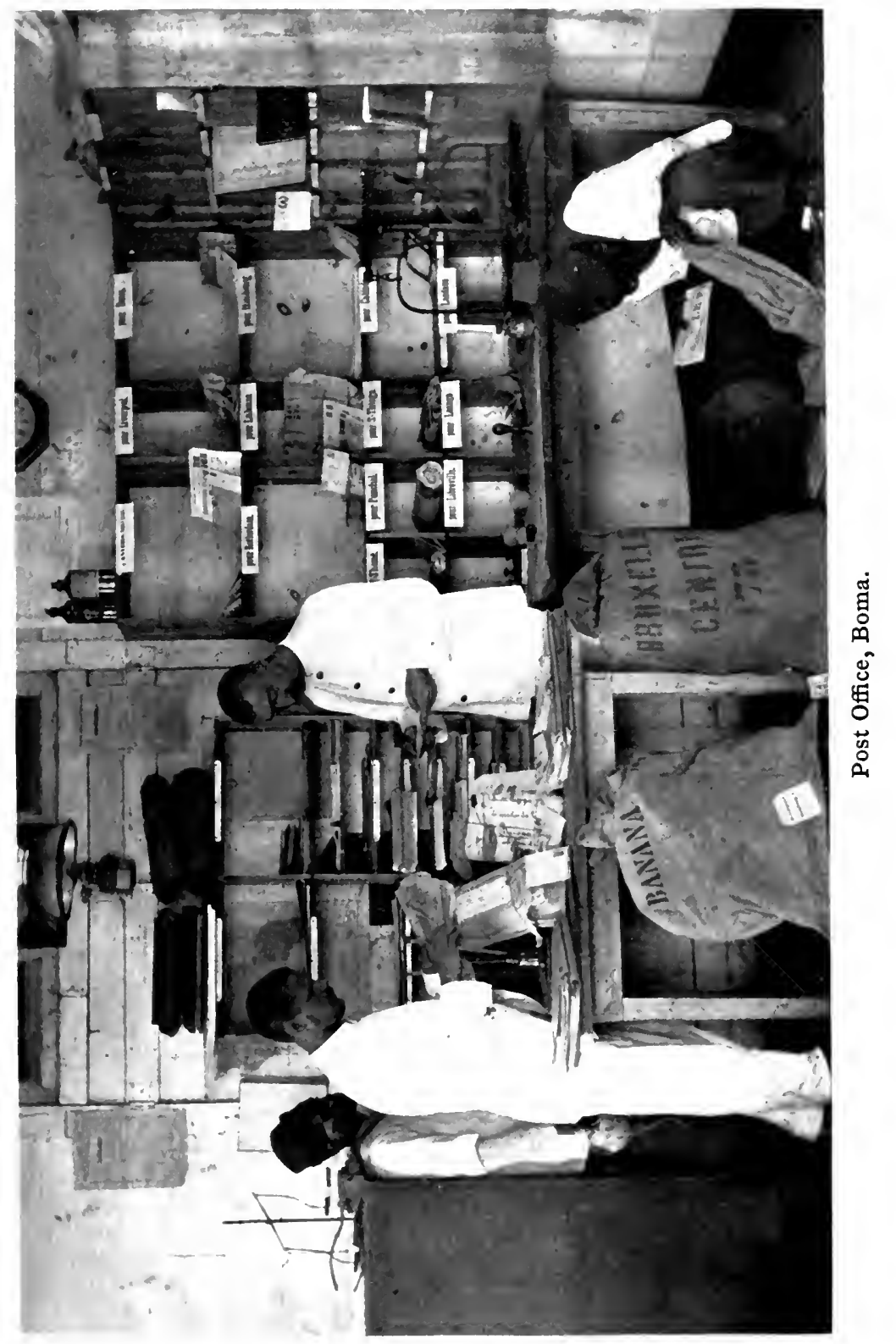



which they expressed in substantial terms when they followed the example of the United States and Germany, and invited the Congo Government to participate in the Berlin Conference as a friendly State invested with all the attributes of statehood which their recognition implied.

It is contended by the advocates of the Congo Free State that the form of its government at any time before or after recognition can not in the slightest degree affect the question of the State's actual existence. It matters not, say the European authorities-Barboux, Picard, Nys, Descamps, Van Berchem, Azcarate, de Martens, and Pierantoni, whether the earlier Government was composed of "federated Negro tribes"; a State ruled by monarchy; territorial and tribal allegiance to an organised central authority; by an autocrat employing civil and military powers, or any other scheme of equitable and civilised domination. The right of the Government to exist cannot be destroyed by latter-day technicalities of law adroitly applied. The point to be noted, says Baron Descamps, is that "the claim to the occupation of vacant territories and to the acquirement by cession of sovereign rights was not inferior to the titles relied upon by European Powers in the course of their colonial expansion." All this was an element patent in the State's foundation, obviously understood and admitted by the Powers which, while they assumed that the Congo Basin contained nothing of material or political value to excite their cupidity, they recognised and treated on a basis of equality - so far, at least, 
as the considerations of the Berlin Conference are concerned.

In the present chapter have been briefly considered the legal and ethical aspects of the birth and baptism of the Congo Free State, its romantic evolution from the enlightened forces put into play by the indomitable personal powers of a Prince of the House of Saxe-Coburg-Gotha. In a succeeding chapter will be observed how the obligations imposed by the General Act of Berlin were discharged by the several Powers which assumed them. ${ }^{x}$

I For a full report of the Committee on Foreign Relations to the Senate of the United States, March 26, I 884, together with the Treaties of Vivi, Leopoldville, Manyanga, and Stephanieville, see Appendix. 


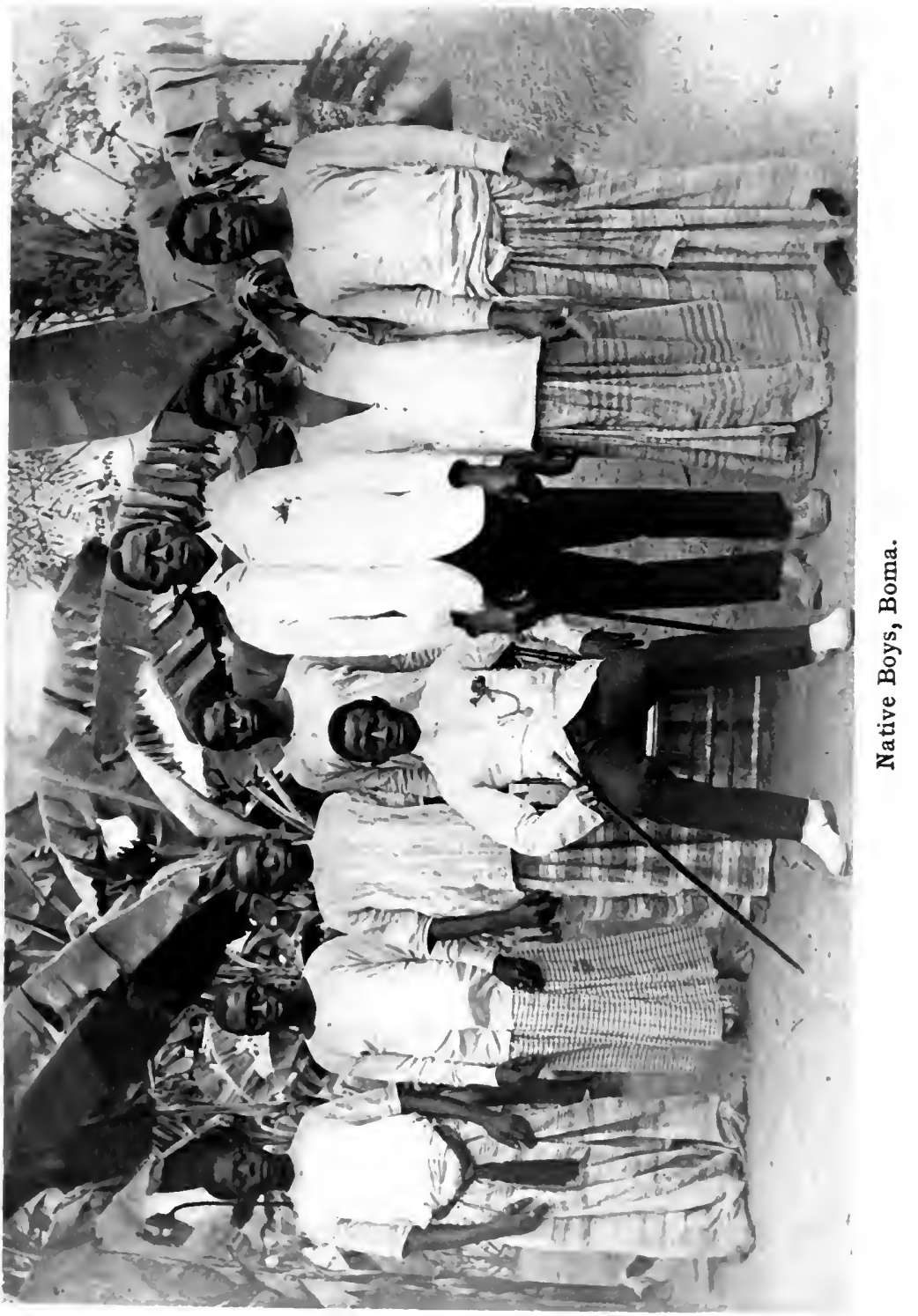





\section{CHAPTER VII}

HORRORS OF THE ARAB SLAVE TRADE .

CLAVERY: the absolute, irresponsible ownership $\checkmark$ of one class of human beings by another class; a contract in which the only factors are might on the one side and helplessness on the other; servitude exacted by force.

Slavery has existed in all countries from

Slavery

Defined. the earliest recorded periods. The most enlightened philosophers of ancient Greece and Rome were unable to conceive a community of which a section was not enslaved by the rest.

As a system, slavery, by its long-continued, universal practice, and the simple solution it affords of what in our modern world is referred to as the labour difficulty, appeals to two powerful human instincts: conservatism and cupidity. The ethical unfairness of one man's being made wholly subservient to the will of another; forced to labour for him without reward; his chattel to retain, sell, or slay, as though he were a horse or a dog, was perceived from the earliest times. But those most interested in the overthrow of the system, the slaves themselves, being ignorant, and purposely kept in that condition by their taskmasters, suffered on, century after century, finding no champion for their 
cause until the advent of the Redeemer of Mankind, preaching universal brotherhood and equal rights for all men.

But the greater the wrong the longer it takes to right it, and Christ's words were but the seed from which has sprung our great harvest of freedom. It has been a harvest of slow growth. For ages after the divine words were spoken on behalf of the slave by the first and greatest of his advocates, slavery was still regarded by many nations as indispensable to their existence. Indeed, eighteen centuries elapsed before there was any appreciable awakening to the deep infamy of slavery. It occurred in England, and was the result of the unwearied efforts of a small band of enthusiasts, whose labours, like those of all reformers, were at first derided.

England, though free from the curse of slavery within her own proper borders, had in the course of history done as much as, nay, more than, any other nation to enslave the Negro. She had acquired him in Africa by thousands in exchange for guns, knives, alcohol, and dry goods; had transported him across the Atlantic to her American cotton plantations in a manner compared with which a modern steerage emigrant's experience may be regarded as a luxurious cruise; and had then extracted the utmost amount of work from him by the aid of the lash.

All the vested interests created by this traffic, long persevered in, as well as the callousness engendered by its brutality, had to be fought against England's and overthrown by a small band of Libera-Retribution. tionists, aided by nothing but their enthusiasm 

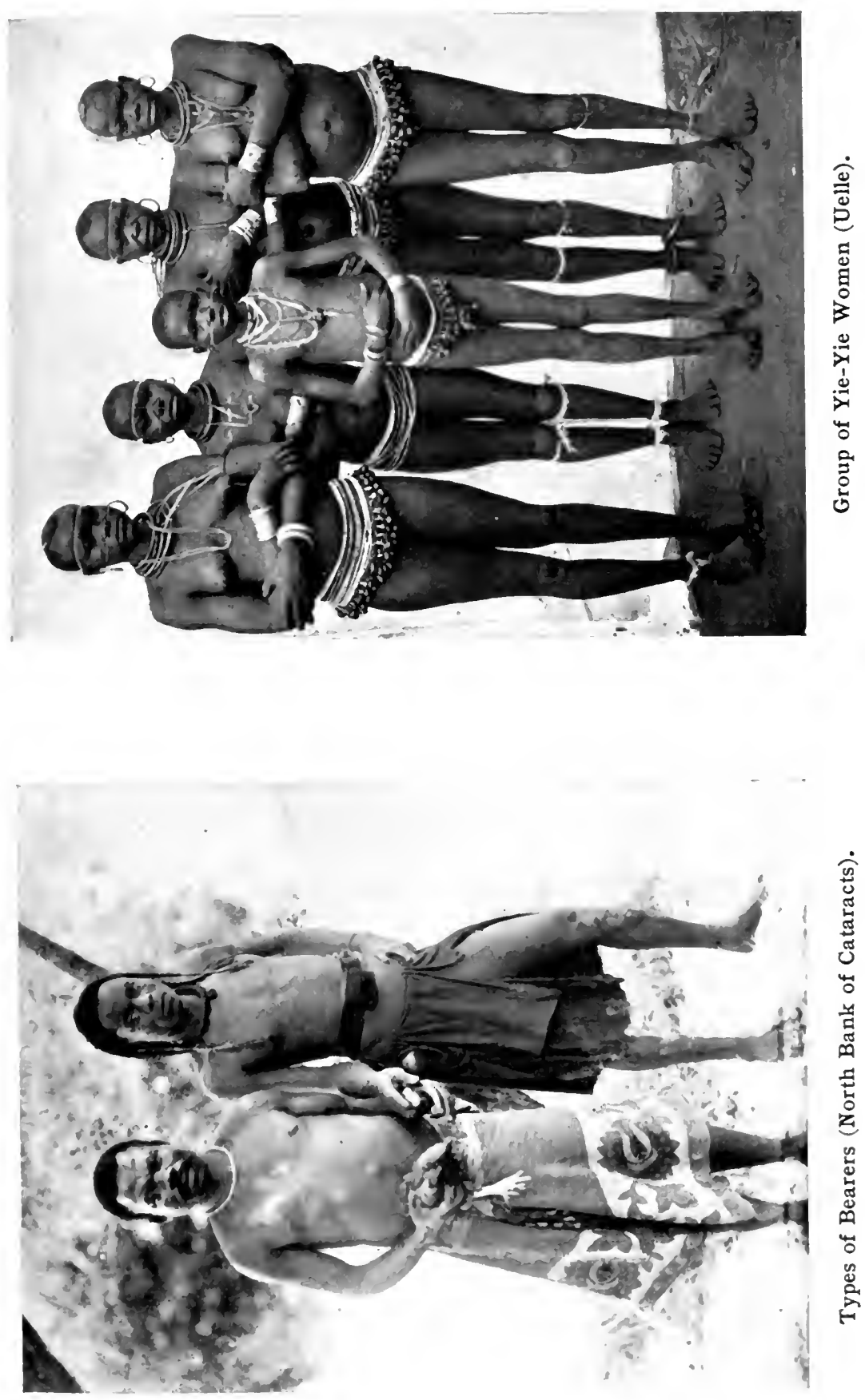

and a just cause. Nevertheless they daily gathered strength, and finally succeeded in inducing the British Parliament to vote a hundred million dollars for the purchase and liberation of every slave in every country where the British flag flies. This grand event took place in the year 1830 .

Three decades later came that tremendous convulsion in the United States, the like of which the world has not seen. It was resolved by the United The Fight States Government to free the slaves, for Right slavery being a system never deliberately and Union. adopted by the United States, but inherited, as it were, from the English Colonial régime, of which they had by revolution become the successors. The slaveholding Southern States, resisting the new law, sought to withdraw from the Union, and civil war ensued, in which the Abolitionists were entirely successful, but at an appalling cost in men and money.

It has been necessary to refer thus briefly to the history of slavery because of the strangely prevalent opinon that when peace was restored within the United States, and slavery finally abolished there, slavery no longer

A Common Error. existed in the world. True, it was known that there was a sort of domestic service, chiefly of women, akin to slavery, practised in China, Persia, and some minor Oriental countries; but that was thought to be all. It came, therefore, as a rude shock to civilised humanity when travellers of unquestionable veracity, such as Dr. Livingstone, Sir Samuel Baker, and Henry M. Stanley, demonstrated 
that the slave trade not only still existed throughout vast regions in Africa, but was rampant there in its most atrocious aspect. At first it was hardly realised that the labours of Granville Sharpe, Clarkson, and Wilberforce, the monetary sacrifices of England, and the devastating war in America had, taken together, fallen so far short of complete triumph. But the evidence was overwhelming that such was indeed the case, the Soudan, the Upper Nile, and the basins of the Congo and the great lakes -more than a third of all Africa, exceeding in area the whole of Europe-being still the field of the iniquity. The Sultans of petty states in the Soudan were shown to be, for the most part, chiefs of ferocious Arab tribes who thrived by raiding Central African villages and carrying off their inhabitants, whom they sold for slaves. The cruelties attending their marauding operations were too great to admit of exaggeration. "All over Africa," wrote Schweinfurth, a German traveller, "dried human skeletons show where the slave-trader has passed."

Acting under heavy pressure brought to bear upon it by the anti-slavery humanitarians in England the British Government coerced the Khedive of Egypt into signing a convention having for its object the suppression of slavery within his dominions. In order to carry out the engagement into which he had entered, the Khedive appointed General Gordon Governor of the Soudan, and that remarkable man, during the six years that he held that office, displayed so much energy and skill that he succeeded in utterly eradicating the evil throughout the entire 


\section{Horrors of the Arab Slave Trade}

region placed under his control. Nevertheless, the general result was not so good as had been hoped for; the slave-traders, despoiled of their huntinggrounds in the Egyptian Soudan, pursuing their nefarious occupation with redoubled vigour on Lake Tanganyika and the Upper Congo. With what extremity of horror they conducted their operations has been so graphically de- A Picture scribed by a Belgian merchant, M. Hodister, in Words. that we make no apology for quoting his account in full.

It is four o'clock in the morning [says M. Hodister]. A great calm prevails, only the soft and melancholy cry of the African owl is to be heard. The village sentinels are either withdrawn, or squatting low, asleep; the houses are closed; every one sleeps; all is repose; the sense of security is absolute. Suddenly the sound of a gun, then cries of terror are raised, breaking the great silence, followed by a fusillade, which seems to come from all sides, piercing the straw walls. The boatmen have fired, leaving their canoes to their women; they have rushed forward, attacking the village in front, while the others are assailing it from the rear. The inhabitants, suddenly roused from their sleep, rush terrified from their houses. They are panic-stricken, and forget wives, children, everything. Their one thought is of flight-to conceal themselves in the wood. The panic is at its height; rifle shots, horrible cries, resound, mixing with the shrieks of fear from the women and children. Then follow the stifled noise of a struggle at close quarters, of falling bodies, a suppressed groan, sharp cries of agony. The ground shakes under the tread of the combatants and fugitives. Soon afterwards appears a star in the blackness of the night, and a dry, crackling sound is heard. It is a detached hut fired by the enemy to light them in their work without the risk of burning the whole village. Before doing that, they wish to 
pillage it. Meanwhile, a few of the inhabitants have seized their weapons and attempt some resistance; but in a little time this is overcome by superior numbers. To the noise of the fight succeed the cries of the prisoners, of the wounded and the dying. The horizon lightens; the sun has risen suddenly and illumined this field of carnage and desolation. Then the Arabs kill the wounded, bind their prisoners, and begin to plunder the village. Every house is visited and despoiled of its contents. Where in the evening there had been a pretty village, surrounded by a plantation like a covering of verdure, a gay and happy population, there is now a great black, empty spot; for on the completion of the sack the village had been set on fire and burned to the ground. Men, women, and children, tied together promiscuously, corpses strewing the ground, blood puddles emitting an acrid smell, and the assassins, horrible in their war paint, which during the struggle has run with their sweat and blood, complete the picture.

Bound together in groups by stout cords around their waists and necks, the wretched procession of captives, often two or three thousand in number, was, after an incident such as this, marched to the coast. Generally, at least a third of them died by the way. The sick and the lamed, unable to maintain the desired pace, were weeded out at each halting-place and ruthlessly butchered by their captors.

It will require no very inventive imagination to appreciate the magnitude of the difficulties confronting the Belgian pioneers in their effort to A Hercu- suppress slavery, carried on with such fero-
lean Task. lean Task. cious brutality over an area so vast as Central Africa. Yet that was but one of several tasks enjoined upon them by their King; but it was first in order and importance, and until it was accom- 


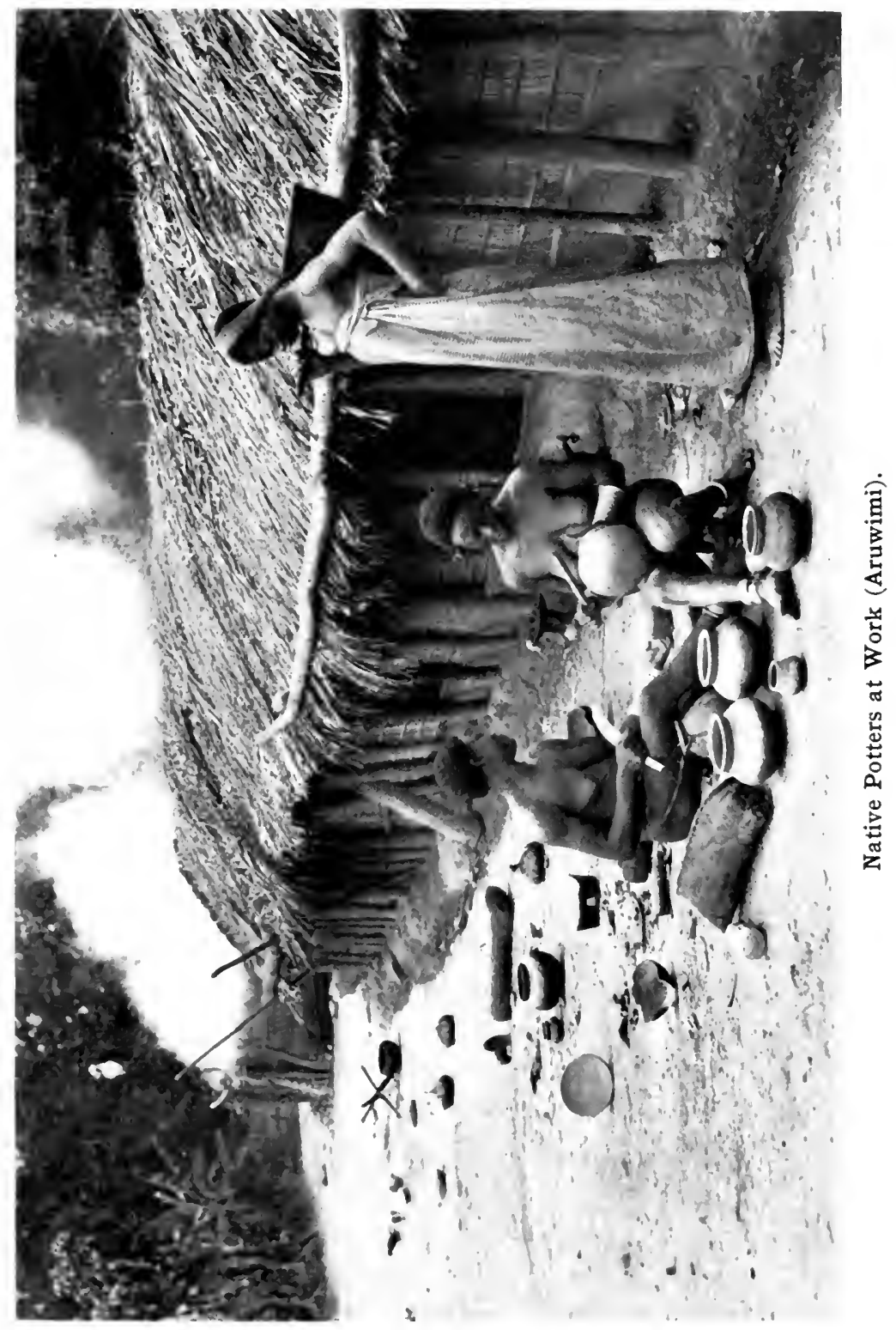



plished little or no progress in other respects could be hoped for. "Crime is not punished as an offence against God, but as prejudicial to society," says the historian Froude. King Leopold saw in the crime of slavery both the offence to God and the prejudice to man, and was prepared to exert his utmost energy and, if necessary, expend the last franc of his private fortune, to stamp out the evil. In this heroic endeavour his Majesty was ably seconded by his minister, the distinguished Baron Lambermont, who has recorded his opinion of slavery in these words: "The slave trade is the very denial of every law, of all social order. Man-hunting constitutes a crime of high treason against humanity. It ought to be repressed wherever it can be reached, on land as well as by sea."

It is not claimed that there is anything original in the sentiment that animates this well-expressed sentence. Similar views to those of Baron Lambermont have been held by all great thinkers since the establishment of the Christian religion; but it is referred to in this place as an additional proof, if any were needed, of the high moral purpose underlying the enterprise of the King of the Belgians, and to show how that moral purpose was sympathised with and shared by his Majesty's ministers and the Belgian people.

That every religious sect without exception has denounced slavery as the blackest spot sullying the fair fame of the nineteenth century need not be reiterated. In logical sequence, every religious sect was prepared to assist, morally and materially, in the 
removal of a disgrace which was felt to reflect upon every civilised community. In an encyclical, dated $5^{\text {th }}$ of May, I888, addressed by Pope Leo XIII. to the bishops of Brazil, congratulating them upon the abolition of slavery in their country, his Holiness referred to the deplorable condition of the Negro in Central Africa, and called upon "all who wield power, those who sway empires, those who desire that the rights of nature and humanity be respected, and those who desire the progress of religion, to unite everywhere to secure the abolition of this most shameful and criminal traffic."

This noble appeal touched the hearts of thousands in every nation of Europe and in America. For CarPope dinal Lavigerie, the Belgian prelate, who Leo XIII. had so long laboured on behalf of the opon Slavery. pressed Congolese, it had a special significance, inspiring him with renewed courage and energy in his glorious work. When, for the first time in history, a small band of Christian Negroes from Central Africa was received in audience by the Pope, a few days after the issue of this encyclical, Leo XIII., replying to the address of Cardinal Lavigerie, who had presented them, said:

Since We have been Pope, Our regards have turned towards that disinherited land, Central Africa. Our heart has been touched at the thought of the enormous amount of physical and moral misery that exists there. We have repeatedly urged all those who have power in their hands to put a stop to the hideous traffic called the slave trade, and to use all and every means to secure that end. And, inasmuch as the African continent is the principal scene of this traffic and, as it were, the house of slavery, We recommend all missionaries 
who there preach the Holy Gospel to devote their whole efforts, their whole life, to this sublime work of redemption. But it is upon you, Cardinal, that We count especially for success.

Cardinal Lavigerie's practical reply to this direct personal appeal from the head of his Church was the formation in Belgium of the Anti-Slavery Society. The agitation on behalf of the Negro was not confined to Catholics. Among the friends of the movement were to be found the best of every creed as of every nation. Great conventions were held in Germany and England having for their object the suppression of slavery in Central Africa, and societies formed in those countries; and France, Austria, Switzerland, Italy, Spain, and Portugal quickly followed suit. Though "man's inhumanity to man makes countless thousands mourn," it was now shown to be also potent to arouse some of the best instincts of human nature to assure its suppression. At last the horrors of the African slave trade were adequately realised, and the world applauded Leopold, King of the Belgians, for his arduous labours for its extinction, and was anxious to strengthen his hands for grappling with the still formidable work that remained to do. 


\section{CHAPTER VIII}

\section{THE BERLIN CONFERENCE}

\section{A CLEAR view of the position of the State pre- $A$ vious to the adoption of the resolutions known as the General Act of the Berlin Con-}

ference may be had from a summary of the signal events which had marked its formative period.

The Congo Free State was born of the Congo International Association founded by his Majesty, Leopold II. in I883, while Stanley was in his service. Prior to the legal foundation of the State, the Association had obtained recognition of its sovereignty as hereinbefore indicated. By treaties concluded in I 884 and I 885 with the United States and with many of the European Powers, it adhered, on the $25^{\text {th }}$ of February, $\mathbf{1 8 8 5}$, to the resolutions of the Berlin Conference, which, embodied in a General Act, established, amongst other things, freedom of trade throughout the Congo Basin, and declared free navigation on the The Congo River, its tributaries, and the lakes General Act and canals connected therewith. The text of Berlin. of the General Act of Berlin, so far as it relates to the Congo, is fully set forth in an appendix. The principal subjects contained in the Act which may concern the reader are briefly stated:

I. A Declaration relative to freedom of trade in the Basin 


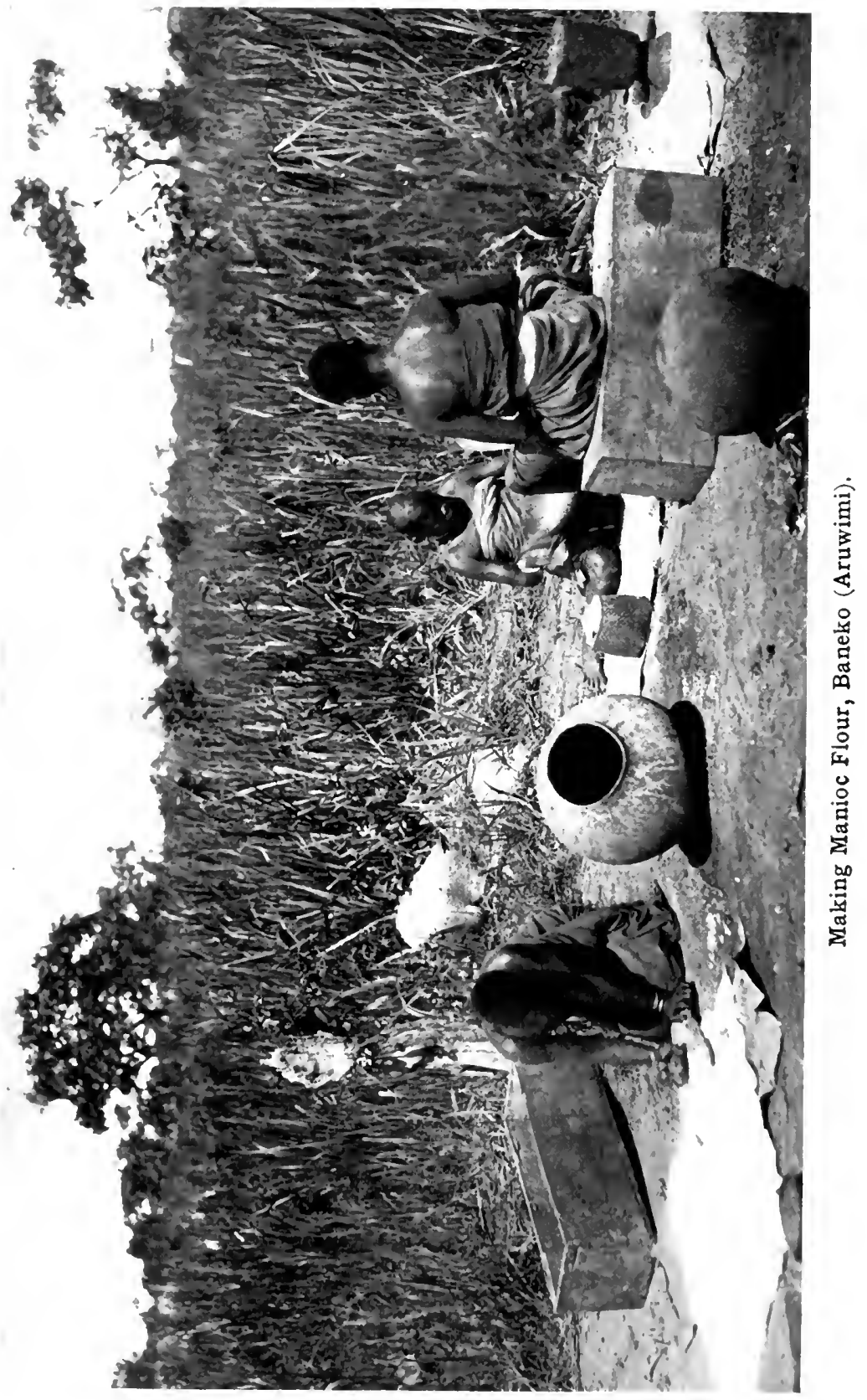



of the Congo, its embouchures and circumjacent regions, with other provisions connected therewith.

2. A Declaration relative to the Slave Trade, and the óperations by sea or land which furnish slaves to that trade.

3. A Declaration relative to the neutrality of the territories comprised in the Conventional Basin of the Congo.

4. An Act of Navigation for the Congo, which, while having regard to local circumstances, extends to this river, its affluents, and the waters in its system (eaux qui leur sont assimilees), the general principles enunciated in Articles CVIII. and CXVI. of the Final Act of the Congress of Vienna, and intended to regulate, as between the Signatory Powers of that Act, the free navigation of the waterways separating or traversing several States-these said principles having since then been applied by agreement to certain rivers of Europe and America, but especially to the Danube, with the modifications stipulated by the Treaties of Paris (1856), of Berlin ( 1878 ), and of London (of $187 \mathrm{r}$ and $\mathrm{r} 883$ ).

5. An Act of Navigation for the Niger, which, while likewise having regard to local circumstances, extends to this river and its affluents the same principles as set forth in Articles CVIII. and CXVI. of the Final Act of the Congress of Vienna.

6. A Declaration introducing into international relations certain uniform rules with reference to future occupations on the coasts of the African Continent.

The treaties which, before the adoption of these resolutions on February 26, 1885, the Congo Free State had concluded with various Powers, were those with the United States of America, dated April 22, 1886; Germany, 8th November; Great Britain, r6th December; Italy, 19 th December; Spain, 7 th January, 1885; France, 5th February; Russia on the same day; Sweden and Norway, Ioth February; Portugal, 14th February; Denmark and Belgium, 
$23^{\text {rd February. These treaties }}{ }^{x}$ were notified to the Conference on the 23 rd February, and the neutrality of the State was declared and published on the ist August in the same year.

At the close of the Berlin Conference on 26th February, 1885 , Prince Bismarck offered his tribute of appreciation for the work which, dePraise from riving its inspiration from the King of the
Bismarck. Bismarck. Belgians, had, by the Powers represented, been formulated into an economic code for the guidance of the four nations, which, besides the Congo Free State, occupied the great Congo Basin. Prince Bismarck's address has the effect of oracular utterance in the light of events since the day when he wisely said that the work of the Conference would be, like every human undertaking, susceptible of improvement. The following is the full text of Prince Bismarck's closing speech:

Gentlemen:-Our Conference, after long and laborious deliberations, has reached the end of its work, and I am happy to state that, thanks to your efforts, and to the spirit of conciliation which has presided at our negotiations, a complete agreement has been established on all the points of the programme which was submitted to us.

The resolutions which we are on the point of sanctioning assure to the commerce of all nations free access to the centre of the African Continent. The guarantees with which commercial liberty in the Basin of the Congo will be surrounded, and all the arrangements made in the Acts of Navigation for the Congo and the Niger, are of a nature to offer to the com-

I For full text of the treaties with Germany, Great Britain, France, and Portugal, and the Declaration exchanged with Belgium, see Appendix. 
merce and the industry of all nations the most favourable conditions for their development and security.

By another series of provisions you have shown your solicitude for the moral and material well-being of the native populations, and there is room to hope that those principles, dictated by a spirit of practical wisdom, will bear fruit and will contribute to bestow on those populations the benefits of civilisation.

The practical conditions under which are placed the vast regions that you have just opened to commercial enterprise have seemed to exact special guarantees for the maintenance of peace and public order. As a matter of fact, the evils of war would assume a particularly disastrous character if the natives were led to take part in the conflicts of civilised Powers. Justly preoccupied with the dangers that such an eventuality would entail in the interests of commerce and of civilisation, you have sought the means of withdrawing a great part of the African Continent from the vicissitudes of general politics, by restraining these national rivalries to the pacific competition of commerce and industry.

In the same category you have aimed at preventing the misunderstanding and contests to which new seizures of territory on the coasts of Africa might give rise. The declaration as to the formalities to be complied with in order to make acquisitions of territory effective has introduced into public right a new regulation, which will contribute in its degree to remove from international relations causes of dissension and conflict.

The spirit of mutual good understanding which has distinguished your deliberations has equally presided over the negotiations which have taken place outside the Conference, with the object of regulating difficult questions of delimitation between the parties which exercise sovereign rights in the basin of the Congo, and which by the nature of their position are called upon to become the chief guardians of the work which we are about to sanction.

I cannot touch on this subject without rendering my homage to the noble efforts of His Majesty the King of the 
Belgians, the founder of a work which is to-day recognised by almost all the Powers, and which by its consolidation may render precious services to the cause of humanity.

Gentlemen, I am charged by His Majesty the Emperor and King, my august master, to express to you his warmest thanks for the part that each of you has taken in the happy accomplishment of the task of the Conference.

I fulfil a final duty in making myself the mouthpiece of the gratitude that the Conference owes those of its members who have discharged the difficult labours of the Commission, notably the Baron de Courcel and the Baron Lambermont. I also thank the delegates for the valuable assistance they have afforded us, and I associate with the expression of that gratitude the Secretaries of the Conference, who by the precision of their work have facilitated our task.

Gentlemen, the work of the Conference will be, like every human undertaking, susceptible of improvement and perfection; but it will mark, I hope, a step forward in the development of international relations, and will form a new link of solidarity between civilised nations.

The brilliant, cordial, and edifying final session of the Berlin Conference presaged no such campaign of Sir Charles calumny as that which has proceeded since Dilke Sir Charles Dilke, on gross misinformation Astray. purveyed by interested persons, and on what appears to have been his wilful misreading of a book entitled The Fall of the Congo Arabs, attacked the Congo State by moving in the British Parliament on April 2, I897, a measure calling for a new Conference to consider charges which no one had presented, but which, for some inscrutable reason, this eminent parliamentarian seemed anxious to dignify by sensational legislation.

When the Berlin Conference concluded its labours, 
it was with manifest sympathy for the King of the Belgians and his voluntary pledge to an African task which practically all the participating Powers regarded as impossible of achievement, such were its glaring difficulties. Now, after twenty years of Belgian sacrifice, there are those who, jealous of the achievements in a task they were so anxious to avoid in 1885 , must destroy where they cannot reap in 1905 . To men of purpose and brave outlook, this is merely one of the many incivilities of civilisation. Success begets envy in one's neighbour; failure often confirms him in his secret contempt.

In Belgium the completion of the General Act of the Berlin Conference evoked a patriotic feeling of satisfaction which, in its address to the King, the Chamber of Representatives voiced in the following language: "To your Majesty belongs the honour of having conceived the African work, of having pursued and developed it by persevering efforts.

We felicitate your Majesty on these important results, and, as Belgians, we are proud of the solemn homage rendered by the Powers to the generous and progressive ideas of our Sovereign." The Belgian nation, for a long time uncertain of the result of the philanthropic work of its King in Central Africa, and having observed that other nations had shrunk from this costly task of civilisation, now uttered its sentiments of approval in many forms. In his speech before the Chamber on March 10, I885, M. Beernaert, then Minister of Finance, said, amongst other expressions of hope for the new State, that the merit of the work accomplished "belongs especially to the 
initiation, to the persistent energy, and to the sacrifices of our King." Then, expressing the hope of extended industries - a hope that was largely, if not entirely, the incentive which actuated the Powers Signatory to the Berlin Act-the Minister concluded his address with the belief that the Congo would offer "to our superabundant activity, to our industries more and more confined, outlets by which we shall know how to profit. May the enterprising spirit of our King encourage our countrymen to seek, even at a distance, new sources of greatness and prosperity for our dear country." The Belgian Chamber and Senate ratified the nation's participation in the General Act of the Berlin Conference without a dissentient voice.

To the loyal address of his Parliament, the King of the Belgians made reply, graciously acknowledging the support his subjects had given him in his great African work.

There remained now the making of a Sovereign for the new State, and, having regard to the universal tribute of praise rendered to its founder at the Berlin Conference, it was clear enough, in its opinion, who should continue to direct the destinies of a wild territory in which so much had been accomplished in so short a time. Belgium, however, was not prepared, in $\mathrm{r} 885$, to take over the Congo State as her colony. There were, at that time, many considerations in Belgium and in the Congo to suggest caution to a naturally conservative Government. The creation of the Congo State had involved many risks and great difficulties. It had required a huge ex- 


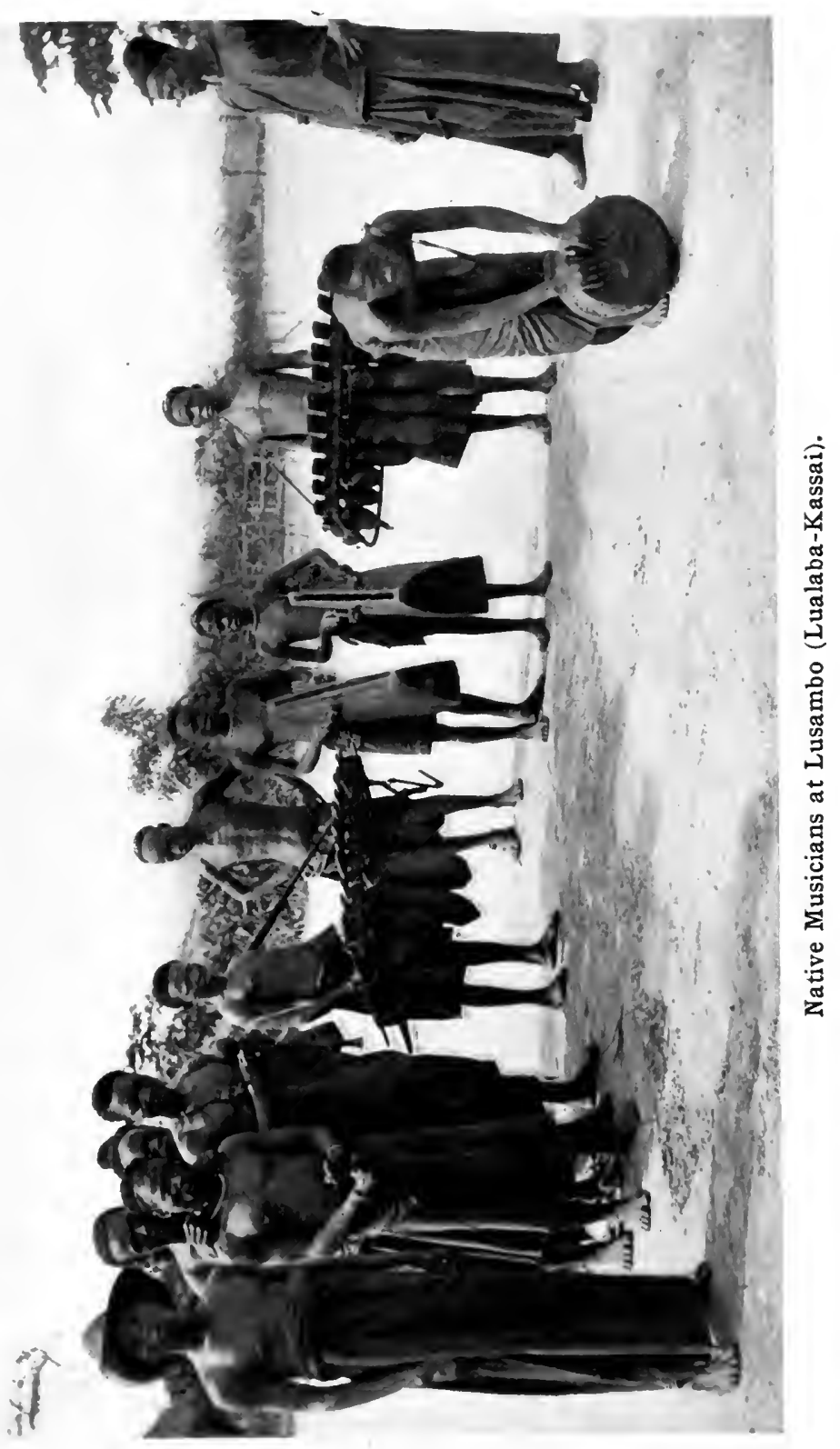



penditure of money, nearly all of which the King had personally contributed without the slightest assurance that his country or his estate would ever recover it, except in so far as his marvellous foresight assured him in this respect. If there were many difficulties at the beginning of his Majesty's African enterprise, there were still greater obstacles to be surmounted. To the ultra-conservative section of the Belgian Parliament the whole project was still enshrouded in doubt. But the King, having so far borne the risks and the cost of civilising the savage African black man, had also given his country the written assurance that the result of his labours -whatever they were when realised-should be at the disposal, by appropriation or otherwise, of the Belgian nation "without costing her anything." As the theory of a purely personal union between Belgium and the Congo State had found much favour, it was proposed that the King of the Belgians should be empowered to become the Sovereign of the Congo Free State without in any respect involving the Belgian nation.

In this eminently practical proposal the King had taken the initiative in the following letter to his Council of Ministers:

Gentlemen:-The work created in Africa by the International African Association has greatly developed. A new State has been founded, its limits are fixed, and its flag is recognised by almost all the Powers.

There remains to organise a Government and an Administration on the banks of the Congo.

The plenipotentiaries of the nations represented at the Berlin Conference have shown themselves favourable to the 
work undertaken, and since then the two Legislative Chambers, the principal towns of the country, and a great number of important bodies and associations have expressed to me on this subject the most sympathetic sentiments.

With such encouragement I could not recoil from the prosecution and achievement of a task in which I had, as a matter of fact, taken an important part; and since, gentlemen, you consider, as I do, that it may be useful to the country, I beg of you to demand from the Legislative Chambers the assent which is necessary to me.

The terms of Article 62 of the Constitution describe by themselves the situation which has to be established.

King of the Belgians, I should at the same time be the Sovereign of another State.

That State would be independent, like Belgium, and it would enjoy, like her, the benefits of neutrality.

It would have to provide for its own needs; and experience based on the example of the neighbouring colonies justifies me in affirming that it would dispose of the necessary resources.

For its defence and its police it would rely on African forces commanded by European volunteers.

There would then be between Belgium and the new State only a personal bond. I am convinced that this union would be advantageous for the country, without there being the possibility of imposing any burdens on it in any case.

If my hopes are realised, I shall find myself sufficiently rewarded for my efforts. The welfare of Belgium, as you know, gentlemen, is the object of my whole life.

LEOPOLD.

There were a few obstructionists in the Belgian Parliament who, impelled by an habitual attitude of opposition to all that the dominant political party proposed, offered considerable criticism. They disregarded the similar expedients adopted by Prussia, Holland, and Great Britain in reference respectively 
to Neuchatel, Luxembourg, and Hanover. But the spirit of the Belgian people favoured the King's suggestion, and his Majesty's Ministers stood firmly by him. When the vote was called on April 28, I 885, the Chamber passed the following resolution with but one dissentient:

His Majesty, Leopold II., King of the Belgians, is authorised to be the chief of the State founded in Africa by the International Association of the Congo. The union between Belgium and the new State of the Congo shall be exclusively personal.

The Senate two days later having passed a similar resolution, the King addressed the following acknowledgment to his Ministers:

Gentremen:-The Chambers, by voting almost unanimously the resolution that you submitted to them, have shown themselves convinced that at the same time that I was pursuing, in the general interest, the international African work, I had it at heart to serve the country, to contribute to the augmentation of its wealth, and to increase its reputation in the world. I have asked you to thank, in my name, the Chambers for the mark of high confidence which they have given me. I also beg of you to accept for yourselves the expression of my very sincere gratitude. Believe me, gentlemen, your. very affectionate

LEOPOLD.

Leopold II., King of the Belgians, had now become Sovereign of the Congo Free State, a territory with a population estimated as five times larger than the Belgium which he had ruled since I865. Many foreign bodies, philanthropic, scientific, and commercial, sent their congratulations; the Lord 
Mayor of London visited the King in state, and offered him the felicitations of the British metropolis, and all the Powers concerned in the Conventional Basin of the Congo expressed their satisfaction with this happy consummation of his Majesty's enlightened undertaking in Mid-Africa.

What, by the Berlin Conference had been sanctioned, now assumed permanent form, organisation, and well-defined onward movement. There were still difficulties ahead, some of them with the State's neighbours, France and Portugal. Their early exactions may be regarded as symptomatic of that febrific goading which has now become the mania of lesser bodies elsewhere. Subsequent conventions with France and Portugal somewhat assured the Congo State that its onward march would not be obstructed by these Powers. On the other hand, the exalted views and edifying principles so generally prevalent at the Berlin Conference soon became stale and innocuous in the official mind of the other Powers who had subscribed to precepts which, from subsequent indifference or self-interest, were disregarded. Not the least among the pledges of the Powers of the Berlin Conference was that designed to regulate the importation of alcohol. Consistent with the Christianising aims of its Sovereign, the Congo Free State has fulfilled this pledge in a manner to put its neighbours to shame for the large percentage of revenue they derive from a debasing liquor traffic.

So if the young State started upon its progressive course in $1885^{-87}$, having paid a heavy price to 


\section{The Berlin Conference}

France and to Portugal for freedom to develop under the government of the strong personality of its magnanimous Sovereign, it was perhaps because such a course would secure the Congo State to the Belgian nation in accordance with the preconceived purpose of its King. By the Congo-French Convention the basin of the Kwilu and the left bank of the Congo, from Stanley Pool as far north-eastward as its explorations had attained, were assigned to France. On the other hand, it insured to the Congo Free State what constitutes its outlet to the sea, the possession of the district of the Cataracts, and the towns of Boma and Banana at the mouth of the Congo. The Congo-Portuguese Convention assigned to Portugal territory south of the Congo as far as Noki, and along the parallel of Noki to its intersection by the river Kwango, which from that point was designated as the boundary in a southerly direction. The territorial assignments of these conventions were subsequently modified, and Germany and Great Britain have since acquired the large areas of the Congo Basin lying east of Lake Tanganyika and its parallel north and south. 


\section{CHAPTER IX}

THE ECONOMIC RÉGIME OF THE BERLIN ACT

$\mathrm{T}^{\mathrm{H}}$

$\mathrm{HE}$ Berlin Act and the economic, that is, domestic, régime which it sought to establish in the Congo Basin occupied by Germany, France, Great Britain, Portugal, and the Free State, were, with various inadequacies and experiEarly mental defects, the logical expression of Colonial the drift that political science as applied Policy to the law of nations had assumed in E1rope as early as 1874 . Under the operation of the old Pacte Colonial, the policy which prevailed in the colon es of the European Powers discriminated greatly against the subjects of all save the mother country. The commercial policy of such colonies was that of the Power which governed the colonial territory, whether that was an extension of the home territory or merely a dependency.

Some marked theoretics freighted the course of international life as the time approached when exploration had revealed all the colonising areas which the known earth contained. Europeans and their descendants already occupied, under different forms of law, as states, colonies, protectorates, leaseholds, spheres of influence, over 82 per cent. of the lands of this planet. Those who followed the evolution 


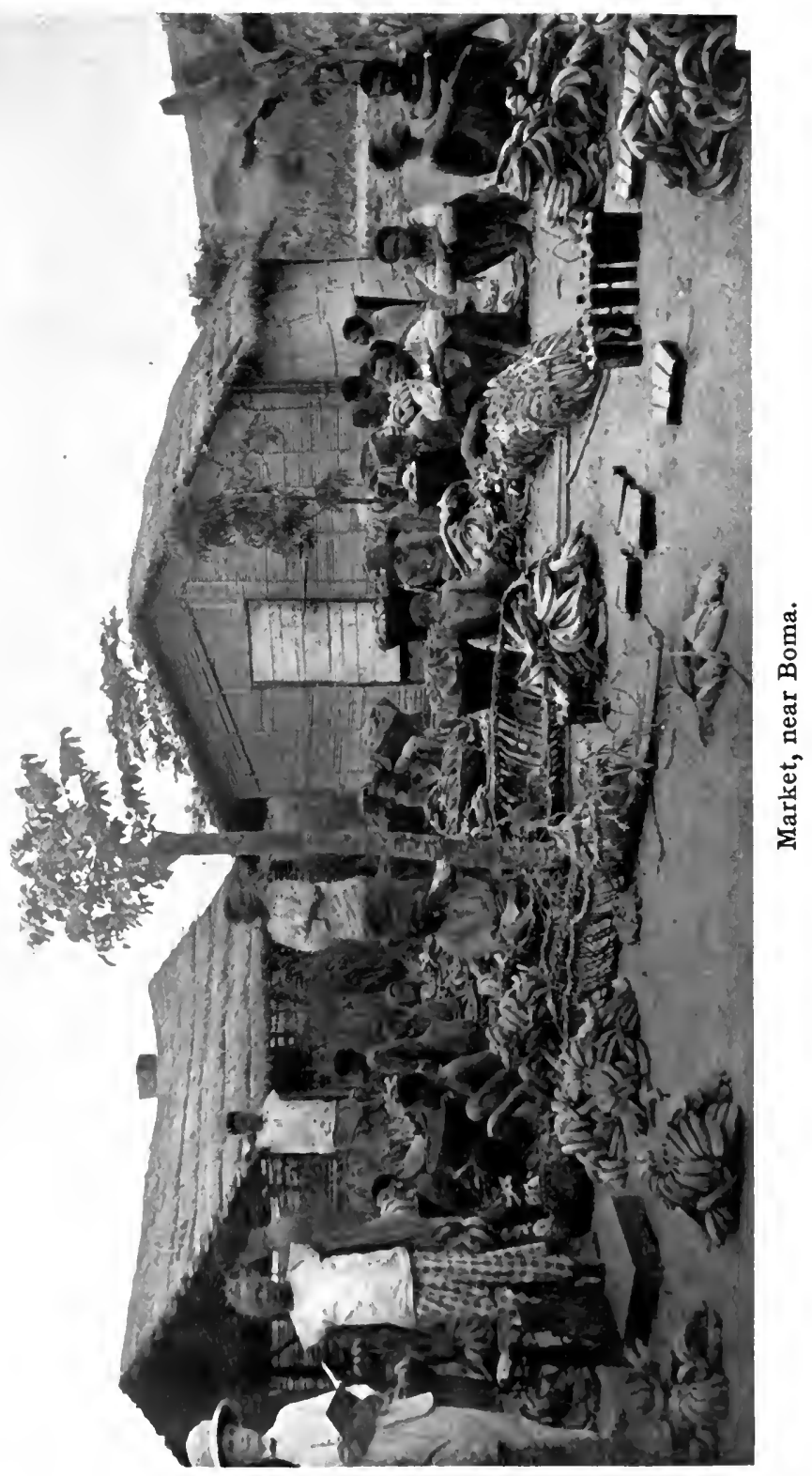



of the law of nations were impressed by an African situation in 1884 which offered opportunity for experimentation with new, and perhaps more elastic, economic principles for the regulation of colonial interests in regions where the character of the country, its natural features, such as waterways and coastal advantages, and the juxtaposition of several governments, tended to a conflict detrimental generally to the civilisation of such possessions and their contributions to the markets of the world.

In the Annales de l'Institut de Droit International, vols. iii. and vii., are to be found the various resolutions of Prof. Égide Arntz relative to practical and co-operative jurisdiction in the Congo Basin. These were offered on September 7, I883, at the Munich meeting of the Institute. But long before, namely, in 1878 , M. Gustave Moynier had raised the question of a concerted civilising movement and the adoption of a scheme of political regulation in the region of the Congo. M. Emile Laveleye and the late Sir Travers Twiss had, thereafter, also discussed the question before the Institute. The essays of Professor Arntz and Sir Travers Twiss, which embody their respective views on what to them at that time appeared to be a signal opportunity for applying principles of colonial government as yet unestablished by tests of practice, are fully set forth in the Report of the Committee on Foreign Relations.

The Berlin Conference of November I 5, I884, may be regarded as the crystallised result of the interest manifested in respect of the Mid-African situation 
by the learned bodies and the eminent legal authorities indicated, and also as the outcome of Germany's Experi- tactful method of superseding the then ments of the imminent treaty between Great Britain Berlin Act and Portugal signed on February 26, I 884, but thereafter abrogated. As pointed out in another chapter, the British-Portuguese treaty met with active opposition in Germany and in England.

It was during the agitation of this feeling that the Conference was summoned at the instance of Germany. If one could analyse in extenso German Astuteness all the essentials which so aptly informed Prince Bismarck of Germany's masked advantages in such a Conference, the Iron Chancellor would stand revealed as an early monument to the German astuteness of to-day. In creating an Areopagus of the fourteen Powers assembled at Berlin and referring to it the questions which, if unsettled, would have led to conflicts, combinations, and confusion prejudicial to German East Africa, Prince Bismarck's workmanship surpassed the materials which his skill employed. As the Prince said at the final session of the Conference, the lofty aims and political idealities proclaimed during its earlier sessions would, when translated into facts, offer opportunity for improvement. Indeed, time and the practical application of its precepts, so enthusiastically proclaimed, have revealed the theorist where the man of practical political sense would better have written certain clauses of the General Act. As it stced in 1885 , it cannot be regarded with that awe which certain persons manifest when they misinterpret its 
inconclusive preachments. Some praise it as "the inauguration of a truly new era in colonial affairs." Others, condemning it without reserve, speak of it as "the work of theorisers without experimental basis." A fair estimate of this unique political palaver, as embodied in its General Act, probably lies The Act somewhere between the extravagant praise Praised and and the untempered condemnation fre- Condemned quently bestowed upon it. If, from a legal and political point of view, it can be regarded as only a tissue of the substance it aimed at, the fact remains that the Berlin Conference has more than justified itself by guiding, often dispelling commercial rivalries which, in their unchecked development, might have nullified the great sacrifices of Belgian blood and money in the cause of African civilisation. The Conference entered the forum when many complications, arising from competing expeditions, conflicting explorations, unregulated trading operations, the advent of evil adventurers, the devastating slave trade, and a combination of other causescommercial and political-had provoked the distrust and avarice frequently observed when several European peoples occupy in common a vast and fertile territory inhabited by savage tribes. At a meeting of a Committee of the Conference held on December ıо, I884, Mr. Kasson, the Plenipotentiary of the United States, gave utterance, in retrospect of early American colonisation, to expressions of historic fact which graphically portray Mid-African conditions twenty years ago:

The first colonies founded in America [said Mr. Kasson] 
have been the work of different nationalities. Even there, where at first emigration was of a free and peaceful nature, foreign Governments were soon installed, with military forces to support them. Wars immediately broke out in Europe. The belligerents had colonies, and soon the field of battle spread to America. In the heat of the struggle, each of the belligerents sought allies amongst the native tribes, where they thus excited their natural inclination for violence and plunder. Horrible acts of cruelty ensued, and massacres where neither age nor sex were spared. The knife, the lance, and the torch transformed peaceful and happy colonies into deserts.

The present condition of Central Africa reminds one much of that of America when that continent was first opened up to the European world. How are we to avoid a repetition of the unfortunate events, to which I have just alluded, amongst the numerous African tribes? How are we to guard against exposing our merchants, our colonies, and their goods to these dangers? How shall we defend the lives of our missionaries and religion itself against the outburst of savage customs and barbarous passions?

Finding ourselves in the presence of those whom we are urging to undertake the work of civilisation in Africa, it is our duty to save them from such regrettable experiences as marked the corresponding phase in America.

Whatever defective novelty may still reside in the Berlin Act, the Conference which begot it gave an The Real immense impetus to the great work of Value of African civilisation. It eliminated movethe Act ments by the various Powers which were accomplishing little or nothing for lack of definition and unity. It organised a scramble, so to speak, into an orderly and intelligently directed set of enterprises, chief among which were those urged forward by the King of the Belgians and his diligent 
subjects. In that amplitude of pledges, which when applied to them the other Signatory Powers found it convenient to forget, little Belgium strove mightily not only to discharge her obligations under the Berlin Act, but to demonstrate her own innate genius for the work of colony-building and civilisation. It is perhaps in the inevitable result of this spirit that we find the explanation of Bel- $\begin{array}{r}\text { Belgian } \\ \text { Dominance }\end{array}$ gian dominance and Belgian progress far excelling that of its African neighbours.

In the United States the Berlin Act has not met with the universal respect of competent legal authorities. It provided no means for its own enforcement, and left the national committees, which were to carry out certain of its provisions, without machinery and without that central authority essential to its life. It also appears that the national committees never acted. Each of the Powers, supreme within the border of its own African territory, pursued a course which it believed was best calculated to develop the resources and the civilisation of that region of the Congo Basin in which it ruled. Nevertheless, the General Act had delimited the territory comprised in the Conventional Basin of the Congo; defined the domain occupied therein respectively by Germany, France, Great Britain, Portugal, and the Free State; applied to the entire Congo Basin the principle of freedom of commerce and of navigation, and concerted the aims of all the Powers to the suppression of the iniquitous slave trade and the horrible practice of cannibalism. It did not deal specifically with questions of territorial sovereignty, 
nor with the internal public and private land system, nor, in fact, with any act or principle of the civil or

Freedom of military government of a State. It did, Commerce however, seek to restrict the duties upon the Congo and its affluents, and stipulated that upon these highways there should be open to all nations the freedom to trade and to navigate. As Baron Descamps aptly says in his essay on Government Civilisation in New Countries:

The broad-minded measures of the Berlin Conference did away with many of the existing anomalies. Doubtless, the general application of those measures to all colonies would have been a step in the right direction; but while their general adoption could have been justified on the same grounds as their special application to the Congo, the Conference would not have been able to accomplish such a gigantic reform of distributive equity. The Conference, however, did what it could in this direction. It felt that the impracticability of the complete scheme did not prevent its partial application; that it was not easy to reform the whole world at once, especially the colonial world; that the field of experience on which it could operate was large enough; and that, last but not least, the nature of the country, where the Government was as yet more or less insecure, was calculated to induce those concerned to make exceptional sacrifices.

The Conference therefore made the following regulations for the Congo Basin:

Art. I. The trade of all nations shall enjoy complete freedom.

Art. 2. All flags, without distinction of nationality, shall have free access.

Art. $3, \S 2$. All differential dues on vessels as well as on merchandise are forbidden.

Art. 5. No Power which exercises or shall exercise sovereign rights in the above-mentioned regions shall be allowed 


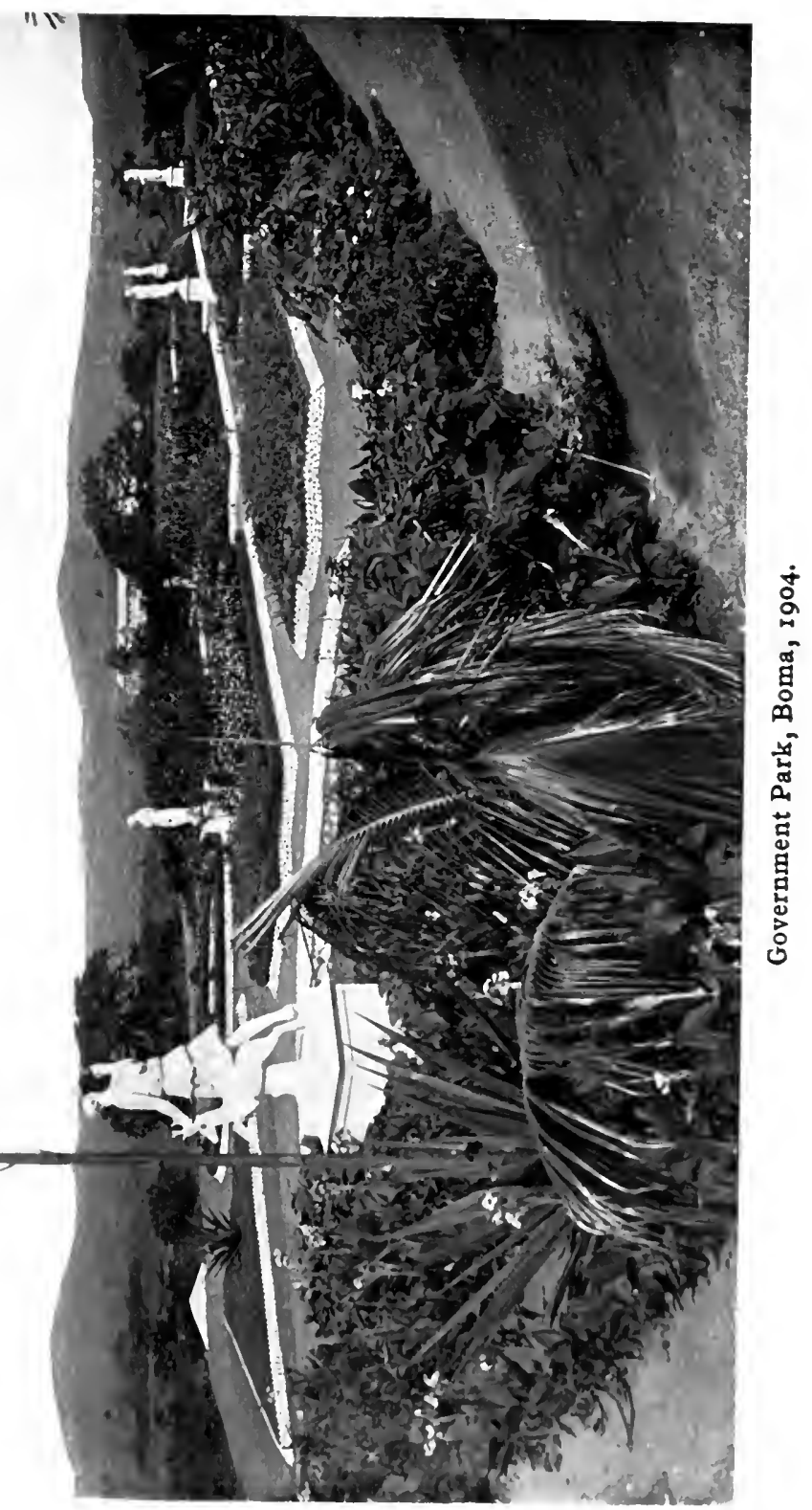



to grant therein a monopoly or favour of any kind in matters of trade.

The five Powers occupying and governing the Congo Basin have here assumed certain obligations in reference to the commercial régime which Freedom of should prevail in their territory. There Commerce shall be freedom to trade, and to navigate Defined in pursuit of commerce; there shall be no differential duties imposed; there shall be no monopoly in matters of trade. In the fourth protocol of the Berlin Conference, Baron Lambermont's report includes a definition of what the Conference meant by monopoly "in matters of trade." This statesman declared that:

No doubt whatever exists as to the strict and literal sense which should be assigned to the term in commercial matters. It refers exclusively to traffic, to the unlimited power of every one to sell and to buy, to import and to export, products and manufactured articles. No privileged situation can be created under this head, the way remains open without any restrictions to free competition in the domain of commerce, but the obligations of local Governments do not go beyond that point.

Notwithstanding the explicit nature of this definition, those who, for reasons which it is not the purpose of this volume to expose in detail, condemn the governmental system of the Congo Free State, and declare that the General Act of the Berlin Conference aimed at much more than insuring the common right (freedom) of all nations to pursue $l e-$ gitimate trade in the Basin of the Congo. How much 
more, and precisely what the Act aims at, according to hostile commentators, varies with the capacity for exaggeration, or the speciousness in argument, of the critic. Some declare that freedom in matters of trade means that anybody may invade the Congo Basin and barter with natives for the produce of the soil and the chase, laws respecting private property and providing regulations to govern traffic notwithstanding. In his essay on Principles of Government in the Congo Free State ${ }^{\mathrm{I}}$ the author briefly indicates The Theory the motif of King Leopold's rule in Central of Congo Africa and the cogent reasons for the sysGovern- tem which has made that rule the envy of ment

persons whose faculty of perception is not as dormant to-day as it was in $\mathbf{1 8 8 5}$, when it was lazily asstumed that the salvation of a territory, not worth much materially, was being imposed upon an enthusiastic and impractical kingly philanthropist. Amongst other things, this essay contains the following exposition of the system of internal government by which the Congo Free State and its people have morally and materially prospered. It is, in substance, the definition of Congolese policy stated by his Majesty, King Leopold:

- . The principles of the Congolese system of internal government appear to be in entire conformity with the General Act of Berlin, wherein freedom of trade is assured to the subjects of all nations. This signifies the liberty to sell and to buy in a legitimate way, not in a way peculiar to the theories of Congo despoilers. It is repugnant to law, and disturbing to civil order and progress, to permit the product of the

September, I904. 
land to be purchased from any person but its legitimate owner. Congo law represses theft, the insidious encouragement of which would appear to be the aim of those who so grossly misinterpret the principle of Freedom of Commerce. A respect for property is essential to all governments which hope to endure, and the law of this attitude is universal in all civilised communities. Trade,

Respect for Property whether free or restricted, could not exist on any other basis. The forces of civilisation are paralysed without it, and untamed natives are left to savage internecine strife.

The principles of the Congo Government are that the soil shall maintain those who develop its resources for the betterment of the sower and the reaper. The civilisation of the native by industry and other forms of instruction in the attributes of order, civic life, and all that he may be capable of absorbing of enlightened freedom. For the privilege of residing within the sphere of a State so governed, the white man is the most taxed member of society in the world. Shall savages alone be exempt from labour and just contribution to organised government? Shall Labour the the white man's rule teach the black that idleness, Great craft, animal instincts, predatory habits in gaining Civiliser his irregular subsistence, are the foundations of civilisation? Or shall the white man by precept and example, and by humane but positive insistence, train the savage in the ways of law and order, industry and thrift?

Reverting for a moment to the assertion that the Government of the Congo Free State is primarily responsible for what its detractors allege to be the enslavement of the native, I fail to find conviction in unfounded statements often repeated, and arguments upon wrong premises, varied only in form, not substance. Ignorance of the motif impelling Congo State method and movement has misled those who have brought prejudice to a subject worth the attention only of the broadest minds. The system, which is the object of attack when new stories of atrocities are scarce, is briefly stated to be to devote the revenue derived from the State's property 


\section{4 Story of the Congo Free State}

as much as possible to cover the State's expenses; that is to say, to the moral and material organisation and regeneration of the country and its inhabitants; to resort to the imposition of a tax in specie as rarely as possible; and to exact a few hours' labour monthly from the natives, in order to give them the habit of work, which is the greatest of civilising precepts. Taxation of In this connection the Congo Government goes bethe Native yond its duty, and pays the natives for this work, teaching them the relation between labour and its reward. The habit of work, when formed, will elevate the natives from the savage instincts which tend to debase them in idleness. The exaction of, and payment for, fortyodd hours' work each month from an able-bodied native, for whose redemption from savagery millions of money and many lives have been, and are being, spent, is a lesser tax than the white man pays on his meagre income from daily toil in the cities of London, New York, Paris, and Berlin. The county road tax alone, levied upon the farmer in the United States, is a greater imposition than this. Those who have the hardihood to argue that the enforced practice of habits of industry upon savages in an African colony, less than twenty years in the making, is an unjust and iniquitous burden, can have no conception of the condition of the white slaves of the Midland counties of England, no understanding of life and its burdens in the centres of the world's highest civilisation.

The Congo Free State, like all other States, acquired possession of ownerless lands, not by bloody wars which have characterised the acquisitive and "civilising" methods of its principal mentor in morals, but only after treaty with the natives who happened to occupy those lands in their savagery. All lands which the natives occupy with at least the rudiments of peaceful industry are guaranteed to them. What for ages The State had been unused and undeveloped for the good of The State mankind, native or foreign, is now being successfully exploited by the State. Before this industrial, civil, and moral era, the vast Congo forests were not even traversed by the indolent native, so long as he could 


\section{Economic Régime of the Berlin Act}

acquire his food in the sluggard idleness which to this day prevails throughout neighbouring African colonies.

The Congo Free State is pursuing a policy for the preservation of its forests, far in advance of other colonies, by enforcing the replanting of rubber trees and vines as fast as the old growth has been sapped, thus ensuring to future generations the results of Belgian foresight and wisdom.

The Congo Free State does not trade as a State. Like other governments it is interested in the development of the Government domain by its inhabitants. The United States first occupied the wild lands of North America by conquest of, and treaty with, the Indians. It then threw the land open to the pre-emption of its citizens under certain restrictions and impositions; for instance, to improve the land within a certain time, to maintain its yield, to pay taxes, build roads, and in other ways contribute to the cost of administering and improving the State.

After vainly waiting seven years for the influx of foreign capital and enterprise to freely enter upon its public lands, and assume the burdens and enjoy the gain of developing the forests for the wealth they contained, the Congo Free State proceeded to cause a part of its lands (one-fourth) to be developed en

The State Develops the Land régie (by trustees), in order that the land might at least contribute to the creation and support of the public works to be established within the State for the benefit and betterment of its native population. Another part (one-fourth) of the forests have been conceded to private companies, in harmony with the system followed by France, England, Germany, and Portugal, whose territories are contiguous to the Congo Free State. But here again we have an exhibition of far-seeing statesmanship, almost unparalleled in colonial history. Instead of doling out the State lands absolutely to favoured concessionaires, which has been the invariable practice in other colonies, the Belgians have exacted a tremendous guarantee and a growing revenue from those who exploit the natural resources of its forests, by retaining in some cases a half interest in the 


\section{6 Story of the Congo Free State}

capital of the concessionary companies. As an example of practical politics, this admirable system alone constitutes a material heritage to the future of the Congo. The revenue thus annually accruing to the support of the Congo budget must play materially in the development and welThe Con fare of the State. Moreover, while the State has cessionaire Companies such large influence in the internal affairs of its concessionary companies, it has a practical power within the companies in addition to the State law. This dual control should ensure a commercial policy in harmony with the spirit and the letter of the underlying principles of the State's government. Under this system, the Congo Free State now exports to European markets 5000 tons of rubber annually, where a few years ago this great asset lay hidden in a forest upon which none of the Powers Signatory to the General Act of Berlin desired to spend its means or its labour.

One of the counts in the complaint by certain perfervid pamphleteers in Great Britain against King Leopold is that there is no freedom of commerce in that part of the Congo Basin occupied by the Free State. Freedom of Commerce under the definition of such persons is the indiscriminate right of traders and adventurers, and purveyors of arms and spirituous liquors, to swoop down on the State and private lands of the Congo, incite the native to invade the forest, steal rubber product and sell it to the trader at the latter's price. One need not dwell upon the preposterous nature of Spoliation and Plunder

that transparent scheme of commercial freedom.

Private property is nowhere open to unlawful invasion. Public property is not open to the spoliation of adventurers and vandals. The 5000 tons of rubber gathered by the several industrial forces at work in the Congo can be purchased by traders as well at Matadi as at Stanley Pool, at Boma as well as at Antwerp, at a proper price. If the freedom of commerce defined by Congophobes were permitted to prevail in any civilised or uncivilised country in the world. anarchy and tribal wars would ensue, all rights of property 


\section{Economic Régime of the Berlin Act}

would be violated, and the larcenous proclivities of the African Negro would be encouraged. In the case of the Congo, a reign of terror would decimate the native population, and denude the forests which the wise laws of the State endeavour to preserve. Upon their ruins the "savagery" of the white man would have succeeded that of the black.

As already indicated, Congo law very properly forbids invaders of the State from buying the product of private property from any one except the owner. In that respect it does not depart from the law of every other country. The desire of adventurers to buy rubber and ivory direct from the natives is not sufficient reason for permitting the latter to trespass upon private property for the purpose of stealing its product. Once establish a traffic on these lines, and you put a premium on the crime of theft, and pit the spear of every native against his brother in their rubber-hunting areas.

The difference between the Congo system of colonisation and those of its principal critic is the difference between a definite State policy which, having the land and its resources for its material basis, applies humane measures for enforcing its development for the benefit and civilisation of the native, and the permanent constitution of the State, and a policy the baneful influence and unprogressive operation of which can be observed in the protectorates and colonies of one of its neighbours, where the budgets are to a large degree sustained by the importation of alcohol as a beverage-a "civilising influence" which, to the honour of the Belgians, is almost entirely excluded from the Congo Free State.

The foregoing exposition of internal policy may be regarded as a brief statement of the principles which underlie the system of government in the Congo Free State.

That the United States did not construe an i1logical meaning into the phrase "freedom of commerce," and warp it out of all semblance to its 
natural character, is evidenced by the terms of its treaty with the Free State made seven years after

Treaty the promulgation of the General Act of between the Berlin Conference, during all of which congo State time the Congo State authorities had acted and United upon the interpretation of the phrase indi-
States

cated in Baron Lambermont's definition, and in the learned opinions of Maitres Barboux, Nys, Van Berchem, and Picard.

Article I. of the treaty of April 2, I892, between the United States and the Independent State of the Congo reads:

The citizens and inhabitants of the Independent State of the Congo in the United States of America and those of the United States of America in the Independent State of the Congo shall have reciprocally the right, on conforming to the laws of the country, to enter, travel, and reside in all parts of their respective territory; to carry on business there; and they shall enjoy in this respect for the protection of their persons and their property the same treatment and the same rights as the natives, or the citizens and inhabitants of the most favoured nation.

In this connection Sir Edward Malet, the British Plenipotentiary at the Conference, clearly pointed out that "freedom of commerce unchecked by reasonable control would degenerate into licence." Reasonable control is only another name for State law and police regulation. The Congo Government maintains that, subject to its internal laws and regulations which affect its own and foreign subjects alike, the subjects of every nation are free to enter 


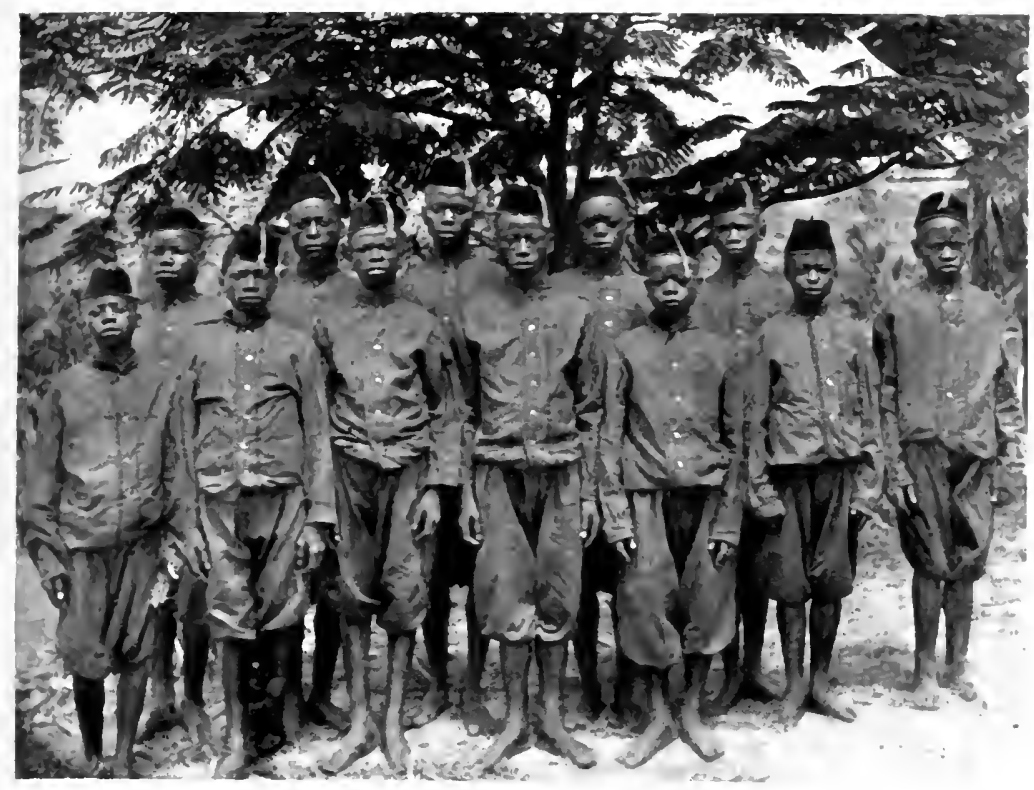

Students of the State Technical School, New Antwerp (Bangala).

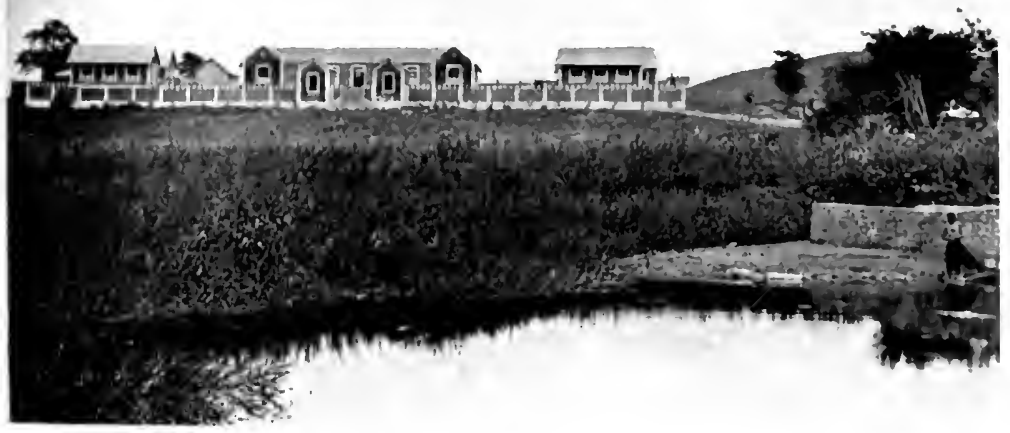

Hospital, Boma. 

its territory in pursuit of legitimate trade. Apropos of this phase of the subject Baron Descamps says:

The power of the State in this connection is incontestable. That power is derived directly from the primary right and duty to maintain public order everywhere and under all circumstances. Nobody can deny the State the right of taking steps, for example, for the preservation of public safety. Government cannot be carried on without a judicial and administrative police system, and a State could not renounce that prerogative' without laying. itself open to a charge of incapacity in its primary and essential functions. Hence, such a renunciation could not be argued from mere presumptions or inductions. ${ }^{2}$

Amongst the innovations attempted by the Berlin Act was that which sought, by Article IV., to abolish all import and transit dues. Little The serious account appears to have been taken Free-Trade - so far as the Act reveals - of the practical Policy necessity for erecting and sustaining works of public utility to commerce, and the equity of imposing proper charges on the wares upon which the benefits of such works were bestowed. The absolute prohibition of import duties created great difficulties for the Free State which, but for the personal munificence of its Sovereign, would have wrecked a liberal undertaking, handicapped and fettered by the fanciful legislation of the Berlin Conference,- "Merchandise imported into those regions shall remain free from import and transit dues." Fortunately the legislators of the Berlin Conference were not to become the practical governors of the Congo Free

${ }^{1}$ New Africa, p. 68. 
State, else they might have realised that the gravest body may enact farce and commit folly. It was the experiment of a new principle in colonial administrative economy which they aimed at, but there is a vast difference in substance between a mirage and a mountain. That there were misgivings in the mind of some members of the Conference as to the logic of driving traders into the Congo, on the one hand, utterly untaxed for the support of the Government and the security it afforded, while on the other the State was charged with the creation of public works and the maintenance of law and order without revenue, is manifested by that final clause of Article IV., which provides that "the Powers reserve to themselves to determine, after the lapse of twenty years, whether this freedom of import shall be retained or not." In this case the Powers did not wait twenty years to revise their principle of free trade. Five years were sufficient to reveal its inapplicability to a new country, and the Second Brussels Conference, assembled in 1890 , made of the freetrade clause of 1885 a clause allowing on merchandise other than spirituous liquors an impost not exceeding ten per cent. "It would never do," said Baron de Courcel, at the Conference, "to renew the colonial experience gained in the sixteenth century, when colonies were brought to ruin by those who pretended to fix in Europe, from a purely metropolitan point of view, their financial and administrative system." The experiment of prohibiting import duties proved, as already indicated, a serious hindrance to the economic life of the new State. 
That the experiment would not, however, be persisted in by the Powers, had been foreshadowed by the suggestion of Baron Lambermont at the Conference when he said: "It is experi-

A Temence which will then inspire the interested Experiment Powers with the most favourable resolutions for the development and commercial progress in their possessions." There were, therefore, after all, men of practical political foresight at the Conference, whose assent to so radical a policy of free trade was accorded for the purpose of the moment only, and while the great question of civilising Central African tribes dominated their early aims even to the disadvantage of the correlated questions of commerce. Article III. of the General Act, therefore, provided that: "Wares of whatever origin, imported into these regions, under whatsoever flag, by sea or river, or overland, shall be subject to no other taxes than such as may be levied as fair compensation for expenditure in the interest of trade, and which for this reason must be equally borne by the subjects themselves and by foreigners of all nationalities." The reasons actuating the Berlin Conference not to fix the rate of such taxation as it provided for at the Brussels Conference, are clearly indicated on page 85 of the protocols to the General Act, from which the following declaration is quoted:

The rate of the taxes of compensation is not fixed in any definite manner. The support of foreign capital ought to be placed, with commercial freedom, amongst the most useful aids to the spirit of enterprise, whether it has reference to the execution of works of public interest or whether it has in view 
the development of the cultivation of the natural products of the African soil. But capital only goes, in general, to places where the risks are sufficiently covered by the chances of profit. The Commission has therefore thought that there would result more disadvantages than advantages from binding too strictly, by restrictions arranged in advance, the liberty of action of public powers or of concessions. If abuses should arise, if the taxes threatened to attain an excessive rate, the cure would be found in the interest of the authorities or of the contractors, seeing that commerce, as experience has more than once proved, would turn away from establishments the access to, or use of which, had been rendered too burdensome.

That contribution by traders to the maintenance of the State under a system of taxation and police regulation is not incompatible with commercial freedom was forcibly reiterated at the Conference by Count de Launay and, of course, by other members who at all dwelt upon a principle so well established. Treating this question with much erudition, Baron Descamps cites the French law of March 2, I 79I, relating to patents, which, he says, "gave the most emphatic assent of modern times to the principle of commercial freedom. The very clause proclaiming freedom of commerce provided for licence dues! Thus: 'Everybody shall be free to carry on any business he chooses; [sic] but he must first obtain, and pay for, a licence, and submit to any regulations of police that may be made.' ",

Obviously the "freedom of commerce" intended by the General Act of the Berlin Conference is not the open door with the key thrown away and ehaos

I New Africa, p. 67. 
prevailing behind it. The State is mistress of her domain. She is alone responsible for its civil order and the just regulation of its life, whether. social, commercial, or political. Her atti- Door and tude upon all fundamental rules of civilised Chaos government has two facets: the one toward her subjects, the other toward the society of nations which surrounds her. She must conduct her affairs with due regard for those broad principles of national morality which civilised communities recognise as a lofty standard of social and political life. Until she prove herself incompetent in this respect, her territory cannot become the subject of international partition or regulation on pretexts of humanitarianism or on any other, nor is it in the justice of nations or of men to undermine the force of her authority or to enfeeble the integrity of her Statehood by any agency whatsoever.

From the latest report of the Vice-GovernorGeneral of the Congo Free State are quoted below statements which shed light upon the belief held by the Belgians concerning their own fiscal policy, and the attitude they

Conditions in 1895 offer to the criticisms of its burly neighbour, Great Britain, in its rule of the Soudan and its other colonial possessions:

In the region of commerce the Congo State, which was the first to inscribe in its international conventions the principles of liberty, has not failed, no matter what any one says to the contrary, in the programme which was drawn up in 1884 , and of which, as has recently been recalled, Stanley was made the spokesman. The régime of the "open door," which has 
just been claimed by the Liverpool Chamber of Commerce, at the very moment, too, when purely philanthropic declarations were being heard in the House of Commons, is that also of the Congo State; and there cannot be discovered in our territory the existence of monopolies such as those of ivory and rubber which the Government of the Soudan has created for its own profit in some parts of the Soudan. ${ }^{x}$

The traders of all nations may sell on the Congo the objects of their commerce, and buy the natural produce from the proprietors of the soil; no limit, no hindrance is placed on this traffic, and that is really freedom of trade. That this freedom may remain complete notwithstanding the existence of the domain rights, and the granting of concessions, has been proved up to the hilt, and to declare, as has been done in the House of Commons, that trade does not exist on the Congo is to put oneself in contradiction with the law and the facts. These statements, by repetition, end by being considered as axioms, and it is not realised that they still await proof. The régime of concessions, besides, has not been established for the exclusive advantage or benefit of the Belgians; the opening was given to foreign initiative and capital without distinction to become interested in the development of the country, and if, by a want of confidence that the event has not justified, English capital was withdrawn from some Congolese undertakings, the prosperous condition of which is now made a grievance, it does not follow therefrom that those who did run the risk inherent in enterprises in new countries should see to-day the results of their efforts and their perseverance assailed.

It is to the astonishment, not to say to the general indignation, of the handful of Europeans who are working, and undergoing hardships on the spot, that these attempts are

I Soudan Gazette, published by authority of the Soudan Government, No. 47, Khartoum, ist May, I903: "It is notified for information that the following articles are governmental monopolies in the following districts: Rubber and gutta percha, in the whole of the Soudan, excepting Kordofan. Ivory, in the Bahr-el-Ghazal and Fashoda. . . . (Signed) Reginald Wingate, Governor-General." 
made abroad to represent them all, from the highest place to the most obscure of the assistants, as associated in an odious work of destruction and inhumanity. The duty of protesting against this legend is imposed on whoever has seen with his own eyes these territories, once disinherited, being opened to civilisation, evangelisation, and progress; populations, formerly troops of slaves, reborn to confidence and freedom; the rapid economic equipment, the railways under exploitation or construction, a flotilla which covers the river and its affluents, routes which open up the most distant regions, telegraphic and telephonic lines to the Upper River, cultivation and plantation gradually extending, cattle introduced into every district, mission establishments opened in all parts, vaccine institutions, and services of medical, sanitary, and hygienic orders. Such are some of the results of what has been called the system of the State, a system which was inspired before everything by the vows of the Berlin and Brussels Conferences, and it could not be explained how it has been possible for the State's adversaries to cry it down if it were not known that their customary tactics are to lay stress on the inevitable imperfections of a work of that extent still, after all, in the stage of its beginning.

As concerns cotton, which before the Mahdist invasion was seemingly cultivated in a sufficiently considerable degree, I hold it on good authority that in Cairo and Lower Egypt some little disquietude is being shown on the subject of the activity displayed by the Belgians on the Upper Nile, and that some apprehension is felt there of a cotton competition in the near future. 


\section{CHAPTER X}

AN APPEAL TO BELGIUM TO SUPPRESS THE SLAVE TRADE

CLAVERY is as ancient as war, and war as old $S$

as human nature. Upon this premise Voltaire philosophised when his thought reverted to the early inequity of human life. Christian nations were deep in the slave trade in the sixteenth century. A black cloud of human flesh, aggregating sixteen million souls, was imported into America upon Western slave dhows in three centuries, exclusive of the twenty-odd million Negroes who perished in transit. More atrocious than the pestilential slave dhow was the slaughter of blacks by the slave-raider, that fiend incarnate who until a few years ago carried on his inhuman traffic under the very gaze of Christian Europe. Indeed, Europe herself was a slave-dealer for centuries. Some of her Governments sanctioned it in terms unspeakably callous. There was little pity and less mercy in officially lading "tons of niggers" for American ports.

Late in the eighteenth century, Great Britain had championed the cause of humanity and sought a remedy for the horrible conditions which slavery entailed. The movement which, assuming definite 


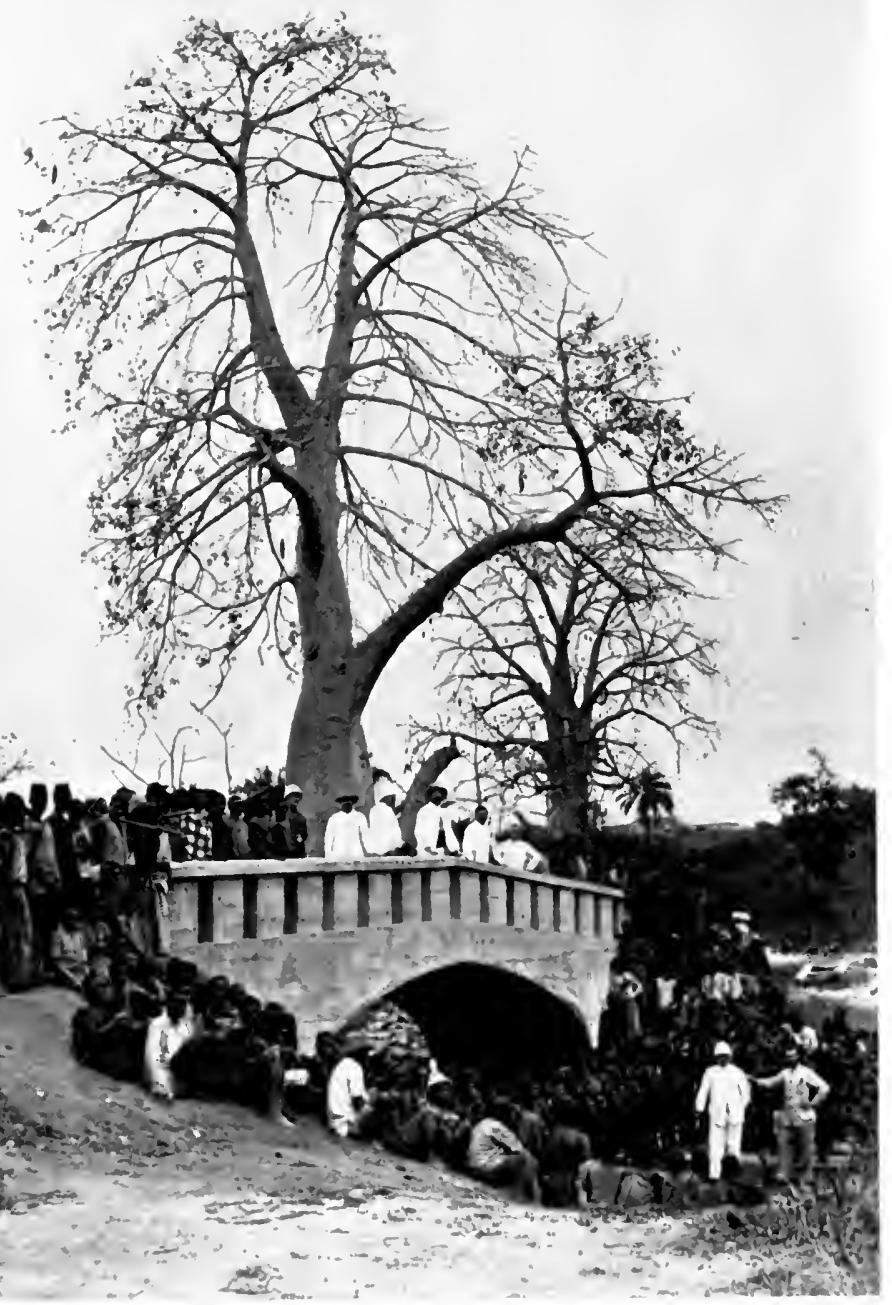

Bridge Made of Cement, Boma. 

shape about the time of the Declaration of Independence, had found able and eloquent advocacy in such men as Granville Sharpe, Clarkson, Wilberforce, and William Pitt. These staunch humanitarians, after what seemed the hopeless labour of many years, finally triumphed so far as to impel the Vienna Congress of $18{ }_{1} 5$ and the Verona Congress of 1822 to forbid any civilised nation to carry on the slave trade.

The next steps, also furthered by the British Government, sought to abolish the legal status of slavery and to suppress slave markets and slave dhows. The Western world began to awaken to a sense of duty. In all directions the noble initiative taken by Great Britain found earnest agency. The Christian nations, now thoroughly aroused to the iniquity of the slave trade, exchanged treaties in I84I, the operation of which was designed to clear the ocean of slave transports. When shut out of the American market, it was believed that the infamous slave traffic would subside. But the scourge continued almost unabated. Driven out of the West, it flourished the more in the East, where large markets still remained open. The northern and eastern coasts of Africa continued to supply the Oriental markets, the Soudan, Upper Nile, and Congo Basin being the slave-hunter's Elysium. The Sultans of the Soudan, whose avarice knew no limit, strove in the cruellest manner to increase their spoil in this man-hunting chase. Khartoum slavers pressed into the Bhar-el-Ghazal, while the Arabs from Zanzibar devastated the Manyema and 
Tanganyika regions. West-coast raiders had even penetrated as far inland as the Upper Kassai, and created that wretched condition of native life in the interior of the Congo Basin which impressed Livingstone, Stanley, Kirk, Bartle Frere, Nachtigal, Wissmann, Serpa Pinto, Massaia, and that great exemplar of Christianising work, Cardinal Lavigerie.

In 1876 , nearly ten years before the Berlin Conference, the King of the Belgians called upon Europe to join in a concerted movement to suppress the slave traffic in Central Africa. In the same year the British Government published its Report of the Royal Commission on Fugitive Slaves. The words of Prince Bismarck at the Berlin Conference of 1885 were an intimation of the legislation which was thereafter effected by clauses 6 and 9 of the General Act. By clause 6 , the Powers agreed "to watch over the preservation of the native tribes and to care for the improvement of the conditions of their moral and material well-being, and to help in suppressing slavery and especially the slave trade." Baron Lambermont stated the distinction between slavery and the slave trade: "The slave trade," said the Baron, "has another character; it is the very denial of every law, of all social order. Man-hunting constitutes a crime of high treason againt humanity. It ought to be repressed wherever it can be reached, on land as well as by sea."

It was with characteristic activity that the Sovereign of the Congo Free State had taken the initiative in making the suppression of the slave traffic an essential aim in the civilisation of an African State 
which had not only been the source of slave supply for many markets, but whose territory touched closely upon a number of slave-dealing countries. In the eighteenth century, the nations of Europe had partitioned the coast of Africa to the French between Senegal and Gambia, to the British on the Gold and Ivory coasts, and to the Portuguese in the Angola and Benguela regions. The object of this territorial apportionment was to facilitate the slave trade and render it more profitable! Now, in the nineteenth century, these same Governments were dividing African territory with the much loftier purpose of extirpating the slave trade. The march of a hundred years had raised European morality and justified the Christian influence of the age.

Undaunted by the material difficulty of realising the excellent theories which European nations were now offering to carry out in the very nest of the slave trade, the Congo Free State formally tackled the problem by promulgating three decrees in November, 1888. The first provided practical means for suppressing the slave trade, amongst which were measures prohibiting trade in firearms, gunpowder, and explosives; the second, seeking to protect and improve the natives, dealt with contracts of service between natives and foreigners, and enacted laws which guaranteed the former from imposition. The third decree established a body of volunteer police to suppress crimes and offences against public order and individual liberty. Then followed the organisation of the Belgian Anti-Slavery Society which, creating a special volunteer corps, operated against 
the slave-raiders in the Tanganyika district. Reference has elsewhere been made to the vigorous manner in which these and similar decrees were enforced, and how the slave-raider was driven from one lair to another, until, almost unaided and alone, the indomitable energy of Belgian officers succeeded in uprooting the institution of slave traffic and opening an immense river basin to the pursuits of civilisation.

A great wave of sympathy for all enslaved races had spread throughout the civilised world. Nations heretofore indifferent to the weal of the black man in the brutal toils of the slave-raider, were actuated by a desire to co-operate with the practical forces already at work for emancipating the Dark Continent. All religions combined in the motherhood of the human race and, now thoroughly alive to the principle of human liberty, lent their support to the great cause of African civilisation. The movement, now become general throughout Europe, gained impetus in 1888 by the abolition of slavery in Brazil. In that year, Pope Leo XIII. reiterated the appeal made by Leopold II. in 1876 , and besought all nations to unite in purging the page of history of a further record of the abominable crime of slavehunting. In addressing that wonderful engine of missionary work, Cardinal Lavigerie, His Holiness pointed out the misery of "that disinherited land," and urged all who are moved by human impulse to devote their lives to "this sublime work of redemption."

The self-sacrificing work which Cardinal Lavigerie has done for the salvation of Africa will for ever 


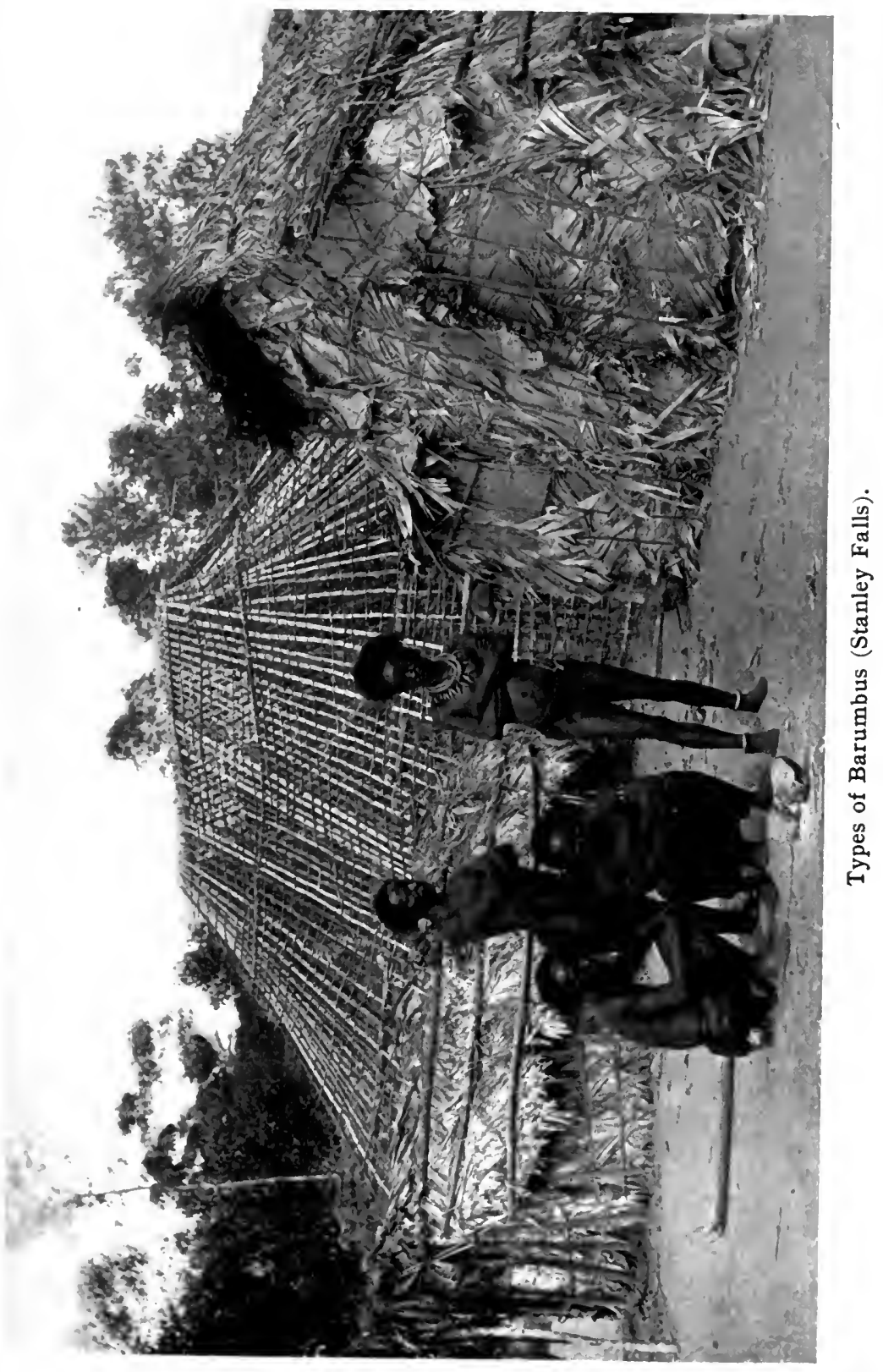





\section{An Appeal to Belgium}

be a white monument in a black wilderness. It was his appeal to the peoples of the Christian world which witnessed the first organised work of Leopold II., and it is this prelate's indefatigable industry, and his love for these savage souls of Africa, which has largely carried that work to its present fruition.

The world-wide adhesion to the cause of Christianising the Dark Continent took diplomatic shape soon after a meeting held in London on July $3 \mathrm{I}$, I888, at which Lord Granville presided. On motion of Cardinal Manning, the following resolution was adopted:

The time has now fully arrived when the several nations of Europe who, at the Congress of Vienna, in 1815 , and again at the Conference of Verona, in 1822, issued a series of resolutions strongly denouncing the slave trade, should take the needful steps for giving them a full and practical effect. And, inasmuch as the Arab marauders (whose murderous devastations are now depopulating Africa) are subject to no law, and under no responsible rule, it devolves on the Powers of Europe to secure their suppression throughout all territories over which they have any control. This meeting would, therefore, urge upon Her Majesty's Govermnent, in concert with those Powers who now claim either territorial possession or territorial influence in Africa, to adopt such measures as shall secure the extinction of the devastating slave trade which is now carried on by those enemies of the human race. ${ }^{x}$

On October 27 th, an anti-slavery convention was held at Cologne, at which the following resolutions were passed and sent to the Reichstag:

I-The suppression of slave-hunting with its attendant horrors, devolves upon Christian States and constitutes the primary condition of the abolition of the slave trade.

I Times, London, August I, 1888. 
2-While the Congo Conference obliges all the Signatory Powers to help in the suppression of slavery and the improvement of the lot of the natives, at the same time the Congo State, Portugal, Great Britain, and Germany, as being directly threatened by Arab slave-traders, are expected to take the initiative in, and to bring to a successful issue, the struggle against the slave trade.

3-The meeting expresses the conviction that the honour of the German flag and German interests, which have been violated by Arab slave-traders in East Africa, will be avenged by the Imperial Government.

4-It also expresses the hope that the Reichstag will support these resolutions, as a proof of the perfect agreement of the German nation without distinction of party or creed.

On November I 3 , the Cabinets of Berlin, London and Lisbon had agreed upon coercive measures against slave-traders on the East Coast of Africa. Meantime, on September I 7, I888, the British Government had appealed, through the Belgian Foreign Office, to King Leopold to take the initiative in assembling a Conference at Brussels to consider the subject. In conveying this invitation to the King of the Belgians, the British Minister to the Belgian Court stated that:

The change which has occurred in the political condition of the African Coast to-day calls for common action on the part of the Powers responsible for the control of that Coast. That action should tend to close all foreign slave-markets, and should also result in putting down slave-hunting in the interior.

The great work undertaken by the King of the Belgians, in the constitution of the Congo State, and the lively interest taken by His Majesty in all questions affecting the welfare of the African races, lead Her Majesty's Government to hope 


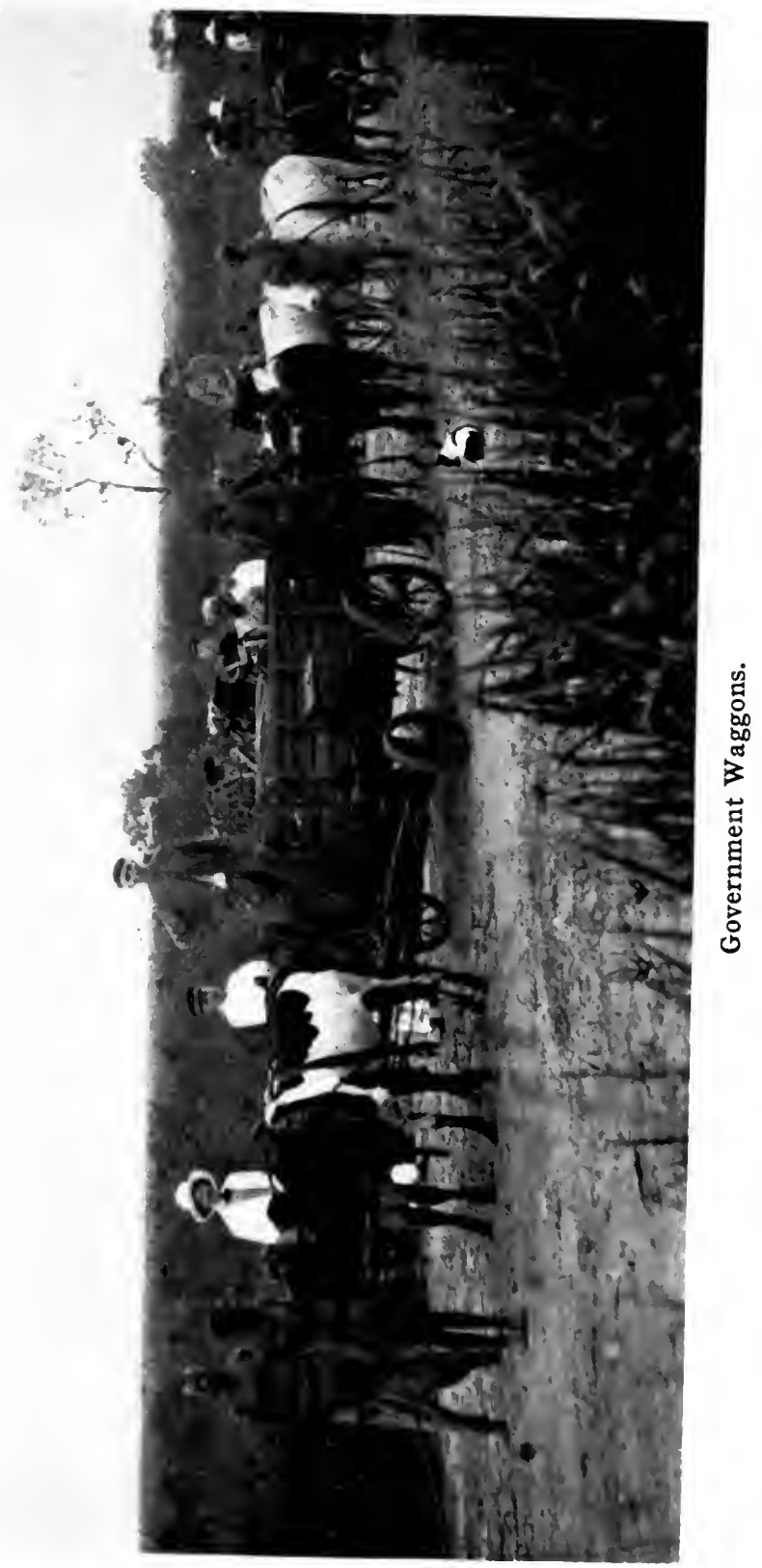





\section{An Appeal to Belgium}

that Belgium will be disposed to take the initiative in inviting the Powers to meet in Conference at Brussels, in order to consider the best means of attaining the gradual suppression of the slave trade on the Continent of Africa and the immediate closing of all the outside markets which the slave trade daily continues to supply.

On August 24, I889, King Leopold deferred to this wish and called a Conference of the Powers for November 18,1889 , to determine upon a course of action for the gradual suppression of slave-hunting on the African Continent and the immediate closing of all markets supplied from that source, and "to put an end to the crimes and devastation wrought by the slave trade, and effectively to protect the native populations in Africa."

Thus, after thirteen years of arduous labour, and the vicissitudes which attend the progressive pioneer in savage lands, where the mission and the plough follow the white man's trail, the Belgians were again called upon to lead in a war against the most degrading of human conditions. 


\section{CHAPTER XI}

\section{THE SECOND BRUSSELS CONFERENCE}

\section{T}

HE zealous labours of Cardinal Lavigerie, Archbishop of Algiers, who had founded the Mission of the White Fathers in 1878 to convert the Soudan and the Congo regions to Christianity, had always been generously supported by the per-

King and sonal munificence of King Leopold. The Cardinal.

rescript issued to this devoted and untiring apostle by Pope Leo XIII. had inaugurated endeavours on behalf of civilisation unexcelled in any colony in the world. King Leopold's earnest and generous encouragement of this evangelistic work equalled the broad-minded and hopeful manner in which he supported Stanley and others in their early expeditions through the unknown forests of the Congo. There was, therefore, a sympathetic tie between His Holiness, the King, and the Cardinal in the world's task in Congoland.

Early in 1888 Cardinal Lavigerie visited Belgium, and, being convinced by his long African experience The Anti- of the necessity for an organised antiSlavery slavery crusade, opened a campaign in the crusade. Brussels Cathedral which, by its popular interest, carried him to many parts of Europe. The eloquence of this truly great prelate was born of 


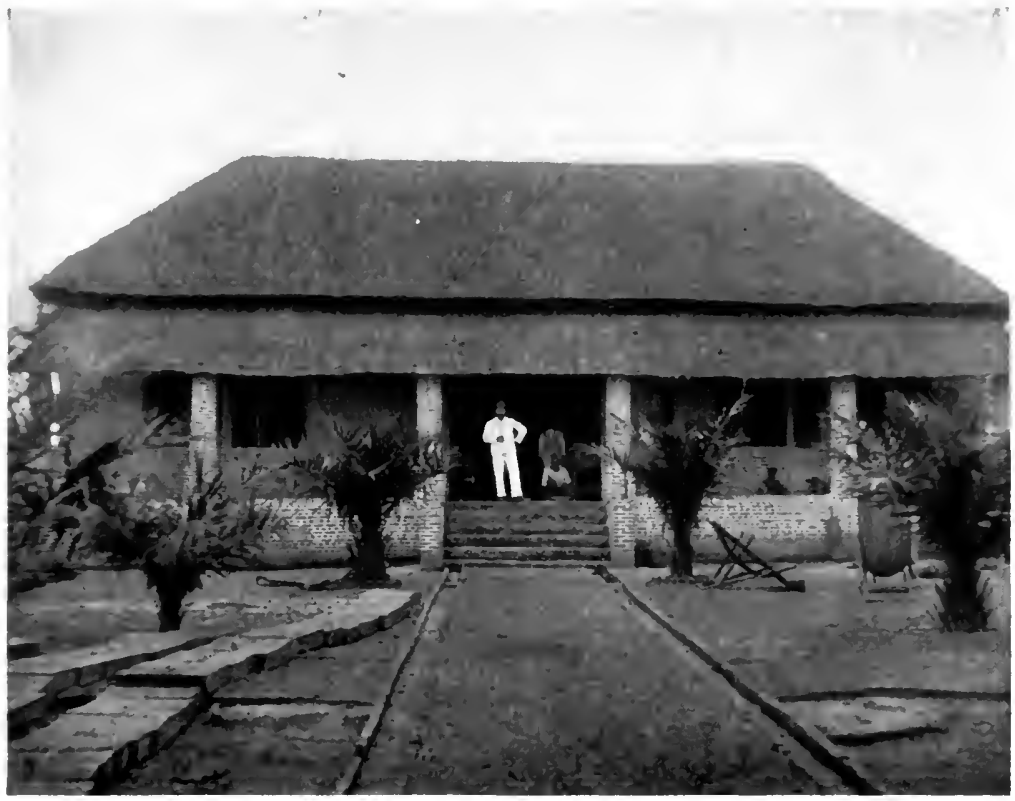

Postmaster's House, Suruango, 1904 .

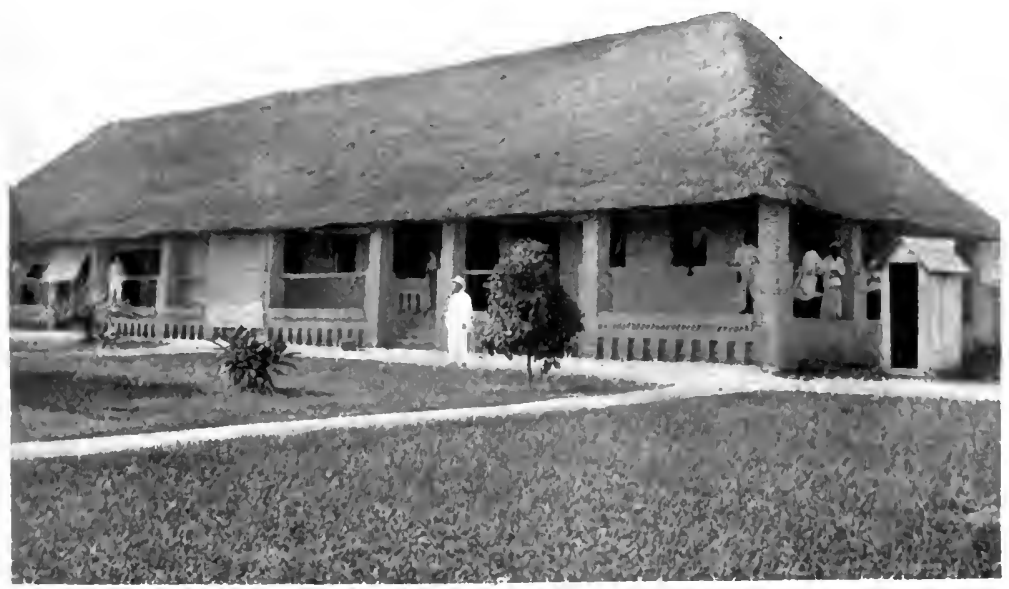

House of Vice-Governor-General, Stanleyville. 

that deep sympathy for the African black derived from his intimate knowledge of the debasing conditions still prevalent in those parts of the Congo Basin where, for many practical reasons, the Belgians had not penetrated with their work and influence. The Cardinal exhorted the Belgians, first of all, to support and emulate their King, who, he said, "would open before you a country seventy times as large as your own-an immense field for the spread of your religion and for charity. . . . You have not given to the struggle with barbarisn all the assistance that was incumbent upon you."

To the avowed support given by his Majesty to the movement which the Cardinal's numerous sermons inspired, may largely be attributed the Belgian campaigns against the Arab slave-raiders which the Brussels Conference of the following year urged upon the interested Powers.

The hundred admirable articles of the General Act of the Conference do not all concern the reader. Their general purpose, already indicated in a previous chapter, was the suppression of the slave trade, the protection of the natives, and the provision of revenue from import duties wherewith to maintain a practical executive to accomplish both aims.

The Conference convened on November I8, I889, and held the last of its thirty-three sessions on the July 2, I89o. The King. of the Belgians had again welcomed the representatives of all the Powers party to the Berlin Act. Persia, having meantime adhered to that Act, was also represented. The Prince de Chimay, Belgian Minister for Foreign 
Affairs, presided at the formal opening of the Conference. At its first session Baron Lambermont was unanimously elected to preside over its deliberations. His able associate at Berlin, M. Emile Banning, also represented Belgium at this Conference, while Baron Van Eetvelde, for many years devoted to its moral and material development, represented the Congo Free State. Chief among other distinguished representatives were Count von Alvensleben for Germany, M. Bourée for France, Lord Vivian and Sir John Kirk for Great Britain, Mr. Terrell, Minister at Brussels, for the United States, and Prince Ourroussof and Professor Martens for Russia.

Foremost in the work of framing a proposed Act, under which the Congo Free State inherited great responsibility and a tremendous task, were the Belgian representatives. The other interested Powers pledged themselves to join, each in its own territory, in the anti-slavery campaign which the Act prescribed. Briefly stated, the signatories to the General Act of this Conference declared that they were "animated by the firm intention of putting an end to the crimes and devastation engendered by the traffic in African slaves, of protecting effectually the aboriginal populations of Africa, and of insuring for that vast continent the benefits of peace and civilisation."

The first article, relating to effective methods of The suppressing slave-raiding in the Congo BaGeneral sin, was divided into seven sections:

Act.

The first provided for the progressive organisation of ad- 
ministrative, judicial, religious, and military services-in fact, the whole machinery of government. The second remedy was to be the gradual establishment in the interior of strong protective and repressive stations. The third clause provided for the construction of roads and railroads, so that human porterage might be ended. The fourth, for the placing of steamers on the lakes and inland waters. The fifth, for the laying down of telegraph lines. And the sixth, for the organisation of expeditions by movable columns. While these clauses were of an active character, the seventh came under the head of prohibition. It provided for restriction in the import of firearms, and especially of modern rifles and ammunition, within the whole extent of the territory affected by the slave trade. The General Act only provided for the restriction in the import of firearms; but the King, in the administrative decree, applying its provisions to the Congo State, interdicted the importation, traffic, and transport of all rifles, as well as of powder, bullets, and cartridges. The same decree imposed severe penalties on those who in any way violated these regulations.

The second article of the Act laid down that "the stations and the interior cruisers shall have for their object the prevention of the capture of slaves, and the interception of the routes of transit. They shall extend their efficacious protection over all the dependent populations within the range of their authority, by prohibiting intestine war, and by initiating them into agricultural labour. They will assist commerce, verifying labour contracts; they will aid the missions, and they will organise a sanitary service." I

The second article, recognising the duty of the Powers to prevent slave-raiding in the territory under their control, adopted, amongst others, the following prescription:

To support and, if necessary, to serve as a refuge for the native populations; to place those under their sovereignty

I Boulger, The Congo State, 1898 . 
in a position to co-operate for their own defence; to diminish intertribal wars by means of arbitration; to initiate the natives in agricultural pursuits and industrial arts, so as to increase their welfare; to raise them by civilisation and bring about the extinction of barbarous customs, such as cannibalism and human sacrifices; and, in giving aid to commercial enterprises, to watch over their legality, controlling especially the contracts for service entered into with natives.

The third and fourth articles contained the pledge of all the interested Powers to assist in enforcing these commendable provisions for the betterment of the black races in Africa. The succeeding apathy of the Powers in no wise abated the energy of the Congo Free State in its heroic effort to realise for civilisation the views which Belgian statesmen had largely inspired at the Conference. The Belgian campaigns against the Arabs, briefly narrated in succeeding chapters, were only one phase of those multiform difficulties which beset the pioneer in savage lands where the heralds of civilisation find it necessary to suppress the old and impose a new order of life upon untutored human beings.

The second chapter referred, amongst other things, to caravan routes, the transport of slaves by land, Alcohol and to providing means of livelihood and and education for liberated slaves. The sixth Civilisation. chapter enumerated the measures to be taken to restrict the trade in spirituous liquors. The six articles composing this chapter forbid the importation of distilled drinks " in the regions where they have not yet penetrated," and "each Power will determine for itself the limit of this zone within its own possessions." It is in reference to these 


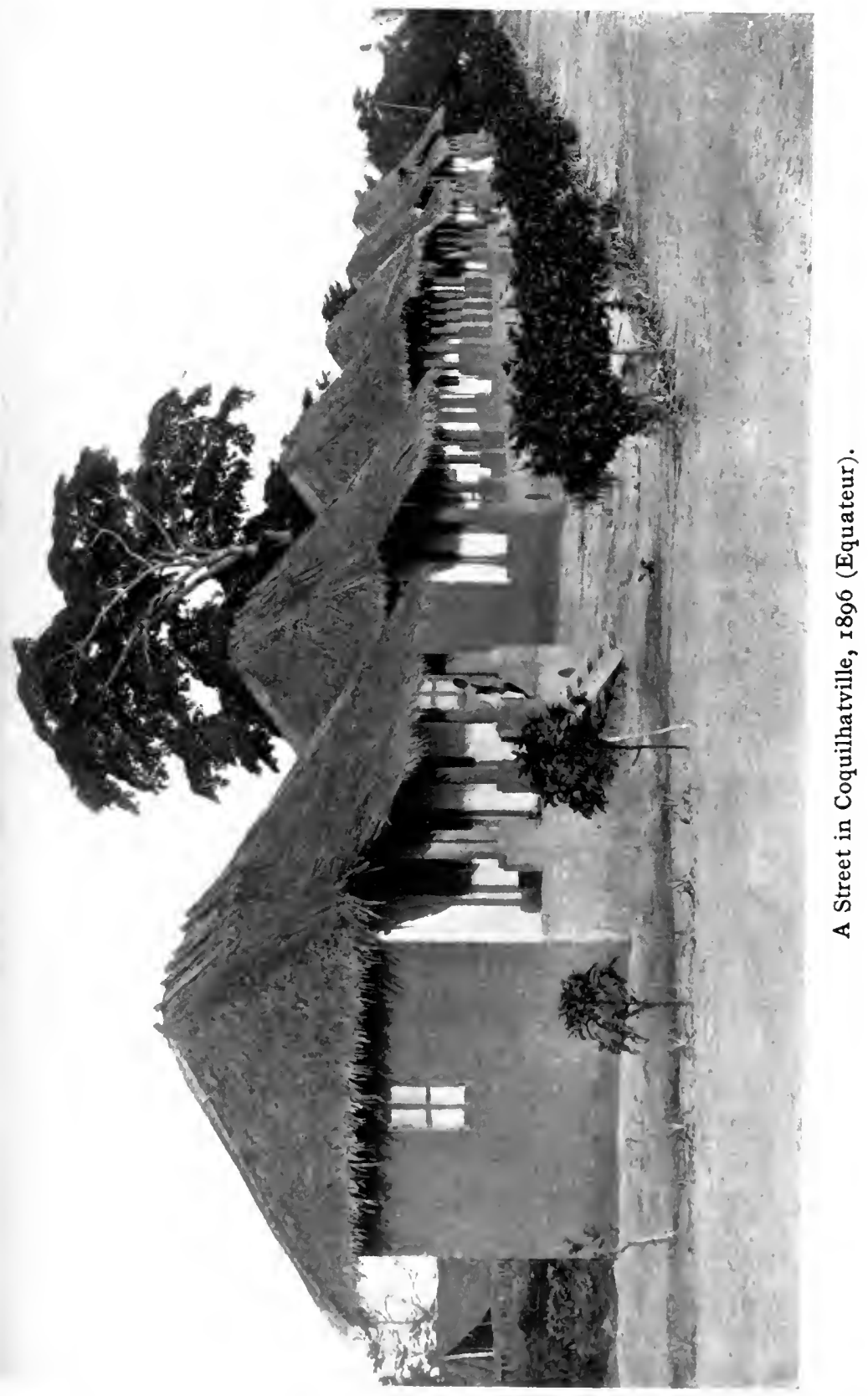



infirm clauses, as elastic as Congo rubber, that the Free State has fulfilled promise with performance that puts her neighbours to shame. Each year of Belgian rule in the Congo has been marked by a contraction of the area in which alcoholic liquors are legitimate traffic even in a restricted form. Today spirituous liquors are practically excluded from more than four-fifths of the entire State. The Sovereign of the Congo Free State does not respect that colonising enthusiasm which is founded on deleterious Scotch whiskey, Holland gin, and Jamaica rum. He has, therefore, carried out the spirit as well as the letter of the liquor clauses in the Brussels Act, and lost revenue for the State from a source which, to a large degree, supports the budgets of neighbouring colonies.

In the eighth article it is declared that

the experience of all nations who have intercourse with Africa has shown the pernicious and preponderating part played by firearms in slave trade operations as well as in intertribal wars, and has clearly proved that the preservation of the African populations is a radical impossibility unless restrictive measures against the trade in firearms and ammunition are established.

It was, therefore, stipulated that in those parts of Africa between the twentieth parallel of north latitude and the twenty-second parallel of south latitude the importation of firearms, and especially of rifles and weapons of precision, powder, balls, and cartridges, should be greatly restricted, and as far as possible prohibited. The only exceptions in later articles to this prescription were made in favour of 
"measures directly by governments for arming of a force publique and the organisation of their defence."

To carry out the onerous duties imposed by the Brussels Act upon all the interested Powers reAttitude quired more than a Conference and its of the lofty ideals and appropriate resolutions. Powers. By the Berlin Act import duties had been prohibited in the Congo Basin only as an experiment. The attitude of the Powers towards this question was now more enlightened and more reasonable. Experience, and admiration for King Leopold's rapid acheivements in the development of the new State, combined, in the face of the slaveraiding enemy, to predispose the representatives of the Powers to a rational view of the practical necessities of governments which were called upon to establish order and a civil community upon the trail of the murderous slave-chaser.

At the thirteenth session of the Conference, held on May Io, I89o, it was proposed that the stipulation of the Berlin Conference prohibiting Import Duties. all import duties for twenty years should be withdrawn, and that the "assenting Powers having possessions or protectorates in the Conventional Basin of the Congo shall be at liberty, so far as authority to this end is required, to establish duties on imported goods, the scale of which shall not exceed a rate equivalent to ten per cent. ad valorem at the port of entry, always excepting spirituous liquors." Applying especially to spirituous liquors are the provisions of articles 90 to 95 of the General Act. 
In supporting this measure, Baron Lambermont said:

Not only has geographical acquaintance with the Congo Basin revealed the wealth of the vast regions it comprises, but European commerce, which was blocked at a short distance from the coast, has penetrated the heart of Africa, in countries hitherto utterly unknown. Civilisation, in divers forms, has made no less progress, and has been permanently established in the very centre of Africa. The rapidity with which this transformation has been accomplished would seem to make it a duty to hasten the revision of the free-trade rule temporarily laid down by the Berlin General Act. The protection due to commerce and missions, the establishment of systematic justice, the opening up of easier means of communication with the interior of the continent, the organisation of public services as auxiliaries to private enterprises, require financial resources which it is reasonable to obtain, by means of imposts, from those who profit by the new order of things. While in most of the African colonies tariffs are among the principal sources of revenue, the countries situated in the Conventional Basin of the Congo alone are deprived of the right of levying customs duties; and yet these are the countries that find themselves at the front in the crusade against the slave trade! The resolutions of the Brussels Conference, in imposing on them new tasks, will also increase the expenses necessary for the carrying out of their civilising mission. The legitimacy of import duties destined to meet these expenses cannot be denied.

In the debate which naturally ensued upon such an important measure, Baron Gericke d'Herwijnen, representing Holland, which has a large spirit trade along the West Coast of Africa, opposed views for a time unfavourable to the adoption of this supplementary Declaration ${ }^{\mathrm{I}}$ to the General Act.

rSee Appendix for full text. 
Notwithstanding his views, the Dutch representative gracefully alluded to "the well-merited homage it [Holland] had rendered to the work of the King of the Belgians from its very commencement."

On the part of Great Britain, Lord Vivian supported the proposition in words which should sear the few unkindly, astigmatic eyes of those who regard King Leopold's rule in Africa with splenetic gaze and caterwauling. His lordship spoke aptly when he said:

As to the question whether this modification is opportune, the fact must not be lost sight of that the Berlin Conference never intended to fix unalterably the economic system of the Free State, which, as was already then foreseen, would undergo radical modifications under the influence of progress, nor to establish for an indefinite period regulations which may hinder, check, and even arrest its development. Provision was wisely made for the probability of future changes, which would require a certain latitude in economic matters in order to secure their easy realisation.

The moment has now come when the marvellous progress made by the infant State is creating fresh needs, when it would be only in accordance with wisdom and foresight to revise an economic system primarily adapted to a creative and transitional period.

Can we blame the infant State for a progress which, in its rapidity, has surpassed the most optimistic forecasts? Can we hinder and arrest this progress in refusing her the means necessary for her development? Can we condemn the Sovereign who has already made such great sacrifices to support for an indefinite period a burden which daily becomes heavier, and at the same time impose upon him new and heavy expenses necessitated by the suppression of the slave trade?

We are convinced that there will be but one answer to these questions. 


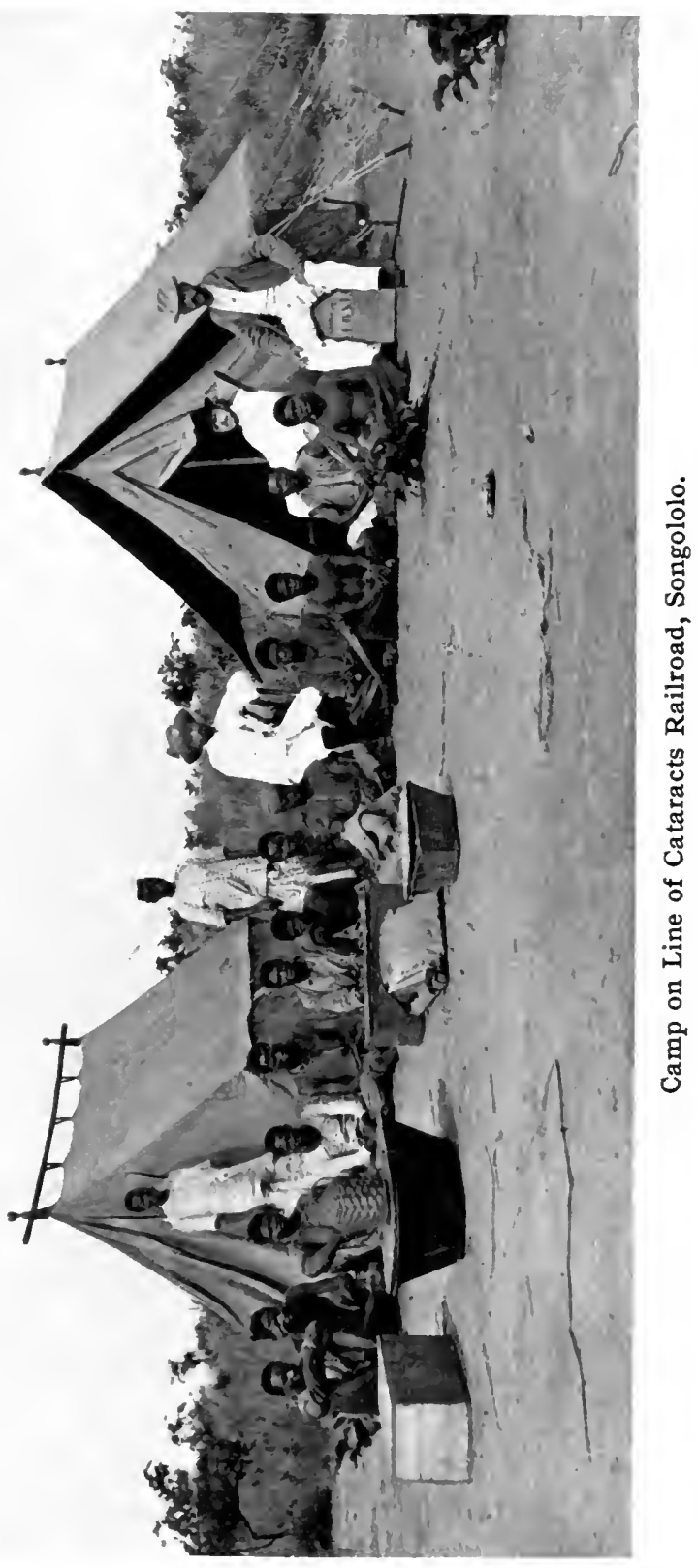





\section{The Second Brussels Conference}

Following the British representative.in support of the proposal, Count von Alvensleben, the German Minister, expressed himself as follows:

The Imperial Government will be glad to have such an opportunity of showing its sentiments of sympathy for the Congo Free State, which, under the wise direction of its august Sovereign, has given such striking proofs of vitality.

The German Government will willingly lend its help in placing the Congo Free State in a. position to acquire the means which may seem necessary to assist its development and to enable it to continue its valuable services to the cause of civilisation and humanity.

Indeed, the expressions of appreciation of the Belgian work in the Congo were unanimous and enthusiastic. The Declaration was adopted, France and and became part of the General Act of the the Slave Brussels Conference by the ratification of Trade. all the Powers-the Dutch Chambers sanctioning the ratification on the intervention of the Queen Regent, mother of the present Queen, Wilhelmina. In giving her adhesion France did so with the reservation that she "would not recognise the articles relating to the zone of maritime search, jurisprudence, arrest, seizure, and condemnation of suspected ships." This has always been regarded as a flaw in the effort of the Powers to suppress the slave traffic with unity of force and aim. France's remarkable reservation. has had the effect of affording to slave-dealers the only existing protection of a civilised Government on the East African Coast. The motive for this is revealed in the fact that slavedealers are still employed in the French possessions 
I44 Story of the Congo Free State

of the Indian Ocean. ${ }^{x}$ It is to be regretted that republican France should stand out from that solid phalanx of the Powers by which alone the abominable institution of slavery can be stricken from the calendar of modern crime.

'Boulger. 


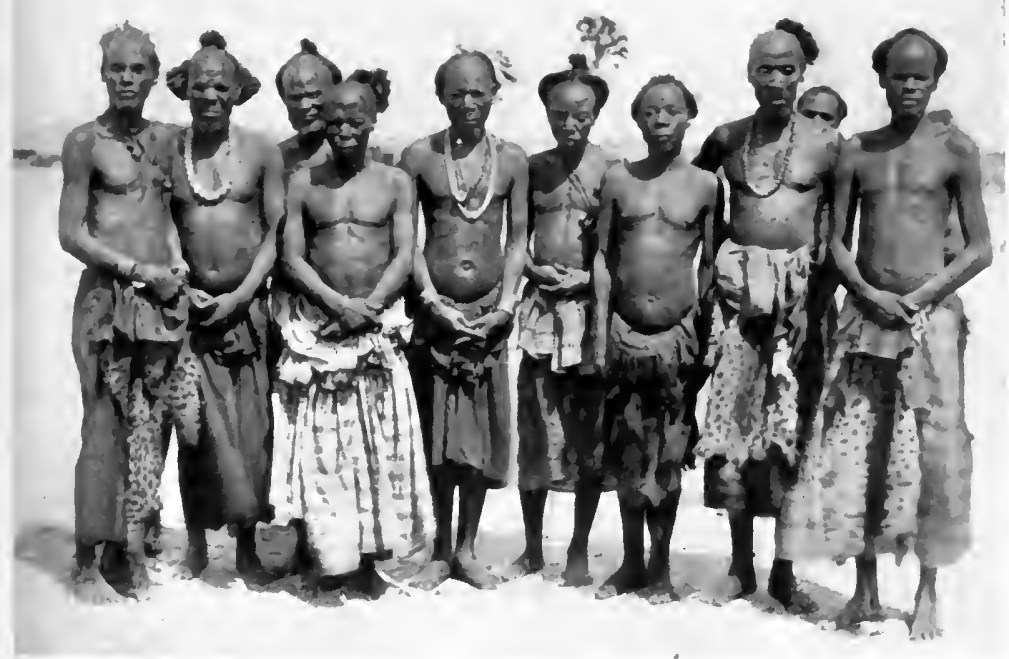

Baluba Chiefs.

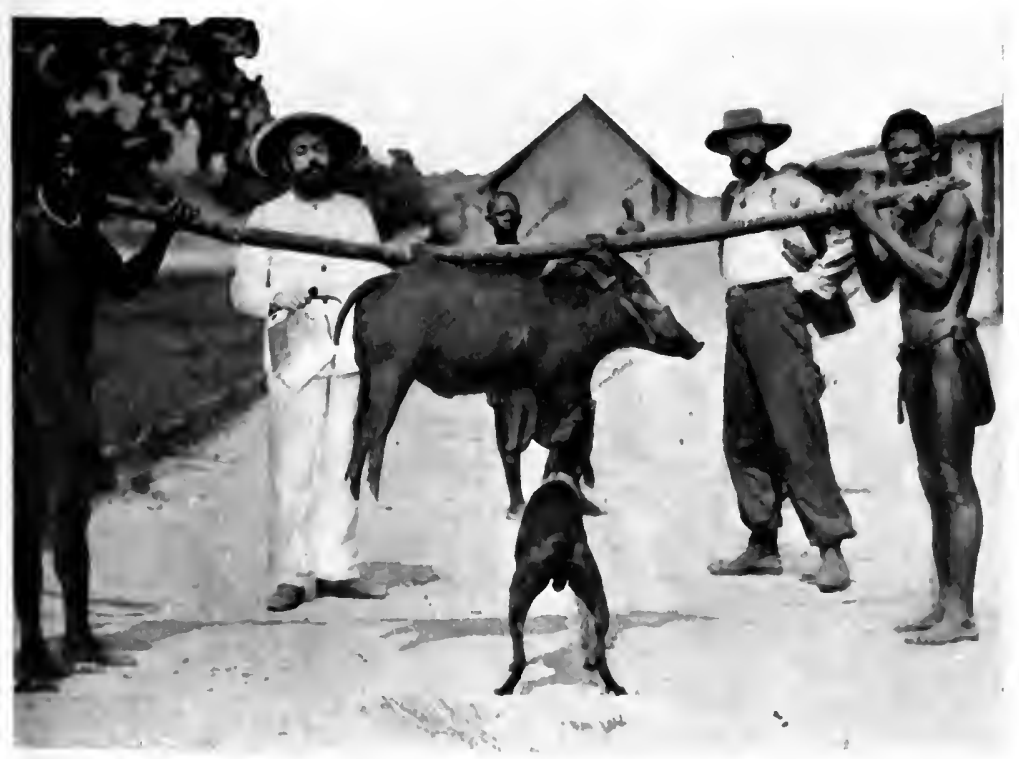

Return from the Hunt at Bumba (Bangala). 



\section{CHAPTER XII}

THE CONGO BEQUEATHED TO BELGIUM

THE Declaration supplemental to the General Act of the Brussels Conference, referred to in the previous chapter, assured an income to the Congo Free State, which, however inadequate for its needs at that time, served, in a degree, to clear its future of the doubt which had caused Belgium, as a nation, to shrink from incurring financial responsibility in support of it. The cost of the early undertakings, from the day in 1876 when Stanley took leave of King Leopold in Brussels and set out upon his expedition up the Congo River, and the expenses of the entire enterprise, including those of the International African Association, had been borne by the King and his immediate adherents. The amounts so expended each year now aggregated a sum approximating $100,000,000$ francs. On 29th April, I 887, the Belgian nation had authorised the Congo State to raise a loan of I 50,000,000 francs, which, however, it did not guarantee. These funds were largely employed to found the chartered companies provided for in the Decree of 27 th February, I887. The time had now again come when the Belgian Chamber should consider the reasonableness of asking the assistance of the Belgian nation, 
especially as the King's African enterprise had been undertaken for the benefit of civilisation and the expansion of Belgian markets.

On the 3 rd July, I 89o, the day after the General Act of the Conference had been signed, a Convention was concluded between M. Beernaert, the Finance Minister, on the part of Belgium, and Baron Van Eetvelde, on the part of the Congo Free State, by which Belgium engaged to lend the Congo State $5,000,000$ francs at once, and 2,000,000 francs a year for the next ten years-25,000,000 francs in all, on condition that Belgium should have the option, six months after the expiration of the ten years, of annexing the Congo Free State "with all the rights and advantages attached to the sovereignty of the State ." provided it also assumed the obligations of the State to third parties, "the King-Sovereign expressly refusing all indemnity on account of the personal sacrifices he had himself made." It was further agreed:

3. From the present time the Belgian State will receive from the Independent State of the Congo such information as it judges desirable, on the economical, commercial, and financial situation of the latter. It may specially ask for communication of the budgets of receipts and expenses, and of the customs dues both on imports and exports. This information is to be given, with the sole object of enlightening the Belgian Government, and the latter will not in any way interfere in the administration of the Independent State of the Congo, which will continue to be attached to Belgium only by the personal union of the two crowns. Nevertheless, the Congo State engages not to contract any new loan hereafter, without the assent of the Belgian Government. 


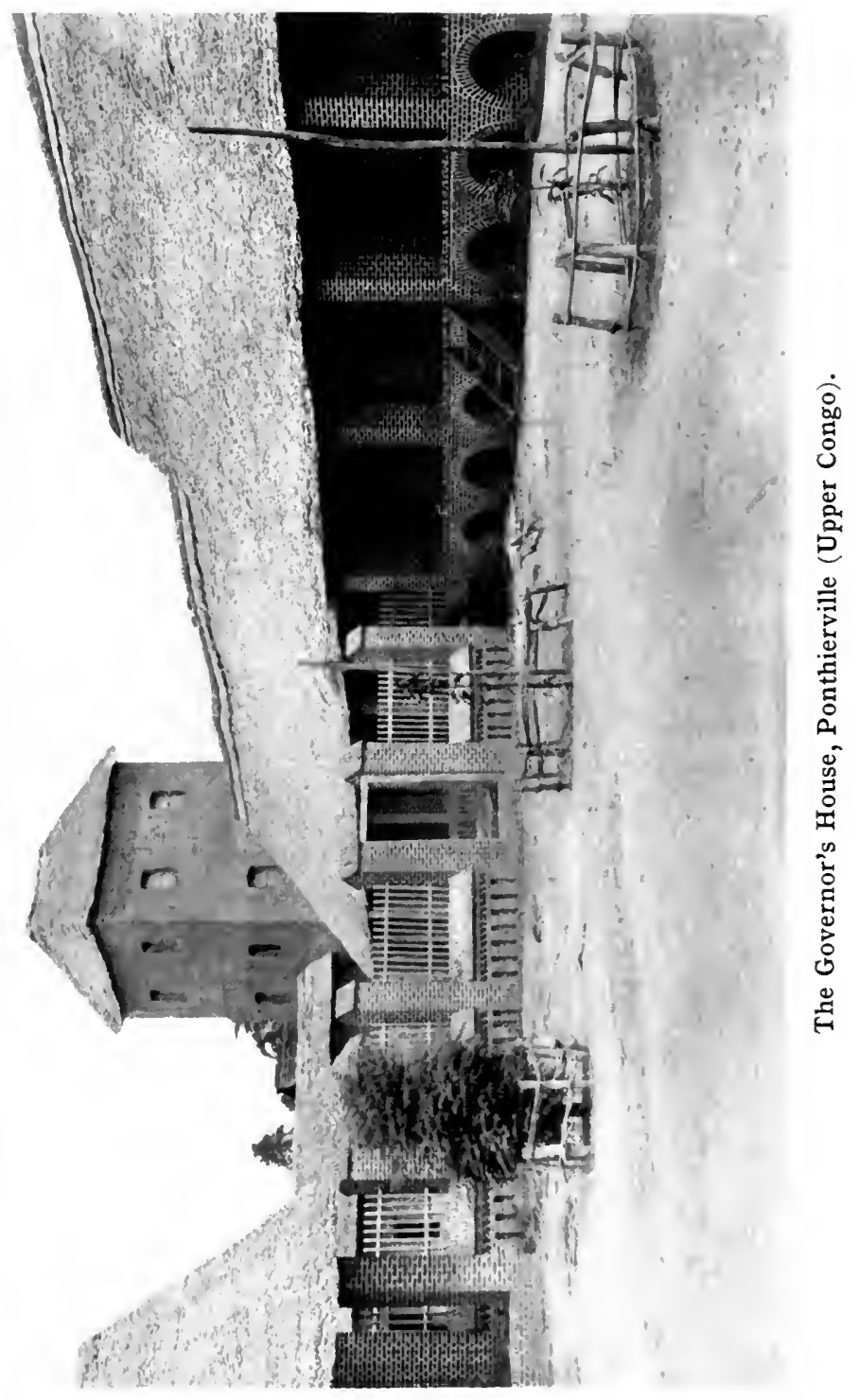



4. If at the fixed time Belgium decides not to accept the annexation of the Congo State, the sum of twenty-five million francs lent, inscribed in the ledger of its debt, would not become demandable until after a fresh period of ten years, but it should bear in the interval interest at the rate of $3 \frac{1}{2}$ per cent., payable every six months, and even before this term the Independent State of the Congo should devote to partial repayments all the sums obtained from cessions of land or the mines of the domain.

Long before the date of the Brussels Conference and the Convention just concluded, King Leopold had written to his minister, M. Beernaert, a letter clearly indicating his unselfish purpose in developing the Congo State. The persons who charge the King of the Belgians with governing the Congo for his personal benefit might temper their mendacity by the fact that this letter is dated 5th August, r889, nearly a year before the conclusion of the Brussels Conference. Having regard to the false charges busily purveyed in respect of his Majesty's true intentions towards his people and the Congo State, it seems but just to quote it:

5 th August, 1889.

Dear Minister [M. Beernaert]. - I have never ceased to call the attention of my countrymen to the necessity of extending their view to countries beyond the sea.

History teaches that States of limited size have a moral and material interest in stretching beyond their narrow frontiers. Greece founded on the shores of the Mediterranean opulent cities, centres of art and civilisation. Venice, later on, established its greatness on the development of its maritime and commercial relations, not less than on its political successes. Holland possesses in the Indies thirty millions of 
subjects, who exchange the commodities of the tropics for the productions of the mother country.

It is by serving the cause of humanity and progress that people of the second rank appear as useful members of the great family of nations. More than any other, a manufacturing and commercial nation like ours should strive to secure outlets for all its workers, for those of thought, capital, and labour.

These patriotic preoccupations have dominated my life. They determined the creation of the African work.

My labours have not been sterile. A young and vast State, directed from Brussels, has peacefully taken its place under the sun, thanks to the benevolent aid of the Powers which have applauded its beginning. Belgians administer it, whilst others of our countrymen, every day more numerous, profitably employ their capital in its development.

The immense river basin of the Upper Congo opens to our efforts ways of rapid and cheap communication, which permit us to penetrate direct into the centre of the African Continent. The construction of the railway of the region of the Cataracts henceforth assured, thanks to the recent vote of the Legislature, will notably increase these facilities of access. Under these conditions, a great future is reserved for the Congo, the immense value of which will soon be apparent to every eye.

On the morrow of this considerable act, I have thought it my duty to place Belgium herself, when death shall have struck me, in a position to profit by my work, as well as by the labour of those who have aided me in founding and directing it, and whom I thank here once more. I have therefore made, as Sovereign of the Independent State of the Congo, the Will that I send you. I ask you to communicate it to the Legislative Chamber at the moment which shall appear to you the most opportune.

The beginnings of enterprises such as those which have so much occupied me are difficult and onerous. I have held myself bound to support the cost. A king, in order to serve 


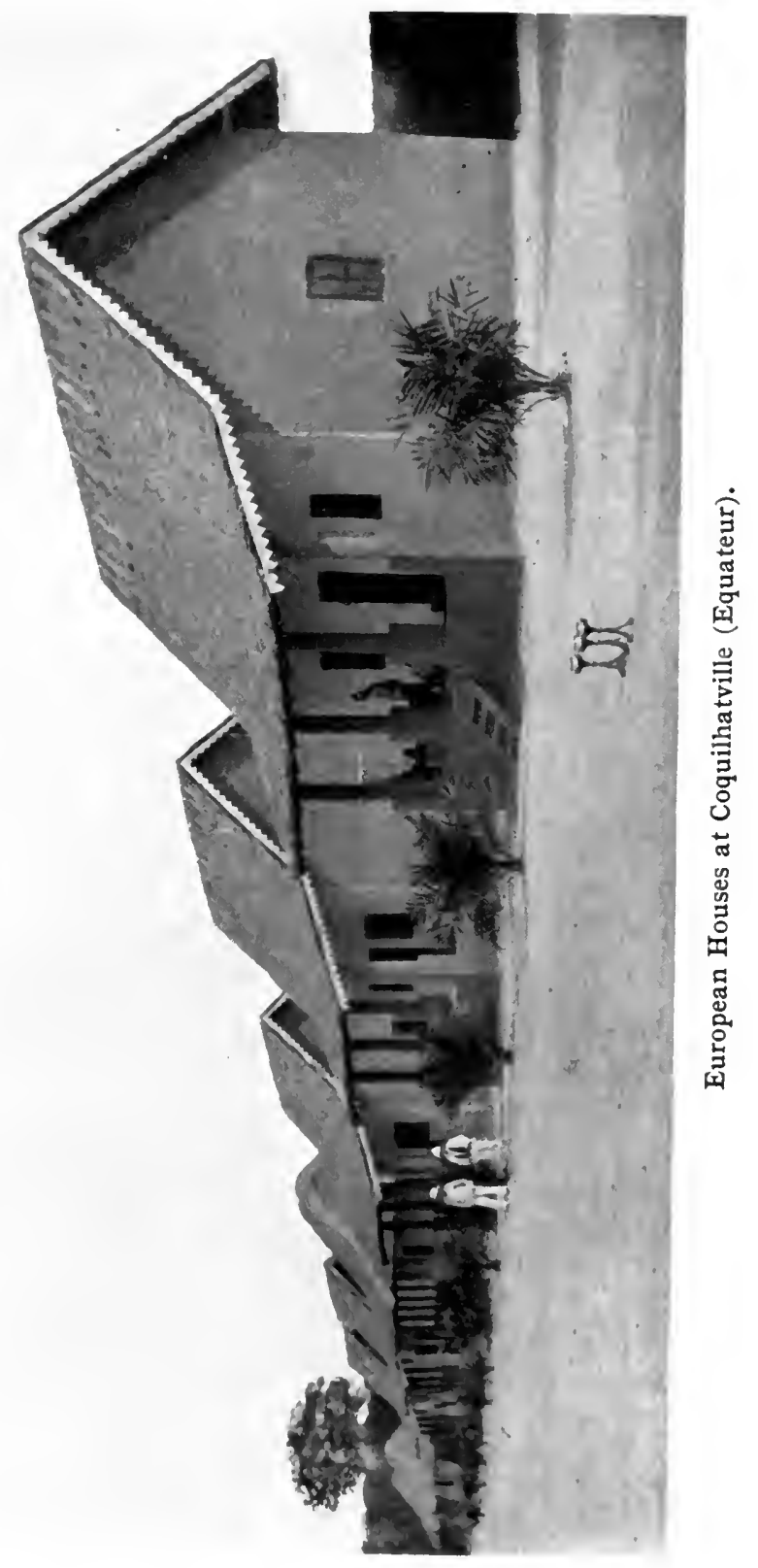



his country, ought not to fear to conceive and to pursue the realisation of a work, even if it be apparently rash. The wealth of a sovereign consists in public prosperity; it alone can constitute in his eyes an enviable treasure, which he should endeavour constantly to increase.

To the day of my death I shall continue, in the same desire of national interest which has hitherto guided me, to direct and sustain our African work; but if, without awaiting this term, it should be agreeable to the country to establish closer links with my possessions on the Congo, I should not hesitate to place them at its disposal. I should be happy to see it, during my lifetime, in the full enjoyment of their possession. Allow me, in the meanwhile, to say to you how grateful I am towards the Chambers, as well as towards the Government, for the aid that they have afforded me on several occasions in that creation. I do not think I deceive myself by affirming that Belgium will derive important advantages from it, and that she will see opening before her, on a new continent, happy and larger prospects.

Believe me, dear Minister, etc.

LEOPOLD.

Accompanying this noble expression of a monarch toward his people on his sacrificial work in their behalf, was the King's Will, as Sovereign of the Congo Free State:

We, Leopold II., King of the Belgians, Sovereign of the Independent State of the Congo:

Wishing to assure to Our well-beloved country the fruits of the work which for many years We have pursued on the African Continent, with the generous and devoted co-operation of many Belgians:

Convinced of thus contributing to assure for Belgium, if she wishes it, the outlets indispensable for her commerce and her industry, and to open new paths for the activity of her children:

Declare by these presents, that We bequeath and transmit, 
after Our death, to Belgium all our sovereign rights over the Independent State of the Congo, as they are recognised by the Declarations, Conventions, and Treaties concluded since 1884 between the foreign Powers on the one side, the International Association of the Congo and the Independent State of the Congo on the other, as well as all the benefits, rights, and advantages attached to that sovereignty.

Whilst waiting for the Belgian Legislature to pronounce its acceptance of Our aforesaid disposition, the sovereignty will be exercised collectively by the Council of the three administrations of the Independent State of the Congo, and by the Governor-General.

LEOPOLD.

Done at Brussels the 2nd of August, r889.

The announcement of the King's Will, bequeathing the Congo State to the Belgian people, was received with a demonstration of popular approval. In I90I the Convention of 3 rd July, r89o, giving Belgium the right to annex the Congo State, was extended for another term of ten years. Meantime the great prosperity of the State and the voice of saner liberalism in the Belgian Chamber are combining to identify the more intimate support of the Belgian Government with King Leopold's progressive African colony. That the Belgian State will take over that colony in 1910 , or on the death of King Leopold, is hardly within the pale of rational doubt. 


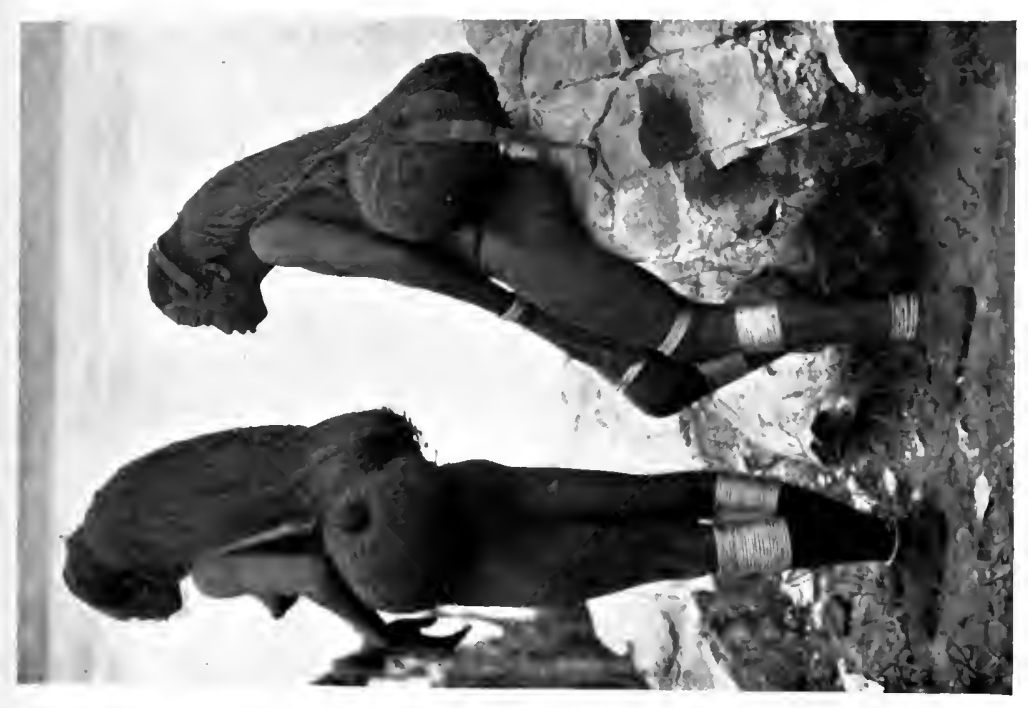

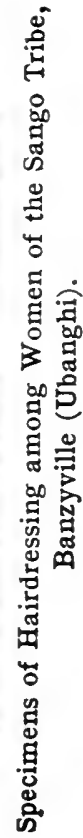

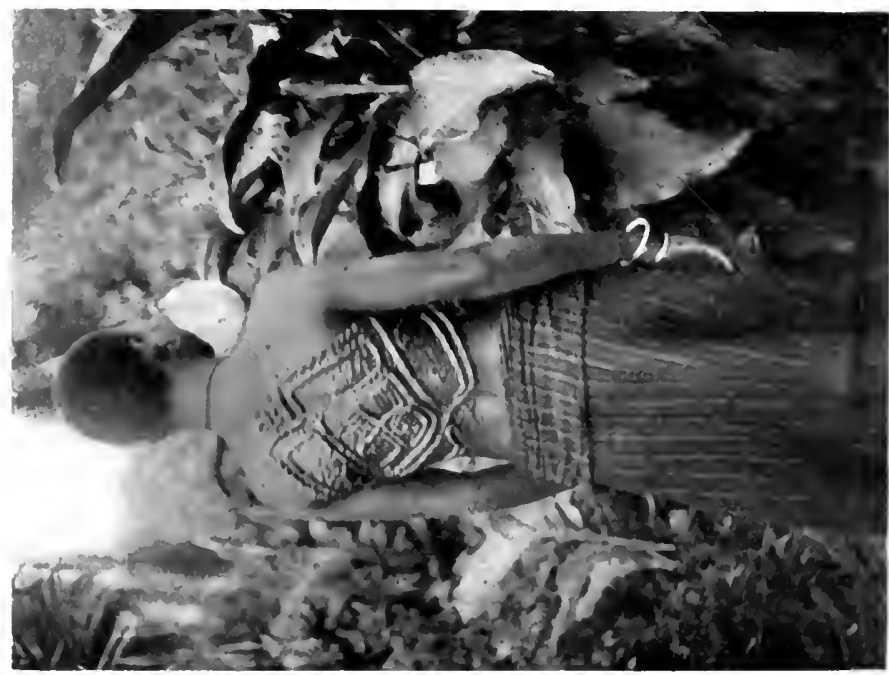

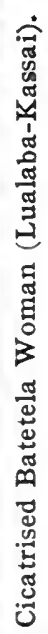





\section{CHAPTER XIII}

\section{TRIBES OF THE CONGO STATE}

THE difficulty in arriving at an estimate of the native population of the Congo Free State that tolerably approximates the truth is very great. Some authorities place it at as high as $30,000,000$, some as low as 15,000,000, Population while other observers, equally entitled to of Congo respect, assert that $20,000,000$ is about State. accurate.

This wide divergence of opinion ceases to be matter for surprise when we reflect that the population of an empire so important as China, known to white men for centuries, is variously estimated by them at anything between 300,000,000 and $400,000,000$.

Compared with our knowledge of China, our acquaintance with the countries and peoples comprised within the boundaries of the Congo Free State is a thing of yesterday. The nomadic habits of the various semi-savage tribes of which the population of the Congo Free State consists renders their exact enumeration impossible. Besides, there can be no doubt but that vast numbers of the dwarf (Pigmy) race inhabit parts of the great Central African forest not yet penetrated by the white man. 
It is certain, however, that all the vast region with which this book is concerned contains no race or tribe that has not come in contact with Advancing
Civilisation. habits and customs have not, in greater or lesser degree, been modified into some semblance of conformity with the standard of civilisation exemplified by their new masters. At present that conformity is far from being general, and where it is found it is invariably more superficial than real. To frankly admit so much is in nowise a reflection upon the extent or value of the civilising influence exerted by the Belgians upon their King's dusky subjects. The complete transformation of the barbarian into the civilised man is not possible in one generation. A consideration of the principal tribes, their habits and customs, as they were when the white strangers first appeared among them, and as to some extent they continue to this day, cannot, therefore, fail in interest.

The nomadic habits of the native races inhabiting the Congo region, discussed at length in another Origin of chapter, render an inquiry into their oriCongo gin a work of great difficulty and uncerRaces. tain result. Sir Harry Johnston, G.C.M.G., K.C.B., whose expert opinion upon this subject is entitled to the utmost respect, believes that the Negro type which originated in Southern Asia wandered across the peninsula of Arabia into Eastern Africa, mingling, perhaps, on the way, with the Caucasians from the north, evolving that negroid race known as the Hamite, whence sprang the early 


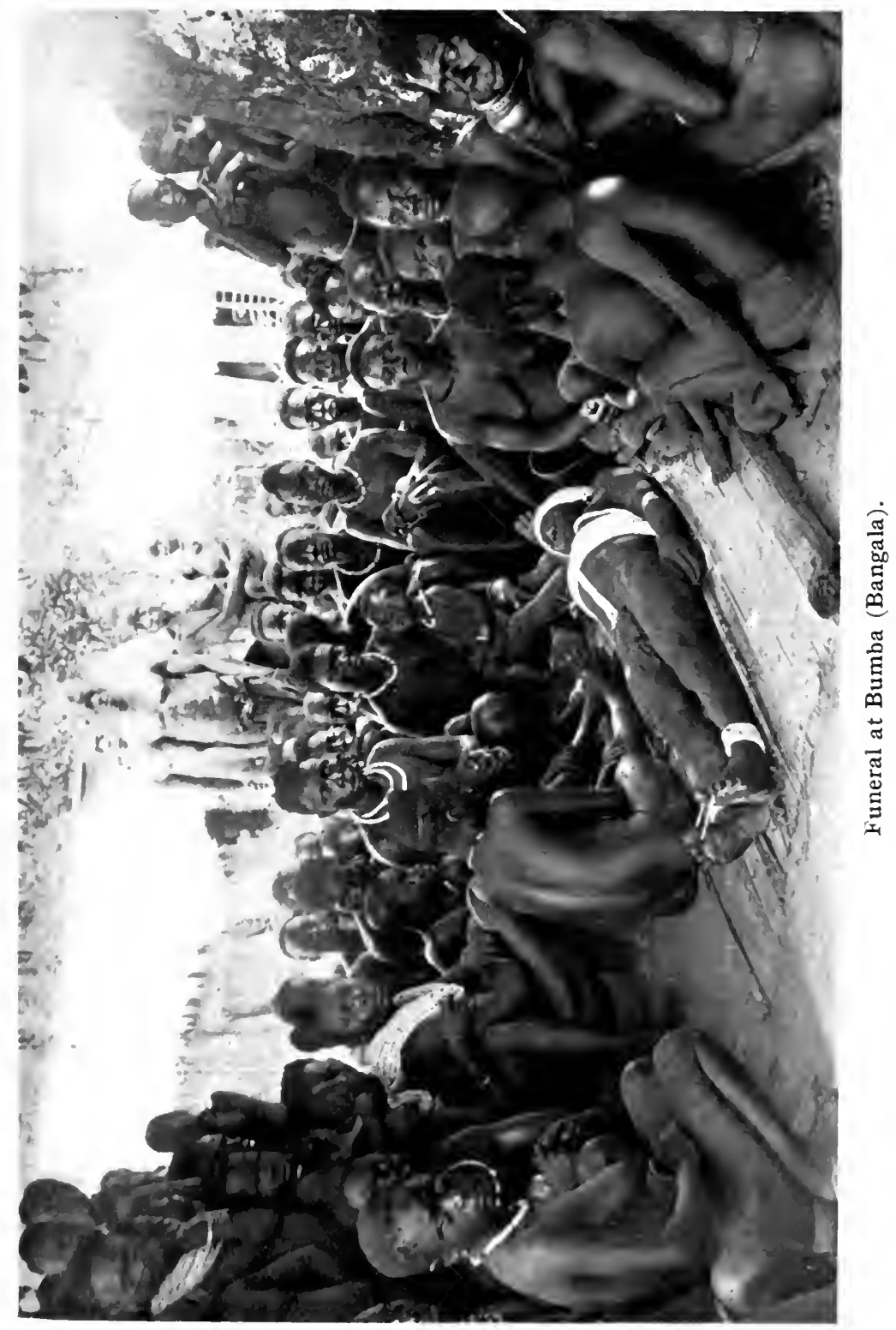



Egyptians, and to which the Somali, Gala, Abyssinian, and Nubian owe their origin.

From Eastern Africa this primitive race is thought to have spread, in the course of ages, throughout all Central Africa, and probably to have penetrated aimost to the southern and western coasts of that continent, changing their physical characteristics according to their environment, and again modifying those characteristics by subsequent intermixture. The numerous Central African tribes, as they exist to-day, exhibit marked differences in height, shape, language, habits, customs, and even in colour, some being an intense black, some of a chocolate hue, some reddish brown, and some of a bronze aspect. The five main divisions, according to Johnston, appear to be: (I) the forest Pigmy; (2) the Bantu; (3) the Nile Negro; (4) the Masai, and (5) the Hamite.

The native tribes in the neighbourhood of Leopoldville consist chiefly of the Musserongés, the Kakongos, the Baoilis, and the Mayombés.

The Musserongés are difficult of approach. Not only do they hold themselves severely aloof from the white man, they are also very shy and guarded in their intercourse with other native tribes, and are never known to com-

Some Tribal Traits. bine with any of them, even when threatened by a common enemy. They are tall, strong, and betterlooking than most members of the Negro race, though this commendation must not be taken for a certificate of beauty. They file their teeth to a point, or cut them square, or into semicircles, their 
object being to provide themselves thereby with a weapon for use as a last resort in a fight, when they literally throw themselves upon their enemies and seize them by the throat with their fangs, as a bulldog might do. They wear their hair short, and indulge in the practice of tattooing, for purposes of ornament, but not to any great extent. Strange to say, the women are taller and stronger than the men, which may perhaps be explained by the fact that all the work of the tribe, except hunting and fishing, falls to their share.

The Kakongos and Mayombés are less intensely distrustful, but the Baoilis are markedly hostile to the white man. They have been known to refuse to barter oysters-their principal diet, of which they frequently have supplies largely exceeding their requirements-for European commodities which it has been certain that they ardently desired to possess.

All these four tribes are of cleanly habits; and their practice of bathing daily, when the proximity Modes et of a river or lake puts it in their power to Robes à la do so, may put to shame some of the incongo. habitants of great cities. The forest tribes, to whom cleanliness by water is impossible, smear their bodies with palm oil and a kind of red ochre, which they afterwards scrape off. The original costume of a few leaves, or an exceedingly small apron made from fibrous bark, for women, and a loincloth of the same material for men, has yielded to the superior attraction of common cotton goods, which now reach them from far-away Manchester 


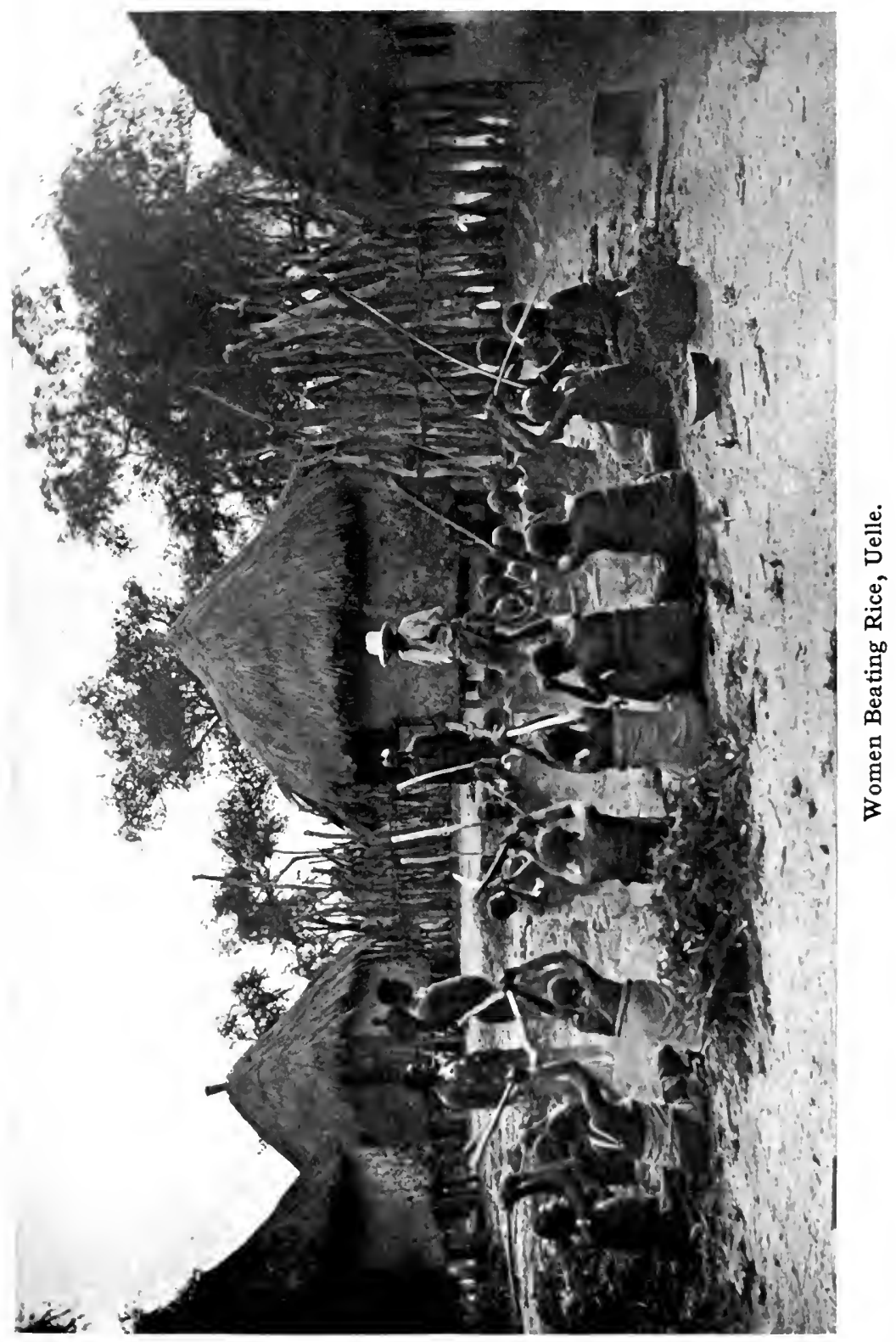



or Saxony. These stuffs, ornamented by large patterns in flaming reds or yellows, delight the eye and rejoice the heart of the Congolese maid and matron, while such of the men as desire to stand well with the gentler (?) sex will also condescend to use them. No time and skill are devoted to making a garment. A piece of the gaudy stuff wound in loose folds around the loins suffices both for men and women. In every tribe, children of both sexes are entirely nude until they reach the age of puberty. In at least one tribe, neither men nor women wear any covering. In a few tribes it is customary for the women to remain nude until they are married. Some women denote their married state by covering their breasts with strange ornaments, while others secure this object by elaborately dressing their hair, which they build up to a great height by aid of palm fibre and gum. Both men and women, of whatever tribe, ornament themselves with just as many collars, bangles, and anklets as they can obtain. Without exception, the possession of a few strings of coloured beads is to them a source of great happiness. They gaze upon such treasures with delight and guard them with jealous care. Some of their customs are very peculiar. Men and women will not eat together. A man guilty of eating in company of his wives would be hopelessly disgraced. In time past they have eaten one another, and would doubtless do so again should existing restraint be removed, but they may not eat together. After their separate repast, the sexes mingle again freely, and both engage in smoking their long-stemmed pipes. 
All the males of the Congo Pigmies seen by Sir Harry Johnston were circumcised, and all in both sexes had their upper incisor teeth and Congo Pigmies. canines sharpened to a point. In their forest homes they go naked, both men and women; but in presence of strangers the men usually don a small covering of genet, monkey, or antelope skin, or a wisp of bark-cloth, and the women leaves or bark-cloth.

The Pigmies [says Johnston] have practically no religion, and no trace of spirit- or ancestor-worship. They have some idea that thunder, lightning, and rain are the manifestations of a Power or Entity in the heavens, but a bad Power, and when (reluctantly) induced to talk on the subject, they shake their heads and clack their tongues in disapproval, for the mysterious Something in the heavens occasionally slays their comrades with his fire [lightning]. They have little or no belief in a life after death, but sometimes think vaguely that their dead relations live again in the form of the red bushpig, whose strange bristles are among the few brightly coloured objects that attract their attention. They have no settled governmént or hereditary chief, merely clustering round an able hunter or cunning fighter, and accepting him as law-giver for the time. Marriage is only the purchase of a girl from her father. Women generaily give birth to their offspring in the forest, severing the navel string with their teeth, and burying the placenta in the ground. The dearl are usually buried in dug graves, and if men of importance, food, tobacco, and weapons are buried with the corpse.

The same authority has observed that all the Bantu-speaking forest folk on the UpCicatrisa- per Congo practise cicatrisation. Scores
tion. and weals of skin are raised either by burning or cutting with a knife, and introducing the 


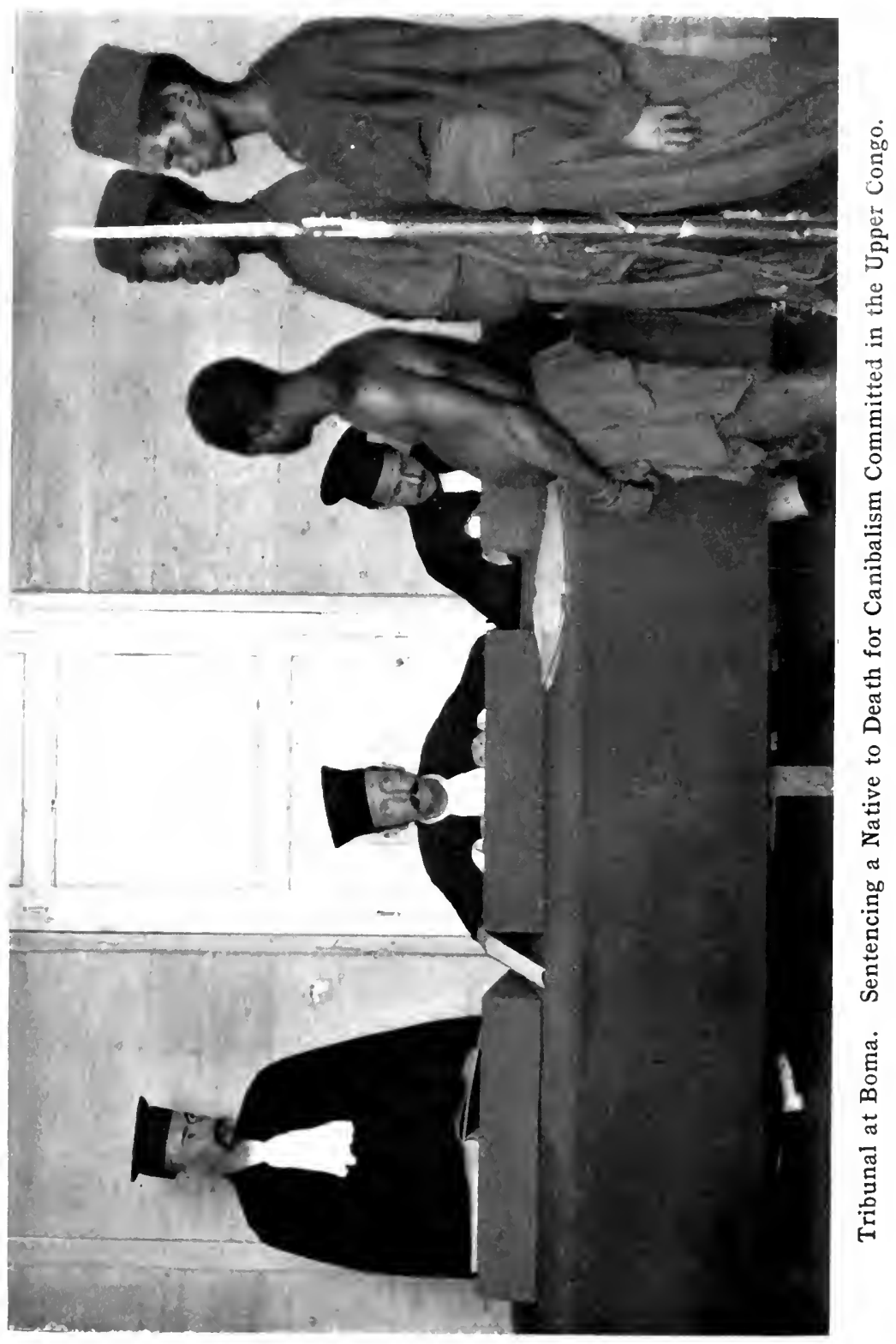





\section{Tribes of the Congo State}

irritating juice of a plant into the wound. The effect of this is to raise on the surface of the body large or small lumps of skin. Sometimes these raised weals are so small that they produce almost the effect of tattooing; at other times they are large, ugly excrescences. The Babira people cicatrise their chests and stomachs; but in the forest, toward the waters of the Congo, their faces are hideously scarred. Both men and women of the Bantu Kavirondo extract the two middle incisor teeth from the lower jaw, in the belief that if a man retains all his lower incisor teeth he will be killed in warfare, and that if the wife fails to pull out her teeth it may cause her husband to perish. For the same reason of averting ill-fortune, a woman inflicts cuts on the skin of her forehead, which leave small scars. The women also, as a means of securing good fortune for themselves and their husbands, make a number of small incisions, usually in patterns, in the skin of the abdomen, into which they rub an irritant, so that huge weals rise up into great lumps of skin. The Kavirondo husband, before setting out to fight or starting on a journey attended with great risks, usually makes a few extra incisions on his wife's body.

The traveller in the Congo will frequently observe repulsive disfigurements in the natives, and is very liable to attribute to the cruelty of oppression what are but manifestations of old-time tribal customs. The danger is

A Gross Fraud. accentuated by the organised campaign of slander now proceeding against the Congo Free State, which 
does not scruple to make capital out of such an opportune circumstance.

Almost all the tribes entertain a hazy notion of an invisible Supreme Being; but they regard themselves as of no account in His estimation, and direct their petitions for supernatural aid to their fetiches, which they endeavour to propitiate by gifts through the medium of their witch doctor or medicine man, a kind of priest who pretends to possess supernatural powers and abuses the credulity of his followers to an extraordinary extent.

Among the Mangbettus, a dead chief is buried in a sitting posture, in the centre of a new hut specially built on the banks of a stream. Five of Strangling his widows are strangled and their bodies
Widows. laid out with their feet towards their dead husband. The bodies are then covered with barkcloth saturated with palm oil, after which the spot is held to be sacred and must not be approached, under penalty of death, by anybody but the ruling chief and one attendant.

At the mouth of the Uelle is found the great mass of the Azandé, a very numerous and important

The tribe, who range the country from 23 deAzandé. grees east to 30 degrees west, and from 6 degrees north to 3 degrees south. There are three subdivisions of the Azandé-the Abandjia. the Avongura, and the Makraka, born fighters all, and devoted to cannibalism. Some of the Azandé men, however, will eat only the flesh of their enemies whom they have slain in battle, declining a diet of human flesh otherwise obtained, though they 

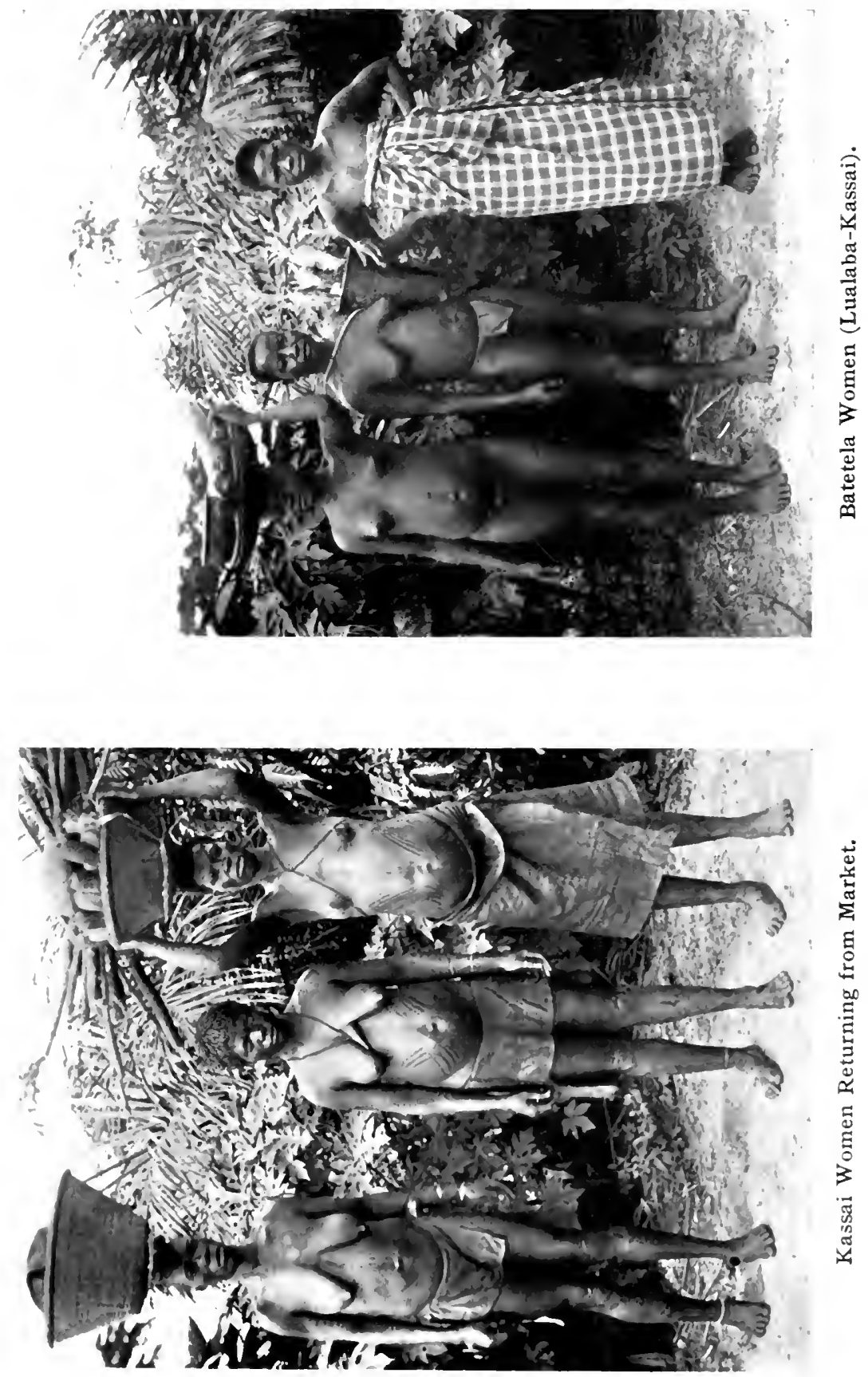



\section{Tribes of the Congo State}

all (except such of them as dwell south of the Uelle) forbid their women and children to touch it.

And here arises a curious subject for speculation. The cannibalistic Azandé are much farther advanced in the arts of peace and war than many other tribes that are not cannibal - the forest Pigmies, for instance. Notwithstanding some peculiar customs concerning them, they hold their women in high regard, and never barter them for goats and cows, the almost universal practice among other Central African tribes. Their skill, too, in agriculture, pottery, and in the making and playing of their musical instruments, seems quite incompatible with their abhorred anthropophagy.

Each. Azandé chief is really a despotic king. His power over his subjects is absolute, and any one of them who is so unfortunate as to offend him is simply handed over to the executioner, a procedure which to the. Azandé mind seems the most natural thing in the world. The courage of the Azandés is beyond praise. They know no fear; and when assailed by a murderous fire, against which they have no chance of success, they will rush right up to their enemy and grapple with him hand to hand, though nine-tenths of their fellows fall by the way. Their favourite weapons are the lance and light throwingspear, and each warrior carries, in addition, a shield.

Among the Azandé, criminals condemned to death are despatched with the lance. Occasionally, however, they employ a peculiar method of trial, known as the ordeal by

Ordeal by Poison. poison, which precludes this method of execution. 
On such occasions the chief acts as judge, and the person accused is made to drink a cup of poison, the theory being that if the accusation is baseless the accused survives unharmed. Of course, the invariable result is that the drinker falls dead within a minute or so. It is safe to assume that an Azandé chief is sufficiently intelligent never to subject one of his tribe to this ordeal whose death he has not previously determined upon.

Another singular custom, not peculiar to the Azandé, but common to all Central African tribes, Blood- is the ceremony of blood-brotherhood. Two Brother- men who are in no way related having hood. agreed to become "blood-brothers," i. e., to live in peace and amity for ever after, meet in the open air, in the presence of the chiefs and people, when a small incision is made in the forearm of each " brother," sufficiently deep to cause a little blood to flow. Each mutilated one then licks the blood from the other's arm, and thenceforth they are related as brothers.

A slight modification of this ceremony was early conceded by the various chiefs to accommodate the pardonable squeamishness of Europeans; and now, instead of licking each other's blood, the "brothers" merely rub their incisions together, so that their blood may mingle. Stanley was made bloodbrother to so many African chiefs that at last his arm was well scored with incisions. Several Belgian commandants, and a few Englishmen, have submitted to this operation; always, it is almost needless to remark, from motives of policy, for it 


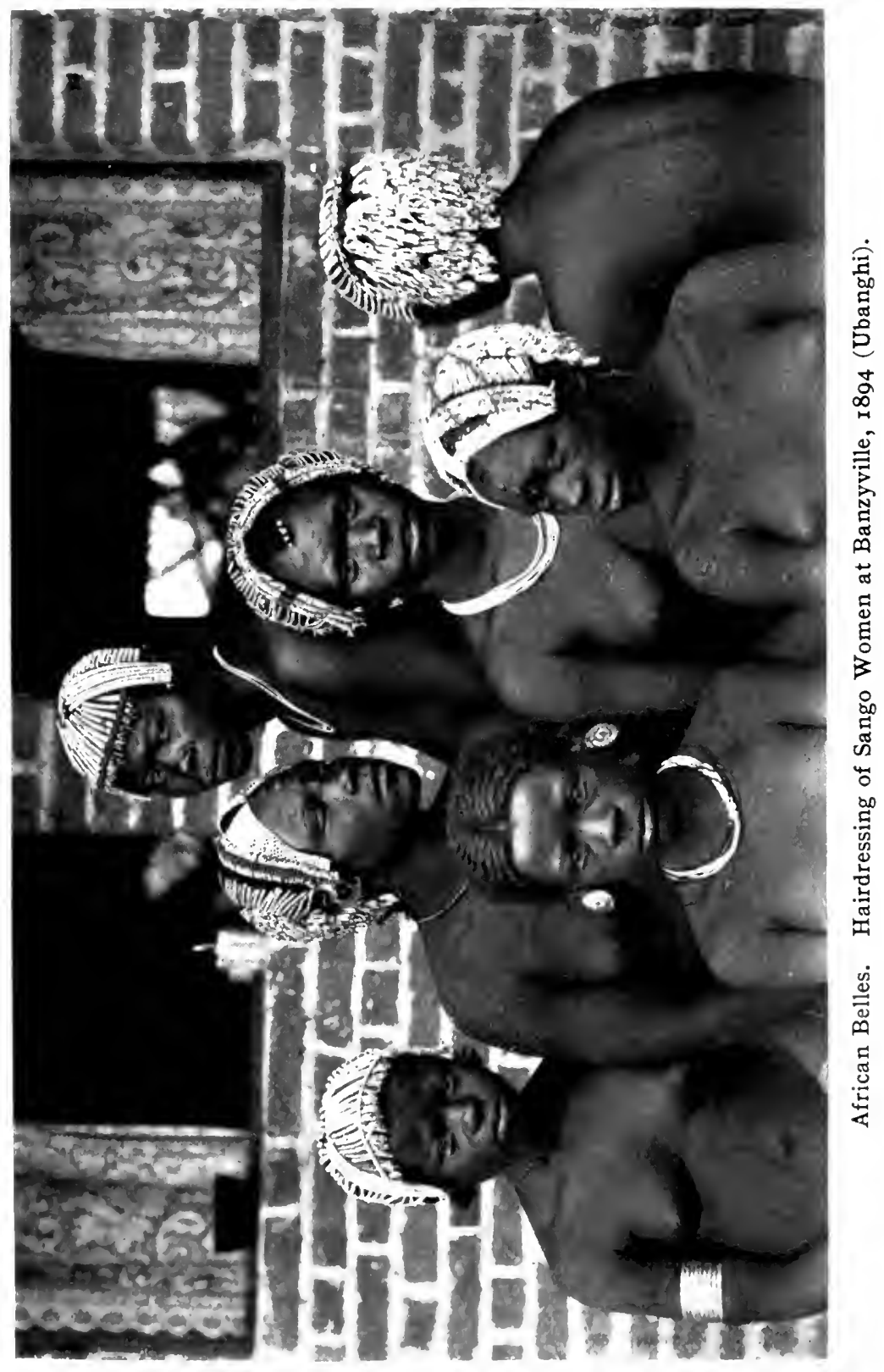



has been proved that Africans regard the rite with real veneration, and esteem the "brother" they acquire by it at least as highly as they would a natural brother.

It is not necessary in this place to give the names of all the tribes of which the native population of the vast Congo region is composed. They are numerous, and for the most part not easily pronounceable. Of the tribes not already referred to, the Basundis, Bakuendas, Batekas, Bayanzis, Bangalas, Batetelas, Mongos, Bantu, and Mombettus are most prominent. While differing in personal appearance, prowess, habits, and customs, clearly denoting that they are not descended from a common stock, there are not wanting certain traits which distinguish them all. All are polygamous, nearly all are cannibal, and the morals of the most advanced among them such as shock the average civilised man upon his first contact with them. Strangely inconsistent with the low moral sense which prevails among most of the tribes, some of them punish the crime of adultery with death, others by horribly mutilating the male offender.

Cannibalism has long been suppressed by the Congo Government just as murder is suppressed among civilised communities; but the hor- Cannibalrid practice is still indulged here and there, ism. as opportunity occurs for evading the vigilance of the authorities. So recently as 1898 , and possibly to the present day, it was necessary to maintain a constant guard at the cemetery in Leopoldville, the chief station on the Upper Congo, to prevent the 
Bangalas unearthing the dead and carrying them off to feast upon. Several such cases were proved against them, and capital punishment had to be resorted to in order to stamp it out. This horrid subject is sickening to contemplate; but no description, however brief or superficial, of the Congo people, can ignore a fact which has occasioned, and still presents, such a tremendous difficulty for civilisation to surmount. This is but one of many difficulties with which the Congo Free State has had to contend, and those who sit in judgment upon that State should bear in mind that the Central African black is not by nature predisposed to civilisation. Not all the cannibal tribes are so repulsive and cruel as the Bangalas. Most of them eat no other human flesh but that of their enemies slain in battle. That source of supply will not suffice for the Bangalas, who make up its deficiency with prisoners or slaves. Having broken their victim's limbs, they place him in a pool of water, with his head supported just above its surface so that he may not drown. After having left him in that position for three days (if he survives so long), he is killed and eaten. Another method is to behead the victim, singe all the hair from the body over an ember fire, and then cut it into pieces for cooking. The portions not immediately eaten are smoke-dried and put aside for another occasion. The teeth are extracted and made into necklaces by the women. Sometimes the skin is used for drumheads.

It is the general opinion of competent observers that polygamy will for many years survive the ex- 

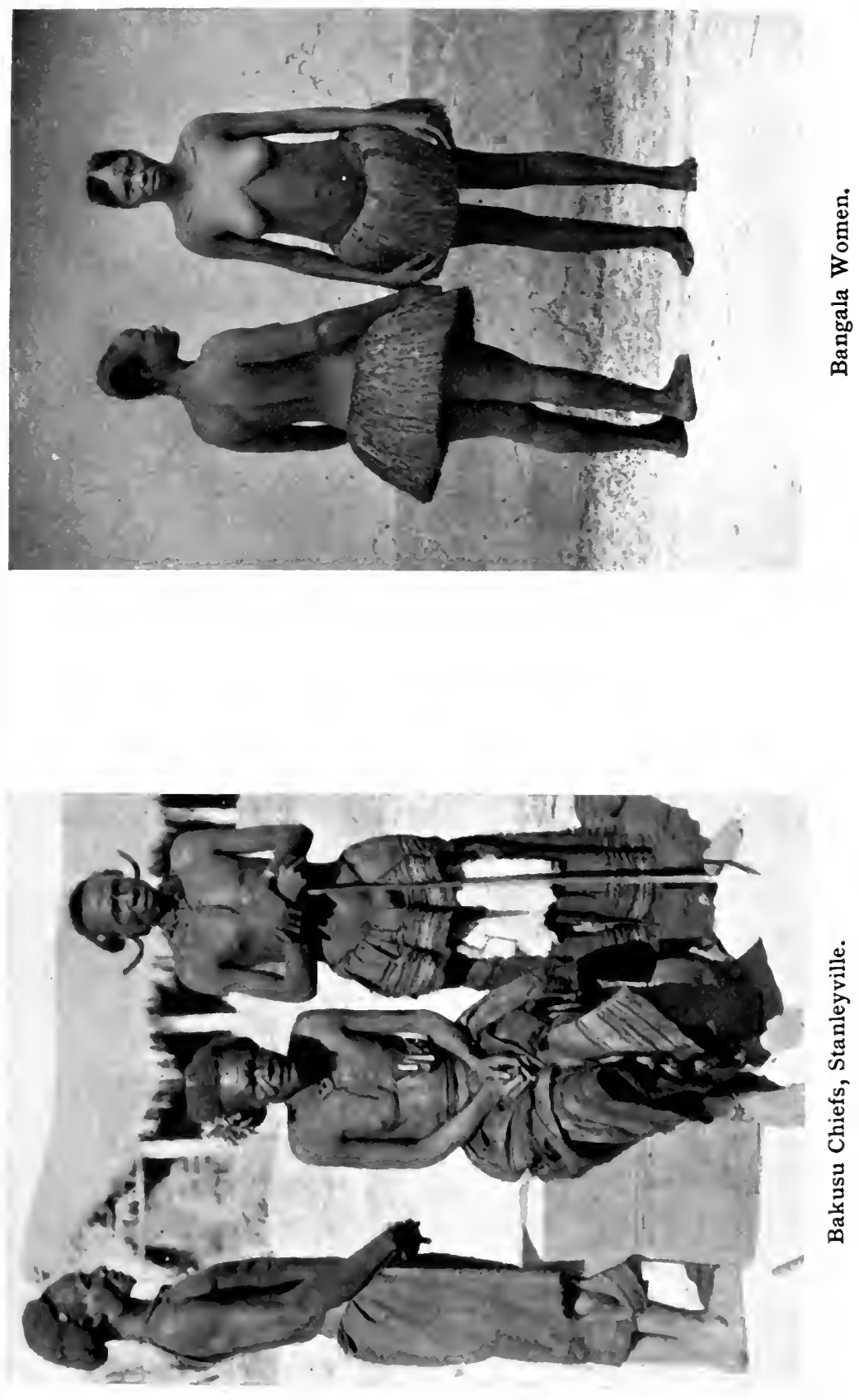

tinction of cannibalism. Nothing but the spirit of Christianity will overcome that evil. The native mind cannot be induced by ordinary argument to see any wrong in it. Why a man

Polygamy. should not have just as many wives as he can afford to buy and keep is too much for his comprehension. He regards woman as created solely for his pleasure and profit, and trades in her accordingly. He buys her from her father for one or two goats or a cow; she becomes the mother of his children, and prepares and cooks his food for him. That is her career, and she shares it with as many other wives as her husband's inclination and resources permit him to buy. When she dies she is buried-sometimes. Certain Central African tribes regard burial after death as a superfluous ceremony for women, and place their bodies where they will be devoured by hyænas and vultures. From two to three wives is the average quantum of the ordinary Central African barbarian, and between thirty and forty for a chief.

After their prodigious effort and expense in suppressing the slave trade, the Belgians set to work to weld into a homogeneous civilised State a vast region full of warring tribes with attributes such as these, utterly oblivious to all sense of right and truth as readers of these pages understand these words.

Looking at the Congolese as they were in 1876 , and again as they are in 1905, who can honestly deny that King Leopold has, so

A Reflecfar, well performed his arduous mission? tion. 


\section{CHAPTER XIV}

\section{THE CONGO PUBLIC FORCE}

7 HE State's military organisation is constituted by what is called the Congo Public Force (Force Publique). It had its origin in the necessities of the International Association before the State had gone far along its difficult way. It was To Main- recruited from the blacks of Zanzibar and tain along the West Coast at Lagos, Sierra Leone, Order. Elmira, and Accra. The first troops were, therefore, foreigners-Zanzibaris and Haussas. Their foreign origin was, in a sense, an element of security to the Association when it had to direct repressive measures against some of the Congolese tribes. The Zanzibaris and the Haussas had great military aptitude and, lacking sympathy for the Congolese, were generally loyal to their commanders. They loved an enemy from the instinct inherent in savage natures.

The maintenance of this early body of troops was exceedingly expensive for the young State. Besides food, uniform, and medical attendance, these mercenaries received one franc twenty-five centimes a day. Moreover, on the expiration of their term of service they were sent back to their homes at the expense of the Government. As the term of their engagement was only three years, this obligation formed an important addition to their cost.

It was beyond the financial power of the State to 

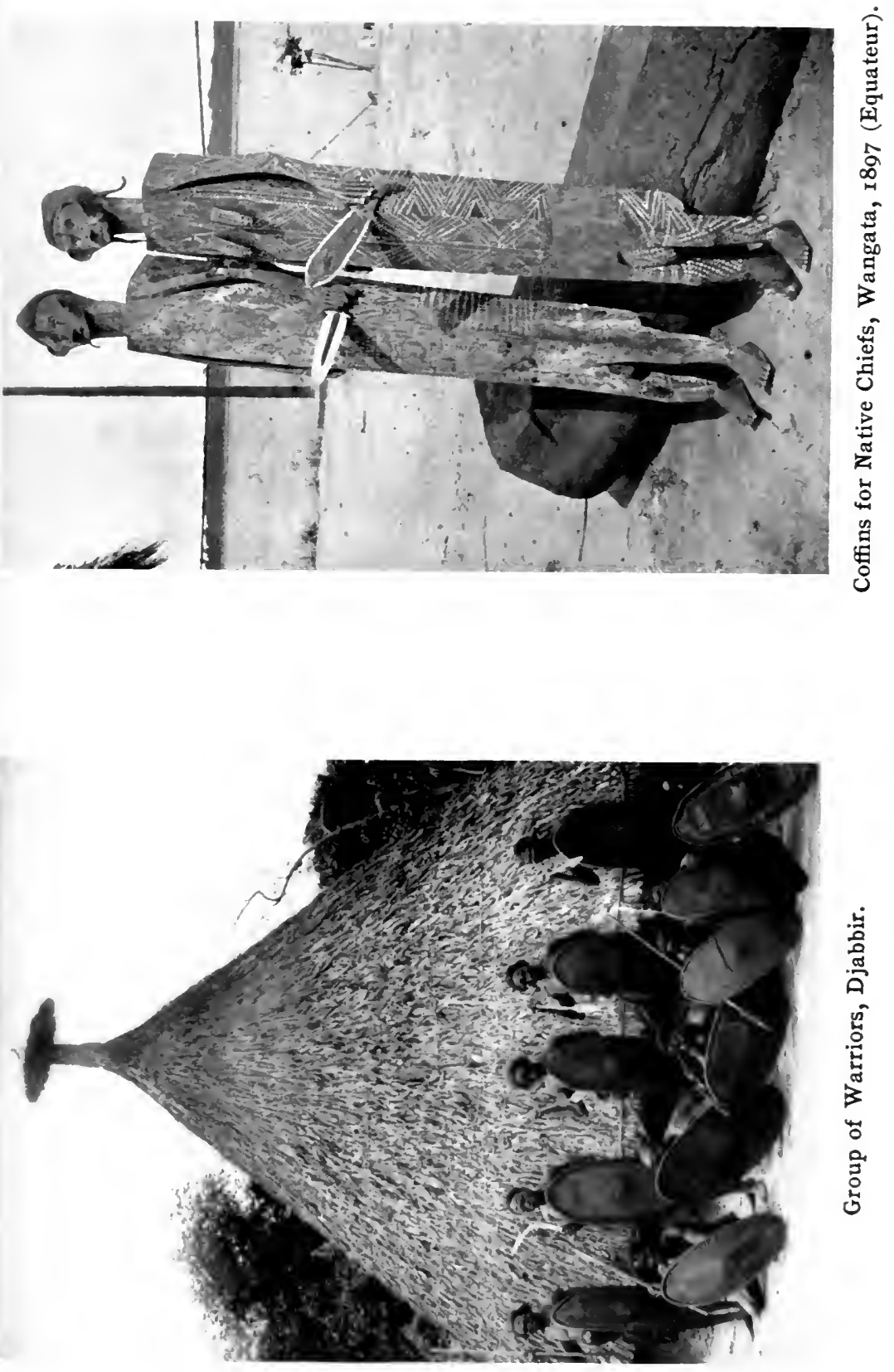

provide an adequate military organisation on such a basis. While the administrators of the Congo were devising means for the support of an efficient force at a reduced cost, the British government on the Gold Coast prohibited further recruiting of Haussas by foreign states. Barred from getting its soldiers from surrounding British territory, the Congo Government proceeded to develop its earlier plans for raising a native local force, the first purpose of which was that it should supplement the main body of regular troops.

The nucleus of what is the present Public Force were the men of the Bangala tribe, whom Captain Coquilhat employed as armed police when he founded Equateurville in 1885. A short time thereafter, Captain Van Dorpe made the same experiment among the Manyanga. Finding the men from both tribes fit for a military career, the principle of employing aboriginal races in the Public Force was followed with the rapid establishment of the numerous posts and stations erected at that time. The wisdom of employing natives for the organisation of such a national force was soon apparent. In I888 an order was issued to form eight companies of one hundred and fifty men, with power to increase the number to two hundred and fifty. It was not, however, till r89 1 that Baron Van Eetvelde and the Governor-General, M. Camille Janssen, drafted a practical scheme for the foundation of a permanent Public Force. Mr. Demetrius C. Boulger, whose volume entitled The Congo State treats at length of the subject up to 1898 , describes the scheme which the Sovereign had approved: 
The principal features of the scheme were, that the force should be divided into twelve companies corresponding with the administrative districts, and that one hundred and twenty European officers, chiefly Belgians, should be appointed to the command and disciplining of this force. The different grades of this army were: one commandant, eleven captains, ten lieutenants, thirty-nine sub-lieutenants, and sixty sergeants. The new system of recruiting was of two kinds. The first provided for the engagement of volunteers for a period not exceeding seven years, and the second for an enforced levy of militia by order of the Governor-General, and arranged between the commissary of the district affected and the local chiefs. The levy was to be made, wherever possible, by lot, among the men between the ages of fourteen and thirty. The term of service for the latter was to be five years, with a further period of two years in the reserve. Each man received, besides food for himself and his wife (if he had one), a daily pay of twenty-one centimes, or a sixth of that which had to be paid for the alien soldier. Moreover, the expense of sending the men back to their homes was reduced to a minimum. The reduction in the cost meant, besides a saving to the Government, the possibility of raising the strength of the force to a figure more in proportion to the requirements of the State. Of the old alien contingent, it has never been found possible to maintain more than three thousand men, and the native contribution to this was about two hundred; but in I89 I the latter was increased to sixteen hundred men, and in 1897 , by which time the alien element had been eliminated, the Public Force was raised to a grand total of eight thousand militiamen and four thousand volunteers. The number of companies had been raised to twenty-two, with a nominal strength of nine thousand five hundred and forty men at the end of last year ( 1897 ), whereas in $189 \mathrm{I}$ the total was only two thousand nine hundred and fifty.

For the purpose of training these forces, seven camps of about five hundred men each were formed, and the period of training the men undergo is fixed at eighteen months. The uniform is blue linen, or, for full uniform, blue cloth, with a 


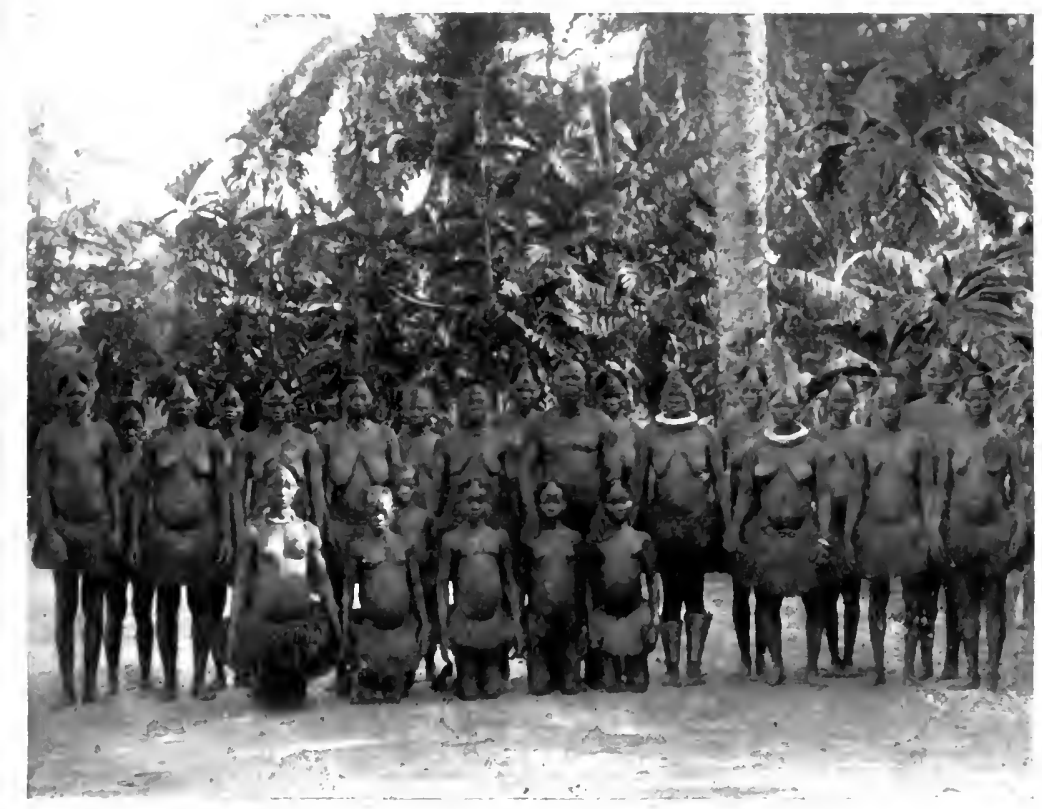

A Bangaia Chief, with his Harem.

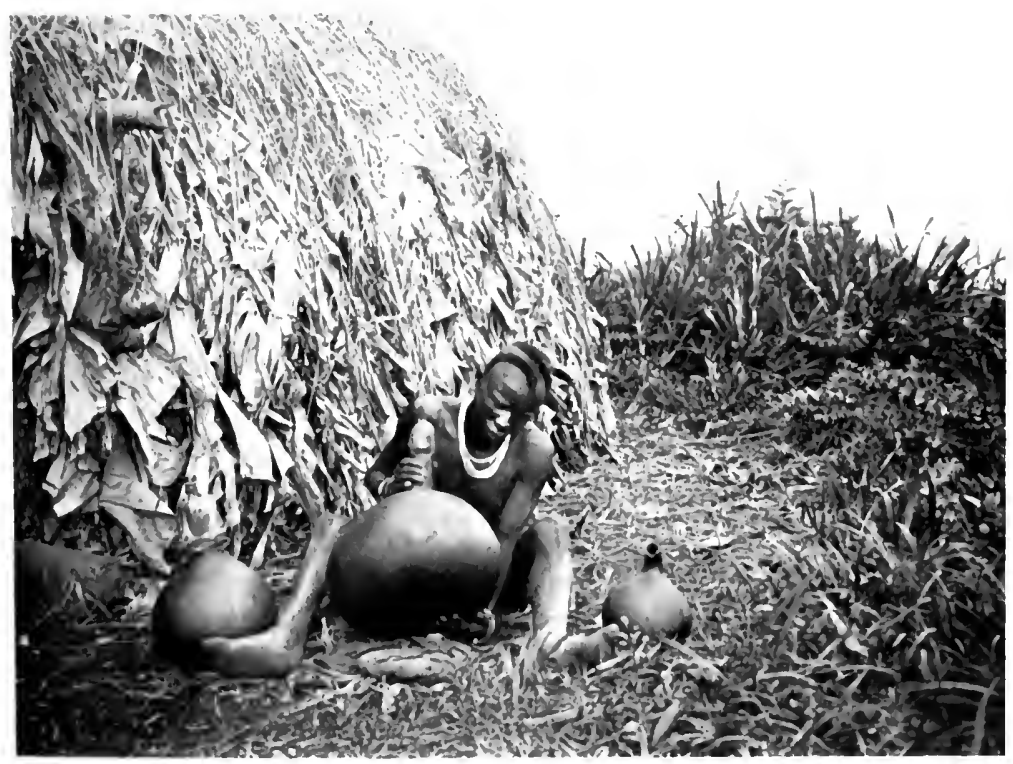

Native Making Butter at his Home in Botandana (Kivu). 



\section{The Congo Public Force}

scarlet fez. The arm in general use is the Albini, with a short bayonet. The white officers carry the Mauser rifle, with a magazine. The greatest pains is taken in the fire-training and discipline of the men. Competitions are held every three months among sections of fifty men, and prizes awarded. A great improvement has been effected in the housing of the troops, who are now almost entirely accommodated in brick barracks. The artillery of the force is of considerable strength, and includes, Krupps, Maxims and Nordenfelts.

The seven camps of instruction are Zambi, for the Lower Congo; Kinshassa, Bolobo, Irebu, Kassongo, Umangi, La Romee, for the Upper Congo. The principal armed camps, as they are called (because they are bases of military power), are those at Lusambo, Bomokandi, and the Aruwimi; but Vankerckhovenville, Dungu, and Redjaf are now of equal, if not of greater, importance. At Kinshassa, on Stanley Pool, a fort with a battery has been constructed for the protection of Leopoldville and the railway terminus; and here an experiment has been successfully tried of utilising the services of prisoners of war. Men selected from the captives of the numerous expeditions have been passed through a probationary course on the works of this place, and in this manner a considerable number of recruits have been obtained for the Public Force on more favourable terms than the militiamen recruited through the chiefs. Kinshassa is not the only fortified place within the State territory; for at Chinkakassa, near Boma, a strong fort has been constructed, commanding the navigation of the Congo and the approaches from the ocean. Here Captain Petillon, of the Belgian Engineers, has placed eight Krupps and a number of smaller guns in an admirably selected position, while the Mongos tribe, from the Equateurville district, has supplied an adequate number of skilful and handy gunners. The authorities of the Congo State will experience no difficulty in procuring suitable men for this arm of their Public Force.

The first and oldest company of the Public Force deserves a special notice to itself. This is the auxiliary company of 
the Congo Railway, and was founded by royal decrec of 9 th August, I890, or twelve months earlier than the decree constituting the general force. Its organisation was entrusted to Captain Weyns, an officer of the Carabiniers. Its strength was first fixed at the modest total of fifty men; in 1892 it was increased to a hundred men, and afterwards it received at further addition of fifty men. The task entrusted to this corps was the protection of the railway works and of the villages through which the railway passed. As eight thousand navvies were employed on the line, and as these were composed of many nationalities, the task was no sinecure, but it was performed with perfect success and without friction. The auxiliary force was recruited in a different manner from the rest of the military. It contained several elements: for instance, twenty-five Senegalese, and fifty Batetelas from the country between the Sankuru and the Lualaba. Although of precisely the same race as the mutineers of the Dhanis column, the latter gave no trouble in 1897 . Like the other militiamen of the State, they serve for five years with the colours and for two years in the reserve, but the cost of maintaining this corps is borne by the railway company. It, however, forms an integral part of the general Public Force, and can be utilised if any occasion arises. Captain Weyns reported so favourably of the quickness of the Batetela recruits and their military aptitude, that all vacancies in this company are now, like those in the rest of the Public Force, filled up with natives of the Congo territory.

In the archives of the Congo State's Administration in Brussels, there are interesting official reports dealing with the question of creating a reliable native force from the most civilised of the Congolese tribes. The problem was not without many peculiar diffculties. Baron Van Eetvelde, whose lofty aims for Congolese civilisation were fortified with many wise measures of great utility to the Government, had 
formulated plans for the establishment of a system of military conscription, as to which in January, I 897 , he reported as follows:

The State has set itself to the task of creating a purely national army, with the view of lightening the budget of the considerable charges which weighed upon it through having to recruit abroad, and also with the view of putting an end, in accordance with the highest dictates of policy, to its dependence in this matter upon foreigners. It considers, moreover, the period of military service as a salutary school for the native, where he will learn respect for authority and the obligations of duty. It is happy, from this view, to see the number of national militiamen increase, and, in order that the institution may preserve all its value, special provisions have been made to prevent abuses, to regulate the recruiting, to assure the welfare of soldiers on service, and to provide occupation for those who have served their term. The decree on the recruiting of the Public Force is not more rigorous than any other similar act of legislation, and the incorporation is made under as sure guarantees of human liberty.,as in the armies of Europe. As is the case in almost all countries, the recruiting, independent of voluntary engagements, is made by annual levies, but "within the limits of the contingent fixed by the King-Sovereign," and within these limits "the Governor-General determines the districts and localities in which the levy is to be made, and also the proportion to be furnished by each locality. . . . The mode according to which the levy operates is determined by the district commissary in agreement with the native chief; and although the drawing by lot is recommended, we must recognise that it would be difficult, in the present circumstances, to have recourse always and everywhere to this method in each village, and to refuse to recognise the customary authority of the village chief, when he designates the militiamen among his own dependants. . . The length of active service is for five years. At the expiration of this term, the men pass two years in the reserve. The time 
passed under the colours, then, cannot exceed seven yearsa term which experience shows not to be excessive; and it is strictly forbidden to keep under the flags men who are no longer borne on the lists, or whose term of service has expired, under pain of misdemeanour. These organic dispositions have been completed by instructions, which prescribe on the officers 'to watch carefully that the men receive a sufficient nourishment, are comfortably housed, that the sick are well taken care of, that the men are always properly treated, that their misconduct is dealt with in conformity with the regulations, and carefully avoiding all excessive severity.'

In fact, this system renders light for the native his obligations as a soldier. We do not desire any other proof than those four thousand volunteers who are actually enrolled, and those numerous re-engagements, which show the taste of the native for the profession of arms. It was not with an army of malcontents that the State could have carried out its antislavery campaign. The State continues to interest itself in its soldiers after their term has expired. The time-expired men, sent back to their homes at its expense, together with their wives and children (if there are any), are the object of special protection, and receive concessions of land in a station at their own choice.

The latest report of the Vice-Governor-General (July, I904) indicates the great improvement to which the Public Force has attained since the date of Baron Van Eetvelde's statement of the system which prevailed in 1897 . Local experience in savage lands should be the foundation of the reforms imposed. In the case of the State's Public Force, many local conditions, traits, and prejudices, and much inaptitude, were encountered to modify or extend those principles of police control which the State's earlier administration had adopted with characteristic hopefulness. M. Fuchs sets forth the present 

position of the Force with considerable detail and suggestion:

The Government is aware that the military service of the black race must be the object of constant watchfulness, in order that it may be impossible for them to practise the cruelties to which their primitive instincts might impel them.

The officers and commanders of the troops have been often warned that they must show themselves inflexible guardians of the observance of those instructions, which have been issued for the protection of the natives against any possible abuse on the part of soldiers left in isolated positions or subject to insufficient control. Instructions have been given to this effect-and I am happy to be able to say that they have been almost everywhere faithfully carried out. Any contravention of the order forbidding the despatch of armed soldiers under the command of black officers is also severely punished, and may entail even the dismissal of the agent in fault. These measures have been completed by the formal prohibition of the employment of auxiliaries under no matter what circumstances.

It has also been laid down that direct relations are to be established between the natives and European agents. In order still further to strengthen the maintenance of discipline among the soldiers of the black race, the regulations on the subject have been completed by the penalty of dismissal from the Public Force. This is the most severe punishment in the eyes of the soldiers, for they highly esteem the profession of arms. Dismissal from the Public Force is inflicted on those soldiers who show themselves absolutely incorrigible or who are unworthy to remain in the ranks. In order to surround this rigorous measure with all the necessary guarantees, the soldiers whom it is wished to dismiss are brought before a Council of Discipline. The dismissal is pronounced, at Boma by the Commander of the Public Force; in the districts by the District Commissioner or by the head of the expedition, after 
examining the charge, the evidence, and the decision of the Council. Chiefs of zones cannot pronounce dismissal.

The Government have just finally decided that, for the future, the soldiers of the Public Force shall not take part in work at the stations, and that their time shall be exclusively given up to their instruction, education, and military service. The former arrangements which put soldiers, during some hours of the day, at the disposal of the territorial chiefs, chiefs of zones, and chiefs of posts, over and above the hours assigned for military duty, have been modified so as to maintain in a more continuous fashion the men under the control of their officers. In order to make this decision of the Government as fruitful as possible, the territorial chiefs have been ordered to reduce to the effective force strictly necessary for the assurance of security, the garrisons stationed at the posts in zones and districts, and to concentrate at the chief places in the territory garrisons as complete as possible. These measures are intended to produce the best results from the point of view of educating and instructing the troops, as well as from that of assuring military discipline, provided the territorial chiefs scrupulously carry out the new instructions mentioned above.

It has also been pointed out to them that it will be expressly recommended to the officials charged with the inspection-and the Government has decided to increase the inspections throughout the State territories-to ascertain if all these instructions, concerning the execution of the new table of daily work for the public force, have been carried out.

The other measures of organisation which have been passed, the formal prohibition to establish posts commanded by black officers, or to confide military operations to them, and finally forbidding the practice of taking sub-officers from their military duties to employ them as chiefs of stations, are of a nature to make us hope that very soon our public force will constitute a body in which we may have complete confidence.

In February, I904, I thought it my duty to point out to the Government the manner in which instruction was given in the camps, and to draw its attention to the necessity that there 


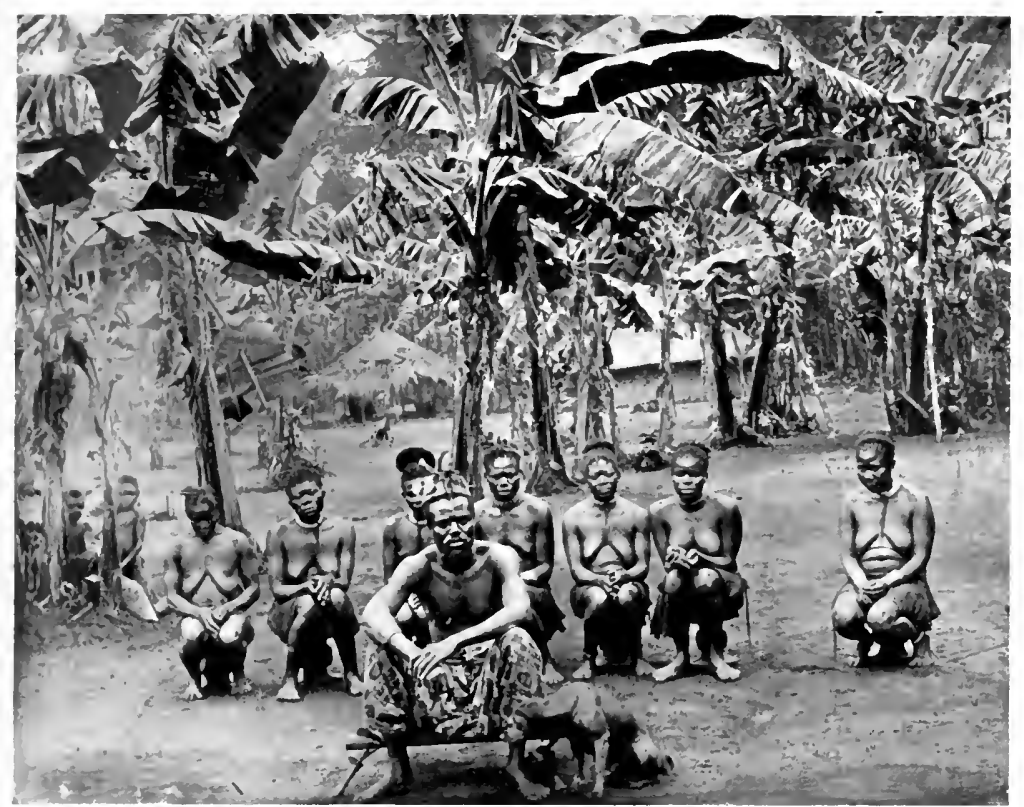

Uelle Chief and his Wives, Van Kerckhovenville.

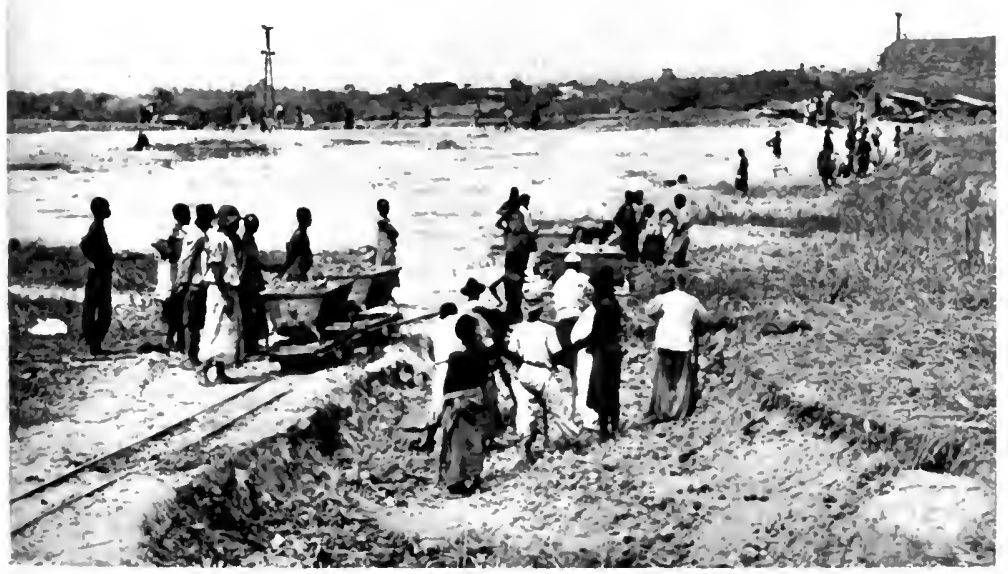

Port of Leopoldville. Natives at Work. 



\section{The Congo Public Force}

would be to engage quickly a superior officer entrusted more especially with the mission of seeing to the higher direction and the general control of all the orders issued concerning the Public Force. The Government, which had also occupied itself with the question, has confided this high employment to a superior officer who will be entrusted with the command of the Public Force.

The Government has resolved to send, at the same time three or four officers of the grade of commandant to be attached to the staff of the Public Force, and whom the commander will be able to appoint to exercise constant control over the companies and camps.

It is right to recall the fact that military service is so far from constituting a laborious servitude for those subjected to it, by virtue of the organic law of conscription, that voluntary cngagements increase from year to year. Besides, the instructions of the Government encourage this state of mind by improving the well-being of the soldier from the triple point of view of habitation, food, and clothing. And they are not only natives of Congolese territory, properly speaking, who seek there military employment; numerous Africans coming from the English colonies of the West Coast solicit engagement at Boma.

The table (on page I74) of the engagements of men, natives of the coast and British subjects, is characteristic in this respect.

The multiplicity of voluntary enrolments will gradually remove, from the absolutely indispensable law of conscription, what might seem rigorous, particularly in the eyes of people not yet thoroughly acquainted with civilisation, and with the idea of the necessity of public order.

It is nevertheless important to note that the efforts attempted with the view of nationalising the police forces are being crowned more and more with success. The State can now renounce the assistance, elsewhere advantageous, of foreign mercenaries, thanks to the methodical, extensive, and wise application of the militia law, and especially to the considerable increase in the number of national volunteers. But there 


\section{Story of the Congo Free State}

\begin{tabular}{|c|c|c|c|c|c|c|c|c|c|}
\hline \multirow{2}{*}{ 总 } & \multicolumn{3}{|c|}{$\begin{array}{l}\text { Accra } \\
\text { (British) }\end{array}$} & \multicolumn{3}{|c|}{$\begin{array}{c}\text { HaUSSAS (LAGOS) } \\
\text { (British) }\end{array}$} & \multicolumn{3}{|c|}{$\begin{array}{c}\text { SIERRA-LEONESE } \\
\text { (British) }\end{array}$} \\
\hline & $\underset{\text { gaged }}{\text { En- }}$ & $\begin{array}{l}\text { Re-en- } \\
\text { gaged }\end{array}$ & Officers & $\begin{array}{c}\text { En- } \\
\text { gaged }\end{array}$ & $\begin{array}{l}\text { Re-en- } \\
\text { gaged }\end{array}$ & Officers & $\begin{array}{c}\text { En- } \\
\text { gaged }\end{array}$ & $\begin{array}{l}\text { Re-en- } \\
\text { gaged }\end{array}$ & $\begin{array}{l}\text { Offi- } \\
\text { cers }\end{array}$ \\
\hline 1883 & - & 一 & - & 50 & - & - & 一 & 一 & - \\
\hline I 884 & 一 & 一 & - & 30 & - & 一 & - & - & - \\
\hline 1885 & - & - & 一 & 20 & - & 2 & 一 & - & - \\
\hline 1 886 & 一 & 一 & 一 & 5 & 一 & 2 & - & - & - \\
\hline 1887 & - & - & - & 642 & 20 & г 6 & 一 & - & - \\
\hline r 888 & - & - & 一 & 300 & 5 & 17 & - & 一 & - \\
\hline I 880 & - & - & - & IO & 5 & 4 & 204 & - & - \\
\hline I 890 & 一 & 一 & 一 & $\mathrm{I}, 200$ & 53 & I 2 & - & - & - \\
\hline $189 \mathrm{I}$ & - & 一 & 一 & 542 & 6 & I I & 9 & - & - \\
\hline 1892 & 一 & - & - & 300 & I 6 & 9 & 125 & 13 & 3 \\
\hline 1893 & 192 & 一 & 3 & 450 & I 3 & 9 & 790 & 3 & 9 \\
\hline 1894 & 295 & - & I & 760 & I 4 & 14 & 710 & 5 & 2 \\
\hline 395 & $3^{6}$ & 一 & 2 & 330 & Io & I I & 72 & 20 & 2 \\
\hline 1896 & 3 & 2 & - & 300 & 28 & I I & I 36 & 40 & IO \\
\hline 1897 & 6 & 6 & 一 & 70 & 6 & 8 & 55 & 43 & 2 \\
\hline 1898 & 8 & I 3 & 3 & 200 & I I & 14 & 200 & 37 & I 2 \\
\hline I 899 & I 9 & I & I & 71 & 40 & 15 & 76 & 52 & 9 \\
\hline I 900 & I & 5 & 一 & 20 & I 7 & 5 & 50 & 38 & 8 \\
\hline $190 \mathrm{I}$ & I & 3 & 一 & 15 & 26 & 6 & $9^{2}$ & 43 & 9 \\
\hline 1902 & 2 & 6 & I & Io & 50 & 4 & 42 & 70 & IO \\
\hline \multirow[t]{2}{*}{1903} & - & 7 & 一 & Io & $2 \mathrm{I}$ & 7 & 37 & 59 & \\
\hline & $5^{6} 3$ & 43 & I I & 5,335 & $34 \mathrm{I}$ & 177 & 2,598 & 423 & 82 \\
\hline
\end{tabular}

could be no question of abandoning the system of recruiting by means of regional conscription. It signifies, indeed, that all the population throughout the whole extent of the territory participates in this public charge as much in the interests of the regular and permanent operation of the recruiting of the national militia as in that also of the natives who benefit by the lessons of their military profession (a sense of order, discipline, cleanliness, clothes, hygiene, habitation, \&c.). The stay in the ranks of the armed force has as its principal advantage their initiation in civilised life, and their preparation for a regular life of work.

The proportion of deaths has become very low among the blacks of the Public Force and among the labourers. This is due in a great degree to the improved conditions under which our men live. The lodgment is well aired and neatly kept. The food is varied as much as possible, and its careful prepara- 


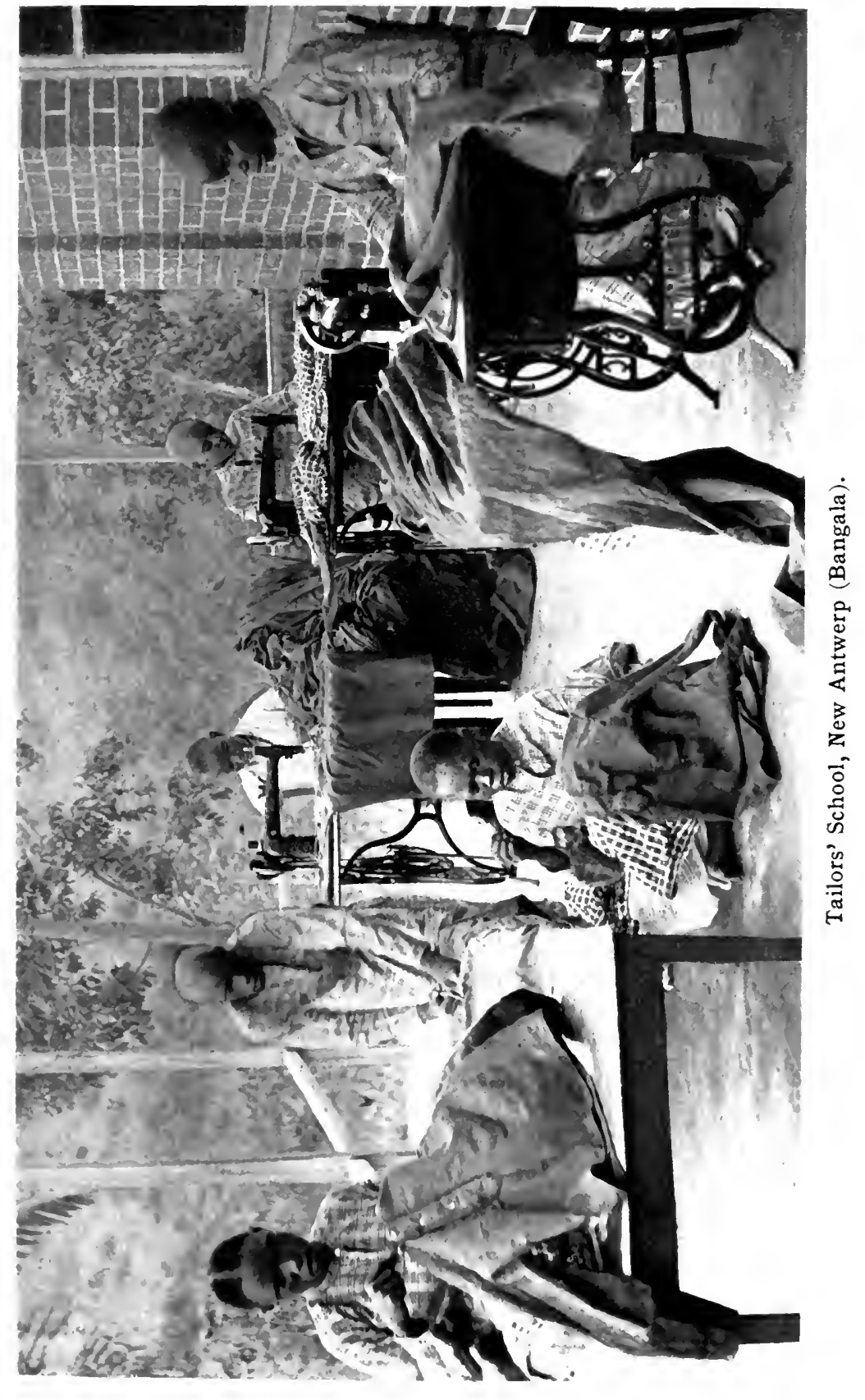





\section{The Congo Public Force}

tion is provided for. The camps of the soldiers of the Public Force are well kept up. Barracks constructed in stone with cemented floors serve in the Lower Congo as lodgment for our troops. The black officers have their habitation separate from that of their men.

In the stations on the upper river these prescripts are also well followed. At Boma the creation of a working city, constructed of well-chosen materials, is in progress.

It is interesting to quote with regard to the constant and progressive improvement in the existence of the natives the following paragraphs from the report of Mr. Casement, His Britannic Majesty's Consul:

"Then (in I 887) I had visited most of the places I now revisited, and I was thus able to institute a comparison between a state of affairs I had myself seen when the natives lived their own savage lives in anarchic and disorderly communities, uncontrolled by Europeans, and that created by more than a decade of very energetic European intervention. That very much of this intervention has been called for, no one who formerly knew the Upper Congo could doubt, and there are to-day widespread proofs of the great energy displayed by Belgian officials in introducing their methods of rule over one of the most savage regions of Africa.

"Admirably built and admirably kept stations greet the traveller at many points.

"The Government station of Leopoldville numbers, I was informed by its chief, some I 30 Europeans, and probably 300 native Government workmen, who all dwell in well-ordered lines of either very well-built European houses, or, for the native staff, mud-built huts.

"On the whole, Government workmen at Leopoldville struck me as being well cared for, and they were certainly none of them idle."

In thus taking care of their employés the agents have performed a duty which has not only resulted in the well-being of the blacks, but has also allowed of a reduction in the number of the workers, and accomplishing better and more rapidly executed work. 
It will be observed elsewhere in this volume that some of those who condemn the State's system of Imper- government point to the Force Publique as fect, but the chief instrument by which the AdGood. ministration encompasses the enslavement of the native population. There are glaring discrepancies in what such persons, either maliciously or in ignorance, represent as the police system which prevails in the State at the present time. There does not exist a police system anywhere in Europe or Africa which has not some inherent defect. To expect the highest discipline and the utmost control in a police body composed of the imperfectly civilised Negroes of Equatorial Africa is only one manifestation of that narrow, unintelligent outlook upon the subject over which certain persons are agitating themselves into suspicious frenzy. The report of M. Fuchs denotes that the State's police system is founded upon high principles of justice, that discipline and order are being maintained without the abuse of power, and that, whatever individuals may have done to transgress in the sphere of their opportunity, no such extravagant charges of misgovernment as a few persons have made can be fixed upon a State with the police laws above indicated. A million square miles of savage territory are governed with 14,270 natives enrolled in the State's military service. This is seven soldiers to about every 625 square miles. Does this not signify native respect for, and tranquillity in, the State? What civilised community maintains its authority with such a meagre force? 


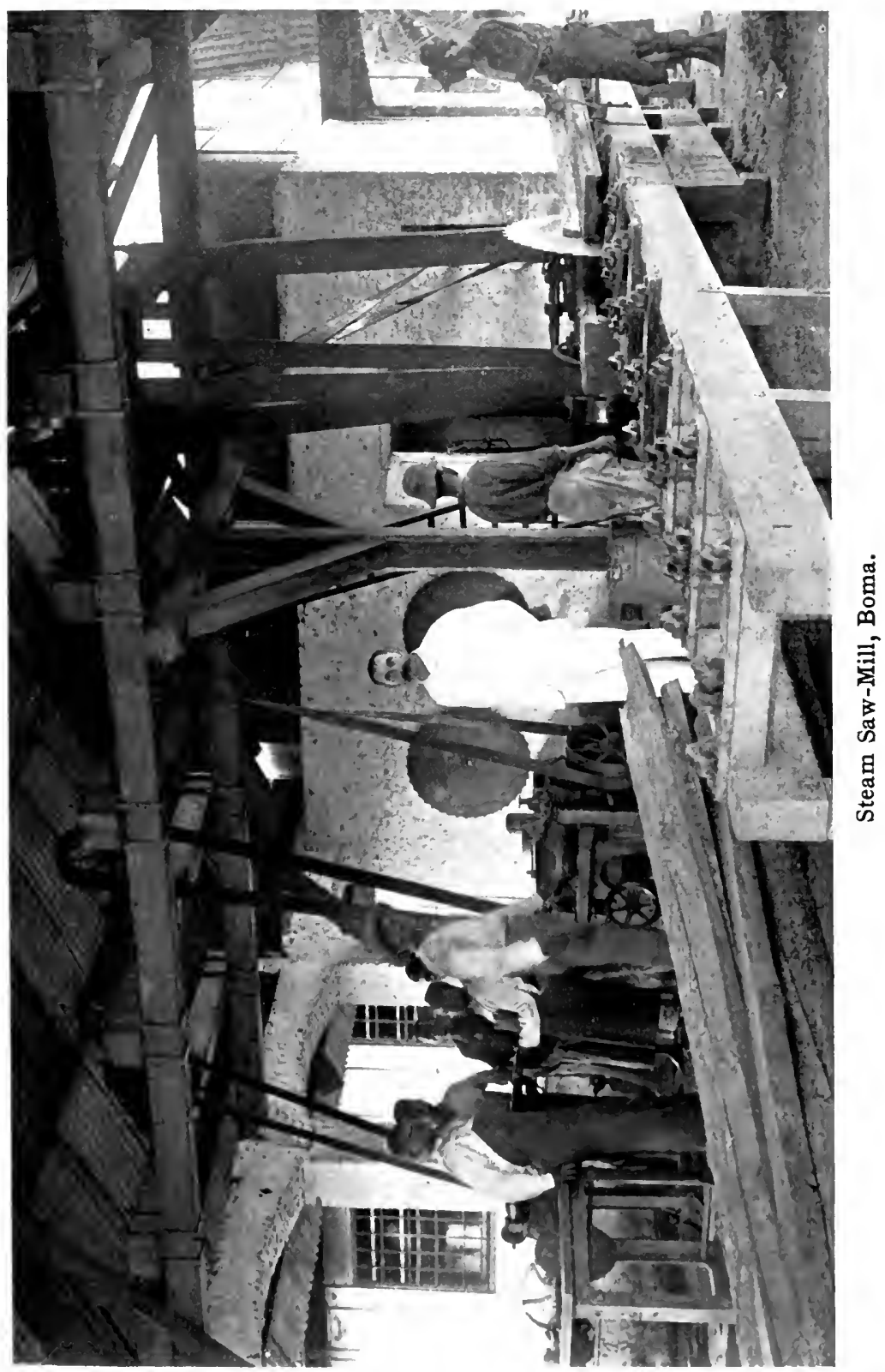





\section{CHAPTER XV}

BELGIAN CAMPAIGNS AGAINST THE ARABS

I had long been foreseen, as an inevitable result of the advent of the Belgians in Central Africa, that a direct conflict between them and the Arabs, continued to the extinction of one or other of the belligerents, must sooner or later take place. The chief cause of the presence of the Belgians in the country being the suppression of A Fight to slavery was in itself sufficient to assure this.

the Death.

As shown in the chapter dealing with that subject, the Belgian pioneers in establishing posts throughout the country were guided chiefly in their selection of sites by a desire to obstruct the natural routes of the slave-traders; and this, as we have seen, had the effect of frequently bringing Belgians and Arabs into collision.

After the Belgian operations on the Uelle and Lualaba, the Arabs became seriously alarmed. They perceived not only their nefarious method of livelihood at stake, but their very existence as a coherent fighting force was also threatened. In dread at this prospect, the Arabs resolved to precipitate matters, and took the offensive. It is not easy to see what other conclusion they could have reached, for the Belgians had now concerted practical measures 


\section{78}

\section{Story of the Congo Free State}

which rendered their raids upon Negro villages no longer possible, while such Negro chiefs as had hitherto been amenable to Arab influence had been either alienated or killed off in fair fight. A tax on ivory, too, imposed by the Congo Government in r $89 \mathrm{r}$, though moderate in amount and perfectly just in its incidence, was bitterly resented by them. It was clear, therefore, that the only hope for the Arabs lay in recovering the country which the Belgians had wrested from them; and as. with every day that passed their chances of doing this became more remote, they resolved to stake all that was left to them upon one desperate effort.

The first practical proof of this intention came upon the Belgians somewhat as a surprise. M. Hodister, acting on behalf of the Belgian Society of the Upper Congo, a company of merchant adventurers, had founded two stations on the river Lomami. In this act, M. Hodister was held by the Congo Administration to have exceeded the range permitted him, Lieutenant Le Marinel, the Belgian officer commanding that region, having foreseen danger in pressing so closely upon the Arabs, a contingency with which he was not as yet prepared to deal. But the opportunity of striking a blow afforded by Hodister's precipitate act was too inviting to be neglected, and the Arabs promptly seized it. The blow fell March I5, 1892, near Riba Riba, on the Congo, the Arabs murdering Hodister and his ten white companions. It was not a fight; it was a massacre. Elated by their success, the Arabs next proceeded to burn the factories belonging to the Belgian So- 

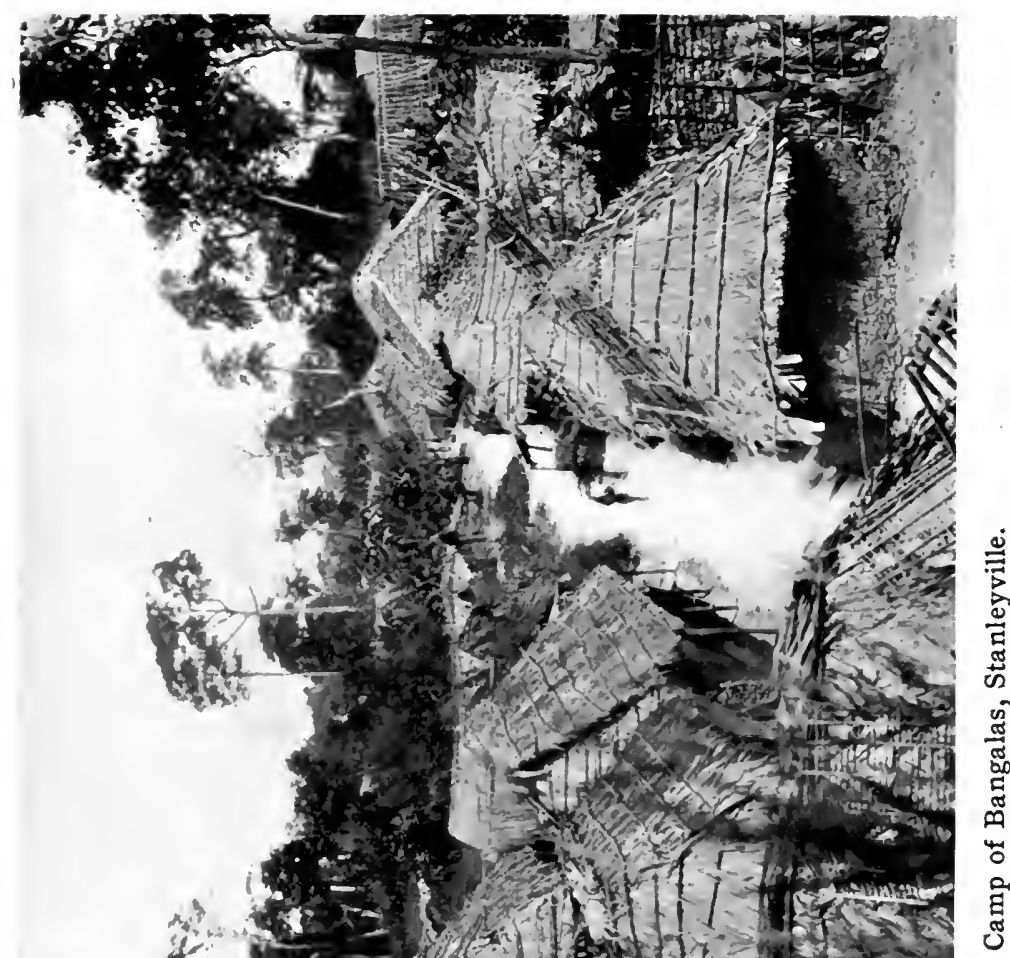

营

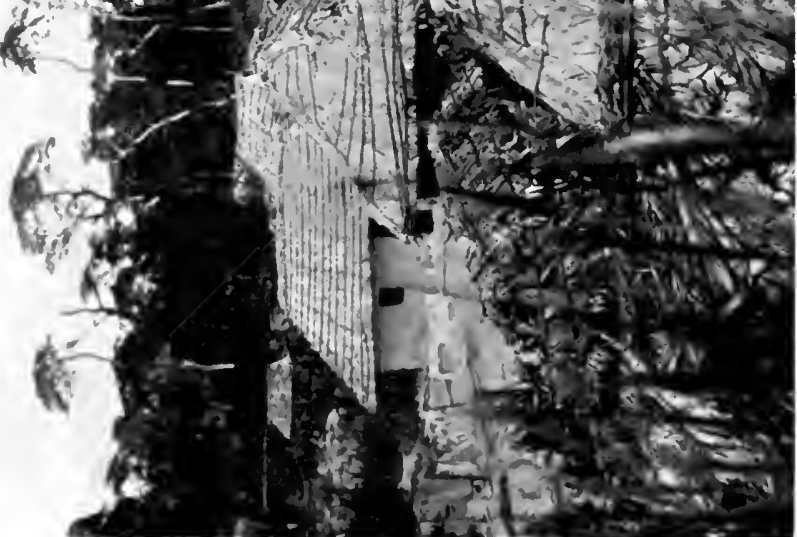



ciety of the Upper Congo, and to kill their inmates; so that, for the moment, the collapse of Belgian power in that section of the country was complete.

Another event that occurred about this time served to emphasise the determination of the Arabs. Rashid, the Arab governor of Stanley Falls, on being invited by the Belgians to assist in obtaining the punishment of the murderers of Hodister and his companions, absolutely refused to have anything to do with the matter, and with difficulty concealed the satisfaction he felt at that tragic event. Sefu, a son of Tippo Tip, began now to realise his father's property, an ominously significant act. On all sides it was felt that a crisis was at hand, and Lieut. Le Marinel prepared to meet it by appointing to the command of the camp at Lusambo Lieut. Francis Dhanis, an officer who had distinguished himself by founding the camp at Bosoko, on the Aruwimi, and in many other ways exhibited uncommon energy and resource.

Immediately upon the arrival of Lieut. Dhanis at Lusambo, intelligence reached him that Gongo Lutete was on the war-path, seeking to pass the Sankuru. This Gongo Lutete was a Negro chief who had allied himself with the Arabs and assisted them in enslaving his own race. The following is a description of him from the pen of Dr. Sidney Hinde:

Gongo Lutete was by blood a Bakussu. He had himself been a slave, having as a child fallen into the hands of the

'A nephew of Hamed-ben-Mohamed, better known as Tippo Tip,i. e., "winking the eye,"-an Arab slave merchant, invested with the government of Stanley Falls by King Leopold, at the instance of Stanley, he having, in consideration of a monthly salary, bound himself to repress all slave-hunting and slave-dealing below the Falls. 
Arabs. While still a youth, as a reward for his distinguished conduct and pluck on raiding expeditions, he was given his freedom. Starting with one gun at eighteen years of age, he gradually collected a band of brigands round him, whom he ruled with a rod of iron, and before long became Tippo Tip's chief slave and ivory hunter. At the time of his adhesion to the State, Gongo was perhaps thirty years of age. He was a well-built, intelligent-looking man of about five feet nine inches in height, with a brown skin, large brown eyes with very long lashes, a small mouth with thin lips, and a straight comparatively narrow nose. His hands were his most remarkable characteristic; they were curiously supple, with long narrow fingers, which when outstretched had always the top joint slightly turned back. One or both hands were in constant movement, opening and shutting restlessly, especially when he was under any strong influence. His features meanwhile remained absolutely immovable. One had to see this man on the war-path to realise the different aspects of his character. The calm, haughty chief, or the genial and friendly companion, became on the battlefield an enthusiastic individual with a highly nervous organisation, who hissed out his orders one after another without a moment's hesitation. He was capable of sustaining intense fatigue, and would lead his warriors through the country at a run for hours together.

With such a redoubtable fighter as Gongo Lutete to contend with, it was clear to Lieut. Dhanis that no time must be lost. Believing, with von Moltke, that the best defence against your enemy is to attack him, Dhanis moved against Lutete without delay, and brought him to battle on the 23d of April, and again on the 5 th and gth of May. The first two engagements were undecisive. The third proved a hard fight. At first the fortunes of the day were all in favour of the Arabs; and when his native aux- 


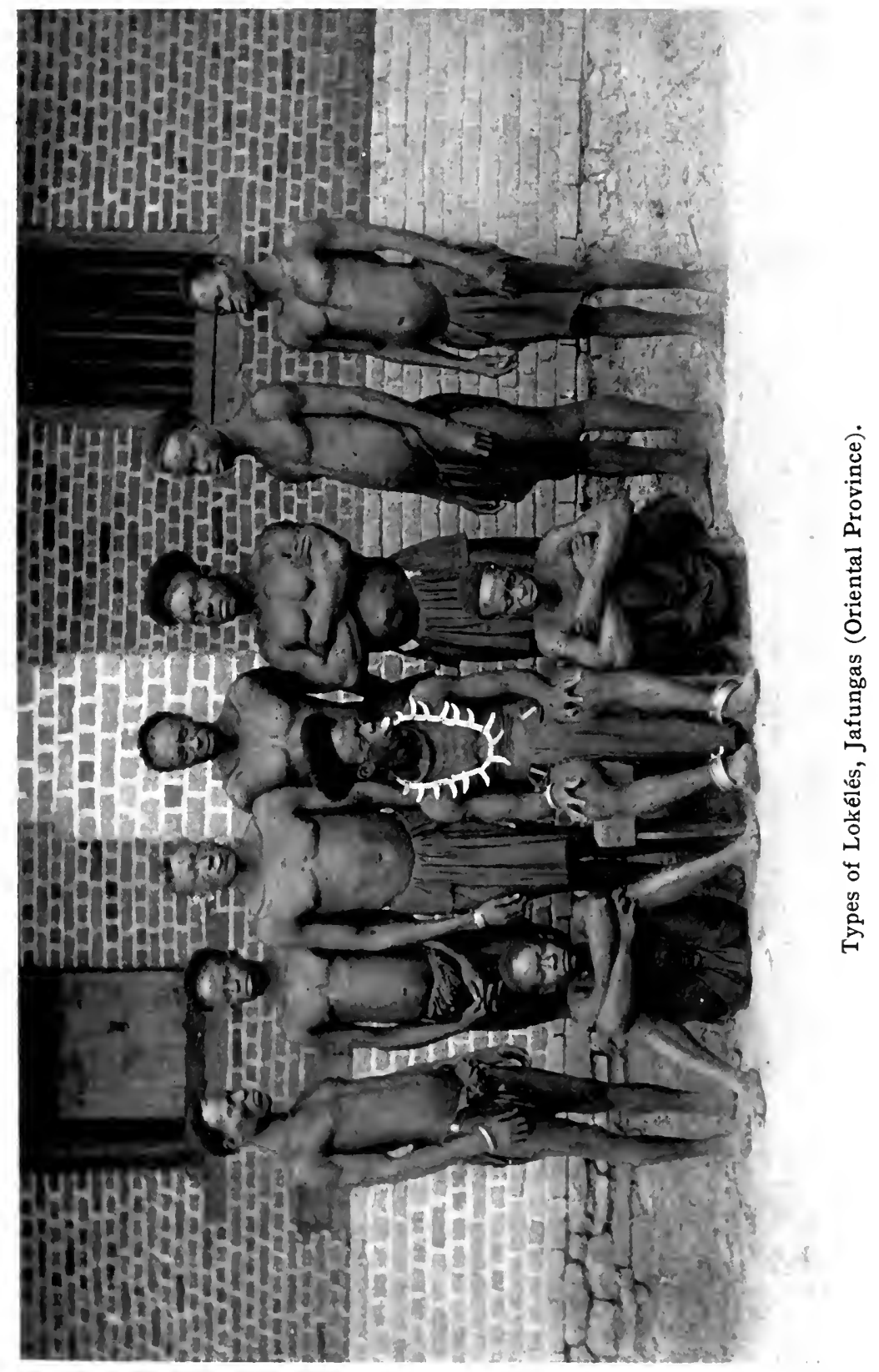



iliaries turned and fled it seemed impossible for Lieut. Dhanis to gain the victory. But that very circumstance, so disconcerting in itself, saved the Belgians. As the Arabs advanced, they shouted: "Do not fire! These are natives; make them prisoners." It was a fatal command. The Belgians rallied, and received their foes with such a tremendous fusillade that they were thrown into confusion and took refuge in flight. Gongo Lutete surrendered unconditionally to Lieut. Dhanis, and professed himself henceforth a faithful vassal of the Congo State. He was an able man, probably the most intelligent of the Negro race in the country, and certainly the best acquainted with the wily Arab and his ways; so, after some hesitation, his overtures of friendship were accepted. The force which Gongo Lutete had commanded being now at the disposal of the Belgians, its first employment under its new masters was the establishment of a new post on the Lomami, at Gandu, on the route to Nyangwe and Kassongo.

Meanwhile Sefu, son of Tippo Tip, had not been inactive. With cunning worthy of his father, he had no sooner returned from Stanley Falls to Kassongo than he made war upon the station there and seized it. Two Belgian

Arab Treachery. officers, Lieutenants Lippens and De Bruyn, were also captured by him, to whom he confided the comforting assurance that he only refrained from putting them to death because he hoped to find them useful as hostages in his negotiations with the Congo Government. Sefu had for his ally Munie 
Moharra, chief of Manyema, a powerful Arab leader. Between them they raised a formidable force, which they hastened to employ against the Belgians. Before doing so, however, they stated the terms upon which they would make peace. As these terms included, among other provisions, handing over to them Gongo Lutete and the establishment of a new frontier to be indicated by them, there was really nothing for the Belgians to consider. Their terms being, of course, refused, the Arabs marched from Nyangwe and Kassongo in the direction of the Lomami. Their exact numbers are not known; but notwithstanding the defection of Gongo Lutete and his following, it is certain that they were very numerous.

The force at the disposal of Lieut. Dhanis, though not so great as that of the Arabs, was yet a considerable one. His staff consisted of seven Europeans, and he had three hundred and fifty regular troops and one 7-5 Krupp gun. The command of the troops acquired by Gongo Lutete's defection from the Arabs, numbering several thousands, was entrusted to Captain Michaux, with Lieut. Duchesne second in command. The Arabs having crossed the Lomami at a lower point than where they had been expected, were met by Captain Michaux and Gongo Lutete at Chige, and a battle ensued. The Arabs numbered sixteen thousand men, not more than half of whom were armed with muskets, the rest carrying bows and spears. Lutete having complained that his men could not fight because their guns had become wet with the rain, Michaux, know- 
ing that the Arabs must be labouring under a like difficulty, ordered a general attack. His men responded nobly and a fierce fight ensued, but it was of brief duration. Perceiving that they were outgeneralled, the Arabs became confused and rushed madly into the river which they had recently been at so much pains to cross, only to find that retreat was impossible. In that situation they were shot down in great numbers. Twelve hundred Arabs were drowned, more than half that number lay dead upon the battle-field, and nearly a thousand prisoners were captured, together with a large quantity of war material. Thus opened the Arab campaign on November 23, 1892, with the battle of Chige.

Having re-formed his forces, Lieut. Dhanis now crossed the Lomami, determined to carry the war into the enemy's stronghold. His army, which had been reinforced, was now quite a large one, numbering six Belgian officers, four hundred regulars, and twenty-five thousand natives, the latter being commanded in detail by their own chiefs. Lieut. Scherlink and Dr. Hinde commanded the advance guard. Michaux and Gongo Lutete marched together, and joined forces with Scherlink and Hinde at Lusana. On the route, several Negro chiefs made their submission and strengthened the force with men and provisions.

On reaching Lusana, the Belgian leaders learned with deep regret that Sefu, son of Tippo Tip, had put to death their brave comrades, De Bruyn A Triple and Lippens, and that he had also exe- Tragedy. cuted a native who had endeavoured to save them, 
in circumstances at once pathetic and heroic. Sefu, it now appeared, accompanied by Munie Moharra, was hurrying to attack Dhanis, and the latter instructed Lieutenants Delcommune and Francqui, then just returned from Katanga, to intercept him if possible.

But the second battle of the campaign was to be fought by Dhanis' force. It took place on December 3 oth, and opened inauspiciously for the Belgians, Gongo Lutete's men being defeated and dispersed. Fortunately they formed only the advanced guard, and on Dhanis and Michaux coming up the fortune of the day changed. Dhanis confined his energies to a frontal attack, while Michaux assailed the Arabs' flank. What Lutete's irregulars had been unable to do, the Belgians accomplished-but not easily. Part of the battle was fought in a swamp.

The Belgians displayed great courage under extraordinary difficulties, and continued the fight until the Arabs broke and fled. The honours of the day rested with the Krupp gun, which killed many and frightened more. The Arabs left two hundred men dead on the field, the Congo State only eighty, in which number is included the wounded. When the Belgians captured their enemies' camp, it was found that they had slain their own women, that being the barbarous custom of the Arabs to which they resort whenever there is danger of their women being made prisoners of war.

Immediately after this battle, the Congo State force crossed the Mwadi to a plateau known as the Gois Kapopa, and, having set up a camp there, 


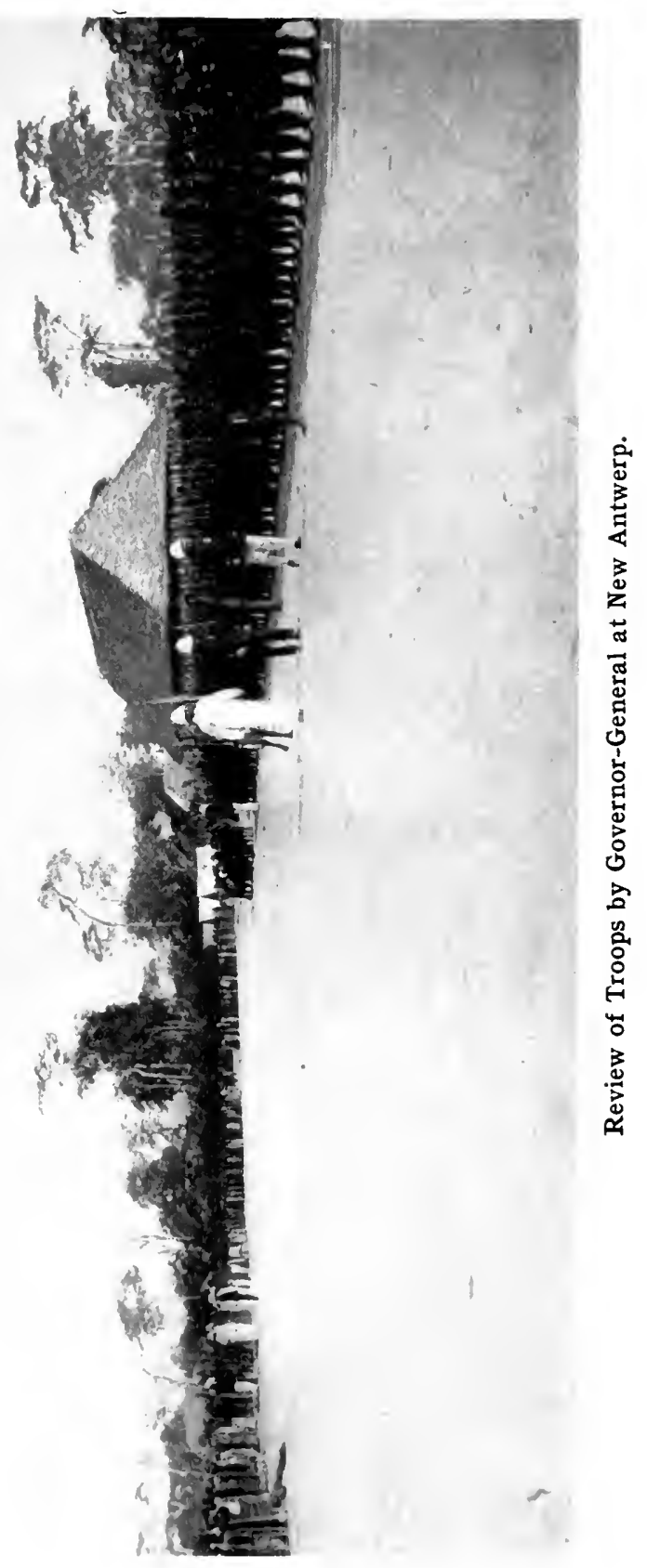



rested for a week. At the end of that period intelligence reached Lieutenant Dhanis that Sefu had gathered about him a vast following and was again threatening trouble. Slightly counteracting the danger this implied, the same messenger also announced that, by order of Lieutenant Delcommune, Lieutenant Cassart, with a numerous body of men, was then on his way to join Dhanis.

Cassart came, as announced, but met with a desperate adventure by the way. He had been entrusted to bring to Dhanis fifty thousand cartridges, and was provided with an escort of thirty European soldiers and about two hundred and fifty of Gongo Lutete's men. All went well with him until dawn of January 9, I893, when he was suddenly attacked by Moharra. A short, sharp fight ensued, as a result of which Cassart contrived to reach Dhanis' camp with a loss of only seven men; he also saved his cartridges, all but the five thousand or so that he had used during the fight.

The conflict between Moharra and Cassart occurred not far from the Belgian camp and was heard there, whereupon Dhanis sent a detachment of his men under Lieutenant De Wouters to join Cassart. De Wouters failed to effect his object; but he came upon a portion of Moharra's men, who mistook his force for a contingent from Sefu coming to their aid. When within twenty yards of the Arabs, De Wouters undeceived them by opening a terrific fire upon them. At the first volley Moharra fell dead. He had been wounded in his fight with Cassart, and was being carried by his wives when he met his fate. 
The manner in which the news of Moharra's death was conveyed to Sefu is a sufficiently strikA Cannibal ing proof of the debased savagery with Feast. which the Belgian civilisers have had to contend. They "broke the news gently" to him, thus: "We ate Moharra a few days ago."

The death of Moharra and defeat of his troops so upset Sefu's calculations that he immediately abandoned his strong camp on the Kipango, and betook himself and his followers behind the Lualaba, on Nyangwe. But for the unfortunate breaking of a bridge, Dhanis would have attacked him in his retreat. In consequence of that accident, Sefu was cnabled to cross the river without molestation. Dhanis, having no canoes, could not come up with him; so the two forces settled down on either side of the river for five weeks and occasionally exchanged harmless shots.

The canoes in which the Arabs had crossed the river belonged to the Wagenia, a tribe who made their home hereabouts and who lived chiefly by fishing. Nearly all their canoes were now in the possession of the Arabs, who evinced no disposition to part from them. Dhanis exerted all his wit to induce the Wagenia to provide him with canoes, but they either could not or would not. Professing friendship for both belligerents, and ready at all times to take bribes from each, they proved useful go-betweens. One day the Wagenia reported that the store of provisions in Nyangwe was almost exhausted. "Here," said Dhanis to his informant, "take these six fowls to Sefu and present them to him from me. Tell 


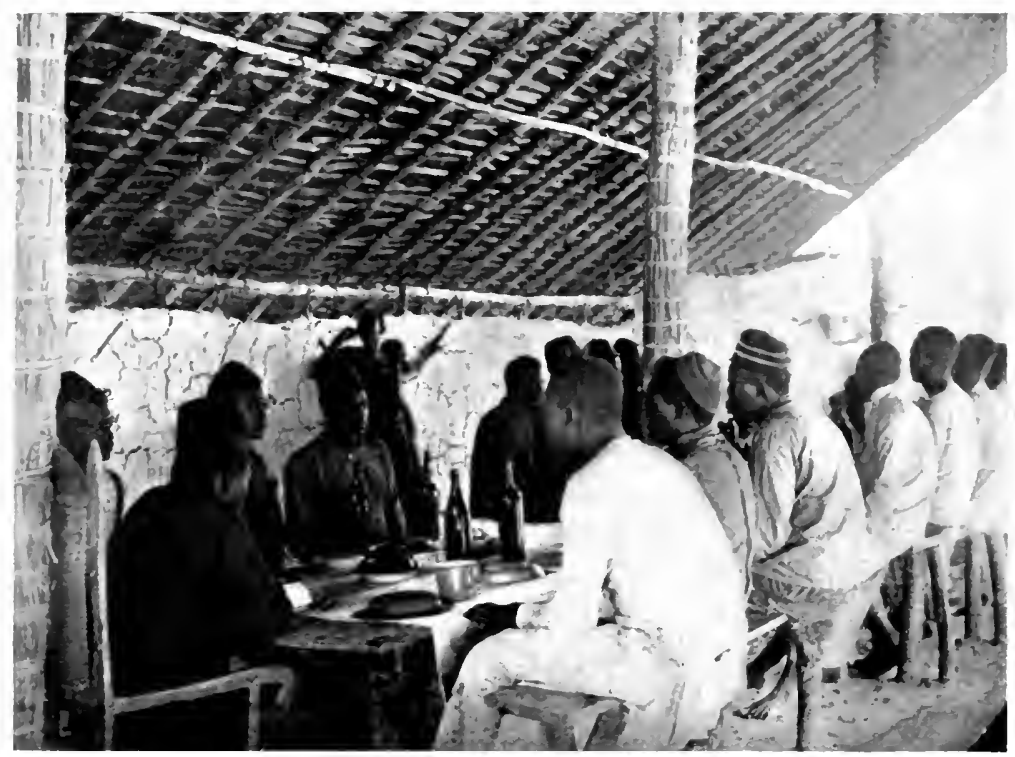

Soldiers' Mess, Suruango, I903 (Uelle).

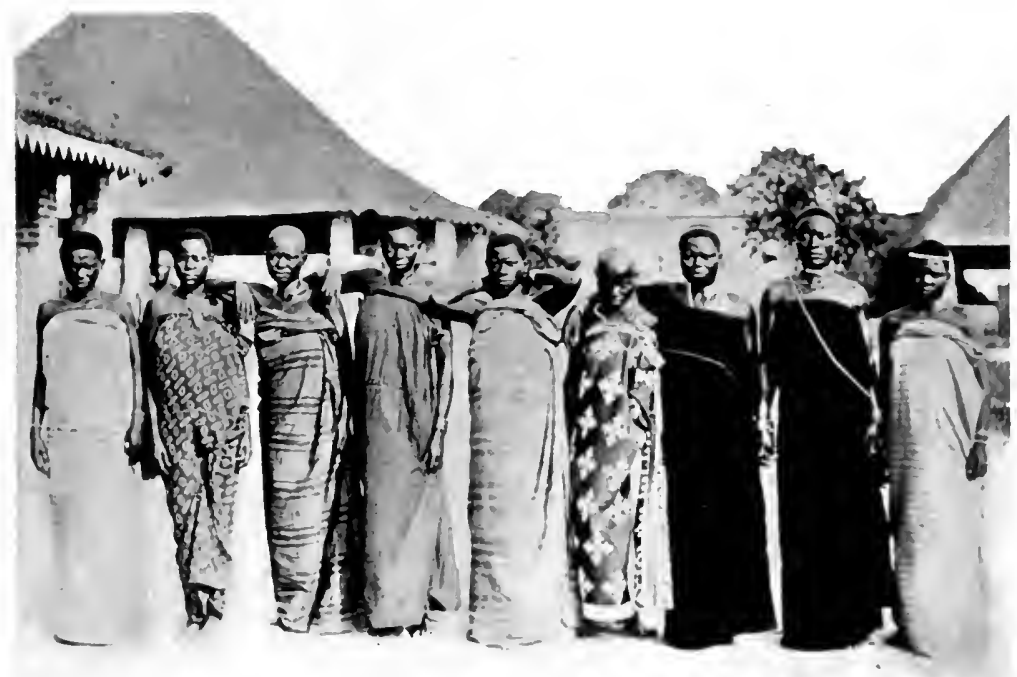

Soldiers' Wives, Bumba. 

Belgian Campaigns against the Arabs 187

him that at present I have plenty, but when my supply runs out I will cross the river." This message deceived Sefu, as it was intended to do. As a matter of fact, the six fowls were the only ones Dhanis had in his camp. The effect of this strategem was perceived before many days, the Arabs coming over to the western side of the river, where they began to build forts, or "bomas," as they call them, a short distance below the Belgian camp. Dhanis resolved to attack them at once, and with this object divided his force into two columns. The engagement that ensued proved a complete triumph for the State troops. The Arabs lost nearly a thousand men, many being drowned in an attempt to swim across the river. The Wagenia, anxious to ally themselves with the winning side, hastened to produce canoes in abundance. Dhanis was now able to transport his troops across the Upper Congo, and, that object achieved, he captured Nyangwe almost without an effort, Sefu retreating to Kassongo without firing a shot. This event occurred on 4th March, I893.

Though Dhanis was now master of Nyangwe, his difficulties were not all surmounted. He had not been installed there many. days before it became necessary to burn down a large part of the town in order to frustrate an attempt by the Arabs to surprise it. Then other and worse dangers threatened. Influenza and smallpox broke out among his men and decimated them. No active prosecution of the campaign was possible until April, when these plagues abated and reinforcements, five hundred strong, under CommandantGillain and Lieutenant Doorme, arrived. 
Leaving De Wouters in command at Nyangwe, Dhanis now marched on Kassongo. It was a bold Civilisation venture, for while the Arabs had sixty Trium- thousand men, and held four "bomas," phant. Dhanis disposed of only three hundred regular troops and two thousand auxiliaries. On April 22, Doorme had the good fortune, at the beginning of the fight, to rush an important fort which commanded the Arab rear. The Arabs were greatly perturbed by this circumstance, and fought with less than their usual valour. Before two hours had passed, Kassongo was in the hands of the Congo State troops, with vast quantities of valuable spoil. The triumph of civilisation over savagery was complete, the only jarring note in Belgian ears being confirmation of the murder of Emin Pasha a month before. $^{x}$

I For amplified accounts of the Arab wars, see The Congo State, by D. C. Boulger; Le mouvement géographique, by A. J. Wauters, I8841898; Rapport de Baron Dhanis sur la campagne arabe dans le Manyéma, 1895; The Fall of the Congo Arabs, by Dr. Sidney L. Hinde. 



\section{CHAPTER XVI}

\section{BELGIAN CAMPAIGNS AGAINST THE ARABS}

(Concluded)

W

HILE the events described in the preceding chapter were being enacted, M. Tobback, Resident for the Congo Free State at Stanley Falls, with his second in command, Lieutenant Van Lindt, and a small force, occupied a position of imminent danger. Rashid, a nephew of Tippo Tip and cousin to Sefu, was installed there. This arch-traitor, while professing An Arab Traitor. the utmost friendship for the State authorities, and accepting favours at the hands of Belgian officers, was really a confederate of the Arabs. His character, which had long been suspected, appeared unmistakably from evidence discovered by Lieutenant Dhanis at Kassongo, when that place was captured by the State troops. On May 13 th, immediately after he had been informed of the fall of Kassongo, Rashid openly attacked the State garrison. A fierce fight ensued, in which three of Tobback's men were killed and seven wounded. Nearly a hundred of Rashid's men were placed hors de combat; but he was better able to stand the loss than Tobback was his. Four days the struggle continued with varying fortune, but on the fifth day it became evident to Tobback 
that it was impossible for him, with the handful of men at his disposal, to successfully resist the large force operating against him. He was perfecting his plans for the evacuation of the station, and had prepared six large canoes, when the whole situation changed by the opportune arrival of Commandant Chaltin. The presence of this officer, and the State troops that accompanied him, justified the experiment of an attack upon the Arabs, which proved entirely successful. The State troops captured all the Arab positions, and took fifteen hundred prisoners, Rashid himself escaping capture in ignominious flight.

At this juncture the Congo State officers came to the conclusion that the Arab power was effectually broken, and they did not anticipate further trouble with the slave-traders beyond, possibly, an occasional skirmish. The State's progress in its campaign against the Arabs had, on the whole, been extremely successful, and its Sovereign had good reason to be satisfied with the work accomplished. When, in June, I893, Captain Ponthier came up the Congo with reinforcements for Dhanis, that event seemed to give emphasis to this optimistic view. Certainly it so alarmed Sefu that he abandoned the struggle and fled to German territory.

Immediately after the flight of Sefu a painful incident occurred which greatly embarrassed the Congo A Fatal State authorities. A Belgian officcr, havBlunder. ing come to the groundless opinion that Gongo Lutete was a traitor, ordered him to be courtmartialled and shot. It was a disastrous event, not 


\section{Belgian Campaigns against the Arabs I9I}

only wrong in itself, but alienating from the State the affection of Gongo's men, and affording its enemies in Europe an opportunity of reviling the Congo Administration; a libel which, though it has been many times refuted, they still industriously disseminate.

It soon became evident that May, I893, was not to be recorded in history as the month in which slave-trading Arabs had been finally repressed. A chief belonging to Ujiji, named Enemy Rumeliza, with a considerable force of Appears. Arabs, now appeared east of Tanganyika. Having penetrated as far as Kabambari, midway between Kassongo and the lake, he encamped there, and explained his presence by avowing his intention to reconquer Manyema.

Rur eliza's following was so numerous and so well equipped that October had arrived before Captain (for such he had recently become) Dhanis thought it expedient to move against him. When he did take the field, his force consisted of five officers (of whom Ponthier was one), about four hundred regulars, and three hundred auxiliaries; and they had with them the Krupp gun which had served them so well in many a battle. Unfortunately, ammunition for it was all but exhausted.

On reaching the Arabs' camp at Mwana Mkwanga, they were found to be very advantageously placed in two large, well-built bomas. ${ }^{x}$ The first efforts to

The following description of a boma is from the pen of Dr. Hinde:

"An Arab force on the march employs a large number of its slaves in cutting down and carrying with them trees and saplings, from about twelve to fifteen feet in length and up to six feet in diameter. 
dislodge them met with no success. The Krupp gun proved of very little service. Of the scanty supply of ammunition, a large portion was wasted by the native troops through lack of skill in manipulating the gun, and finally they abandoned it, after which it was worked by European officers who could be ill spared for the duty. When one of his officers, De Lange, fell wounded, Captain Dhanis decided to retire, and a position was taken up scarcely inferior to that held by the Arabs.

Emboldened by what they erroneously regarded

As soon as a halting place has been fixed on, the slaves plant this timber in a circle of about fifty yards in diameter, inside which the chiefs and officers establish themselves. A trench is then dug, and the earth thrown up against the palisades, in which banana stalks, pointing in different directions, are laid. Round the centre, and following the inequalities of the ground, a second line of stakes is planted, this second circle being perhaps three or four hundred yards in diameter. Another trench is then dug in the same way, with bananas planted as before in the earthwork. The interval between the two lines of fortifications is occupied by the troops. If the boma is only to be occupied for two or three days, this is all that is usually done to it; but if it is intended for a longer stay, a trench is dug outside the palisades. The object of using banana stalks in this way is ingenious. Within four or five hours they shrink, and on being withdrawn from the earth leave loopholes, through which the defenders can fire without exposing themselves. Little huts are built all over the interior of the fort, and these huts are also very ingeniously devised, and are, furthermore, bombproof. They consist of a hole dug a yard and a half deep and covered with wood. This wood forms a ceiling, over which the earth from the interior is placed to the depth of a couple of feet, and a thatched roof placed over all to keep off the rain. In many of the bomas we found that the defenders had dug holes from the main trenches outwards, in which they lived, having lined them with straw. The whole fort is often divided into four or more sections by a palisade and trenches, so that, if one part of it is stormed, the storming party finds itself in a cross fire-a worse position than when actually trying to effect an entrance. We found that the shells from the 7.5 Krupps did little or no damage to these forts." 


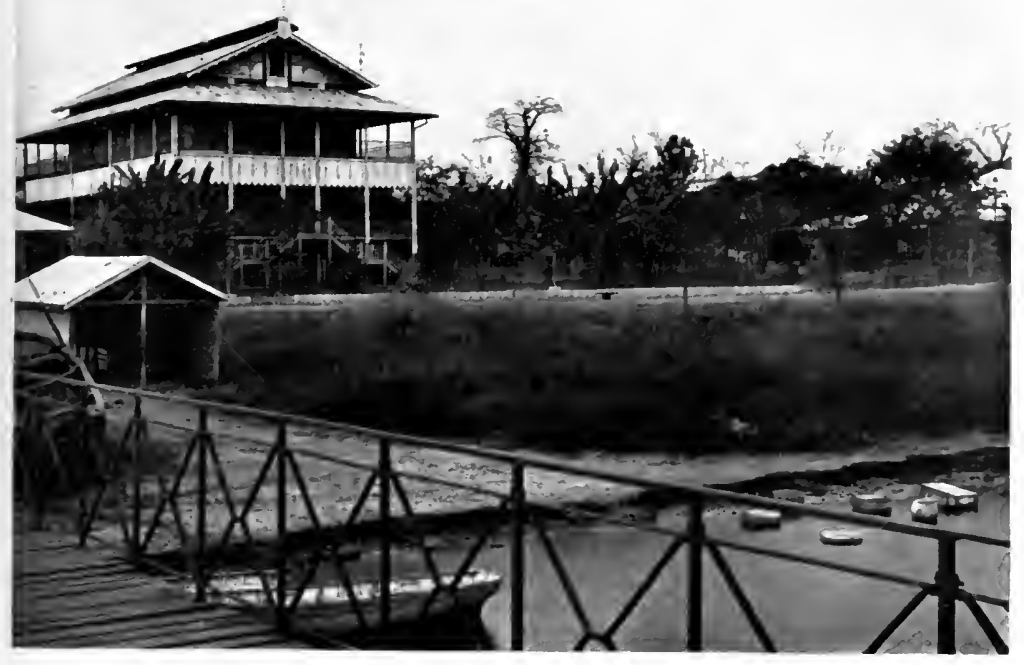

Post Office on River Bank, Boma.

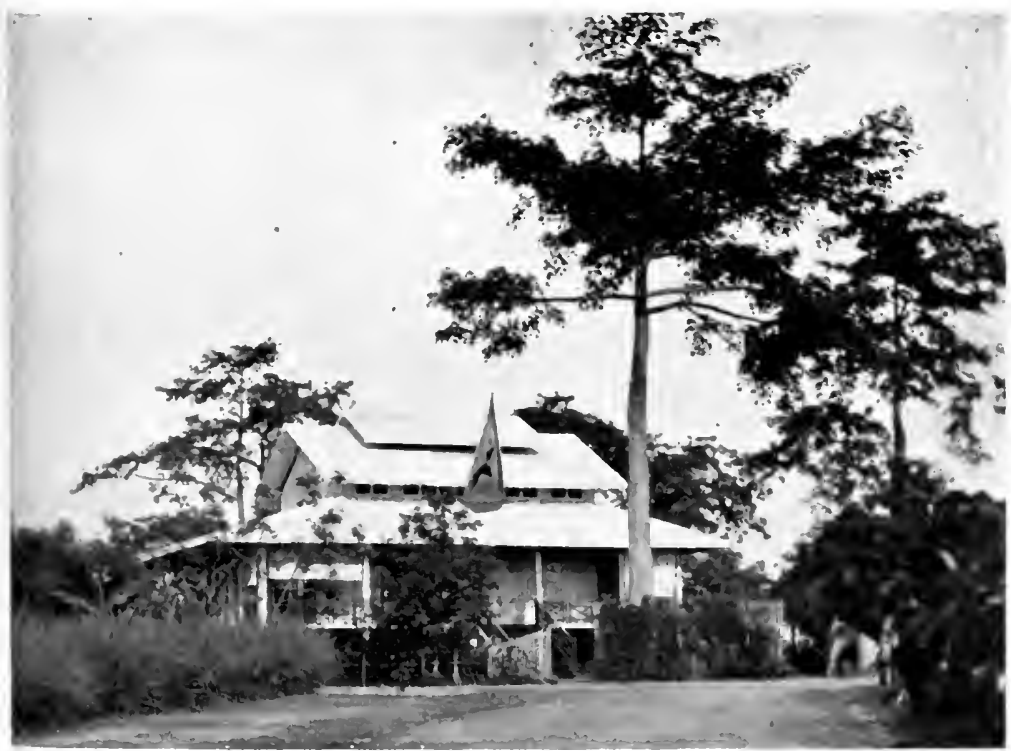

Office of Secretary-General, Boma. 

as a great victory, the Arabs lost no time in attacking the State camp. But this time the tables were turned, and they were repulsed with heavy loss. The arrival of reinforcements from Kassongo contributed to this result; but in consequence of some error, Kassongo was left without sufficient guard. This fact coming to the knowledge of the Arabs, they hastened to take advantage of it. To avert this calamity, De Wouters, by order of Captain Dhanis, marched night and day, through a violent storm, and effectually intercepted them. Not a day passed without a fight, victory inclining first to one and then to the other belligerent. On the whole, the Congo State troops continued to hold their own fairly well against great odds. Wearying of the protracted struggle, the Arabs decided to make a desperate attack in full force upon the State camp. They selected a foggy day on which to make their assault, and were greatly aided thereby. At first they succeeded so well that they actually entered the State camp and engaged the Congo troops in a hand-to-hand combat. The struggle lasted five hours. The State troops lost fifty men, including the brave Captain Ponthier, notwithstanding which they succeeded in completely repulsing the Arabs, whom they chased right up to Rumaliza's boma. The Arab losses were far heavier than the State's. Captain Dhanis had every reason to be satisfied. Leaving De Wouters in active command, he now returned to Kassongo to reorganise.

After the departure of Dhanis, De Wouters continued the aggressive policy of his chief. In attacking 
the boma of Lubukine, Lieutenant De Heusch was killed, and so hot was the fight that his men fled. De Wouters lost five men killed (including De Heusch) and ten wounded; but the Arab loss was far heavier, and included Sefu, the son of Tippo Tip, who had returned from German territory and was pursuing his old courses.

It was not until nearly the end of December that Dhanis was again strong enough to take the offensive. By that time his troops had been rested and reinforced. They were none too early in taking the field, for information now came to hand that Rashid had rallied his forces after their defeat at Stanley Falls and was hastening to join Rumeliza.

To deal with this combination, Dhanis despatched Commandant Gillain with one hundred and eighty soldiers and two hundred auxiliaries to cut off Rumeliza's retreat, while De Wouters attacked Rumeliza's great boma at Bena Kalunga, Dhanis, with two Krupp guns, personally commanding the reserve. Rumeliza's boma proved impregnable, the Krupp guns failing to injure it, and news arrived that fresh forces were on their way from Tanganyika to aid Rumeliza.

Matters stood badly for the State when the opportune arrival of Commandant Lothaire, with three hundred men, changed the outlook entirely. This occurred on January 9, 1894, a day marked by another singular piece of good fortune. The boma which had so long defied the best efforts of the besiegers was set on fire and destroyed, a shot from one of the Krupp guns having blown up the Arab maga- 
zine. In their haste to abandon it, many Arabs were shot, while others were drowned in a desperate attempt to cross the river. By cutting off their water supply, the other garrisons were compelled to surrender, so that within three days over two thousand Arabs were taken prisoners by the State troops.

The Arab power was now effectually broken. To break it was an arduous task, expensive both in blood and money, but on the whole it was conducted as humanely as it is possible to conduct military operations. The sufferings of the Europeans were fully as great as, if not greater than, the sufferings of their enemies. Proportionate to their numbers, their mortality was higher. More succumbed to disease and the hardships of the campaign than were killed by the enemy's bullets, among them the gallant De Wouters, who passed away in the very hour of his triumph.

The chief honours of the Belgian campaigns against the Arabs undoubtedly rest upon Dhanis, who had exhibited foresight, patience, and skill in his every act. His ability and success $\begin{array}{r}\text { Honours for } \\ \text { Dhanis. }\end{array}$ were recognised by King Leopold, who conferred upon him the title of Baron. In his final report to King Leopold of the Arab campaign, dated December 20, I894, Baron Dhanis thus tersely sums up the results of that memorable struggle:

The annihilation of the Arab power has brought about the complete suppression of the devastating bands which, in order to procure slaves, had been ravaging the country with fire and sword, from the Uelle in the north down to the Sankura in the south. With them the slave trade disappears from the 


\section{Story of the Congo Free State}

regions they exploited, and very soon, we may hope, it will no longer exist in the Congo State. The native chiefs who have submitted have been reinstated in authority; others who have disappeared have been replaced by intelligent soldiers of the State; and some of the Arabs, who made their submission, have been left in enjoyment of their possessions. All have been disarmed and warned that their authority must be exercised under the direction of the State's agents, who are charged with the pacific settlement of any differences that may arise. . . . Large camps will be formed at Kassongo and Kabambari, and the numerous soldiers instructed there will form the nucleus of the national army. From this point of view the Arab campaign has forcibly shown that the natives of the various districts of the Congo are in no way inferior as soldiers to the blacks of the coast, who are most famous for their bravery. The Baluba and others trained and led by Lieut. Doorme, the Bangala under Captain Lothaire, etc., have been admirable. In the near future we may expect that it will no longer be necessary to recruit soldiers abroad at great expense. The country will mainly supply its own requirements, and the Manyema will be of great importance, alike from the number of men they can furnish and from the special aptitude of these men to the profession of arms. 


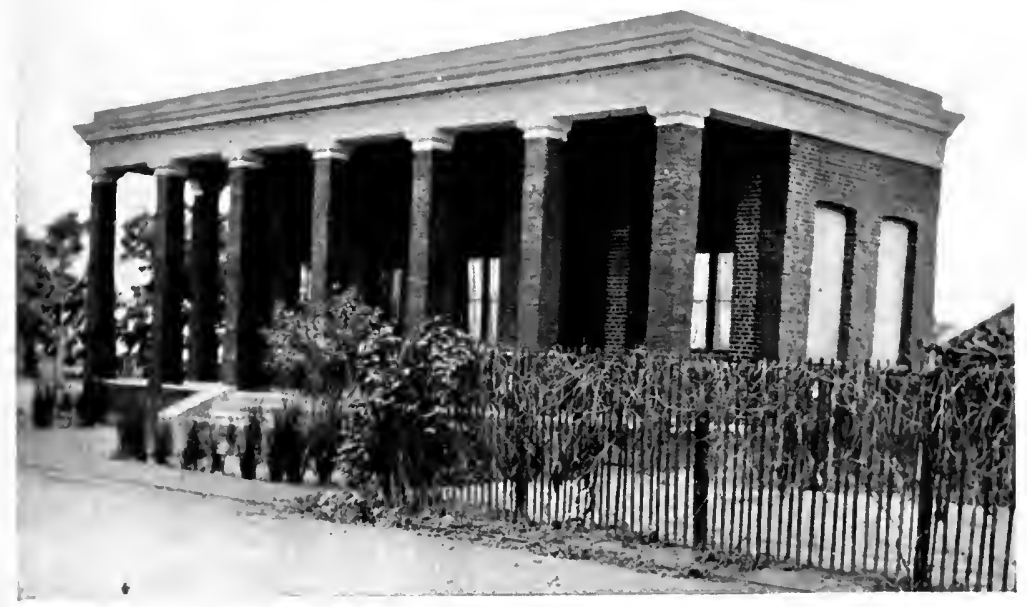

Office of Director of Transport, Boma.

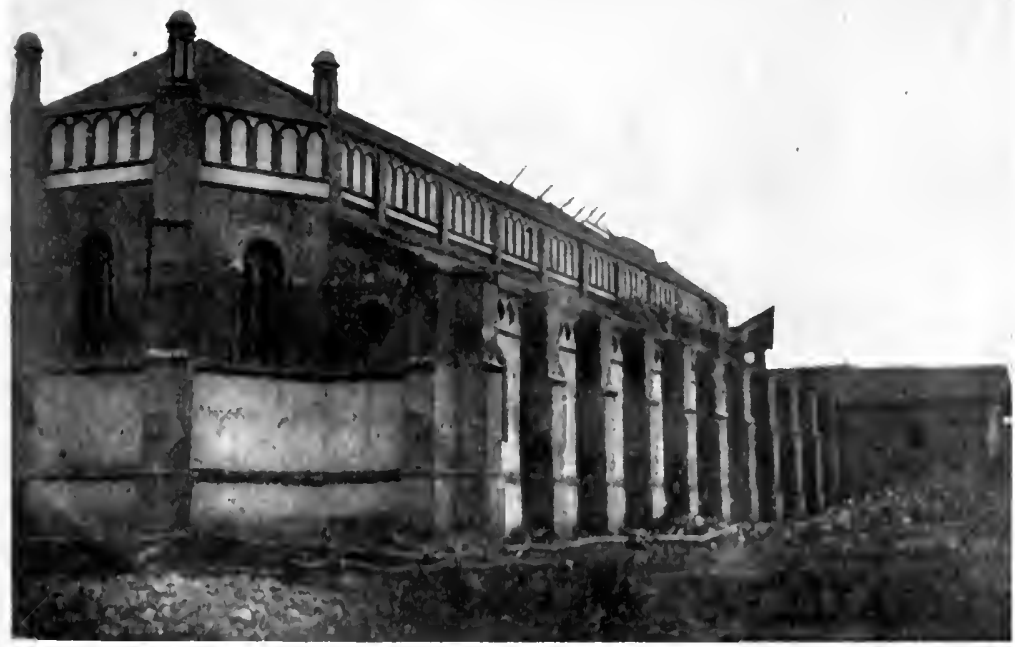

Bishop's Palace, Mission of Our Lady of M' Pala (Tanganyika). 



\section{CHAPTER XVII}

\section{THE SUPPRESSION OF SLAVERY}

I $\mathrm{T}$ is an old world-truth, supported by countless historical instances, that the way of the reformer is hard. When his progress is not opposed by vested interests, his enthusiasm is regarded with chilling indifference. However just his cause, he may safely count upon numerous oppon- The World ents, every one a giant. Even when he has Conservasucceeded in establishing a clear case for tive. reform, he is merely set free from one set of difficulties in order to confront other, and generally more formidable, obstacles.

When it first became known to the world that his Majesty Leopold II., King of the Belgians, had seriously determined to suppress the slave trade in Central Africa, the news provoked but little comment. "Is there any slave trade carried on in Central Africa?" people asked one another-for notwithstanding the wide dissemination of records of travel by Livingstone and Stanley, and the numerous reports from missionaries belonging to every religious sect, all affirming it, the great bulk of civilised mankind, too busy to regard them, rested content in the delusion that the iniquitous traffic was a thing of the past. 
This apathy, if apathy it may be called to be indifferent where the facts are not properly known, had to be fought and overcome by King Leopold, first among his own countrymen, and afterwards in the other countries of Europe and in America. By many the King's enterprise was regarded as quixotic, impossible of achievement; some continued indifferent, and yet others commended the King warmly, and lent their moral support in furtherance of his scheme. The material support, however, which was proffered to amplify his Majesty's own huge outlay came almost entirely from Belgians. On the whole, it was an uphill fight; but King Leopold won all along the line. As we have seen, his Majesty, by his wise initiative, patient labour, and lavish expenditure, first created the Congo State, and afterwards obtained from the great powers their recognition of the State so created, and of his own sovereignty of that State, accompanied by their hearty approval of what had from the first been King Leopold's main object in the founding of the Congo State, viz., the suppression of slavery.

It will be noted that an important epoch had now been reached. King Leopold's mandate was clear King and irrevocable. If it had been an arduLeopold's ous struggle to win that mandate, the effort Mandate. counted for little when compared with what was needed for the accomplishment of the task now opening out before him. The King of a small State, and with a depleted fortune, Leopold II. had, as materials for his task, his own natural ability, the righteousness of his cause, and the unswerving 
loyalty of his people - three grand factors, it is true, but hardly commensurate with its magnitude. The suppression of slavery in a region a third as large as the United States, populated by diverse and hostile tribes, among whom slavery and cannibalism had prevailed from time immemorial, would have been no light undertaking for a missionary Crœsus with a huge army at his back. King Leopold was no such Crœsus, and his pioneers were few in number. But what they lacked in numbers they made up in geographical knowledge, in bravery, and in tact in their dealings both with the Negro and his oppressor, the Arab. Being human, some few mistakes were made; but they were very few-fewer than has frequently marked the establishment of a European colony in countries where there has been no question of slavery awaiting solution, no cannibalism to stamp out, no climatic dangers to encounter. When the time comes for King Leopold to be assigned his place in history as an empire builder, the future historian will probably designate as his Majesty's most brilliant work his solution of the problem of the suppression of the slave trade in Central Africa.

A wrong may be persevered in until its perpetrator comes to believe it is right. The Arab had for so many centuries harried the Negro race-and, taking advantage of their tribal disputes, plundered, enslaved, and sold them, under circumstances of revolting cruelty - that he had long ago grown to regard the Negro as his natural prey, and was seriously alarmed at the appearance in Congoland of the white-faced strangers with their unwelcome 
creed of liberty for all men, which they dreaded even more than their weapons of precision. To the Arabs this was a strange doctrine, inimical, they conceived, to their vital interests, and it behoved them to resist it to the death. That their alarm was well founded the sequel will show.

One of the first acts of the newly recognised Congo Free State was to forbid trade in firearms, guncongo powder, and other explosives. Another Free State act defined contracts of service between Laws. natives and foreigners, affording the former special protection. A third act created a volunteer corps whose chief business it was to protect individual liberty. Before any aggressive action, however, could be taken by this corps, the consent of the sovereign's delegate was necessary.

Concurrent with these three acts, the Belgian Anti-Slavery Society raised another, and quite distinct, volunteer corps for similar work, but restricted to the neighbourhood of Lake Tanganyika. In addition, about this period the same Society despatched to Congoland, in rapid succession, three expeditions of a missionary and civilising character. In such circumstances, collisions between the Belgians and Arabs were inevitable. During the first few years of the existence of the Congo Free State these collisions occurred chiefly on the Upper Congo and its tributaries, the currents of the interior slave trade, particularly those from the eastern and southern provinces, being checked by fixed military posts and flying columns. For two years-from I 892 to 1894 -a continuous campaign was in progress, having 


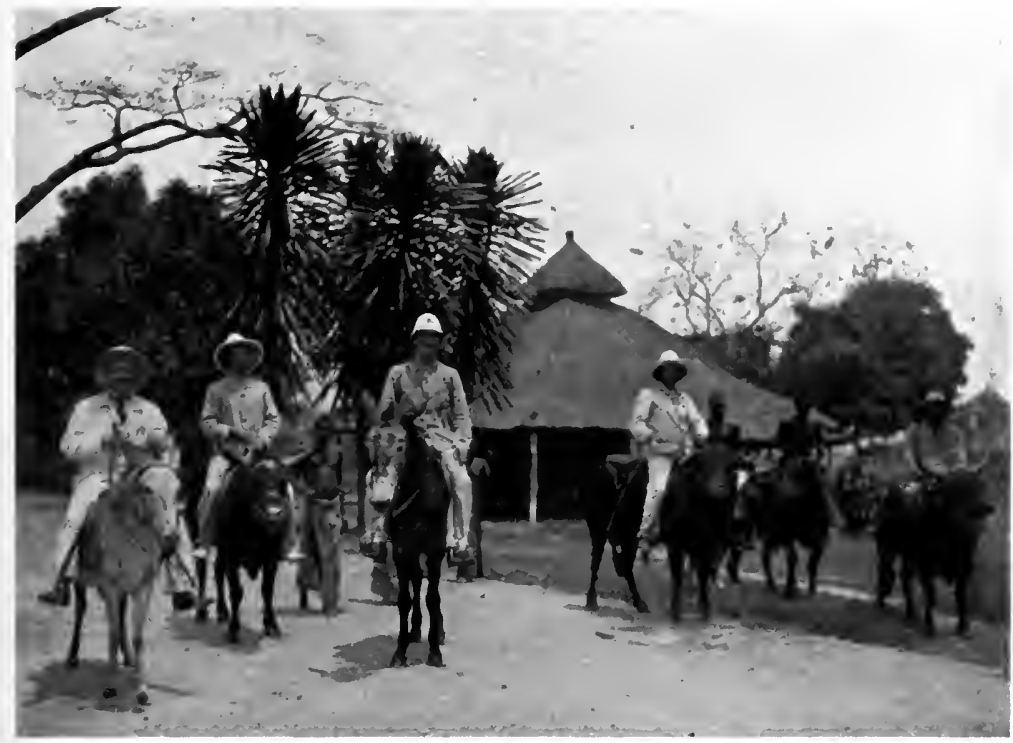

Various Mounts, Lusambo. (Lualaba-Kassai).

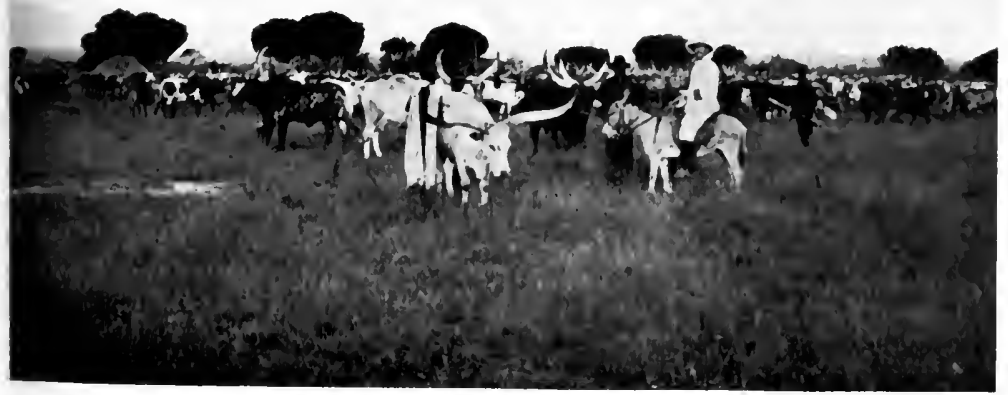

Cattle, Luvungy (Kivu). 

for its object the interception of the slave caravans accustomed to come from the south and east, which was entirely successful. In the vast territory known by the name of Lualuba-Kassai, at a time when the resources of the State were unequal to the expense of maintaining a line of posts, it was usual, up to so recently as 1902, on the appearance of a gang of slave-dealers to despatch a detachment of troops from Lusambo or Luluabourg to intercept them. Many engagements were thus brought about between the State volunteers and the slave-dealers. Now military posts are established on all the principal roads formerly used by the slave-traders, and the barrier is complete.

In the north, Commandant Chaltin struck a damaging blow to the Dervishes in February, 1897 . After traversing with his force the whole of the Uelle territory, he encountered the Dervishes at Redjaf on the Nile. The place was strongly held by four thousand soldiers, more than half of whom were armed with modern rifles. A severe battle ensued, lasting nearly all day. Victory lay with the Belgians, the Dervishes being forced to evacuate Redjaf. They accepted their beating badly, making several attempts to retake the place, but without success.

Thus we have seen that it was in the districts of the Lower Congo that the slave trade was first stamped out; that it was next eradicated from the Middle Congo; and finally extinguished on the Upper Congo, where Belgian bravery and military skill succeeded in effectually crushing the last vestige of Arab power. 
The Negro was quick to respond to the revivifying influence of security for life and property, and his

Negro Adrapid progress in civilisation may be said Nancement.
vang date from the day when this essential primary condition was established. From a report to King Leopold made by Baron Van Eetvelde, Secretary of State for the Independent State of the Congo, the following passage is extracted:

Slowly but surely the black is being transformed, his intellectual horizon is being enlarged, his sentiments are being refined. A thousand facts, in appearance insignificant, mark the halting-place left behind. The black to-day has his place marked out where ten years ago no one thought of using him. $\mathrm{He}$ is to be seen, according to his aptitude, as a clerk in the Administration, as a postman, as a warehouseman, as a pilot or sailor on the river boats; also as a smith, mechanic, sawyer, or brickmaker. Porter in the region of the Cataracts, navvy on the railway, he offers his arms and his labour when the remuneration satisfies the new needs that have taken birth in him. Trader above all, he becomes of a more delicate taste in the acceptance of merchandise in exchange; the stuffs, the tissues of striking colours but mediocre quality, formerly sought for, have to-day no demand, and must give place to articles of a superior kind. He accepts money; he is even acquainted with paper money, for many purchases are effected by means of bonds, which are then cashed at the European revenue offices. He is conscious of his own personalityclaims loudly the redress of any wrong which he conceives himself to have suffered. Grown more sociable, he receives, without distrust in his house, the stranger and the traveller. He begins to repudiate his old primitive customs, such as the casque, or the proof of poison. He sends his children to the missionary schools; and, to encourage him in this, the State has started a system of colonies of schools, the pupils of which are rapidly increasing. Fetishism is beginning to lose ad- 


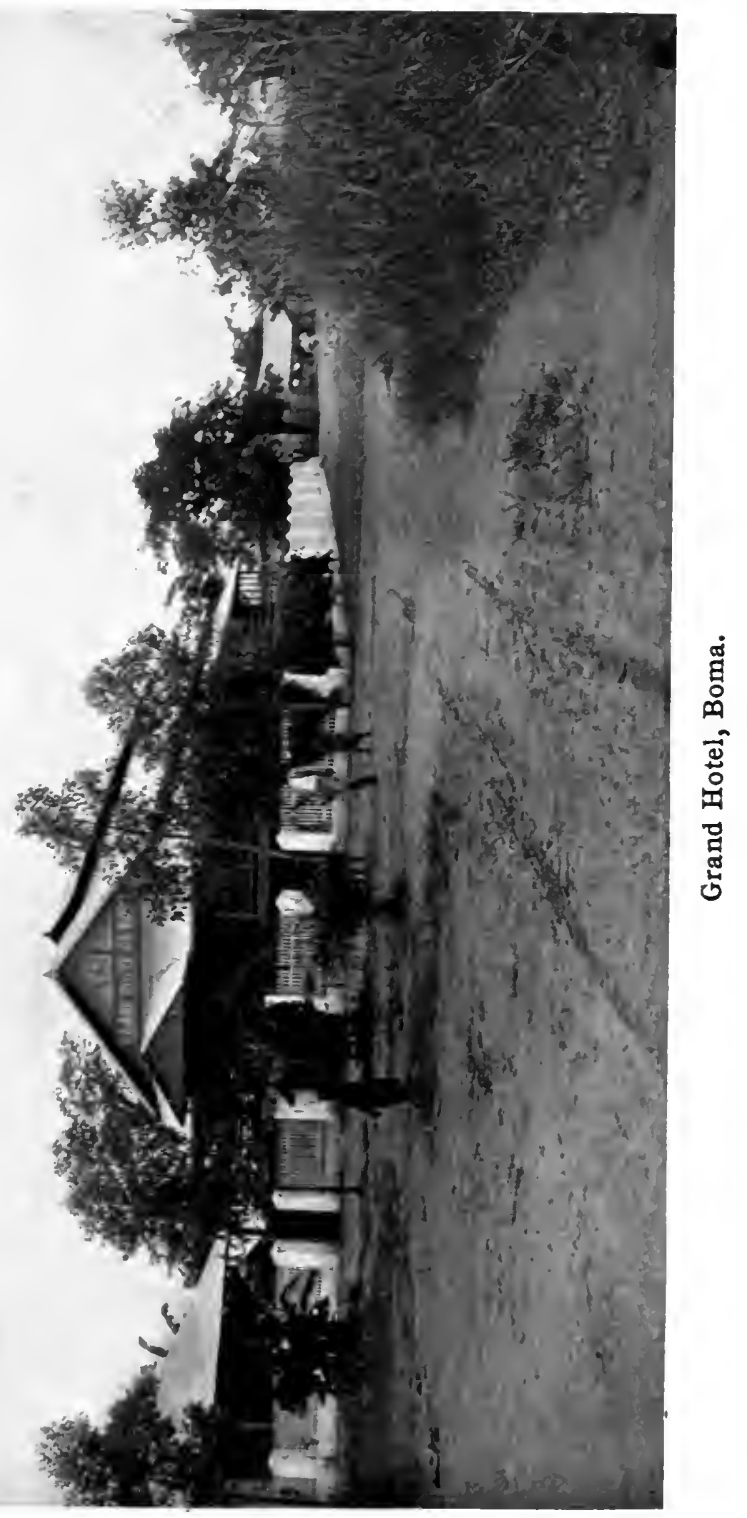



herents, and religious proselytism proceeds not without success. The legend of the Negro opposed to all improvement can no longer be maintained in face of this experience. We may consider it as certain that the native, well conducted and well directed, is fit to be assimilated with civilisation. Guarding ourselves against optimism, we do not disguise that there remains much to be done in order to introduce by successive stages that civilisation to the farthest frontiers of the State. But the facts warrant our believing in the possibility of such a result, which is the final object of the enterprise of your Majesty. The Congo State in the few years which have elapsed since its creation, has not failed in its task. Time and perseverance will crown the work, and it will be to Belgium, if she wishes it, that its accomplishment will belong.

In a later report-the last from which it will be necessary to quote-Baron Van Eetvelde reviews the complete work of the Congo Free State from its creation to the date of his writing (1897), and very ably sums up the situation then existing:

The Congo State [says Baron Van Eetvelde] inherited from its birth the heaviest and most perilous task in the antislavery work. The territories which fell to it had the sad privilege of being in their greater part handed over to the razzias, and of including the principal slave centres and the most important markets of human flesh. However willing were the Powers, who in the Berlin Act solemnly condemned the slave trade, the most optimistic only dared to hope for the disappearance of the abominable practices, like those Stanley had witnessed on the banks of the Upper Congo, in a distant future.

In truth, the crusade against the slave trade, in some measure ordered by the Berlin Conference, remained in the follow. ing years in the condition of a mere vow; and the Congo Government, which on its own account had then already organised a chain of posts of defence against the invasions of 
the slave-hunters, was condemned to deplore that, despite some partial successes, a great part of its provinces still remained in their power. Such were at that epoch the horrors and cruelties denounced to the civilised world, such was the deplorable situation in which the people of Central Africa, decimated and massacred by their oppressors, passed an agonising existence, that, struck by a sentiment of legitimate indignation, the Powers again decided by the Act of Brussels (I 890) to deal a decisive blow at the slave trade.

The Brussels Conference characterised the part reserved to the Congo State in the anti-slavery campaign, the importance of the undertakings which devolved upon it, the difficulties of the task which assigned it the perilous honour of being the advance guard on the battle-field. The number of enemies to be fought, the organisation of their bands, their installation from a remote date in the regions which they terrorised, their supply in firearms and munitions, the subjection even of the natives, were so many grounds of apprehension and disquietude as to the final issue of the struggle undertaken, and as to the fate ultimately reserved for the African populations. It really seemed, in that encounter between civilisation and slavery, of which the stake was the life and liberty of millions of human beings, as if failure would dispel for ever the hope of a better future. Thus it was that circumstances had placed in the hands of the Congo State the destiny of Central Africa and its tribes, and the situation was tersely defined by an English missionary when, with the experience acquired during a long residence in Africa, he wrote in 1893 , during the progress of the military campaign: "I am convinced that, unless the Arabs be annihilated, a general massacre will ensue. This is the moment for the Europeans to play their last card against the Arabs. Whether they will carry the day or not, I cannot say."

Civilisation did carry the day. And has not history to register that this victory for the Congo State, due to the bravery of Belgian officers, entitled it to merit well of those interested in the fate of the native populations? If to-day there opens for them a new era of liberty and regeneration, if 


\section{The Suppression of Slavery}

the amelioration of their material and moral condition can now be pursued, they owe it to the annihilation of the promoters of slavery.

Elsewhere has been told at the price of what sacrifices of men and money, at the price of what valour in every case, these results have been attained. The facts are there to attest that these sacrifices have not been in vain. The men-hunters reduced to impotence, their bands dispersed, their chiefs disappeared, the fortresses of slavery laid level with the ground, the natives rebuilding their villages under the shadow of the posts of the State, giving themselves up to the peaceful pursuits of cultivation of the soil-an era of tranquillity succeeding the sombre and sanguinary episodes of the old régime. Every mail from Africa brings proof of the progress of this period of pacification, and shows the natives, delivered from an odious yoke, recovering confidence, and living peaceably in their own abodes.

That the problem of the suppression of slavery in Central Africa had now been solved, we have had abundant incontrovertible evidence. That A Gratifyits solution was effected with a minimum ing Retroof bloodshed, and in a marvellously short spect. period of time for the accomplishment of so gigantic a task, we have also seen. The first and greatest of the objects for which King Leopold had so long laboured was at length realised. The applause of all civilised peoples had been justly earned, and was ungrudgingly given, and substantial reward was soon to follow. 


\section{CHAPTER XVIII}

\section{FRONTIERS AND DIPLOMATIC SETTLEMENTS}

\section{$\mathrm{T}$}

HE Conventional Basin of the Congo contains about $\mathrm{I}, 500,000$ square miles, of which the Free State occupies $1,000,000$, and its neighbours, France, Great Britain, Germany, and Portugal, about 500,000. On the east of the Free State, and divided from it by Lakes Tanganyika, Kivu, and Albert Edward, is German East Africa, on the coast of the Indian Ocean; on the south-east lie British possessions; on the south the Portuguese, and on the east and north-east the French Congo and Soudan; on the north-east, in the Nile Valley, lie the Egyptian Soudan and the Uganda Protectorate, the one on the west, the other on the east bank of the Nile.

The Berlin Conference of 1885 had not dealt with questions of territory except to delimit the area comprised in the Congo Basin. By the AngloGerman Agreements of 1886 and I890, the borders of German East Africa had been generally defined. France, however, still fostered the hope of acquiring dominion of the Egyptian Soudan and, perhaps, of nearly all of the northern part of Africa. The arrangement with the Sovereign of the Congo Free State, giving her a right of pre-emption of the State 


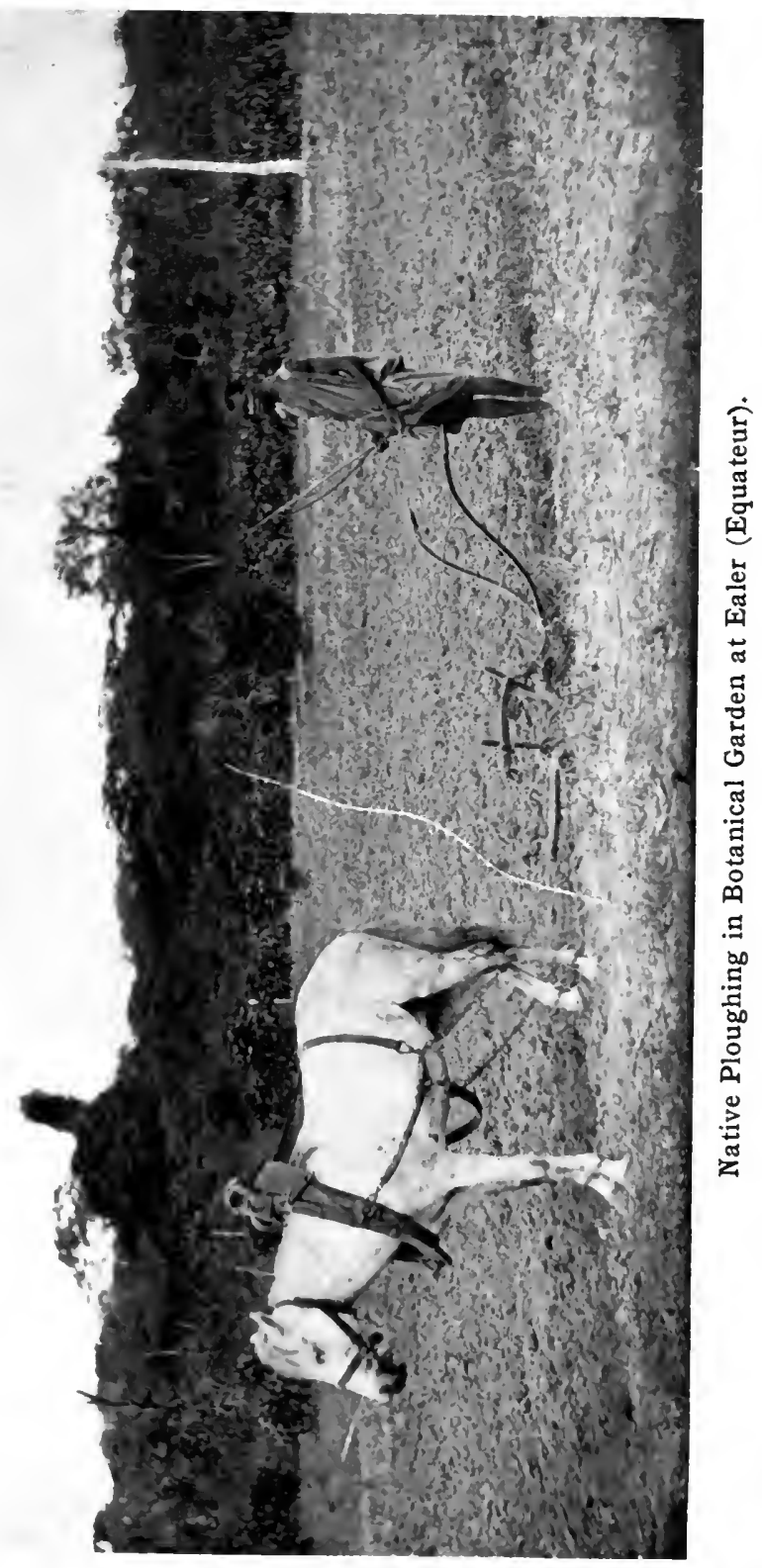



over other Powers, would indicate an ambition in this direction. That France endeavoured to achieve her aim in this respect was forcibly demonstrated by the expedition of Captain Marchand and the Fashoda incident. So far as Germany and Portugal were concerned, the Congo Free State's boundary had been well-nigh firmly established, but with France and Great Britain there was a lack of settlement on this important question which threatened the State with future insecurity.

The first convention on this subject was concluded with Great Britain, and concerned the Bahrel-Ghazal, referred to in the succeeding chapter.

The Franco-Congolese Convention of 14 th August, 1894, was of great importance to the young State, albeit the price it paid for the friendly attitude of France may appear greater than the security afforded. The relations which existed between France and the State, when the upper course of the Ubanghi became the object of frontier settlement, were defined by the Convention of 5 th February, 1885 , and that of 29 th April, 1887 . In the first, France agreed, in return for the right of pre-emption conferred on her in 1884; to determine her own Congolese limits and those of the Free State, and to guarantee the latter's neutrality. In the second, the Belgian Congo surrendered a considerable territory to France by substituting the Ubanghi to the 17 th degree of east longitude for the boundary defined in the third article of the treaty of 5 th February, 1885 , and the modification of her right of pre-emption in favour of Belgium in certain contingencies. These 
negotiations, beginning in $189 \mathrm{I}$, were not settled until 1894 , owing to conflicting views as to the course of the Ubanghi. Moreover, the French Government had expostulated vigorously against the British proposal to lease the Bahr-el-Ghazal to the Congo Free State, while Germany protested against British possession of the strip of land between Lakes Tanganyika and Albert Edward, which the Free State intended granting in payment for its lease of the Bahr-el-Ghazal. The article conveying this strip, manifestly intended for the Cape-to-Cairo railway conceived by Mr. Cecil Rhodes, was, in fact, withdrawn by arrangement between the British and Congo Governments on June 22, I894. Meantime, the French Government had contended that the river Uelle was the true upper course of the Ubanghi, and that the State had no rights north of it, "even though it resulted in moving the State's frontier line south of the fourth parallel secured to it by the Convention of February, I885." There were, however, on the part of the Congo State, the advantages of possession and effective occupation of the territory north of the Uelle and the right bank of the Mbomu, which had now been geographically established as the uppermost course of the Ubanghi. An offer was made by the Congo State to arbitrate the matter in accordance with the provisions of the Berlin Act. France, however, declined to submit the case to such tribunal. Finally, after three years' delay, a convention between France and the Congo Free State was signed in Paris on 14th August, 1894, which contained six articles. The first conceded part of 
the Belgian claim by constituting the river Mbomu the upper course of the Ubanghi.

Article I. The frontier between the Independent State of the Congo and the colony of the French Congo, after following the thalweg of the Ubanghi to the confluence of the Mbomu and the Uelle, shall be formed in the following manner:First, the thalweg of Mbomu to its source; second, a straight line joining the crest of the water-parting between the basins of the Congo and the Nile. From this point the frontier of the Independent State is constituted by the said crest of the water-parting to as far as its intersection with the 3 oth degree of east longitude (Greenwich).

Article 2. It is understood that France will exercise, under conditions which shall be determined by a special arrangement, the right of police on the course of the Mbomu, with the right of pursuit on the left bank. This right of police will not be exercisable on the left bank, but exclusively along the course of the river, and so long as pursuit by the French agents is indispensable to effect the arrest of the authors of offences committed on French territory or on the waters of the river. France shall have, when necessary, a right of passage on the left bank, to assure her communications along the course of the river.

The third article stipulated for the gradual surrender to the French of the posts established by the State north of the Uelle; and the fourth and the final articles "bound the State to renounce all political action of any kind to the west or north of the following line - the 3 oth degree of east longitude, from its point of intersection with the crest of the waterparting of the basins of the Congo and the Nile to as far as the point where this meridian meets the parallel $5^{\circ} 30^{\prime}$, and thence that parallel to the Nile." 
By these articles, and the good feeling that has since prevailed between the French and the Belgians, all matters likely to have caused dispute have been settled. A well-defined boundary has been laid down between the French possessions and the Congo State from the Atlantic to the Nile. If the King of the Belgians surrendered to France what others would have retained, it was so dealt with because of that wise political foresight which has characterised his Majesty's diplomacy in other respects. The friendly relations between France and the Congo State, the settlement of northern boundaries along the Mbomu, and the lease of the Bahr-el-Ghazal from Great Britain, have dispelled much Belgian anxiety. The question which now appears to forebode difficulty is what the Belgians believe to be Great Britain's scheme for a pretext to break the lease of the Enclave of Lado, a rich and prosperous territory in the Bahr-el-Ghazal, where the Belgians have established posts along the Nile as far north as Lado. As to Great Britain's purpose in this connection there have been many recent signs. 


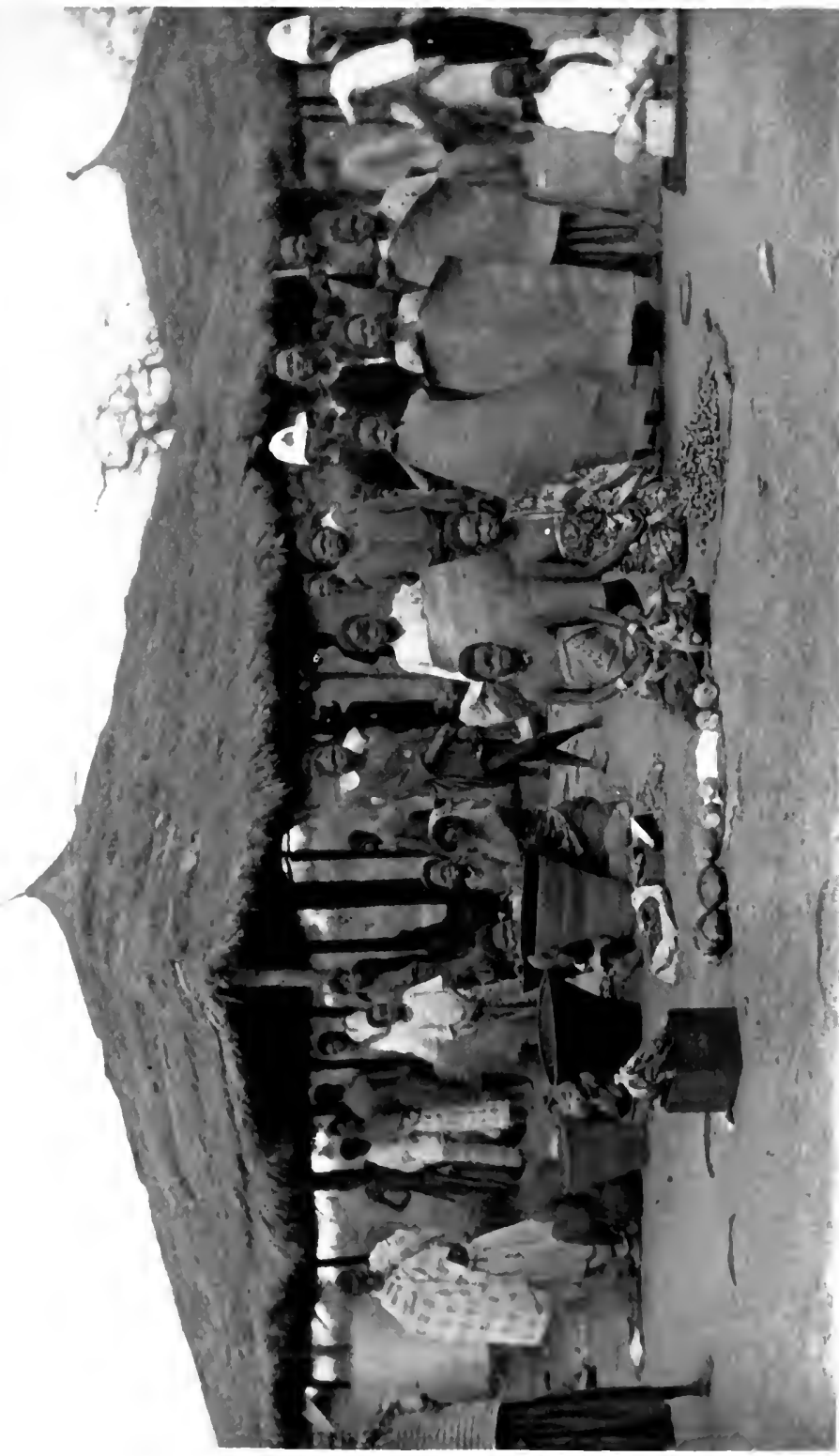

: 



\section{CHAPTER XIX}

\section{THE BAHR-EL-GHAZAL AND THE NILE}

I $\mathrm{N}$ addition to the territories of the Congo Free State proper, the sovereignty of which is vested in Leopold II., King of the Belgians, and his successors, King Leopold holds on lease from Great Britain the Bahr-el-Ghazal up to $10^{\circ} \mathrm{N}$. A treaty entered into between the Congo Free State and Great Britain on I 2 th May, I 894, determines the duration of this lease, and the extent of the territory to which it applies. The conditions are somewhat complicated, partaking in a measure of the nature of an exchange, the Congo Free State, by Article III., leasing to Great Britain a strip of territory between the lakes Tanganyika and Albert Edward.

To be more precise: In 1890 the Congo Free State despatched several missions to its frontiers, some of which penetrated the Nile region and made various political arrangements with the ruling chiefs there. It happened also at that period (July, I89o) that Germany and Great Britain entered into an agreement whereby Germany acknowledged the paramount influence of Great Britain in the Nile Basin. This agreement was no sooner concluded than Great Britain opened negotiations with the Congo Free State, offering to grant thereto, on 
lease, certain territories situated west of the Basin of the Nile, if the Congo Free State would accord to Great Britain's presence in the Nile Basin recognition similar to that which it had just obtained from Germany. Out of this overture grew the treaty of I 2 th May, I894, between the Congo Free State and Great Britain, to which allusion has already been made.

By that treaty, Great Britain leases to Leopold II., King of the Belgians and Sovereign of the Congo Free State, the territories limited by a line starting from a point situated on the west bank of Lake Albert Edward, south of Mahagi, to the point of intersection of the zoth meridian east of Greenwich, the frontier line of the territories so assigned following the head of the division of the Nile and Congo waters to the 25th meridian east of Greenwich; and along this meridian to its intersection with the roth north parallel, and along this parallel direct to a point north of Fashoda; thence to the west bank of Lake Albert Edward, south of Mahagi. These territories comprise the entire basin of the Bahr-el-Ghazal River and its affluents (except the upper portion of the Bahr-elArab), and are generally referred to as the Bahr-elGhazal. The treaty further provides that the lease is to remain operative during the reign of King Leopold II. only, except as regards that portion of the Bahr-el-Ghazal west of the 3 oth meridian, permanently vested in the Congo Free State.

France, which had never recognised British influence in the Nile Basin, at once protested against this arrangement, asserting that Great Britain had 


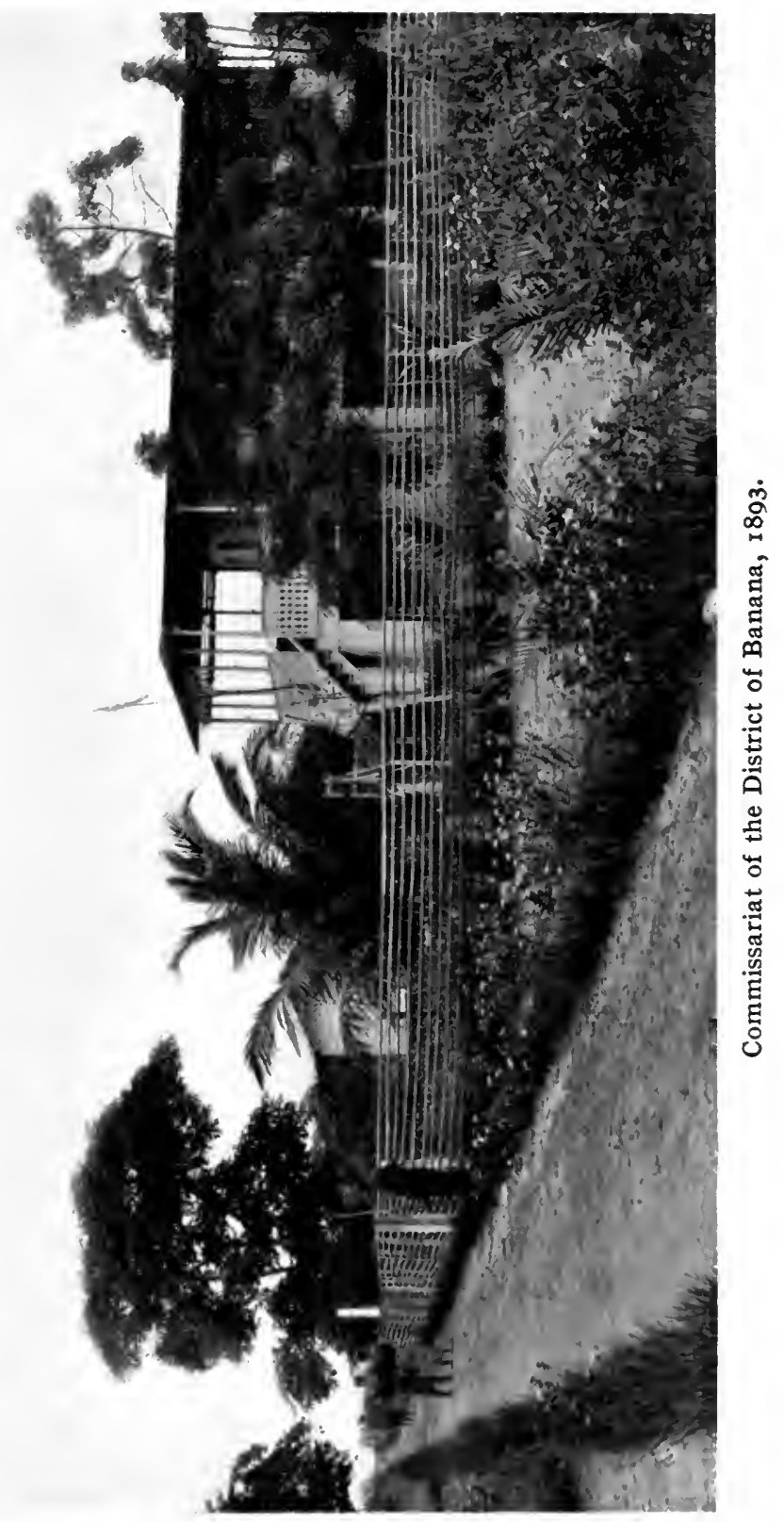



leased territories which did not belong to her. While this delicate question was sub judice there arose the celebrated Fashoda incident which brought Great Britain and France perilously near to war. The circumstances of that incident are too near our own times, and too remote from the purpose of this book, to need recounting here. But it is important to refer to it in this place, because in the settlement of the Fashoda dispute between Great Britain and France the latter recognises the paramount influence of the former in the Basin of the Nile.

The only obstacle in the way of the execution of the treaty of 12 th May, I894, was now removed, Great Britain's right to dispose of the territories leased to the Sovereign of the Congo Free State being everywhere admitted. But now Great Britain herself sought, without justification, to annul the treaty. Because the Congo State had made therein certain reservations in regard to France-a perfectly natural proceeding at a period when the rights of Great Britain over the Bahr-el-Ghazal were in disputeGreat Britain contended that the treaty of $\mathrm{r} 2$ th May, I894, had practically lapsed. After the battle of Omdurman, the British even went so far as to give, in part, practical effect to this extraordinary view of their treaty obligations, occupying, upon several occasions, Meshra-er-Rek, at the confluence of the Bahr-Djur and the Bahr-el-Ghazal.

From information which reached Europe and America early in November, 1904, it would appear that Great Britain has resolved to carry this matter with a high hand. A British expedition was said to 
be then in process of formation, composed of 2500 native troops, officered by Englishmen, to penetrate Central Africa, ostensibly to restore order among the Niam-Niam tribe.

Now the Niam-Niam tribe inhabit the Bahr-elGhazal country. That is one reason why Great Britain concerns herself with that tribe; but there is another, and a much stronger, reason. Recently it has been discovered that vast mineral wealth exists in that region, and Belgians, Frenchmen, Germans, and particularly natives of that country which "seeks no gold mines and seeks no territory," have busily employed themselves in prospecting it. Trading relations have been established by small companies supposed to be engaged in exchanging fire arms and ammunition for ivory, but really prospecting for ore.

Side by side with this information comes the official announcement that the British Government has given orders, either directly or through a subsidised company, for the erection of a permanent telegraph connecting Khartoum with the Bahr-elGhazal, and that transport for traders up the White Nile is guaranteed as far as Fashoda. Already a section of the British newspaper press is advocating the establishment of British military stations and posts upon ground of which King Leopold holds a perfectly valid lease granted by Great Britain!

Is it too high a flight of the imagination to suppose that the patience with which the British Government has listened to the libellous tirades against the Congo Free State, in the form of petitions to the House of 

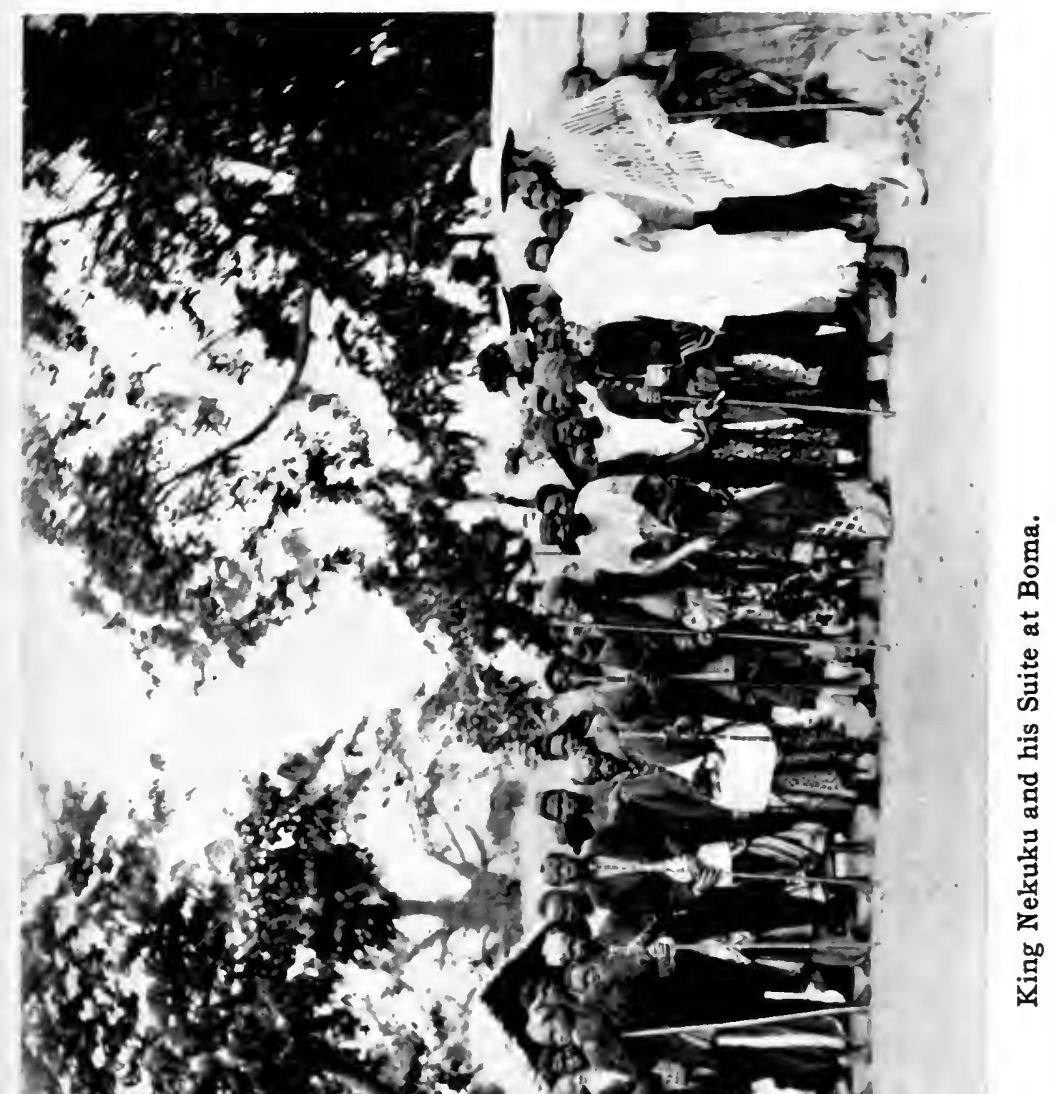

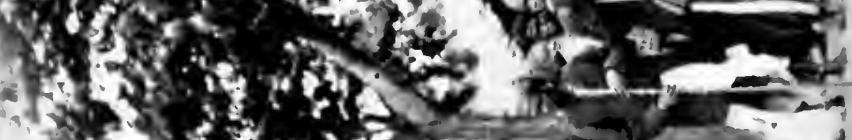

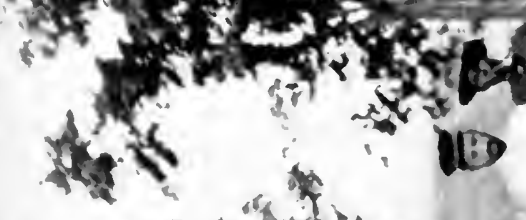

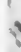

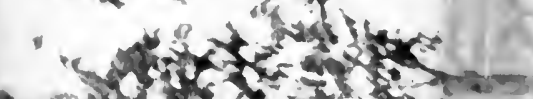

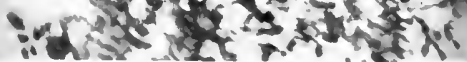





\section{The Bahr-el-Ghazal and the Nile $\quad 215$}

Commons, is to be explained by its evident desire to cut loose from its treaty obligations, and forcibly take away what it voluntarily ceded to the Congo Free State for a valuable consideration? 


\section{CHAPTER XX}

MUTINIES OF THE BATETELA TRIBE

$\mathrm{T}^{\mathrm{n}}$

HE hasty and ill-advised trial and execution of the chief, Gongo Lutete, described in another chapter, proved a source of much danger and tribulation to the Congo Free State. It was the act of a misguided and over-zealous officer,

The without doubt undertaken in good faith, Batetela but none the less disastrous upon that Grievance. account. The incident has never been defended, but always deplored, by the Congo Government, to which it occasioned grievous loss in men, money, and reputation.

Lutete's men were loyal to their chief and bitterly resented his execution. So threatening did their attitude become that it was decided to remove them to some considerable distance from the scene of the tragedy. At the moment of their departure, they fired upon the people and vowed complete vengeance whenever opportunity for it should occur. Later, at Luluabourg, when they accepted an invitation to enter the Force Publique, all danger from them was thought to have been averted. But the apparent content of the fierce Batetelas was simulated; they were merely biding their time. 


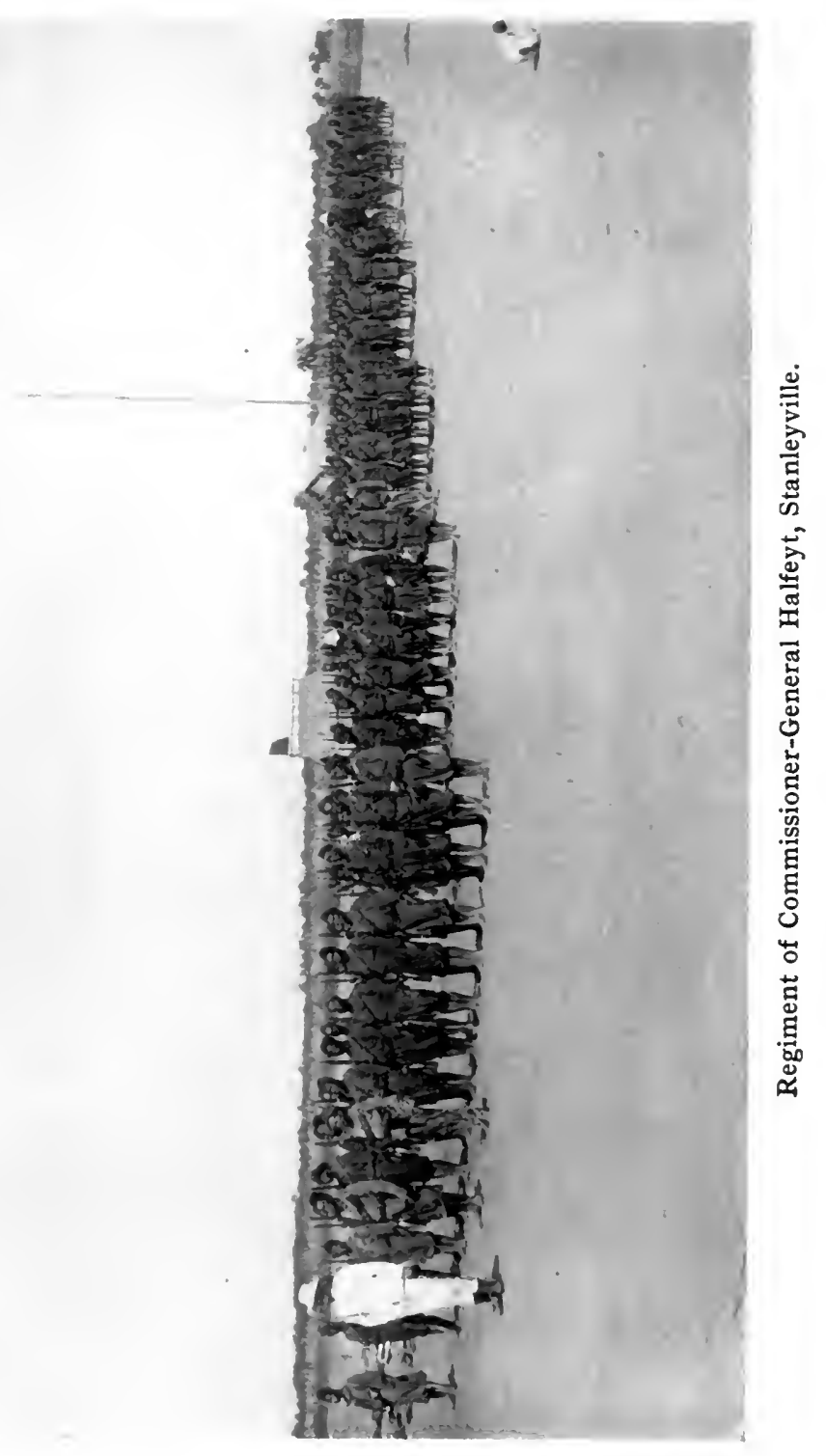



It was during the summer of 1895 , at Luluabourg, that the Batetelas openly revolted. After murdering some of their officers, they attacked the post at Kabinda. Next, they struck out to the north, with intent to surprise LuThe sambo. At Gandu, and on the Lomami, they murdered more Belgian officers, and for a time it was impossible to foresee a limit to their depredations.

Though the mutineers were less than four hundred in number, in the circumstances they were potent for a vast amount of mischief. They were well armed with modern weapons of precision, were abundantly furnished with ammunition, and had, besides, some military knowledge, acquired from their Belgian officers, which rendered them almost the equal of European troops. To these advantages must be added the natural valour of the Batetela, and the desperation with which men, knowing that their treason will be punished by death in the event of their capture, may be expected to fight.

Commandant Lothaire, on hearing of the misfortune that had befallen the State, hastened with a small force to intercept the Batetelas, then marching on Nyangwe. He met the mutineers on the r 8 th of October, near Gandu, and, notwithstanding that the force he commanded was much inferior, at once assumed the offensive. A fierce fight ensued, in which the mutineers were badly defeated, losing many killed and prisoners, and having finally to fly. Previous to this engagement another Belgian officer, Lieutenant Gillain, had been active to retrieve the fortunes of the State. Having gathered together 
such remnants of the State's forces as remained loyal, and were to be found scattered about the Lomami district, he boldly attacked the mutineers. The battle opened greatly to his disadvantage, but ended in his victory. Lieutenant Gillain then added his forces to those of Commandant Lothaire, and the combination, as we have seen, was far less in number than that of the mutineers, though it proved superior to them.

After their defeat on the 18 th of October, in which they lost the greater part of the spoil taken at Luluabourg, Kabinda, and Gandu, the Batetelas broke up into small bands, and sought refuge in a forest, into which it was impracticable for the State's forces to pursue them. The latter had now become nearly a thousand strong, and numbered among its officers the brave Michaux, Svensson, De Besche, Jürgens, Konings, and Droeven - a force sufficient, it was believed, to deal with any recrudescence of the trouble.

A few days later an incident occurred which rudely dispelled this notion. The scattered bands of mutineers again united, to make safe their retreat, and were probably about to march to the Manyema country, when they accidentally met a Belgian column. Both were surprised. The Batetelas, by far the more numerous, at once attacked the Belgians. At the very opening of the fight, the four Belgian officers who were leading the Congo force were shot dead. The bands which had to the present refrained from joining the main body of the Batetelas now hastened to do so. 
Perceiving that their power would continue to grow so long as they were left unmolested, Commandant Lothaire determined to attack the Batetelas again with all the force at his command. The battle took place November 6th, at Gongo Machoffe, and resulted in a complete victory for the State forces. The Batetelas lost heavily in killed and prisoners, while such of them as survived fled for protection to various local chiefs, who soon, however, handed them over to Commandant Lothaire.

Again, notwithstanding their bitter experience, the Congo State and its advisers, military and civil, permitted themselves to be lulled into the confidence of security. Nearly two years of quietude on the part of the Batetelas led the Belgians to believe that that fierce race had forgiven, if they had not forgotten, the injury unwittingly inflicted upon themthat the trouble had been fought out, and the incident from which it originated relegated to its proper place among the unfortunate happenings of a bygone period.

The awakening from this dream came in 1897 . Commandant Chaltin had driven the Dervishes as far as the Nile, and Baron Dhanis, with a larger force than Chaltin's, had been sent to take possession of the Lado territory to found posts there, and to fortify it against possible Dervish inroads. With a column of more than three thousand men, a third of whom were Batetelas, Dhanis set out from Avakubi towards the Nile.

In the second week of February, I897, Captain Leroi, with two thousand men, had just reached 
Dirfi, when the Batetelas, of which the force was mainly composed, suddenly mutinied. The mutiny began with the murder of Captain Leroi and his fellow officers, after which the mutineers retreated upon the Obi. As soon as news of this event was brought to Dhanis, he threw his force right across the path of the mutineers, and a desperate battle ensued (March I8, I897). The pages of history afford few parallels to this singular conflict. No sooner had the fight begun, than about five hundred of the Batetelas commanded by Dhanis deserted, and went over to the enemy, their kinsmen. The result, as may be imagined, was chaos. With great difficulty Baron Dhanis effected his retreat. His losses were grievous. Ten Belgian officers fell, among them a brother of Baron Dhanis. Among those who specially distinguished themselves by their gallantry upon this occasion was Lieutenant Delecourt, who, with a miserably small following, covered the retreat, at the cost of his own life and the lives of every member of his faithful company. Having at last succeeded in reaching Avakubi, Dhanis entrenched the handful of men left to him in the little station there, and, leaving Commandant Henry in command, hurried to Stanley Falls, to report the disaster and concert measures for regaining what had been lost.

Meanwhile the Batetelas were not inactive. Making straight for Stanley Falls, they destroyed all the stations on their way; but just before they reached what was thought to be their objective they struck out eastward. Baron Dhanis at once concluded 


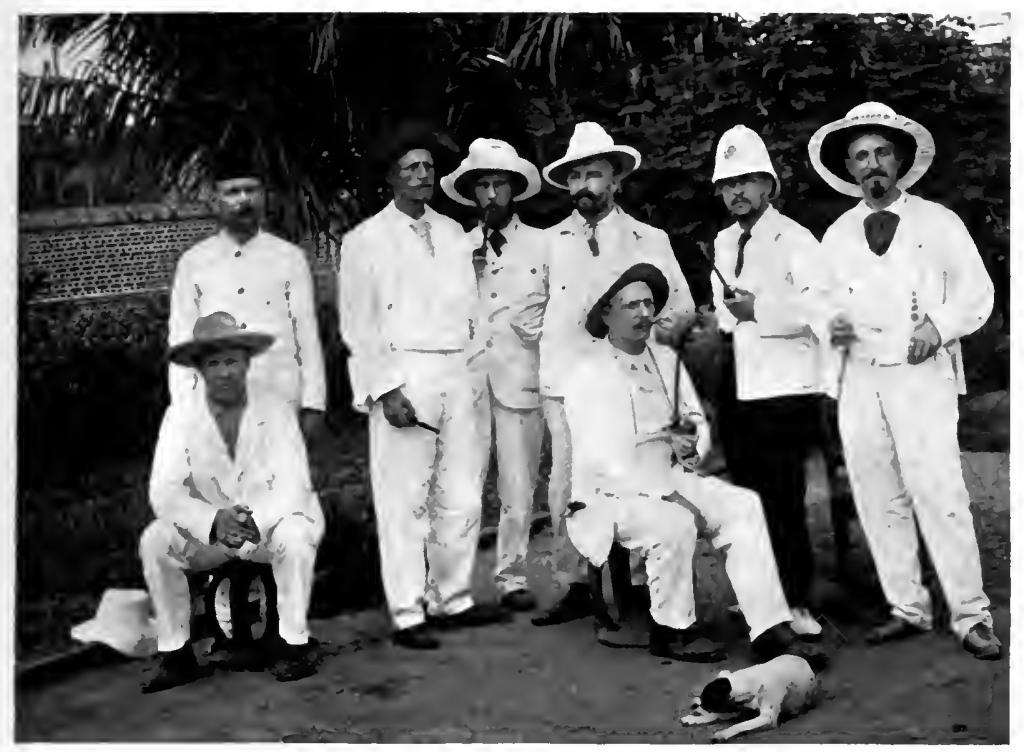

State Officials at Ponthierville.

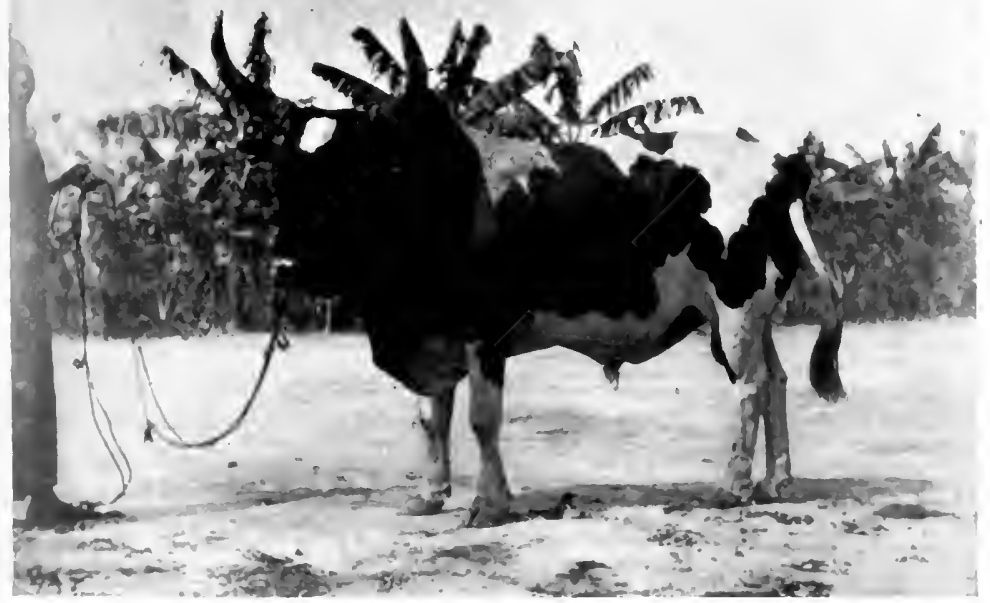

Saddle Ox, Lusambo (Lualaba-Kassai). 

that they were bound for their native country, Manyema. The assurance that they contemplated no invasion of State property was a relief, but the possibility that so considerable a number of wellarmed men, flushed with victory, reaching their tribe and reporting to it how they had defeated the redoubtable Baron Dhanis was very disquieting, for such an event would infallibly have led to the uprising of all the Batetelas. Baron Dhanis, having returned from Stanley Falls, placed a body of picked men at Nyangwe and Kassongo, to intercept the mutineers if they chanced to pass that way, while troops, with European officers, were sent from Stanley Pool to pursue them.

At this juncture, the Belgian cause was aided by an outbreak of smallpox among the mutineers, which compelled them to encamp near Lindi, not far from the British frontier. At that place Commandant Henry, fresh from Avakubi (which he had found deserted), with seven hundred men, came upon them and almost succeeded in driving them into British territory. Meanwhile, Lieutenant Sannaes had successfully repelled an attack upon his post at Katué (Semliki), which so enraged the mutineers that the leader of the attacking party, a man named Malumba, was murdered by one of his own men who held him responsible for its failure.

June had arrived before Commandant Henry and Lieutenant Sannaes could join their forces, and then the regular pursuit of the mutineers began; but another month elapsed before they could be brought to battle. The result was a great victory for the 
Congo State forces. Over four hundred Batetelas were killed, and they lost, besides, five hundred rifles and ten thousand cartridges. And then ensued what had happened in like circumstances beforethe surviving mutineers broke up into small bands and dispersed in various directions. Though victorious, Commandant Henry was exhausted, and fell back upon his base. Baron Dhanis, who had been guarding the Lualaba to prevent the mutineers' crossing it, now found it safe to pursue their scattered bands.

At last the Batetela revolt was broken. Thereafter some minor skirmishes occurred here and there; but they were as the feeble flickerings of an expiring flame-a flame that had seared the growing Congo State only to enable it to show to the world an admirable example of discipline and resisting power in circumstances of extraordinary difficulty. 


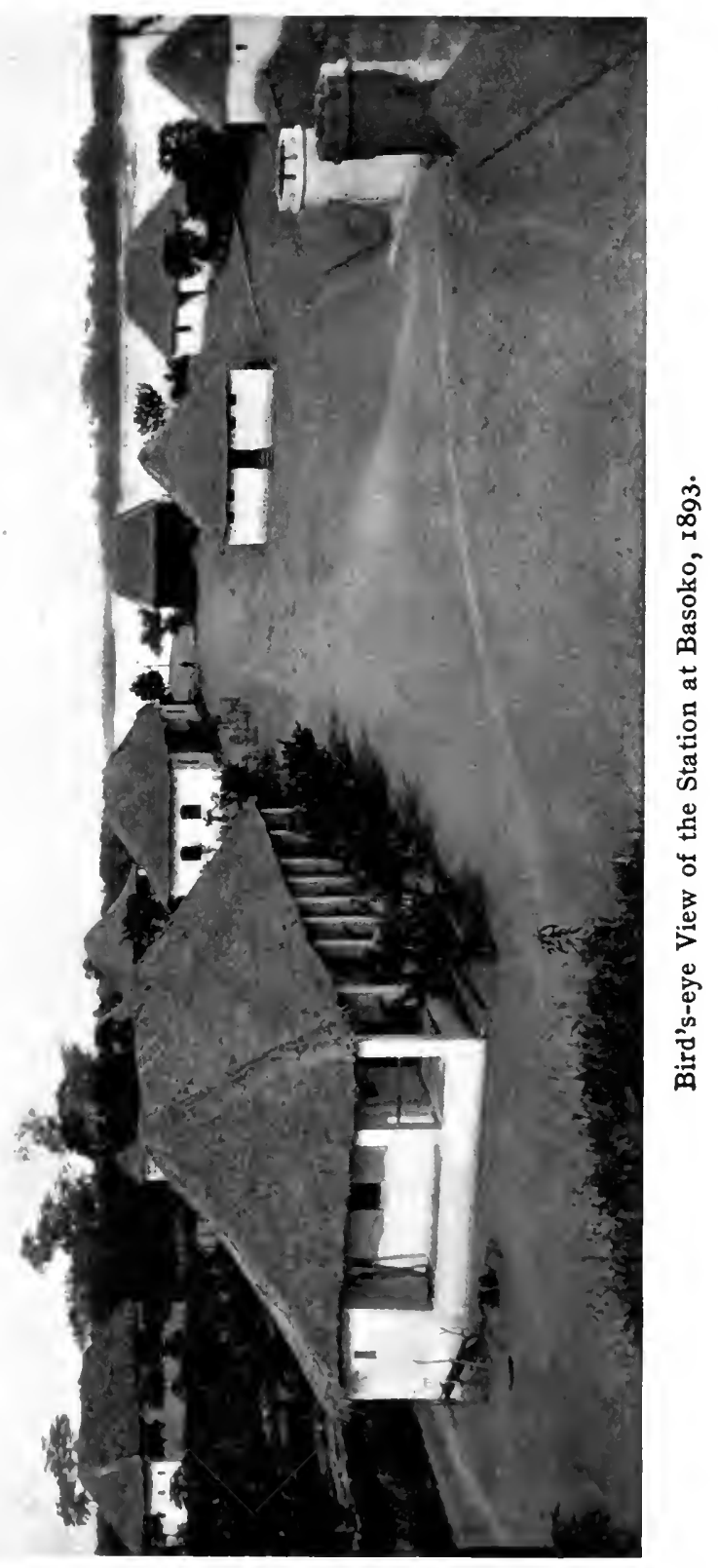





\section{CHAPTER XXI}

\section{DISPLACEMENT OF THE POPULATION}

$\mathrm{T}$

$\mathrm{HE}$ instinct of the nomad largely prevails in all savage races, but in none does it prevail to a greater extent than among the black tribes of Central Africa. It is one of their marked characteristics, and a fruitful source of trouble.

Central African tribes are greatly influenced by their superstitions. Like the North American Indians, they have their medicine men who victims conjure up all sorts of occult prognosti- of Supercations of imminent and mysterious phe- stition. nomena. With them the fetish doctor is little less than a god. If this wise man asserts that a village has suffered ill-luck because the new moon dips to the left or right, his deluded followers collect their effects, devastate the village, and move into some region which he may indicate is free from that curse. If rain has not fallen in sufficient quantity, and the crops surrounding the village have withered, or if the rain has been too abundant, the fetish doctor may forthwith present an explanation based upon some new superstition. Indeed, there are thousands of tribal beliefs in the Congo Free State which are for ever disturbing the settlement of the population. Implacable enemies of the Congo Free State, not 
wholly ignorant of these tribal beliefs and customs, pretend to regard the migratory nature of the Central African savage as evidence of his fear of the State's government, arising from a feeling of insecurity. Such persons point to the native's incorrigible habit of moving his abode as an unmistakable sign of his desire to escape from the barbarities practised upon him by officers and soldiers of the Congo Government. In this way it is sought to deceive those who are unacquainted with the habits of the black man-the man who, a few years ago, ate his brother with a relish which civilised white men can hardly conceive.

The State, however, fully cognisant of the natural habits of its black subjects, has often considered the question of how to deal effectually with these displacements of the population. There are times when neither superstition nor tribal custom causes a large exodus from a well-established village. Sometimes the fertility and luxuriant grass of another region attracts the more enterprising black, who has learned to cultivate his own land. Allured by glowing accounts of such a nature he gathers about him his friends and family, and makes off to what he considers to be a new Eldorado. In a short time, the diablerie of the fetish doctor has again unsettled him.

Then, again, there have been occasions when the natives have migrated to avoid payment of the taxes imposed upon them by their own chief on behalf of the State, taxes which are infinitesimal in value as compared with the benefits of civilisation which 
the State confers. To deal generally with the displacement of the population of the Congo Free State has been a matter of much concern to the Government. A case of sleeping-sickness or smallpox has occurred, and away goes the whole village pell-mell into another region. The movements of the native tribes are often inscrutable, and afford the State no clue as to how they may be prevented. Like some species of wild animals which instinctively avoid certain districts of the forest at particular seasons, or on account of some unusual phenomena, the black man will sometimes quit his residence for no apparent reason at all. Nine times out of ten, however, he migrates on account of things entirely unconnected with any administrative act of the State. Entire villages have been removed because a death has occurred there the cause of which was inexplicable to the black man. Occasionally the fetish doctor, inspired by some unexplained caprice, will decree that the tribe shall move-he knows not where. Ignorance and superstition invariably follow a leader whose pretence is some occult power. The tribe moves; and another tribe, moving from a similar or other impulse, may occupy the very village which the first tribe had abandoned a few weeks before.

These removals along the banks of the river have sometimes created the impression on a superficial observer that the population of the Congo Free State has diminished or disappeared. Regardless of the impression these deserted villages have made upon those who seek to find opportunity for vilifying the Congo Government, the inconvenience resulting 
from the constant removals has been very great. There is often at one point an aggregation of people too numerous for their subsistence, and public order and tranquillity are disturbed, with disastrous results. More strife between village and village and tribe and tribe has been occasioned by this migratory habit than by any bloodthirsty instinct inherent in the Congolese black. This is notoriously true; and it has had a gravely adverse effect, too, upon the population of the Soudan, with regard to which the statements in Lord Cromer's report of 1893 are conclusive.

Vice-Governor-General Fuchs, always seeking to improve the governmental machinery of the Congo Free State, has recently made the following Possible suggestions, which, if adopted, he believes would tend to control the migratory nature of the subjects over whom he so intelligently rules:

I think that it would be opportune to pass the necessary legislative measures, so that an end may be put to this collective kind of vagabondage. The administrative authority finds itself at present unarmed, the Congo courts having declared the absolute right of the native to move about and to dwell where he likes. But it appears to me that public order is directly interested in having these emigrations in a mass, from region to region in the interior of the country, regulated by law. This regulation would also result in assured stability for a fair distribution of native taxes. It would also facilitate the establishment of definite and permanent means of communication throughout the country.

There is, however, still a special case to be taken into consideration. Some natives on removing in this, way are ready to establish themselves on the territory of one or other of 


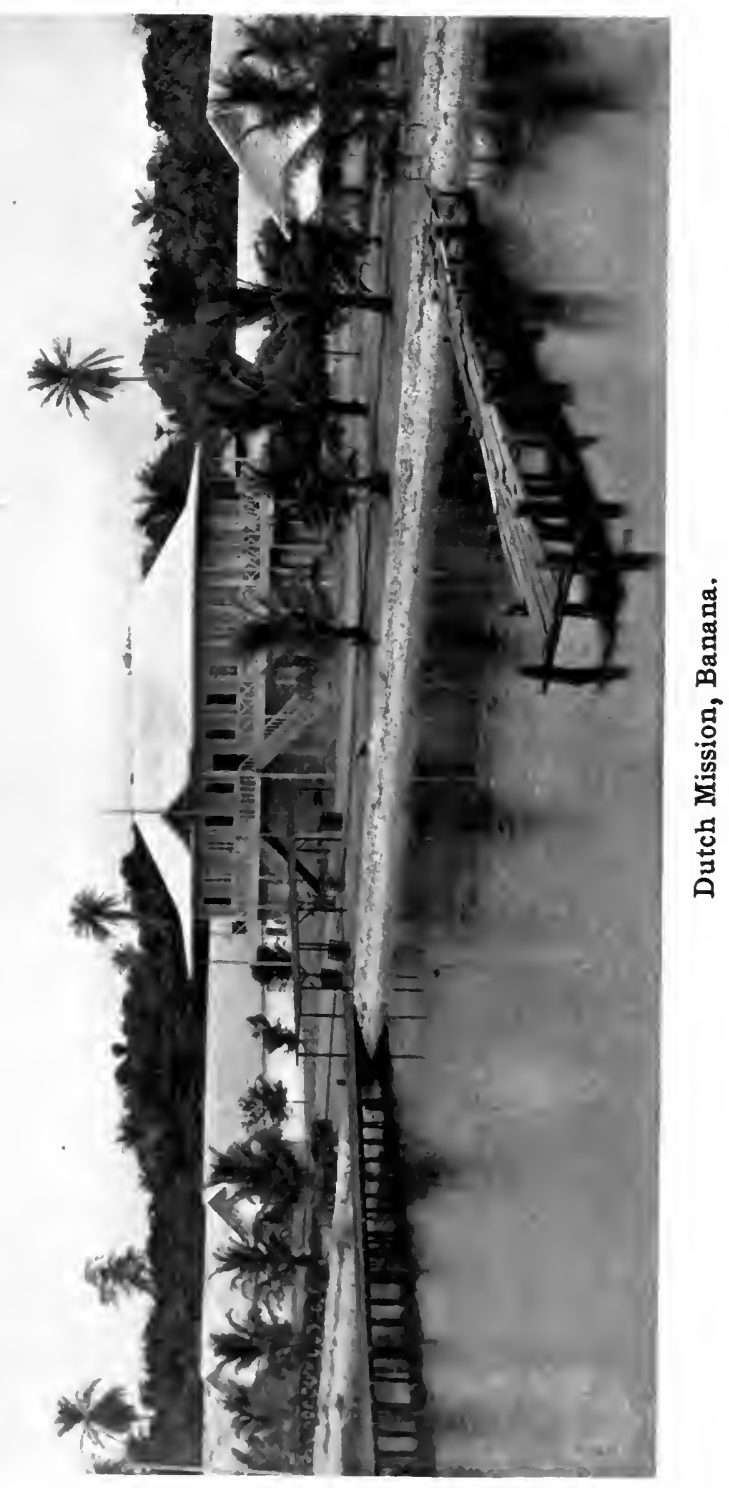



those Sultans whose native authority extends beyond, as well as within, the political frontiers of the State. The determination of the sovereign power such individuals may wield might, owing to the silence of our laws, not be without future difficulty, when, for instance, Sultans, established on foreign territory and dependent themselves for it on foreign power, are concerned. It would be well if all doubtful elements were removed by a decree which in a general manner might establish the principle that every native of Congolese origin who, by naturalisation or otherwise, shall endeavour to modify his national status, will still be considered as a subject of the Congo State, and remain amenable to Congolese law, so long as he shall reside, in fact, within the limits of the State territory.

From this it will be observed that in addition to the numerous other difficulties with which the new State has to contend, it is now called upon to legislate for the solution of a problem which the State's detractors have distorted and misrepresented as a result of the State's cruel system of government.

The importance of this question cannot be overstated, as it forms a great hindrance to the proper organisation of so vast a territory as the Congo Basin. That the potentialities of King Leopold's beneficent rule in Central Africa will eventually legislate wisely, and permanently abolish this native inconsistency, no one who has observed the intelligent governmental genius of the State can doubt. 


\section{CHAPTER XXII}

\section{THE STATE'S ADMINISTRATION}

\section{JUSTICE-NATIVE CHIEFTAINCIES}

$\mathrm{T}^{\mathrm{o}}$

provide a just and equitable process for giving effect to the civil laws of a savage country requires an administrant force of exceptional powers, of rare patience, and of wide sympathies. Highly civilised communities largely govern themA Difficult selves by the aggregate contribution and A Difficult example of all orderly persons. The very
Problem. momentum of their civilisation and the habits and tendencies of a cultured people conduce to the observance of law and the tranquillity of the social life to which the law applies. Rules of State and municipal procedure for the government of European countries have, by use and the experience of time, long ago attained to an automatic operation. The social phenomena of all civilised communities are well established, and they form part of that large body of academic theory called social science. The development of human society has its constitution and its philosophy, yet those who are charged, by a duty arising from exceptional circumstances, to apply social and political principles to savage tribes distantly situated from all civilising contact with 


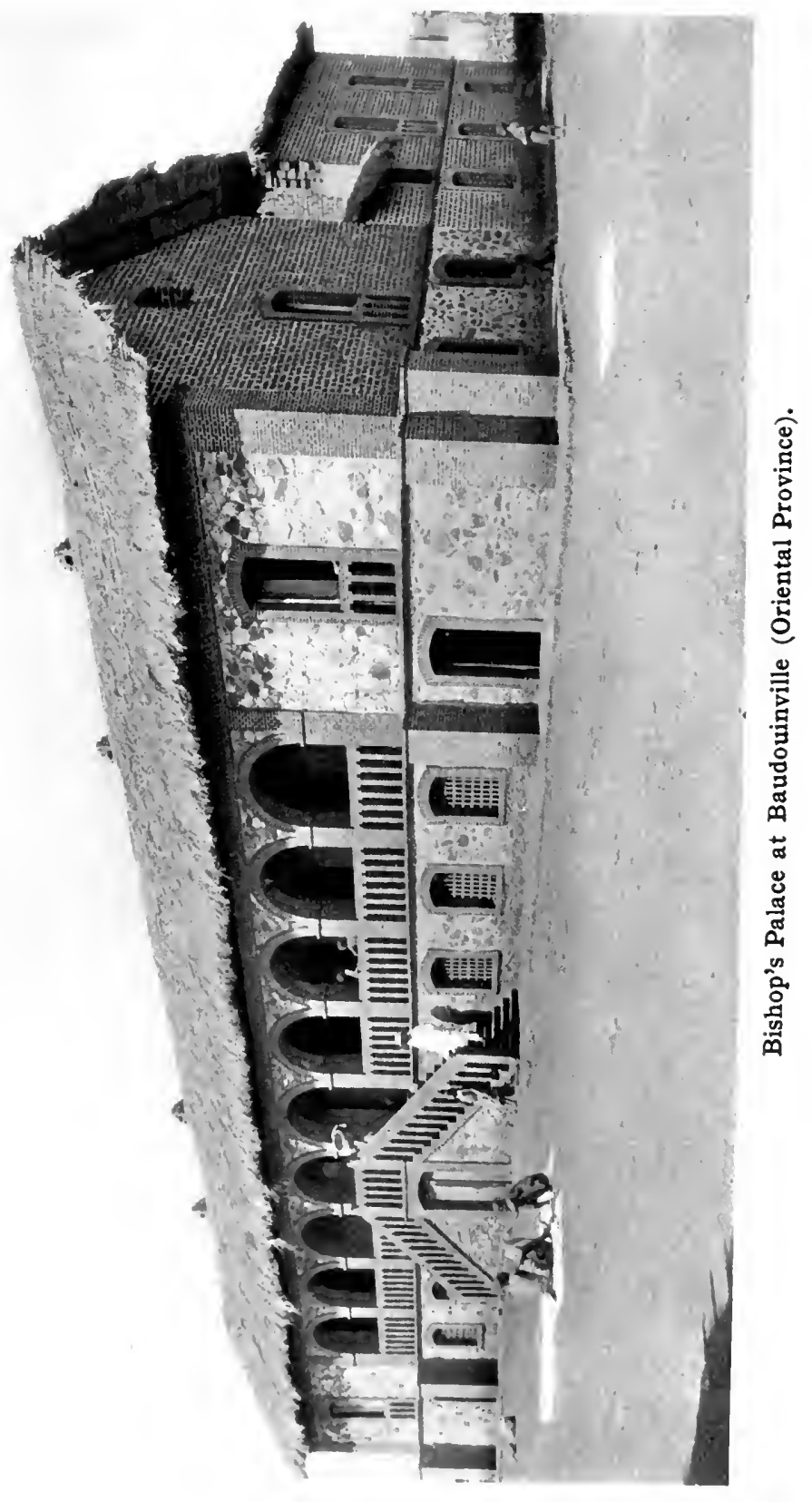



human beings of superior attainment, are charged with a task of unknown and multiform difficulty.

The characteristic thoroughness with which the Belgians have established their administrative machinery in the Congo Free State is apparent in the latest report (July, I904) of Vice-Governor-General Fuchs, the acting head of that Government. Monsieur Fuchs has had twenty years' experience in Central Africa. He is, perhaps, the best-qualified living colonial official dealing with the black races of the African Continent. The great progress of the country he governs, and the moral and material betterment of the tribes which thrive under his liberal rule, are astonishingly revealed in the report from which the following quotations are made:

The development of the State administration is attested in a general way by the ever-increasing number of Posts of different kinds that are in operation in its territories.

Thus there are at the present time 233 Posts and Stations, all of them under the command of white men, scattered over the 14 districts.

The European staff attached to the services of the districts mentioned is distributed as follows:

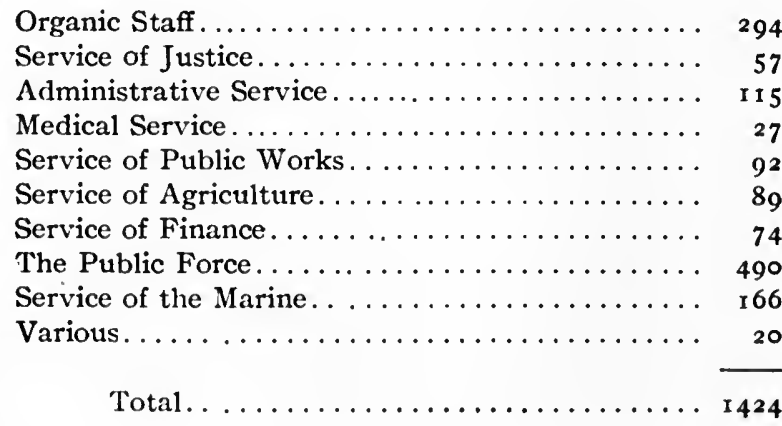


The number of blacks attached to the different services of the districts is about 20,000 men.

I here render justice to the zeal and devotion of the servants of the State; besides Belgians, who form the great majority, they also comprise Italians, Swiss, Scandinavians, Germans, English, etc., according to the following order:

Belgians, 898; Italians, 197 ; Swiss, 89; Swedes, 86; Danes, 34; Germans, 31; Norwegians, 22; Finns, 19; English, 16; Dutch, 9; Russians, 5; French, 4; Austrians, 3; Americans, 2; Turks, 2; Luxemburgers, 2; Portuguese, 2; Greeks, I; Spaniards, I; Cubans, I; total, 1424 .

To whatever nationality they belong they vie with each other in the ardour with which they perform their numerous duties. All are penetrated with the greatness of their rôle in the heart of savagery, and impelled by the noblest emulation compete in the gradual realisation of our civilising work. Numerous are the testimonies that I have collected during my last official tour of their fruitful activity exercising itself in all directions, of their protecting benevolence with regard to the natives; and these testimonies emanate from missionaries, from learned men, from travellers, and even from persons inclined rather to criticise than to praise our works.

In order that this staff may become more experienced, by acquiring progressively a knowledge of the country, its resources, and its inhabitants, it has been particularly recommended to the agents composing it that they should learn the native dialects. Knowledge of the local idioms is, indeed, indispensable to the European who seeks to enter into direct relations with the blacks-to study their manners and customs, and by that means take account of the measures to employ for the introduction and development of our ideas of civilisation.

The judicial statistics show the vigilance and impartiality with which the Parquet (Public Ministry corresponding to our Public Prosecutor) inquires into breaches of the law, no matter who their authors may be, and aims at allowing no offence to remain unpunished. If some faults have been 
committed by our agents, the guilty have been prosecuted conformably to the law.

The attention of the members of the service besides has been frequently called to the consequences which would result for them from transgressing the laws and instructions of the Government. In order to ensure their faithful and complete execution, the Government has just again added to the staff of superior officials new State Inspectors.

\section{DEPARTMENT OF JUSTICE}

The magistrates by profession number at the present time 32 ; they are assisted by 25 judicial agents properly so called.

The judicial services of Boma, to which are attached seven magistrates by profession, and a dozen judicial agents, allow of:

I. An Appeal Court, composed of a President and two judges, of the State Prosecutor who occupies the seat of the Public Minister on this jurisdiction, and of a Registrar;

2. A Council of War in Appeal, the presidency of which devolves on the President of the Appeal Court, of two judges, officers of the Public Force, of the State Prosecutor, and of a Registrar;

3. A Court of First Instance, composed of a professional judge, of a substitute, a doctor of laws, and of a Registrar;

4. A Council of War of First Instance, composed of a judge, officer of the Public Force, of the substitute attached to the Court of First Instance, and of a Registrar.

These four jurisdictions are competent in penal cases. Those occurring under $I$ and 3 are competent also in civil and commercial matters. They sit in such cases without the Public Minister. A report of the Registrar of the Court of First Instance attached to this sets forth the order of civil business.

The other professional magistrates are distributed between the territorial courts and the councils of war.

Territorial courts exist at Matadi, Leopoldville, Popokabaka, Coquilhatville, New Antwerp, Basoko, Stanleyville, Toa 
(Albertville), Lukafu, Kabinda (Katanga), Lusambo, and at the chief place of the Rusisi-Kivu zone (Uvira), independently of the councils of war, which will be shortly replaced by ordinary courts as the number of magistrates is increased. The Parquet attached to these courts is represented by the substitutes of the State Prosecutor, all of whom are doctors of laws.

Among the following officials of judicial rank the majority are Belgians. There are also Italians, Danes, Swiss, and Norwegians.

President of Court of Appeal: Baron G. Nisco.

Judges, Court of A ppeal: M. Horstmans, M. A. Gohr.

Judge, Court of First Instance: M. T. Beeckman.

Prosecuting Attorney: M. F. Waleffe.

Director: M. A. Gohr.

Magistrates (Territorial Judges and Substitutes): Ernest Dupont, Hermann Weber, Iwan Grenade, Louis Rossi, J. Jenniges, P. Vincart, C. M. B. L. Greban de St. Germain, Stanislas Lefranc, Martin Rutten, Albert Sweerts, Robert de Meulemeester, Michel Cuciniello, Angelo Cagginla, Mario Falcetti, Gennaro Bosco. Frederic Erdrich, Manlio Scarpari, F. J. S. M. Lambin, Torquato Polimante. Louis Tessaroli, Paul Bossolo, T. C. Lund, H. G. Moth-Borglüm, C. J. R. Vandekelder, A. A. A. Celletti, C. E. A. M. Smets, C. L. Gianpetri, Jacob Vogt, Ragnvald Koht, T. Fessante Adrien Beeckman.

The administration of justice shows that its representatives are conscious of the responsibility of their mission. No one has ever been able to impugn its impartiality and independence, and the judgments and sentences awarded establish its anxiety to reach all the guilty, and not to leave unpunished any breach of the laws for the protection of the natives. I will not mention any other examples of this than the judgments recently pronounced against the agents of a trading company, upon whom heavy sentences of penal servitude were passed for crimes committed upon natives. The tribute which the Government on that occasion paid to the Courts' sense of their duties will be a valuable encouragement for them. I am confident that the Government's appeal 
to the vigilance of the Department of Public Prosecution to prevent any offence of the kind passing unpunished will not be in vain.

The superior administration of Boma is instructed to follow the principle of bringing before the competent courts all cases of abuses of natives that are pointed out to it by the authorities, by the direct complaints of residents in the Congo, or by criticisms in the press. These last accusations, the frequency of which is found to coincide with the campaign conducted against the Congo State, are regularly submitted on the spot to careful examination in detail. The impression that is left by the investigations that have been made, and some of which are still unfinished, is that as a general rule the complaints formulated are wanting in the precision necessary to fix the responsibility, if any, for them; or that they rest exclusively on the gossip and statements of natives which have not been sufficiently verified. In this latter respect a long experience of African affairs has shown me with what circumspection, not to say with what distrust, the statements of the blacks must be accepted. Their peculiar mental characteristic renders them inclined to

The Negro as a Witness. lie with an ease that is disconcerting, and magistrates are obliged to direct their inquiries and questionings with real skill and untiring patience in order to arrive at the truth amongst the inaccuracies and omissions of coloured witnesses. That will reveal how much and how often the stories of sensational facts circulated by natives are distorted by them, when they are not absolutely invented, and what disappointments those who accept them too easily prepare for themselves. A typical case is that of a Protestant missionary who was accused by natives of having inflicted on the black engineer of his mission's steamer blows and wounds that caused his death. The judicial investigation disposed of this charge, which had been fabricated in all its details by the natives with the view of avenging themselves on the missionary, with whom they were engaged in a dispute on a 
question of wages. And yet the natives making the accusation never ceased for a moment, despite the proofs to the contrary, from maintaining their lying charges with a persistency which could not fail to create an impression. It is to be regretted that Mr. Casement " was not put on his guard against the statements of the blacks, and especially by this incident, of which he could not have been ignorant, since the missionary concerned accompanied him during the inquiry into the case of Epondo, whom the natives also represented to have been the victim of a criminal act.

I will, by another example revealed during a recent inquiry, show how much the charges brought against the Administration of the State are wanting in prudence. Some correspondence from a missionary published in England has given rise to violent comments in the press of that country upon the Congo Free State. When invited by the State Prosecutor to formulate and present his charges, this missionary did not allege anything against the State agent. whom, in his writings he had charged with responsibility for odious crimes. He had invoked, as corroborating his own statement, the affirmations that other European agents had made to him; he declared by what follows that these affirmations were to be kept strictly confidential. "It is true," he adds, "that these facts have been published, but as the publication was made in England I thought that the confidence placed in my discretion was not betrayed." He also declares that "before accepting the responsibility of revealing and specifying in a precise manner the facts, he desires to consult, and take the opinion of, if not a barrister, at least some one knowing Congolese law, and that the extracts published of his letter have not perhaps been made with strict precision of language." In short, the want of clearness, the subterfuges of the examination, attracted the attention of the State Prosecutor, and left on his mind the most unfavourable impression as to the good faith of

His Britannic Majesty's consul, author of the Report referred to in a succeeding chapter. 


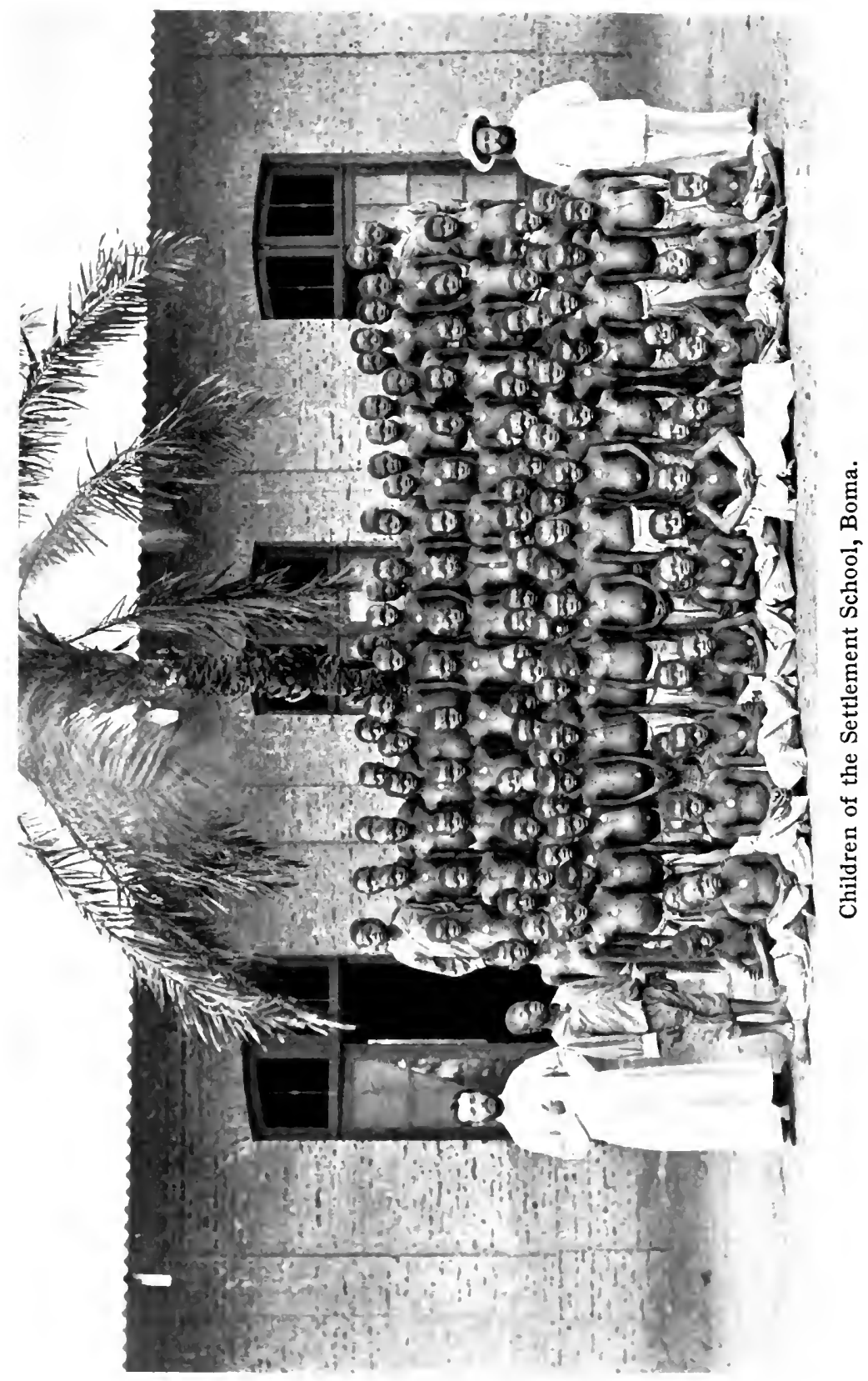



this missionary, and as to his highly blameworthy manner of recognising the hospitality that he has hitherto enjoyed in the Congo.

I have entered into these few details in order to show the occasionally inconsiderate character of the attacks directed against our Administration.

And I owe it to truth to make another reproach, not less grave, with regard to certain foreign elements which do not seem to have an exact view of their duty in inculcating the natives by their example and teachings with the respect due to the authority of the State and to its representatives. It is impossible not to

Intrigues against the State. be struck by the strange rumours in the vicinity of the Protestant missions, which for some time have been announcing to the population a change in the established order, and predicting the end of the State. There natives have been seen to offer insults to the European agents; officers of the Companies have lodged complaints as to the arrogant attitude of part of the population subject to certain influences; a tendency to shake off the duty due to the State, and to repudiate respect for our laws, has manifested itself among them. It is not doubtful that here we see the result of the underhand intrigues sapping, more or less intentionally, the legal authority. The remark inevitably follows that this position reveals itself solely in the neighbourhood of some evangelical posts, and it assumes a more significant character when it is known that the tendency of these establishments is to exercise over the surrounding population a sort of sovereign power, in opposition to "Boula Matari," ' thereby creating a state of antagonism between the influence of the mission houses and the authority of the State agents. I have pointed out for the attention of the Government this grave position, and the measures that it ought to take if it continues. Already local agents have been obliged to act on their own initiative to safeguard the State's authority, and if

I The name which the natives applied to Stanley. It is now used to designate the State. 
it becomes necessary the Governor-General will consider the occasion for making use of the means placed at his disposal, by the decree of 15 th September, 1889 , for dealing with foreigners who should employ against the State their influence over the natives.

It would be desirable that an appropriation be provided to carry out the plan at present under examination, of establishing on the Upper Congo a number of civil courts and a second Court of Appeal.

In my opinion the Government ought to go farther in the way of developing our judicial machinery. A point which has not ceased to attract attention is, in the first place, the recruiting of the staff. Whatever may be the goodwill of the judicial agents, it is beyond doubt that some newcomers have not always possessed, before their entrance into our judiciary, a sufficiently long experience of judicial practice. I here renew the wish, already expressed, to hear that judges of Belgian courts and parquets be authorised to obtain leave of absence to occupy judicial posts in the Congo.

The spirit in which this recommendation by the Vice-Governor-General was received in Belgium is clearly indicated in the following announcement on behalf of the Minister of Justice at Brussels:

The Minister of Justice has just authorised Belgian magistrates who may be desirous to do so, and be accepted by the Congo Free State, to undertake, by a limited engagement, to serve as judges in the Congo,--and for that purpose, to obtain leave of absence without pay, save that their rights of seniority in the Belgian magistracy are to be reserved.

The Congo has been for us a field of heroism. It has enabled numerous Belgians, who were smothering within their frontiers, to prove their value in a much broader sphere, where territorial, political, and diplomatic conditions permitted some display of their inborn qualities, and to reveal themselves first-class pioneers, soldiers, and administrators. 
If considered only from an ideal point of view, this advantage is well worth something. And those of our officers who out there have put down slavery, pacified the native tribes, opened the ways of navigation, commerce, and industry, created agricultural stations, depots, railways, forest exploitations, and roads will surely from this point of view alone have rendered our little country as much service as they could have rendered it in the service of our garrisons.

It has often been said that narrow frontiers mean narrow ideas. To broaden our horizon, is to broaden our ideas. It seems to us that without going beyond these considerations, this decision taken by our Department of Justice deserves to be commended.

Without any burden on our Treasury on that account,since the Belgian judges serving in the Congo will, during the term of their service, cease to draw upon our budget,- - our magistracy will be losing nothing of their value, so justly appreciated, by delegating a few of their members-selected from the youngest-in those new regions where their knowledge of law, coming into more direct contact than at home with nature and practical needs, will acquire renewed strength at the very springs of equity and juridical conscience.

At the same time, their authoritative participation in the colonial undertaking will contribute to do away with the very suspicion of those abuses which, after being systematically exaggerated by interested opponents, have been used as a pretence for this deplorable Congophobe campaign which has led away in England a few minds more generous than enlightened.

Fortified in this manner, the Congolese magistrates, who even now worthily bear comparison with any colonial magistracy, will, by the mode of their recruitment, and their own merit, command respect from our adversaries.

They will be continually renewed, which is advisable in these tropical regions, where the conditions of climate very soon exhaust individuals, and the new and continued relations which will thus progressively spring up between 


\section{$238 \quad$ Story of the Congo Free State}

Belgium at home and its African extension will contribute to force into our colonial undertaking the best part of our traditions and of our national spirit.

It would be also useful if the ambulatory character attributed by Congolese law to the Courts of First Instance were made more effective, by rendering it an obligation for these courts to move about periodically throughout the extent of their province, to sit regularly at important centres, and to betake themselves to all points to which the necessities of their presence required them to proceed. This object might be easily attained, if only there were placed at the disposal of the magistrates the material means - with regard to transport, provisions, and lodging - that the frequency of these movements on circuit might call for.

I would also recommend a new measure which would consist in establishing in the different jurisdictions a corps of special agents who should be remunerated by the Government, and whose mission would be to discharge in the interests of the natives the rôle of barristers. At present it is to the magistrates themselves that the native addresses himself in order to obtain the necessary counsel for the protection of his rights. It would be preferable that those who may be called upon to lay down the law on a conflict of civil right, should not fill also the post of being counsel to one of the parties. On the other hand, from the penal point of view the measure that I propose would permit of professional defenders being assured to the accused. This institution, which it would be necessary to render of as general application as possible in the Upper as in the Lower Congo, would thus place on the spot, at the disposition of those natives who thought they had ground of complaint, gratuitous defenders of their interests.

Indeed it would be useful to constitute in Belgium a Court of Cassation to which the sentences and definite judgments in penal matters which might possibly be contrary to the law should be submitted. Such a court might be composed of members of the Belgian Court of Cassation, or of the Appeal Courts admitted to the grade of emeritus, or actually practising. 


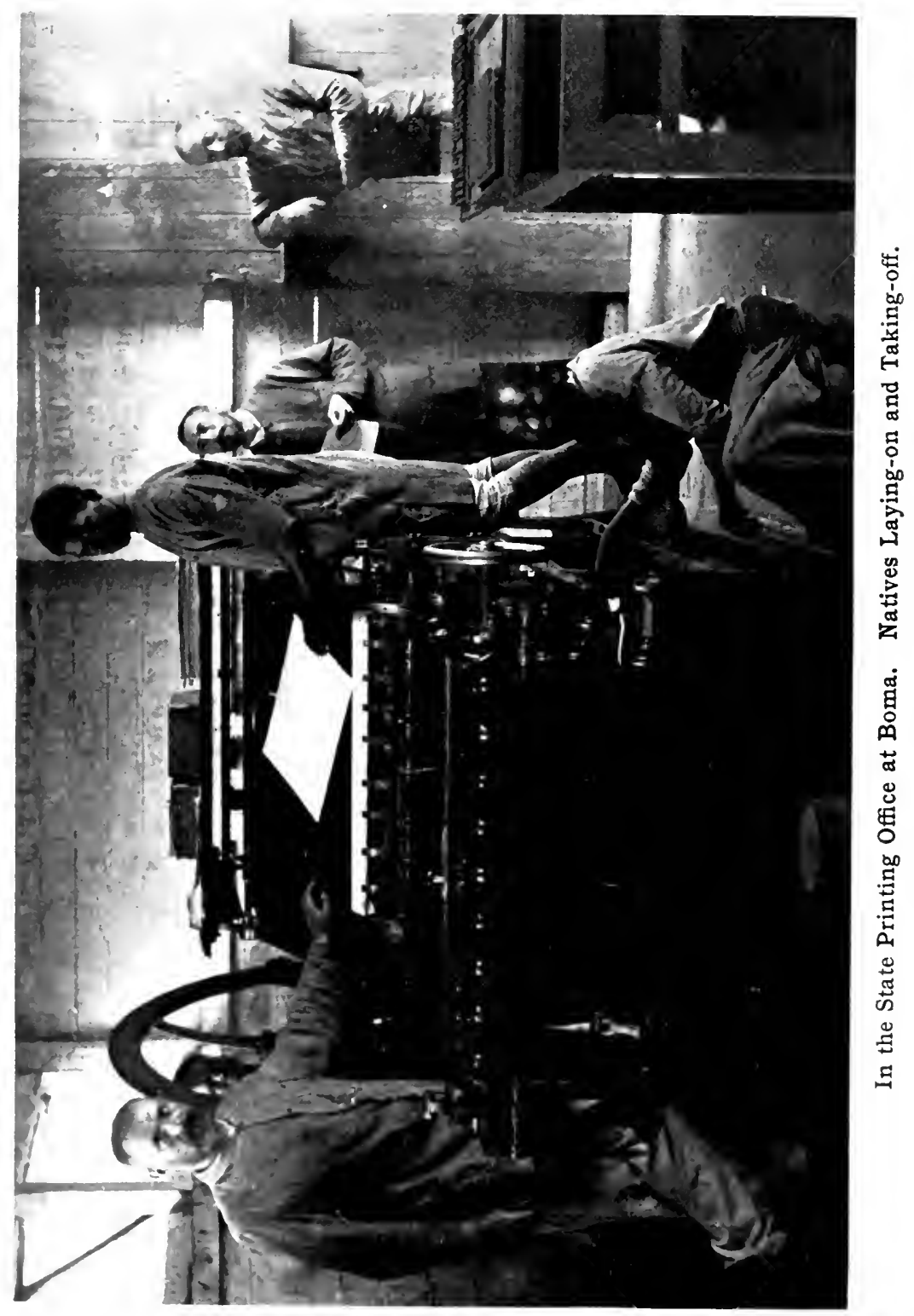



It will certainly seem natural that these different opportunities of co-operating in the Congolese work should be given to the Belgian magistracy. Belgium would see therein, as it seems to me, the occasion of drawing closer the links of a moral nature which already unite it to its future colony, and the mission not without distinction which Belgian officers have fulfilled and are fulfilling in Africa would find its complement in the collaboration of jurists of merit who can be counted in our country in great numbers.

\section{NATIVE CHIEFTAINCIES}

The institution of native chieftaincies, due to the decree of 6th October, I89I, realises an idea too just and too politic for it not to receive all the extension possible. If during the first days that followed the promulgation of that decree the district Commissioners displayed praiseworthy emulation in recognising native chieftaincies, it is not less certain that these have not rendered, up to the present, all the services which we could expect, so far as they were called upon to create between the European authority and the natives a natural intermediary, having its duties and responsibilities, and calculated to facilitate the action of the Government.

The cases in which it has been applied still show the advantages of the system and testify to the greater facility with which the natives rally to the new order of things when it is personified in their eyes by the chief whom they have always recognised. It is proved that respect for the orders of authority, obedience to the laws, the execution of legal obligations, such as military recruiting and the payment of taxes,in a word the principles of an organised social state, are more easily accepted by the natives forming part of a chieftaincy than by those who are quite independent. The chiefs, besides, have generally a real influence over the population, and thus, as has several times been said, if they feel themselves supported they will succeed in making our ideas prevail and in imposing them on the natives through our support.

Another appeal has just been quite recently made by the 
local government to all the chiefs of districts and zones in order to inspire them with these views, and so that they may increase the official chieftaincies to a great extent.

The instructions issued are inspired by a double object: to maintain and even to extend the authority of the chiefs over their subjects, to avoid all intervention in the internal affairs of the tribes which would be of a nature to compromise the prestige of that authority.

"It is the right of the chief," these instructions declare, "to assure the execution of his orders according to rative rules and particularly to bring to his decision the sanction demanded by native custom."

The only restriction on the authority of the recognised native chiefs lies in the necessity for them not to run counter, in the decisions taken, to public order, that is to say, principles which are at the base of the organisation of society, as it is comprehended and wished to be by the legislator.

The chief's authority ceases as soon as the measures taken are contrary to that public order.

Thus, in matters of private right, the native chief could not legitimately take any course which would assail the organisation of families constituted under the régime of the civil Code, and according to its prescribed form,- -in other words, entered on the European statute.

On the other hand, he could not establish slavery, oppose religious liberties or commercial liberty, or order acts contrary to the penal law.

Still it is necessary to remark that he may employ coercive and repressive measures to ensure, as chief, and within the limits of his power according to custom, the execution of his orders.

But this sanction itself would be contrary to public order if its character differed from our ideas of what repression should be, more especially if it were accompanied by torture, mutilation, or other acts of cruelty, or if it were surrounded with superstitious practices, such as the proof by poison; in a word, if it were really to run counter to our ideas of humanity and the civilising object of the State. 


\section{The State's Administration}

Corporal punishments, similar to those employed by the State and in a similar measure to what is employed by it, inflicted by the native chief according to custom, would evidently not be contrary to public order.

Such are the regulations set forth in a general way which govern the $25^{8}$ recognised native chiefs in their participation with the political life of the State.

These instructions recommend to the territorial authorities "continual relations with the native chiefs, incessant instructions and recommendations, a direction and control without interruption, and a moral and material support in order to maintain and increase the chief's authority with a similar object," and to the judicial authorities "an intervention marked by prudence in order not to diminish uselessly the chief's authority, and not to destroy, or even weaken, the influence that he should have, and of which the Governinent means to make use for the spread of civilisation."

The care of maintaining intact and of developing the principle of the chief's authority might perhaps one day be carried farther. It would indeed be permissible to wish that, in the future, all the decisions of an administrative and judicial character, passed by the European authorities themselves, should be executed by the intermediary of the recognised chief; in other words, the native would receive orders only from his natural chief.

This measure, when it becomes possible, will produce the best results with regard to order and discipline, the natives being less inclined to rebel against the orders of the chief whom they have freely chosen.

In order to avoid the abuse which might result from ignorance of our laws, and to make the native chief acquainted with his rights, there should be attached to the procés verbaux of investitute of the chiefs a protocol setting forth the penalties that it will be permissible for the local authorities to continue to apply, as in the past, with a specific mention of the offences subject to their jurisdiction. They will be made acquainted with this act on their investi- 


\section{Story of the Congo Free State}

ture, at the same time as they are instructed as to the general obligations imposed on them by the State, and which should also figure in the document in question.

All that precedes evidently relates only to native chiefs properly so-called, and not to the present sultans who, as prescribed by the Government's instructions, must not have the authority which they at present possess increased. 


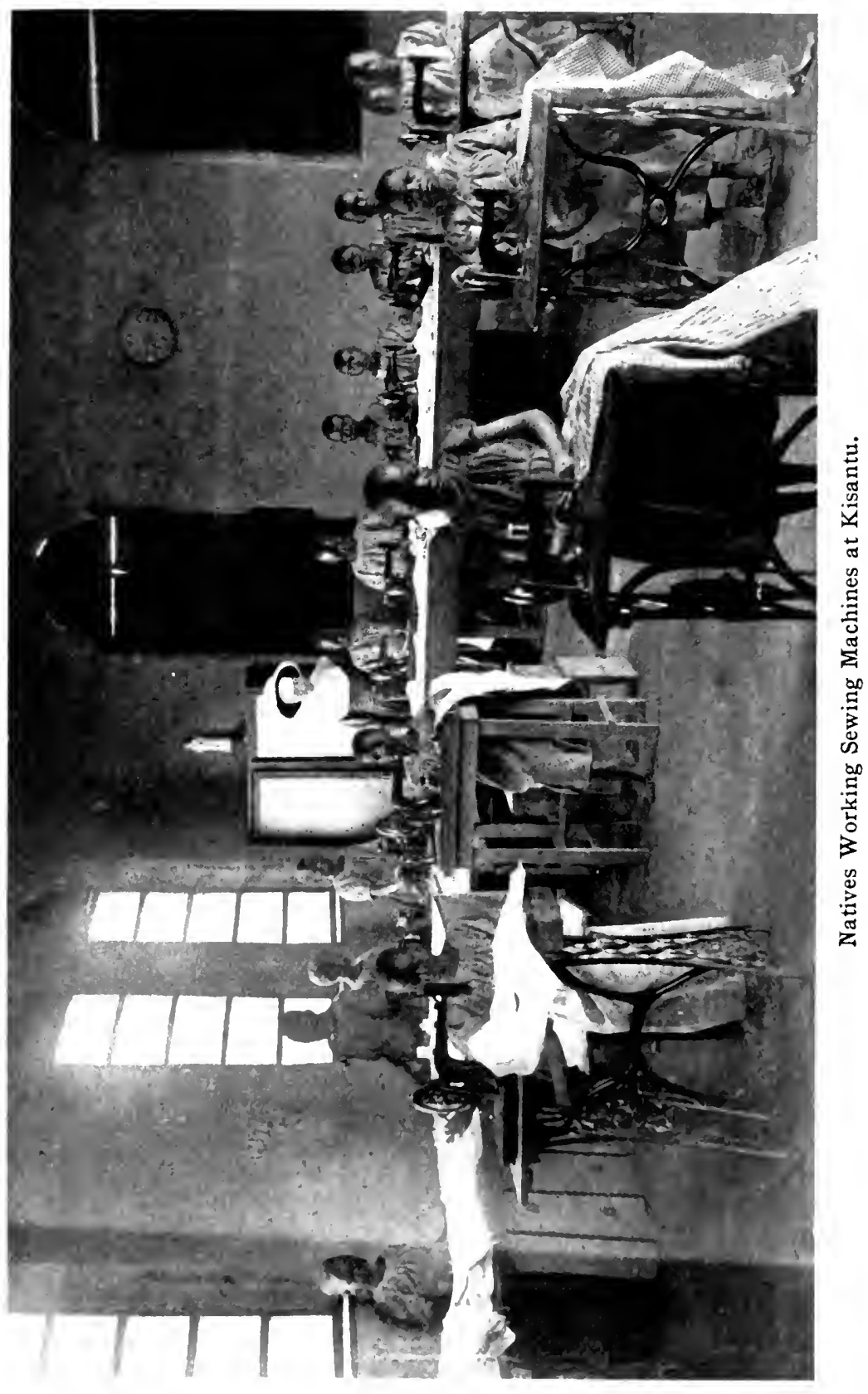





\section{CHAPTER XXIII}

THE POSTAL, TELEGRAPH, AND TELEPHONE SERVICE

$M^{\circ}$

ODERNS regard the post-office and the mission school as substantial signs of civilisation wherever the two are found in mutual endeavour. In compliance with Article VII, of the General Act of Berlin, the Congo Free State joined the Postal Union, and has sent Civilisers. official representatives to its periodic congresses.

In the Belgian Congo the postal service is very efficient. It already penetrates to districts most remote from the central office at Boma. It was effectively established in 1885 when the irregular service was succeeded by the rudiments of the present system. In 1887 it was, in fact, a piece of perfect governmental machinery. On the 28th of February that year it signed a formal Postal Convention with Belgium. It was soon thereafter apparent that a postal money-order service was required to facilitate the transit of small sums between Europe and the Congo. Agreements in this respect were made with Belgium on May I 3, I893, and November 24, I898. The rapid development of the Congo Basin already calls for even further extension of the system. 
The latest report on the subject is that of ViceGovernor-General Fuchs, which follows:

\section{POSTAL SERVICE}

There are at present on the Congo: 23 post-offices, subpost-offices, and depots for stamps.

According to the returns before me, there were transported in 1885 only 33,140 letters and printed objects, whereas for 1902 the postal movement was represented by 372,007 letters and printed objects.

Correspondence is conveyed by either railway or steamer; on the roads it is forwarded to its destination by special native couriers.

The weight of the despatches enclosing letters and printed matter may not exceed, for transport by land, ro kilogrammes." The porters required for this service are furnished by the chiefs of posts.

The transmission of correspondence into the interior of the country is, besides, regulated by instructions, to which the local authorities frequently draw the serious attention of the territorial chiefs. Thus, in all parts of the State territory, the couriers must leave on a fixed day, and they have a certain time, which has been calculated after much experience as sufficient, for the journey from one point to another.

It is expressly forbidden to the authorities to detain the native couriers after the date fixed for their departure, or to entrust them with correspondence not sealed. All postal packages must be paid for (with the exception that certain officials have the right to post free) and enclosed in a sealed envelope having the address clearly shown.

Each postal despatch contains a ticket of advice which is to be returned to the originating office, dated and signed by the agent of the office that received it, after he has found the contents exact. The carrier of the mail is also in possession of a route ticket which informs him of the number of sacks and envelopes composing the mail. It must be checked and dated,

About 22 lbs. 


\section{Postal, Telegraph, and Telephone Service}

and must show in a special column, for the way out and back and for each station, the hour of the arrival and departure of the couriers.

The sub-controllers of the post-offices must forward each month, for the purpose of verification, to the Controller of the post-office at Boma, the route tickets of the couriers sent during the previous month.

The Director of Finance sends, as often as possible, the Controller of the Post-Office to examine the accounts of the various offices which are run by selected agents appointed from the Belgian administration.

In districts where sub-post-offices are established, the District Commissioner sees to the strict observance of the instructions regulating the important postal service.

It has been found that in several districts the services of soldiers in the garrison have been utilised for the mails. Not only did these not always render the services which workmen or other men specially engaged for the service of transports of all kinds render, but even there was reason to fear that the soldiers, on account of their uniform and arms, as well as being without control, sometimes abused their powers to make levies on the villages through which they passed. But now the strict instructions of the Government forbid soldiers being taken away from their garrison and military duties, and require that they should always remain under the control of their chiefs. It has, therefore, been positively forbidden to send any mail by soldiers of the Public Force.

\section{TELEGRAPH AND TELEPHONE SERVICE}

On 27 th November, 1893 , the State ordered by decree the first telegraphic line, and in July, 1895 , a first wire was stretched across the river; and on $15^{\text {th }}$ September, 1898 , it became possible to telephone and telegraph from Boma to Leopoldville, or for a distance of $45^{2}$ kilometres (282 miles). Later on, and when the transport of material had been made easier by the opening of the Matadi-Leopoldville railway, the telegraph line was extended to Coquilhatville. 


\section{Story of the Congo Free State}

At the present moment there are thirteen telephone and telegraph offices working in the State.

The principal offices and distance separating them from each other are:

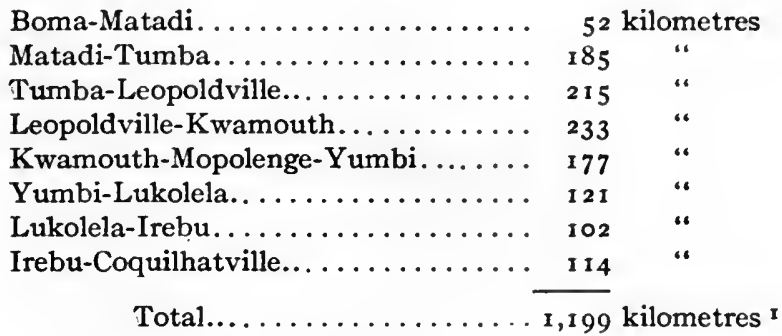

(nearly $75^{\circ}$ miles) of development. This extensive telegraph and telephone line is carried on iron posts from Boma to Leopoldville, and from Leopoldville to Coquilhatville the wire is supported in some places on steel posts, in others on trees, in the proportion approximately of 4494 steel posts and 2782 trees.

The line has to make two very important crossings of water, one across the Congo a little above Underhill Point (Hell's Kettle), the other across the Kassai near its mouth.

At the crossing of the river at Underhill the wires are supported by trellised steel towers, the piers of which are distant 800 metres from each other; and they are placed 73 and 63 (2) metres ${ }^{2}$ respectively above the bed of the river at the highest flood.

The crossing of the Kassai is made by two casts of the line, one being $45^{\circ}$ and the other 670 metres in length. Fourteen steel towers, of $36.5^{\circ}$ and of $38.5^{\circ}$ metres in height, help crossing the river. One of the towers is placed on an island, and four conductors ensure the proper working of the telegraph line.

The camps of Lisala and Umangi are also connected by a telephone line 22 kilometres in length. Besides a strong permanent body of native workers and European linesmen, the

I A kilometre is .62I of a mile.

$2 \mathrm{~A}$ metre is 39.37 inches. 


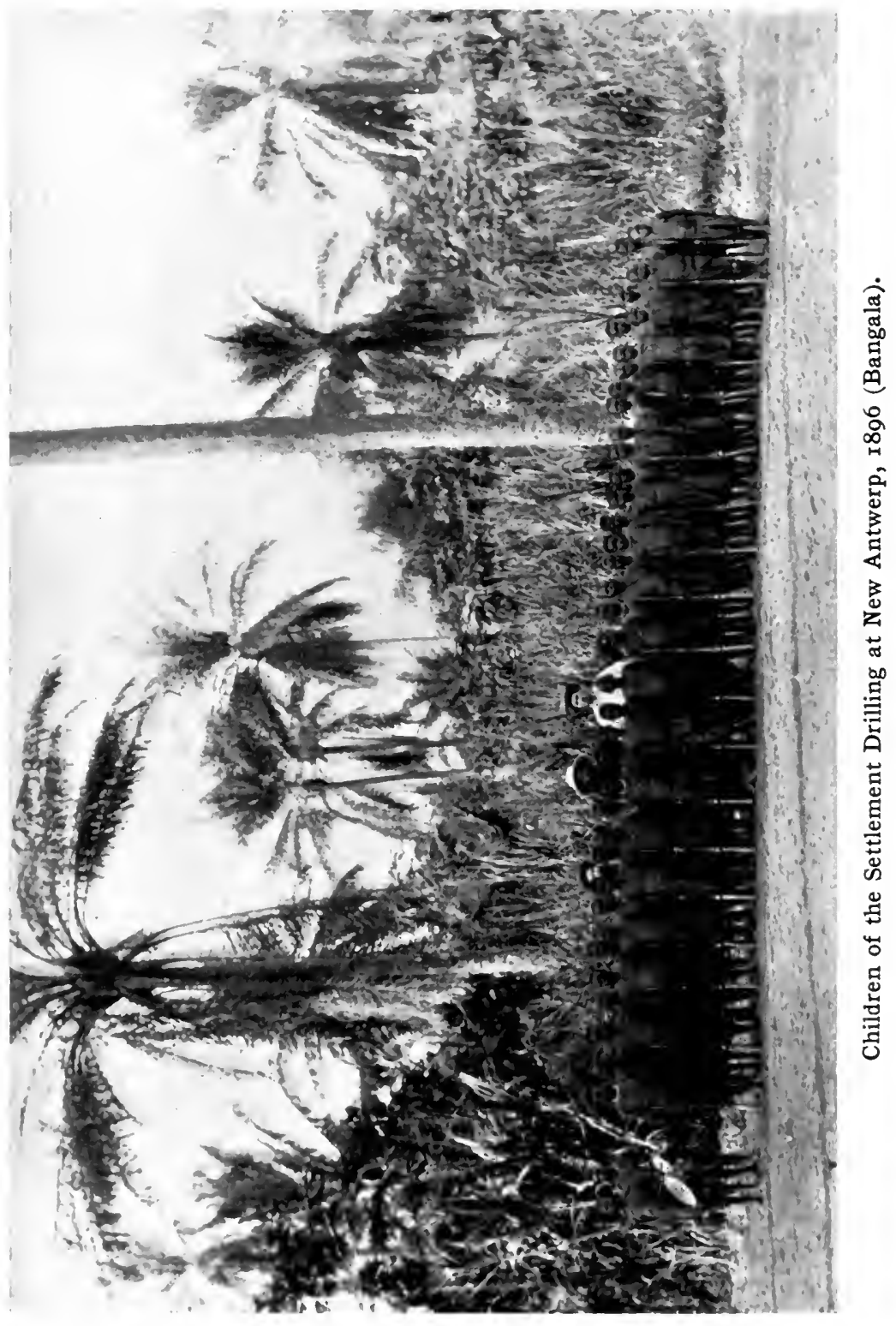



line is maintained by the natives of the villages through which it passes. The natives receive ample compensation in monthly payments.

Another telegraph and telephone line of about 320 kilometres, which leaves Kassongo on the Lualaba for Baraka on Lake Tanganyika, was opened on 5 th December, 1903. It connects the telegraph and telephone offices of Kassongo, Kabambare, Kalembe-Lembe, Baraka. This line will be extended to Lake Kivu, in the extreme eastern part of the Free State.

For about two years past experiments have been in progress to establish communication by wireless telegraphy between Banana and Ambrizette, so as to connect the Congolese system with the rest of the world.

Telegrams for Europe are at present brought either by the State steamers or by ocean steamers from Boma to St. Paul de Loanda, to San Thome, and to Sierra Leone, whence they are transmitted to their destination. Telegrams can also be sent from the Congo for Europe by the French route of the Gaboon by taking them to the French office of Brazzaville. A convention recently established between the French Republic and the Government of the Congo Independent State will allow the telegraphic systems of the two States to be connected by sinking a cable in Stanley Pool between Brazzaville and Kinshassa. This work finished, the Congo State will be connected with the telegraphic system of the globe. 


\section{CHAPTER XXIV}

\section{NAVIGATION, RAILWAYS, ROADS}

\section{$\mathrm{T}$}

HE Sovereign of the Congo Free State adheres to a gospel of labour of which he is personally the greatest exemplar in Europe. His Majesty's industry is in motion at five o'clock every morning. It gathers force as the sun rises, and subsides only when his ministers and attendThe Strenu- ants have retired. In this respect much
ous Life. might be written to attract the world's admiration to a monarch who has the false reputation in America of toying with time and its tintinnabulation.

Tremendous are the energies which the King's example inspires, not only in the Belgium which his rule has beautified, and which he has made the leasttaxed country in Europe, but also in the heart of blackest Africa. There are, in that vast territory, manifold monuments to the infectious spirit of endeavour which prevails in the palace at Laeken, at Brussels, and in the lofty chalet at Ostend. These monuments, by their nature, appear to confirm Belgian intention to occupy the future of the Congo State with structures of enduring substance, whether they be material, political, ethical, or social. The charge, sometimes uttered against King Leopold, that his interest in the Congo is merely what it can be made to yield him during his lifetime, dissolves 248 
into the mist of the slander it becomes in the presence of the physical improvement going on, with mighty strides, in Congoland.

When the Congo Free State was founded, communication by water with Europe was infrequent and uncomfortable. Liverpool and Lisbon sent a few ships at irregular intervals. Later Germany and Holland followed their ex-

Benefits of State Rule. ample at a time when Fuka-Fuka was the farthermost settlement on the Congo coast. No means of transport into the interior existed except by canoes, or by native carriers. To-day all this has been altered by Belgian capital, skill, and industry.

The maritime development of the Congo began in I 89 I, when the State, joining the commercial companies of the region, concluded an agreement with certain German and English steamship lines to establish a monthly service between Antwerp and Matadi. These ships left Antwerp on the 6th of each month and arrived at Matadi in about fifteen days.

In 1895 , under the auspices of a syndicate composed of the masters of these ships, there was incorporated at Antwerp La Compagnie Belge Maritime du Congo, which provided a monthly service of steamers sailing under the Belgian flag. The success of this enterprise induced other companies to engage in the Congo trade, among them being L'Empresa Nacional de Navigaçao, of Lisbon; Les Chargeurs Réunis, of Bordeaux, related to Fraissinet et Cie., of Marseilles; The Woerman Line, of Hamburg; The African Steamship Company, combined with the British and African Steam Navigation Company. 
Extensive harbour works have been erected at Banana, Boma, and Matadi, and several signal lights have been placed at the mouth of the Congo to indicate the entrance to the channel. The Lower Congo, from Banana to Matadi, has been charted by buoys, and a pilot service has been organised at Banana. The river channel is being constantly improved by dredging, and Matebe, which in the dry season was inaccessible except to small craft, is now on the line of general navigation. A regular service of steamers plies the Lower Congo, and the State boats go regularly to Landana to meet the Portugese mail.

In 1890 the shipping in the ports of Banana and Boma amounted to only I66,028 entries, and I63,7 I6 departures. The present tonnage into and out of these ports is over 500,000 .

On the Upper Congo a large flotilla carries on an excellent service. The State operates thirty-two of these vessels and the companies about forty-five, besides which there is a considerable number of smaller craft belonging to private individuals and to missions. The tonnage of the Upper Congo flotilla is 1675 tons. The marine service numbers I66 whites and I 300 blacks.

The first steamers launched on the Upper Congo were of only five tons, their component parts having been carried on men's backs along caravan routes long before the construction of the railway of the Cataracts. Even before the completion of the railway from Matadi to Stanley Pool the State had launched twelve five-ton boats on the Upper Congo, each of which had a capacity of nearly 50,000 pounds. 


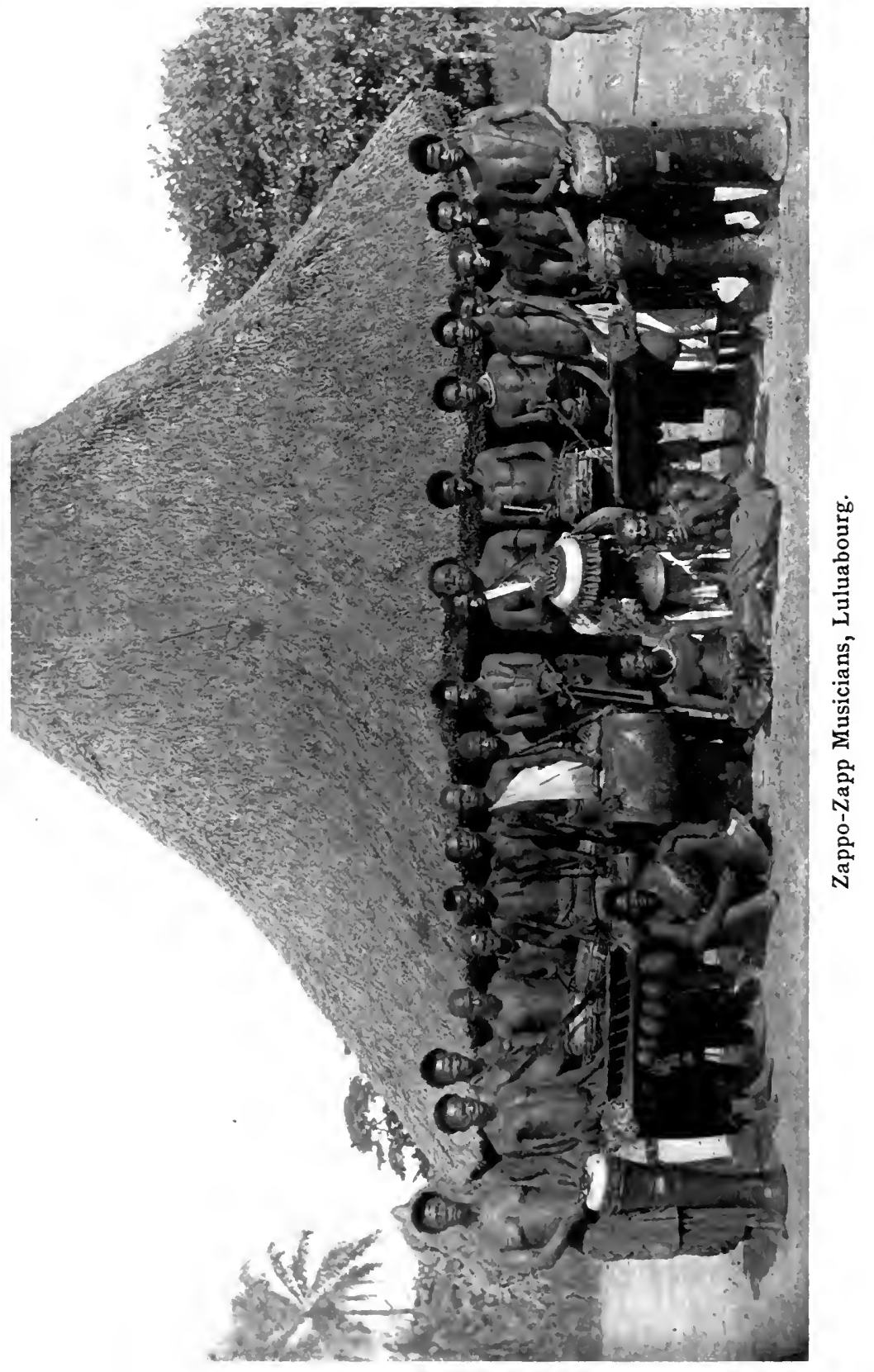



Besides these, the Government launched one steamer of twenty-three tons and four of forty tons burden.

With the completion of the railway, the necessity for considering the weight of the loads ceased, and a new type of craft, the stern-wheel, was chosen. Its system of propulsion offered greater advantages against the variable conditions of navigability with which the vessels had to contend. The ports and landings are in a state of complete organisation at numerous points on the river, and cargoes are now moved with great facility. At regular intervals along the watercourse, posts at which Government workmen gather wood, supply the steamers with this form of fuel. In order that the forests along the banks may not be denuded, a State law enforces the replanting of trees as fast as they are cut down.

In 1896 the Government established a regular fortnightly steamship service between Leopoldville and Stanley Falls. The three steamers, Brabant, Hainaut, and Flandre, have been assigned to this service. The dates of their departure from Stanley Pool have been fixed to correspond with the dates of arrival of European ships. In order to ensure service on the navigable stretches beyond the Falls, steamers have been launched on the rivers Lualaba, Itimbiri, and Ubanghi. A sailing vessel has been launched on Lake Tanganyika and a steamer on the Nile. Native rowing crews have been organised in many regions, and their services are often of great value. All in all, the I02 steamers plying the Congo River in the governmental and private service, the efficient port facilities, the means of transport up the navigable 
affluents, and the hydrographic surveys constantly going on constitute a condition of colonial development which truly merits the commendation of Herr Von Puttkamer, Governor of the Cameroons, in which, amongst other things, he says: "The energy and practical sense displayed here deserve the greatest admiration."

As the Congo steamboat largely abolished the laborious native carrier system through the riverain districts of the State, so has the Congo Railway, popularly known as the Cataracts Railway, largely contributed to relieve the black man, under Belgian rule, from lugging fifty-six pounds dead weight through the African jungle. The iron horse in Central Africa has given great momentum to the industries of a fertile region. In constructing the railway from Matadi, near the mouth of the Congo River, to Stanley Pool, traversing a distance of 260 miles over as tortuous and steep a route as ever daring engineers ventured to follow; climbing the Pallaballa Mountains at gradients of 150 feet in the mile, and finally steaming over a summit $\mathrm{I} 7,000$ feet above the sea, Belgian skill has again manifested its extraordinary quality, a quality observed in all that it has accomplished in the Congo Basin.

To connect the navigable regions of the Lower and the Upper Congo by a line over the route just indicated seemed at first to be beyond the possibility of achievement. On July 6, 1898, after nine years of unremitting toil and the expenditure of sixty million francs, the line was in complete and regular operation through a region which, on account of its 
picturesque scenery, may be likened to the Simplon Pass in Switzerland.

Without a railway running round the thirty-two great cataracts which tumble furiously in their descent of eighty miles to the sea, the Congo River, in the opinion of Stanley, would not have much value in the development of the Basin.

The first estimate of the cost of constructing the line was twenty-five million francs. This was based on the surveys of Major Cambier for the Compagnie du Congo pour la Commerce et l'Industrie, which, as early as the year I 887 , had been granted certain rights and privileges if it would undertake to build the railway. On July 29, I889, the Belgian Chamber agreed to provide ten million francs of the Company's first capital, the remaining fifteen million francs having been subscribed chiefly by Belgian investors. The work so enthusiastically undertaken met with one setback after another, owing mainly to the engineering difficulties encountered in the rocky side of the mountain of Pallaballa, forming a spur of the great Crystal range, the western rampart of the Central African plateau. It required four years and indomitable perseverance to construct the section of the line from Matadi over the summit of Pallaballa, a distance of only twenty-six miles. In December, I893, Colonel Wahis opened this part of the line with appropriate ceremonies, which many Europeans interested in Congo affairs attended. In the Mouvement Geographique appeared the following interesting description of this unique engineering triumph: 
The train, on leaving the station of Matadi, passes in front of the works of the State and the Belgian and Portuguese commercial establishments, and debouches immediately by the Neck of the Guinea Fowls (Col des Pintades) into the Leopold Ravine, which it crosses by a bridge of sixty-five feet. It follows for a few minutes the right bank of the ravine, and is then on the bank of the Congo, whose magnificent panorama is suddenly exposed. Here commences the sensational part of the journey. For four miles, first alongside the Congo and then alongside the Mpozo, the way is hooked on to the side of the strong rock of Matadi. It mounts by a gentle incline, having on its right a perpendicular rocky wall, in some places seven hundred feet high, and on its left, in the foreground, the river rolling in rapids; and in the background the grand landscape of the right bank, with Vivi and Mount Leopold. At the sixth kilometre, where the Mpozo flows into the Congo, and before entering the valley of the former river, the view is exceedingly grand. At this point the railway is two hundred feet above the river-the Congo, enclosed in a gorge, rolls its tumultuous waters with extreme rapidity, as they have just made the descent from the Falls of Yellalla. On the left, to the north-east, the scenery is quite wild. It is equally so to the south-east, while the water is closed in in the narrow valley of the Mpozo. It was in these parts, at the very commencement of the work, that the difficulties were the greatest. From the Leopold Ravine to the bridge oi the Mpozo, or for over four miles, the platform of the line had to be cut in terraces on the side of an immense rock of hard stone, through the thick equatorial vegetation which encumbered every ravine. Beyond Sleepy Hollow (Ravin du Sommeil), and after passing the ancient camp of Matadi-Mapembe, commences the famous ascent of Pallaballa. At the tenth kilometre the line attains a height of three hundred feet, or a rise of six hundred feet in four and a half miles. Beyond this the line traverses the Devil's Ravine to reach the summit of the mountain, one thousand seven hundred feet, and in the course of this part of the work several bridges have had to be thrown across the intervening chasms or ravines. The whole 
of this part of the journey is really inspiring. The scenery is grand, works of skill succeed each other every minute, the perspective modifies itself to each of the numerous curves the road makes at every passage across the ravines. The railway ever ascends, hanging on to the mountain, suspended in places from three hundred to five hundred feet above the bottom of the Devil's Ravine. The engine blows with force to the very moment of reaching the station of Pallaballa. Here the most interesting portion of the journey is over. The great difficulties, the long slopes of ascent at a maximum incline, recur no more.

It had now become apparent that the railway would cost more than double the sum originally estimated. Additional powers having been granted to the Company and a tripartite convention having provided the Congo Free State and the Belgian Government with power to buy the road, capital was raised to bring the total up to sixty million francs. By an extension of the time when the Congo State and Belgium may buy the line, the railway Company has possession until I908.

The Cataracts Railway has some unique characteristics. It maintains a first- and a second-class car on each train. Trains leave Matadi every other day. Persons returning from the Congo refer to it as the strangest as

A Unique Railroad. well as the most profitable railway line in the world. It runs the distance between Matadi and Stanley Pool in twenty-four hours. First-class passage costs 500 francs, the second-class 50 francs. The former is, therefore, at the rate of 40 cents a mile. This, it is to be hoped, is at least some compensation for the great difficulties encountered in the construction of 
the line. For the final accomplishment of what is regarded in Europe as one of the great engineering feats in Africa, the energy and skill of Lieutenant Thys, the original surveys of Major Cambier, and the support of the King and the Belgian Parliament are largely to be credited. Outside assistance was almost entirely lacking.

The Mayumbe Railway is the second which was undertaken in the development of the Congo Free State. It connects Boma with Lukula, eighty kilometres (about fifty-four miles) distant, and has been in operation since I90I. It is narrow gauge ( 0.60 metre), while the Cataracts Railway is 0.70 metre.

On the completion of the Mayumbe Railway, the State inspired the construction of three lines of onemetre gauge, with a total length of I 600 kilometres (ro80 miles). These lines are being undertaken by the Compagnie des Chemins de Fer du Congo Supérieur aux Grands Lacs Africains under an agreement made with the State on January 4, I902. The latest report of the Vice-Governor-General (July, I904) indicates the present stage to which these lines and others have attained:

A route for a railroad from Stanleyville to the Great Lakes has been surveyed. This survey comprehends a principal trunk line, Stanleyville-Bafwaboli-Mawambi-Irumu, 762 kilometres in length. Near Irumu the track branches off in two directions, one, Irumu-Mahagi, of $35^{8}$ kilometres, the other, Irumu-Beni, of 135 kilometres. At present the surveys are being made for a track from Beni to Lake Tanganyika.

In addition, the track has been completely surveyed for a railway from Dufile to Redjaf, following the left bank of the Nile, which would be 157 kilometres in length. 


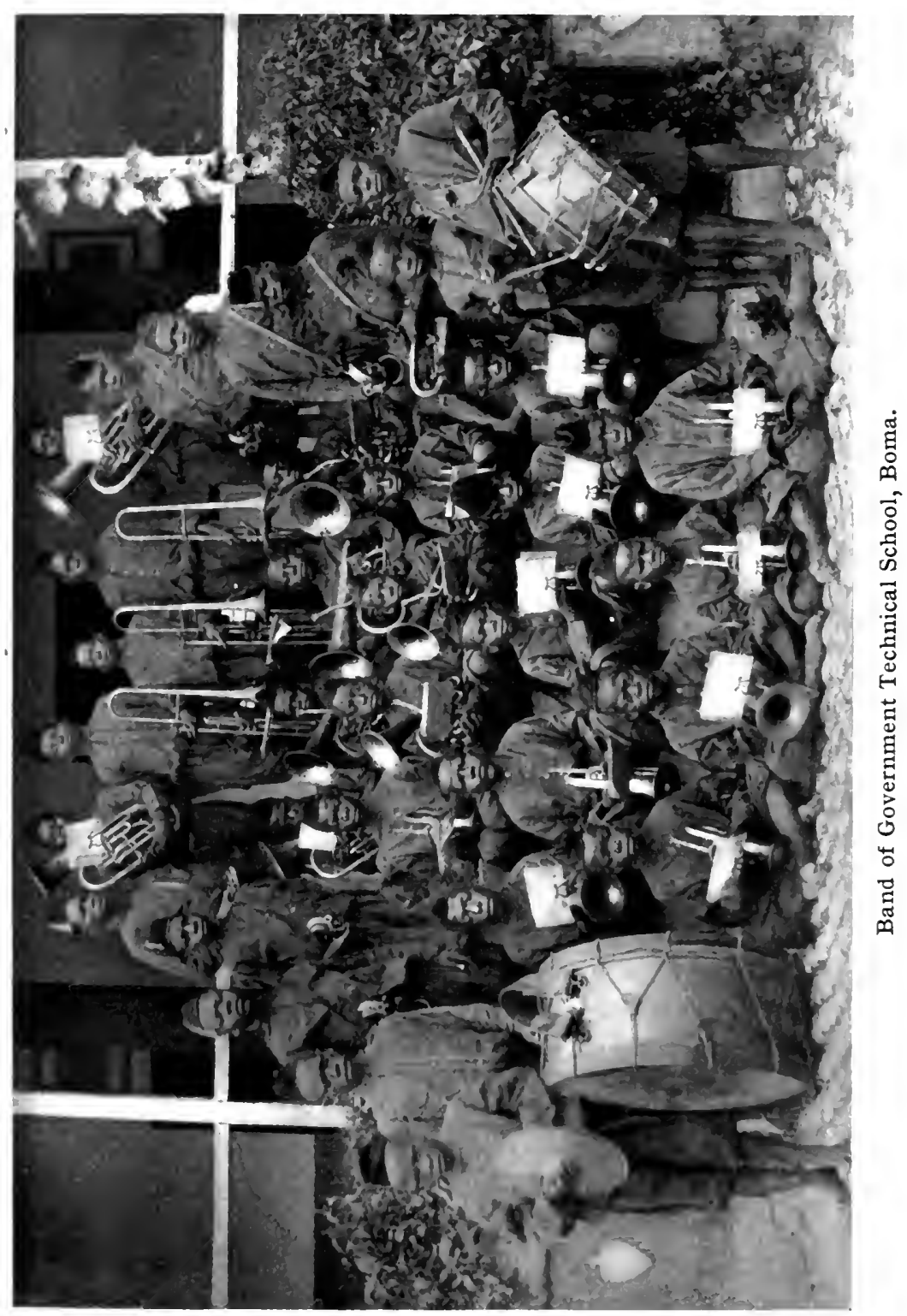



This railway would turn the unnavigable part of the river.

At this moment a line is being constructed between Stanleyville (left bank) and Ponthierville. This line will be ${ }_{4}{ }^{\circ}$ kilometres in length. The rails have been placed over ten kilometres, and the embankment finished for fifty kilometres. This line will permit of transports being made on the river above Ponthierville. As soon as this first line is finished, others will be constructed along the unnavigable parts of the river.

At the present moment surveys are also being made for a railway connecting a point on the southern frontier of the Congo Independent State (Katanga) with a point situated on the Lualaba, south of the junction of that river with the Lufila.

The approximate length of this line, the survey of which commenced as far back as 25th April, 1903, will be about 500 kilometres.

Having regard to those articles of the Berlin General Act which relate to the free navigation of the Congo and its affluents, the legal status of railways within the Conventional Basin of the Congo becomes a matter of considerable importance, especially in view of the growing controversy as to the proper construction of the Act.

Baron Descamps has ably treated this subject in his New Africa, a volume of exceptional interest at this time. After pointing out that the "freedom of navigation" declared by the Berlin Act must not be confounded with freedom of railway traffic, inasmuch as the latter admits of grants of monopoly and the former does not, this eminent writer on questions of general and special law says:

The idea of considering railways as continuations of watercourses, or as junctions between water-courses, was quite a new one, as was pointed out at the Berlin Conference. The 
Conference realised the necessity of providing for the logical consequences of such an idea, and therefore it drew up special regulations which are worthy of careful examination.

The general legal standing of railways in the Congo, the essential rights of the authorities as to their construction, their concession, their running powers, their charges, their position as public highways, their administrative and judicial policy are the same as those of railways in other countries.

The Berlin Act, as regards railways destined to provide transport where the Congo and the Niger become unnavigable, made special provision in clauses 16 and 23 on the one hand, and 29 and 33 on the other-the only clauses which are concerned with railways-for certain details of these communications. After declaring that these railways, as means of communication, are considered as auxiliaries of the rivers, the Act dwells on the legal consequences attaching to the introduction of this new idea, this conventional innovation in international relations. The consequences are as follows:

I. The obligation of opening the railways to the traffic of all nations (Art. I6, $\S \mathrm{I}$ ), and the inviolability at all times of the lines thus opened to the trade of all nations (Art. 25, § I).

2. The obligation to refrain from any excessive railway rates, that is to say, "not calculated on the cost of construction, maintenance and management, and on the profits due to the promoters." The Berlin Act states but these general principles, its object being to give the basis of calculation rather than a detailed solution of the problem, since it does not draw up a schedule of rates with respect to the nature of goods or the scale of the charges.

3. The obligation to observe, in fixing a tariff within these broad limits, "equality of treatment for the strangers and the subjects of the respective territories."

Thus, equality is sure to be observed as regards the tariff, both in the case of subjects and foreigners, and especially so in business which may be called the sphere of private activity, i. e., commerce. Thus also the power of the State to allow exclusive access to the railways, to impose extra or unfair charges, is minimised. The Berlin Act goes so far, but does 


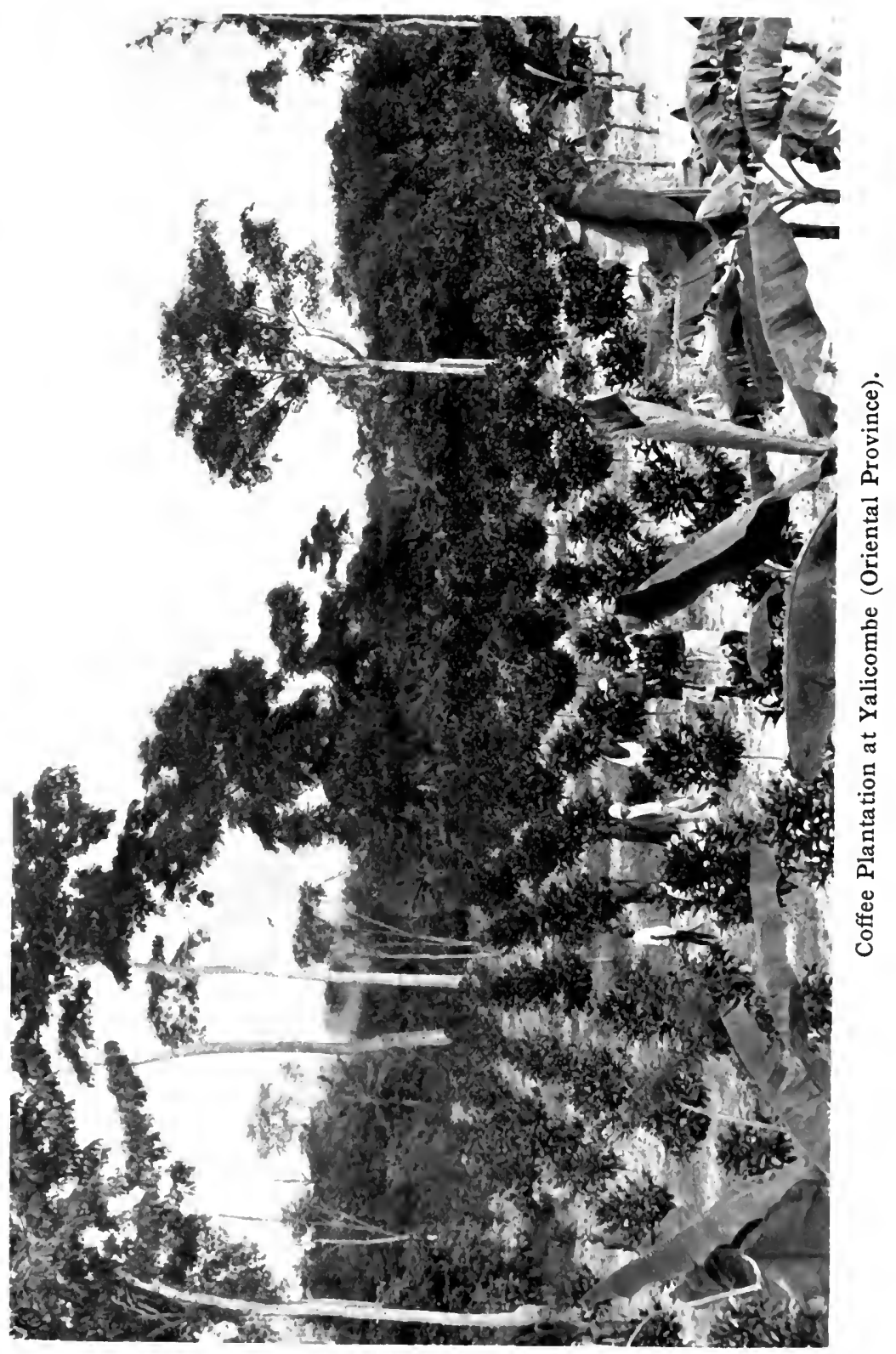





\section{Navigation, Railways, Roads}

not pass these limits. Beyond this, it does not affect the sovereign prerogatives of the State as regards its territory.

According to the usual right of the Powers in all that regards railways, the State can order the establishment of the same, can have them constructed, run them itself, and fix their tariff. It can also, if deemed preferable, authorise a concessionaire to collect the charges on the contemplated line, on condition that he shall undertake the construction and maintain the established tariff.

The Berlin Act respects these fundamental rights. It offers no opposition against whatever arrangements the State makes with its concessionaire as regards a schedule of rates with respect to the nature of goods or the scale of the charges. It does not intrude upon the internal organisation of the rates, except so far as it circumscribes them within the following limitations: I, all are free to use the railways ; 2 , no distinction can be based on the nationality of individuals; 3 , and no excessive rates are to be imposed.

Circumstances may render changes in the tariff advisable, and the State may modify the rates periodically. ${ }^{\mathrm{I}}$ It may also exercise the right of ordering its concessionaire to make certain modifications and reductions.

This was the course adopted by the Free State in relation to the Congo Railway in its initial estimates. It also reserved the right of repurchase. This latter reservation, however, it abandoned for a time by Act dated November I 2, I901, which also stipulated in what manner its optional power of reducing rates was to be exercised. That power it exercised by imposing a comprehensive system of reduction, and without at the time committing itself to any declaration as to the specific classes of goods on which the rates were to be reduced. It does not concern strangers whether it be exercised in one act or in two, and whether the concessionaire acts by special agreement with the State or under general powers. The main consideration is whether the procedure followed for the attainment of the reductions aimed at is in accordance with the

Is this volume is going to press, the announcement is made that the rates have been reduced. 
Berlin Act. In the present case, the procedure certainly was in accordance with that Act.

From a legal point of view, nothing can be said against the State's reducing railway rates, inasmuch as it was invested with the right of primarily drawing up those rates.

By the same Act of November I2, 1901, the State enjoys certain special conditions of transport for carrying out works of public utility. That right is quite legitimate for the Government, and does not entitle private citizens to demand its application for their own purposes. The State could have enjoyed these advantages if it had itself built and worked the line. The mere fact of a concession by no means robs the State of all its rights in this respect. These advantages are justified, for the State has made real sacrifices in ceding a part of its territory and in abandoning the repurchase clauses. The advantages accruing to the State do not in any way interfere with the equal treatment of individuals stipulated for in Article 16, which says: "As regards the rate of these tolls, foreigners and subjects of the respective territories shall be treated on a footing of perfect equality."

No distinction is made on account of nationalities; the only difference made rests on a service of public utility, regardless of nationality. Neither subjects nor foreigners can say that their civil or commercial liberties are endangered.

There are certain authoritative interpretations of the Berlin Act which confirm our view of this question. The German Government, for example, considers no breach of equality the exemption of all dues granted to a German railway concessionaire. Below are two clauses of the Imperial German decree, dated December I, I89I, and relating to the railway in German East Africa (Usambara line).

"Clause I.-The Imperial Government shall grant to no other contractor, either individual or corporation, the right of constructing or working a railway line joining the said localities or liable to compete with the line ceded by the present decree or any parts of same."

"Clause 9.-The Imperial Government guarantees to the German East African Railway Company, subject to compli- 
ance with the prescribed formalities, an exemption from all taxes on materials, engines, working tools, and all other implements and articles which may be imported into German East Africa for the construction, repair, renewal, and running of the railway."

In drawing up special tariffs with its concessionaire, it may be asked whether the State can base these rates on the actual working expenses-that is to say, with.neither profit nor loss for the concessionaire. From an economic point of view, such a tariff is perfectly justifiable. Transporting operations, per $s e$, cannot be separated from the transactions to which they are related. These transactions must be considered in view of all the surrounding circumstances. In negotiating transport operations, which of themselves entail neither profit nor loss, a contractor is quite justified in calculating on present or probable advantages which may result from the whole of the operation; as, for instance, the opening of new markets and the renunciation to the right of immediate repurchase of the concern. To forbid him to do this would be to spoil his chances and deprive him in many cases of a part of the profit to which he is justly entitled.

Neither can it be argued, in the case of a railway like that of the Congo, that the contractor should require rates superior to his actual expenses, in order to realise an immediate profit. Clause 16 states "that there shall be collected only tolls calculated on the cost of construction, maintenance, and management, and on the profits due to the promoters." To argue in the sense indicated would be against the purport of the clause which aims at forbidding excessive rates, but which in no way interferes with a gradual realisation of average profits by the contractors. To arbitrarily forbid the contractor to make such profits would be to. fly in the face of Clause i6, inasmuch as it refers to the profits $d u e$ to the contractor. It is equally fallacious to imagine that because certain merchandise is carried for a time without profit, the rates for certain other merchandise must needs be increased. Finally, it would still have to be shown that the Berlin Act forbids a proper and reasonable equalisation of contractors' charges. But the Berlin Act 
does not meddle with such arrangements; it does not establish a detailed and proportional schedule of rates. It only says that such charges must not be excessive-that is to say, they must not exceed the comprehensive amount of the necessary expenses and due profits. The Act, moreover, fixes no maximum for such profits, neither does it fix any maximum rates on produce. Its intentions in this respect are shown by its refusal to define, even by means of a maximum scale, the extent of compensatory rates.

Time was when the native Congolese, lazily living out his torpid life in a land where Nature in her Africa Un- luxuriance yielded him subsistence without known to the ennobling concomitant of his labour, Africans. avoided the great forests, the jungles, and the marshes of Equatorial Africa. He moved about to regions of easy access where the land afforded his indolence the greatest pleasure for the least responsibility. Explorers and the early builders of the Congo Free State often experienced great difficulty in preventing the desertion of their native carriers over a trackless course, such, for instance, as Stanley, Wissmann, De Brazza, cut out on their several expeditions. In short, the African Negro regarded his feet with such solicitude that he waited for the white man to show him the thickets and the fastnesses which contained those natural resourcesrubber, oil, gum, ivory, nuts-which certain library philosophers and untravelled colonisers assert were the conscious property of the savage who neither knew of, nor cared for, their existence. Industry was not worth while to him who could supply his wants in idleness.

The State, on the other hand, has not only taught 
the native Congolese the enlightening influence of honest labour, it has set him an example of colonial industry the like of which can not be found in the possessions of any other European Power. It built its railways where the engineering skill of its more powerful neighbours predicted failure; it sought the hidden treasure of a vast domain with routes and transport services which, in part, account for prosperity which others observe with manifest envy. Not content with these, it has lately penetrated the forests with wide avenues, hundreds of miles long, upon which to operate an automobile service. On this subject Vice-Governor-General Fuchs says:

The Government has also given attention to the construction of routes for motor cars; two chief routes of this kind are being constructed.

The first in the Uelle between Redjaf and Ibembo. It will be about 1250 kilometres in length, of which, according to the latest information furnished, 400 kilometres are now open to use. Experiments are being made there by means of three steam waggons.

The second starts from Songololo, a station on the railway from Matadi to the Pool, and proceeds to Popokabaka on the river $\mathrm{Kwango.}$

Routes destined for transport by waggons are, besides, in course of construction, and in some parts of the territory are sufficiently advanced to permit of transport by oxen, particularly in the Uelle, Katanga, and Manyema. The MahagiIrumu route is working for a length of ${ }_{1} 65$ kilometres; eleven large villages are now established along this route, at distances of from I 3 to 16 kilometres from each other. 


\section{CHAPTER XXV}

SCIENCE, AGRICULTURE, CIVILISING MEASURES

$\mathrm{W}^{\mathrm{In}}$

THIN the lifetime of men who may still be accounted young, the words that stand at the head of this chapter had no application to any part of Central Africa. Science, in A Marvel- all its forms, was utterly unknown there; lous Trans- agriculture can hardly be said to have exformation. isted, though a few of the tribes raised scanty crops of a nature that needed little or no attention; while of civilising measures there were absolutely none. These concomitants of long-established civilisation followed naturally the advent of the Belgians; and they have ever since, year by year, taken root, and spread until there are no two countries in the world more dissimilar than the Central Africa of thirty years ago and the Central Africa of to-day.

Realising to the full that complete success in any undertaking is only possible where all the conditions The Gospel affecting it are thoroughly understood, of Thor- the Congo State, early in its career, esoughness. tablished nineteen scientific stations, at various points throughout its territories, for the collection of data relating to anthropology, botany, ethnography, geology, philology, pisciculture, miner- 
Science, Agriculture, Civilising Measures ${ }_{265}$

alogy, zoölogy, etc., and for trigonometrical and astronomical surveys. Each of these stations is in charge of an expert, with properly qualified assistants. They have transmitted to Europe a whole literature of monographs, of great interest and value, upon all sorts of subjects, and their field of work is still far from being exhausted. The study of the Congo climate by these savants has proved especially valuable, their recommendations as to regimen, dress, habitation, etc., for travellers and settlers, having reduced the death rate of the whites to six per cent., thus dispelling for ever the old notion of the deadliness of Central Africa, and showing it to be at least as healthful as India, and healthier than either German East Africa, the Cameroons, the Niger Territory, or Cochin China. A small, but continual and increasing, influx of Europeans and Americans demonstrates the gradual abandonment of fear of the Congo climate, and faith in the hygienic system inaugurated by the Belgians,-a system which maintains sixteen State doctors to watch over and report upon the health of the various stations, and a permanent Hygienic Commission, which sits at Boma.

At the royal palace of Tervueren, near Brussels, now used as a public museum, are exhibited nearly eight thousand objects illustrating industry and art among the primitive peoples of Museum at Central Africa, such as costumes, dwellings, musical instruments, and implements of hunting, fishing, agriculture, river navigation, and war. The museum also contains several thousand geological, 
mineralogical, and zoölogical specimens, and a very comprehensive herbarium, all collected within the borders of the Congo Free State. The latter is of particular interest, containing specimens of more than four hundred new species.

From the first it has been the unswerving policy of the Congo Free State to promote, by every means at its disposal, the advancement of science as it affects, and as it is affected by, conditions prevailing within its territories. Until the Belgians came among them, smallpox from time to time decimated the natives, and was as great an evil as the slave trade or their own internecine wars. They had no conception of its prevention or cure, and submitted to its ravages with unintelligent dumb passivity as a providential visitation impossible to resist. The white man with his vaccine was a revelation to them; and though they at first refused to believe in its efficacy, and would not accept vaccination, they soon perceived the error of their disbelief; and now they voluntarily come to the Belgian medical officers asking to be vaccinated. Both Boma and New Antwerp have vaccine producing institutions, and vaccine is also distributed from Coquilhatville and Stanleyville. The results are most gratifying; for although, unfortunately, smallpox is by no means stamped out of the Congo State it is far less prevalent and less virulent than formerly, so that it is not unreasonable to look for its practical extinction in the near future.

To the present, Science has proved powerless to cope with that strange malady, the sleeping-sick- 
ness. The ablest physicians, not only of Belgium, but of England, France, and Germany, have studied the disease exhaustively. Though much The Sleepvaluable data relating to its cause and ing Sickeffect have been collected, the discovery ness. of its antidote seems as far off to-day as ever. The prevalence of this fatal sickness among its people makes it a subject of vital concern to the Congo Government, which is unceasingly vigilant in seeking to discover the means for its extinction or alleviation. In its pursuit of this object, all possible facilities have been afforded to foreign doctors visiting the Congo State. By request of the English medical faculty, three Congolese patients, suffering from sleeping sickness, were recently sent to the School of Tropical Medicine at Liverpool. On another occasion two others were sent to the Charing Cross Hospital in London. Animals have been infected with the germs of the disease, and its every symptom, from inception to climax, noted with minute accuracy. The disease, which is invariably fatal, appears to be on the increase, and there have been many victims of it on the Gold Coast as well as in the Congo State. For some obscure reason this dreadful malady has been strictly confined to individuals of the black race. Notwithstanding its want of success in combating the evil, the Congo Government may congratulate itself that it has neglected no precaution, and spared no expense, in its effort to mitigate what may conceivably develop into a veritable plague. ${ }^{\mathrm{x}}$

In the opinion of scientists, sleeping sickness is due to a trypanomous microbe, the propagating agent of which is the tsetse fly. 
In numerous ways has the Congo Government applied modern science to the uplifting and general betterment of the people over whom it rules, without distinction of colour or creed. Twenty-seven medical men, holders of European diplomas, twenty Health Committees scattered throughout the country, a Bacteriological Institute, and a Hospital for Natives at Boma not only labour for the cure of disease, but disseminate as widely as possible among the natives knowledge of the laws of health. On the whole, the work has been marvellously productive of good results, and the native is now incomparably more healthful, cleaner, better fed, and better housed than at any previous period of his history.

Thirty years ago what is now the Congo Free State was a wild tangle of luxuriant tropical growth Progress of through which hordes of black savages Agriculture. roamed, fought, and practised their unspeakable barbarities, living almost entirely upon the spontaneous products of Nature. The white magician has waved his wand and the scene is transformed. In, and far around, each of the numerous governmental stations or posts, life and property are as secure now as in any part of Europe or America. The spade and the hoe have displaced the throwing-spear and poisoned arrow in the hands of the native. Where the shy antelope or spring-bok browsed, remote from human intrusion, the soil is now turned up by the plough, and devoted to the growing of coffee, cocoa, tea (of the Assam variety) and various condiments, cinnamon, pepper, ginger, 
nutmegs, cloves, vanilla, etc. The establishments for the breeding of cattle, horses, and donkeys, particularly in the Enclave of Lado, in Ruzizi-Kivu, Equateur, Bangala, and Lualaba-Kassai, are numerous and increasing. Latest accounts to hand state that they exceed seventy. Many of the natives display considerable aptitude in learning how to tend herds of cattle. Great expense has

been incurred by the State and by various $\begin{array}{r}\text { Horses and } \\ \text { Cattle. }\end{array}$ companies in the purchase and importation of pedigree horses and cattle. The animals have been selected from the best European stocks by experts, and assigned to various breeding establishments throughout the country. The enterprise has proved extremely successful, the number of cattle of European origin now in the State being no fewer than 4500 , with sixty horses, and nearly as many donkeys.

In following agricultural employments the natives receive liberal encouragement from the Government. The State offers rewards for the cultivation of coffee and cocoa. At all suitable stations is a coffee and cocoa nursery, established by the State; that is to say, the State has supplied the necessary seeds, and contracts to allow an indemnity for each shrub on its attaining two feet in height, and to pay the native half the value of its produce less the cost of transport to Europe.

Coffee has been found to flourish most in the districts of Equateur and Aruwimi, and in the zone of Stanley Falls. Liberica, Ar-

Coffee. abian, and Guadaloupe are the varieties which have 
been selected as suited to the Congo soil and climate. The number of coffee plants has increased from $6 \mathrm{I}, 5 \mathrm{I} 7$ in 1894 , to $\mathrm{I}, 996,200$ in 1902 . Cocoa plants numbered no fewer than 298,003 in 1902 , an increase of $284, \mathrm{I} 36$ in ten years!

In 1899 the State erected a factory for the preparation of coffee at Kinshassa, and adopted several new methods, improvements upon the practice in vogue in countries where coffee has been cultivated for generations. After being dried at the plantations, the coffee is placed in sacks and sent in State steamers to Stanley Pool, and thence to the Kinshassa factory. So good is the quality of Congo coffee that in 1894 it realised no less than roo francs per roo kilogrammes in the open market at Antwerp.

Caoutchouc (rubber), for countless ages wholly a spontaneous product of the forests, every year becomes more and more an object of cultivation. By a decree dated January $5, \mathbf{1 8 9 9}$, it is provided that in all the forests of the domain caoutchouc trees shall be planted in the proportion of 150 feet to the ton of caoutchouc collected during the same period. By a subsequent decree, dated six months later, the number of caoutchouc trees to be planted for each ton of caoutchouc collected was raised from 150 feet to 500 feet. The enforcement of these decrees is attended to by a staff of foresters, consisting of eight controllers and twelve sub-controllers, working under a chief inspector.

Until prohibited by State decree, the method of collecting caoutchouc practised by the natives was 


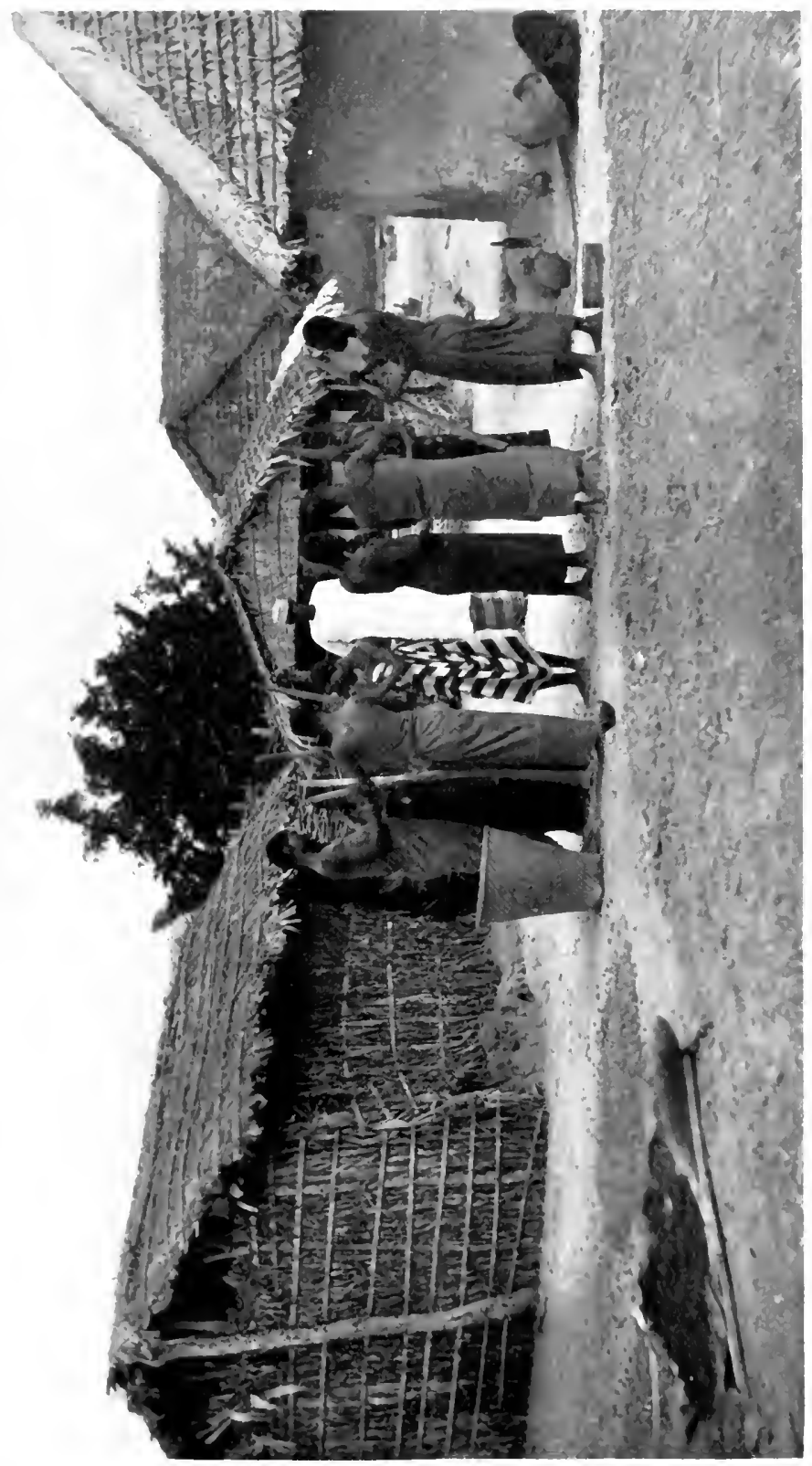

 

to make an incision in the plant (liana), and allow the fluid to run into a jar. Sometimes they allowed it to run into their hands, and afterwards smeared it over their bodies, and in that manner it was conveyed to market,

\section{Collecting} Rubber. where it was rubbed off with sand. It was an exceedingly wasteful method, or rather want of method, for the plant thus drawn from was necessarily killed. Only the prodigious quantity of plants existing on the Upper Congo and its tributaries has saved it from extinction. Now caoutchouc is harvested by extracting the fluid from the stem of the plant in a way that does it no injury, a scientific yet simple operation easily performed by women and children. The industry has assumed enormous proportions. The number of caoutchouc plants put into the ground by companies and by the State are valued at five million francs. The rubber annually produced in the world amounts at present to something over 30,000 tons, of which the Congo Free State exports 5000 tons.

In the African forests the caoutchouc or rubberbearing plant grows to a great height, often exceeding roo feet. It is commonly about six inches in diameter at its base, and shoots ${ }_{\text {Plant. }}^{\text {The Rubber }}$ upward to the light through a dense mass of tropical growth until, failing to find further support, it falls upon the branches of the tallest trees, and spreads itself over them. There are numerous other plants of the same genus which closely resemble it, but their sap lacks the qualities of true rubber. For several years past the State has experimented 
with these plants, and has sent specimens of them to the authorities at the Botanical Gardens at Brussels, Kew, Berlin, and Paris, for investigation. The ever-increasing demand for rubber for use in the industries stimulates the inquiry as to whether or not it is possible to so treat what is now regarded as "false rubber" that it shall serve all the purposes of "true rubber."

Amongst the true rubber lianas in which the Congo Basin abounds are the following: Ficus altissima, ficus Eetveldeana, ficus elastica, ficus nekbuda, ficus religiosa, manihot glaziovii (French name, ceara), clitandra Arnoldiana (native name, mondongo), funtumia elastica (French name, Ireh), landolphia gentillii, and the landolphia owariensis (native name, matofe mengo).

Constant experiments are being made, privately and by the State, in the production of copal, sugar, tobacco, and cotton, with results that justify the confident expectation that at no distant date they will be profitably exported. The cultivation of the vine, and of numerous fruits and grasses, receives also much attention, and is full of promise.

African ivory is everywhere esteemed for its superiority in colour and hardness to the Indian Elephants and Ivory.

variety. The large herds of elephants inhabiting the forests of the Congo State provide, at present, an enormous supply; but the Government wisely takes into account the possibility of its exhaustion, and has prohibited the shooting of elephants. Wise laws also regulate the cutting and export of lumber; and the folly of 


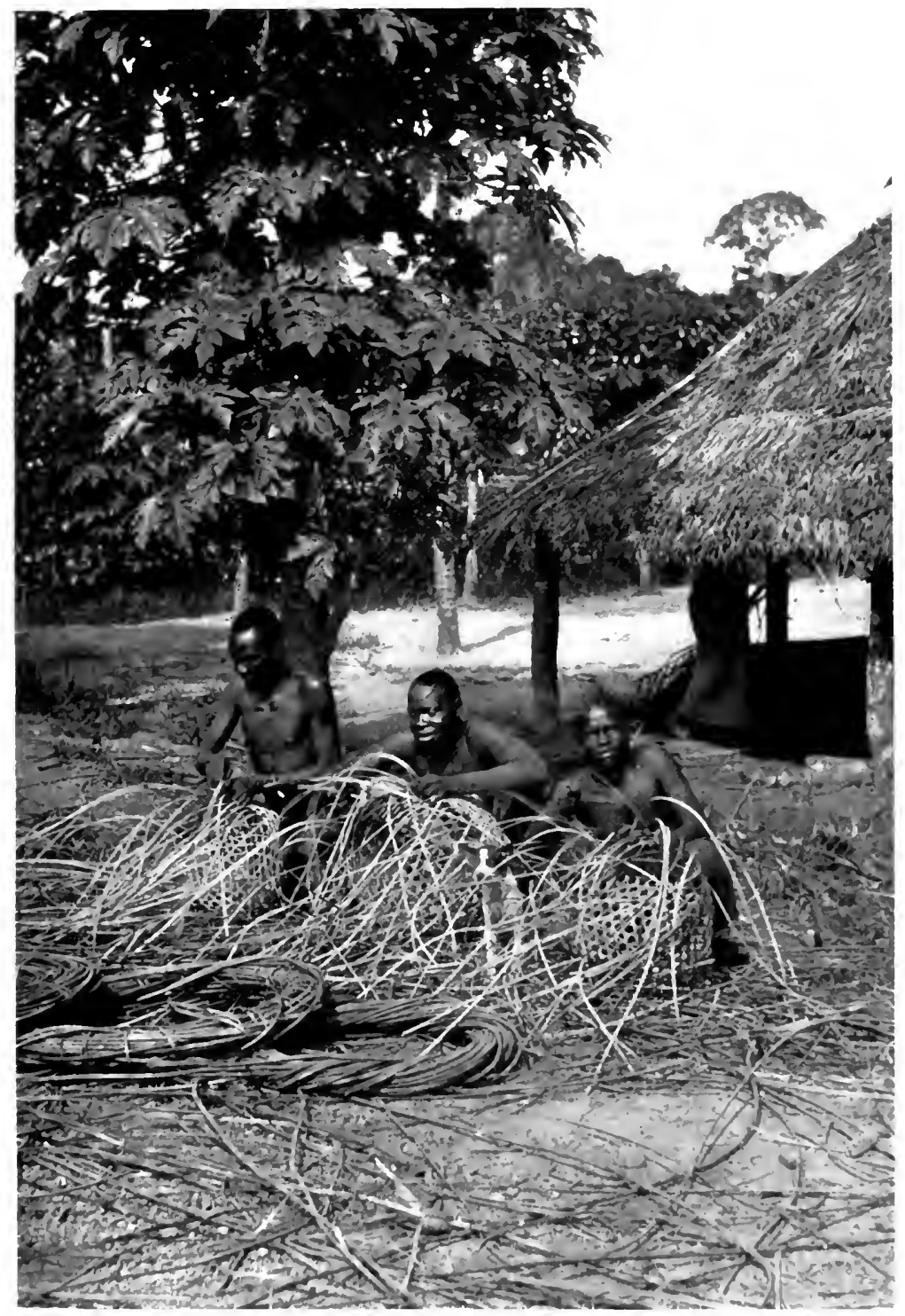

Making Baskets for Transportation of Rubber (Kassai). 

denuding vast regions of trees, such as we have been guilty of in America, will not be repeated on the Congo.

In every way the State has exerted its utmost influence to effect the moral improvement of the native races, and its efforts have met with much success. Their liberty and property Civilising are very carefully guarded. Polygamy is not only discountenanced, it is penalised, no polygamist being eligible for employment, whether military or civil, by the State. Christian marriages between natives, which ten years ago numbered eighty-four, now take place by thousands every year.

Alcohol is prohibited over $2,337,500$ square kilometres of Congo territory, the zone within which its sale is tolerated extending to only I 2,500 square kilometres, where its abuse is guarded against by carefully devised restrictions, rigidly enforced. The sale of absinthe is absolutely forbidden in every part of the Congo Free State.

It thus appears that, as the guardian of the welfare of its people, the Congo Free State has nothing to learn, either in theory or practice, from the most enlightened governments of the world. 


\section{CHAPTER XXVI}

TRADE, REVENUE, AND TAXES

MONG the earlier trading companies on the
West Coast of Africa was the house of Regis
et Cie., established at Banana in 1858 , whose successors, Daumas, Béraud et Cie., were carrying on a considerable business when Stanley explored inland from the mouth of the Congo in $\mathrm{r} 878$. The old Dutch house, the Afrikaansche Handels-Vennootschap, of Rotterdam, had a branch at Boma in I860, and the Portuguese firm of Valle \& Azvedo, and the agents of Hatton \& Cookson, of Liverpool, opened trading depots near by a few years later. These firms had, however, very little direct trade with the interior of the Congo Basin, commerce in their early time being confined to the coast. Trade with the interior is almost entirely due to the Belgians.

Before the Free State was founded the trade of Central Africa was chiefly in slaves. As a Belgian writer quaintly observes, the slave was at once the means of labour, the main capital, the vehicle of transport, the common currency, and the usual tribute given to satisfy the covetousness of native chiefs. The slave was the standard of wealth and the element of power. In order to estimate the influence of the slave trade as an economical factor 
in barbarous communities, and compare it with the trade régime of civilisation, it would be necessary to imagine dealings in some object representing all these uses in our markets. ${ }^{\mathrm{T}}$

To destroy the slave trade creates the problem of substituting a trade that is legitimate, that is founded upon the natural resources of the country. It simultaneously creates the problem of labour. The soil depends upon the man in the ratio in which man depends upon the soil. The Belgians heard from Stanley what vast wealth the Congo contained; but that wealth lay behind difficulties so great that no one in Europe ventured to pursue it until the indomitable personality of one man inspired men with the courage to undertake a seemingly hopeless task. Without a railway from Matadi to Stanley Pool commerce could not develop in the Congo Basin. This was Stanley's opinion. His judgment that the Congo had little value without such a railway in the region of the Cataracts has been justified. The Belgians built the railway at a cost nearly treble that of the original estimate. In fact, while others have been groaning and droning and musing upon the ethical theories of ideal colonisation and civilisation, in pamphlets and innocuous books, the Belgians have followed their own gospel of work and been at their task throughout the waking hours of each day. Spontaneous initiative, timely energy, unremitting labour, these appear to be the characteristics of Belgian dominance in Congoland. Having regard to the habit Europeans have of considering

I Descamps. 
Americans the great exemplars of an age of materialism and hustle, there is almost an element of humour in the fact that one of the first Congolese companies formed under the ægis of the Free State was founded by an American, General Henry S. Sanford, sometime United States Minister at Brussels. This was the Sanford Exploring Expedition, constituted by General Sanford and M. Georges Brugmann in 1887 . Its business was that of dealing directly with the natives for rubber and ivory, and it and the Mateba Syndicate and the Compagnie du Congo pour le Commerce et l'Industrie are generally regarded as the pioneers of organised trade in the interior of Central Africa. It would seem, therefore, that the accident of a king's friendship with an American minister, whose wise counsel he often consulted, might justify at least sentimental interest in the welfare of a region where the restless spirit of strenuous American life had manifested its tendencies nearly twenty years ago. Since the day when General Sanford set the example, forty-eight Belgian and fourteen foreign companies, with an original capital of $\mathrm{I} 36,000,000$ francs, have established a commerce in Congoland which is attracting the envy of some and the admiration of many throughout the world.

Before indicating the practical details of the trade and revenue of the State, a brief glance at the ten years before the Brussels Conference enabled it to create its support by levying import duties will recall the fact that from 1878 to 1890 King Leopold personally expended upwards of $3,000,000$ francs a year 
for the founding and maintenance of the State, irrespective of the meagre support derived from other sources. Indeed, no one felt disposed to support an African enterprise which promised to yield only "enlightened niggers." As Stanley sarcastically said in his lectures in England, too many of his audience measured "civilisation" by the dividends it produced. The inability of the Free State to support itself from enthusiastic humanitarians outside of Belgium was significantly indicated in 1886 , when the revenue of the State was less than 75,000 francs! The exports, chiefly ivory, were only I,750,000 francs, and the Congo Association, when it was merged in the State, possessed only thirteen stations. Out of two hundred and fifty-four foreigners on the Congo in $1885^{-1886}$, only forty-six were Belgians. In fact, nothing looked gloomier than the prospect of the new State in the African jungle; and yet one man, with a superhuman sense of the future, continued to pour gold and his labours upon that dark and distant land with its thirty million unenlightened souls. Now, when from a wilderness and savagery have been evolved civilisation, a thriving industry, a prolific field and growing market, religion, order, and prosperity, all that the early pioneer did is utterly lost and forgotten in the noisy controversy over a rich spoil.

It was by the Brussels Act of 1890 that the State acquired the right to levy taxes and impose customs dues. What Leopold II. had expended on behalf of the State in its long formative period was beyond recovery. It will be recalled that the Belgian 
Parliament had sanctioned a loan to the State of 25,$\infty 00,000$ francs, $5,000,000$ francs to be paid soon after the Brussels Conference, the remainder at the rate of $2,000,000$ francs a year. To this sum the King, having abandoned all claim to the huge sum he had previously advanced to the State, now added an annual subsidy of $1,000,000$ francs. The State, therefore, began the development of its resources with an assured income of 3,000,000 francs a year-not a large sum when compared with the responsibility of fighting cannibal slave-raiders with one hand while tilling the soil, constructing railways, creating posts and missions, and organising the State's machinery with the other. Beside the task in Congoland, the early American colonist enjoyed a holiday in a land of greater security and healthfulness.

The revenues first provided were on the export of rubber and ivory. These were fixed, after agreement with the neighbouring States of France and Portugal, at ten per cent. The duty on vegetable products was fixed at five per cent. Import duties were as follows: On arms, ammunition, and salt, ten per cent.; merchandise of any kind, six per cent.; on spirits, fifteen francs per hectolitre ${ }^{\mathrm{r}}$ at $50^{\circ}$ of the centesimal alcoholmetre; boats, machinery, and articles for industrial and agricultural use were exempt till May, I898, and thereafter paid only three per cent.

The tax on caoutchouc (rubber) was first fixed at twenty-five centimes a kilogramme (about five cents on two pounds) equivalent to four per cent. on its r About twenty-two gallons. 
value in Europe. When, however, the Cataracts Railway was finished, and human porterage along the route from Stanley Pool to Matadi abolished, the tax on rubber was increased to eight per cent. of its European value. Another decree of the same date (February, I 898) provided for the payment of a licence of 5000 francs by all persons establishing a rubber factory or depot in the domains. Other sources of revenue are coffee, tea, cocoa, gum-copal, palm oil, palm nuts, rice, tobacco, maize, sugarcane, vegetables, fruit, cinnamon, pepper, ginger, vanilla, nutmegs, cloves, and spices.

Great credit is due the local administrators of the Free State for the progress they have made in a long list of cultivated products, and the growth of the country's export trade resulting from Belgian and native co-operation and industry. For instance, in I 887 the total exports amounted to only I, $980,44 \mathrm{I}$ francs ${ }^{\mathrm{x}}$; in $\mathrm{I} 89 \mathrm{I}, 5,353,5 \mathrm{I} 9$ francs, and in 1903 , $54,597,835.2 \mathrm{I}$.

The following tables indicate at a glance the products imported and exported, their comparison with previous years, and their value:

I Reported in the Bulletin Officiel, 1898 . 
STATISTICS OF PRODUCTS EXPORTED FROM THE CONGO FREE STATE DURING I903

\begin{tabular}{|c|c|c|c|c|}
\hline \multirow{2}{*}{ EXPORTS } & \multicolumn{2}{|c|}{ Special Commerce } & \multicolumn{2}{|c|}{ General Commerce } \\
\hline & Quantity & Value & Quantity & Value \\
\hline & Kil & Frs. & $\kappa \imath l$ & Frs. \\
\hline $\mathrm{rac}$ & 463 & $65,692.60$ & $65^{2}$ & $92,330.40$ \\
\hline & 148 & $129,340$. &, 674 & $164,040.30$ \\
\hline & $5,917,983$ & $47,343,864.00$ & 804 & $5^{2,758,432.00}$ \\
\hline & $34 \mathrm{I}, 883$ & 577.70 & & 402.30 \\
\hline & 1,64 & 97 & 1,8 & $1,090,374.28$ \\
\hline & & 3,79 & & 7,2 \\
\hline & 4,95 & 1,487 & 5,9 & 970.00 \\
\hline & 89,365 & $125,111.00$ & 9,365 & $125,111.00$ \\
\hline & 740 & 222 & 740 & 222.00 \\
\hline & $4,75^{\circ}$ & 546.25 & $4,75^{\circ}$ & 546.25 \\
\hline & & I $5,000.0$ & & $15,000.00$ \\
\hline & 33,654 & $16,827.00$ & 54 & $16,827.00$ \\
\hline & $\ldots \ldots$ & $\ldots \ldots$ & 35,810 & $17,905.00$ \\
\hline & 235 & & 235 & \\
\hline 10000 & & & $5 \mathrm{~m} \cdot 3$ & 750.00 \\
\hline Totals..... & & $54,597.835 .21$ & & $63,955,400.53$ \\
\hline
\end{tabular}

I kilogramme equals $2.20 \mathrm{lbs}$.

TOTAL VALUE OF

\begin{tabular}{|c|c|c|}
\hline Place of Export & $\begin{array}{c}\text { Special } \\
\text { Commerce }\end{array}$ & $\begin{array}{c}\text { General } \\
\text { Commerce }\end{array}$ \\
\hline 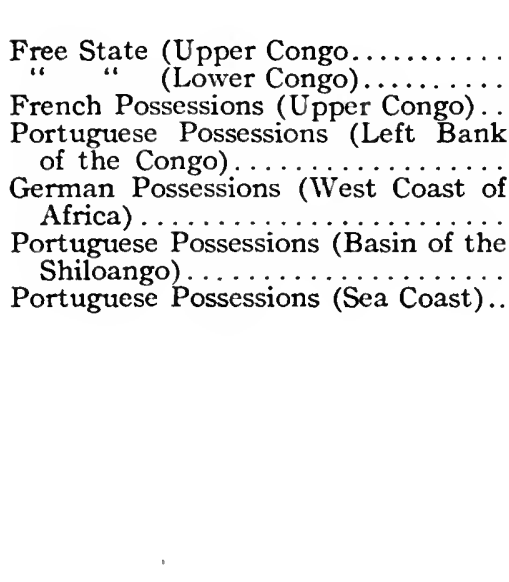 & $\begin{array}{c}\text { Frs. Cs. } \\
51,790,451.05 \\
2,807,384.16 \\
\ldots \ldots \\
\ldots \ldots \\
\ldots \ldots \\
\ldots \ldots\end{array}$ & $\left\{\begin{array}{rr}\text { Frs. } & C s . \\
54,597,835.21 \\
6,738,689.35 \\
1,293,043.47 \\
895.611 .50 \\
271,840.18 \\
158,380.82\end{array}\right.$ \\
\hline Totals.... & $54.597 .835 .2 \mathrm{I}$ & 6.3 .955 .400 .53 \\
\hline
\end{tabular}




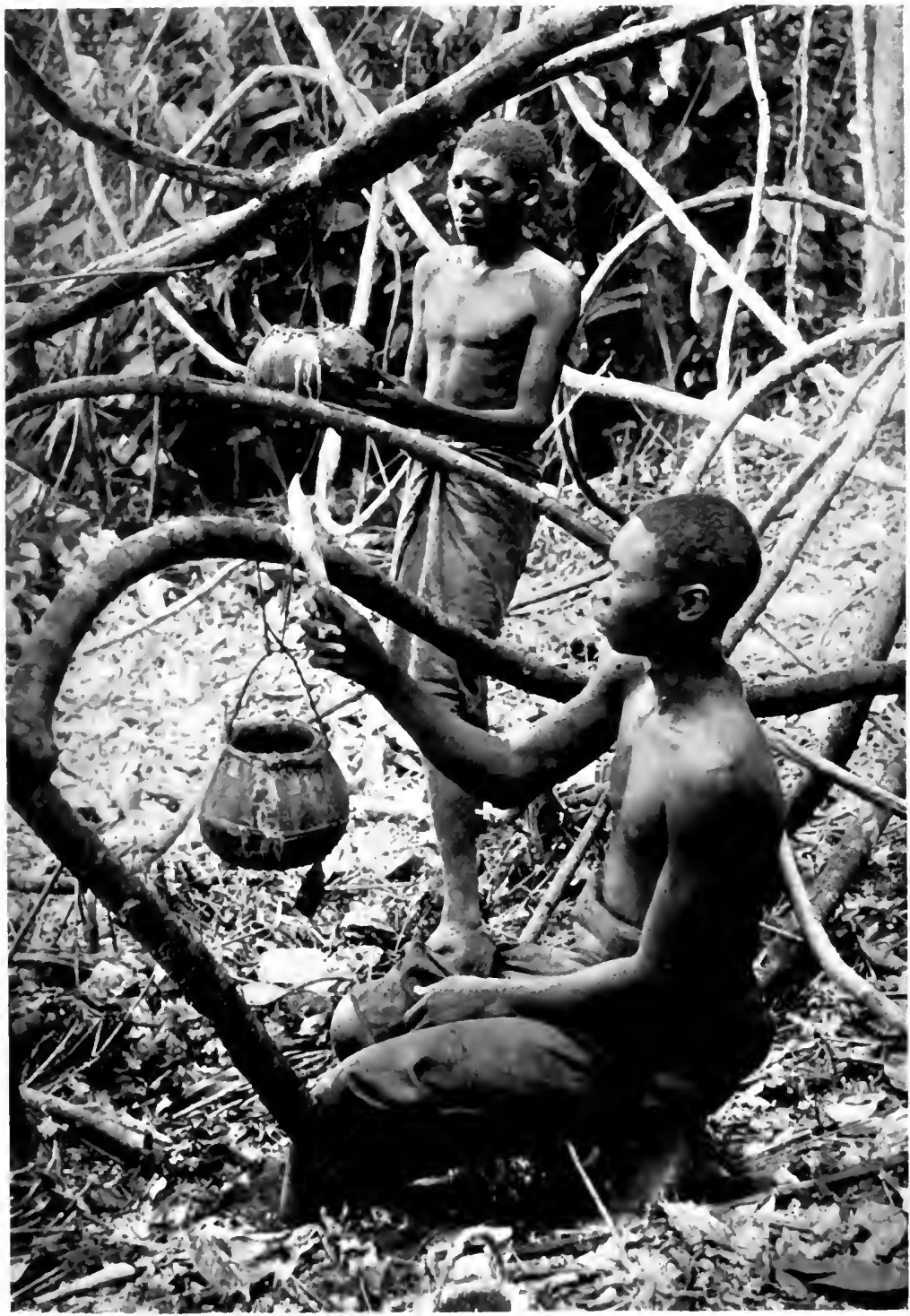

Collecting Rubber in Forest of Lusambo (Lualaba-Kassai). 

COMPARISON OF EXPORTS FOR 1903 WITH THOSE OF PREVIOUS YEARS

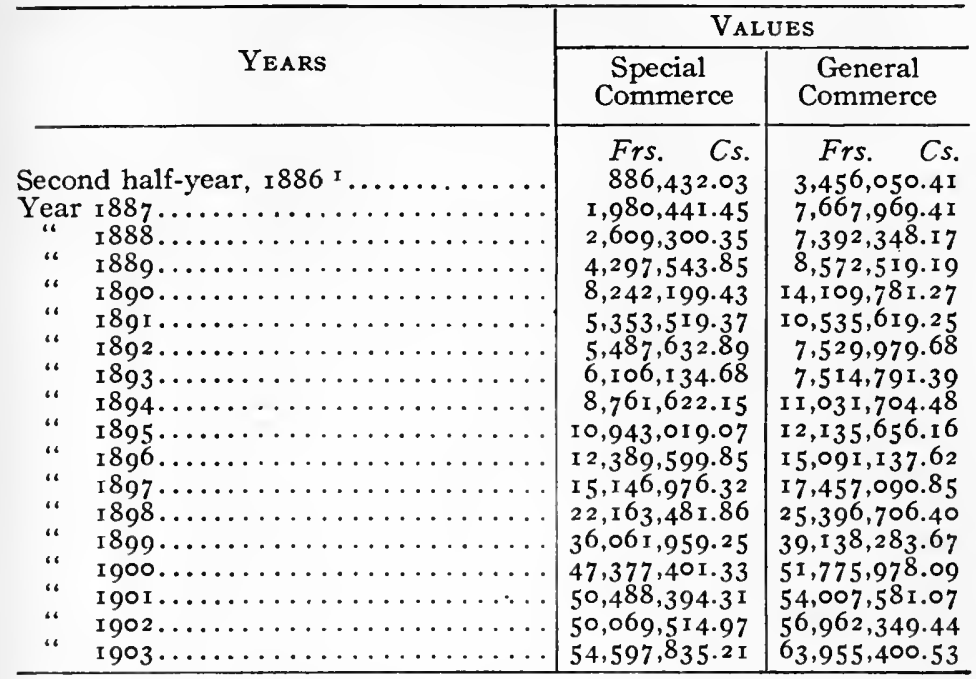

${ }^{r}$ Statistics of exports were not taken until after July I, 1886 .

EXPORTS FOR I 903

\begin{tabular}{|c|c|c|}
\hline Destination & $\begin{array}{c}\text { Special } \\
\text { Commerce }\end{array}$ & $\begin{array}{c}\text { General } \\
\text { Commerce }\end{array}$ \\
\hline 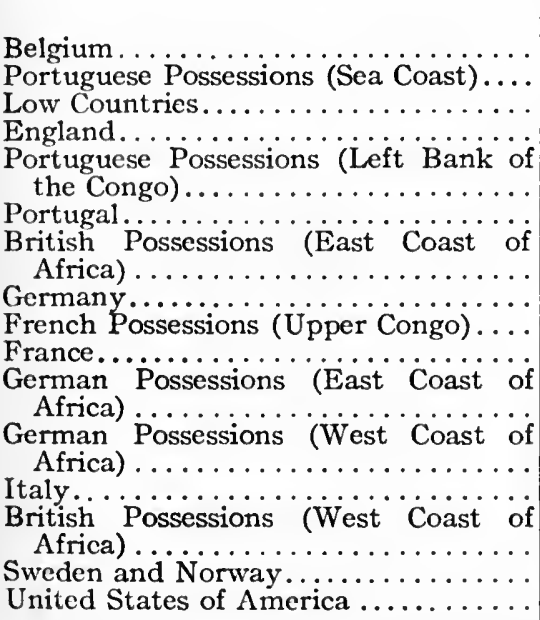 & $\begin{array}{r}66,433.75 \\
63,471.62 \\
\\
50,327.50 \\
22,074.48 \\
16,269.75 \\
6,238.00\end{array}$ & $\begin{array}{rr}\text { Frs. } & C s . \\
60,119,981.46 \\
1,872,934.45 \\
1,293,801.56 \\
297,676.91\end{array}$ \\
\hline & $54,597,835.2 \mathrm{I}$ & $63,995 \cdot 400.00$ \\
\hline
\end{tabular}




\section{2 Story of the Congo Free State}

STATISTICS OF GOODS IMPORTED INTO THE CONGO FREE STATE DURING 1903

Summary

\begin{tabular}{|c|c|c|c|}
\hline & \multirow{2}{*}{ Goods } & \multicolumn{2}{|c|}{ Values } \\
\hline & & $\begin{array}{c}\text { Special } \\
\text { Commerce }\end{array}$ & $\begin{array}{c}\text { General } \\
\text { Commerce }\end{array}$ \\
\hline \multirow[t]{2}{*}{ Matches. . } & Horned Cattle........ & $\begin{array}{l}\text { Frs. Cs. } \\
17,367.67 \\
15,360.00\end{array}$ & $\begin{array}{l}\text { Frs. Cs. } \\
21,375.79 \\
15,360.00\end{array}$ \\
\hline & Sheep............. & $2,197.20$ & $2,197.20$ \\
\hline \multirow{7}{*}{$\begin{array}{l}\text { Live Ani- } \\
\text { mals and } \\
\text { Fodder }\end{array}$} & 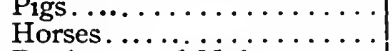 & $\begin{array}{r}48.00 \\
7,379.48\end{array}$ & $\begin{array}{r}48.00 \\
7,379.48\end{array}$ \\
\hline & Donkeys and Mules....... & $10,370.40$ & $10,370.40$ \\
\hline & $\begin{array}{l}\text { Others } \ldots \ldots \ldots \ldots \ldots \ldots \ldots \\
\text { Fodder } \ldots \ldots \ldots \ldots \ldots \ldots \ldots\end{array}$ & $\begin{array}{r}227.40 \\
1,654.08\end{array}$ & $\begin{array}{r}227.40 \\
1,654.08\end{array}$ \\
\hline & 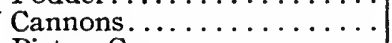 & $66,306.18$ & $66,306.18$ \\
\hline & Piston Guns $\ldots \ldots \ldots \ldots \ldots$ & $34,788.66$ & $48,541.45$ \\
\hline & $\begin{array}{l}\text { Flint Guns } \ldots . . . . . . . . . . \\
\text { Other Guns (Improved Sys- }\end{array}$ & $26,848.44$ & $74,585.18$ \\
\hline & $\begin{array}{l}\text { tems) } \ldots \ldots \ldots \ldots \ldots \\
\text { Pistols and Revolvers. . . . }\end{array}$ & $\begin{array}{l}68,2 \text { I } 5.97 \\
10,295.82\end{array}$ & $\begin{array}{l}90,044 \cdot 5^{\circ} \\
12,347.82\end{array}$ \\
\hline \multirow{10}{*}{$\begin{array}{l}\text { Arms, Am- } \\
\text { munition, } \\
\text { and belts }\end{array}$} & Charge Pieces......... & 23.516 .53 & $23,834.7$ I \\
\hline & Side Arms.......... & $1,356.26$ & $1,356.26$ \\
\hline & Cartridges............. & $292,323.80$ & $308,606.84$ \\
\hline & $\begin{array}{l}\text { Caps....................... } \\
\text { Gunpowder........... }\end{array}$ & $\begin{array}{r}8,889.14 \\
167,024.44\end{array}$ & $\begin{array}{r}16,558.34 \\
271,145.04\end{array}$ \\
\hline & Ordinary and Blasting & & \\
\hline & Explosives................ & $\begin{array}{r}2,040.01 \\
48,183.67\end{array}$ & $\begin{array}{r}2,963.4 \mathrm{I} \\
48,183.67\end{array}$ \\
\hline & 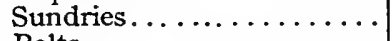 & $76,749.90$ & $79,268.93$ \\
\hline & Belts.......... & $33,720.30$ & $34,141.26$ \\
\hline & Steamers. .............. & $845,957.00$ & $845,957.00$ \\
\hline & Charge Pieces for Engines & $30,920.00$ & $5^{0,33^{2} .83}$ \\
\hline \multirow{7}{*}{$\begin{array}{c}\text { Boats, En- } \\
\text { gines, and } \\
\text { Detached } \\
\text { Pieces for } \\
\text { Boats }\end{array}$} & and Boilers $\ldots \ldots \ldots \ldots$ & 223.517 .94 & $302,308.83$ \\
\hline & Boats and Sailing Vessels.. & $66,950.00$ & $66,950.00$ \\
\hline & 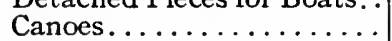 & $22,981.20$ & $\begin{array}{r}73,050.90 \\
22,981.20\end{array}$ \\
\hline & Sail-Cloth................ & $5,216.44$ & $6,553 \cdot 18$ \\
\hline & 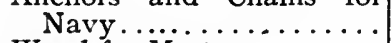 & $2,5^{8} 5 \cdot 7 \mathrm{I}$ & $2,848.27$ \\
\hline & $\begin{array}{l}\text { Wood for Masts } \\
\text { Other Rigging and Ap- }\end{array}$ & & 120.60 \\
\hline & 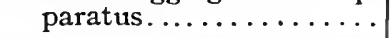 & $8,78 \mathrm{r} .9 \mathrm{I}$ & $9,3 \circ 2.88$ \\
\hline
\end{tabular}

N. B.-The Special Commerce includes goods for consumption which are declared directly they arrive, or at the time of their removal from the warehouse.

General Commerce embraces all goods which enter the territory of the State that may be declared for consumption, transit, or warehouse. 


\begin{tabular}{|c|c|c|c|}
\hline \multirow{2}{*}{\multicolumn{2}{|c|}{ Goods }} & \multicolumn{2}{|c|}{ VALUES } \\
\hline & & $\begin{array}{l}\text { Special } \\
\text { Commerce }\end{array}$ & $\begin{array}{l}\text { General } \\
\text { Commerce }\end{array}$ \\
\hline \multirow{3}{*}{$\begin{array}{l}\text { Jewelry } \\
\quad \text { and } \\
\text { Clock-work }\end{array}$} & $\begin{array}{l}\text { Gold and Silver Jewelry..... } \\
\text { Other Jewclry............ }\end{array}$ & $\begin{aligned} & \text { Frs. } C s . \\
& 183.30 \\
& 4,806.60\end{aligned}$ & $\begin{array}{r}\text { Frs. } C s . \\
183.30 \\
7,144.68\end{array}$ \\
\hline & Watches and Fittings......... & I $1,315.99$ & $11,635.07$ \\
\hline & Clocks and Alarums....... & $5,8 \div 9.75$ & $5,963.75$ \\
\hline \multicolumn{2}{|c|}{ Carved Wood and Wooden Obj } & 287, I 43,01 & $325,245.95$ \\
\hline \multirow{3}{*}{ Liquors } & 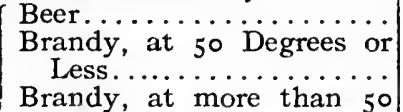 & $\begin{array}{r}203,181 \cdot 34 \\
96,725 \cdot 40\end{array}$ & $\begin{array}{r}207,279.72 \\
116,101.64\end{array}$ \\
\hline & $\begin{array}{c}\text { Degrees......................... } \\
\text { Other Brandy (including }\end{array}$ & I I $3,987.22$ & $147,452.99$ \\
\hline & Liqueurs) $\ldots \ldots \ldots \ldots \ldots$ & $85,148.69$ & I $33,834.9$ I \\
\hline \multicolumn{2}{|c|}{ 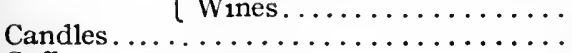 } & $890,618 \cdot 56$ & $1,053,073 \cdot 73$ \\
\hline \multirow{2}{*}{\multicolumn{2}{|c|}{ 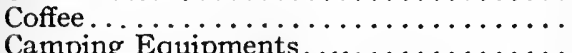 }} & $\begin{array}{l}39,473 \cdot 91 \\
16,041.49\end{array}$ & $\begin{array}{l}49,133.16 \\
24,265.51\end{array}$ \\
\hline \multirow{2}{*}{\multicolumn{2}{|c|}{ 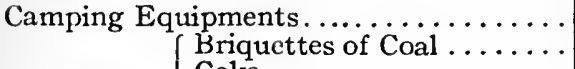 }} & $60,143 \cdot 5^{2}$ & $66,217.44$ \\
\hline & & 220,68 I.79 & $220,68 \mathrm{r} .79$ \\
\hline \multirow{2}{*}{ Fuel } & 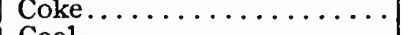 & 103.20 & 103.20 \\
\hline & Charcoal. & $\begin{array}{l}1,470.36 \\
1,574.83\end{array}$ & $\begin{array}{l}I, 470.36 \\
I, 574.83\end{array}$ \\
\hline \multirow{2}{*}{\multicolumn{2}{|c|}{ 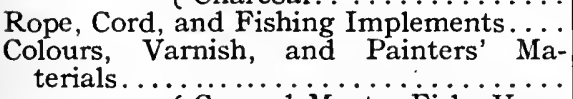 }} & $\begin{array}{r}1,574.03 \\
49,973 \cdot 37\end{array}$ & $\begin{array}{r}1,574.03 \\
54,429.73\end{array}$ \\
\hline & & $90,181.70$ & $96,694.46$ \\
\hline \multirow{7}{*}{\multicolumn{2}{|c|}{ 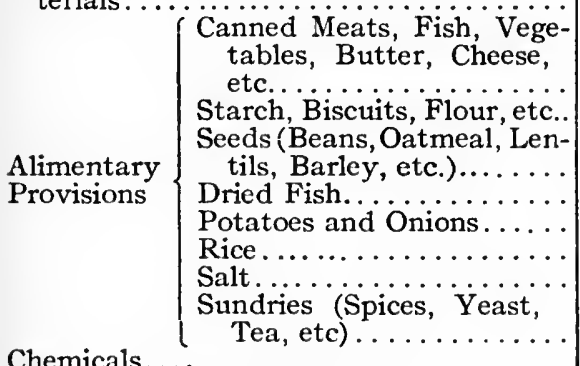 }} & $\begin{array}{r}2, \text { I I } 7,536.8 \text { I } \\
378,337.04\end{array}$ & $\begin{array}{r}2,501,029.49 \\
478,102.87\end{array}$ \\
\hline & & & \\
\hline & & $\begin{array}{r}8,696.69 \\
516,2 \text { I } 6.60\end{array}$ & $\begin{array}{r}9,331.56 \\
547,520.61\end{array}$ \\
\hline & & $67,376.77$ & 73,2 r 1.63 \\
\hline & & $412,772.93$ & $472,494 \cdot 35$ \\
\hline & & $101,206.70$ & $132,471.30$ \\
\hline & & I $75,696.59$ & $220,038.06$ \\
\hline \multirow{2}{*}{\multicolumn{2}{|c|}{ 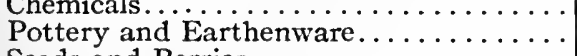 }} & $42,450.49$ & $46,085 \cdot 27$ \\
\hline & & $51,218.48$ & $58,014.07$ \\
\hline \multicolumn{2}{|c|}{$\begin{array}{l}\text { Seeds and Berries.... } \ldots \ldots \ldots \ldots \ldots \ldots \ldots \\
\text { Clothing and Lingerie } \ldots \ldots \ldots \ldots \ldots \ldots\end{array}$} & $\begin{array}{r}33,491.80 \\
\end{array}$ & $36,869.80$ \\
\hline \multicolumn{2}{|c|}{ 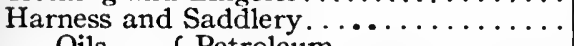 } & $35,262.87$ & $\begin{array}{r}1,284,929.00 \\
51,670.17\end{array}$ \\
\hline \multirow{3}{*}{\multicolumn{2}{|c|}{ 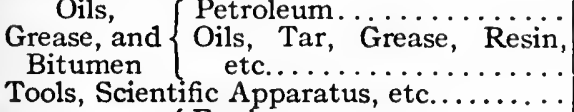 }} & $4 \mathrm{I}, 865.9 \mathrm{I}$ & $44,597.69$ \\
\hline & & $126,940.40$ & I 33.992 .10 \\
\hline & & I $26,258.93$ & $134,216.20$ \\
\hline Machines, & 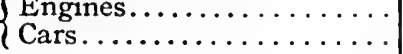 & $\begin{array}{l}29,400.00 \\
46,073.88\end{array}$ & $\begin{array}{l}29,400.00 \\
46,073.88\end{array}$ \\
\hline
\end{tabular}




\begin{tabular}{|c|c|c|c|}
\hline & & VAL & \\
\hline & GOODS & $\begin{array}{l}\text { Special } \\
\text { Commerce }\end{array}$ & $\begin{array}{l}\text { General } \\
\text { Commerce }\end{array}$ \\
\hline & & Frs. Cs. & Frs. Cs. \\
\hline $\begin{array}{l}\text { Machinery, } \\
\text { Tools, }\end{array}$ & Machines and Various Ma- & & \\
\hline Telegraph & Charge Pieces and Acces- & $244,595.21$ & $291,491.2 \mathrm{I}$ \\
\hline and & sories............. & $147,997.82$ & $150,09^{2} .90$ \\
\hline Telephone & Various Tools $\ldots \ldots \ldots \ldots$ & $300,77^{\circ} \cdot 3^{8}$ & $322,553 \cdot 56$ \\
\hline $\begin{array}{l}\text { Apparatus, } \\
\text { Metallic }\end{array}$ & $\begin{array}{l}\text { Material and Apparatus for } \\
\text { Telegraph and Telephone }\end{array}$ & $32,45+\cdot 55$ & $40,776.55$ \\
\hline Structures & $\begin{array}{l}\text { Various Metallic Structures. } \\
\text { Bricks. . . . . . . }\end{array}$ & $\begin{array}{r}337,512.43 \\
2,098.38\end{array}$ & $\begin{array}{r}40,782.43 \\
2,098.38\end{array}$ \\
\hline Building & 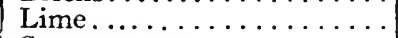 & $13,166.52$ & $14,541.84$ \\
\hline Materials & $\begin{array}{l}\text { Cement } \\
\text { Other Material..... }\end{array}$ & $\begin{array}{r}98,351.29 \\
116,396.30\end{array}$ & $\begin{array}{l}\text { I } 00,560.4 \mathrm{I} \\
\text { I } 28,908.6 \mathrm{I}\end{array}$ \\
\hline Mercery anc & Perfumery ........ & $135,047 \cdot 3 \mathrm{I}$ & $163,413.99$ \\
\hline & Steel Bars........ & 596.46 & $\begin{array}{l}1,68 \mathrm{I} .08 \\
2,202.10\end{array}$ \\
\hline & Steel Rails.... & $\begin{array}{r}209 \cdot 5^{2} \\
378,287.50\end{array}$ & $\begin{array}{r}2,292.10 \\
378,287.50\end{array}$ \\
\hline & Steel Plates....... & $4,94 \mathrm{I} .6 \mathrm{r}$ & $7,587.61$ \\
\hline & Other Steel. ............. & $\begin{array}{r}1,335.60 \\
\end{array}$ & $\begin{array}{r}1,454.40 \\
5,8506\end{array}$ \\
\hline & Other Copper and Brass... & $\begin{array}{r}479,350.07 \\
21.45^{2.05}\end{array}$ & $\begin{array}{r}522,850.00 \\
27,190.16\end{array}$ \\
\hline & Tin $\ldots \ldots \ldots \ldots \ldots \ldots$ & $1,667.14$ & $1,979.14$ \\
\hline Metals & Iron Bars.... & $885 \cdot 32$ & $1,583.24$ \\
\hline & $\begin{array}{l}\text { Pure Iron } . . . \ldots \ldots \\
\text { Iron Nails. }\end{array}$ & $\begin{array}{r}2,772.24 \\
55.678 .83\end{array}$ & $\begin{array}{r}2,772.24 \\
58,704.06\end{array}$ \\
\hline & Iron.$\ldots \ldots \ldots \ldots$ & $6,544 \cdot 36$ & 9.386 .68 \\
\hline & Iron Girders. & 602.48 & 602.48 \\
\hline & Sheet Iron... & $68,334 \cdot 43$ & $77,021.87$ \\
\hline & Other Iron & $3^{2,279 \cdot 45}$ & $49,102.97$ \\
\hline & & 348.90 & 348.90 \\
\hline & & $1,489.99$ & $2,704.75$ \\
\hline & & $6,792.88$ & $8,515.78$ \\
\hline Furniture a & Furnishings...... & $\mathrm{I} 19.458 .27$ & I $33,537.33$ \\
\hline Papers, & Account-Books and Papers. & $73,873.84$ & 76,4 I $3 \cdot 49$ \\
\hline $\begin{array}{l}\text { Cards, } \\
\text { Office }\end{array}$ & $\begin{array}{l}\text { Papers and Cards } \ldots . . . \\
\text { Office Stationery and }\end{array}$ & 28.598 .79 & $31,7+3.82$ \\
\hline Stationery & Printed Matter (Sundry). & I I $5,664.8$ I & I $39,694.47$ \\
\hline Chemical Pr & oducts $\ldots \ldots \ldots \ldots \ldots \ldots$ & $63,644.8 \mathrm{I}$ & $70,509.15$ \\
\hline Pharmaceut & cal Products...$\ldots \ldots \ldots$ & $224.577 \cdot 48$ & $248,789.45$ \\
\hline $\begin{array}{l}\text { Ironmonger } \\
\text { hold Artic } \\
\text { and Iron }\end{array}$ & $\begin{array}{l}\text { (Kitchen Utensils, House- } \\
\text { les, Sundries such as Copper } \\
\text { Bands, Mirrors, etc.)........ }\end{array}$ & $640,032.60$ & 784.070 .20 \\
\hline Soaps..... & & $91,364.23$ & $106,753.67$ \\
\hline Tobacco & Cigars and $\mathrm{C}$ & $80,874.89$ & $102,18 \mathrm{I} .7 \mathrm{I}$ \\
\hline & 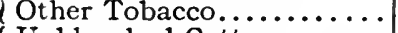 & $72,897 \cdot 57$ & $91,313.90$ \\
\hline Tissues & Unbleached Cotton. ........ & $835,792.11$ & $895,633.90$ \\
\hline & acher & $1+1,243.69$ & $180,482.79$ \\
\hline
\end{tabular}




\begin{tabular}{|c|c|c|c|}
\hline & \multirow{2}{*}{ Goods } & \multicolumn{2}{|c|}{ Values } \\
\hline & & $\begin{array}{c}\text { Special } \\
\text { Commerce }\end{array}$ & $\begin{array}{c}\text { General } \\
\text { Commerce }\end{array}$ \\
\hline Tissues & 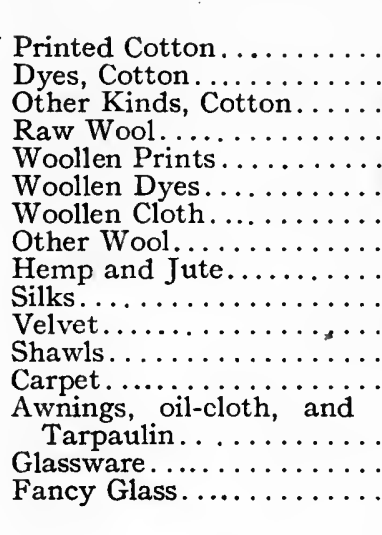 & $\begin{array}{r}\text { Frs. Cs. } \\
688,813.04 \\
3,966,602.10 \\
123,052.95 \\
\cdots . \\
446.94 \\
52,766.94 \\
1,060.20 \\
48,863.76 \\
190,920.12 \\
8,914.84 \\
6,995.52 \\
2,036.26 \\
17,685.73 \\
58,068.92 \\
50,128.43 \\
253,278.71\end{array}$ & $\begin{array}{r}\text { Frs. Cs. } \\
77^{2,302.83} \\
4,632,076.80 \\
132,819.78 \\
152.06 \\
446.94 \\
54,174.68 \\
1,060.20 \\
60,844.02 \\
223,715.70 \\
14,228.44 \\
9,300.42 \\
7,083.20 \\
22,616.82 \\
\\
60,320.68 \\
58,606.07 \\
324,955.06\end{array}$ \\
\hline $\begin{array}{l}\text { Glassware } \\
\text { and Fancy } \\
\text { Glass }\end{array}$ & Totals........ & $20,896,331.02$ & $23,933,375.02$ \\
\hline
\end{tabular}

\section{IMPORTS}

YEAR I 903

RECAPITULATORY TABLE, SHOWING COUNTRIES FROM WHICH PRODUCTS WERE IMPORTED

\begin{tabular}{|c|c|c|}
\hline COUNTRIES & $\begin{array}{c}\text { Special } \\
\text { Commerce }\end{array}$ & $\begin{array}{c}\text { General } \\
\text { Commerce }\end{array}$ \\
\hline 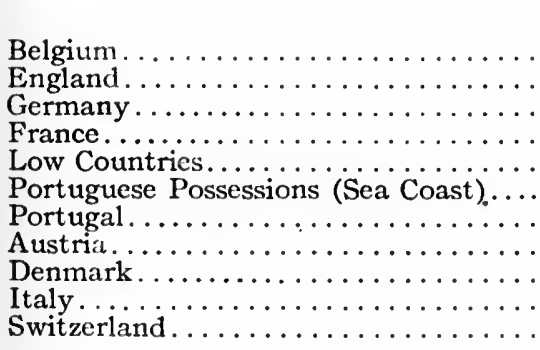 & \begin{tabular}{|r} 
Frs. Cs. \\
$15,699,535.09$ \\
$2,390,779.79$ \\
$639,098.72$ \\
$584,372.36$ \\
$491,758.23$ \\
$451,903.78$ \\
$155,500.81$ \\
$110,976.30$ \\
$85,195.04$ \\
$76,616.46$ \\
$69,763.40$
\end{tabular} & $\begin{array}{r}\text { Frs. Cs. } \\
16,524,451.18 \\
2,790,509.07 \\
781,608.72 \\
1,724,921.27 \\
975,031.13 \\
478,443.69 \\
160,004.16 \\
115,275.70 \\
85,607.06 \\
81,730.76 \\
69,857.22\end{array}$ \\
\hline
\end{tabular}




\begin{tabular}{|c|c|c|}
\hline Countries & $\begin{array}{c}\text { Special } \\
\text { Commerce }\end{array}$ & $\begin{array}{l}\text { General } \\
\text { Commerce }\end{array}$ \\
\hline 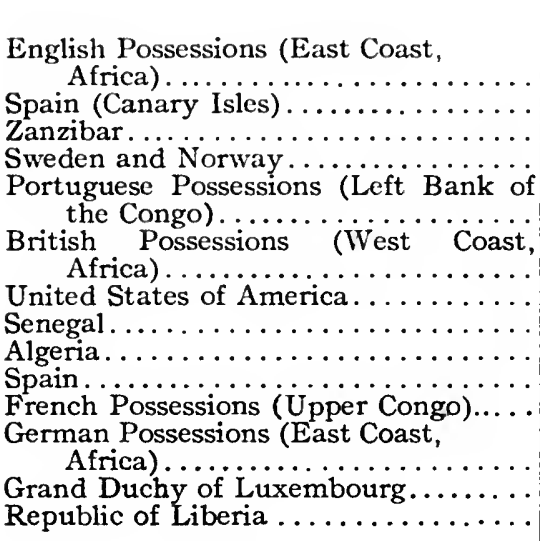 & $\begin{array}{rr}\text { Frs. } \quad C s . \\
\\
59,210.70 \\
27,645.02 \\
13,301.28 \\
11,790.87 \\
\\
8,245.69 \\
5,467.20 \\
5,274.33 \\
4,800.00 \\
2,647.20 \\
1,141.55 \\
731.28 \\
\\
434.82 \\
84.00 \\
60.00\end{array}$ & $\begin{array}{rr}\text { Frs. } \quad C s . \\
\\
5,210.079 \\
27,645.02 \\
13,301.28 \\
12,077.07 \\
\\
8,245.69 \\
\\
5,467.20 \\
9,285.88 \\
4,800.00 \\
2,971.20 \\
1,166.03 \\
1,121.28 \\
\\
434.82 \\
148.86 \\
60.00\end{array}$ \\
\hline Totals. . & $20,896,33^{1.02}$ & $23,933,375.02$ \\
\hline
\end{tabular}

COMPARISON OF IMPORTS FOR I903 WITH THOSE OF PRECEDING YEARS

\begin{tabular}{|c|c|c|}
\hline \multirow{2}{*}{ YeARS } & \multicolumn{2}{|c|}{ VALUES } \\
\hline & $\begin{array}{l}\text { Special } \\
\text { Commerce }\end{array}$ & $\begin{array}{c}\text { General } \\
\text { Commerce }\end{array}$ \\
\hline 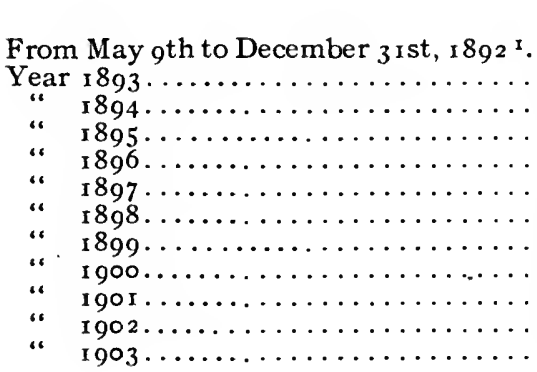 & $\begin{array}{r}\text { Frs. Cs. } \\
4,984,455.15 \\
9,175,103.34 \\
11,194,722.96 \\
10,685,847.99 \\
15,227,776.44 \\
22,181,462.49 \\
23,084,446.65 \\
22,325,846.71 \\
24,724,108.91 \\
23,102,064.07 \\
18,080,909.25 \\
20,896,331.02\end{array}$ & $\begin{array}{r}\text { Frs. Cs. } \\
5,679,195.16 \\
10,148,418.26 \\
11,854,021.72 \\
11,836,033.76 \\
16,040,370.80 \\
23,427,197.83 \\
25,185,138.66 \\
27,102,581.18 \\
31,803,213.96 \\
26,793,079.37 \\
20,699,723.98 \\
23,933,375.02\end{array}$ \\
\hline
\end{tabular}

I The collection of import duty commenced May 9, 1892 . 


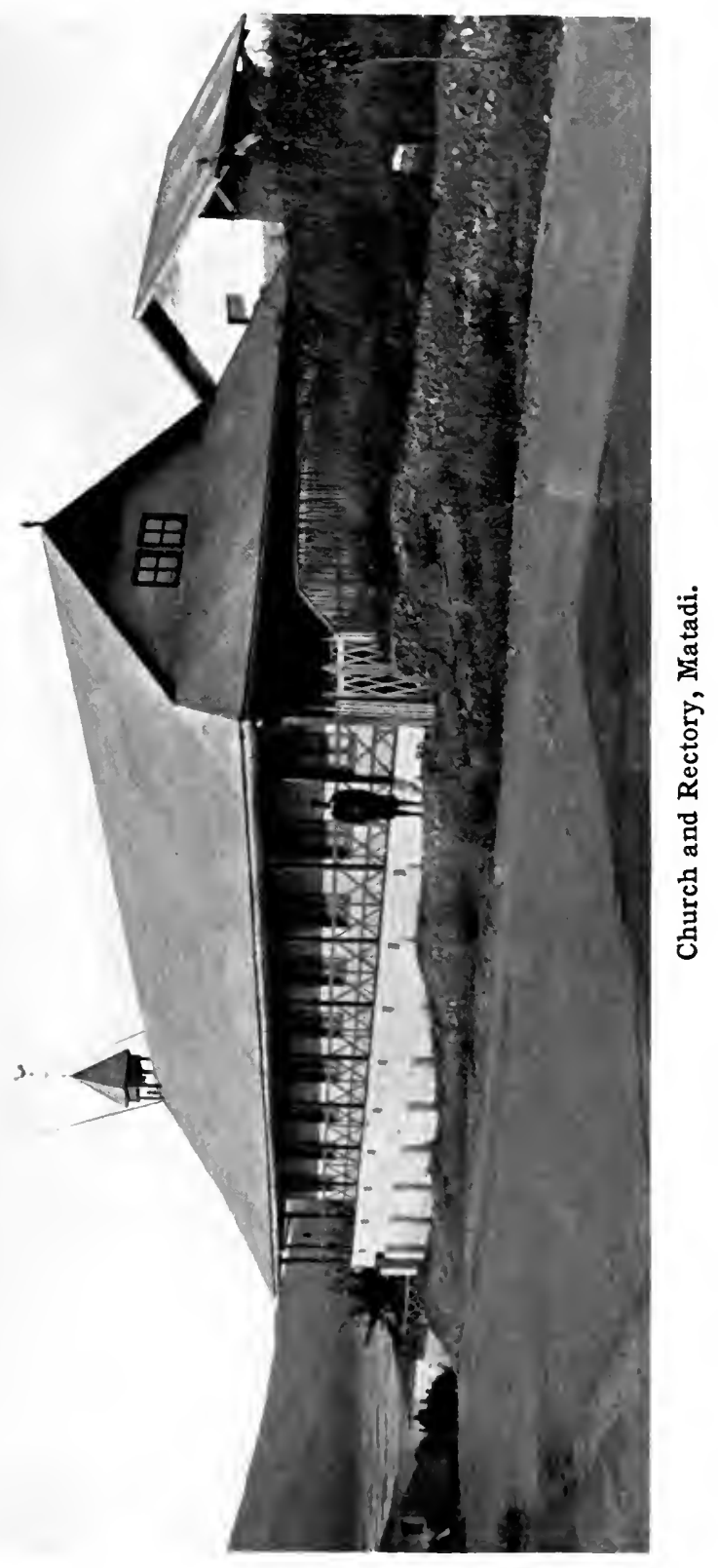



These tables show what has provided the enemies of the Congo Free State with a great deal of puerile prattle - an excess of exports over imports which is more apparent than real. One of the bitter critics who write from Liverpool repeats the charge in the press that the Sovereign of the Free State is denuding the Congo of its natural resources by exporting more than he imports. In this respect a German writer in Der Tag, Berlin, September, 26, 1904, not at all friendly to the Congo State (because it is diverting the Zanzibar trade of the Fatherland), has some pertinent things to say of the excess of exports over imports in the British colonies of South Nigeria and Lagos. Herr Eberhard von Schkopp discusses the Congolese, British, French, and German trade statistics in the following concise manner:

In I90I the Congo State importations reached twentythree million francs whilst the exports attained fifty millions, and the transit trade seven millions. This excess of exports over imports has been turned to account to support the attacks-justified besides-upon the Congo State's system of government.

If that circumstance is of a kind to weigh in the balance, it ought to be imputed as a ground of complaint against all nations carrying on a practical colonial policy, and whose possessions export more than they import. The Congo State is neither the only nor even the first colony where this excess has been exhibited.

The exports of the English colony of South Nigeria have always surpassed the imports. Here are the figures:

$\begin{array}{ccccc}1896 & 1897 & 1898 & 1899 & 1900 \\ \text { Imports. .750,000 } & 655,000 & 640,000 & 73^{2,000} & 7^{23}, 000 \text { pounds ster. } \\ \text { Exports . .844,000 } & 785,000 & 750,000 & 774,000 & 888,000 \text { pounds ster. }\end{array}$


Statistics of the trade of the English colony of Lagos:

\begin{tabular}{|c|c|c|c|c|}
\hline I 896 & I 897 & 1898 & 1899 & 1900 \\
\hline $88 \mathrm{~T}$ & $75^{8,0}$ & $89^{2,000}$ & $960, c$ & $832,000 p$ \\
\hline ports. $.975,00$ & 810,000 & 882,000 & 915,000 & 885,000 \\
\hline
\end{tabular}

Herc also, except for 1898 and 1899 , the total of exports exceeds that of imports. The case is the same with the commerce of the Gold Coast and the Gambia.

The French colonies also-Ivory Coast, Dahomey, Guinea, and French Congo-can also boast of having frequently had their exports higher than their imports.

No one has ever yet pretended to make that a grievance against the English and the French, and it must appear astonishing that the favourable trade statistics of the Congo State should lead to an attack on the system of its administration.

It would be very desirable if, following the example of the Congo State, and as we have seen of the English and French colonies, our possessions [the German] across the sea were to show exports exceeding their imports. For a commercial firm that is the best proof of success, and it cannot in any way be concluded from this fact that the "poor" blacks of Africa are being exploited by Europeans devoid of conscience.

But let us see if the Congo State exports really do exceed the imports, and if so, by what sum. The exports of the State are estimated in the tables at their value in Antwerp, after they have been harvested, prepared for transport from remote parts of the Congo Basin, stood charges of porterage, freight, export duties, taxes, insurance, brokerage at the African and European terminals, and merchant profits of an indefinite measure-in all, at least half their European value. The original value of Central African ivory, rubber, palm oil, gum copal, and other exports is, in fact, less than half their market value in Europe. In other words, if the exports of 
the Congo State were estimated at their value as they left the forests or the native collector, instead of aggregating $54,597,835.2 \mathrm{I}$ francs for the year 1903 , they would show but $27,298,917.16$ francs.

On the other hand, the imports, also estimated at their European value, but having similar distances to undergo and similar charges to bear, represent when they reach their consumers at least double their invoiced European cost. On a proper basis of value in their ultimate African market the imports for the year 1903 would amount to $42,792,662.04$ francs. Thus the exports would stand at $27,298,9$ I 7 .I 6 francs, and the imports at $42,792,662.04$ francs for the year 1903 .

But even this is not a just comparison with the exports and imports of the British colonies, inasmuch as in the colony of Lagos, for instance, the imports include about sixty-five per cent. of alcoholic liquors, ${ }^{\mathrm{x}}$ leaving the native the beneficiary of an

I The revenue of the British colony of Lagos for the last three years available was derived as follows:

$$
\begin{array}{ccc}
1898 & 1899 & \text { I } 900-1 \\
\text { Fcs. } & \text { Fcs. } & \text { Fcs. }
\end{array}
$$

Alcohol ..............3,386,450.00

Tobacco........... 273,250.00

Salt............. $40,075.00$

Cotton Goods........ 428,075.00

Other Articles........ 366,650.00

$3,288,250.00$

$266,125.00$

$43,750.00$

$382,850.00$

$661,350.00$

$3,345,850.00$

$379,150.00$

I $40,800.00$

$432,450.00$

$799,775.00$

The following is a comparison between the alcoholic liquor imported into Lagos and the Congo Free State:

\section{Lagos \\ Congo Free State}

Gin.......4463,380 gallons

Rum....... I29,780 "

Whiskey.... 8, 8, “

$\overline{601,260}$ “ Total consumption $=43,300$ gallons.

Thus for every gallon of alcohol imported into the Congo Free State 
aggregate import of really civilising products of only thirty-five per cent. of the total, while the Congo imports, containing only five per cent. of alcoholic liquors, bestows upon the native legitimate products for his civilisation to the extent of ninety-five per cent. of the total of all the imports of the State. Deducting, therefore, from the Lagos imports sixty of their sixty-five per cent. of gin, rum, and whisky, thereby placing them on an equation with the imports of the Congo, we find in Herr von Schkopp's figures an arraignment of Lagos "civilisation" which indicates where the real curse of Central Africa abides.

The foregoing is an astonishing record of exports and imports for a country practically developed in the short period which has elapsed since r 886. Congolese products are largely sent to Antwerp and, as the tables show, Belgium is by far the largest exporter and importer. A few years ago England was the chief exporter to the Congo of its cotton stuffs and other goods, but the same laggard spirit which caused Englishmen once interested in the AngloBelgian India-Rubber Company (known as the Abir) and other undertakings to abandon their Congolese enterprises has lost England a large and growing market in Central Africa. That the Belgians have developed the Mid-African trade by dint of hard work, organisation, and the risk of capital, is a state of things intolerable to those who have neglected and lost it. The awkward English monetary system is alone responsible for a large percentage of the $(\mathbf{I}, 000,000$ square miles in area,) there are imported into British Lagos $(3,460$ square miles in area), thirteen and seven-tenths gallons, or as 5 per cent. is to $68 \frac{1}{2}$ per cent. of total revenus. 
world-wide diminution of British trade. All other nations have shown greater adaptability to the characteristics of foreign markets, and the capabilities and peculiarities of the peoples who compose those markets. The Germans, French, and Americans circulate their catalogues and price lists in the language of the country where they seek a market and quote prices in its coin, giving the equivalents in francs, marks, and dollars. British merchants, on the other hand, have adhered to their ancient custom of employing a monetary system so needlessly cumbersome that it can hardly be attributed to intelligent origin.

Belgian manufacturers have patiently studied the needs of the natives and have successfully endeavoured to supply them with the textures and food stuffs, machinery, agricultural implements, and building material which, being of simple construction, they are capable of putting to intelligent use.

The mineral wealth of the country which prospecting during the last five years has revealed in many sections of the Congo Basin, it is not the purpose of this volume to more than mention. Fine outcroppings of gold, coal, and copper have been discovered in the Katanga district in the south-eastern corner of the State. It has lately been rumoured in Europe that foreign prospectors have discovered territory marvellously rich in gold near the borders of British East Africa in the south, and again in the Enclave of Lado in the north. On this subject, and the likelihood of early and interesting mineral developments in that region; the Congo State authorities 
appear to have considerable knowledge. They do not, however, discuss the matter with any degree of candour. When the secret of certain political phases of Congolese history shall have been revealed, a connexion may be found between the mining and rubber industry and the calumnious campaign now proceeding against the State. But with that story, the present volume has naught to do.

The State's revenue, consisting of import and export dues, tolls, excise, and direct personal taxation, is indicated in the following table:

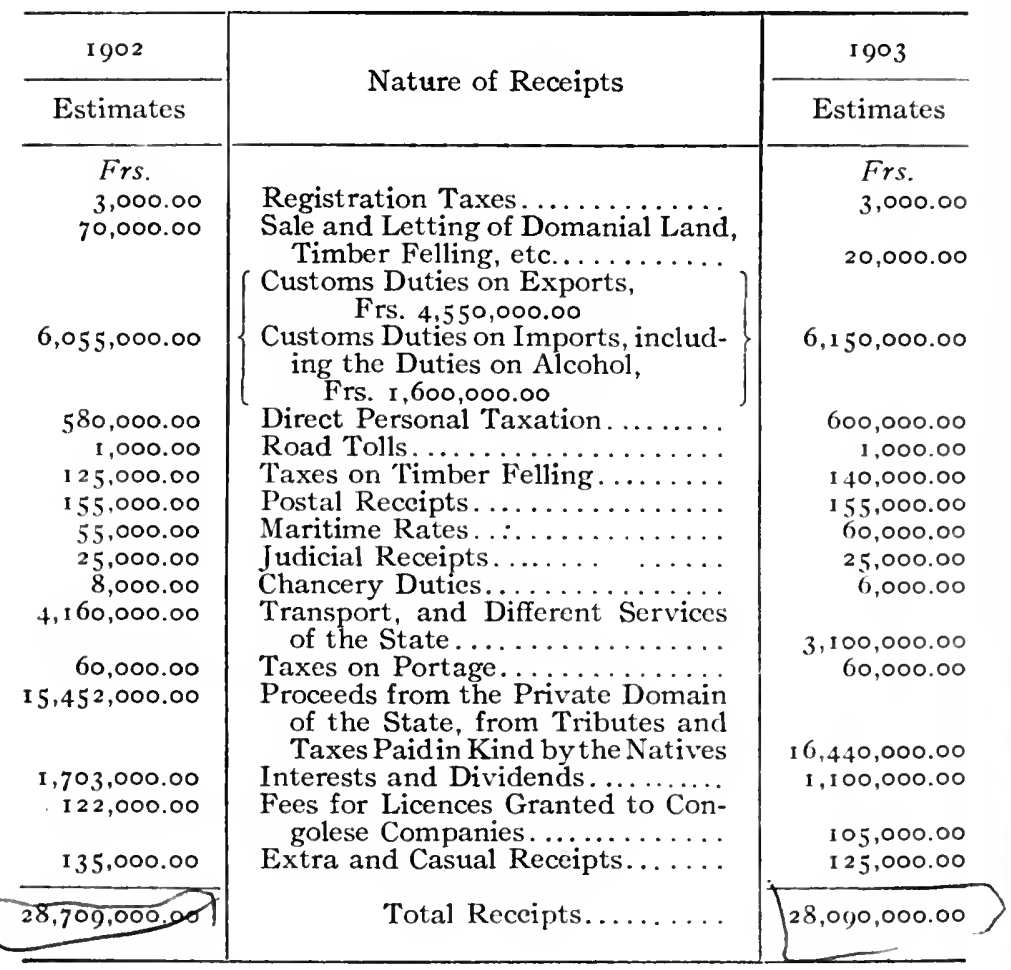


It will be observed that by far the greater proportion of the State's revenue is derived from the State lands (Domaine prive), which is fully considered in a succeeding chapter. (Direct personal taxation is a comparatively small item, being only 600,000 francs, or one forty-seventh part of the year's budget. ' Import duties, including duties on alcohol, are only I, 600,000 francs, while duties on exports amount to 4,550,000 francs. These duties were, as hereinbefore stated, fixed by arrangement with France and Portugal on April 8, 1892 , for a term of ten years, and by a protocol dated May IO, I902, extended until July 2 , I905.

The export duty collected on India-rubber and ivory under these tariff agreements between the interested Powers are as follows:

Ivory, in pieces or sticks............Frs. Io per kilo.

Tusks of less weight than 6 kilos........ " I 6 " " "

Tusks above 6 kilos. in weight......... " 2 I " “

India-rubber.................." 4 "

"Personal taxes," says Descamps, "are levied upon three bases: I, The area of inhabited buildings and enclosures; 2, the number of employés in service; 3 , the ships and boats used by tax-payers." As to the taxes en nature, levied upon the natives and already referred to in a previous chapter, the Chevalier de Cuvelier, Secretary of State of the Congo Free State, says in his official capacity in the Bulletin Officiel for June, 1903 , that "it is as legitimate as any other kind of tax. It does not impose upon the native obligations of a different nature or heavier than the system of taxation employed in neighbour- 


\section{Story of the Congo Free State}

ing colonies, such, for instance, as the British huttax. It is the native's contribution to the public charges incurred by the State in exchange for the protection given him. In the Congo State this participation in the State's support is light, seeing that it represents on an average not more than forty hours of native labour in a month." It is the payment of tax in this form that the State terms prestation, which, if literally translated, would mean enforced labour upon roads.

In 1902 a general reduction of direct taxation was decreed. At the same time the taxation of all religious, charitable, and scientific institutions and enterprises was reduced to $5 \circ$ per cent. of the rate which prevailed when the State had no revenue from import dues or from its domain lands. By a decree

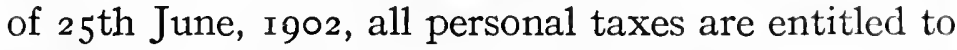
one-fifth reduction so long as the State lands (domaine), tributes, and taxes in kind, yield the sum of I 7,000, 000 francs annually. In order to develop and extend the public highways, and works increasing the facilities of commerce, religion, agriculture, etc., the native prestations and their proper distribution have formed the subject. of numerous decrees, all seeking to equitably adjust this form of taxation. One of the later decrees, that of 18 th November, 1903, provides, amongst other measures protective of the native, that "In order to fix the tax justly and equitably among the natives, the territorial chiefs must take into account the nature of the work to be done, the age and the skill of the natives subjected to the prestation, and finally the obligation of the 


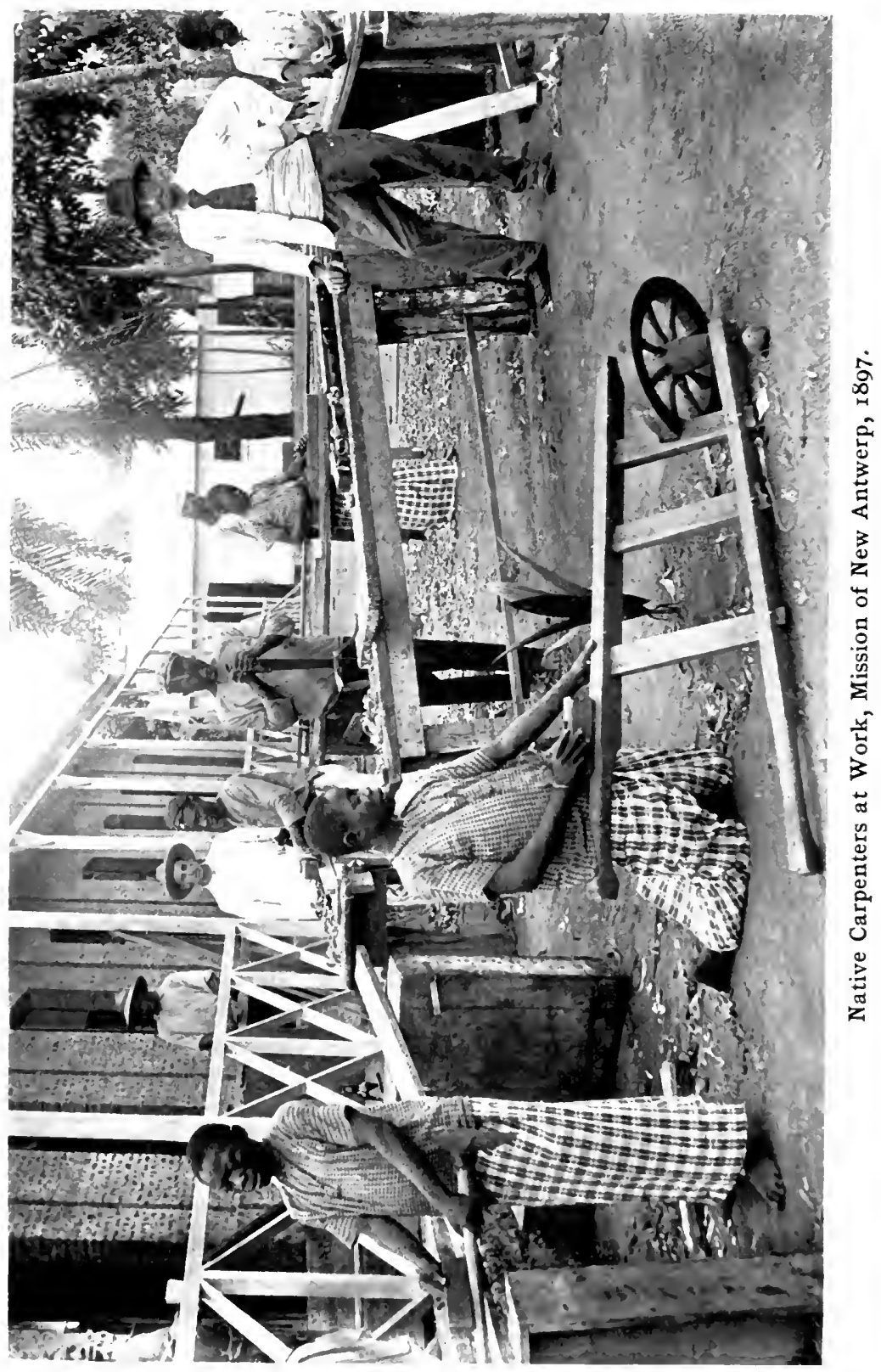



State to remunerate the natives for all work done by them."x

The items constituting the State's annual expenditure throw an interesting light on the subject of these native prestations in the Congo State. The State's enemies found their charges of slavery largely upon the fact that the State enforces this labour upon the natives instead of imposing a tax in specie. In 1903 the State paid to its European officials and employés in the Congo force publique the sum of I, 800,000 francs, whereas during the same period the wages it paid to natives in the same service amounted to $2,050,000$ francs. In developing the State lands at a cost of $6,014,790$ francs during that year, the sum of $2,802,190$ francs was paid to natives as wages. For extending agriculture and replanting India-rubber vines the sum of $1,373,93^{2}$ francs was expended in 1903. The following items, taken from the table of expenditure for the same year, may be interesting:

\section{Home Department}

The Administrative Scrvice of Europe.......... Frs. The Administrative Service of Africa........... 3,180,310.00 The Army...................... $7,701,765.00$ Naval Expenditure.................... 2,023,376.00 Sanitary Department.................... 504,120.00 Public Works........................ 1,08 1,885.00 Missions and Educational Establishments.......... I 1 1,425.00 Expenses relating to some Transports in Africa, not Drawn up in the Budget.................. $1,600,000.00$

\section{Financial Department}

The Administrative Service of Europe.......... 99,000.00 The Administrative Service of Africa............. 503,065.00 Agriculture......................... I, 373,932.00 Exploitation of the Domain..................6, 6,790.00 Savings-Bank, Interest of the Loans and Guarantecd Stock........................ ז $655_{5,228.00}$

1 Report of Vice-Governor-Gencral, July 1904. 
Foreign Office and Justice

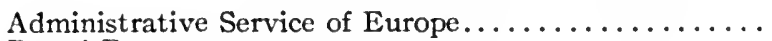

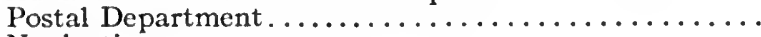

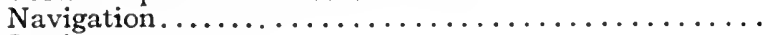

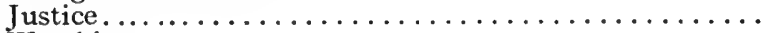

Worship

$227,100.00$

$66,000.00$

$140,200.00$

$910,000.00$

$250,000.00$

The currency of the Congo Free State consists of copper, silver, and gold coins and paper notes. The former are issued under a decree of 27 th July, I887, which established the monetary system upon the gold standard. The gold coins are of the value of twenty francs; the silver coins are the five, two, one franc, and the fifty centime piece. The copper coins are the ten, five, two, and one centime pieces.

Paper Currency. By a decree of February 7, 1896 , with the object of facilitating business transactions between the different parts of the State, banknotes of the State, payable to the bearer at the General Treasury of the Congo Free State, in Brussels, were issued. This decree sanctioned a first issue of notes to the value of 400,000 francs.

An order of the Secretary of State of February 8, 1896 , limited the value of the issued notes to a sum of $269,85^{\circ}$ francs, comprising 2,000 notes of 100 francs each, and 6,985 ten franc notes.

Formerly, in the Lower Congo, agents of the State and merchants were accustomed to give the natives, in exchange for their services, a mokande or cheque, which enabled them to purchase what they required at the factories.

It is evident that silver, copper, and paper currency of the State have a great advantage over the mokande or cheque system, these latter often being only payable at a fixed date and by certain persons. At first the circulation of money was slow and difficult. It was only with a good deal of trouble that foreign money was displaced in the Lower Congo, and in the interior there was the same difficulty in abolishing the custom of barter, and the usage of the mitakn, or brass wire. 


\section{Trade, Revenue, and Taxes}

Finally, to accelerate the introduction of State currency, the Government decreed:

I. To pay the soldiers and native workmen in cash, and also to pay in the same manner for all goods bought from the natives by the State;

2. To stop all payments in kind at the stations of the Lower Congo;

3. To substitute for the rations formerly issued by the State to the agents, an equivalent in cash, and so forth.

Immediately after the enforcing of these measures the State currency began to circulate rapidly, and merchants no longer hesitated to open retail stores, where the natives in the employment of the State and commercial companies, and other natives as well, came to exchange their money for European goods.

At the present time, in the region south of Stanley Pool, the greater part of the commercial transactions between Europeans and natives is carried on through the medium of the State currency, and in the native markets it is no longer possible to purchase anything except with the silver or copper Congolese money-the preference being given to silver. ${ }^{1}$

The native's love of tinsel causes a large quantity of the silver and copper coins put into circulation to disappear from the sphere of commerce. Congolese vanity manifests itself in many forms. Necklaces, earrings, bracelets, anklets, and other ornaments are made of the State coins, and worn by the men and women of all the tribes which come in touch with the Congo coinage. Powerful chiefs are often buried with many coins placed upon their bodies.

I Descamps. 


\section{CHAPTER XXVII}

\section{MISSIONS AND SCHOOLS}

I $\mathrm{T}$ will be remembered that clause VI. of the Berlin Act enacts that "They [the interested Powers] shall, without distinction of creed or nation, protect and favour all religions, scientific or charitable institutions, and undertakings created Berlin and organised for the above ends, or which Act on aim at instructing the natives, and bringing Missions. home to them the blessings of civilisation. Christian missionaries, scientists, and explorers, with their followers, property, and collections, shall likewise be the object of especial protection."

For this enlightened enactment the thanks of the world are due to the Count de Launay, of Italy. In proposing its inclusion in the Berlin Act, Count de Launay said: "It is to scientific men and explorers that we owe the marvellous discoveries made during these latter years in Africa. The missionaries, for their part, lend valuable assistance in winning these countries over to the civilisation which is inseparable from religion. It is our duty to encourage them, to protect them all, both present and future."

How faithfully the Congo Government has carried out clause VI. of the Berlin Act, impartially and completely administering it in the spirit in which it 
was conceived, is apparent in the number and diversity of the Christian missions at present existing in the Congo State.

Upon Protestants rests the honour of being first in the endeavour to evangelise the races inhabiting the countries of the Congo Free State. Of their numerous missions, the Baptist Mis- $\begin{gathered}\text { Protestant } \\ \text { Missions. }\end{gathered}$ sionary Society of London was first in the field, it having been established so long ago as 1877 . It has posts at Matadi, Tumba, Takussu, Bopoto, Monsembe, Bolobo, Lukolela, Kinshassa, and Gombe Lutete, and its missionaries are the Messrs. George Grenfell, Ross Phillips, J. H. Weecks, A. E. Scrivener, Kerend Smiths, Lawson Forfeit, Whitehead, Stapleton, Bentley, J. Howell, Kirkland, Frame, and Kempton.

Next, in respect of age, comes the American Baptist Missionary Union, founded in 1883 , which now includes the earlier Livingstone Inland Mission, founded in I879. It has posts at Matadi, Pallaballa, Lukungu, Kimpese, Banza, Leopoldville, and Bolengi, and is served by the Messrs. C. H. Harvey, A. M. D. Sims, W. S. Leslie, J. Clarke, and Faris.

The Congo Balolo Mission is very active. Though it has but six posts-Lulangi, Bongandanga, Bonginda, Ikau, Leopoldville, and Baringa-it has a numerous staff, including Mr. and Mrs. Morgan, Gilchrist, Whiteside, Armstrong, Ellery, Lawes, Ruskin, Gamman, Jeffrey, Harris, and Frost; the Messrs. Beale, Bond, Padfield, Rankin, Boudot, Wallbaum, Steel, McDonald, and Stannard; and the Misses Padfield, Cork, and Amory. 
Other important missions are the Christian and Missionary Alliance, the Swedish Missionary Society, the Garenganze Evangelical Mission, the Foreign Christian Missionary Society, and the Bishop Taylor Self-Supporting Mission.

Each mission owns lands, either absolutely or in tenancy, the Baptist Missionary Society Corporation heading the list with no fewer than fifteen, being followed by the American Baptist Missionary Union with fourteen, and the International Missionary Alliance with thirteen. The other missions have between one and eight locations each, their field of action being throughout the Upper, Middle, and Lower Congo.

All these missions are Protestant. Their work is done by between two and three hundred white missionaries, to say nothing of native evangelists, and they dispose of a considerable revenue, subscribed, for the most part, by the Protestants of Great Britain and the United States.

Of the five large missionary steamers in the Congo State, four are owned by Protestants. The Peace Mission and the Goodwill belong to the English Mission
Steamers. Baptist Mission, the Henri Reed to the American Baptist Mission, and the Pioneer to the English Balololand Mission. Roman Catholics own only one mission steamer, Our Lady of Perpetual Help. ${ }^{x}$

As might be expected from its history, the prevailing faith in Congoland is the Roman Catholic.

In the French Congo there is only one small launch devoted to missionary work. 
The Congo Free State tolerates all religions, no one of them enjoying a privilege denied to the others. Unfortunately the Protestants are split up into several sects; but there is no division among the Roman Catholics, and this fact

Roman Catholic Missions. has resulted largely in favour of the growth of the latter.

The White Fathers began their mission in Congoland in 1878 , a year later than the first Protestant mission. They were followed by the Scheut Fathers in I888; the Trappists, I892; the Jesuits, I893; the Priests of the Sacred Heart, I897; the Prémontré Fathers, I898; and the Redemptionists, 1899 . There are also the missionaries of the Ghent Sisters of Charity, the Sisters of Notre Dame, the Trappistines, the Franciscans, and the Sisters of the Sacred Heart of Mary.

The wide-reaching results of the earnest labours of these self-denying evangelists is apparent in the existence to-day of 59 permanent and 29 temporary posts; 384 missionaries and sisters; 528 farm chapels; I 3 churches and chapels; 523 oratories; 3 schools of the second degree; 75 primary schools; 440 elementary schools (in which native teachers instruct in the elements of reading, writing, and arithmetic); 7 hospitals, 7 I Christian villages, and 72,383 Christians and catechumens.

From statistics such as these, pregnant as they are with proof of the onward march of civilisation, it is a relief to turn to records in words. Here are two extracts from a diary kept by the Rev. Father Grison, missionary in charge of St. Gabriel's, Stanley 
Falls. The diary from which they are taken was written in odd moments snatched from an exceptionally busy life in a far-off land, with no idea that any line of it would ever be given to the world.

Aug. 16, 1902. Yesterday we had 17 baptisms and I administered Holy Communion to more than 300 people.

Holy WeEk. If it had not been for the colour of the congregation kneeling before the Blessed Sacrament, you could not have believed you were in Central Africa. The church was filled with flowers, and a large number of people kept coming during the whole time.

We did not know exactly how things were going on at Banalya, but we did hear that our Christians were prosperous and had won over several catechumens. As soon as we came within a distance of about one and a half hours from the place, a number of the village people came out to meet us, laughing, singing, and kneeling in the mud of the marshes for our benediction. They told us that some little catechists, who could hardly read themselves, had managed to teach a number of the others to pray every morning and every evening, and then to teach them some catechism, so when we came over we found that a large number of the people had already been converted. We immediately landed i 50 catechumens at Banalya, 80 at Yambuga, and nearly 200 at Basoko, where a young woman, baptised the year before,-although she is unable to read,-superintends morning and evening prayer for the whole village.

The following, from the diary of the Rev. Father Wulfers, written at Yanonghi (Romee Mission), June 22, 1902, accurately portrays the hopes and fears, the triumphs and disappointments, which attend the life of a missionary in Central Africa. 


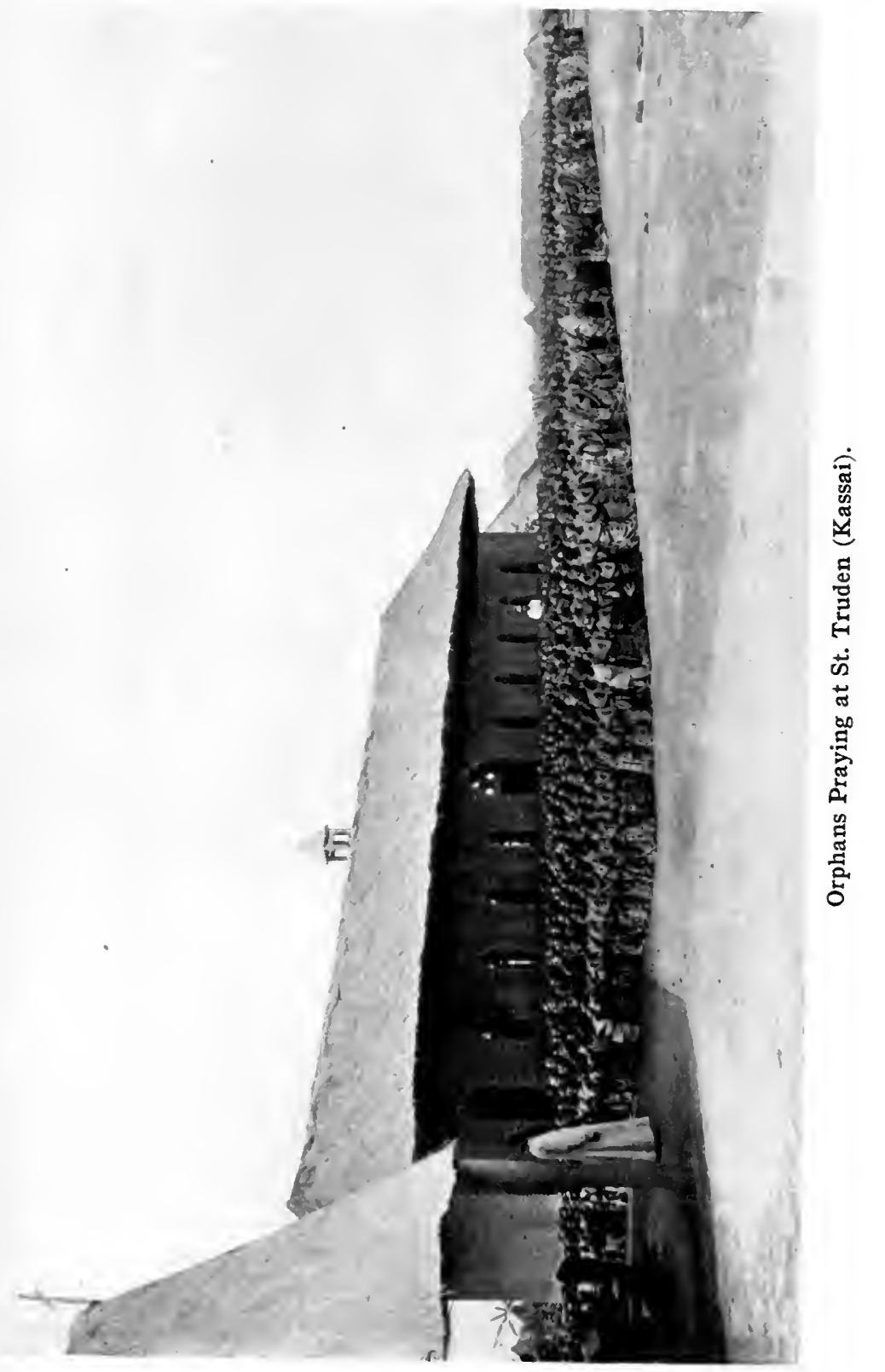



Our Station is flourishing. We have a fine spring of rock water near the house, and a beautiful vista across the river, about two miles wide. The coffee groves begin near the house, affording shaded walks for hours. Within a short distance, we find the Arab settlements; and, somewhat further away from the river, immense rice fields. Fruits and agricultural products abound. It is from here that rice is supplied for a number of stations and missions, all the way down to the Falls and Leopoldville. The missionary of Romee supplies our other posts with large quantities of rice, besides the seeds furnished by the State Agricultural Station, and a number of articles which we get from the Arabs in exchange for cotton cloth. Of course everything has to be bought; they will give nothing for nothing. The railroad-Romee-Ponthierville-will start from here. The survey is progressing. That branch will help to avoid the rapids on the river on both sides of Bertha Island and the Lakes, which frequently interfere with navigation. Our situation, therefore, is pretty good from the material point of view; but, of course, we have some troubles. The Arabs are not peaceful, and the State contemplates the establishment of a military post here to protect the whites against them and the Turumbus, who are fierce cannibals. When Monseigneur van Ronsle was here last year, he wanted to establish a mission at Romee, because the State maintains there a force of about 600 men to protect the new rubber plantation. At present there are here about $\mathrm{r} 20$ catechumens and 20 Christians. I baptised ten of them last March and three in May. They come to Mass every Sunday, sometimes arriving Saturday evening to sleep here. I expect to have a great many more Christians when the work on the railroad begins. Although the Turumbus are still very savage, I hope to do a good deal with them, for they have already helped me to build my house. Yesterday I gave them some presents. One got a pipe; another a looking-glass; another some cotton cloth, with some rice for their children. They went away very happy, saying the Father is a good man. The people of the neighbouring villages sometimes come to me saying they want to stay a year and then be baptised. I 


\section{Story of the Congo Free State}

promise them when the chapel is built that I will visit them, teach them to read and write, and then get them to teach the catechism to others. They seemed very happy. As regards the Arabs, I am afraid they will not come to the catechism so soon. They sometimes listen to it out of curiosity. They appear to understand it, and acknowledge that it is true; but a virtuous life seems hard to them, and they have no inclination to it. Their Chief often inquires about the beginning of the world, the origin of the white settlements in Africa, the story of Christ, etc. He works with me, comes to see my pictures, and asks for explanations. Some of the Arabs want to learn French. I shall teach them some in order to gain their confidence. When the chapel is finished I will see what I can do to Christianise the Arabs, who are about 200,000 strong.

I have had a disheartening experience at Yafolo, where I found the community, which had inspired me with so much hope, had gone over to the Dilwa worship. This is a form of public worship of the Dilwa. It lasts for two or three months. During that time all the young men, from seven to twenty years of age, devote themselves to the Dilwa. Of course I denounced the falsity of that superstition. I went into the middle of the crowd with a revolver in my pocket, because I did not know what they might do. They were sorry that I came, because they thought I was going to drop dead as a punishment for my temerity. They told me if I touched any of the Dilwa men my arm would wither and fall off. I touched some of them, and of course nothing happened; but they kept on, and during the three months of the Dilwa work I could not do anything for them. I went again a month ago and learned that about two-thirds of the catechumens were willing to return to Christianity, but their parents would not let them come, believing all those who have gone through the Dilwa to be sacred people and to have no further need of God. Some old people told me that when the Dilwa is over they will all come back. I wonder if they will!

The same missionary records yet another of his experiences, which throws a vivid light upon the 
horrid subject of cannibalism. It is dated February 7, 1903 .

While the Rev. P. Kohl was staying with me, a young chief named Kalonda visited us. He told us that he had said to his warriors: "Come, let us visit our Father. He is such a good man that he is sure to give us something!" Speaking to the Rev. Kohl, he added, "He certainly is a very good man. $\mathrm{He}$ visits our village and tells us beautiful things about God. You will see that he loves us, because he certainly is going to give us something." In the meantime he was slapping his stomach, to show what he expected. We could not help laughing, but he took no offence. Turning to his warriors, he began again: "Children, here is the Good Father of whom I have so often spoken to you." There I stopped him, saying: "That will do, Kalonda. Look here, now. If you answer my questions well, I shall give you a present."

"To be sure, Father, I am going to tell the truth."

"Are you a great chief?"

"Yes, Father."

"And you formerly used to go to war very often?"

"Now listen, Father! I used to have a great many more men than I have now. They were vigorous, and understood war. I went through all the villages with them as far as Lindi."

"Then you have killed many people?"

"To be sure."

"You have carried away and eaten quite a number of women and children? Of course," said I, immediately, in order to prevent an explosion of wrath on his part, "you do not do so any more?"

"No," said he, very deliberately, "I do not do so at all now; but formerly we ate a number of men. We used to kill as many as we wanted at the time and take away the rest to fatten. The flesh of the women and children is the best."

"How does it taste?" I asked of the young boy who was standing near the chief [his father].

He answered quite naturally: "It tastes like boiled rice." 
It is out of material such as Kalonda that Christian missionaries and just laws carefully administered are evolving a peaceful, pastoral people. That so large a part of this prodigious task should have been achieved during the brief period that the Congo State has existed places its triumphant completion in the near future beyond all doubt. The patience, skill, and energy of the men who in circumstances so difficult have achieved so much, if not appreciated at their true worth now, will assuredly be regarded by posterity as one of the brightest pages in the history of our time.

There are no harder workers in the world than the Catholic missionaries of the Congo. The following passage from the diary kept by the Rev. Father Grison, missionary in charge of St. Gabriel's, Stanley Falls, by no means depicts an exceptional experience:

Oct. 19, r902.-It is Sunday, 9.30 P.M. I have been busy in the church since 6 A.M. Said Mass at 7 , and preached. Had a little coffee and wanted to retire to my room for a brief rest, when from 60 to 80 people called. They had come from Vincent yesterday in order to hear Mass to-day. They complained that they had not brought enough supplies and they wanted me to give them some rice; which, of course, I did. Then an important palaver turned up at Adela, and I was called upon to act as interpreter between the natives and the State. Then I had to patch up the quarrels of three or four married couples who had fallen out. Next, I had to grant about sixty permits to work on account of its being Sunday; and, finally, I found a little time to do my Breviary. My brother missionaries are in the same fix. The Rev. Father Kohl, who has charge of the Sisters' Convent, gave them a lecture, and then had to busy himself with the choir boys to whom he teaches the ceremonies. About noon I received a 
visit from two gentlemen from Stanley Falls, who are on their way towards the Great Lakes surveying for the railroad. Towards one o'clock the blacks warned us that the boat was coming on, and we knew that in about an hour we should have news from home. The steamer arrived, bringing some stores, which we hurriedly landed, deferring until to-morrow to put them in their proper places in the storerooms. After that we said the Rosary and gave Benediction. Then came the Catechism lesson and a Marriage; then a sick call, Breviary again, and then supper. Such is our Sunday, supposed to be a day of rest!

The Rev. Father Grison is typical of Catholic missionaries in Congoland. Other missionaries there are, of the Protestant faith, equally sincere and ardent; but it is an unfortunate fact that among the latter have been included certain quasi-political agents who believe that they find advantage in depreciating the Government under which they voluntarily elect to live. Others, again, for the purpose of increasing the zeal of the congregations of the churches in their fatherland to provide for them sufficient support, have permitted themselves to excite the sympathies of the home associations by exaggerated tales of oppression and cruelty. Acquisitiveness is not an unknown quality among missionaries. Mr. Stokes, the so-called martyr, who suffered for supplying arms in time of war to the enemies of the Congo Free State, was originally a Protestant missionary, but he abandoned that vocation to become a trader. 


\section{CHAPTER XXVIII}

\section{STATE LANDS AND CONCESSIONS}

$\Gamma^{\mathrm{T}}$

$T$ would seem reasonable that practical colonial government should begin the pursuit of its objects by a policy so flexible that it might readily conform to the altering conditions upon which it operates. The exceptional nature of the The State's task imposed upon the Government of the Congo Free State, its varied and numerous difficulties, and the uncertainty of the radical principles imposed upon it, left its administrators no choice of colonial precedent to follow, no governmental model to adopt. It stood alone, in a unique enterprise not devoid of new hazards, pitfalls, and strange terrors. It had been regarded at first as an adventure, then as a serious experiment. A civil community was to be created of savage hordes; to maintain itself by its own people led on to civilisation by a few Europeans with a courage and zeal the equatorial sun should not subdue. The vast field it occupied and the untamed characteristics of its large population, the early philanthropic aims of its royal patron, and a general desire to carry out the principles enunciated at the Berlin Conference, all contributed to invest the Congo State Government with a special character, and to saddle it with original duties supposedly beyond its powers to per- 


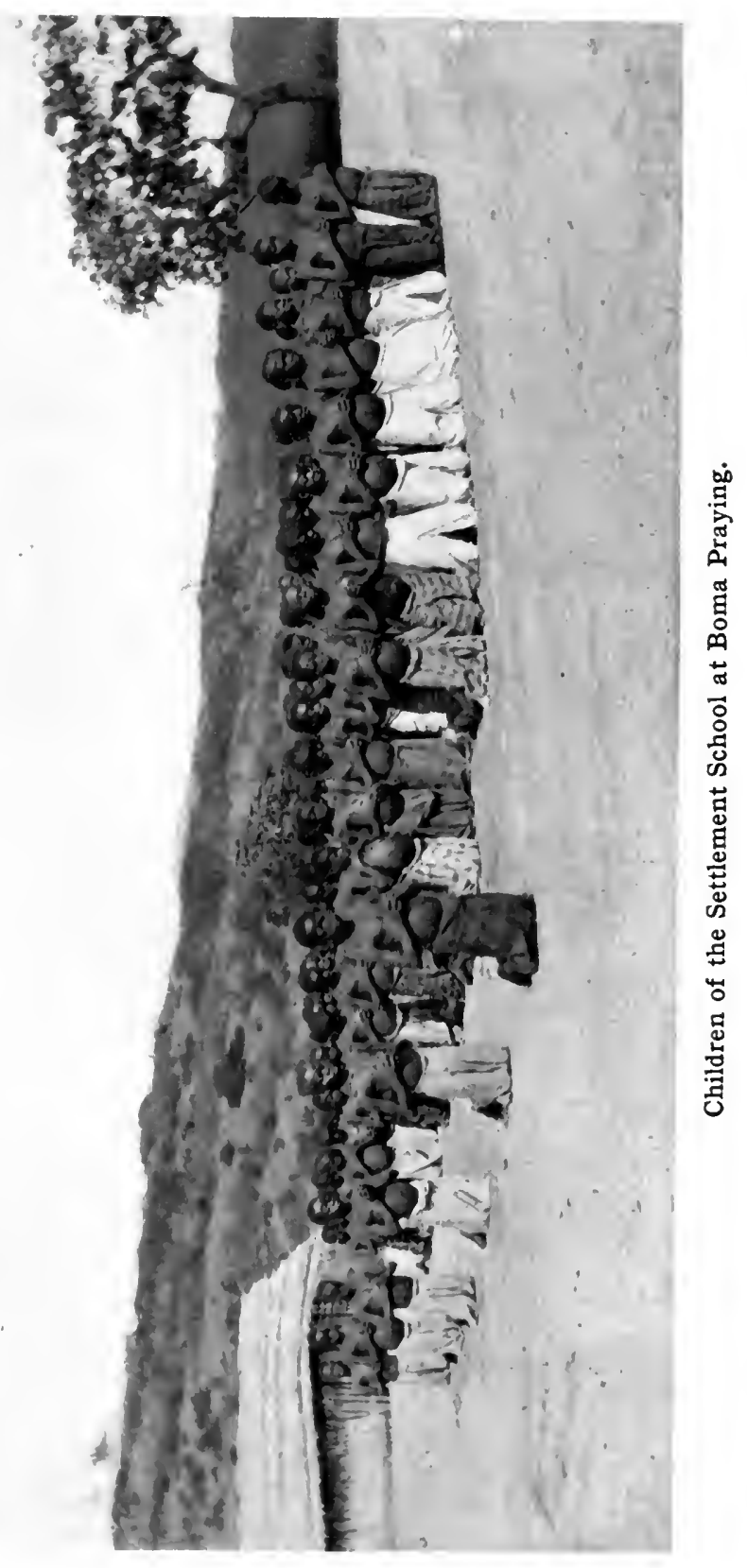



form. Thus, in the midst of an unexplored and barbarous land, with everything before it unknown, with all behind it seemingly unsuited for employment here, ways and means and a state system of government had to be adopted not only for internal regulation and development, but also to maintain the integrity of its relations with the rival Powers which surrounded it. The natural problems of the sovereignty of an unknown land and savage people were difficult enough; but when these had been intensified and their practical solution hindered by the fine theories and high ideals of the Berlin Conference, there appeared reason for the belief that a West African Don Quixote had been charged to assault a windmill. Colonial traditions appeared to the men on the spot to be inapplicable to the Congo. There was no tax-burdened home government to rely upon for support. Nor were the African forests or the palaces and mansions of Europe crowded with philanthropists desirous of dedicating their fortunes to the welfare of the Bantu race in the distant Congo. In popular parlance, the King and his Congo were left to subsist on fine sentiments and a jug of water. If in these circumstances a colonial policy of self-support was adopted and carried out with an economic skill which in its results excites foreign envy and covetousness to-day, it should not be attributed to wrong motive, but to that of stern necessity. Concerning this formative. period of early Congolese policy the recent exposition of Baron Descamps may be aptly quoted:

The problem had to be solved without bringing into conflict 
certain elements which are difficult to assimilate, namely, the exigencies of commercial freedom as recognised by the conventions, the civilisation of the natives and their material and moral improvement, the exigencies of the life and progress of the State itself considered as the organic principle of the new political society, and finally the exigencies or rather conditions relating to the personal union of the Free State with Belgium.

In the accomplishment of this complex task, the State was first inspired with the principle of a scrupulous respect for international engagements. This principle was never lost sight of, even at the critical periods of its life following on the Berlin Conference, when a régime of complete exemption from import duties weighed heavily upon its economic existence.

The State was also filled with the determination to faithfully respect the declaration of permanent neutrality which it made a short time after the Berlin Conference. As we have remarked elsewhere, this was an honourable action towards the Powers who were thus reassured concerning the policy and pacific autonomy of the new State. It was also an act of prudence which protected the Congo State from the solicitations of other States interested in influencing its political life. ${ }^{\mathrm{I}}$

The policy of the new State was to be "fruitful activity" in peace and order as soon as the Arab wars had ceased and the slave trade had The State's been superseded by an agricultural and
Policy. industrial régime. With a neutralised State this seemed to be a permanent function commendable alike to its people, its Government, and its international associates and sponsors. Whether we regard the moral concomitant of an era of fruitful activity or only the material essentials of a community so employed, the bald reality called for men

${ }^{\mathbf{R}}$ Report to the Belgian Senate, July $25, \mathrm{r} 893$. 


\section{State Lands and Concessions}

and money for its accomplishment. Of white men there were few in a region where a tropical sun, and other climatic disadvantages, counted heavily against their labour. The Negro alone appeared to thrive in conditions more suited to his physical characteristics. The problem of creating a State of the Negro population involved social and material questions of vast import to those who had undertaken to develop and govern this unknown and savage land. Should the Negro be taught the nobility of labour-informed of the glorious edifices to civilisation it had reared and what benefits its pursuit would shower upon him if he would but follow the white man's precept and example in the sphere of honest toil?

The trade in black men had been suppressed by the courageous white men of Belgium. Trade in the material resources of the country was now but a phenomenon of the law of self-preservation and the principle of self-support. It is in the adoption of practical measures to develop that trade for the greatest good of the greatest number that the Belgians have shown an executive skill which gives the character of indolent farce to the droning administration of certain other African colonies, particularly British Lagos, which derives sixty-five per cent. of its supporting revenue from traffic in alcoholic liquor, ${ }^{x}$ as compared with five per cent. derived from the same source by the Congo Free State.

If the Government of the Congo Free State had to deal with a white population capable of co-operation

I For statistics supporting this statement, see page 287 . 
as independent political units in the State's development, it may easily be conceived that measures perhaps more in consonance with certain European theories might have been devised. The candour of this suggestion in no wise detracts from the fitness and happy efficacy of the measures by which the Government of the Congo State has achieved one of the greatest colonising successes of modern times.

It is the co-operative principle-so utterly lacking in the uncivilised native Congolese-which often inspires those governmental speculations in new countries whereby it is sought to solve the problem of sustaining the State upon its own undeveloped resources. There can be little doubt that this principle, now well recognised in the industrial world and constantly adopted and expanded in the United States and Great Britain by enlightened labour leaders and great corporations, unconsciously influenced the Belgian statesmen who framed the land and taxation laws of the Congo Free State. The civilisation of Central Africa was, and forsooth, still is, an immense task, and the State's early attitude of welcoming quasi private enterprise to co-operate with it in the development of lands which indolent native races had ravaged-first for their own immediate wants, later at the behest of adventurers and despoiling traders, whose coin was alcohol and shoddy tinsel-was not only justified in a Government seeking rational progress, but it followed the soundest principles of what the higher socialism terms community of interest. If more modern in theory, the Congo State has in practice often fol- 
lowed the most experienced of old-world colonisers - the Dutch and the British. Where practicable under like conditions "it imitates these experienced colonisers, without, however, following them blindly" or attaining at once what it has taken them several generations to accomplish. "Neither does it persist in methods which have been recognised as erroneous, but it alters and corrects them where possible." Being like all governments, old or new, in savage lands or civilised, unable to reform its domestic policies at command, it seeks the betterment of its system with that gradation of movement which shall not disorganise and disrupt the structure of its statehood. Those who avowedly speak for the Congo Free State say that "its policy is essentially a work of methodical experiment and practical adaptation. Even when colonial science is more advanced than it is to-day, that policy will retain its raison d'être and its merits."

Having considered those early causes which evolved a State land policy largely founded on the principles of co-operation and self-support, it is pertinent, at this point, to examine the theory of the State land system which has met with the criticism of commercial interests in Great Britain.

The origin of the land system of the Congo Free State may be said to have assumed legal form by the official order of Sir Francis de Winton, The State's who, it will be recalled, was appointed Governor-General of the State when Henry

Land M. Stanley returned to Europe. The order is dated Vivi, July I, I885. 


\section{Story of the Congo Free State}

A Decree of the Sovereign will presently request all nonnatives who now possess, by any right whatever, land situated within the territory of the Congo Free State, to make an official declaration, describing the land in question, and submitting their titles to be examined and approved by the Government. The object of the said Decree will be to secure, in the prescribed form, the acknowledgment of acquired rights, and to make the regular organisation of land property in the said State possible in the near future.

In the meantime, with a view to avoiding disputes and abuses, the Governor-General, duly authorised by the Sovereign, orders as follows:

ARTiCle I. Dating from the publication of the present proclamation, no contract or agreement with the natives for the occupation of portions of the land will be acknowledged or protected by the Government, unless the said contract or agreement has been made in the presence of a public official, commissioned by the Governor-General, and according to the rules laid down by him in each particular case.

Article 2. No one has right to occupy without title any vacant land, nor to dispossess the natives from their land; all vacant land must be considered as belonging to the State.

This order provided for the official recognition of title to land appropriated by foreigners before July State Pro- I, I885; land occupied up to the same date tects Lands by natives, and land which, having been of Natives. neither occupied by natives nor appropriated by foreigners, was declared to be the property of the State. Particular emphasis was given to the clause protecting the native in his occupation of land whereon his industry had created improvement, where he lived in the peaceful pursuits common to his tribe.

As the appropriation by the State of vacant lands 


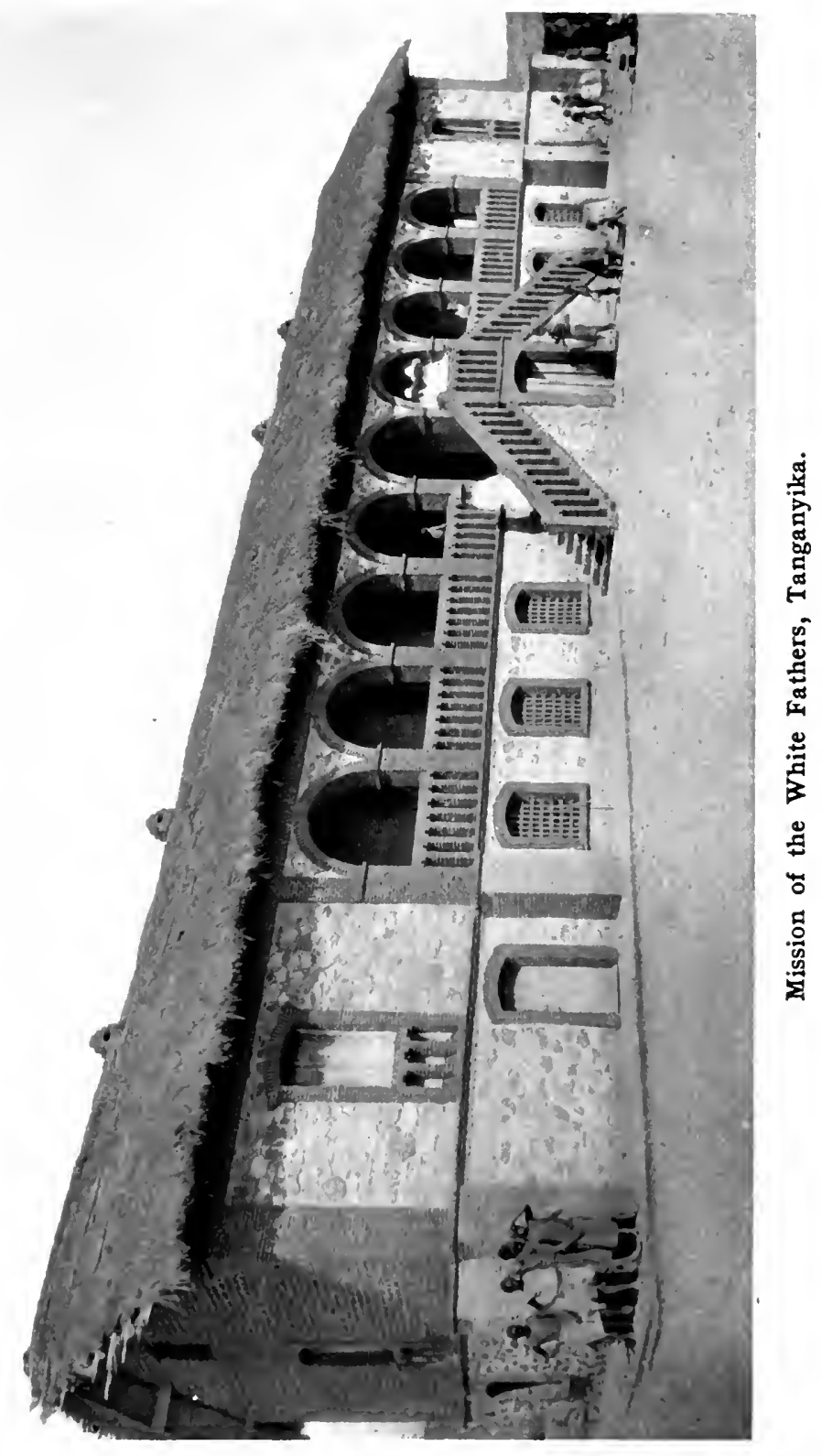



in the Congo has inspired many of the specious arguments which have lately emanated from England alone and more particularly from the claque of the Congo Reform Association in Liverpool, it may be opportune to consider first what the Belgians have said in justification of a course which every student of political history knows has been followed by all civilised States

In his essay, New Africa, Baron Descamps briefly analyses the theory of the State's unquestionable property in all vacant lands within its territory:

Territory is that part of the globe over which a State exercises its sovereign rights; it is the material basis of sovereign influence.

The mere fact of the acquisition of a political sovereignty over a certain territory does not in itself confer on the Sovereign-at least according to modern law-the ownership of all property over which private individuals have acquired rights. But the recognition of these same rights, the fixing of just titles of acquisition, the regulation of the legal system relating to property and especially of the condition of vacant land, all that constitutes an essential attribute of sovereignty, in conformity with the necessities of public order and the general welfare of society.

As a sovereign and independent State, the Congo State has been, and continues to be, invested with that prerogative.

In appropriating vacant and ownerless land, the State has made lawful use of an indisputable and perfectly legal right, sanctioned by international custom and acknowledged by the law of nations.

When regularly in possession of vacant land, is it expedient for the State to appropriate certain portions for public uses; to transfer other portions gratuitously or for a consideration, with full rights of ownership or with the right of using them only, to private individuals; to preserve other parts for 


\section{Story of the Congo Free State}

revenue purposes, by means either of direct administration or of tenure, with a view to employing the revenue according to the needs or convenience of the State? That is a question of internal administration which may be discussed theoretically, as we have already observed, but which must be left, in practice, to the sovereign decision of the State.

Before the Congo State was founded, a few European traders and missionaries in the Lower Early Congo were occupying certain undefined European lands under agreements-more or less preSettlers. carious in term and effect-with native chiefs. These occupations partook largely of the temporary nature of the native occupations on the banks of the river. As these occupations ceased and the land was abandoned, it reverted to the State, precisely as it reverts, under certain conditions, in other States and colonies throughout the world.

That the Congo State dealt equitably with foreigners who had seriously squatted upon lands in the basin, is plainly indicated in its next decree, dated 22 August, I885:

Considering that it is necessary to take steps to recognise the rights of non-natives who acquired property situated in the Congo Free State before the publication of the present Decree:

On proposal of Our Council of General Administrators,

We have decreed and do decree as follows:

Article I. Non-natives who have rights to substantiate on land situated in the Congo Free State, may have them registered by presenting a request for registration in the form prescribed by the following regulations:

This request must be presented in duplicate, before April 
I, I886, to the public officer, who will have to record the deeds of land.

Our Governor-General has the power to authorise the admission, after this date, of demands for registration, which for some exceptional reason could not be presented within the prescribed time.

ARTICLE 8. The manner in which requests for registration will be controlled shall be settled by Our Governor-General.

When a non-native shall have duly proved his rights over a portion of land, the Recorder of Deeds shall give him a registration certificate which shall constitute a legal title of occupation until such time as the land system has been definitely settled in the Congo Free State.

Under this decree, practically every land claim presented was admitted by the Government. Further decrees provided for the compulsory measurement of land held by private owners; the Torrens Act system of transferring the title to land was adopted; rules of survey and its certification were prescribed; deeds were registered at the office of a Registrar, and generally the complete and practical machinery of an efficient Land Department was established for the benefit of natives and foreigners alike. As the State progressed in its organisation it defined its earlier improvisations with greater precision, provided laws in regulation of native "occupations," private lands and the lands of the State. Its respect for the equities in property of those who had hazarded life in that wild region extended also to a scrupulous care for the native whose lands it guarded from invasion and trespass. By decree dated September 14, I886, the State provided that 
"Lands occupied by native populations under the authority of their chiefs shall continue to be governed by local customs and uses," thus insuring aboriginal tranquillity in the presence of a scheme of civilisation which the administrators of the State wisely refrained from imposing with disturbing rigour. The savage black man at first instinctively shrinks from the civilised white, and the Belgians, with knowledge of this almost universal timidity of the African races, offered him a mild measure of civilising rule as distinguished from the bluff and peremptory subjugation which has always characterised the decimating colonial methods of its burly neighbour in the Uganda and Soudan countries. By the same decree the Government of the Congo State provided that:

All acts or agreements which might tend to expel the natives from the territories occupied by them or to deprive them directly or indirectly of their freedom or means of subsistence, are forbidden.

Where natives occupy, or have moved upon, lands which it is sought to lease from the State, provision has been made by the decree of April 9, I893, that:

When native villages are enclosed in the land acquired or let, the natives may, as long as the official measurements have not been made, carry on agricultural pursuits without the consent of landlord or tenant, on the vacant lands surrounding their villages.

All disputes which may arise in the matter between the natives and the grantee or tenant, shall be finally settled by the Governor-General or his delegate.

A decree of February 2, I 898, appointed a Land Commission charged to consider whether certain 
lands, as to which claims may have been made, "shall be reserved either on grounds of public utility or with a view of promoting their cultivation by the natives." Reference has already been made to the bounty paid by the State to natives who cultivate coffee and cocoa plants. Even in the mining laws of the Congo the State has continued its solicitude for the native and decreed that he shall not be disturbed in the pursuit of those rude industries which tend to elevate his moral nature and provide him with means of self-support. By a decree dated June 8,1888 , the native is exempted from the prohibition, under a previous decree (July I, I885), of working a mine without a concession from the State. Under this exemption natives are expressly authorized to "continue to work mines for their own account on lands occupied by them." Indeed in all cases where local tribal customs do not directly conflict with civilising tendencies, the rule of the State has been to observe them in all their integrity. To facilitate this policy in its intercourse with natives, the State has dealt with the aboriginal population largely through the chiefs of the native tribes. This means of linking the black man to the State which is striving to civilise him by the gradual substitution of the white man's methods for those of the savage, has been attended with much success and inspired confidence where instinctive distrust might have long prevailed. Amongst the local customs which are safeguarded by the State are what are known as contumes de rations, a form of royalty to which the natives are entitled on the produce of certain land. 
So far has the State concerned itself in perpetuating this form of support to the tribes where the custom prevails that, by an order of the Governor-General dated November 8, I886, it has provided that:

The issue of registration certificates does not exempt the interested parties from observing, in their dealings with the natives, existing local customs, especially those relative to royalties known as coutumes de rations, although these royalties may not be mentioned in the certificates, among the encumbrances affecting the property.

If, in consequence of the non-payment of the rations or contumes, usual in such cases, disputes occur between the landed proprietor and the natives, the certificate of registration may be cancelled by the Courts on the application of the curator of land titles.

From the foregoing and many similar decrees intended to secure the property and other rights of the natives, it will be observed that the administrators of the State consistently undertook to carry out all that was implied in King Leopold's early declaration of his aims in Central Africa. If in the execution of the Congo State laws there has sometimes been laxity, error, and perhaps individual cases of perversion, the fact remains that the law is sound and the land system in respect of native possessions an equitable scheme devised in the interest of their general welfare and protection. The administration of the Congo Free State should be judged with due regard to the nature of its savage population, its unexplored territory of a million square miles, its early lack of organised governmental forces, the necessary newness and the rudeness of its civil in- 


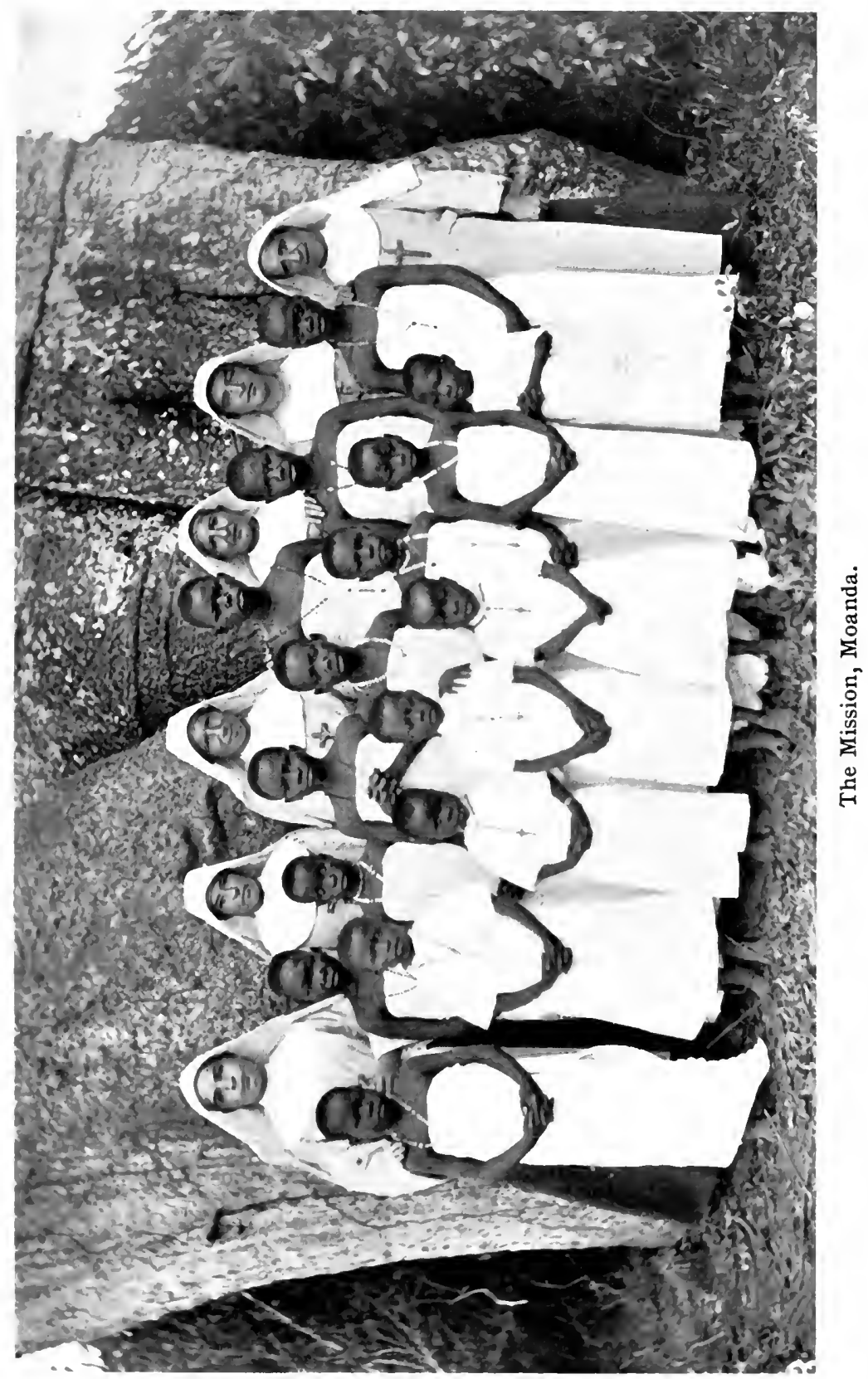



stitutions, and the thousand and one uncatalogued difficulties which must have beset such ambitious pioneers as that little band of Belgians which dared venture into an abyss from the safe walls of which Europe smiled derisively and shouted orders to the men below.

Having provided laws securing to natives the lands occupied by them, and regulated the land titles of foreigners, the State declared as its own State Claims all unoccupied lands not subject to the Vacant ownership of the native or the foreigner.

Lands.

This governmental possession of unoccupied territory is not only sanctioned by the most enlightened laws of the age, it is the express duty of a State to bring under its care all territory which, if abandoned, might become the object of dispute, internecine strife, and sanguinary warfare. The very element of, and respect for, ownership of lands, chattels, or other objects of material value, preserves that order which all law seeks to enforce, for which civil society is organised on foundations of equity and justice. Was it not the very principle which actuated the Berlin Conference when, in order to remove the Congo Free State from the covetous rivalry of the Powers-their disputes and possible wars-it recognised the occupants of the Congo Basin and neutralised the Congo State? If, during the twenty years that have elapsed since the Berlin Conference settled the matter, the Congo Free State had remained in the position of territory open to the preemption, adverse possession, invasion, and trespass of anybody, the savage European war of words, of 
diplomatic missiles, or perhaps of actual arms, would have been a deadly substitute for the native savagery of the African black. Civilisation without property vested in the State or its citizens is inconceivable.

The categories into which the lands within the borders of the Congo Free State naturally fall have various already been briefly indicated in a previous Tenures chapter. The land system includes, first, of Land. a reservation of land exclusively for the use of the public. Second, lands sold upon an official scale of prices through a Land Department composed of five members. Third, concessions of land granted for a certain term of years, or as freehold, to companies organised to develop its productivity. Fourth, grants of use extended to those who, by arrangement with the State, thereby obtain the right to work a prescribed area for india-rubber. Certain zones of rubber-bearing territory are not subject to grants of use, the State reserving therein the exclusive right to work the forests, thereby following the system in force in the Soudan and in other neighbouring colonies. Finally, there are leases of three, six, or nine years, of land for commercial purposes, and leases for twenty to fifty years of lands for agricultural uses and the establishment of missions, schools, and churches. The latter possess areas aggregating about six thousand acres.

The principal concessionary companies, operate over approximately one-fourth of the State. The lands conceded to such companies are transmitted 
under contracts very similar to those employed in the Soudan, and provide for the improvement of the land by the erection of buildings, planting rubber vines, coffee, cocoa, breeding cattle, and collecting rubber in a manner which will not deplete the growing stock. The Congo State law imposes upon the rubber companies the duty of planting at least five hundred feet of rubber vines or trees for every ton of rubber harvested. The forests are safeguarded in respect of wood and other products, and special inspectors see to the rigorous enforcement of the law. There appears to be a different state of things in the rubber-bearing districts of British Lagos, where reckless destruction of the vines, waste, inattention, and lack of intelligent organisation have reduced the rubber yield in 1900 to one-tenth its harvest in I 896, with the decline still continuing. The same measure of rapid decline is going on in the Gold Coast and Sierra Leone. "The decrease in the export of rubber from $£ 347,72 \mathrm{I}$ in $\mathrm{I} 896$ to $£ \mathrm{I} 60,3 \mathrm{I} 5$ in 1899 is clearly due to the reckless and unskilful manner in which rubber was collected " 2

This report is corroborated by the statistics of the British Gold Coast, which in 1899 exported rubber to the value of $£ 555,731$, but in 1902 to the value of only $£ 88,602$; Lagos, $1896, £ 347,72 \mathrm{r}$, in $190 \mathrm{I}$, $£ 14,749$; Sierra Leone, 1895 , £86,940, in r9o2, $£ 8,192$. Indeed, the table from which these quotations are made shows that the rubber exports from

Sale of Government Land in the Anglo-Egyptian Soudan, Times (London), July i 8, r 904.

2Annual Colonial Report, Lagos, 1899. 
eight British colonies have greatly decreased since I 898, despite the increased European value of that product. It would seem that the care and skill which during these same years caused the Congo exports to rise from less than a million francs in 1886 to over fifty-four millions in 1903 were at least worth the emulation of the Gold Coast, Lagos, and Sierra Leone muddlers hiding defeat behind the humanitarian pretexts of Liverpool rubber merchants and their agents, whose conscience is as flexible as their trade product.

Concerning the concessionary scheme which prevails in the French Congo, and which the Congo Free State Government has so successfully carried out in its own territory, M. Eugène Etienne, a distinguished French scholar, Vice-President of the French Chamber of Deputies, and leader of the French colonial group, has said and written some pertinent things. The French Congo, lying on the coast west of the Free State, has been also assailed by the few interested British merchants and their religious and secular agents and reform associations for having been forbidden to trespass upon and despoil Central African territory which has so far escaped the acquisitive proclivities of John Bull. M. Etienne's dissertation contains the following passages as applicable to the Free State as to the French Congo:

I stop in the enumeration of the results obtained by the Independent State of the Congo, and I will not put in the opposite column the balance sheet which gives little enough to rejoice over of the progress realised in the neighbouring 
French colony. Certainly from the point of view of the exploration of the country, and the management of the natives, our officials have obtained what might be French and called, in a formula borrowed from mechanics, Belgian the maximum of result with the minimum of Systems expense.

Compared.

The constitution of landed property in the Congo, regulated by the decree of 28 th March, 1899 , and the attribution of vacant lands by important lots to companies bound by a cahier des charges, form a work carefully thought out and elaborated on the advice of eminent jurists. It does honour to the Minister of the Colonies who took the initiative in the matter, my eminent colleague in the Chamber of Deputies, M. Guillain, as well as to the Councillor of State, M. Cotelle, who gave his active collaboration as President of the Commission of Concessions.

The justification of the large concessions is to substitute a regular and methodical exploitation of the products of the soil for the system of trading which destroys the natural riches, leaving behind it only the exhausted and mutilated bush. Is it a question of the Concessions Justified. collection of caoutchouc [rubber], - the native cuts the lianas, bleeds the producing shrub to complete exhaustion. Is it a question of ivory, - the precious product disappears rapidly with the increase of the price, and the easier destruction of the elephants by means of arms of precision. Left to himself the native destroys, and does not concern himself to ask the earth to restore what he has taken from it. At the most he scratches a little of the soil round the villages he inhabits in order to carry out thereon some cultivation of food stuffs. Thus has it already been recorded in our Congo colony that the caoutchouc lianas have nearly disappeared from the coast, and from the banks of the rivers. It would be the same in the end in the regions further removed from the sea, if wise regulations did not put a stop to it.

Quite different would be the value of the soil if new plantations replaced those exhausted by successive harvests, and added new products to those which come without cultivation. 
Coffee trees and cocoa trees succeed admirably on the Congo. The soil lends itself to all tropical cultivations. As to the collection of caoutchouc, which will long remain one of the principal resources of the country, it demands management and care. It is for this motive that, according to one of the clauses of the calier des charges annexed to the decrees of concession, the concessionaire companies are bound "to plant and to maintain to the termination of the concession, by replacing those which shall have disappeared, at least 500 feet of caoutchouc plants per ton of caoutchouc produced."

The contract signed between the State as the proprietor of vacant lands and the concessionaire is the following: The concessionaire is authorised to establish himself on the lands assigned to him, he exercises there for a period of 30 years all rights of possession and exploitation (under reservation of lands allotted to the natives, and of rights of proprietorship previously acquired by third parties); but this lease of 30 years is to be changed into definite proprietorship for all lands which shall have been improved. How is it to be decided whether the lands may be considered as improved? The cahier des charges answers this question with precision. Shall be considered as improved:

I. Lands occupied over at least one-tenth of their surface by buildings;

2. Lands planted over at least one-twentieth of their surface with rich cultivation such as cocoa, coffee, caoutchouc, vanilla, indigo, tobacco, etc.;

3. Lands cultivated over at least one-tenth of their surface with food cultivation such as rice, millet, manioc, etc.;

4. The pasturage on which shall be maintained during at least five years beasts for breeding and fattening at the rate of two heads of large beasts or four heads of small beasts per ro hectares ';

5. The parts of forests of a superficies of at least roo hectares of a single tenancy in which caoutchouc shall have been regularly collected for at least five years at the rate of at least 20 feet of trees or lianas as the average per hectare. . . .

${ }^{x}$ Approximately twenty-four and one-half acres. 


\section{State Lands and Concessions}

In exchange for these advantages the concessionaire assumes charges which are not defined with less rigour: Fixed annual rents to be paid to the colony, share of the profits, $x 5$ per cent. of the company's receipts going to the local budget, obligation to float on the watercourses traversing the concession steamboats of a fixed model, all without prejudice to the payment of a security.

The British merchants ${ }^{\text {I }}$ complained of being deprived of the rights which they had exercised during many years of sending their contractors to collect the caoutchouc on the lands conceded to the new companies, a dispossession for which they demanded reparation. The Court, after having ascertained that the English firms did not claim any permanent establishment on the domain conceded, non-suited them, objecting with reason that the State as proprietor of free lands in the Congo had the right to dispose of them, and that the long tolerance which the merchants had enjoyed for the collection of the products of the soil could not constitute an acquired right in their favour. Beaten in the French courts, the Liverpool firms lodged an appeal before a tribunal where they were certain of being heard. They set in movement the English Chambers of Commerce, interested the press and public opinion in their cause, and made the British Foreign Office intervene.

I have always admired the ardour and solicitude with which British diplomacy takes part and cause for the grievances of British subjects abroad. The British citizen, as formerly the Roman, is assured of being protected and defended. I know citizens of other countries who cannot always say as much. The complaints of the Liverpool merchants furnished in their way a fine platform for diplomacy. The Congo with the guarantees stipulated by the Berlin Conference, should it not be the chosen land, the last refuge of commercial freedom? To the complaints of merchants established in the French

Two Liverpool firms, Messrs. Hatton \& Cookson and John Holt \& Co., have alone figured in the cases brought before the Courts of Libreville. 
colony were added those of the English merchants and consuls resident in the Belgian Congo. It was the placing on trial of the Independent State in its entirety-of its commercial policy, of its native policy, which formed the subject of inquiry in the press and before the British Parliament. . . .

Now in no country of the world has freedom of commerce been considered as interfering with the rights of property. The proprietor of the soil alone has the right to dispose of the products of the land which belongs to him. Do people in England think that freedom of commerce is violated because the first passer-by of a rich and extensive manorial domain cannot take the fruits and vegetables, kill the bucks and the hinds, and lay the axe to the trees? Why should it be otherwise on the Congo? The whole question is, whether the State, which in the French Congo (as in the Independent State) has proclaimed itself the proprietor of vacant and unowned lands, has this right legitimately. If it has, it can in one form or another alienate the lands belonging to it. That this exercise of the law of property may inconvenience those who formerly enjoyed the products of the soil, I do not deny. There are countries where hunting is not forbidden, and the game belongs to the killer. A day arrives when the proprietor reserves his rights. He forbids hunting, he institutes suits. It is very disagreeable for those who used to traverse his land freely. But it does not follow that they have the right to an indemnity. Still that is the strange suit that England wishes to bring before the European Areopagus. The Congo has protected its hunting grounds; the poachers exclaim against the injustice and claim damages! $\mathrm{s}$

Has the State been right in considering itself the legitimate proprietor of vacant and unowned lands in the Congo? If any doubt existed on the subject, the luminous British opinion given to our concessionaires by Maitre in Canada. Henri Barboux should suffice to remove it. After having recalled that in all countries, at all periods, the exercise of the right of sovereignty implied the appro-

Italics by the author. 


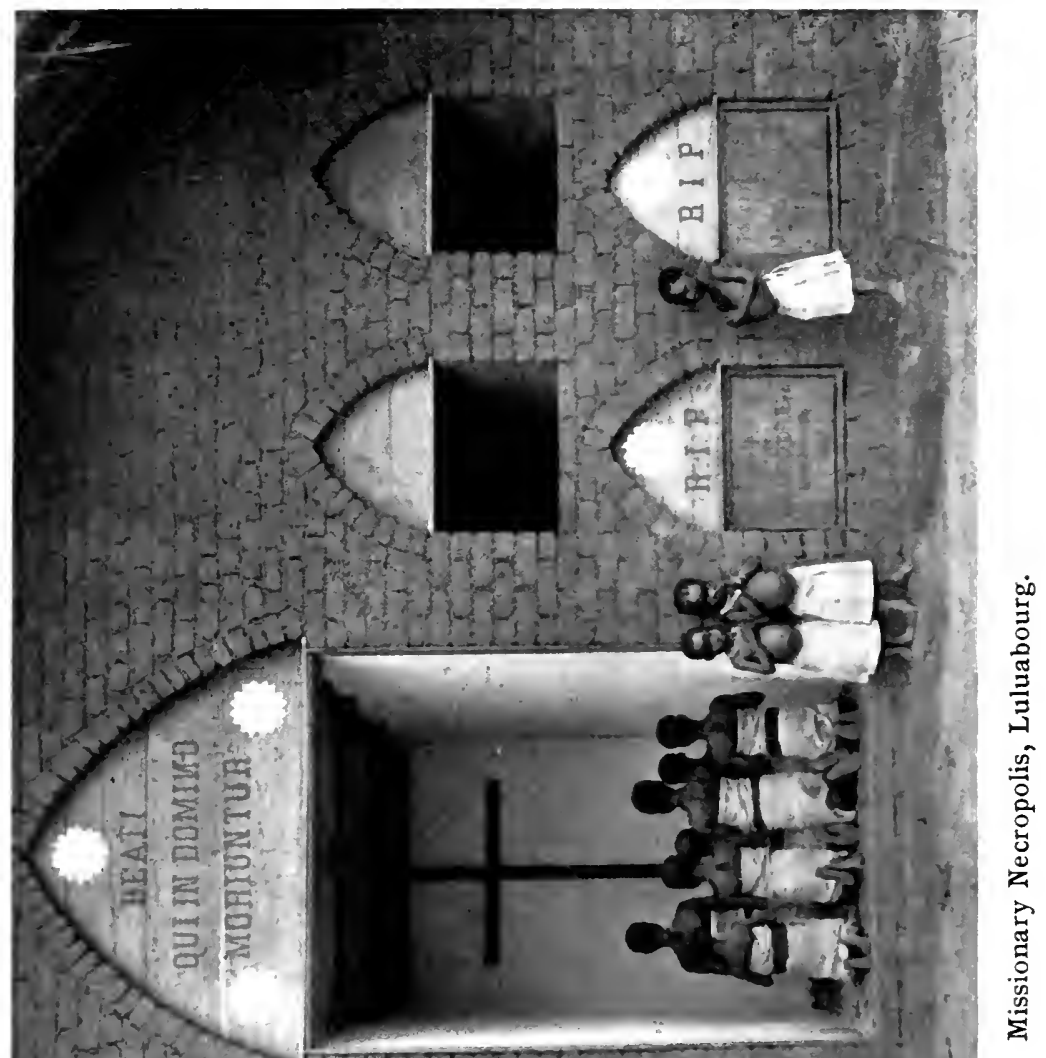





\section{State Lands and Concessions}

priation for the profit of the State of conquered lands, the eminent advocate shows how England has made use of that prerogative; in Lower Canada where a single Governor granted I,425,000 acres to sixty persons; in Upper Canada where in 1825 out of $17,000,000$ measured acres, an extent almost equal to Ireland, I 5,000,000 had been given in concession; in Australia where the distribution of lands to colonists in gratuitous concessions or by sale was never considered "as in contempt of the rights of the primitive inhabitants of the country, nor as contrary to the largest principles of commercial freedom." In India, Ceylon, at Hong-Kong, in Africa (Cape Colony, Natal, Bechuanaland), in the Fiji Islands, Great Britain has always admitted that "the whole country falls to the Crown, and that the Crown can attribute to individuals portions of the country, while reserving as its own domain all which is not given in concession" (Creasy, The Imperial and

Crown

Lands in

British Colonial Constitutions of the Britannic Empire, p. 66). Holland applies the same rules. In Germany the Imperial ordinance of 26 th November, I895, ordains in these terms: "Under reserve of the rights of property or other real rights that individuals or juridical persons, native chiefs or communities, can invoke, as well as of the rights of occupation of third persons resulting from contracts passed with the Imperial Government, all the land of German East Africa is vacant land of the Croum. The proprietorship of it belongs to the Empire."

These very same principles have been applied by the European nations which have shared amongst themselves the Conventional Basin of the Congo. The reservation of the rights acquired by third persons, the reservation of the rights of natives are stipulated for in our contracts of concession with a precision which leaves nothing to be desired. "The society having the concession cannot exercise the rights of enjoyment and exploitation which are accorded to it except outside villages occupied by natives, and the lands reserved to them for purposes of cultivation, pasturage, or as forest. The perimeters of these lands if it is a question of natives 
with a fixed residence, or the successive perimeters to be occupied or reserved if it is one of natives with a changeable residence, shall be fixed by the decisions of the Governor of the Colony, who shall equally determine the lands over which the natives shall preserve the rights of hunting and fishing. The lands and rights thus reserved shall not be ceded by the natives either to the concessionaire or to third parties except with the authority of the Governor of the Colony." (Art. ro of the decree of $28 \mathrm{th}$ March, 1879 , on concessions.) These stipulations are the most liberal that could be carried out in a country where native proprietorship is not regularly constituted, where the land surrounding the villages is alone cultivated, where the villages are shifted about with extreme ease, what was field or plantation one year returning to the state of the bush in the following. As to lands really occupied by Europeans, they have always been left outside the new concessions. What it has not been thought proper to respect is the pretension which some traders have put forward of being masters of what they never possessed, of trading in what did not belong to them.

Up to the present I have spoken only of the concessions given on French territory. The Independent State has employed the same system. In a part of its territory it even inaugurated it. All that may be said to defend our administration from having violated on the Congo the principle of commercial liberty is, then, applicable to the Belgian concessions.

The Private Domain (Domaine Privé) of the Congo Free State embraces approximately one-fourth of the unoccupied lands within its borders. Grievances This is the feature of the State's general
of Traders. Thi scheme of physical development which excites its enemies to make many foolhardy assaults and become voluble with fallacy and hollow argument. It was created by a decree dated December 
5, I892. All the net revenue derived from the Private Domain is placed in the State's treasury and applied to the payment of the cost of its public improvements and all its undertakings seeking to improve the condition of the native population, the facilities for their civilisation and the elevation of their moral nature.

The revenue from the Private Domain is derived from the State's direct exploitation of its lands. Rubber and ivory are its chief products at the present time. Various kinds of wood abound in its forests, and cocoa and coffee plantations, experimental farms, live-stock ranches, agricultural areas, all are being developed under the direct supervision of State agents.

The question which is periodically enlivened concerning this governmental scheme for acquiring necessary revenue is: Can the State, in occupation of its own lands in the Congo Basin, develop the land by direct cultivation, or en regie (by trustees), for the benefit of the State budget, which, in its integrity, is devoted to increase the power of the State to civilise and elevate its native people? There can be no doubt about the State's right to develop territory which for lack of private initiative and capital would produce nothing for the benefit of the society for which the State has been created. This right has been recognised not only by the Powers at the Berlin Conference in reference to Central Africa, but, in varying aspects, by all civilised countries in reference to other parts of the globe. Belgian, French, English, Russian, Swiss, and Italian jurists have 
considered this question at great length. The opinions of Messrs. Van Berchem, Van Maldeghem, de Paepe, John Westlake, K.C., Sir Horace Davey, K.C., de Martens, Barboux, Nys, Pierantoni, and Azcarate, besides the weight of opinion expressed by United States authorities which have been consulted, all concede the State's right to develop its territory for the benefit of a treasury devoted to the welfare of its people. Moreover, this scheme of self-development is not peculiar to the Free State. France, Germany, Great Britain, and Portugal declared unoccupied land to be the property of the State. The establishment of that principle at once implies the adoption of that other by which the State may improve its own property and turn it from a wilderness into a productive garden. In addition to innumerable earlier decrees by the Governments surrounding the Congo Free State, many of which are set out in the Bulletin Officiel of the Independent State of the Congo for June, I903, new ordinances, amplifying and extending the early decrees, have been recently (September 20 and October 23, 1904) put into operation. Their inclusion herein would unduly extend the text of this volume. A brief indication of their provisions will be found in the Appendix under the title: Features of the Land System in the African Colonies of Germany, Great Britain, France, and Portugal. ${ }^{\mathrm{x}}$

From the Neue Hamburgische Börsen Halle, 20 October, 1904, we quote the following comment upon the German decree of the same date, inasmuch as it 
reveals what, in general, is the European opinion of the British criticism of the Congo State land system:

The decree brings under the designation of forest products the products from all woodlands, whether fenced in or not, and even from isolated plantations, from bush and underbrush, bamboo and elm trees, and from all liquaceous plants, especially the lumber, the bark, the sap, the rubber, the leaves, the flowers, and the fruit. In such part of the territories as have, after effective occupation, been declared forest reservations by a public notice of the government, it is strictly forbidden to gather any kind of forest products, for such harvesting is made an exclusive right of the Treasury.

That decree is interesting in many ways. First, it shows that the German Colonial Office has decided to systematically protect the forest domain of the Colony in order to prevent indiscriminate deforestation, which would rapidly bring disaster upon the country. But it also reminds one of the violent onslaught made by some English people, and especially by the Liverpool rubber dealers, against the Congo Free State.

What England unceasingly argues against the Belgian Congo-for the humanitarian movement is only a pretextnamely, the exploitation by the Government of such parts of the territory as are not private property of individuals, is actually made a rule by the [German] decree just referred to. A previous decree of the Government has still more closely indicated what parts of the territory are assigned to the Treasury as forest reservations. Added to the other Treasury lands of various description they cover more than nine-tenths of the Colony.

The conclusion is that in German East Africa, as well as in the Congo Free State, the rubber harvest, in which the Liverpool merchants take such lively interest, is gathered from crown-lands only, and practically constitutes a State monopoly.

Now, a large part of German East Africa comes under the provisions of the Berlin Act. And, in order to show the 
extent to which British hypocrisy will go, it is enough to recall that for years, both in British East Africa and in Uganda, which also partly come under the scope of the Berlin Act, the same government rules have been enforced, declaring india-rubber a State monopoly not only on the crown-lands, but even on private estates.

What is lawful for one party must be lawful for the other, and we cannot reproach the Congo Free State for upholding against British would-be interference such rights of the Crown as other governments maintain in their own colonies.

This example of vigorous Teutonic candour might be repeated from the columns of many other European journals, but the desire to avoid passing from the historical to the controversial in the present work must limit the use of abundant similar material.

To show that the direct exploitation of domanial forests is made a legitimate source of revenue in Eastern countries, the instance of Japan may be cited. That brave little country, so heroically engaged in fighting for the unmolested right to pursue its brilliant course of modern progress, directly cultivates and harvests for the benefit of its treasury a State domain equal to seven times the entire area of Belgium!

When the ministers of his Majesty, King Leopold, were requested to indicate the principles upon which the Domaine Privé of the Congo Free State was developed, they stated that, having in view the necessity for revenue from the soil, the civilising influence of labour, and the social, physical, and moral condition of the African black, they had devised that scheme which would attract the only existing available labour in the country, the co-operation of 
the native, for which co-operation the State not only paid him, but provided him with liberating and enlightening opportunities for participating in the growth of African civilisation. In its official reports the Government of the Congo Free State refers to its aims in this respect:

The object which the Government aims at, is to succeed in turning the private domain of the State to profit, exclusively by means of voluntary contributions [of labour] from the natives, and inducing them to work through the allurement of an earned and adequate payment. The rate must be sufficiently remunerative to stimulate in the natives the desire of obtaining it, and, as a consequence, to induce them to gather in the products of the domain.

Where the attraction of commercial benefit is not sufficient to assure the working of the private domain, it is necessary to resort to the tax in kind; but, even in this case, the work is remunerated in the same manner as the voluntary contributions. The Government's orders in this respect are positive. Properly speaking, the tax in kind is not a real tax, since the local value of the products brought in by the natives is given to them in exchange.

The Government has never neglected an opportunity to remind its agents, intrusted with the collection of taxes in kind, that their part is that of an educator: their mission is to impress on the mind of the natives the taste for work; and the means available would fail of their aim if compulsion was changed into violence.

What is called the Domain of the Crown is a limited territory defined by decrees dated March 8 , I 896, and December 23, I90I, lying in the basins of Lake Leopold II. and of the Lukenie River, in the basin of the Busira-Momboya River, and between certain boundaries at the confluence of the Lubefu 
and Sankuru rivers, to the western summit-line of the Lukenie basin, and including certain contiguous areas. These lands include six discovered mines which have so far not been worked. The Dumain of the Crown is a corporate body administered by a committee of three persons appointed by the Sovereign.

The forests of the Congo are the finest in the "world. They contain a great variety of hard and soft wood, fruit-bearing trees, rubber trees and vines, and gum trees, and constitute an industrial wealth which is being preserved by enforcing rigorous laws. A decree dated July 7, I898, and orders dated November 22, I898, and March 21, I902, regulate timber cutting. Under these, steamboats may take on supplies of wood fucl on payment of an annual tax measured according to their tonnage and speed.

The mining laws of the State are embodied in the decrees of June 8, I 888, and March 20, I893. They provide, amongst other things, that the purchase of land from the State or from individuals does not "confer the right of working the mineral riches beneath the surface"; that "mineral riches remain the property of the State"; that "no person can work a mine except by virtue of a special concession from the State"; that "the Government fixes by decree the regions where mining researches are authorised either in favour of all persons without distinction, or of the persons specified in the decrees." A licence fee of 2500 francs and other fees are imposed upon those who, having discovered mineral-bearing 


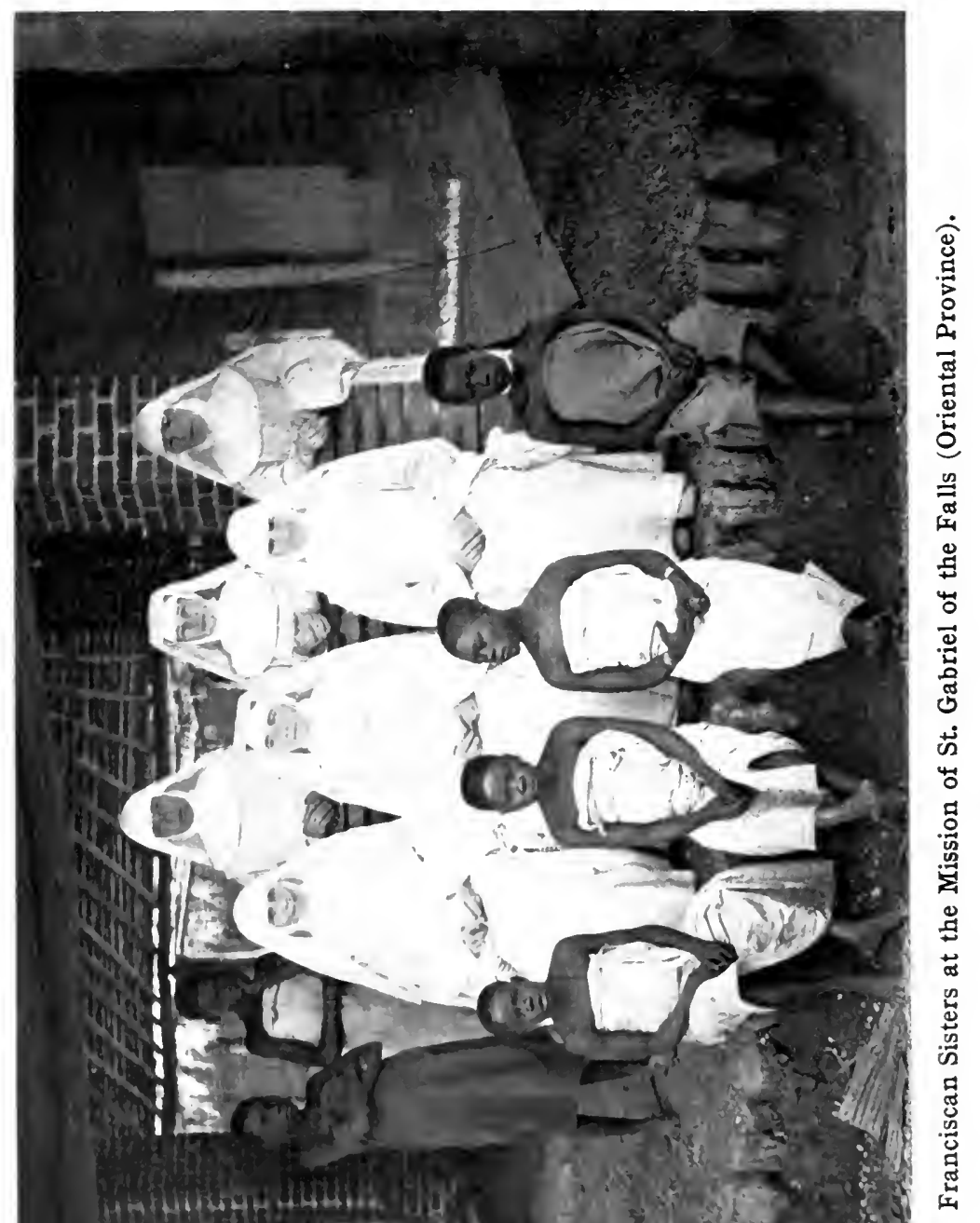





\section{State Lands and Concessions}

properties, desire to work them. A mining concession is limited to an area not exceeding 24,000 acres. Article 4 of the decree of March 25, I893, provides that:

Whoever shall discover a mine in the regions where he is authorised to make researches in conformity with Article 3, can obtain a right of preference for ten years for the concession of this mine, on condition that he complies with the regulations laid down in the present Decree.

All mining concessions are limited to a term of ninety-nine years. On its expiration the State succeeds to the property as it stands. A system of royalties on the product of the mine is stipulated in all concessions. Such royalties shall not be less than one dollar a year on each 2.47 acres. These fixed annual charges may be commuted by arrangement with the State.

In commenting upon the criticism which British merchants and their allies have uttered against the entire land system of the Congo Free State, an eminent Belgian closely identified with those who support the Congolese policy has said:

It is an easy matter to point out, in an undertaking such as the Congolese enterprise, the inherent imperfections and difficulties of the task, and the accidental defects in the instruments which the State is called upon to employ.

It is, however, very unfair to hide under a bushel the good results which have been obtained, and the progress which has been realised, and to expose on a pinnacle a few exceptional and regrettable facts, to draw a conclusion from particular cases to the detriment of the general rule, and to condemn wholesale an institution which draws forth the admiration 
even of its enemies, and of which a witness, certainly to be little suspected, has been able to say: "In the whole history of Colonial life, there is no example on record of such a result obtained in such a short period of time."

We are far from overlooking the important rôle which criticism plays in a matter which is as yet so little advanced as the art and science of colonisation, but in order to play this role properly, the critic must remain impartial.

After all, if these severe criticisms have been at times formulated, there are ample compensations in many authoritative comments from abroad. For instance, M. de Lanessan, formerly Minister of the Admiralty in France, says:

"Belgium has shown that, in matters of colonisation, she possesses more practical and rational ideas than ourselves, and a better understanding of the methods of modern colonisation."

As to the condition of the natives, this is the opinion of Sir Harry Johnston, speaking from experience of that part of the Congo which was formerly the most backward:

“This portion of the Congo Free State was inhabited by cheerful natives who repeatedly, and without solicitation on my part, compared the good times they were now having, to the misery and terror which preceded them when the Arabs and Manyema had established themselves in the country as chiefs and slave-traders."

As this volume is going to press, advices are to hand that M. Gaston Doumergue, the French Minister for the Colonies, submitted to the President of the Republic of France-and on October 23, 1904, procured his signature to-a decree consolidating the Republic's legislation concerning French West Africa. This decree reaffirms that "all vacant lands in the colonies of French West Africa are the property of the State"; that the property of the State may be alienated, leased, or developed according to the 
methods employed in the.Free State; that concessions may be granted; that property held in common by tribes under their chiefs may not be sold by them without the State's consent, etc. In short, the success of the land régime practised by the Congo Free State having convinced the Germans and the French of its wisdom, both countries have now conformed their own laws to it. 


\section{CHAPTER XXIX}

\section{THE NEMESIS OF LIBEL}

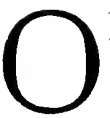

N Friday, the $25^{\text {th }}$ of March, 1904, in the King's Bench Division of the High Court of Justice, London, the case of Captain Henri Joseph Leon De Keyser, and his colleagues-in-arms, Commandants Chaltin and Dubreucq, against Captain Guy Burrows, an Englishman, one time in the service of the Congo Free State, and his publishers, Messrs. R. A. Everett \& Co., London, came on for trial before Mr. Justice Ridley and a special jury.

The trial of this action for libel is the first which has, so far, been determined against those who are charged with traducing the men whose courage in, and devotion to, the Congo cause has erected a prosperous State in the heart of savage Africa. The case irradiates much that has been long proceeding in Great Britain, and that has recently received significant impetus in the United States through the action of certain persons operating from the city of Boston.

The author has no acquaintance with any of the parties to this case, but deems it incumbent upon one who essays to write a full history of the Congo Free State to include an account of litigation which in its proceedings and result reveals and explains 
many things with which the present work will not otherwise specifically deal.

Belgian officers brought this action against an English officer, whom they charged with libel and attempted blackmail, before a British jury. Captain Guy Burrows, the defendant, had published a book containing false statements of atrocities in the Congo. $\mathrm{He}$ had followed the Liverpool and Boston custom of attributing villainy to the officers of the Congo State Government. But unlike the Liverpool and Boston general allegations, Captain Burrows attributed the wrongful acts to Captain De Keyser and Commandants Chaltin and Dubreucq. What the Court thought of the case as it sensationally unfolded itself may be gleaned from the observations and summing up of Mr. Justice Ridley. What the jury felt is indicated in its verdict for damages against the defendants in all the cases.

To ensure the fairest statement of this interesting and informing suit, the following quotations, verbatim et literatim, are taken from a stenographic report of the trial.

There was a fine array of learned counsel on both sides, among whom Sir Edward Clarke, K.C., Mr. J. Eldon Bankes, K.C., and Mr. Lewis Thomas (instructed by Messrs. Bird, Strode \& Bird, solicitors) appeared for the plaintiffs; Mr. Crispe, K.C., and Mr. Swanton for the defendant Burrows; and Mr. Germaine, K.C., and Mr. G. A. Scott for the defendants, Messrs. R. A. Everett \& Co.

Defendants' counsel opened the case by asking leave of the Court to withdraw his clients' plea of 
justification, by which, in popular terms, he stated that Captain Burrows was unable to prove any of the monstrous accusations he had made against Captain De Keyser and his colleagues, in the book which contained the libels complained of. After this dramatic collapse of previous pretence, Sir Edward Clarke proceeded with the case as follows:

May it please your Lordship.-Gentlemen of the Jury, I feel bound to preface the observations that I have to make to you upon this case by just a very short reference to what has taken place this morning. A very sudden transformation has occurred in the condition of the case, and in the issues which are to be put before you. In February last year Captain De Keyser, a gentleman who has served in the Belgian Army, and who has been employed in the Congo Free State, found himself compelled, by circumstances which I shall explain to you in a few minutes, to take the opportunity of bringing this action against Captain Burrows and against some London publishers in respect of accusations against him of the gravest possible kind-accusations dishonouring to his character as a man of honour and as a man of humanity, and dishonouring to him as an officer in the Belgian Army; and he brought his action in February last year. Thereupon, in the course of the year, Captain Burrows puts on a defence in the month of April or May, and Messrs. Everett \& Company put on a defence in the month of August, in which they say that those accusations against Captain De Keyser were true; and what were called Particulars, to which, however, I need not now refer, were put in, in which it was alleged that Captain De Keyser had been guilty of infamous conduct as a servant of the Government of the Congo Free State. This case has gone on month after month. There have been questions as to the time when it should be tried, and those who were advising Captain De Keyser and those who are interested in this matter have had the anxious duty of taking care that it never could possibly be said that the Defendants did not 


\section{The Nemesis of Libel}

have a fair opportunity of trial. The case stood over for a considerable time, and even so lately as when it was before the Lord Chief Justice there was a practical assent on the part of the Plaintiffs to the postponement of the case in order that no one should ever say that the Defendants had not the fullest opportunity of putting their case before you; and now, at this moment, when we come into Court to-day, suddenly, the statement that the accusations are true is absolutely struck out. Not only do the Defendants say that they are not prepared to call witnesses to support the allegation that those allegations are true, but they appear not to be prepared even to challenge Captain De Keyser himself, or to ask him any questions as to his conduct in the Congo Free State. I do not know how far I may be allowed to go-how far it may be possible in the present state of the Pleadings for me to get any absolute vindication of Captain De Keyser in this Court. I daresay my Lord will be indulgent with me with regard to that, looking at the very cruel position in which this gallant officer has been placed by accusations made against him which might affect, and, I believe, have affected him, very seriously in private life-accusations which have come to be known and to be talked about-accusations, as he was prepared to show, which were absolutely untrue, and accusations at the very last moment withdrawn, struck away from the Record, when not only has he been here prepared to give his evidence, but when we have tried to get, and succeeded in getting, as many of those as could be possibly called here who were associated with him in his responsible work in the Congo Free State to carry to a demonstration the proof that he could give that there was not a tittle of foundation for the injurious statements that have been made about him. Now, at the last moment, it comes to a question of publication, and my learned friends have taken the position that if I can prove against them that there was a publication of these libels, then they are without a defence, and are not able to say that there is any truth in the statements that they have made, and must submit to such verdict as you may give in the matter. As to the verdict, I do not know whether, in the ultimate results, 
the amount of it will matter very much, but you may think, when you hear the statement I have to make to you with regard to the publication of these accusations, that it is a case in which, whether there is ever any possibility of recovering the money or not, at all events there should be a very definite expression of your view with regard to the conduct that these parties have pursued. I shall prove not only a publication, but I shall prove an attempt to blackmail the Belgian authorities, and the authorities of the Congo Free State, by these people in conjunction, Captain Burrows and Everett \& Co. I believe I shall prove it up to the hilt, and then it will be for you to say, by your verdict, what you think of the conduct of which they have been guilty.

Gentlemen, I must limit very closely the observations which I was going to make to you. My learned friend and I had somewhat laboriously prepared ourselves for dealing with all the possible issues of fact that might be raised in this case that were suggested by the accusations against Captain De Keyser. That has passed out of the case, and I must treat very shortly the questions with which I should otherwise have had at some length to deal. It is essential when you are considering the persons against whom, if I prove the publication, your verdict must go, for you to consider who those persons are. The accusations which were made have been made by Captain Burrows and published by the Everetts, and were accusations which concerned the course of government in the Congo Free State, a matter which has attracted great attention from time to time and with regard to which certain very strong statements have been made in this country and elsewhere.

Now, Gentlemen, the Congo Free State is a State which, as a separate and independent State, has not existed very long. It was in the year 1884 or 1885 that that State was constituted under the Government of the King of the Belgians, who is called the King Sovereign of the State, and it has from that time been administered by Belgian authorities as the authority of the Free State. It has been a Government in process of construction, and it was not, perhaps, until the year I $89 \mathrm{I}$ 


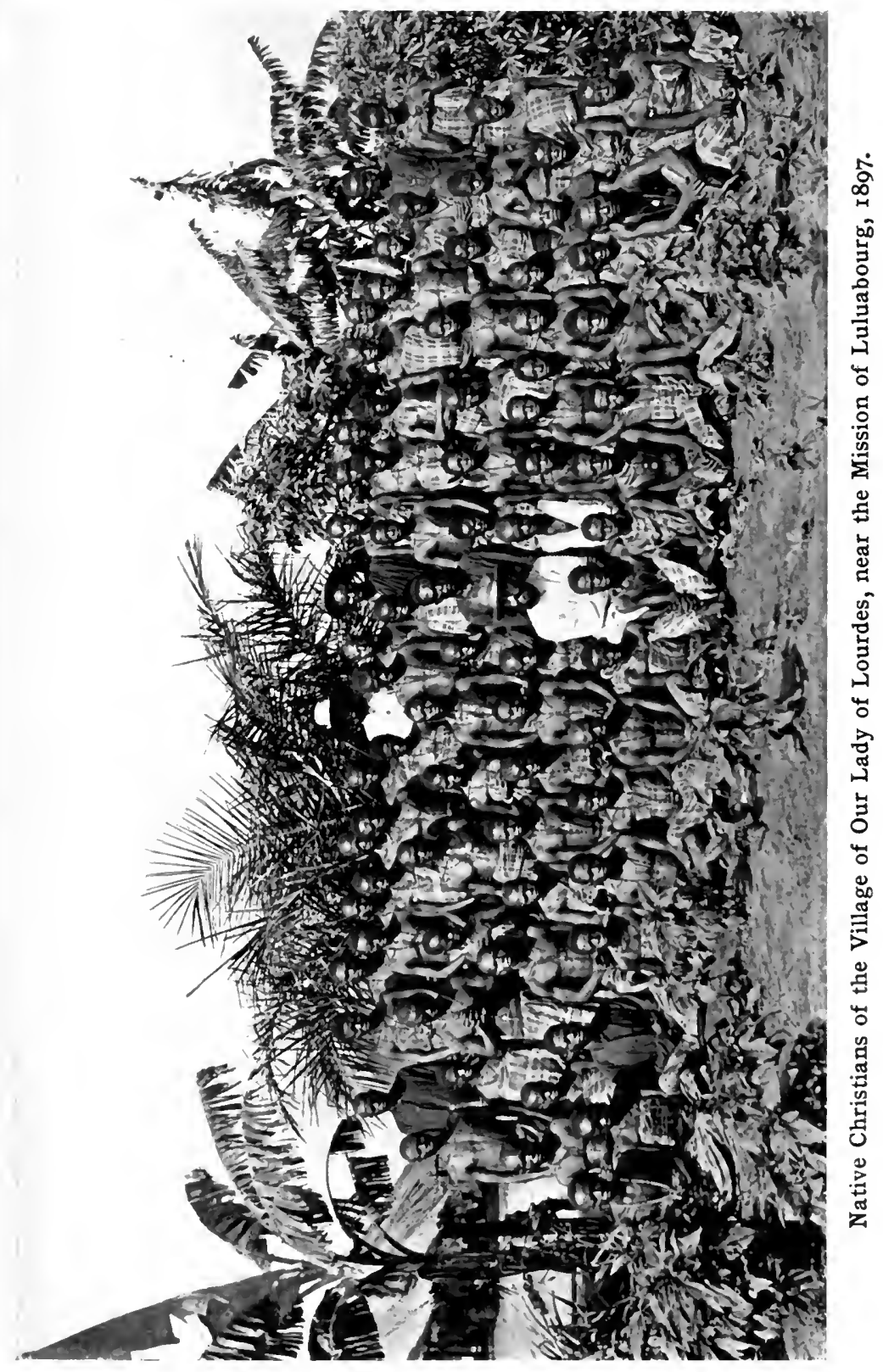



that it can be said that there was an organised system of government extending over the Congo Free State. It is an enormous area of over 800,000 square miles. It is an area scantily populated, but populated by savages of almost the lowest type of existence, savages among whom the practice of cannibalism, the practice of mutilation of enemies who have been killed in battle, and of violent punishments as between one tribe and another, had reigned without check until the representatives of civilisation came, in the officers of the Congo Free State, and established some sort of organisation and government throughout that country. The difficulties have been enormous. The difficulty of dealing with an area of more than 800,000 square miles with only a very few hundred white men who were in command of black troops, drawn from the very tribes whose habits I just now referred to, has been enormous. It has been one of the most anxious and difficult tasks that a civilised country ever undertook. That task has been fulfilled-on the whole with signal success. No set of men are absolutely free from reproach. The position of the representatives of the Congo Free State has been an extremely difficult one. At the time when Captain De Keyser went out, a captain and seventy-five men had been killed a few weeks before, very near to the place where he was sent to carry on his work. Every white man is surrounded by hundreds or thousands of black men, and is in a position not only of great responsibility but of great personal danger and of great difficulty, and there may have been here and there a default on the part of now one and now another of the officers in the employ of the Congo Free State. It has not been the fault of that State, for from time to time orders have been issued to the officers of the Free State, by which it has been attempted to prevent any sort of misconduct, and there have been administrative orders by which severe punishments have been inflicted on the natives for cannibalism or for the mutilation of persons who have been killed in battle, and this amelioration of the condition of the people has been going on with great success. Captain Burrows, who wrote against Captain De Keyser these most atrocious libels, has been on 
two occasions in the employment of the Congo Free State. $\mathrm{He}$ was employed there from June, I894, until September, 1897. He never had an opportunity of seeing or knowing the character of the work which Captain De Keyser did, for they were together only fourteen days in the year 1897 . But from 1894 to 1897 Captain Burrows was out in the Congo Free State. He came back to Europe in 1897 , and the first interesting circumstance about him is that he became at once the champion of the Congo Free State against allegations made by Captain Salusbury. In I 896 Captain Salusbury had made accusations against certain officers of the Congo Free State, and one of his allegations had been that there were mutilations-hand-cutting and the like. Captain Burrows made himself the defender of the Congo Free State and of its administration. He had had four years' experience, and he sought an interview with the Etoile Belge, and had a conversation with the representative of that newspaper, which was published; and you will find in a letter from Captain Burrows that he takes to himself the credit for what he had done in getting rid of, or answering, the accusations of Captain Salusbury. I will read a line or two from this statement: "As for his accusations,"--that is, Captain Salusbury's accusations against the Congo State and the Belgian officers who employ him,- "they fail from the outset. It is without any compulsion that the natives enlist in the public forces. The harvest of ivory and caoutchouc gives rise to no atrocity. I have witnessed none of the odious deeds related by Captain Salusbury, and they certainly would have come to my knowledge if they had been real. I say this for the simple reason that it is true." Then at the end he says as to the action of the Government: "With such accounts one is silent instead of becoming an accuser. I do not pretend that all is perfect at Congo. It certainly commits errors sometimes, but truth compels me to state that the Government seeks only to redress them, and to punish those who have been guilty of it. The Belgian officers do not use their men brutally at will as Captain Salusbury has affirmed. Indeed, the soldiers are much attached to the greater number of their white chiefs, and the latter 
can confidently count on their courage and devotion in time of war."

The close of it all was-and this you will find extremely important when you see what Captain Burrows was saying later: "The tales that have been told of cut hands are all pure legend. I have never seen a living native mutilated. As for the cannibal customs of certain tribes of the Congo, they should not be charged to the whites, who do what they can to modify them, but who can only succeed in doing it after lapse of time." That was as explicit as it was possible to be. That was published in the year 1898 . He came back in 1897 . You will find a reference in the letter which I am going to read. He published a book. I will read the letter first. The letter is the 20 th November, I897. "Dear Mr. Liebrechts,I send you the last article of Mr. Salusbury. . . . I do not like asking anything for myself, but if it were possible for you to obtain for me the order of the 'Lion,' and that I should be named the Captain Commandant of the first class, Salusbury would know it, and this would be an absolute denial of his exposures. . . . I have an idea of writing a book entitled The Truth about the Congo. It should be dedicated (I do not know if that is the word) to the King, and an introduction written by Stanley. What do you think of the idea? Yours always, Burrows." M. Liebrechts is the Secretary General of the Congo Free State, resident in Brussels. He has had the administration of the Congo under the King for years past. He himself served for six years in the Congo, came back, and has been Under Secretary for the Congo Free State since I 889. He has been Secretary General for the State, and has had the responsibility for the administration of the place, and is at present here in Court.

In that letter he refers to an introduction written by Stanley-that is, Sir Henry M. Stanley. Here is the book that was published. It was not called The Truth about Central Africa; it was called The Land of the Pigmies. It is dedicated to the King of the Belgians by permission, and it does contain an introduction by Stanley. It purports to give a full account of the Congo State, and I need hardly say there is not the 


\section{Story of the Congo Free State}

smallest reference in it as to any sort of atrocity. At one page there is a statement of a man being caught, who had been guilty of inhuman conduct, and of his being most severely punished, but that is given as an instance of the untruth of the stories that inhumanity was allowed. This was the position in 1898 . Captain Burrows went back in June, 1898 , and was at Basoko from r 898 till February, rgor. Then he came back to Europe on the 2 ist of May, igor. He wrote a letter to Mr. Liebrechts. You will be interested to note the attitude he takes with regard to his treatment by the Congo Free State. "Sir, I have the honour to ask you to have the goodness to request the Government to permit me to convert into capital (i.e., sell) my allotment of the public debt 4 per cent. Congo Free State, granted by your letter dated the igth April, rgor." The explanation is that when an officer has served in the Congo for a certain time and retires from the service there is allotted to him a certain income from the Public Debt, and he is allowed to take that as a lump sum, instead of receiving the interest from year to year upon the proportion which is allotted to him. "The motives which have decided me to make this request are as follows: It is more than probable that I shall not return any more to the Congo. I shall in all probability go to the Transvaal, and in that case the stock granted to me would be almost useless. It would indeed be difficult for me to again enter into service with the State after having been four times passed over for promotion by officers of shorter terms of service. Moreover, I have never received any increase of pay during the two years. and six months of my last term of service as Commissioner of the district of Aruwimi. In spite of services rendered since my arrival in the Congo in July, 1898 , I was the object of unrelenting suspicion on the part of several functionaries of the State, and I am informed that many of these gentlemen disparage me to the State. Amongst the services which I have rendered I can remind you that it was I who silenced Captain Salusbury. I wrote and published a book distinctly favourable to the State, for which Sir Henry M. Stanley was pleased to write the introduction. I regret, Sir, that such cir- 


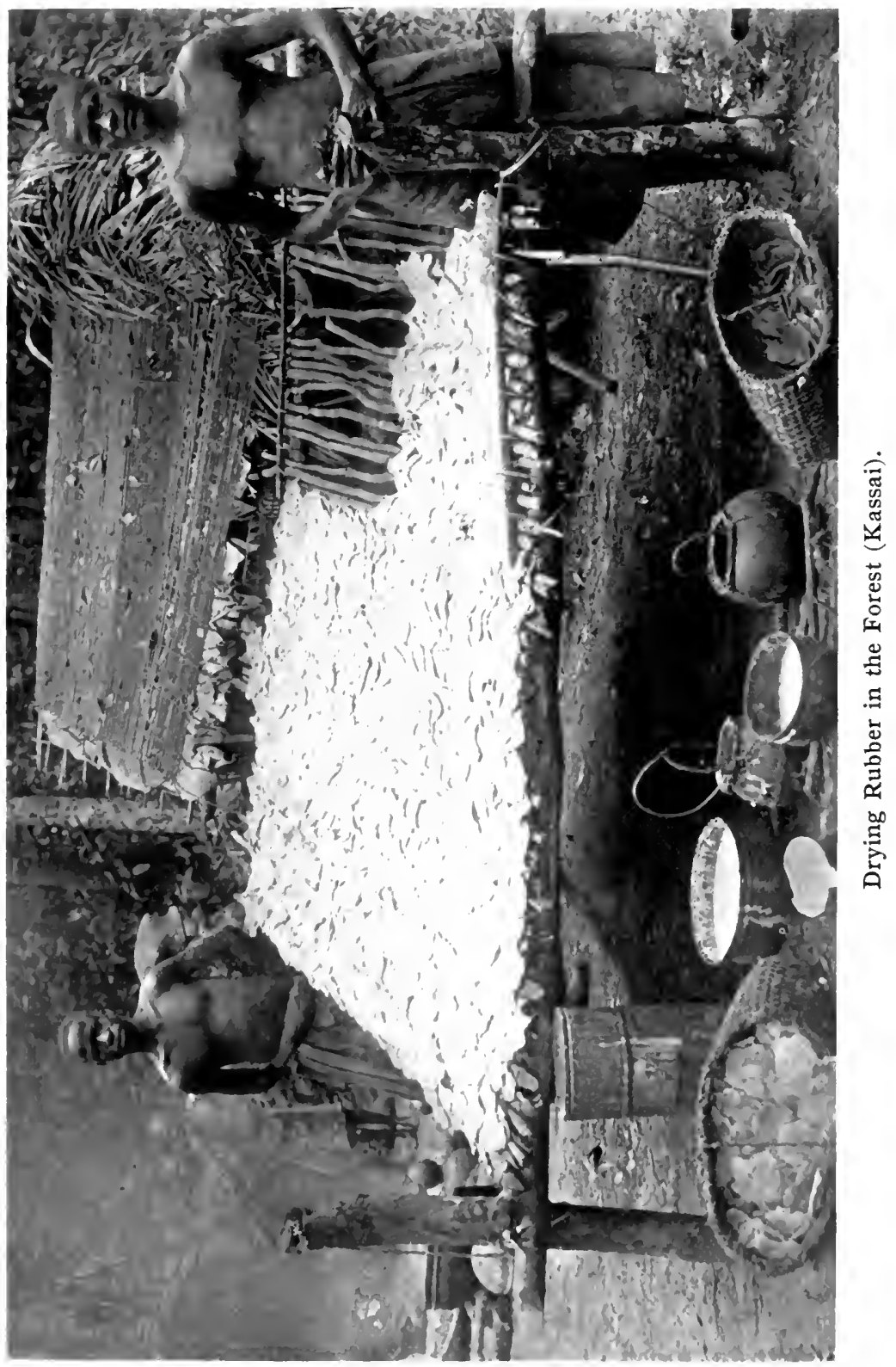



cumstances oblige me to quit the service of the State. I have the honour to remain, District Commissioner Burrows." You see by that that he was leaving the service. He was stating his grievances: that his pay had not been properly raised, and that he had not received sufficient distinction. The next thing that happens is on the ${ }_{5}$ th $^{\text {th }}$ of November, $190 \mathrm{I}-\mathrm{a}$ note which is the beginning, as you watch from this point, of the scheme by which it was attempted to blackmail the Government of the Congo Free State, or anybody else, by the combination of Captain Burrows and Messrs. Everett, publishers of his second book. On the I 5 th of November, $190 \mathrm{I}$, this very curious note was written: "Dear Monsieur Liebrechts. I should be very grateful if you would have the kindness to tell me if the State wishes to employ me again. If so, will you let me know the conditions? Mr. Canisius is here. He says that he is engaged in writing a book on the Congo." That is a very interesting bit of information. Monsieur Canisius was a gentleman who had been in the employment of the Congo Free State, and had left that employment to go into the employment of a private Company, and then had desired to come back into the employment of the Congo Free State. He had been refused. It is a rule, I think, with the Congo Free State not to take back into the State service those who have left to serve in private companies. Captain Burrows says: "Canisius is here. $\mathrm{He}$ is engaged in writing a book on the Congo." M. Canisius was not there; M. Canisius at that time was on the Gold Coast! It was a very curious notification to send: "Are you going to have me back into the State service? There is somebody here who is writing a book." On the 23 rd of November he was answered by Commandant Liebrechts: "I have duly received your letter of the I 5 th of November and hasten to thank you for the communication you have been good enough to make me. I heard Monsieur Canisius was spreading certain calumnies about the State." On the r6th December Captain Burrows writes again: "I presume that your letter is a refusal on the part of the Free State to re-engage me for a third term of service. I beg you to enlighten me on this point, then I shall 
know whether I am free or not to do what I wish"-another very interesting suggestion; it is enlightened very much by what you will hear shortly. On the 2 Ist of December M. Liebrechts writes thus: "I quite understood at the time of our last conversations, that you no longer wished to resume service at the Congo, and we seemed to be agreed that a post suitable to your capabilities would be very difficult to find in Africa. You must not, however, conclude that we shall no longer be able to make use of your services should an occasion arise, for special missions, such as may arise at any moment in other regions. If you were inclined to hold yourself at our disposal, I should be obliged if you would let me know." On the 3 Ist December Captain Burrows wrote: "I do not remember the conversation alluded to in your letter of the 2 Ist December, in which I said quite plainly that I no longer wished to resume service at the Congo. I understood that it was a question of the conditions under which it would be impossible to resume such service. You ask me if I am disposed to hold myself at the disposal of the State with a view of being employed for special missions which may arise at any moment in other regions. Am I to understand that I am still in the service of the State or not? And if so, under what conditions of remuneration, etc.?" On the 2nd of January, 1902, Commandant Liebrechts writes: "In reply to your letter of the 3 rst December, I9or, I hasten to inform you that your agreement ended with your return to Europe, and that since then you have, according to our laws and regulations, ceased to be a member of our staff. It is precisely for this reason that I asked you in my last letter if it would suit you to hold yourself at our disposal for a certain period-let us say two years. You will have to undertake during that period any mission with which we might entrust you. Of course, if you accepted this proposal, an annual salary would be allowed to you for that period of two years. But before deciding this point I should like to know if, in itself, our proposal commends itself to you. I should be obliged if you would reply as soon as possible."

Gentlemen of the Jury, we have come now to January, I 902. 


\section{The Nemesis of Libel}

There was an end of the negotiations, so to speak, between Captain Burrows and Commandant Liebrechts, and Captain Burrows found himself, to use his own expression, free to do as he chose.

During the early part of 1902 , he began writing some things, and an advertisement appeared in the Wide World Magazine in which an announcement was made of "Life in the Congo Free State," a series of articles which were to be published, written by Captain Guy Burrows. The advertisement reads: "Captain Burrows was recently in the employ of the Congo Free State Government, and in his official capacity has seen much of the misgovernment which prevails in that littleknown territory. He has a good deal to say about the atrocities which have taken place in connection with the rubber industry, and the sworn testimony and photographic evidence which he holds will no doubt create a sensation in high circles. Captain Burrows' articles in the Wide World will be illustrated with his own snapshots." That was the advertisement that appeared. Why there was a mention of atrocities in it appears presently. The articles appeared in April, May, and June, in the Wide World. They are articles with regard to the Congo State, and there is not one syllable in them about any atrocity of any sort or kind. That is what he was doing in the early part or middle of the year 1902. In the latter part of this year an agreement was entered into between Captain Burrows as author, and E. A. Everett \& Co., London, as publishers, for the publication of a work then entitled The Congo Free State. This was signed on November I $7,1902$. On the 24th of November, 1902, this letter was written by Everett \& Co. to the Secretary of State of the Congo Free State at Brussels: "Sir, we have recently concluded a contract with Captain Guy Burrows, well known to the English public as having served some years in the service [sic] of the Congo Free State, to publish an important work on the Congo Free State. The information contained in this book is of such a startling character, and contains so many revelations concerning the administration of the Congo Free State of Belgium, that we thought it well to advise you of its publication 
beforehand, and at the same time to enquire if we may have the honour of offering you the Belgian rights for publication in your country. We are arranging for simultaneous publication in Italy, Germany, France, Norway, and Sweden, and the United States of America. We need hardly say that the book will be well got up, and illustrated with a very large number of valuable and unique photographs taken on the spot by the author and others. If you wish to move in the matter of this offer, we should be glad if you would let us know at your earliest convenience.." That, written on the 24 th to the Secretary General, was followed by a curious communication sent to the editor of the Independance Belge at Brussels, on

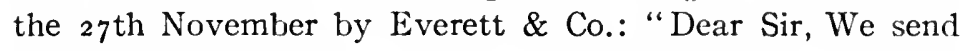
you the advance notice of the enclosed valuable work, and trust you may find room to insert the same in your literary column. If you have an agent here, we could, perhaps, tell him of some of the marvellous revelations in this book, but which we could not put on paper." On the 8th of December Commandant Liebrechts wrote to him: "I have received your letter of the 24th ulto., in which you inform me that you have agreed with Captain Guy Burrows for the publication of a work on the Congo State, and you offer me the rights of publication in Belgium. Before replying to your proposition I wish to see the manuscript or a proof of the book." On the 9th Messrs. Everett \& Co. wrote: "We are in receipt of your letter of the 8th inst., for which we have to thank you, and we much regret that we are unable to comply with your request in sending you the MSS. of this book, as we are under a contract with the author not to part with the MSS. under any consideration whatever. We should, however, be happy to send you the title and contents so as to give you some idea of the nature and scope of the book, and we should also be willing to show the MSS. to any of your accredited agents in London (by appointment). The MSS., signed documents, and photographs are of such vital importance that we should not care to put them through the post, for fear of loss. We understand that the author, Captain Burrows, was lately a District Commissioner for the Congo Free State, and is a Chevalier of 
the Order of the Lion of Belgium." In consequence of their offer to show those documents to anybody who was sent over, Mr. Bigwood came over to this country, and he saw Messrs. Everett. He met them and had a conversation with them, and then there was shown to him the document of which this is a copy, called "The Curse of Central Africa." It was the same document as had already been sent to the Independance Belge. At the end of chapter xxv., the very last chapter, there is this: "A Belgian's treatment of a native chief-more bestial than human-goes unpunished." That was afterwards applied to Captain De Keyser. Then comes a list of illustrations. At the end there is a list of Belgian officers and officials who, the author alleged, are responsible for the atrocities mentioned in this book; and a series of names included the name of Captain De Keyser.

Captain Burrows was in England on the $\mathrm{I} 6$ th of December. He had a conversation with Everett on the $\mathrm{I}$ th of December. This note was written to Mr. Bigwood at the Hotel Metropole by R. A. Everett: "With reference to your visit yesterday at my office, I think it would be to your advantage for you to call upon me at my club. I shall be here during the evening." That was the National Liberal Club, Whitehall Place.

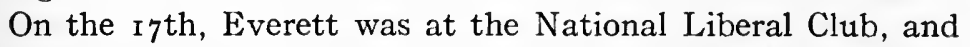
he was there with Captain Burrows and young Mr. Everett, and then a very interesting agreement was signed which throws a very clear light indeed upon the correspondence that had been going on with Brussels. It is witnessed by A. E. C. Everett, that is, the son, who went over to Brussels and posted the post cards in bad French. Captain Burrows signs it: "I hereby agree to pay Mr. John George Leigh the sum of $f_{5} 500$, if and when my publishers, R. A. Everett \& Co., 42, Essex Street, Strand, receive the amount which may be paid by the Belgian Government for the non-publication of the manuscript written by myself and him entitled 'The Curse of Central Africa.' In case the book is published I agree to pay Mr. J. G. Leigh one third of the profits accruing from such publication as per agreement with the said publishers." There never was more definite evidence of the intention with which 
these communications had been made with Brussels. If they had succeeded in extorting from the Belgian Government by any apprehension of the publication of these documents, a substantial sum of money- $£ 500$-was to be paid under that agreement.

Mr. Leigh is a brother-in-law of Mr. Canisius, and Mr. Leigh eventually signed the introduction to the book. He is a journalist. That agreement having been made on the ${ }_{1} 7$ th, on the 30 th Mr. Everett writes another letter to the State Secretary: "At the request of Mr. Bigwood, who called upon us recently on your behalf, we send you a revise of the titlepage, and one or two chapters of this book" (you will hear from Mr. Bigwood that that is not true; he did not request them to send anything at all), "and we shall be glad if you will let us know definitely, and at once, whether you wish to go any further in this matter. The more important photographs detailing the cruelties are being enlarged from the originals, so please do not take the enclosed to be the size.We have the honour to remain your obedient servants, R. A. Everett \& Co."

In the documents you will find the passages to which I have now come, which are contained in this: "Flogging a native by order of De Keyser. At Basoko, the headquarters station of the district of the Aruwimi, where the notorious De Keyser [meaning thereby the Plaintiff], of hand-cutting fame, was in command, women were daily flogged for the most trivial offences, etc." This, you will notice, is stated to have occurred in November, I897. It was a time when Captain Burrows himself was not in the Congo State at all, but you will hear from Captain De Keyser that there is not the smallest ground for the allegation of cruelty that was made against him. It is true that a chief was taken down in the steamer on which Captain De Keyser was, but the suggestion that he was treated in that barbarous fashion is entirely untrue. The next passage which has to be read is with regard to Basoko, and as to Basoko, what I have told you is that at Basoko, for fourteen days only, Captain Burrows was at the place where Captain De Keyser had his 
command. "At Basoko, the headquarters station of the district of the Aruwimi, women used to be flogged almost daily for the most trivial offences. In one case five women were beaten for daring to go to a village a short way up the river to buy food without having previously informed the commandant." Thus, after six and a half years, during which no breath of accusation has been made with regard to these matters by Captain Burrows, there comes this extraordinary attack: "De Keyser, of hand-cutting fame"; "De Keyser's massacre"; De Keyser described as walking about the station where he was employed with his gun, and shooting with reckless cruelty at the natives-De Keyser, who is accused of taking a man prisoner and practically roasting him on the stack-pipe of the boat as he is going down the river. There was not only that, but the imputation of habitually flogging women at this place. These odious and appalling accusetions, the echo of which follows a man through his whole life, are made against him, and made against him by whom? By a man who had been in the service of the Congo State itself, who, in the year 1897 , as I have shown, made himself the defender of the administration of the Congo State, and declared in an article which was put in the interview which he had with L'Etoile Belge, that there was no foundation whatever for the accusations which had been made against the Belgian officers, and he was able to say so because he knew the truth. He attacked Captain Salusbury and disposed of that. This man, who in 1897 was taking that attitude, who afterwards leaves the service of the Congo State and feels himself aggrieved because he has not been so highly. paid, because he has not had such distinction conferred upon him as others have had conferred,- - he, seven years afterwards, enters into this-is it too much to call it a conspiracy? They are grave accusations, accusations which, if there had been any semblance of truth in them, or if there had been any honest reason for their being made, would have been made long before in different circumstances and in a different way. At the time when they are eventually made, they are made in a way which will not do public service, but 
will put money in Captain Burrows' pocket and into the pockets of the publishers who are joining with him in publishing. It is perfectly impossible to misunderstand the correspondence with Commandant Liebrechts. If this had been an honest thing, honestly done by Captain Burrows in the performance of any public duty, do you think there would have been a going first to a publisher and then a letter from that publisher inviting the Belgian Government to consider what it would be worth their while to pay for the suppression of this book? There is no question as to the meaning of that letter. What do you think was the object of putting a crowd of names into the revise, some of which afterwards disappeared? Why, it was because the object was the illegitimate object of endeavouring to bring pressure upon the Belgian Government and to induce them to pay money to buy up this book. It was not for any public object at all, but because the mention of these names, showing that there was a list of persons formerly or at present in the Congo Company's service against whom accusations might be brought, might make it worth the while of the Belgian Government to prevent a great scandal by procuring the suppression of this book. But the Congo Free State or the Belgian Government was not going to buy up the book in order to suppress it or in order to prevent its publication. As one of the witnesses, Commandant Liebrechts, said, "For the first time we found that we should be in a position to deal with specific statements." It is all very well for people to be spreading over the world-I do not care whether they are in reports or interviews or anything else-general statements with regard to things that are done in the Congo Free State. Commandant Liebrechts says there had been complaints: "I had heard on more than one occasion of complaints being made as to conduct in the Congo. Whenever it was known, and found out, it was dealt with and it was punished. These allegations about maladministration of the Congo Free State had been spread about from time to time by interviews, suggestions, newspaper reports, and the like, but here we saw that there was an opportunity for the men who were personally attacked to come and vindicate themselves 


\section{The Nemesis of Libel}

from the charges which were made against them." Therefore, there was no attempt to buy this book, and the conspirators were disappointed who had been preparing this revise, and cramming it with an enormous amount of material which it was thought would frighten the Belgian Government from permitting it to be dealt with. I do not know what the price might have been which they would have asked for, but that there was a price they were thinking of you will see in a minute or two. What did they expect to get for it? We do not know. But we do know this, that there were two principals in the matter, and there was by way of being a subordinate. I speak of Mr. Leigh as a subordinate. I do not suggest in the least that he was associated with the attempt that was being made in Belgium, but what we know is, that he was doing a minor part of the work, that the manuscript was said to have been Captain Burrows' manuscript, that the materials for this book were supposed to be Captain Burrows' materials, and Captain Burrows therefore was the principal person, and Messrs. Everett had lent their name and their work, and were acting with Captain Burrows, and no doubt expected a very large share of the money that would be got from the Belgian Government. If Mr. Leigh, in his modest inconspicuous, and irresponsible position, was to get $£ 500$ for helping in putting together the materials for this book, what do you think that Captain Burrows and Mr. Everett thought that they might be able to extort from the fear of the Belgian Government that this thing would go all over the world?

The address to the jury of Mr. Crispe, counsel for the Defendant Burrows, was often eloquent, always adroit, and showed great skill in defending a cause to which the main defence had been abandoned when the pleas of justification were withdrawn.

Gentlemen [said Counsel for Everett \& Co., one of the defendants], apart from what Commandant Liebrechts termed "moral damage," there is no evidence of actual damage 
suffered by Captain De Keyser in this having come to the knowledge of Commandant Liebrechts. Commandant Liebrechts says that he had investigated these charges and found out that they were false. If so, the repetition of them could have no effect upon his mind as regards the complicity of Captain De Keyser in them, and therefore, so far as that is concerned, no damage could have been suffered with reference to Commandant Liebrechts.

Those are the facts on the question. I now ask you to deal with the printer in this case in the most general and lenient manner that you can. He has, as I told you in opening, been compelled to accept the evidence given him by the man who brings him the material. He safeguards himself to an extent, or at all events his bona fides [sic], he safeguards by obtaining the statement in that agreement that these allegations are true, and that there is nothing libellous in the work that he is about to produce. Mr. Everett has not been able to establish the plea of justification, and if the statements, as Captain De Keyser says now, in the books are untrue, Mr. Everett can only express his regret that he should have accepted from Captain Burrows, on Captain Burrows' assurance that they were true, statements which were false, and which have led Mr. Everett to being made a Defendant in an action for libel.

Gentlemen, I ask you to say that throughout Mr. Everett has believed in the truth and the proof of these allegations; that otherwise he would not have published the book, and placed himself in such a dangerous and perilous condition; and I ask you further to say that whether the Plaintiff comes here to-day to vindicate and clear the character of Captain De Keyser, or whether he comes here to vindicate and clear the character of the Congo Free State administration, there was no necessity, in order to do that, to try and blacken the character of the Defendant, Mr. Everett.

Mr. Justice Ridley, in charging the jury, after disposing of several minor matters, said:

What is the real case here? The action is brought by Cap- 


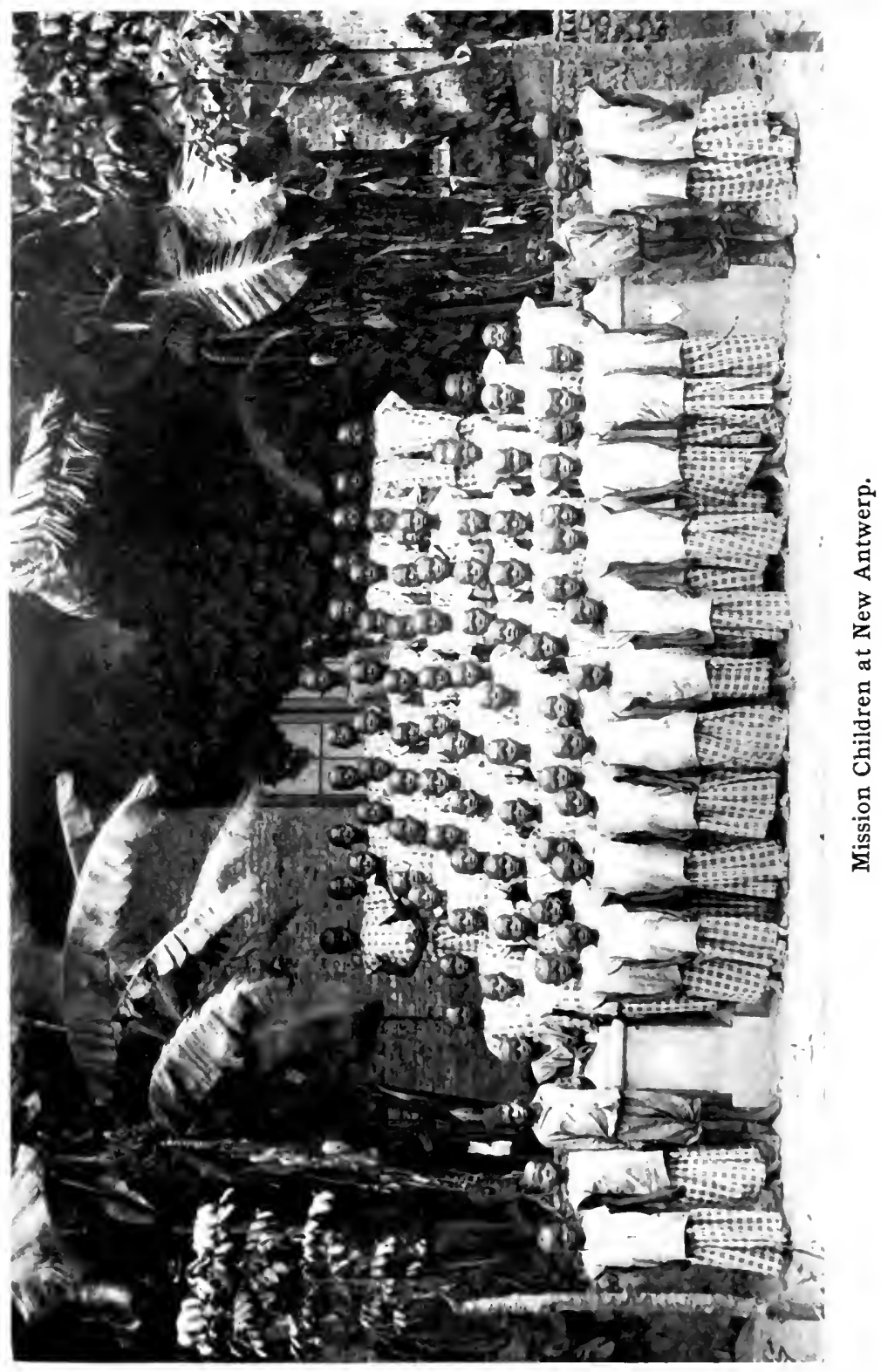



tain De Keyser to clear his character against libels which have been published. I do not wish to use epithets in a case like this, but they are certainly libels of a most serious character. It is charged that he had been guilty of abominable outrages against the natives, against men and women who were under his government, a thing which is of an atrocious character, enough to blacken the good name of any one for the rest of his life. That is what he came here about; he came to say that this was a libellous statement, to say that it was untrue, and to ask for a verdict from you. The answer of the Defendants is that it was true. That has remained their answer until yesterday morning, when it ceased to be their answer.

We have been listening this afternoon to statements made by Counsel, in which it appears that they complain because they cannot cross-examine, or they cannot examine, or they cannot do something or other. It seems to me that, upon the other hand, it is the Plaintiff who has the right of complaint, that he has been brought here with such a plea on the Record until the very last minute. That is very late, is it not? It is absolutely untrue that he ever did any one of those things. There is not one tittle of evidence to that effect, and nobody dare say so.

It appears that Captain Burrows, who is one of the Defendants, was out in the Congo at an earlier year. I am not sure when; he returned to Europe on November 20, I897. He was at that time a supporter of the Government in respect of the charges made by a person named Salusbury. In 1898 he brought out another book, called "The Land of the Pigmies," against which I have nothing to say. It contained nothing at all in the shape of a charge against anybody in respect of this matter. He then went back again to the Congo, but he returned in I90I, and then commenced a correspondence between him and Commandant Liebrechts. There is an earlier letter in which he states that he is proposing to bring out another book. Later on there is correspondence as to which I agree, that it shows that he and the Belgian Government parted on terms not of dismissal of him, but upon a proposal being made that if he liked to place himself at their disposal 
for two years they would pay him a salary, and that lie must be ready to accept any expedition on which he was asked to go. He declined that service. That was at the end of 1901 . In the following year he published certain articles in the Wide World. They contained nothing at all about cruelties, as I understand, although they contained articles about the administration of the Congo Free State. That was in the year 1902; but when we get to the autumn of 1902 a new state of things commences, because up to that time you will see there is nothing to indicate that he had taken up a hostile position against either the administration of the Congo Frec State or against any one who had been concerned in it. But on the $\mathrm{r} 7$ th November things begin to assume a somewhat different complexion. There is the Agreement of the $i 7$ th November, 1902, made between Captain Burrows and Messrs. Everett \& Co., under which the author warrants that the work is to be an original work. He names the work then as The Congo Free State. The publishers agree to pay him the sum of $£ 25^{\circ}$ on account, and a royalty of 15 per cent. On the 24 th November, when that agreement was in force, a letter was written by Messrs. Everett \& Co. to Commandant Liebrechts. Now the point of this letter is: Was the action of the Defendants bona fide in this matter? Are they persons who have unwittingly fallen into a false statement, or have they done a thing with a purpose regardless of the consequences? Have they done the thing which is what we commonly call blackmail, or forcing people to pay over money unless they wish to have a foul charge made against them?

These are the letters which bear upon this matter. The first is November 24th: "We have recently concluded a contract with Captain Guy Burrows, well known to the English public as having served some years in the service of the Congo Free State, to publish an important work on the Congo Free State. The information contained in the book is of such a startling character, and contains so many revelations concerning the administration of the Congo Free State by Belgium, that we thought it well to advise you of its publication beforehand, and at the same time to inquire if we 
may have the honour of offering you the Belgian rights for publication in your country." That may mean nothing but what it says, but it may have a sinister meaning in it. It may be that the fact that "the information contained in the book is of such a startling character, and contains so many revelations concerning the administration of the Congo Free State," that the point which is meant to be taken by those to whom it is written is: Is it worth your while to buy it up and stop it; not to publish it, but to have the right of publication so as to prevent it from being published in the ordinary way? Is that the meaning of the letter, or is it merely a bona fide offer of trying to push a book which is supposed and intended to be innocent, and to get people to push the sale of it? If that was the object, one is rather at a loss to understand how it could be to their interest to publish revelations concerning the administration of the Congo Free State by themselves, and, of course, contrary to the good faith and to the proper administration of the Government. That it might be to their interest to buy it up, and refuse to publish it, I can understand; the other part I have a difficulty in following. It states: "We are arranging for a simultaneous publication in Italy, Germany, France, Norway, Sweden, and the United States of America." I suppose this could not also be bought up through some agents of the Government of Belgium, but if so, it would be a larger sum to come to the publishers. That is the letter of the 24 th. On the 27 th, by the same people is sent to the paper in Brussels an "advance notice of the enclosed valuable work." That is the first issue which contains a list of the persons who are implicated in the atrocities. It does not contain the chapter which is the subject of this libel, but it contains a list of Belgian officers and officials responsible for the atrocities mentioned in this book. That is sent to the leading paper in Belgium. With what object? Do you think it possible that they thought that by some means or other it would come to the knowledge of the Government through the Press, or through some other means, that there was something which it would be worth their buying?

Now came Mr. Bigwood. The result upon the Belgian 
Government was not that they made an offer; they made nothing of the sort. . They said, We will find out what this is; and they sent Mr. Bigwood over, whose evidence we heard yesterday, and who says that he then saw and took back with him not only the first issue, which is the one I have just been mentioning as containing the names of the officers, but that he also saw upon the table the second issue, which is now put forward as the first of the two libels in the case, but he did not take it with him. It was sent upon the zoth December, as you know. Now, an important thing upon this part of the case seems to me to be the document of the 17 th December. That is, you see, between the two dates; it is after the $24^{\text {th }}$ and the $27^{\text {th }}$ November, and it is about the time of the visit of Mr. Bigwood, or just after he had left. Mr. Bigwood had seen on the table the second issue, but he had not taken it; it was not sent until the 3 oth December. In the interval we have got a document which is signed by Captain Burrows, and which says: "I hereby agree to pay to Mr. John George Leigh" (who is the man whose signature appears in the introduction), "the sum of $£_{500}$ if and when my publishers, Messrs. Everett $\&$ Co., receive the amount which may be paid by the Belgian Government." What for, do you think, gentlemen? You will say, of course, for the publication of the book. But it is not so: it is for the non-publication of the book. Therefore he is to get $£ 500$, which is to be paid by the Belgian Government for not publishing the book; that is to say, for suppressing it. Nothing could be plainer. "If the Belgian Government think it worth their while to buy it up, so that it should not be published, I will pay you $£_{500}$." It is under his own hand and signature, and I cannot see what the answer to it is. To my mind it is absolutely conclusive. I do not know whether you will consider that the meaning of the first letter is not that the book should be published broadcast but that the rights of publishing it should be bought up with the view of stopping its being published broadcast. He goes on: "For the non-publication of the manuscripts written by myself and him, entitled 'The Curse of Central Africa.' In case the book is published, I agree to pay Mr. Leigh one-third of the 
profits accruing from such publication as per agreement with the said publisher." That, of course, goes for nothing. It is the first part, and it appears to me to be clear upon that, that the meaning of such words must be that the object was not to get the Belgian Government not to publish, but to prevent the publication. Now, if so, of course I am perfectly aware that that is not the point of the case, but you cannot keep out of your mind in a case of this kind what has been the conduct of those who are responsible for the libels which have been published. Is it a case in which they have done the thing with a bona fide intention to produce and to bring to light, and to make to cease outrages and atrocities which have been committed in any part of the world, or is it, on the other hand, to make a profit out of something which has been brought to their knowledge to the detriment of other people? If you think that this was done to get a profit by forcing the Belgian Government to buy their silence, it would appear to me that you would deal with the matter upon a different footing to that on which you would be willing to deal with it if you thought that the Defendants, from beginning to end, had done their best to alleviate the mischief which their published statements might have unfortunately brought about.

You must also, I think, look at the conduct of those who were guilty of having published this libel. Have they done the best they could to alleviate the consequences, or have they, on the other hand, maintained the fact that it was true until almost the eleventh hour; and have they also, or have they not, whilst this matter has been going on, been actuated by other motives, not merely the motive of bringing to light in the public interest a scandal that was going on, but by the idea that out of this business they would make some ugly profit for themselves?

The jury retired at 3.22 o'clock. In ten minutes it returned a verdict for the plaintiff, Captain De Keyser, awarding him $£_{500}$ damages and costs. Sir Edward Clarke, plaintiff's counsel, having moved the Court to make the preliminary injunction forbidding 
publication of the book perpetual, defendant's counsel gave expression to the thought that if the Court complied, it would be a "very hard and cruel proceeding." In replying to this observation, Sir Edward Clarke said:

I do not know that the interference with the business of persons who publish libels like this is a public misfortune; but it would be very unfortunate indeed if after the Jury have found a verdict in my favour upon this matter, and awarded substantial damages, that the Defendant should be free from the Injunction which has gone on for the last year. I do not ask your Lordship to vary the Injunction, but I ask your Lordship that the Injunction which lasted while this matter was in dispute shall be made perpetual.

The terms of the Injunction which was granted by Mr. Justice Bigham are these: "Ordered that the Defendants, their servants and agents and each and every of them be restrained and an Injunction be granted restraining the Defendants, their servants and agents, and each and every of them, from printing or selling or otherwise distributing a book entitled 'The Curse of South Africa' under that or any other title, or any portion of the said book under that title or any other title." I submit that I am at least entitled to be continued in the protection which existed while the action was pending.

I was so protected when it was uncertain whether I had sustained any grievance or not. Now it has been established, and I have recovered substantial damages for that grievance, I surely am entitled to a continuation of that protection.

Mr. Justice Ridley: I shall make it perpetual.

Thereupon counsel for defendants in the remaining cases of Chaltin versus Captain Burrows and Everett $\&$ Co., and Dubreucq versus the same, agreed to submit to a verdict in favour of the plaintiffs for $£_{5}^{\circ}$ damages and costs. The jury returned verdicts for 
this sum, and the Court made perpetual the injunction against the publication of the book.

So resulted the first opportunity Belgian officers in the service of the Congo Free State have had to vindicate their characters during the long campaign which certain persons have, from varying motives, waged against the youngest and most progressive State in Africa. 


\section{CHAPTER XXX}

\section{THE CONGO CAMPAIGN IN ENGLAND}

\section{T}

HE English are an admirable people, who have excelled in every department of human effort; but the evidence of the more critical among them, with whom love of fair play counts for as Some much as pride of race, has never failed to English reveal in the national character (as of Traits. course in the character of every nation) a goodly number of weak spots whereat the critic and the wit may profitably direct their shafts. John Bull, the trader, is a keen-eyed, hard-headed bargainer. Good; it behoves every merchant to be no less. He regards the whole world as his farm by right divine, and resents his exclusion from any part of it. When his remonstrance is met by counter-remonstrance, he points to his home markets and his colonies, and emphasises the fact that these British markets are open (long after his own trade has been firmly established therein) to the traders of the world.

But it is in his ultra-sentimental mood that John Bull is seen at his worst. Has there been a conflict between some semi-barbarous tribes in that seething cauldron of discontent, the Balkans, and the Sultan's troops have thrashed them indiscriminately 


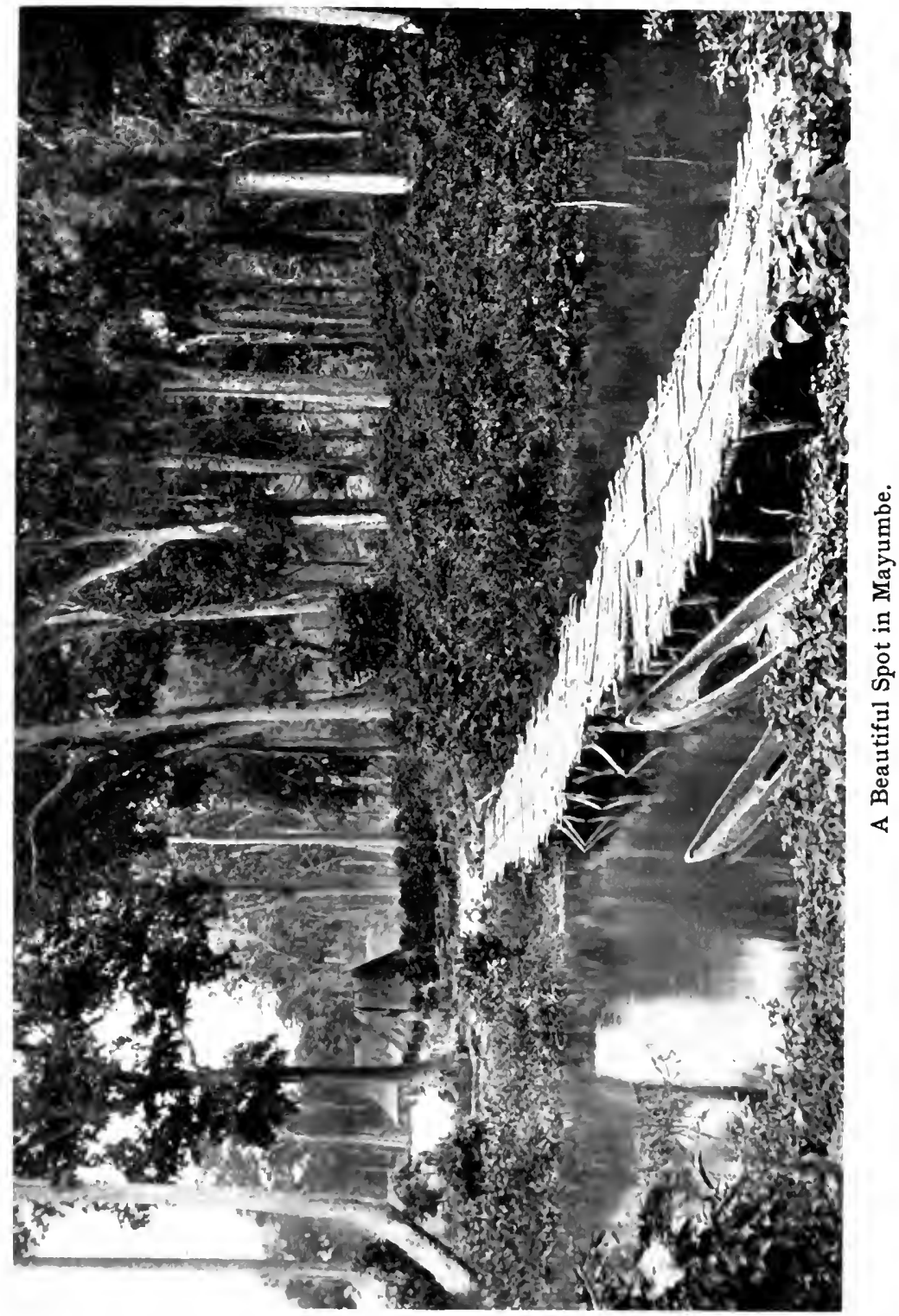



and dispersed them, John Bull, or at least that part of him which wears white ties and is described as "reverend," rushes off to Exeter Hall and demands the prayers of the churches and the forces of his Government for the suppression of the inhuman atrocities which he denounces. (Incidentally, but in unmistakable terms, he at the same time calls the attention of his audience to the joyful fact that it is their duty and privilege to assist in this good work by giving liberally of their money.) Of course it is but a section of the English people which approves and supports this sort of thing, and a still smaller section that exploits it. But in a country politically constituted as England is, where the suffrage is almost universal, it is sufficiently large and influential to influence from time to time the conduct of the British Government. This is more particularly the case where the interests of the pseudo-humanitarians and those of the traders happen to coincide. On such occasions, fortunately somewhat rare, the spectacle of Cant and Commerce in alliance is enough to bring a smile to the face of a sphinx.

Protestant missionaries of various sects, in rivalry with each other, but often alike in being envious of the superior results obtained by Roman Catholic missionaries in the Congo Free State, denounce the Congo Government as

A Strange Alliance. a gang of barbarous extortioners, oppressors, murderers. A small but active set of Liverpool merchants, dismayed at finding that what twenty years ago they regarded as worthless has, under judicious 
Belgian administration, become a valuable asset, and some of whom appear willing to resort to any means by which they may at least be enabled to share the prize, join their forces to those of the missionaries. Lies fall as thickly as leaves in Vallombrosa. No sooner is one mendacious story refuted than ten others take its place. The Congo campaign multiplies its adherents, it gathers force daily, its voice becomes more and more thunderous, until at last it invades the British House of Commons and moves a British minister to write a puerile dispatch to the Great Powers, which the Great Powers, in the exercise of their common-sense, politely ignore. Only up to a certain point does Baron Münchausen triumph. Verb. sap.

What magnificent material for the mouthings of certain English ultra-humanitarians would be the Why is lynching of Negroes in our own Southern John Bull States! The jail-breakings, the hangings, Silent? shootings, and burnings-could more effective subjects for stereopticon slides and the perfervid oratory of paid lecturers be devised? And all true and ready to hand, needing neither lies nor distortions! Alas! nothing can be made out of that campaign. It will not pay to call our country to account for its neglect or failure to suppress these things. The United States own a fleet which, if not as strong as it should be, is sufficiently powerful to inspire respect; and our President can at any time call up an army of a million citizen soldiers, volunteers of proved valour. With the Congo Free State this is not the case. Caution was ever a prominent charac- 
teristic of John Bull, and he has carefully noted that fact. Neutral little Belgium may safely be bullied, her King libelled, and his enterprise misrepresented and held up to the scorn of an undiscriminating world, too busy to undertake a careful analysis of motives or even to distinguish between the true and the false.

Judicial consideration of the English campaign against the Congo, naturally a difficult task, is rendered doubly so by the general suppression of material evidence favourable to that State. From motives best known to their proprietors, one or two important London newspapers, ever ready to afford space for an attack upon the Congo Government, however violent or by whomsoever made, frequently decline to publish replies thereto. Indeed, the more complete the refutation, and the greater the authority of the writer, the less chance of its acceptance for publication in these newspapers. Upon several occasions has Major Harrison been refused space for his temperate letters to the Morning Post, and the Daily News, the principal support of the Aborigines Protection Society, is avowedly against the continued existence of the Congo Free State. A complete answer to Mr. Roger Casement's Report, prepared by the Congo Government, was unanimously rejected by London editors. This most unjust partisanship extends even to English press reports of proceedings in the House of Commons, of which one might reasonably expect to find in English journals a complete record; or where the exigencies of space necessitate condensation, that at least that editorial 
operation should be performed without bias. That expectation meets with disappointment.

On June 9, 1904, Sir Charles Dilke, with a fine show of virtue which has not always characterised his conduct, delivered a speech in the House of Commons wherein he assumes the truth of the various libels upon the Congo Government prepared by missionaries, merchants, and dismissed employees. That speech, and the speeches of such other members of the British House of Commons as for various reasons have been induced to follow a similar course, have been reported in extenso, while the speech of $\mathrm{Mr}$. John Campbell, member for South Armagh, has not so much as been referred to. Mr. Campbell derided the Congophobes' plea that they have at heart only the interests of humanity.

The gold [he remarked] of that fine phrase is alloyed with other arguments. Commercial considerations have also their weight. Some speakers began by talking of humanity and ended with commerce. Others began with commerce and ended with humanity. One honourable member had thrown overboard the humanitarian theme and flatly talked business. But, in spite of all the ornamental flowers of philanthropy, the groundwork of all these speeches is-commerce. The true motive which prompts the Anti-Congo campaign, conducted with such vigour in this country and within these walls, was exposed in a few words by Stanley when he said: "The sentiment that inspires the charges against the Congo is jealousy. The Congo is succeeding better than any other State in Africa."

One would suppose that sentiments such as these, supported by the authority of Stanley, would at least be as worthy of a few lines in an English news- 


\section{The Congo Campaign in England}

paper as the vague charges of cruelty alleged by some missionaries based upon what they have been told that somebody else has heard, etc. But, no! such references are rigidly suppressed in a large section of the English press, just as much of Mr. Casement's Report that is favourable to the Congo Government has been suppressed. ${ }^{\text {. }}$

r The following letter, addressed to the Secretary of the Congo Reform Association, Liverpool, on December 8, 1904, by the editor of the Catholic Herald (London), indicates that certain British journals are sincerely seeking to expose the truth concerning the Congo and the motives underlying the campaign against the Frce State in England. The writer of the letter is the publisher of the thirty-odd leading Catholic papers in the United Kingdom. As a Member of Parliameni, and as an editor, his attitude towards public questions has always been conscientious and fearless.

"SiR,-The following matters so intimately concern your veracity, and, therefore, decply concern the public, in connection with your anti-Congo campaign and your Congo Reform Socicty, that I draw your attention to the fact that this letter will be printed in full in the Catholic Herald of next week, and will also be sent out broadcast to the newspapers of this country, so that you may have a full opportunity of defending yourself from the most serious charges made therein.

"On the 24 th of November last, in defending an abusive attack made by the London Daily News on the Belgian people, in which it referred to them as 'barbarians,' you made a statement to the effect that fifteen Congo officials were then in prison at Boma for the grossest outrages upon natives, and that ten more were awaiting their trial.

"In reply to a communication sent to a member of the Belgian House of Representatives, a statement is made by the Belgian autlorities, that only two officials are in prison in Boma. This statement was forwarded to the Daily News, which has lent itself to the disgraceful and lying campaign against the Congo, but, although the editor has been several times requested to publish it, he has up till now declined to do so.

"I, therefore, draw your attention to this emphatic contradiction of your story, and, having every confidence in the honesty and truthfulness of the statement made by responsible gentlemen in Brussels, state that your assertion can only be treated as a gross invention, quite on a par with the other methods of your anti-Congo campaign.

"But this is not the most serious matter. On the following point, 


\section{Just as this book is going to press particulars come to hand of an incident which throws a strong light}

I charge you with putting forward a statement in the Daily News, with reference to the Congo Reform Society, which you knew to be untrue, for the purpose of deceiving and misleading the public of this country. It was stated in a letter which appeared in the Daily News on November $25^{\text {th }}$, that Liverpool shippers and merchants were aiding the Congo Reform Society, and financing it. On the 29th November a letter appeared from you in the Daily News, in which you denied this, and called upon the writer to offer an apology for his statement. You proceeded to assert that you had enclosed (for the private information of the Editor of the Daily News) a list of the subscribers to the Congo Reform Socicty, and the editor supported your statement by the assertion that 'the list of donors and subscribers supplied does not contain the names of any British merchants or shippers.'

"The clear purport of your letter was to makc it out that there was no co-operation between the Liverpool shippers and merchants and this so-called Reform Society, which is nothing morc or less than a bogus name adopted to cover the campaign of falsehood and calumny which you and your friends have entered upon.

"On November 3 oth the following statement was published in the Daily News in answer to your denial :- 'With reference to the Liverpool merchants I have not seen the "private list" that he (Mr. Morel) forwards to you. I cannot tell whether it contains the names of all the subscribers to the Congo Reform Society, but I cannot accept the denial of the secretary with reference to the Liverpool merchants, in view of the candid admission of Mr. Fox Bourne that some of the merchants in Liverpool are working with the Society, and his further admission that they had helped to finance it. I believe Mr. Fox Bourne's statement, and if an apology is required for perversion of the facts, the secretary of the Congo Reform Society must make that apology.'

"To that emphatic disproval of your statement, you have up till now made no reply. In fact you cannot deny Mr. Fox Bourne's honest admission, which has already appeared in our columns, and of which evidently you were entirely ignorant at the time you attempted to throw dust into the eyes of the readers of the Daily News by your untruthful denial.

"Now, one of two things: either you are in a position to free yourself from this charge of deception and untruthful statement put forward for the purpose of deceiving the public, or you are not. If you are in a position to do so, come forward immediately, in the interests of the Congo Reform Society, and of yourself as its secretary. If you are not in a position to disprove this statement and to substantiate your words, you stand convicted of flagrant deception and falsehood on a most 


\section{upon the methods adopted by the enemies of the Congo Free State in manufacturing evidence against}

important public matter, and the people of this country will know how to judge a person, or a society, which descends to such methods for the purpose of bolstering up selfish and disgraceful designs.

"At the very moment that you were writing this denial in the columns of the Daily News, you were in treaty with a former Congo official, and bribing him for the purpose of giving evidence against the Congo State, and as a witness to the document that passed between you, you called in Mr. John Holt, merchant, 8 r, Dale Street, Liverpool, who was associated with you in this attempt to purchase testimony, and who actually paid, at the Exchange Hotel, Liverpool, on the 2 Ist November last, a sum of $£ 40$ to Mr. Benedetti, the Congo ex-official referred to, and yet you have the impudence and the hardihood to assert that the Liverpool shippers and Liverpool merchants are not associated with the Congo Reform Society!

"Nor are these all the inventions, perversions, and misrepresentations which can be proved against you in connection with this movement.

"The book that you have just written and published is packed with such lies and suppressions of truth. You print a travesty of the case of the man Stokes, who was executed in the Congo, and you say that the charge against him was 'of trading with natives,' whereas, as a matter of fact, he was proved to have supplied the cruel and barbarous Arab slave raiders of the Congo, who have been put down by the Congo Government, with guns and ammunition for the purpose of carrying on their nefarious work.

"These slave raiders evidently receive your warm sympathy, and the man Stokes, who helped them to carry on their trade, is held up by you as a martyr! Yet you dare to appear before the people of this country as a friend of the natives of the Congo, and your present campaign is ostensibly carried on for the amelioration of their condition!

"Again, you have ventured to make a most infamous charge against Catholic missionaries in the Congo. In a letter to the Times you said that 'they dared not state in public what they have said in private.' In other words, you accuse them of double dealing of the basest character, like Mr. Fox Bourne, who says, 'they offer religion to the natives only as a bribe, or to terrorise them into further enslavement.'

"You have never produced a single iota of evidence in support of this statement against the Catholic missionaries, who are doing such splendid work in the Congo territory. We characterise the statement as a gross and palpable invention, but, in that respect, it has only been on a par with the general policy of yourself and the so-called 'Congo Reform Society' in connection with these matters. 


\section{it. The paid officers of the Congo Reform Associa- tion in Liverpool, the Aborigines' Protection So-}

"It has also been asserted by the secretary of the Aborigines' Protection Society - which has been mainly responsible, with yourself and the Liverpool shippers and merchants, for working up this campaign of calumny - that the clerical party in Belgium is supporting the King in his Congo policy, irrespective of any atrocities that may be committed, because the King has agreed to support them in Belgium. This is not only a libel on Belgian Catholics and the Belgian people-who have been insolently referred to by the Daily News as 'barbarians'but is amply disproved by the fact that the most recent exposure of your tactics, and the tactics of your society, has been made in the columns of the well-known anti-clerical paper, The Independance Belge, of Brussels, which has published the disclosures with reference to your bribing of a Congo official to secure evidence from him, and has amply exposed, on many occasions, the selfish and dishonest character of this anti-Congo campaign.

"You have printed the grossest inventions with reference to the treatment of British natives in Congo territory. You have said that at Lagos, and in the surrounding district, if the word 'Congo' is mentioned to a native he will make for the bush if he is on land, and will jump into the water if he happens to be on sea, in order to escape going to the Congo!

"A full and impartial inquiry made by a number of English gentlemen at Lagos, and the evidence of one hundred and seventy-five natives taken on oath, shows how baseless and unscrupulous is your statement. One English gentleman declares that 'in a single week's time he would undertake to send two thousand natives to the Congo, if the English Government would permit their enrolment'-the taxation being so much heavier in British territory than in Congo territory, that natives have to seek in the latter the means of earning the taxation which they are compelled to pay to the British administration.

"Missionaries of all classes, Catholic and non-Catholic, have borne ample testimony to the humane and civilising influence of the Congo administration. Englishmen like Lord Mountmorres, Major Harrison, of Hull, Mr. Grenfell, Mr. Bell, Mr. Holland, Mr.. Maguire, as also Mrs. French-Sheldon, Mrs. Doering, and others, have borne the most emphatic testimony to the lies and misrepresentations that have been so sedulously spread by yourself and your friends with reference to the Congo administration.

"You cannot have failed to notice that in La Vérité sur le Congo for October-November, 1904, page 3, you are accused of actually having faked certain photographs which appeared in your book-one on page 49 , in which certain natives are represented holding cut-off hands. 


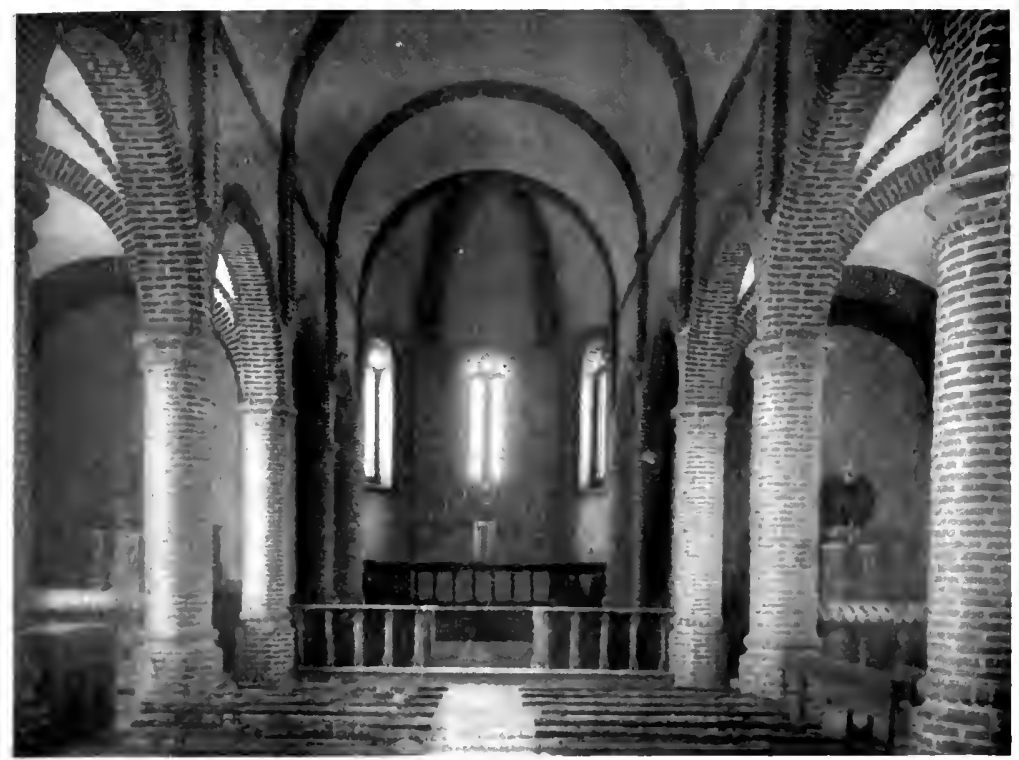

Interior of Cathedral, Baudouinville (Tanganyika).

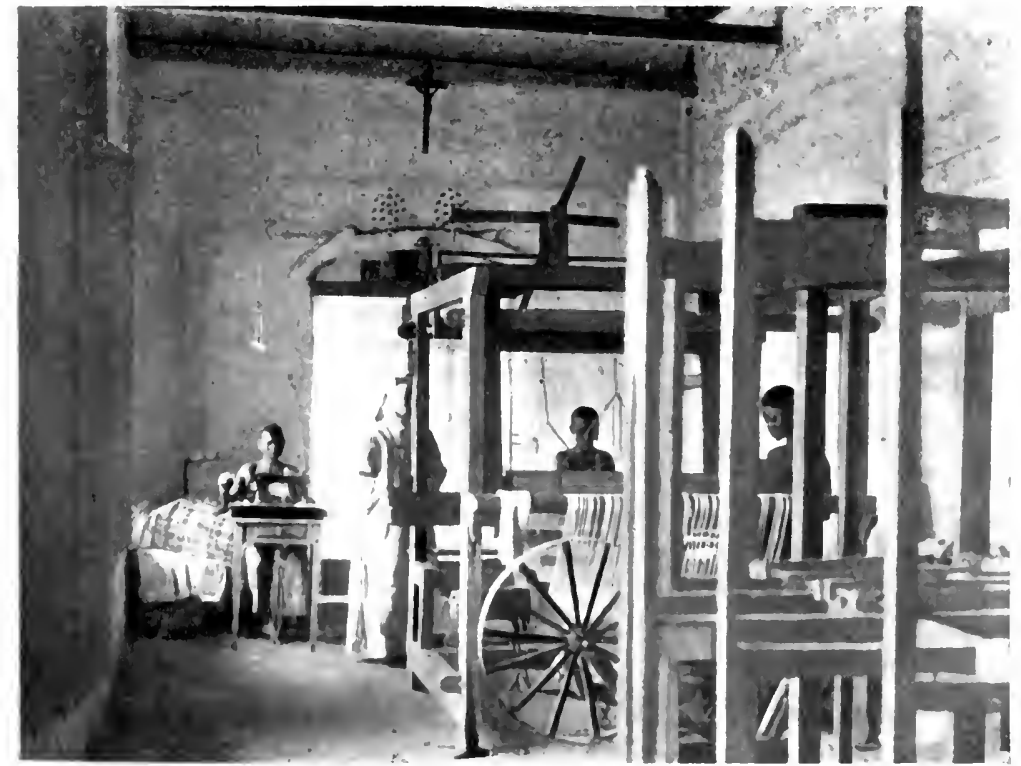

Sisters of New Antwerp Teaching Natives to Weave. 



\section{The Congo Campaign in England}

ciety, and kindred organisations, must find it increasingly difficult to justify their existence when

The publication referred to says that 'the hands seem to have been added afterwards'; and, with regard to a photograph on page 225 of your book, the same publication says that the chains around the necks of the natives would also appear to have been designed on the plate.'

"You have put these photographs forward as real. Will you produce the negatives and the rame of the person who took the actual photographs? Or will you remain content to rest under the charge of fabricating evidence of this description to deceive your readers?

"The Catholic Herald denounces, and will denounce, outrages upon natives and wrong-doing and maladministration of native territories, whether by Belgians or by any other people. No doubt wrong-doing has taken place; but is it of such a character as justifies people in this country taking up arms against those responsible for it?

"Is it not rather inseparable from the administration of native territories? Let any onc responsible for native administration answer this question, but let not the good cause of fair play and justice for the natives be disgraced and besmirched by the recklessness and viciousness that have been displayed in connection with this Congo agitation.

"The Catholic Herald accepts in full all responsibility for the statements made hcrcin, and for the publication of them, and for their circulation broadcast through the Press of this country, and belicves that in doing so it is discharging a public duty, not only to the Catholic name, which you have foully libelled, but also to the cause of international peace and goodwill, which this anti-Congo campaign, based on selfish and sordid motives, has done so much to impair.

"The administration of the Congo will compare more than favourably with the administration of native territories under British rule. There is more consideration shown to the natives, more care evinced for their interests, and they are less heavily taxed, and more humanely treated in the Congo, than is the case in any British territory in Africa to-day.

"Some of the lies sent forth on the wings of the Press are hereby nailed to the counter, and it is to be hoped that yourself, or your Society, will at once disprove, by any means at your disposal, charges which, if not so disproved, clearly show that your evidence in connection with these matters is discredited and untrustworthy, and that no one will be justified in paying attention to any statement of yours, unless supported by evidence that has not been purchased or invented.

"The EDITOR,

"The Catholic Herald." 
tactics such as are here exposed have to be resorted to. ${ }^{x}$

In 1902 , on the recommendation of a high official of the Free State, Mr. Antoine Benedetti, a cultured A Typical gentleman belonging to an ancient and Congophobe

Method. chief commissary-a post which had never before been conferred on a foreigner on account of its special responsibilities. This rapid promotion shows in what esteem Mr. Benedetti was held by his chiefs.

Mr. Benedetti returned to Europe on November 7 , 1904, and when requested to give his chiefs some information on the existing situation in the Congo, related circumstances which might well be considered fit for a novel, if their accuracy were not vouched for by authentic documents.

I From The Transvaal Trouble, an Extract from the Biography of the late Sir Bartle Frere, by John Martineau (pp. 21 I, 21 2):

"During these years, about 1879 , a society in London, called the Aborigines' Protection Society, took upon itself the function of judging between the white and the black races in South Africa, and of arraigning the conduct of the white race whenever there was a question between the two. That a society in London, with paid officers bound to justify their employment by finding something to complain of, should take upon itself to pronounce judgment upon difficult and complex questions between races in South Africa was, on the face of it, not more reasonable than that a society should be started at Cape Town, say, to protect women and children in London. By its constitution, which was practically that of advocatus diaboli against the white man, such a society must always of necessity take a one-sided view, from which misapprehension and mischief could hardly fail to result, however carefully considered were the methods employed.

" The methods employed by the Aborigines' Protection Society bore some resemblance to those of medixval Venice. The Blue-books of the time are full of letters from the society to the Secretary of State, detailing stories of alleged oppression or cruelty, and demanding an inquiry; or sometimes a question was asked to the same effect in Parliament. It would be many months before the reply to the in- 
While at Boma, Mr. Benedetti noticed that a Negro named Shanu, a British subject from Lagos, was trying to discover his opinions on Congo policy and administration. Shanu having been at one time in the employ of the State, Mr. Benedetti suspected nothing; but in the course of conversation with the Negro, he perceived what Shanu wanted to get from him. Shanu boasted to Mr. Benedetti of the humanitarian character of the English campaign against the Congo, and he further hinted that, if he were correctly informed, Mr. Benedetti would surely join in the said campaign, a course which would be of great advantage to him. Mr. Benedetti pretended to share the views of Shanu, who thereupon pushed the matter home by producing some letters of $\mathrm{Mr}$.

quiry could come back from the Cape, and, in the meantime, the story was circulated, and the refutation came too late to be listened to. The society generally refused to give the name of its informant, or the particulars of time and place, so that, like the lion's mouth at Venice, it offered an opportunity to any one-agitator, place-hunter, or criminal having a spite against a magistrate or official-to injure him anonymously. . . . The fear of being denounced by some scoundrel to the society in some districts seriously interfered with and often perverted the administration of justice. . . . In one instance, a man, on whose testimony is placed special reliance, was discovered to be a disfrocked clergyman who had been in custody for swindling another informant, who in turn was a trader who had been in jail for gun-running.

"Mr. H. Nixon, writing to Sir Bartle Frere, says:

"'The lawlessness of the coloured races and their hopeless state of degradation, their drunkenness, and general dissolute habits may fairly be laid to the baneful influence of the Aborigines' Protection Society, which has done everything it possibly could to paralyse the arm of the law in the execution of justice, and I consider the demoralisation of the natives is entirely due to their persistent agitation. The drunkenness in this province is quite alarming and unprecedented." 
Edmund Deville Morel, Secretary of the Congo Reform Association.

In one of these letters, Mr. Morel informs Shanu that Mr. Benedetti, commissary at Boma, has been spoken of to him as one who would be a valuable acquisition in the English campaign against the Congo. Mr. Benedetti at once saw what was expected of him; he realised that efforts were being made to enlist in the anti-Congo campaign the numerous Italians in the service of the Free State; and, with the sole desire of protecting the honour of his fellow-countrymen in the Congo, he resolved to defeat Mr. Morel's plans. With a view of gaining Shanu's confidence, he declared himself to be on the Negro's side, and by so doing compromised himself in the eyes of his official colleagues. He told Shanu -who lost no time in informing Mr. Morel-that by virtue of his position, he was able to make some startling revelations. Shanu thereupon suggested that he should send in his resignation, giving as the reason certain compromising allegations against the Free State. Shanu then wrote to Mr. Morel to the effect that he and Mr. Benedetti agreed that the latter was just the man to lead the campaign against the Congo. On the receipt of Mr. Morel's reply, the departure of Mr. Benedetti was decided upon.

Mr. Benedetti was promised his passage money to Europe, as well as compensation for the loss of his place under the Free State, and, later, a handsome bonus. Mr. Morel requested Mr. Benedetti to meet him at the Exchange Station Hotel, Liverpool, on 
the igth November, and to announce his arrival by the following telegram:

"Morel care Jellani arrived Benedetti."

Under these circumstances, Mr. Benedetti sent in his resignation, alleging that private business called him to Europe. He left by the SS. Philippeville, and the British Consul at Boma gave him ten pounds sterling for his travelling expenses. The receipt for this sum was made out by Mr. Benedetti in the name of Shanu.

Up to the time of his departure, Mr. Benedetti had discharged his duties so well that he was congratulated by the local authorities. Having spoken to nobody about the course he was adopting, so little was his sudden departure understood that his colleagues were mystified. He could not, of course, enlighten them without showing his hand. $\mathrm{Mr}$. Benedetti landed at Antwerp on November 7 th, and on the 17 th arrived at Liverpool, having previously despatched to Mr. Morel the telegram agreed upon. After some delay Mr. Morel went to see Mr. Benedetti at the Exchange Station Hotel in that city.

Mr. Morel appeared somewhat distrustful, and asked Mr. Benedetti if he had authenticating documents. The latter produced some unimportant papers, which he pretended were valuable, and told the Secretary of the Congo Reform Association some sensational stories of absolutely imaginary crimes. In short, Mr. Benedetti played his game so well that Mr. Morel no longer hesitated to close the affair, but said he would introduce to him a gentleman who was greatly interested in the Congo. 
In response to a telephonic message from $\mathrm{Mr}$. Morel there arrived Mr. John Holt, a merchant, of Dale Street, Liverpool. Mr. Holt is Vice-President of the Liverpool Chamber of Commerce and a member of the Congo Reform Association. Mr. Morel told Mr. Holt what Mr. Benedetti had said, and then certain practical questions were discussed. It was agreed that Mr. Benedetti should relate in the West African Mail the stories that he had just invented; but Mr. Benedetti, wishing to gain time, stated that he would rather publish them first in Italy, after which the organ of the Congo Reform Association might reproduce them. It was decided also to issue a pamphlet, for which Mr. Benedetti was to receive eighty pounds. Some generous promises were made to Mr. Benedetti: five hundred pounds as damages and his fare paid to Teneriffe by the Congo Reform Association. At Teneriffe, it was agreed, he should seek to poison the minds of Italian officers returning from the Congo. Later, Mr. Holt was to go to Italy where, together with Mr. Benedetti, he was to subsidise a newspaper to attack the Congo, and if this newspaper war resulted in the King of Italy recalling Italian officers serving in the Congo, Mr. Benedetti was to receive a further sum of four thousand pounds.

The former commissary of Boma would not accept verbal promises; he requested a document. $\mathrm{He}$ demanded first of all a contract for the publication of the pamphlet. Mr. Benedetti invited Mr. Morel and Mr. Holt to dinner, and it was during this dinner on the igth of November that the clauses of the contract were discussed. Conversation was carried on 


\section{The Congo Campaign in England}

to a late hour and Mr. Holt, in an unguarded moment, remarked that in England everything was done by and for the sake of business, and that sentiment was obliged to give way to trade. The signing of the contract was fixed for eleven o'clock on the morning of the 2 Ist of November, I904, when the three gentlemen concerned attended and the following document was drawn up and signed. The text is in English and French:

Between Mr. Benedetti and Mr. Morel it is agreed as follows:-Mr. Benedetti agrees to publish in a special pamphlet all the statements that he made and proved by means of documents on the evening of the rgth of November at the Exchange Station Hotel, in the presence of Mr. Morel and Mr. Holt, as well as various other facts the evidence of which is in his possession in Italy.

Mr. Benedetti shall first submit to Mr. Morel, before the $5^{\text {th }}$ of December, a rough copy of his pamphlet in English and Italian. Upon this rough copy Mr. Morel reserves the right to make corrections, and to send these corrections to Mr. Benedetti by the 9 th of December, unless prevented by force majeure.

As soon as the pamphlet has been approved by Mr. Morel, Mr. Benedetti shall send to Mr. Morel a corrected copy (if corrections have been made) in English and Italian, as well as a copy of the original documents in his possession, certified by the British Consul on the original text.

Mr. Benedetti undertakes to be ready to publish all by 22nd December, or by such date as Mr. Morel shall telegraph to him.

In any case, Mr. Benedetti will not publish all or any part of the pamphlet without previous understanding with $\mathrm{Mr}$. Morel as to the date.

Mr. Benedetti undertakes to place at Mr. Morel's disposal, after the publication of the pamphlet, all original papers 
referred to in the said pamphlet, and Mr. Morel undertakes to return them, if required.

Mr. Morel deposits a thousand francs for Mr. Benedetti's travelling expenses from Boma.

Mr. Morel undertakes to pay Mr. Benedetti the sum of two thousand francs, which sum represents the loss to Mr. Benedetti of his situation in the Congo State, owing to the publication of statements made in the said pamphlet, as soon as he receives from Mr. Benedetti notice that the pamphlet has been published in Italy, and a copy of the pamphlet.

Mr. Morel undertakes to pay the expenses incurred in publishing the pamphlet in Italy up to the sum of five hundred francs. Mr. Benedetti undertakes to send two hundred copies of the pamphlet to Mr. Morel.

It is understood on both sides that the above entirely covers all relations between Mr. Benedetti and Mr. Morel.

Mr. Morel undertakes to obtain from Mr. Shanu, of Boma, the receipt for the two hundred and fifty francs handed by Mr. Benedetti to Mr. Shanu, and to deduct the sum from the two thousand francs above mentioned.

Signed the 2 Ist November, 1904, at Liverpool Exchange Station Hotel.

E. D. MOREL.

A. Benedettr.

Witness to signatures of A. Benedetti and E. D. Morel: JoHN Holt, merchant,

8r Dale Street, Liverpool.

It is not without interest to call attention to the final clause, concerning the receipt for the 2,50 francs which Mr. Benedetti had given to Shanu, as a guarantee of the Ero which the British Consul at Boma had given him before his departure.

As to the clause concerning the thousand francs 


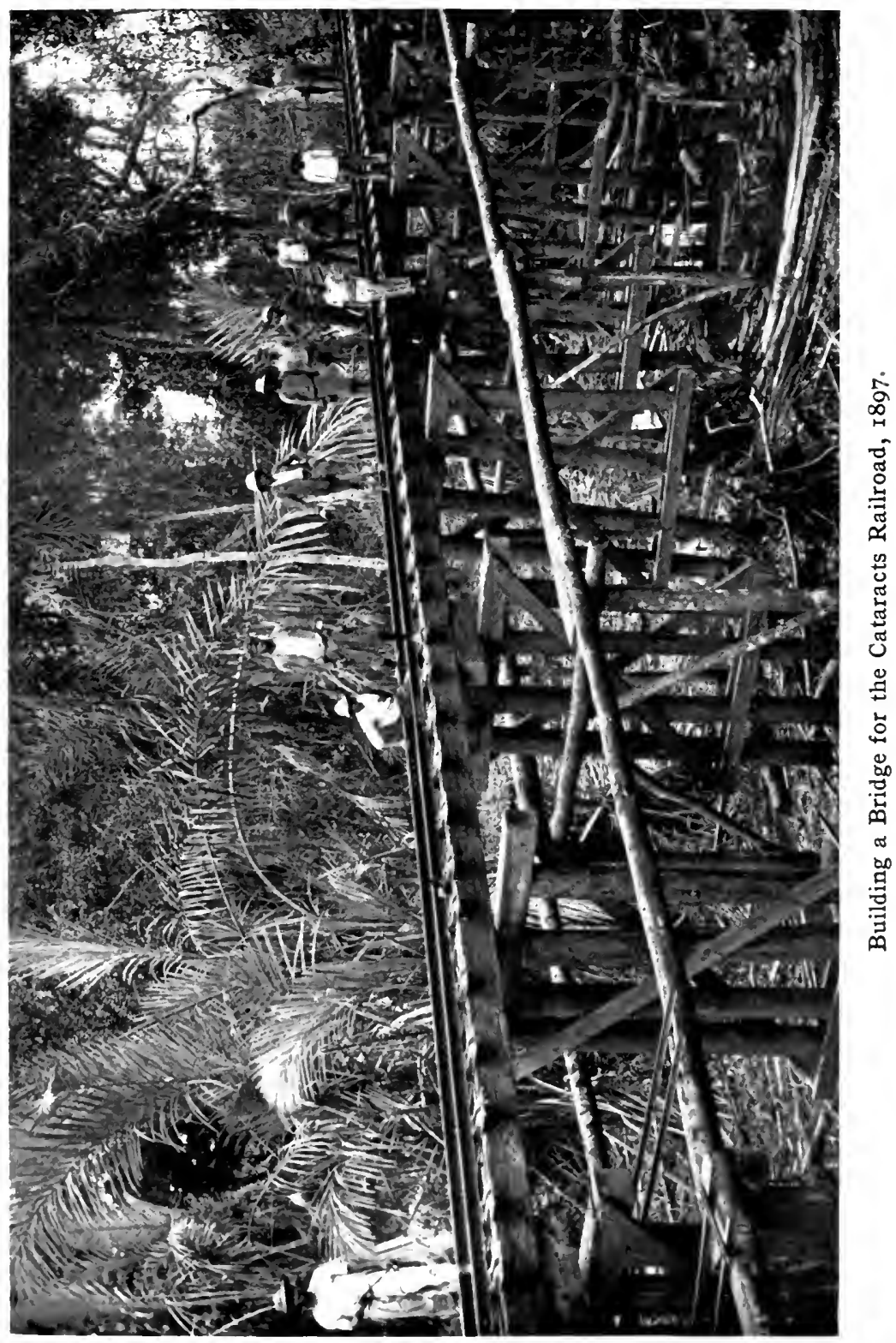



which Mr. Morel undertook to pay Benedetti for his travelling expenses from Boma, it came about through the fact that his departure from Boma was not in accord with the regulations. As his engagement was not terminated, the question of his being sent home at the expense of the Congo Free State was not settled. Mr. Holt took from his pocket a roll of Bank of England notes and paid Mr. Benedetti $£ 40$.

As soon as he was in possession of this contract, Mr. Benedetti returned to Brussels, whence he sent Mr. Morel the following letter:

Mr. E. D. Morel, Liverpool,

BRUSSELS, 3 oth November, 1904 .

I have the pleasure of remitting herewith to you a cheque on the South Wales Bank, Limited, No. Io9,880, to the order of Mr. John Holt, merchant, Dale Street, Liverpool, for $£_{4} \circ$, which this latter gave me in the Exchange Station Hotel, Liverpool, on the 2 rst of this month.

I will also send you a sum of $£$ ro in exchange for the receipt of Shanu, which you promised to procure for me.

You made a mistake, Sir, when you thought I would play into your hands in your campaign against the Congo, and thus do grievous harm to my countrymen working in the Congo.

Believe me, my conduct, from my first interview with Shanu, when acting for you, till my telegram from Paris on the 28 th of this month, was dictated by a sentiment of duty and patriotism.

\section{A. BenedetTi.}

The telegram to which Mr. Benedetti alludes was addressed to Mr. Morel from Paris, and was to call his attention to an article in the Tribuna favourable to the Congo, and to ask him for arguments in answer 
to this article for publication in an Italian paper. Mr. Morel replied that he had not had time to get the Tribuna article translated.

This edifying incident needs no comment. When the denial of its genuineness, or a qualification of its meaning and purpose, comes, it is understood that the Congo Administration will publish a facsimile of Mr. Morel's contract with Mr. Benedetti, bearing his signature and the signature of Mr. John Holt, merchant-philanthropist, Vice-President of the Liverpool Chamber of Commerce, etc., in order that intelligent people may form their own conclusions upon it at first hand.

Mr. Morel writes to the London Times of December I9, I904, defending the part he has played in this Benedetti incident. "You persist," says Mr. Morel (addressing M. Roland de Marès), "to make readers believe that I proposed to pay M. Benedetti for false testimony, whereas my rôle was limited to giving him the opportunity he asked for (that is to say, to come to Europe and to publish under his own name, in the interests of truth and of his fellow-countrymen), by defraying the expenses of his journey and the positive pecuniary losses which his action would involve, and by participating in the printing expenses of his pamphlet." 


\section{CHAPTER XXXI}

\section{THE CONGO CAMPAIGN IN AMERICA}

THE interest taken by Americans in the affairs of the Congo Free State has never been very keen. What little of interest, however, we do take in that distant region has been sentimental, for the greater part based upon the national respect for Stanley and his work. The campaign in England against the Congo, therefore, fails to evoke any substantial sympathy on this side of the Atlantic. Citizens of the United States are better employed than in undertaking knight-errantry at the behest of certain disappointed British merchants and fanatics.

But, inasmuch as it is vital to the enemies of the Congo Free State that our country should be with them in their crusade, the Rev. Mr. W. M. American Morrison, of Lexington, Virginia, a gentleman whose Christianity is liberally leavened

Aid

Wanted. with business acumen, was brought to the front and set upon a pedestal. The light of publicity was turned upon the reverend gentleman, who then proceeded to relate stories of outrage and oppression, examples of which he had seen and heard-chiefly heard-during six years' residence in the Congo Free State as a missionary of the American Presbyterians.

Mr. Morrison's stories are of the stock variety, and include looted villages, wholesale deportations, 
mutilations, burnings, State slavery, and refusal of land concessions to missionaries - in brief, the whole catalogue of infamies without which, real or alleged, men such as Mr. Fox Bourne, the Secretary of the Aborigines' Protection Society in England, and Mr. Morel, who built the Congo Reform Association around himself, would find their occupation gone. The italics are mine. Why I have used them will at once appear.

"Concessions or grants of land, however small," wails Mr. Morrison, "can now no longer be obtained A Morris- from the State by other than favoured indionian viduals or corporations . . . Not only Jeremiad. are concessions refused to traders, they are also refused to missionaries." Alas! yes, in the case of a missionary who demands, as Mr. Morrison did, "that no taxes shall be levied, and no soldiers drawn from certain populations around Luebo." I

The refusal of Mr. Morrison's demand for the creation of an Alsatia which should be equally attractive to the idle and the thrifty, from which the State was to receive no support, and which, in the circumstances, would certainly at once become the most populous district in all the Congo Free State, seems to have angered the reverend gentleman, for thereafter followed his discovery of atrocities committed by State officials against natives. Land was offered to Mr. Morrison upon equitable terms, identical with those agreed upon between the State and numerous other missions.

When Mr. Morrison was in Brussels in the spring

I The scene of the Rev. Mr. W. M. Morrison's mission. 
of 1903 , negotiating with the Congo Government concerning the concession of land, and in constant touch with officials of that Government, he said not one word about any atrocities which he had seen or heard of in Congo-

A Belated Discovery. land; but a few weeks later, he was in London, associating with the English Congophobes, and calling upon the Government of the United States to combine with that of Great Britain to coerce the Congo Government, though in what manner and to what effect is not quite clear. What, however, is perfectly clear, is the bad faith of the men who make it their business to vilify and misrepresent the Congo Administration. For example, here is Mr. Morrison's statement about the almost impossibility of obtaining concessions of land for missions, when up to May, 1903, there had been fifteen grants of land conceded in the Congo State to the American Baptist Missionary Union; two to the American Congo Mission; fifteen to the British Baptist Society Corporation; seven to the Bishop Taylor's Self-Supporting Mission; seven to the Congo Balolo Mission; eleven to the International Missionary Alliance; nine to the Swedish Missionary Society, and forty-four to the Roman Catholic Mission.

The campaign against the Cong in this country was opened on the I9th of April, I904, by the presentation to Congress of a huge inflated Few Facts memorial, accompanied by numerous sub- in Many stantiating documents of great length. It Words. was gotten up by the Rev. Thomas S. Barbour, 
Chairman of the Conference of Missionary Societies and Secretary of the American Baptist Missionary Union, Boston, with the assistance of the Rev. W. M. Morrison and six other gentlemen interested in missionary work. Senator Morgan, of Alabama, undertook the work of presentation, and performed his task with as much moderation and grace as its nature permitted. The memorial was referred to the Committee on Foreign Relations and ordered to be printed.

On the whole, the reception of this strange literary budget-a rechauffe of oft-refuted fables and adroit Not Uncle distortions of events that occurred long Sam's ago-was decidedly passive. The prevailAffair. ing impression among Senators seemed to be that even if all that is asserted in the memorial be true (a monstrous supposition which surely. its promoters never seriously entertained), to play into the hands of John Bull's merchants at the bidding of John Bull's missionaries is hardly a suitable rôle for Uncle Sam.

The next move in. the campaign against the Congo Free State in this country took place at A Mischiev- Washington on the 3oth of September, ous Busy- 1904, when the Secretary of the Congo body. Reform Association (an English organisation of which Mr. John Holt, the merchantphilanthropist, of Liverpool, is one of the pillars) presented a memorial to President Roosevelt concerning affairs in the Congo Free State, and asking for his intervention therein. The memorial was politely received, acknowledged with graceful platitudes, 
and laid aside. During the few weeks that the Congo Reform Association's agitator was in this country, he talked freely to every newspaper reporter he met, and disseminated broadcast the old libels which had grown stale with use in England.

When the Belgian people learned of the presentation to President Roosevelt of the second anti-Congo memorial, wherein the agents of the British ${ }_{\text {The Belgian }}$ merchants strove to make it appear that People the United States ought to do what all the Speak. continental powers had, by their silence, refused to do when the British Foreign Secretary appealed to them in August, 1903, their leading citizens took a hand in the literary carnival and sent President Roosevelt their reply to the series of slanders which were being so widely disseminated in America by the Liverpool organisation. Although the anti-Congolese resolutions of the Boston Peace Conference were published in extenso in the secular and religious press throughout the United States, for some inscrutable reason the Belgian reply to the second Liverpool memorial sent to President Roosevelt on October 3, 1904, has so far never had the advantage of similar publicity. This fact alone would indicate that his Excellency, Baron Moncheur, Belgian Minister to the United States, and his talented coadjutor, Professor A. Nerincx, an eminent Belgian advocate, author, and instructor in the University of Louvain, were quite indifferent to that campaign of publicity which the enemies of the Congo Free State began in England and now continue in America. In justice, however, to the Federation for the Defence of Belgian 
Interests Abroad, a Belgian society numbering over fifty thousand adherents, it is deemed desirable to quote in full the only communication bearing upon the anti-Congolese campaign which the official of the Free State or the Belgian people have ever addressed to the people of the United States:

\section{FÉdERATION POUR LE DEFENSE DES INTERETS BELGES $A$ L'ETRANGER.}

Brussels, October 3, I904.

To His Excellency, Theodore Roosevelt, President of the United States.

Mr. President:

The Federation for the Defence of Belgian Interests Abroad presents its compliments to the President of the United States and begs leave to state:

That we are loth to impose upon the President of the United States considerations which are foreign to the interests of his Government. But inasmuch as certain persons are conducting within the United States a movement to involve the Government of the United States in the consideration of their unfounded charges and interested misrepresentations against the Government of the Congo Free State, we feel it our duty to present a brief statement of the objects of the Congo Government to the President of a friendly Power in order that the unjust methods being employed by the enemies of the Congo Free State may not mislead the President to encourage Congressional action prejudicial to our interests before we shall have been fully heard.

Our Association has been formed for the defence of Belgian interests and possessions abroad. Our people esteem and admire the people of the United States and we have great respect for their President. The Belgians desire that they shall not be slandered and vilified in the midst of the American people. They feel it their duty to assist the American people to a proper understanding of the lofty purposes which actuate the 


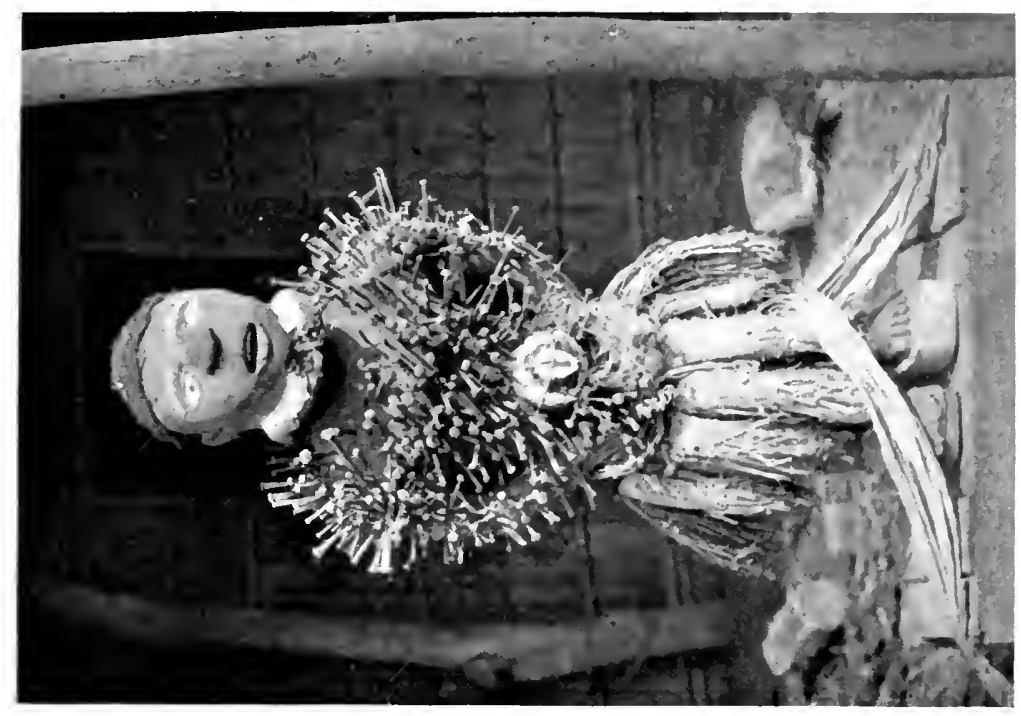

00

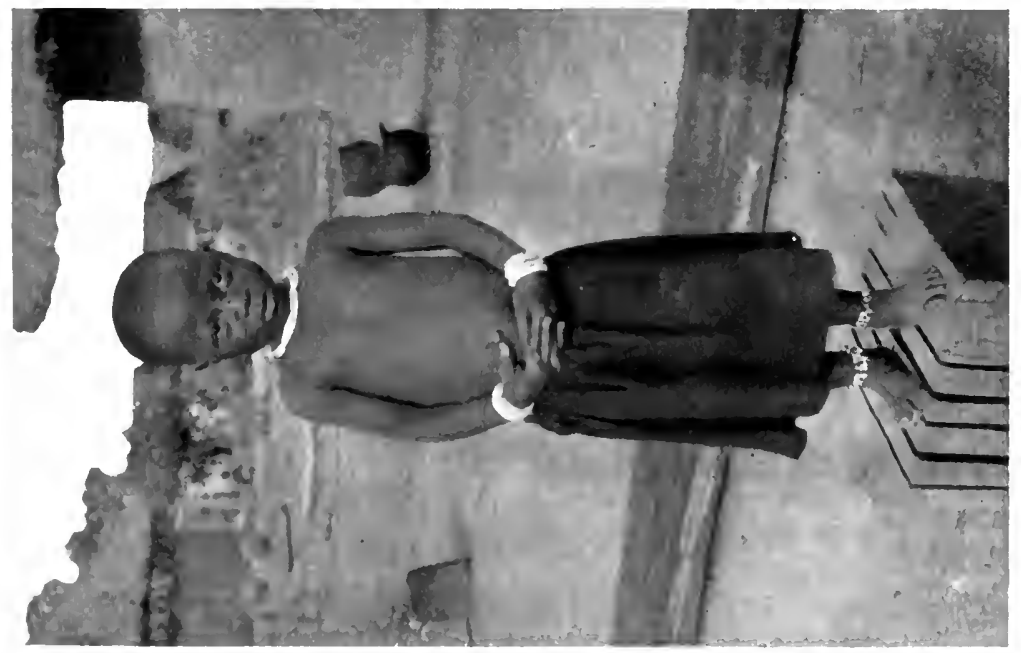

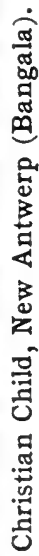





\section{The Congo Campaign in America}

Government of the Congo Free State. In this connection the Belgians recall with pleasure and with pride the fact that the Government of the United States was the first great nation to recognise the flag of the International Association of the Congo as that of an independent State. By its treaties and by its adherence to the Berlin and Brussels Acts it promised liberty of trade in its part of the Congo Basin, and it respectfully asserts that it has fulfilled that promise in spirit and to the letter in so far as the short term of its existence in a savage country has enabled it to establish an organisation which, by its prosperity and progress, now excites the envy of those who seek to disrupt it.

The principles which actuate the Congo Government are tersely set out in an essay written by a highly qualified American citizen, which is herewith enclosed. We humbly beg the President of the United States to honour us by perusing this concise exposition of the fundamental principles which underlie, and which have given such progressive momentum to, the Government of the Congo Free State.

The principles of the Congo Government are devoted to progress and civilisation. The State's motto is "Work and Progress." We have always felt that to intelligently follow that motto was to firmly establish in the midst of conditions of savagery the habit of industry and a respect for property as well as for life, according to the universal law of nations.

Concerning the term "Freedom of Commerce," which Congo enemies are interpreting to mean ungoverned license, we beg to. refer the President to the laws of the United States and penalties concerning trespass upon and pillage of public lands and their product. Perhaps no nation in the world has so precisely developed the law of private and public property, nor administered it with finer understanding of the principles of equity and justice, than the United States. The Congo law relating to property is in consonance with the law of the world's greatest nations. The great success which has been attained by the Congo Government for the betterment of its native inhabitants by the operation of this law, and the order which exists thereunder, has excited the envy and the avarice 
of those whose ulterior motive is being cloaked in the garb of humanitarianism and questionable philanthropy. On the one hand it is charged that the Congo Government by its method seeks to enslave the native in order that he may serve it with his hands for the benefit of interests whose welfare he does not share. On the other hand, the libellers of the Congo wilfully utter not only the unfounded accusation but the inconsistent charge, that the Government cuts off the hand whose work it seeks to enslave. Concerning the untruthful character of the testimony in this respect which has been published against the Congo by the promoters of the so-called "Congo Reform Association" of Liverpool, we beg to refer your Excellency to the great mass of genuine and reliable evidence by Englishmen, Frenchmen, Germans, Americans, Italians, and Belgians in direct contradiction of the falsehoods which form the traffic of the Association, whose leading spirit has never been near the Congo nor the natives who form the pretext of his search for personal notoriety and aggrandisement.

We also call your Excellency's attention to the fact that the Congo Government, when assailed by missionaries at all, is assailed by a few individual missionaries operating in conjunction with the Liverpool Association, whose object we shall in due course expose. The Congo Government has not been assailed by other missionaries at all. The Catholic missionaries are in reality all seeking the moral, spiritual, and intellectual betterment of the native races, while those of a material faith, who have sought from the Congo Government and been denied personal concessions of material value solely, are secretly working in directions entirely unconnected with the spiritual and moral welfare of the Congo population. In due time and in the proper place the Government of the Congo Free State will produce its testimony bearing upon this phase of the campaign begun in England, and now carried to the United States, against an undertaking which within twenty years has done more to promote civilisation than was ever before attempted in all the great continent of Africa. 
We beg your Excellency to receive from the hands of our representative an abundance of carefully prepared matter upon this subject, and to command him in any further desires which you may wish to express. A cursory outline, limited to only a few phases of the questions which the enemies of the Congo so confusedly mince in their wild condemnation of a State justly founded and intelligently and humanely governed, is not of course intended as a sufficient statement of our case. It is merely intended to introduce your Excellency to the subject on which our representative, and the evidence and literature he will offer to you, may lead you to those wise and equitable conclusions which have always characterised the highest tribunals of the American people.

Your Excellency is too well versed in the science of government to be influenced by the statement that where individual acts are committed in violation of enacted penal law the Government should be primarily charged therewith. If such were the case, penal institutions for the incarceration of violators of police law would be no part of a nation's structure.

It is not infrequent that the cable conveys to us intimation that in some sections of your own free and glorious country an inflamed mob seizes upon a black inhabitant and burns him at the stake. Our governmental experience has taught us that such acts would have been impossible if your Government had been advised in time to prevent them. And yet we know that your Government is the subject of harsh criticism by self-constituted associations formed in the same country whence come those who accuse the sincere governmental effort of the Congo Free State. The law of the Congo Free State is based upon the loftiest ideals of humane control of a vast territory and undeveloped interests, and every part of the State's machinery is employed to ensure equal justice to all.

The "method of the State," at which Congo accusers hurl their shafts, cannot be charged with responsibility for lawless acts in a vast territory of a million square miles where the Government of that State is vigilantly and earnestly seeking, 


\section{Story of the Congo Free State}

by the extension of its organisation and police powers, to suppress and punish crime and redress wrong. If the subjects of one nation were compelled to submit to the opinion of its unfriendly neighbours as to the correctness of their habits and conduct, and obliged to submit themselves to the penalties that their neighbours would attach to the alleged misconduct, the subjects of one nation would inhabit the prisons of another.

We need hardly call the attention of your Government to the great and humane work which your Government is now so earnestly, and with so much sacrifice, furthering in the Philippine Islands, to meet with that broad and sympathetic view of the situation in all savage countries; which, if fairly and justly applied to the Congo Free State, would place us upon that plane where co-operation, not criticism, were the reward of our sacrificial work in the darkest part of Africa.

It has been the pleasure of our beloved King, Leopold II., Sovereign of the Congo Free State, to appoint a Commission, composed of eminent men, to undertake with the utmost freedom a judicial investigation upon all and singular the vague charges from time to time used by the promoters of the Congo Reform Association in prostituting certain public journals in England. Your Excellency may be assured of the utmost integrity of the gentlemen who compose this Commission, and that the Congo Government will afford them all the help in its power to place the truth before the eyes of the world.

In this connection Congo reformers pretend that the decisions of the Congo Courts indicate that the government is bad, when in fact these very decisions are, in our opinion, proof of unimpeachable good faith and judicial independence.

Concerning the Congo standing army of 14,000 natives, as to which some criticism is uttered by the same persons, we need only indicate that the State Government is so well respected in the Congo Basin that it is able to control its vast territory with only seven soldiers to every 625 square miles. We have no doubt that if the Congo governmental system had not included this meagre police force for the repression 
of tribal strife and the maintenance of order, its critics would have represented the Congo Government as unprepared to guarantee protection to persons and property, and as unable to maintain the integrity of its frontiers. The Congo army is recruited in conformity with the Belgian law of conscription, which is a restriction of the universal service in Continental Europe. When the Government enlisted a part of its army in a neighbouring colony it was requested to desist, the promises of England to permit such recruiting notwithstanding. Now the Congo army is characterised as barbarian! Doubtless the Congo Government would have no objection to recruit its army in China, as miners are recruited for the Transvaal. But would it thereby escape censure? We think not. Some things which are right and proper in a British colony become crimes when done in the Congo Free State.

It is the earnest desire of the Belgian people, and those who are interested in the welfare and progress of the native population of Mid-Africa, that the good-will and respect of the people of the United States and their President may continue, by their sympathy, to enliven the devotion, energy, and sacrifice which the builders of the Congo Free State are expending upon races which but a few years ago were in a state of the wildest savagery.

We are, Mr. President, with great respect,

Your obedient servants,

(Signed) A. Dufourny,

President of the Federation for the

Defence of Belgian Interests Abroad.

At the Peace Congress held at Boston in October, I 904 , to attend which was as much the reason of the visit to these shores of the Secretary of the Congo Reform Association as the presentation of a memorial to President RooseKing Leopold Attacked. velt, he recited his usual tirade against the Congo Government and the person of King Leopold with 
somewhat more than his customary unction; but his contentions were utterly demolished by the superior information and saner reasoning of his fellow-countryman, Mr. George Head, and by a letter which was read from Cardinal Gibbons (vide Chap. xxxiv), warmly defending the aims and achievements of the Belgians in Central Africa.

The net result of the Peace Conference to the Congophobes is to expose and appreciably weaken their conspiracy.

There remains in our country a small section of the press obedient to the will of anti-Congolese conspiracy and the eloquent sophistries of Messrs. Fails. Morrison and Barbour. But these forces are surely inadequate to cause the Government of the United States to forget all of our political traditions, and to so abate our natural shrewdness, as to become a catspaw for an avaricious foreign commercial clique. 


\section{CHAPTER XXXII.}

TESTIMONY OF TRAVELLERS AND THINKERS

SIR HENRY M. STANLEY

I T will ever be esteemed a fortunate circumstance by all who have regard for historical accuracy, that the late Sir Henry M. Stanley, discoverer of the course of the Congo, who assisted so materially in the creation of the Congo Free State, did not pass away without recording his opinion of the campaign of calumny against the Congo Administration. Incomparably the greatest authority of his time upon this subject, what Stanley had to say about it must be given here in full. It took the form of an interview with a representative of the Knowledge press, and was first published in the Petit and Truth. Bleu (Brussels), I 3 th November, I903:

I do not believe [said Sir Henry Stanley] in the charges brought against the Congo, and I do not share the opinions that inspire them. I do not think that any State will be inclined to step in, and to spend the money that Belgium and the King of the Belgians spend to adapt the darkest part of Darkest Africa to the interests of commerce. King Leopold lately assigned $£_{1} 20,000$ a year to the Congo administration. He thereafter gave $£_{40,000}$ and Belgium $£ 80,000$. Tell me, what other country would be ready to do as much?

When I consider the limited number of years which have 
elapsed since the Congo became a State, I hold that the work which has been accomplished there does great honour to Belgium, and I am certain that not one of the countries who are invited by the newspapers to put itself in its place would have been able to do better.

You can feel certain that the King of the Belgians interests himself personally in the smallest detail of the administration. I do not pretend that he can superintend the acts $8 \mathrm{f}$ each individual, but what Government, what State could do that? But the recitals of atrocities, and of bad administration which have of late been spread about are almost all, if not all, pure reports. Naturally, if it is question of seeking cause for a quarrel there is no difficulty in finding it; but if the Congo of r 885 is compared with the Congo of to-day, it must be allowed that its progress has been remarkable.

The English Note of the month of August is founded, I am convinced, on reports stamped with partiality. The assertions of a missionary have been reproduced, according to whom the natives flee at the approach of the Congo State officials. They fled before me also when I was there. The mere apparition of a white man, the simple sight of an unusual being or object, puts them to flight. That is part of the animal instinct of self-preservation. Whites and blacks always approach one another for the first time with a general sentiment of distrust. Little by little they learn to know one another, and this sentiment disappears.

The Congo was in truth the darkest part of Africa. To-day with its forests pierced and open, its routes, its stations, it. is in advance of all other African States. Take the French Congo, German East Africa, Portuguese West Africa, and compare them! The Congo State prospers in a greater degree than any other part of the black continent.

The Congo State is accused of employing as soldiers cannibal Negroes. When I was on the Congo, and I accused a tribe of cannibalism it replied: "We are not cannibals, but our neighbours are." The neighbouring tribe said: "It is not we, it is the next tribe that you will meet"; and that tribe referred us on to the next, and so on continually. They 


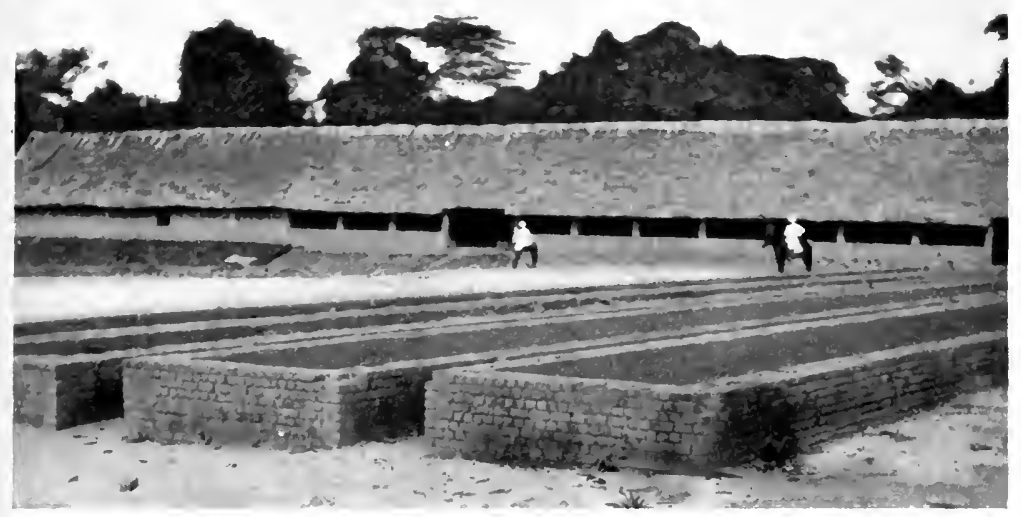

Coffee-Drying Grounds, Coquilhatville (Equateur).

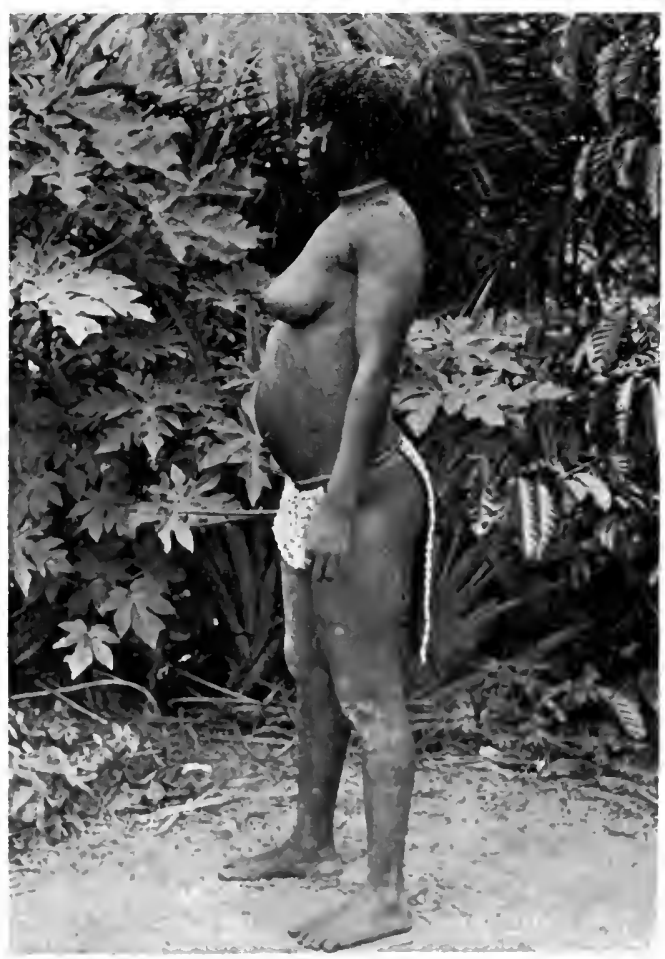

Bakusu Woman (Lualaba-Kassai). 

seemed to be ashamed of their cannibalism. They concealed it. Yet there was no doubt as to the existence of this practice. I frequently met with trenches freshly disturbed, from which corpses had been taken to be eaten. It was very seldom that I could discover the guilty. How then in recruiting its troops was the Congo State to distinguish the black cannibals from those who are not cannibals?

I am convinced that since I left Africa King Leopold has done his best to prevent all crime on the Congo. But he is no more responsible for the crimes which may be committed there than for those occasionally committed on the soil of Belgium itself. There are on the Congo 300 officials who report to the Governor-General, who in his turn addresses a summary of these reports to the King. They discharge their mission under the most difficult conditions, and I believe that I may assert that from the Governor-General down to the humblest official there is not one of them guilty of cruelty. Moreover, it is for those who speak of atrocities to furnish proof of them.

I know by experience what a large number of stories are put forward, then refuted, and afterwards resuscitated year after year. These are legends for travellers. Use is made of them with every change of the wind in Africa. Those who relate them are often the prey of climatic maladies.

The Congo has not the most enviable climate in the world. The maladies contracted there are often debilitating, and things are seen and things are described through the malady, which distorts the morale and changes the optic.

I had on the Congo under my orders 300 men-English, Germans, Dutch, Portuguese, Belgians. There were 80 English, but the majority were Belgians. I found no difference between them. All did their best, according to their means. All were, in the course of duty, the object of some charge. I examined the charges minutely, and always found them to be without foundation. That did not prevent these stories reaching Banana, and from there Europe. Well, that is what happened on the Congo in my time; that is what is happening there to-day. 
The sentiment that inspires the charges against the Congo is jealousy. The Congo is succeeding better than any other State of Africa.

I do not think that the Congo State would be administered better by France, the United States, or Germany. Under French administration the Congo would retrogress. Germany would content itself with fortifying it in a military sense. And commerce does not develop when it is covered with a coat of mail. Germany does not permit and will not permit the English to penetrate into its territory, except under certain restrictions. England would not have managed the Congo better than King Leopold has done if she had been mistress of it, as she might have become in 1877 .

The white man must remain master of the Congo. Drive him out of it, and you will see war arise anew between one native village and another, a return to barbarism. It is difficult to govern so vast a country; yet, in a limited number of years, the King of the Belgians has put an end to the horrible Arab slave trade. I do not think there is another sovereign living who has done so much for humanity as Leopold II.

SIR HARRY JOHNSTON, G.C.M.G., K.C.B.

About a year previous to the publication of Stanley's vindication of the Congo Administration, appeared a remarkable book, entitled The Uganda Protectorate, written by the distinguished English traveller, Sir Harry Johnston, from which the following passage is taken:

In spite of an element of Arab civilisation which the slavetrader had certainly implanted in the Congo Forest, he had made himself notorious for his ravages and cruelties. Numbers of natives had been horribly mutilated, hands and feet lopped off, and women's breasts cut away. These people explained to me that these mutilations-which, as only a Negro could, they had survived-had been the work of the Manyema slave-trader and his gang, done sometimes out of wanton 
cruelty, sometimes as a punishment for thieving or absconding. May it not be that many of the mutilated people of whom we hear so much in the northern and eastern part of the Congo Free State are also the surviving results of Arab cruelty? I am aware that it is customary to attribute these outrages to the native soldiery and police employed by the Belgians to maintain order or to collect taxes; and though I am fully aware that these native soldiers and police under imperfect Belgian administration, as under imperfect British control, can commit all sorts of atrocities (as we know they did in Mashonaland and in Uganda), every bad deed of this description is not to be laid to their charge, for many outrages are the work of the Arab traders and raiders in these countries, and of their apt pupils the Manyemas. This much I can speak of with certainty and emphasis: that from the British frontier near Fort George to the limit of my journeys into the Mbuba country of the Congo Free State, up and down the Semliki, the natives appeared to be prosperous and happy under the excellent administration of the late Lieutenant Meura and his coadjutor, Mr. Karl Eriksson. The extent to which they were building their villages and cultivating their plantations within the precincts of Fort Mbeni showed that they had no fear of the Belgians, while the Dwarfs equally asserted the goodness of the local white men.

Great value attaches to the evidence of Sir Harry Johnston, it being impossible to impute to him any particular bias. He travelled independently, visiting the Congo on three occasions- $1882-83, \mathrm{r} 89 \mathrm{I}-96$, and rgoo. In a letter published in the Daily Chronicle (London) of 28th September, 1903, he thus further expresses his opinion of the Congo Administration:

I was present on the Congo at the birth of the Congo Free State. In I $88_{2-1883}$ I paid a prolonged visit of eight months 
to Stanley. During the course of this visit I travelled up the Congo nearly as far as the point where it crosses the Equator. I came into continual contact with the Belgian officers and officials who had been sent out on the part of the Comité d'Etudes du Haut-Congo to assist Stanley. I may mention that I was "nobody's" man. I paid my own travelling expenses, and had no reason to espouse any one cause more than another. I conceived, however, the highest admiration for Sir Henry Stanley, personally, and for the work he was doing. I convinced myself over and over again by constant cross-examination of the natives of the Congo, and of Zanzibaris and Somalis, that Sir Henry was always just and never cruel, and that the first interests he had at heart were those of the natives of Africa. His memory still lingers. in all the regions from the mouth of the Congo to Zanzibar, and any one who doubts the justice of my opinion has only to do as I have done through many years-question the natives as to their impressions of "Bula Matadi" (the Breaker of Stones). Nor did I at that date see anything to object to in the conduct of the Belgian officers, for many of whom I entertained feelings of warm friendship and esteem. The work of such men as Nilis, Van Gèle, Hanssens, Coquilhat, Braconnier, Janssen, and Roger, not to mention others, was such as no missionary could or did find fault with.

\section{And again:}

Subsequently when I returned to the vicinity of those regions as Commissioner for British Central Africa, I came a good deal into contact with the Belgian officers sent to control those countries. I never received any complaints from natives or Europeans at that time which tended to show that the natives were ill-treated by the Belgians.

Lastly comes this convincing pronouncement:

In I 900, whilst at work in Uganda, I had occasion to visit the adjoining regions of the Congo Free State along and 


\section{Testimony of Travellers and Thinkers 403}

across the Semliki River. In this portion of the Congo Forest (into which my expedition penetrated for about thirty miles west of the Semliki) I questioned many natives-Pigmies, Babira, Bambuba, Lendu, Bakonjo, and Basongora. From none of them did I receive the slightest complaint as regards the treatment they received from the Belgians, and indeed the sight of their villages, plantations, and settlements, the fact that they so freely came and talked to the white man, were sufficient to show that they were perfectly content with their present lot. The Belgian and Swedish officers whom I met in this portion of the territory of the Congo Free State were men of the best character. In short, this portion of Congo territory left little to be desired, and in some respects was better organised than the adjoining districts of the British Protectorate. One Musongora chief complained to me that the native soldiers in Belgian employ had taken away some of his wives. He expressed himself so dissatisfied with this treatment that he asked permission to cross over into British territory. That permission was given him; but when he found that he had to pay the hut tax on Uganda soil he returned to his old quarters. In addition to the foregoing experiences I might say that I took into my employ about this time natives of many districts along the Upper Congo, from the country of Bangala on the west to the mouth of the Aruwimi on the east. I did this with the idea of making studies of their languages, and they lived with me for about a year, accompanying me on all my journeys through the Uganda Protectorate. I did not ask the permission of the Belgians to recruit these people, for the very good reason that, having apparently complete liberty of action, they had walked through the Congo Forest to the British frontier to offer themselves for work. It cannot be said therefore that the Belgians selected people especially to fill my ears with pleasing stories as to Belgian administration. I questioned these natives of villages all along the great northern bend of the Congo. Not one of them had any complaint to make against the Belgians. When I was preparing to leave Uganda to return to England I offered these men (who were accom- 
panied by their wives) plots of land in the Uganda Protectorate; but they were quite decided in wishing to return to their homes on the Upper Congo; and so far as I know they did so, as every facility was given them in that direction. It strikes one that if these particular people were living under a reign of terror they would hardly have been so eager to return to their homes with the wages they had earned.

The absolute impartiality of Sir Harry Johnston's review of the Congo Administration well appears in the few following words; in which it will be noted, that while he claims no immaculate perfection on behalf of every Belgian official, he compares them as a body, and that not to their disadvantage, with his own countrymen:

There are, no doubt, bad Belgians, as there have been bad, cruel, and wicked Englishmen and Scotchmen, amongst African pioneers. In the early days of African enterprise I have seen too many misdeeds of my own countrymen in Africa to be very keen about denouncing other nations for similar faults.

\section{MAJOR JAMES HARRISON}

This eminent authority on the Congo has recorded his impressions of the social and economic conditions prevailing in that country, and of the false statements regarding them disseminated by interested parties, in the following letter, which appeared in the London Times of June 10, 1904:

\section{To the Editor of the "Times"}

SIR,-Having just returned from a shooting trip across the Congo Free State from the Nile to Boma, on the West Coast, I naturally feel much interested in the correspondence now 


\section{Testimony of Travellers and Thinkers}

going on with regard to that country. As I came down the Congo River a copy of Mr. Casement's report was lent me to read, and I was more than surprised at the contents of a letter written by Lord Cromer, which was inserted as a prelude to the more serious indictment following.

Now, Sir, had this letter been published alone it might not have seemed so serious, but taken in conjunction with what followed it formed a most damaging article.

As my experience of the Government of the Lado Enclave is so entirely opposite to the view taken of it by Lord Cromer, I feel compelled, in fairness to the Belgian officials, to give my views of the country and its Government. That I am not alone in discovering so much that is good in the Belgian administration of the Lado Enclave is vouched for by other English officers who have hunted and travelled among the natives beyond the waters west of the Nile.

I assume from Lord Cromer's report, and from what I was told at Lado, that he only landed at the Kiro and Lado stations, so that the greater part of his report must have been founded on information supplied by others, which, besides being often incorrect, might possibly have reference to times gone by, when, I believe, a certain official was promptly dismissed the service for unfair treatment of the natives.

Lord Cromer compares the deserted appearance of the west banks of the Nile with the east bank between Kiro and Lado.

My experience of this part was that you could hardly see anything of the west bank, owing to the channel lying well over to the east, and endless sudd stretching to the west. The reasons for natives not living near the bank I give later on.

Again, Lord Cromer contrasts the peaceful, settled state and the confidence of the tribes under English rule on the Nile as compared with those on Belgian territory; yet within a few months of his visit a whole British force was annihilated on the Bahr el Ghazal, while in the Game Ordinance published last year it stated: "The whole of the left bank of the Nile is at present closed to sportsmen, owing to the unsettled state of the natives."

Since my return I see that yet another British force has been 
severely handled by the natives. Through the whole of my Congo trip, absolutely alone, I wandered about, visiting $5^{\circ}$ different tribes and hundreds of villages, armed as a rule with a camera, umbrella, and, at times, a collecting gun. Yet I had no unpleasant experiences; on the contrary, I was received with kindness far different to any I ever met with when hunting among British African natives.

As I went up the Nile I heard the same stories Lord Cromer did-as to how all the natives were flying across the river from the Belgian country owing, I was told, to ill-treatment. As I spent a month hunting all the district 40 miles inland from Lado and Kiro, looked after by the two big Bari chiefs, Kenion and Fariala, I took great interest in learning all I could, and, owing to my capitow talking Arabic, the chiefs' favourite language, I had excellent chances for finding out all I wanted.

To my question as to whether many of their tribes went over the river, and why, they replied: "A few boys ran away the other side, but mostly bad boys who won't work." Asked again, if a few good men went, and, if so, why, they answered: "English pay in money; some boys, if once had money, like it better than being paid in cloth or beads," but no mention of ill-treatment.

Lord Cromer considers because the native villages happen at these particular posts to be several hours' distant, that this is also owing to bad treatment. I wish to point out that the villages must either be right on the Nile bank, or inland where they are, for the whole country between is waterless during four months. Another reason given for not living on the Nile was that in olden days the few who did so were all killed or taken prisoners by the Dervishes; hence the survivors kept clear of waterways.

Again, there are no sites for villages near the river, as nearly all the banks, lying low, are covered with marsh and sudd, harbouring millions of mosquitoes, whereas a few miles inland there is good water, not a single mosquito, plenty of game, with good grass and tillage land.

When I visited Gondokoro every one was complaining at 


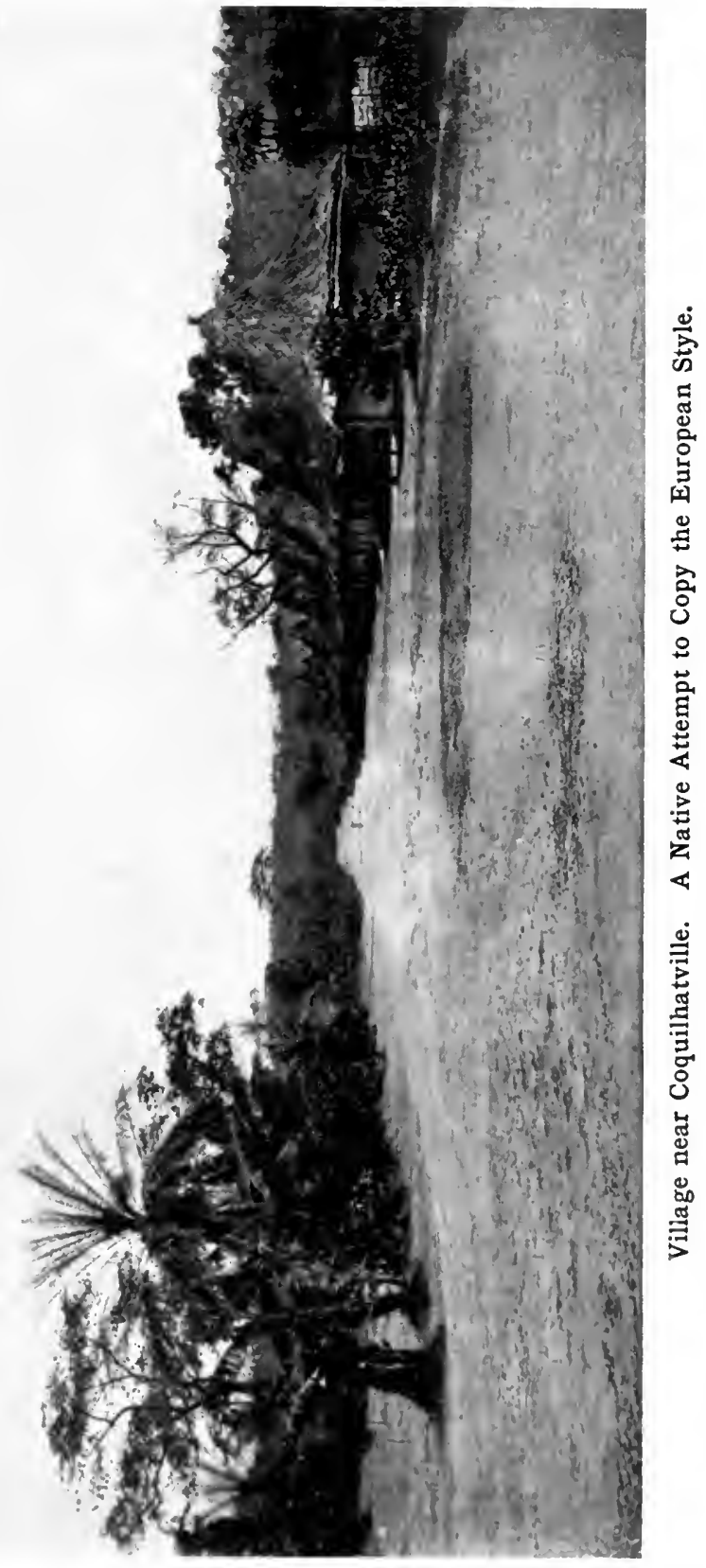



having the station on the Nile, instead of a few miles inland, for similar reasons.

One of the wisest rules of the Congo is not to allow native villages adjoining the posts; and $I$ hear we are copying the same on the West Coast; it means a reduction of 75 per cent. in sickness.

That no natives live near Lado arises from purely natural causes. Lord Cromer would find plenty of posts in the interior, with thousands of natives settled as near as they are allowed to.

Another statement, that "the soldiers are allowed full liberty to plunder the natives," is by no means correct. During my journey I saw hundreds of soldiers being sent off on different work-such as postal, Government despatches, fetching in porters, etc.; but not one ever left without having received cloth, beads, or wire sufficient to purchase all necessary food. I quite admit a few of the soldiers helped themselves now and again, and I found the worst sinners in this respect were our own Sierra Leone boys, a number of whom take service in the Congo. Should their acts be reported they are quickly dealt with.

During my trip I must have employed over 1200 porters. I can only say I never came across a more cheerful, welldisposed set of men. I never had the least trouble with them, though asking them to march 30 and 40 miles a day. How often I thought of my woes and worries in British Central Africa, never knowing how many porters would run away each night, though only marching ten miles a day! Had all the accounts of ill-treatment and non-payment been true, would men have come in so readily and worked for me as these carriers did? Many an hour at night I used to spend getting them to talk about the country, its ways, and any grievances. I found, naturally, two or three officers who were evidently disliked (no doubt I will be added to that list after our long marches); but, on the other hand, they talked of many officers as their "white fathers." As for the way in which the Belgians have opened out the country, it is wonderful. The posts are now all well-built brick houses, and in a few 
months' time most of the barracks will be similar; excellent roads connect many of the posts, while all sorts of vegetables and fruit are being grown, cattle and sheep also being introduced in many parts. Though I was told in Khartoum by several of our officers who had been stationed on the frontier how well the Lado Enclave was run, I was quite astonished at such progress. I am glad to see my views are shared by Major Gibbons and Captain Bell, both of whom have had chances of seeing life inland from the Nile.

I met during my wanderings several English and American traders having concessions both in Uganda and the Congo. These men have to visit all the villages. They all said the same thing-that there was nothing wrong with the Government of the Enclave. I also had a long and interesting talk with Father Maguire, of the Roman Catholic mission station at Amadi. He spoke most warmly in praise of the work done by the Belgians in such a few years. He said: "Think of what this country was only a few years ago, overrun with Dérvishes, decimated by the slave-dealers, the natives all cannibals-and now you walk in here with only an umbrella as a protection."

I can only add that I admire the excellent work being done by such men as Commissioner General George Witerwulge, Commandants Ravello (Lado), Menwnaer (Redjaf), Wacquez (Buta), Holmes (Dungu), Grazione (Lodka), and all the many other officers, too numerous to mention, who are quietly working hard, day after day, opening out those vast regions to civilisation; and I shall never forget the kindness met with at the hands of all, from the Nile to Boma.

I must apologise for trespassing on your valuable space, but if I were to try and refute many of the statements $I$ have seen in print I should have to trespass considerably more.

Yours truly,

Bachelors' Club, London,

JAMES J. HARRISON.

June 6 th.

P. S.-Since writing the above I see in to-day's Morning Post quotations from some English trader in Matadi. He 


\section{Testimony of Travellers and Thinkers}

says: "From all I hear, things up country are worse than ever. In the Mayumbe country, behind Boma even, the State has begun collecting rubber by force from the natives."

As I happened to travel home on the same boat as Mr. Ave, an American missionary, who has for some years been in charge of this Mayumbe district, his statements to me may be of interest. Mr. Ave said all these reports were untrue; that the district was governed by an officer who was most kind and considerate in all his dealings with the natives; that he had carefully readjusted the taxation so as to fall as fairly as possible with regard to villages and population of same; and that the officer was universally respected by all the natives as a kind and just man. The same Morning Post article seems to be slightly inconsistent. It quotes one Equatorial missionary as saying that "the white man will be swept out of the Congo and a revolution will take place within two years," while farther on it quotes the Matadi trader "as deprecating the founding of a new post for I,000 soldiers at Bomasundi."

Surely, if the first assumption is correct, the wisdom of the second is sound. I am glad to find since my return that few people take notice of or believe those wonderful statements, copied from a more wonderful paper-the West African Mail.

This is the way Major James Harrison a few days later demolishes a side issue raised by $\mathrm{Mr}$. Morel. The letter is addressed to the Editor of the Morning Post (London), and appeared in that journal of June 25, I904:

Mr. Morel in your paper to-day himself answers the question asked him by others, viz., Why has the Congo Reform Association noticed my statements? If they were incorrect surely his letter would have dealt with them, instead of which all he can say is that I am attacking a man of Mr. Casement's standing.

While quite ready to take full responsibility for any letter or interview alluded to by Mr. Morel, I absolutely deny having attacked the character of our Consul in any way, nor did I 
find in Boma Belgian officers "showering abuse" on him. Like myself they (and most people over here with whom I have discussed it) did not think it a wise appointment, and certainly it placed Mr. Casement in an awkward and unenviable position; but after all he would only carry out his orders. But as to the travelling about on a mission steamer I most strongly assert it was a most unfortunate error. It is well known to all natives on which side most of the Protestant and Baptist missionaries are, and to expect them to give contradictory evidence in such circumstances was attributing to them virtues unpossessed. I have noted Mr. Morel places much of the Belgian evidence (say, the Epondo case) out of court for the selfsame reasons. After the using of a mission steamer I hardly see that any work Mr. Casement might have been interested in originally could make any difference. Still, for his own sake it might be wise if Mr. Morel stated exactly what occupations or duties he was interested in, say, between 1885 and 1900 . I trust Mr. Morel in his next letter will deal more fully with my "absurdities" put forward in my letter, and not have to simply try and find an imaginary attack on a gentleman for whom, through mutual friends, I have every respect.

My object in entering this Congo controversy is to try and place before the English public a more broad-minded view of the question, and while making allowances for the well-nigh insuperable difficulties the Congo Government have had to contend with, at the same time try to help on improvements for the future, rather than dwell entirely on the past. I can assure Mr. Morel that I am by no means alone in my "absurd views," but will be supported by others who have lately crossed the whole Congo State, blessed with an open mind.

Yours, \&c.,

Bachelors' Club, London,

JAMES J. HaRrison.

June 24th. 


\section{CHAPTER XXXIII}

\section{TESTIMONY OF TRAVELLERS AND THINKERS}

\section{(Continued)}

THE three authorities whose testimony was given in the preceding chapter are all distinguished travellers of British nationality. It is now proposed to lay before the reader the opinions held upon Belgian Administration in the Congo by three well-known Americans-Mr. James Gustavus Whiteley of Baltimore, member

American Opinion. of the Institute of International Law, who has represented the United States Government at several international congresses; the Rev. W. H. Leslie, a missionary of the American Baptist Missionary Union; and Mr. Mohun, a former United States Consul at Boma.

\section{MR. JAMES G. WHITELEY}

It is unfortunate that so many false impressions about the Congo have been accepted without examination. For example, there is a popular belief that the King runs the Congo "for revenue only," and that he oppresses the natives in order to extort money from them. The exact opposite is the truth. The King receives no revenue from the Congo Government; on the contrary the State owes its very existence to the generosity of the King, who advanced several million dollars to keep the Government going in its early struggle for existence. 
It is true that there are in the Congo extensive Crown lands, the revenue from which belongs to the King, but His Majesty refuses to take the receipts from this land and has turned the money into a fund for the erection of schools, the encouragement of science, and similar purposes. He does not even manage the fund himself, but has placed it in the hands of three trustees.

I have seen the statement in several newspapers that the Congo State was created by the Berlin Conference in 1885 and placed in the hands of King Leopold for administration, the Powers reserving a sort of right of guardianship over it. This is entirely erroneous. The Congo was a sovereign State before the Berlin Conference was thought of. The first official acknowledgment of the new State came from the United States in the spring of 1884 . It was afterwards formally recognised by the other nations, and it entered the Berlin Conference on an equality with the other Powers. It has never placed itself under the guardianship of any Power or collection of Powers. It has no connection with Belgium except the fact that King Leopold happens to be king of each of them. The two Governments are entirely independent.

One of the great achievements of the Congo State has been the suppression of the Arab slave-traders, who were in the habit of invading Central Africa, carrying off slaves to the eastern markets, and laying waste the country through which they passed. It is estimated that 100,000 natives were killed each year in these slave raids. I recently saw an erroneous statement to the effect that the slave raids are still carried on, and that they are encouraged by King Leopold and his agents as a means of revenue. It is difficult to see how the King or his Government could reap any profit by encouraging the slaveraiders to destroy the villages, and kill off a hundred thousand or so of the inhabitants. Such lack of logic is damaging to the case of the gentlemen who put it forward as a serious argument. As Lord Westbury once said to a young English barrister: "Never make a mistake in your logic; the facts are always at your disposal."

In this case, however, the anti-Congo critics have availed 


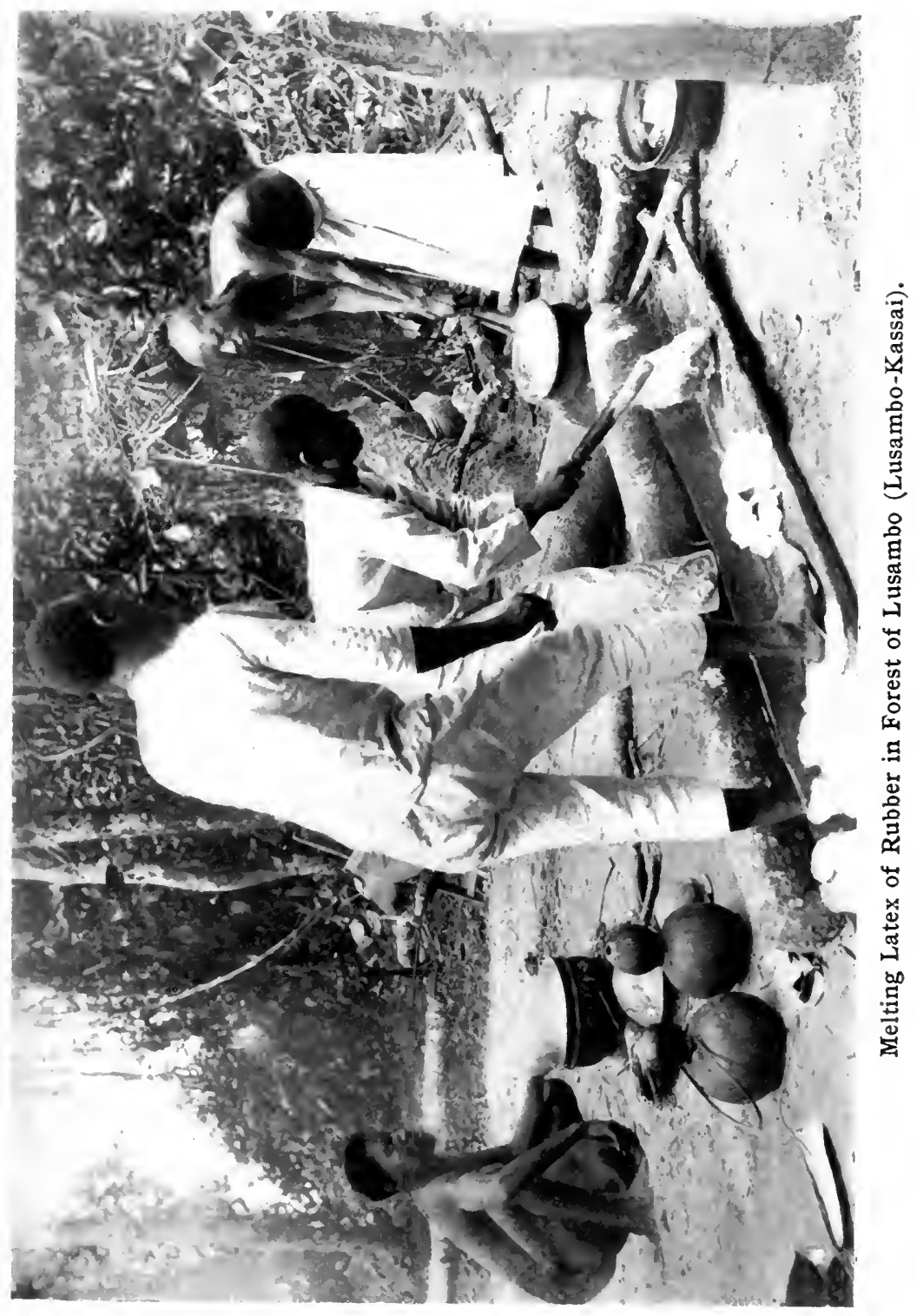



themselves of both false logic and false "facts." The facts are that the slave-raiders were finally vanquished and driven out by the Congo forces in the early nineties, after a severe struggle and at the cost of much Belgian blood. As the present Viceroy of India said some years ago: "The Congo Free State has done a great work and by its administration the cruel raids of the Arab slave-dealers have ceased to exist over many thousand square miles."

Another prevalent error about the Congo Government is in regard to the treatment of the natives by the officials. An impression has got abroad that there are many atrocities committed.

There have been cases in which the natives have been maltreated by minor officials, but these are isolated cases, and are severely punished by the authorities. Such cases have occurred in all public services where an attempt has been made to govern inferior races. Such things have happened in the Philippines, in British Africa, and in India. No colonising nation can cast a stone at King Leopold on that score. Among a large number of officials scattered over a vast territory there will often be one or two wicked stewards who despitefully use the natives. All that any State can do is to keep vigilant watch and to punish the wrongdoers, and this the Congo State has done. It has even established a Commission for the protection of the natives. By the decree of 1896 , this Commission consisted of seven members, three being Catholic priests and four Protestant missionaries.

It has been said, among other things, that the State practically enslaves the natives by forcing them to pay a tax in labour. The tax is light. According to a statement made the other day by Baron de Favereau, it consists of 40 hours' work per month, and for this work they are paid at the regular rate of wages obtained in the district. It is a tax which helps the State and also helps the native, for it teaches him to work. It is one of the most civilising influences in African colonisation, for it is only by teaching habits of industry to the natives that civilisation can make any progress in the Dark Continent. 
The detractors of the Congo administration make a great outcry, but as Burke said in one of his celebrated speeches: "You must not think because the crickets make a great noise that they are the only inhabitants of the field. The cattle browsing in the shade make less stir, but they are infinitely more important." Those who cry out against the Congo are a small band, and generally of small importance. Their evidence is light in comparison with the testimony of such men as the Count de Smet de Naeyer, the Baron van Eetvelde, Baron Wahis, the Chevalier Descamps, and Mr. Nys, but if these witnesses be considered as in any way prejudiced on account of their official positions, you have only to look at the evidence of Sir Harry Johnston, late British Commissioner to Uganda, as well as the evidence of such men as Cardinal Lavigerie, Paul Leroy-Beaulieu, the great authority on political economy, Mr. Pickersgill, the British Consul, besides the missionaries, such as the Rev. G. Grenfell, of the British Baptist Missionary Society, Mgr. Augouard, Rev. Holman Bentley, Father van Hencxthoven, Rev. Herbert S. Smith, Mgr. Streicher, Rev. Lawson Forfeit, Father Gabriel, and Rev. W. Verner of the American Presbyterian Mission.

The Congo State furnishes a model for civilisation in new countries. A great work has been accomplished in Equatorial Africa, and, as a distinguished missionary said, "Posterity will place the name of Leopold at the head of human benefactors for the princely enterprise, perseverance, and sacrifices contributed by him in such a cause."

THE REV. W. H. LESLIE

In a recent number of the Missionary Revicw of the World, a magazine published by Messrs. Funk \& Wagnalls of New York, there appeared an article written by the Rev. W. H. Leslie, a missionary of the American Baptist Missionary Union, stationed in the Congo. In that article Mr. Leslie refers to the exceeding degradation of the Congo people twenty 
years ago. He states that, naturally, not a little evil remains, that immorality and various heathen practices are still prevalent. But he speaks with much enthusiasm of the social and moral uplifting and the industrial development within that twenty years. He says that the people are learning to work, are learning to read and write, are clothing themselves, and are building better houses. In other words, they are gradually adopting the manners and customs of civilisation.

\section{MR. MOHUN}

Of course you must understand that for the moment I am in the service of the Congo Free State, and a great many people might consider anything I should say in favour of the Congo as being biased; but I can assure you that, in my opinion, it would be impossible for any one to give other than a favourable report on the work of the Free State in the Eastern province. The administration is excellent. The country is quite quiet from the Falls to Tanganyika. The native tribes seem contented and happy, and are paid by the Government for every stroke of work they do. The price of rubber has increased, and every man who brings in rubber receives pay for it. Formerly robbery and murder existed to a great extent among the native tribes, but are now quite rare; and the old "Mwavi," or ordeal by drinking poison, seems to be disappearing. Justice is administered with an impartial hand, and I firmly believe the natives are beginning to appreciate the benefits of good government.

Some months ago a woman was shot dead near my camp. I immediately sent for the chief, and told him I wanted the murderer arrested and brought in. Three hours later he returned with him and also two accessories to the crime, together with all the stuffs they had stolen from the woman. The principal actor in the crime was tried and hanged, while 
the others received long terms of punishment. This incident is merely cited to show that when the natives are living in a contented way, and are satisfied with their surroundings, they will assist the Europeans wherever possible. I could enumerate a dozen cases where natives have themselves arrested and brought to justice thieves, ravishers, \&c., of their own accord. They never received a present for these services. In the Manyema, which is very thickly populated, a great market has been established at Vieux Kasongo, and this serves as a meeting-place for thousands twice a week. Caravans come from Ujiji nearly every month, and the natives journey there by a I 5 or 20 days' march. I never saw a disturbance at the market, either going or returning. By common consent guns, knives, spears, and knobkerries are excluded from articles of exchange, and the men only carry thin walking-sticks. There are no soldiers guarding the market, but immunity from thieves is guaranteed by some ten or twelve native policemen, who receive no pay, and are highly pleased to have an opportunity of showing their authority.

I have been astonished in coming down river from Kasongo to the coast to see what extraordinary changes have taken place. First, the administration is now established on a good, firm basis, and all the officials take an intelligent interest in their work, with the result that scandals are quite a thing of the past. The stations are all splendidly and solidly built in brick, and the grounds are laid out in a very pleasing way. The transport service by canoe between Kasongo and Stanley Falls goes without a hitch, and thousands of loads go up river every year, absolutely unguarded, and the loss by theft is almost nil. The steamer service between the Falls and Pool is good, and an enormous improvement over the old days, especially in the matter of messing. The large steamers Hainaut and Brabant are most imposing-looking craft, and comfortably fitted up. They carry 200 tons of cargo and 600 troops, in addition to 40 white passengers. The new steamer La Flandre, of 250 tons, is on the slip at Leo, and I think will make her first trip in February next year (1904). She is to be lighted by electricity. So far as I know, the whole country 


\section{Testimony of Travellers and Thinkers}

is tranquil, with the exception of a small portion of the Bangala district north of Bumba.

It has been the fashion during the past for travellers who have been in the Congo State to run it down in every way, but it gives me the greatest pleasure to be able to affirm that only a most captious critic would be able to find fault with its administration to-day.

With regard to specific pronouncement on the alleged murder of several hundred natives who failed to supply the required quota of rubber, I can say nothing, it having been out of my district. Personally, I do not believe it, excepting in a vastly modified degree; and I must point out that the authorities are taking such steps as must bring any offenders to summary justice. I absolutely deny the absurd attempt to fasten responsibilities upon the authorities for any acts of violence they cannot control from this side. Such acts committed while I was there would have been reported, and it is evident they are now taking steps to prevent, in so far as possible, any recurrence of them. In all human institutions there are imperfections; here and there employees prove themselves unworthy of the trust reposed in them; but these, in my opinion, are exceptions rather than the rule. 


\section{CHAPTER XXXIV}

\section{TESTIMONY OF TRAVELLERS AND THINKERS}

(Continued)

\section{ALEXANDER DAVIS}

\section{$7 \mathrm{HE}$ following valuable testimony is extracted from an interesting volume written by this gentleman, entitled The Native Problem in South Africa:}

The Congo atrocities campaign is fed upon just a sufficient substratum of truth to make it plausible. But the public in their administered sentimentality travel very wide of the true case. After a full career of blood-curdling horrors unhesitatingly placed at the door of the administration in highest authority irrespective of conditions of environment or personal responsibility, a Sir Harry Johnston, accepted authority, in plenitude of personal knowledge and experience presents a rock of fact which checks the wave of misrepresentation.

In the Congo Free State in addition to the superior council to advise the King in Belgium, the Governor General has the assistance of a similar nominated body at Boma. Local conditions here do not admit at present of following the French system, but it is guided largely in its deliberations by the reports and advice of the district commissioners who with the co-operation of the local chiefs and their own officials form really limited autonomous administrations.

Turning to the Congo Free State the general division of the territory, from an administrative point of view, is based on the 
districts at the head of each of which is a district commissioner representing the State. The commissioner is assisted by sub-commissioners, but is alone responsible for the good order of his district. Their principal instructions, on which the State lays great stress, are to maintain friendly relations with the natives and wherever possible to prevent or patch up intertribal disputes; they are also charged with abolishing as far as possible barbarous customs and especially human sacrifices and cannibalism, still practised over a large extent of the territory. . . . In close co-operation with the district commissioner is the native chief or chiefs of the district. The institution and recognition of these are encouraged by the State in order to improve the relations between it and the natives, to consolidate authority over individuals, to ameliorate their condition, and to facilitate their regular contribution to the development of the country. The chiefs have, as a rule, to be first recognised as such by native custom, and are then officially recognised by the Government, and receive a certificate to that effect. They are allowed to exercise their usual authority according to native usage and custom, provided the same be not contrary to public order and is in accordance with the laws of the State. They are held personally responsible for their tribe's supply of public labour as notified to them annually. The acknowledged native chiefs number $25^{8}$.

The safeguards provided by the co-operation of the chiefs, and the supervision of the central authority are now on the Congo supplemented, as far as human action under such conditions can go, by a very thorough organisation of the judicial side of the Government. It has pleased many of the critical theorists who have attacked the Congo Free State to say that this latter has been established merely as a blind to the actions of the administration. It may be merely remarked that no infant struggling State is likely to go to the great expense of such an elaborate and widely organised system of justice as has now been called into existence on the Congo pour rire, and furthermore that jurists of the character of those now serving on the Congo are not those capable of lending themselves to 
such practices. A certain amount of latitude must of course be made for the different conditions in individual countries, especially when in a state of savagery, but generally speaking the Congo tribunals do their duty as well as similar ones in British colonies.

The Sovereign and Government of the Congo Free State have stated over and over again that they desire justice to be rendered impartially, and that as it is necessary that offences committed by natives should not remain unpunished, so penal laws must also be applied to the whites who are guilty of illegal doings. The mere fact of having constituted a superior court of appeal with judges of different nationalities and of appointing foreign lawyers and magistrates as judges and officials of the lower courts in the interior of the country is a proof, and a more than evident guarantee, of the impartiality and seriousness of the judicial administration aimed at. The writer holds no brief for the Congo Free State; rather the contrary in fact, but in common fairness after a very lengthy study of its judicial machinery, laws, and decrees, and the instructions given to its officials, he finds it difficult to conceive what more King Leopold could have done to safeguard its internal affairs than has now been done-given the peculiar conditions of the country. The abuses which have from time to time arisen in the past have been due, as far as one acquainted with similar conditions in West Africa can see, to three things, viz.: (I) to the abuse of power by agents of the concessionaire companies before the State had fully rcalised the necessity of keeping a sharp control over these semi-independent individuals; (2) to the want of experience of early officials; and (3) to the lack of trained colonial servants whose known antecedents and constitutions fitted them for isolated and arduous responsibility in an unhealthy, tropical, and savage country. It is only right to add, however, that though isolated misdeeds may still continue to occur here as everywhere else, the measures now in force guard as far as possible against a repetition of the former regrettable occurrences, and where these occur the offenders are brought to trial without delay. 


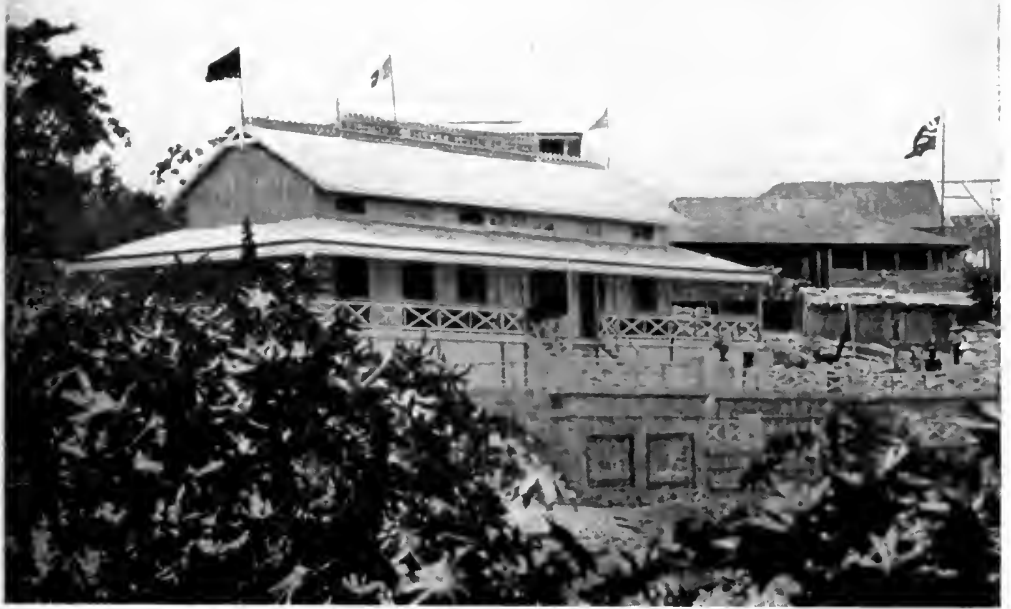

Public Library, Matadi.

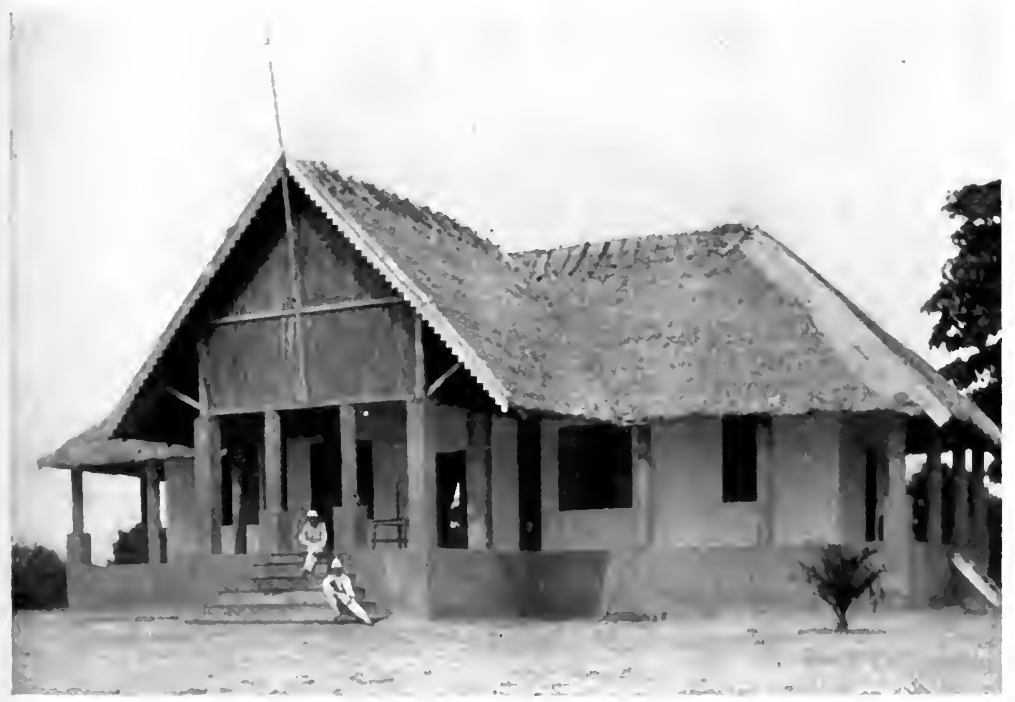

Soldiers' Mess at Coquilhatville, (Equateur). 

The native idea represents that of primitive society everywhere in the world, the European that of latter-day civilisation; and if this were always borne in mind, less nonsense would be written by those ill-informed sentimentalists who insist on treating the former on the lines of the latter.

Nothing is more astounding in regard to the Congo campaign-to take a very flagrant case in point-than the utter ignorance displayed by those who, while violently denouncing every detail of Congo administration, appear to be totally unaware either of the past history of social evolution, of modern civilisation in Europe, or of the conditions existing in other African countries at the present day.

We have here (British Central Africa) admitted, as in Uganda where we have shown that it has been actually carried out, the right of the British Crown to assume ownership of "vacant lands," and the principle enunciated that the reserves allotted must be sufficient to allow of the lying fallow of the ground for a period of three years in addition to allowing a proportion for the natural increase of the family. Had the same principles set forth above been applied to the early days to British West Africa that country would be far more prosperous and advanced than is the case to-day.

Bearing these facts in mind it is possible to understand more fully the situation on the Congo where the general system has been pursued of assuming possession of the vacant lands and allotting to natives reserves throughout the country, though it may be remarked that on the plea of conquest alone the State has a valid title to a large part of the country apart from that set forth.

In the case of the Congo Free State, however, the opposite course has been taken, i. $e_{\text {., }}$ the State has undertaken the direct exploitation of its private domains, the profits realised being allotted to public works and the expenses of administration; and without stopping to examine the necessities of the case its critics have eagerly seized on this as a point of attack.

When criticisms, however, are raised against the very complete system of land tenure now in existence on the Congo as 
regards the State, non-natives and natives, it is as well to remember that the exploitation of the land by the State is an after and separate act quite unconnected with the assumption of sovereign powers over the land in the State, which latter is in accord with general European and universal American custom, though after all whether a State raises money for public revenues by selling, leasing, or by personally exploiting the State lands seems to be a mere matter of detail in which the principle of the action is exactly the same. En passant it may be remarked that the Royal Niger Company, though an administration, raised its principal revenue and paid its dividends by its trade-not by duties or taxes.

Further south, getting down to the Congo again, we find a State which, sharing these views, has the courage of its convictions and acts upon them to the great scandal of our own Exeter Hall set, no doubt, but to the very marked improvement of the native races affected as well as to the development and opening up of the State.

It will have been observed in what special terms Mr. Davis repudiates personal interest in championing the Congo Administration against its detractors. Should any reader be so sceptical as to question the accuracy of that repudiation, attention is invited to the following declarations by three English statesmen, two of them of high political attainment, and all three by social position and actual record of approved bona-fides.

VISCOUNT CURZON, VICEROY AND GOVERNOR-GENERAL OF INDIA

It is only fair to remember that the Congo State has done a great work, and by its administration the cruel raids of Arab slave-dealers have ceased to exist over many thousands of square miles. 


\section{Testimony of Travellers and Thinkers 423}

THE LATE MARQUESS OF SALISBURY, K.G., PREMIER OF THE BRITISH PARLIAMENT

Look at the Congo State. Everything has not gone there as well as could be wished, but still a great domination is maintained. There are two sets of opinions; but what is undoubtedly true is that Belgium-a very much less powerful country than Great Britain-has been able to maintain the dominion of her King over a territory larger than the Sudan.

\section{THE MARQUESS OF SALISBURY}

Lord Cranborne, now Marquess of Salisbury, declared, during the debate of 20 th May, 1903 , in the House of Commons, that "There was no doubt that the administration of the Congo Government had been marked by a very high degree of a certain kind of administrative development. There were steamers upon the river, hospitals had been established, and all the machinery of elaborate judicial and police systems had been set up." 


\section{CHAPTER XXXV}

\section{TESTIMONY OF TRAVELLERS AND THINKERS}

(Concluded)

$A_{\text {MONG the denunciators of the Congo Adminis- }}^{\text {tration a prominent place must be assigned to }}$ DR. H. GRATTAN GUINNESS

\section{(English)}

a part medical, part missionary, wholly illogical perverter of facts. The plunges made by this eccentric individual into the depths of human credulity would certainly receive no attention in this place but for the strange circumstance that some people have actually so far belied their intelligence as to accept them without investigation. Strange to relate, Mr. Booker Washington (a singular lapse of sagacity in a man so generally intelligent) is among those whose credulity has been abused by stories of strings of Negroes' hands being set to dry in the sun, the said hands having been cut off from natives by wicked European officials of the Congo Administration as a punishment for failure to collect a sufficiency of rubber, etc.

In the course of a recent lecture in Scotland, Dr. Guinness said: "To our knowledge the natives never 


\section{Testimony of Travellers and Thinkers 425}

mutilated their. victims by cutting off their hands. The wild Ngombe never practised the mutilation referred to. It was reserved for civilisation to introduce this certificate of death."

Now it is a matter of history, quite outside the realms of argument, that punishment by bodily mutilation has been practised by natives of Central Africa from the earliest times of which we have any record. Here is a sentence taken from a book entitled The First Christian Mission on the Congo, published before the Congo State came into existence, written by Mrs. H. Gratten Guinness:

From half a million to a million of lives are annually sacrificed in the slave trade, and as many more in all probability in inter-tribal wars and contests. Physically a land of sunshine and beauty and redundant life, it is spiritually a land of darkness, deformity, and death.

This evidence, given by the wife of Dr. Grattan Guinness in I882, is a strange foundation for Dr. Guinness to erect his I904 statement upon. Let us hear what other people have to say upon this subject.

\section{COMMANDER LOVETT CAMERON}

\section{(English)}

In Ouroua only two punishments are know11, mutilation and the penalty of death. Both are much in use, but especially the former. For the least offence the chief and his lieutenants cut off a finger, a lip, a portion of the ear or of the nose. For more serious offences, they cut off the hands, etc.

DR. WILLIAM JUNKER

(German)

Mazindeh wished to punish the man according to A-Zandeh law by cutting off a finger. . . . I saw a man who had been 


\section{Story of the Congo Free State}

punished by the loss of his finger and of another important member. A Malingdeh told me he knew about twenty men who had been similarly punished.

\section{SIR JOHN KIRK}

\section{(English)}

If slavery were abolished, all criminals would probably be put to death or mutilated.

\section{CARDINAL LAVIGERIE}

\section{(Belgian)}

King Wemba, near Tanganyika, finding the wooden drumsticks too harsh for his ears, cut off the hands of his slaves so that they might beat the drums with their stumps.

\section{MR. J. A. MALONEY}

\section{(English)}

The offender was lucky if he escaped with instant death, for Msiri delighted in diabolical refinements of cruelty. Quite minor crimes were punished by the lopping off of a hand or the docking of an ear. In fact Msiri practised mutilation almost as extensively as Kasongo.

\section{MR. FREDERICK STANLEY ARNOT}

\section{(English)}

Mr. Giraud noticed some men whose noses or ears had been cut off. Mkewe's six drummers had a thumb on each hand but no fingers. . . . Mr. Giraud says that everywhere the Bemba people practise these barbarous customs. First the fingers and toes are cut off.

These quotations will surely prove that bodily mutilation is essentially an African barbarity that 


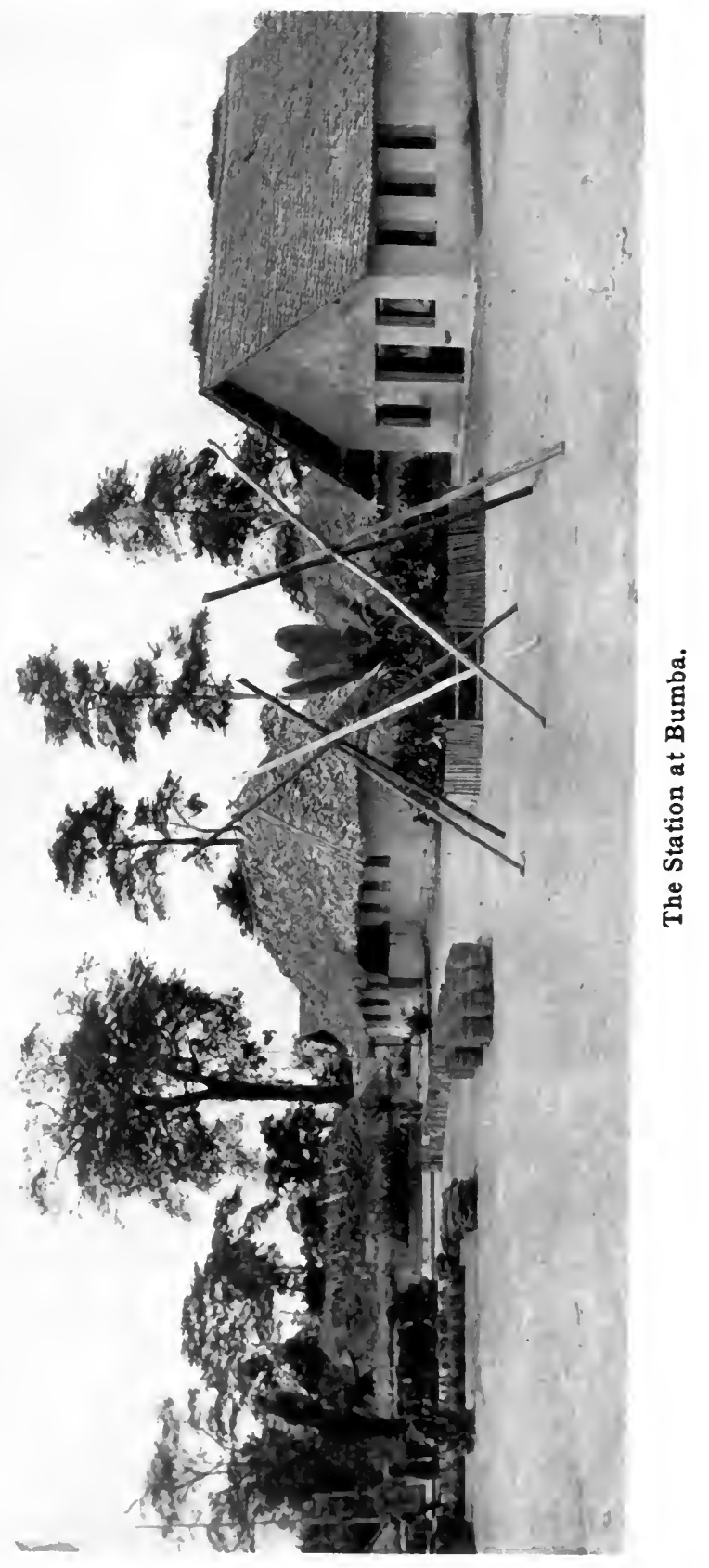





\section{Testimony of Travellers and Thinkers}

prevailed more or less among all the tribes of the Congo region, but is now almost entirely suppressed, thanks to Belgian civilisation. The charge brought by Dr. Grattan Guinness against that civilisation, that it introduced and practises this certificate of death, is a libel so monstrous that it carries with it its own refutation.

\section{MR. GRENFELL}

\section{(English Missionary)}

The welcome that I have received and the facilities accorded me everywhere in the course of my journey through the Eastern Province have made this journey very agreeable. This is now the third day that I have received the hospitality of this post, and before leaving it, which I expect to do tomorrow morning, I consider that I must write and tell you how happy I have been to have had the opportunity of making this most interesting journey. In the course of my tour I have been much struck by the order which has been established, and by the real progress accomplished. When the position of the country under the Arab domination is recalled, and when the relatively brief number of years since the termination of the military operations rendered necessary by the revolts is taken into account, the progress that has been made is nothing less than marvellous. If in spite of such numerous difficulties so much has been done, I am sure that when the railway towards Ponthierville has been completed the progress will prove more rapid still.-May $3 I, 1903$.

\section{MR. WILLIAM FORFEIT}

\section{(English Baptist Missionary)}

We arrived to-day at New Antwerp in order to take our farewell before leaving for England. I much regret that we 


\section{Story of the Congo Free State}

are not able to see you. I desire to thank you for the kind interest and consideration for the mission at Upoto which you' have always displayed.

The condition of the natives is much improved, all the villages of the district can be visited in absolute safety, and I beg to congratulate you on the tranquillity of the district of which you are the Commissary-Genera 1.-March 14, 1903.

\section{MESSRS. ASCENSO AND POLIDORI}

\section{(Italian Physicians)}

The dwellings for soldiers and labourers are numerous in Kabinda. They are symmetrically arranged and separated from one another by wide alleys from to to 15 metres across. Each black family has a separate house sufficiently large, divided into two rooms. Each dwelling is raised half a metre (nearly 20 inches) above the ground, and surrounded by a verandah one metre broad. The soil has been well beaten down, and the walls are whitened with lime. The roofing is without a ceiling, with a large opening admitting ventilation; each man sleeps on a bed raised one metre. The ground surrounding the post is formed into separate small gardens in which each soldier cultivates maize, manioc, etc.

All the villages around Kabinda are united to the post by wide and long avenues, well kept up and bordered by trees and pineapples. The natives greatly feel the effects of the neighbourhood of the white man, and make every effort to rival him in the maintenance, cleanliness, and prettiness of their villages. The houses are placed on an elevation, and are built in the same way as those of the soldiers with truly remarkable care and propriety. Each house has two or three rooms containing from $\mathrm{I} 2$ to 15 cubic metres, with good verandahs, and meets the prescribed hygienic conditions.

Large free intervals separate the dwellings from one another, and in them are the vegetable plantations.

A detail worthy of being pointed out is the great cleanli-

I The Commissary-General of New Antwerp. 


\section{Testimony of Travellers and Thinkers}

ness of the natives of this region: During the course of my journey from the West Coast of Africa to Kabinda I remarked many things, and I ascertained that at Kabinda all the natives, in place of sleeping on the ground, have a raised bed, formed by means of flexible canes with coverlets, stuffs, and mosquito nets. There are houses that contain magnificent sarcophagi of truly artistic work.

Everywhere there are small pieces of furniture coarsely sculptured, but which reveal the artistic taste of this people and their progressive march towards civilisation. It must also be said that they have a marked desire to dress decently. In conclusion, they are, in my opinion, the first people I met in Africa who, without being spoilt by money, possess a relatively advanced degree of civilisation, and an hygienic system beyond dispute.

The fertility of the soil and the abundance of provisions of all kinds allow of changing the food of the soldier and the native. Their food generally consists of chickens, goats, wild animals, manioc, maize, vegetables, and various fruits. They feel the effects of this good nourishment. They are strong, robust, support fatigue well, and consequently give little hold to sickness.

On a hill close to the post a hospital has been constructed by the natives. It contains three large rooms separated from each other and containing roo cubic metres.-February $2 I$, Igo4.

\section{MR. MAGUIRE}

\section{(English Missionary)}

Though I have travelled by boat and on foot from Boma to Amadi and higher up to Surunga, calling at all the State stations; though I have visited many establishments, both Catholic and non-Catholic, as well as some stations of independent companies; though I have passed nights and days in my tent in the forest and in villages of the natives; though I have had ample opportunitics of seeing much in my journeys as to how the natives are treated, I have never seen or 
heard of any of the atrocities with which the agents of the Free State are charged. On the contrary, one cannot but admire the wonderful progress that has been made in so short a time, the commendable way in which the natives are treated, the little work that is exacted of them, and the manner in which they are punctually paid for every service rendered or work done. The little work which is occasionally exacted of them by way of tax in porterage or otherwise is as nothing when compared with the immense benefits conferred upon them by the State. In fact the methods of the Belgian officers drew a highly complimentary eulogium from the Sirdar during his recent visit to the Enclave of Lado-methods which, he stated, might be followed with advantage by our English officers: "Messieurs," said the Sirdar, "nous avons d'excellentes leçons devant nos yeux."-March 31, 1904.

\section{DR. CHRISTY}

\section{(English Physician)}

I went to the Congo last September as a member of an expedition of the Liverpool School of Tropical Medicine, which was despatched especially to investigate sleeping sickness in the Congo, the same disease which so recently, as the public know, broke out in such virulent epidemic form in Uganda. For a considerable time I was in Leopoldville, which is the Bombay of the Congo-that is, everybody throughout the whole of the Congo goes through Leopoldville in order to reach Europe and the outer world. Hence you can quite understand that any one, like myself, for instance, stationed for a time in Leopoldville, must, if he take any trouble at all, come across all the officials from the whole of the Congo, who, from various causes, are bound at intervals to be in or passing through Leopoldville. Thus, whilst there I had excellent opportunities of finding out exactly what happens in that country, particularly as these men-that is, the officials of the Congo--are extremely ready to talk. Besides opportunities of acquiring information in that way, I have travelled on foot 
in the Belgian Congo State, and personally observed the condition of things which prevails there. I assure you that if I were to tell you all I know against the Congo Administration it would amount to a very little indeed compared with what I know in its favour. The credulousness of the British Government in respect of the Casement report is something marvellous. Casement travelled up the river in a missionary steamer, arm in arm with missionaries practically all the time, and obtained all his information from the river bank instead of personally investigating the various stories of outrage and mutilation which he received. It is the most astonishing thing that the British Government have given the Casement report so much credence.

The agitation now going on with respect to atrocities in the Congo is based on things that happened a long time ago. There is no doubt that in times gone by atrocities have occurred; but, thanks to the altered methods and conditions of administration, such things are not likely to recur. The basin of the Congo, mainly the Belgian Congo, is practically the sole rubber-producing area of the world. This territory also contains the lowest class of natives in the whole of Africa. The natives all over the East Coast-the Masai, the Nandi, the Kaverondo, the Bukedi, the Baris, the Madis, the Dinkas, the Shiluks, and others-stretching right away up to the Soudan, are all a magnificent class of Negro, a fighting people, a manly, upstanding people, who impressed me immensely. I have been through parts of all their territories, and they are indeed a magnificent set of people. Then you get towards the West Coast - the basin of the Niger, where I was for nearly two years, and you see a lower class of natives. On the Benue, where the present punitive expedition is operating in Niaiger, you have again a distinctly lower class of natives. Then, as you go farther South, and get into the Congo watershed, you come upon a still lower class of natives. The natives over large areas in the Congo are cannibals to the present day. They are a very low class of native indeed. That is the territory which the Belgians have so successfully opened up for the rubber trade. In that opening-up process they have had, as I say, 
to contend with absolutely the lowest class of natives in Africa at the present day. As you travel through the Congo you cannot help feeling - at all events any one like myself, who has been through the British tropical colonies-that the amount of general advancement and civilisation in the Congo Free State is far ahead as compared with our own. This is doubtless owing to the fact that the Belgians have made the natives work. The Belgians have gone on the principle, to begin with, that the native must be a participating element in the development and civilisation of the country-that is, that he must work with and for the white man, and thereby benefit not only the white man but himself. I was immensely impressed with the state of government and the advancement and general opening-up of the Congo, the more so as I can compare it with other districts under British control in which I have been. We do not attempt to make the native work, with the result that we do not get the benefit we should from our Protectorates. Uganda and British East Africa are far behind the Congo Free State. Not more than a third of Uganda is opened up to administrative control. I once spent ten months in Uganda, and visited every station in it, walking 2300 miles and returning down the Nile. The Belgians have got stations everywhere in the Congo practically, and most of the natives, except in one or two areas, are entirely under control. The Uganda native is a fat, lazy chap, who will do no work. There is no industry in Uganda. The Belgians pay the Congo natives for their labour. They realise that the native is a valuable asset in the country, and treat him accordingly. It is surely obvious that it is not to the interest of the Congo administrators to maim the native.

All the mutilations and cruelties which have been spoken of took place in the early days of the opening-up process to which the country has been subjected and before the railway was constructed. The men who have been guilty of the atrocities have not been Belgians in all cases. In many instances they have been Italians who have been appointed to the smaller outlying posts, the better and higher positions being kept for Belgians. These Italians and other foreigners 


\section{Testimony of Travellers and Thinkers}

who have been given the charge of outlying stations have in some cases perpetrated cruelties in times gone by. These men were not accustomed to exercise power, and this led them to ill-use the natives. That is how the atrocities such as these were originated. But that has all gone now; they are all cleared out. I have seen nineteen such men, chiefly Italians, in prison at Boma on charges of cruelty, which proves that the Belgians are doing their best to put a stop to the kind of thing complained of. The agitation that is now going on about atrocities is exaggerated out of all proportion to the amount of the atrocities that happened at any time. The Belgians are doing everything they can to supersede the men who have acted improperly in the past; they have appointed inspectors for different districts, and they have allowed inspectors appointed by the Italian Government and the Scandinavian Government to go out into the Congo for the purpose of keeping an eye on those of their own nationality in positions of responsibility and control in the Congo Free State. Things in the Congo now are very different to what they were even two or three years ago. The King of the Belgians has sent out Baron Dhanis-who had more to do with opening up the Congo in the early days than anybody else-to reorganise the whole military system of the Congo Free State. There are to be two or three large military centres in the Congo, and the soldiers will be much more highly trained and be more under control. Hitherto the small posts have recruited men from the surrounding villages, and given them a bit of uniform and a rifle, and they have gone about, supposed to be doing their duty, instead of which they have probably been ill-treating the natives. The whole thing will be changed now, however, for they will have a much more highly organised army and a much higher class of officer. It has been these unscrupulous foreigners-Italians, etc. - who have been guilty of the cruelties reported. Another pfoof of the endeavours to stop any existing abuses of administration is the fact that a Belgian officer who for many years held a high post in the Congo has recently been sent out by the King as Royal High Commissioner, to investigate all 
questions of maladministration and, particularly, payment of State employees and the natives for labour, with power there and then to rectify or alter any existing rules which he thinks might be amended in any part of the Congo, the territories of concessionary companies included. With regard to the mutilations in the Congo, described by Mr. Casement, I may tell you that only last year in Uganda I saw similar mutilations, which, it is well known, were done by the natives in Uganda, notably in King Mtesa's day. In walking through Toro and Unyoro, I have seen men without noses, ears, and, frequently, without hands.

With regard to Lord Cromer's assertion that in the Lado Enclave the natives have left the banks of the river and the immediate regions of the Belgian posts,--well, I have walked along the Nile from the Albert Nyanza into the Soudan, and visited the Belgian stations on the river, besides having seen a good deal of the natives on both banks. I feel sure that Lord Cromer is wrong when he states that the natives are leaving the Belgian side and going over to the Uganda side. The natives certainly had nothing to complain of, and certainly are not migrating across the river. As for there being no villages round Lado Enclave, the explanation is that there is for several months of the year absolutely no water and, therefore, necessarily no villages. But at many other places along the banks in the Lado Enclave there are large villages. I saw several thousand natives at Wadelai, employed by the Belgians in rebuilding the old fort of Emin Pasha, preparatory to making a large station there, and they seemed quite contented and happy, and worked like a hive of bees. The conclusion to which I am irresistibly driven as a disinterested observer is that the present administration of the Congo is not only free from cruelties, but is of the most complete and efficient description, and counts for the fullest commercial and industrial development of the Free State. I am sure that that administration is doing its level best in every way, from the highest to the lowest officer, to make the country prosperous, and the native happy and useful.- June 23, I904. 


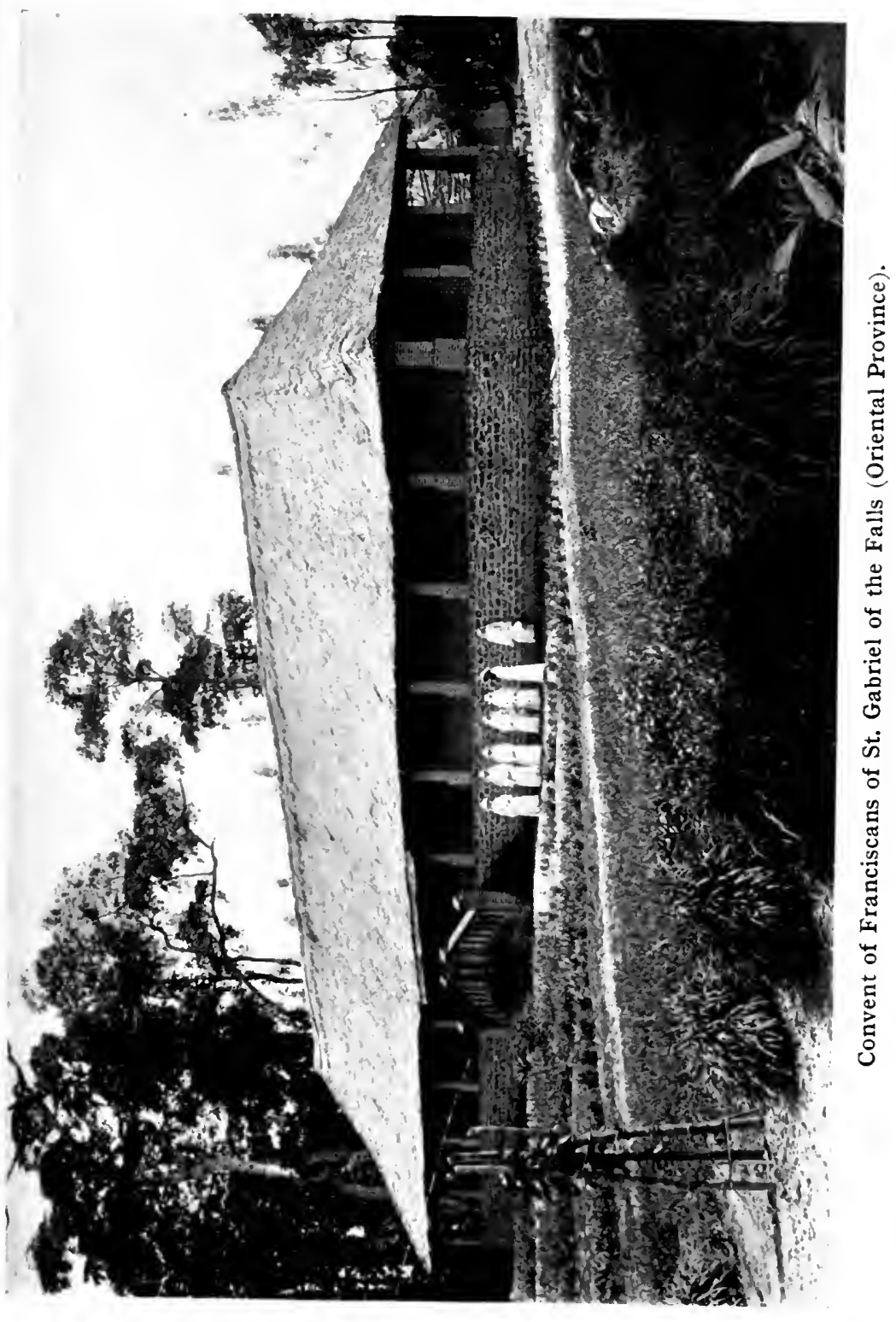





\section{Testimony of Travellers and Thinkers}

MR. GREY

\section{(English Civil Engineer)}

\section{From the "Morning Post" (London), Fanuary 20, 1903.}

Since I returned to England a few weeks ago I have read some correspondence in the Morning Post on the subject of the administration in the Congo State. I am an Englishman, and have during the last two years led an expedition of the Tanganyika Concessions (Limited), organised in Rhodesia to explore and search for minerals in the Katanga district of the Congo State. During the latter part of $190 \mathrm{I}$ and the whole of 1902 sections of this expedition have explored and settled in the district of Katanga, and at the same time the representatives of the Special Katanga Committee have occupied and governed the country. It is almost impossible for one man to have intimate knowledge of more than a portion of the territory of the Congc Free State, and I can only claim to know a small and remote section. Still, seeing that so much attention has been directed of late to Belgian administration in the Congo, my experiences in that country may be of interest. It is, perhaps, necessary to explain that the Special Katanga Committee, the governing body in Brussels of the territories of Katanga, is composed of the representatives of an amalgamation between the separate interests of the Congo Free State Government and the Katanga Company. The former originally owned two-thirds, the latter one-third, of that portion of the Congo State. This administration is entirely Belgian, and the African staff is composed of a representative of the committee, whose headquarters are at Lukonzolwa, on Lake Mweru, and who occupies the position of administrator, and of numerous officials, civil and military, in charge of the various sections of the district and departments of the administration. The country is garrisoned by a large force of native troops, with European officers. My duties have confined me to the section of the district called the Upper Luapula Section, which borders on the south and east with Northern Rhodesia. I have visited the chief of that section, 
Mr. Vervloet, at his headquarters at Lukafu, and an officer of the Katanga force with a few soldiers has been attached to my expedition.

I have, therefore, had considerable opportunity on the spot of learning the instructions which the Special Committee give their officials, and how those instructions are carried out. I myself and many members of my expedition have become fairly intimate with the native inhabitants of large portions of this district, and have from time to time employed as carriers and miners several hundred labourers. That the natives of this country had never suffered ill-treatment from white men was evident to me from the time I entered the country. They showed no hesitation in working for my expedition and in bringing quantities of food to sell, and always seemed quite confident that fair payment would be given, both for labour and food. I have lived for many years in parts of Africa in which the native inhabitants were for the first time coming under the influence of European government, and where conditions rendered the aid of such government by native troops necessary. It is almost impossible constantly to restrain the tendency to oppress and ill-treat his less powerful countrymen which is inherent in the native soldier, and I do not believe that it ever happens that the advent of that form of government is unaccompanied by acts of injustice and oppression. Generally there is a constant effort on the part of the European officer to prevent such acts and punish offenders. My experience is that this is especially the case in the district of Katanga. The regulations of the Special Committee provide that no armed parties of soldiers should travel or patrol without a European officer. Native soldiers are not allowed to enter villages alone, and weekly markets are held at which a European official buys food for his soldiers from the neighbouring villages, so endeavouring to do away as far as possible with direct dealing between the soldier and the people. My experience of the last two years has convinced me that in the district of Katanga at any rate the Belgian officials endeavour to treat the Central African native with justice and leniency, and in as great a degree as officials 
of any other nation look on him as a human being, with a perfect right to sell his labour and his food on terms satisfactory to himself. When I first entered the Congo, at the time that the officials of the Special Committee were establishing their government, and before I had come into personal contact with them, I found some armed natives who posed as soldiers of the Belgian Government, and who lived more or less the life of robbers, raiding and stealing wherever they went. The natives believed that these men were the authorised police of the European Administration, whose white officials they had not yet seen, and members of my expedition reported to me on the shocking behaviour of the Belgian Askari. I later learnt the complete mistake we had made in believing these men to be Government employees. In a short time they completely disappeared, caught or driven out by the agents of the committee. The Ba-Luba and Wasanga, the tribes we have been working among, are, we find, a peaceable, industrious race, with practically no warlike propensity, an easy prey to any organised hostile force. I am led to believe that their numbers have decreased during the last fifty years owing to a continuous traffic in slaves with the Arabs of the East and Mambunda of the West. To-day the slave trade has ceased in this particular district, the traders being afraid to come anywhere near the Belgian posts. To such an extent have conditions changed with the advent of Belgian administration that many small chiefs are now recovering individuals raided from them by their stronger neighbours and not already sold to the traders when European control reached the country.

In all discussions and criticism of the mistakes made by European administration in Central Africa there is one condition which seems to me to be never taken into account. That is the necessity of employing officials who have to spend a long time learning how to do efficiently the work that they have to carry on from the day they arrive at their posts. There is no school in which to learn Central African Civil Service except Central Africa, and it is impossible in Africa to obtain a sufficient number of qualified officials. Not many go to 
Central Africa with the idea of making their permanent homes there. It has been my own good fortune to settle in a healthy part of Central Africa, but from my knowledge of the Continent as a whole, I think it is not an exaggeration to state that two-thirds of the officials who leave Europe are, within five years of their arrival, either killed by the climate, invalided home, or have left the country at the termination of an agreement. All these have to be constantly replaced by inexperienced men, with their job to learn. What wonder then that grievous mistakes are sometimes made by some of these untried men, necessarily placed in responsible positions? In writing this letter to you, I state only my own experience and opinion of the spirit and effect of Belgian administration in the district of Katanga; but it seems natural to me to suppose that the same spirit extends throughout the whole of the Congo territory; and it seems almost the duty, at the present time, of any Englishman who has had opportunity to judge of the general methods of Belgian administration to give publicity to his knowledge.-Yours, etc.,

G. Grey.

In presence of testimony such as this, it is not matter for surprise that His Eminence, Cardinal

Cardinal

Gibbons, should have characterised as inGibbons opportune the consideration by the recent Speaks out. Peace Congress at Boston of the oft-refuted accusations brought against the Congo Free State. Where not absolutely false in every particular (as the majority of these slanderous stories most certainly are), they are grossly exaggerated, distorted out of all resemblance to the events they are based upon, and mendaciously attributed to a Government that has consistently and unswervingly repressed wrongdoing, of whatever kind, or by whomsoever done, and brought the light of civilisation to a vast 


\section{Testimony of Travellers and Thinkers}

barbarian population more thoroughly and in less time than was ever done before.

The opinion of Cardinal Gibbons upon this point well appears in a letter addressed by His Eminence to the Honorary Secretary of the Congo Reform Association, of which the following is the full text.

\section{HIS EMINENCE, CARDINAL GIBBONS}

\section{(American)}

The Honorary Secretary,

BALTIMORE, Oct. 2 I, 1904.

Congo Reform Association.

SiR,-I avail myself of the first opportunity which has presented itself to acknowledge your letter of the I8th instant. In that letter you call my attention to certain resolutions adopted by the Peace Congress at Boston. I fail to see in these resolutions any vote of censure upon the Congo Free State. They express rather a desire for information in regard to the international status of that State.

It appears that those who voted for the resolutions were in need of enlightenment on the subject, but this information lies near at hand. There is no need to appeal to any tribunal. Diplomatic history, diplomatic correspondence concerning the Independent State of the Congo, and the acts and the protocols of the Conference of Berlin, as well as of the Conference of Brussels, all prove conclusively that the Congo Free State is an independent sovereign State, and that the powers have no right of guardianship or intervention.

Your letter also refers to certain documents, such as the British Parliamentary White Book, Africa, No. 7 (I904), which, however, has not escaped my attention. Permit me to say that this book, instead of proving your contention, proves the exact contrary, and shows that both the adminis-

- tration and the courts of the Congo are using their endeavours to correct such evils as may exist-for no human government is perfect. 
The interpellation in the Belgian Chamber of Representatives, to which you refer, seems to have been simply a fruitless attempt on the part of the Socialist leader to annoy the Government. The very fact that the Chamber considered Mr. Vandervelde's charges against the Congo, and refused to sympathise with him in his views, is in itself a significant indication of the baselessness of his accusations.

In your letter you are also pleased to say that in speaking in defence of the Congo Government I have spoken "unwittingly," and to imply that I have not considered the facts nor weighed the evidence. I can assure you that I have not spoken without due consideration. As to the evidence, it is overwhelmingly against your contention.

It is only some score of discontented men, depending largely on the untrustworthy hearsay evidence of natives, who have raised an outcry against the Congo Administration, out of a great band of 500 or 600 missionaries, both Catholic and Protestant, who are working on the Congo, and who give thanks to the Congo Administration for its support to the missions, and for its successful efforts to introduce Christianity and civilisation into Central Africa.

Overwhelming evidence in favour of the Congo Government has been given recently by missionaries and by travellers, and it is not only Catholic missionaries, like Monsignor Van Ronsle and Father Van Hencxthoven, who have spoken in praise of the State, but also the most distinguished Protestant missionaries, such as the Rev. Mr. Bentley and Dr. Grenfell.

As it is not likely that you will convert me, and as I see no probability of convincing you, I, for my part, think it best to consider the correspondence closed.

Very sincerely yours, (Signed) James, Cardinal Gibbons.

\section{Viscount Mountmorres}

In the summer of 1904 , an Irish peer, Lord Mountmorres, began a journey through the Congo Free 


\section{Testimony of Travellers and Thinkers 44I}

State, whence his lordship is sending an admirable series of letters, descriptive of his experiences and impressions, to the London Globe. The dismal scenes of torture, desolation, and death, in which the missionary-agents of the Liverpool merchants assure us that unhappy country abounds, appear in some way to have escaped the observation of this traveller. "The further one goes into the interior the more civilised one finds it, the better organised, and the more developed," says Lord Mountmorres at the opening of his second letter:

I was utterly unprepared [he continues] for what I found at Irebu and at Coquilhatville, buried away there on the equator in the very heart of the great forest. For what are these stations? Large haphazard jumbles of native dwellings and white men's bungalows in an arid clearing, with illkempt roadways, such as one would find in the Western States? No; here we have great open towns of really artistic brick houses, with palm-thatched roofs and wide verandahs, each standing in its own little garden, bright with roses and hibiscus, Spanish iris and flamboyants, and set well back along straight, wide avenues shaded by bamboos, mangoes, papayes, acacias, bread-fruit trees, or one of a dozen other leafy and ornamental equatorial trees. In spacious grounds will be found the residence of the local governor, chef-deposte, or commandant, as the case may be, with its twenty to thirty-foot verandah and its flagstaff in front, placed usually so as to command the full view of the river front. Round one or more spacious squares at the intersections of the principal avenues will be the various public offices-the Directorate of Transports, the Post Office, the Magasins de l'État, the headquarters of the Force Publique, the Office of Agriculture, and the rest. At Bikoro there are 2200 acres overlooking the lovely Lac Tumba, sometimes miscalled Man Tumba or M'Tumba, a corruption of Mai Na Tumba, water 
(or lake) of war. Round Coquilhatville there are little short of 4500 acres of these plantations, and round Irebu and Imesse something like $\mathrm{r} 200$ acres in each case. Then near to each station will be the extensive market gardens, where every manner of vegetable, both European and tropical, is raised in profusion, and also the large, well-kept farm or farms, which supply the principal officials with beef and mutton, goat and pork, poultry and ducks, and in which a ceaseless series of experiments in breeding and raising stock adapted to the climate is carried on.

And this has been achieved not in one isolated spot near the coast, where material and transport were ready to hand, but at every "white post" up here in the very heart of the black continent, cut off until a few years ago from the capital and the seaboard by that deadly, costly barrier-the white man's cemetery of the Cataract caravan road. How has it been done? Let us take Irebu as a typical case. Seven years ago a young Belgian lieutenant, Jeuniaux by name, was sent out to take charge of the military training camp at the junction of the Ubanghi, the Congo, and the Tumba Canal, on the site of a former larger and flourishing native village. $\mathrm{He}$ came, and he found an unhealthy and pestilential swamp covered with the ruins and the filth of the then almost deserted village of Irebu. Among these unpleasant surroundings was a large group of ill-kempt and badly constructed mud and thatch huts - the training camp; and here he was doomed to pass at least three years. But he was young and energetic, and had passed unscathed along the latter half of the caravan road in the cataract district, for the railway was then but half completed. He had seen brick houses in other stations, and clean, well-kept, well-arranged little townships. He would have the same. But his first difficulty was that this was a training camp, whither the raw, untutored savage was drafted in his naked ignorance to undergo six months' tuition only; and, so soon as he had acquired a sufficient training to make him of use to the white man, he was hurried on elsewhere and a new batch of raw material took his place. Jeuniaux had but a hazy notion of architecture, but, unaided, 


\section{Testimony of Travellers and Thinkers 443}

he planned and designed his barracks, and acted as his own foreman, devising quaint methods to construct weather-proof walls and roofs from the materials at hand, and instructing his workers, man by man, in these methods, and that without even the medium of a common language.

At last his barracks were built, and the old huts destroyed; coffee, cocoa, maize, sweet potatoes, and bananas grew in well-ordered plantations, between parallel, palm-lined avenues, where formerly had been a wilderness of insanitary ruins. Then came the great feat of all-brick houses for the whites and for the Departmental offices. Bricks, bricks. He knew that bricks were made somehow from some sort of clay, and he had a hazy notion that straw was essential to their composition. So he started on a series of experiments. In the intervals of his work-with two sub-lieutenants to help him, he was responsible for training, feeding, and controlling from 1000 to 1500 soldiers, with their wives and families, for maintaining order in his district, and developing its commercial resources, and for ruling the natives in it; how well he had done this work I will show in a moment-but, in the intervals, he went on clay-hunting expeditions, and then sat up at night experimenting on what he had found, and at last he produced what he recognised as the real red brick-the philosopher's stone of his research. And so the first brick house in Irebu was built in one year from when Jeuniaux first came. And he built other houses for his lieutenants and white non-coms., and a residency for himself, and a guest house large and comfortable, and post-office, state stores, guard-house, pharmacy, armoury, and houses for all the other whites. One by one they were built, and Jeuniaux, now Commandant Jeuniaux, and his ever-changing pupils built them all, until he had realised his ambition, and had constructed a model station, with its lovely avenues, its riverside promenade, its fine landing-stage, its parade ground, where I 200 men may, without crowding, manœuvre in companies at once, and its pretty public gardens. And when his first term of three years was over he left, with the sense of work accomplished, for his six months' holiday. All the 
time in Europe he pictured the growth of his plantations and his palms, and told his friends he should be glad to get back "home" to Irebu, the town he built with his own hands. And the night before he reached it he could not sleep for excitement; and all day he strained his eyes to catch a glimpse of it, and at last it came in sight. But not the Irebu he knew. The plantations had reverted into jungle, the avenues had disappeared, lost in the quick, rank growth; the pleasure gardens were a wilderness; the finest of the palms had been cut down; and he went through the coarse, wild vegetation that clogged the entrance to his house, and into the damp hall-way that was become the home of bats, and of rats, and of lizards, and he sat down there, and he wept. For so, in six short months, had an idle officer left in charge during his absence undone the labour of three years.

But he is not a man to be easily daunted. To-day Irebu is as spick and span and as beautiful as he first conceived it. The benefit that accrues to the natives as well as to the whites from so well-built and arranged a station is shown by the change that has occurred in the health of Irebu. One of Jeuniaux's first cares was to make the place sanitary. Now, since he built the station, $i . e$. , in the five years since summer, I899, there have been only two deaths among the whites,although their number has been increased,-and of these one was a case of sunstroke, the other one probably of deliberate intent to die by disobeying orders during an illness on receipt of bad news. Since 1901 there has not been one death among Europeans. The mortality rate among the soldiers has decreased to 14 per 1000 average, and for the current year to I 2 per I000, or a fraction under. And this despite the fact that the sudden change in their mode of life when they enter military service must be a severe strain on the recruits, and also that Irebu, lying at the junction of waterways, is constantly having dumped down in it cases of infectious diseases, which are discovered on the river steamers, and which are put ashore at the nearest station.

Now, I mention all this about the building of Irebu, not simply to glorify Commandant Jeuniaux, but because the 


\section{Testimony of Travellers and Thinkers 445}

work that has been done there, the difficulties he has had to contend with and has overcome, the result that has been achieved, are identical with what every commandant has met with in each of the beautiful stations that you will find in the Middle Congo. Each of these represents the personal exertion of one individual, and their existence is eloquent testimony to the ability and devotion with which the State is served by its servants.

\section{Mrs. M. French Sheldon}

Mrs. French Sheldon, the traveller and author, returned to Europe in December, I904, after a tour through the Congo Free State.

I have witnessed [she says] more atrocities in London streets than I have seen in the Congo, which remark applies to the rubber country as well as the rest of the State. I travelled through every part of the country, and am convinced that the allegations of maladministration are groundless. Wherever I went I found the natives treated with kindness and consideration, while the improvements in the condition of the land and its inhabitants are almost incredible. 


\section{CHAPTER XXXVI}

THE ATTITUDE OF EUROPE AND THE UNITED STATES

$7 \mathrm{HE}$ Congolese kaleidoscope has revolved so swiftly since 1896 , that it is with difficulty the European attitude towards the Congo Free State notoriety can be completely indicated. It would be unfair to the English people-that great, sane mass of them which sits imperturbably serene and looks on-to say that the British attitude towards the Congo is of that bitter hostility which a few hysterical Liverpool merchants and writers wish the outside world to believe. Indeed, it would appear to be part of their plan to make sufficient noise to induce the Germans, French, and Americans to attribute the agitation to the entire British public. The fact is that the severest condemnation of the anti-Congo campaign is being uttered by Britons against the clique which is striving to entangle British ministers in an affair that may some day redound to England's humiliation. The shifts have been many to which certain Liverpool merchants and their chief crier have been put to maintain a hubbub which they hope will, by accident or the logic of events, create an opening for their ulterior commercial plans. 


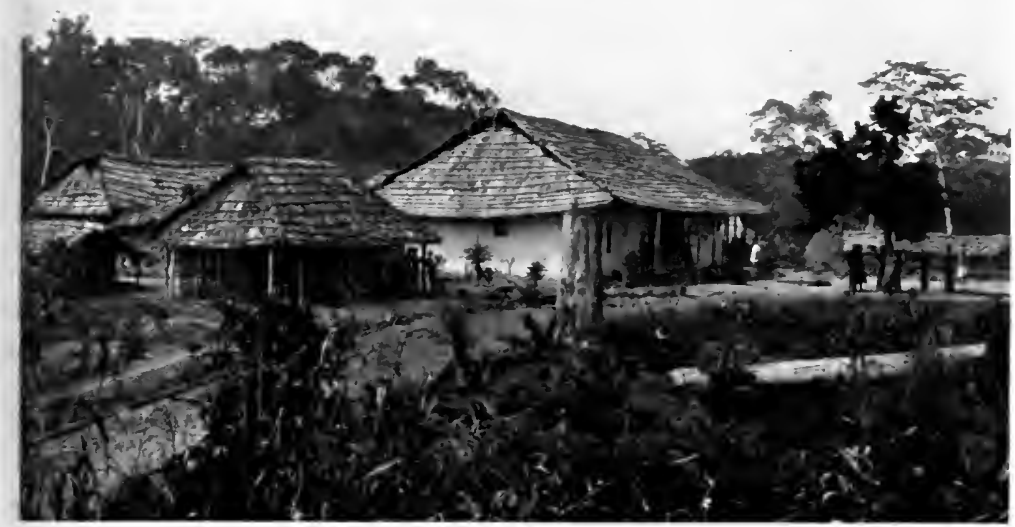

Native Planter's House, near Stanley Falls.

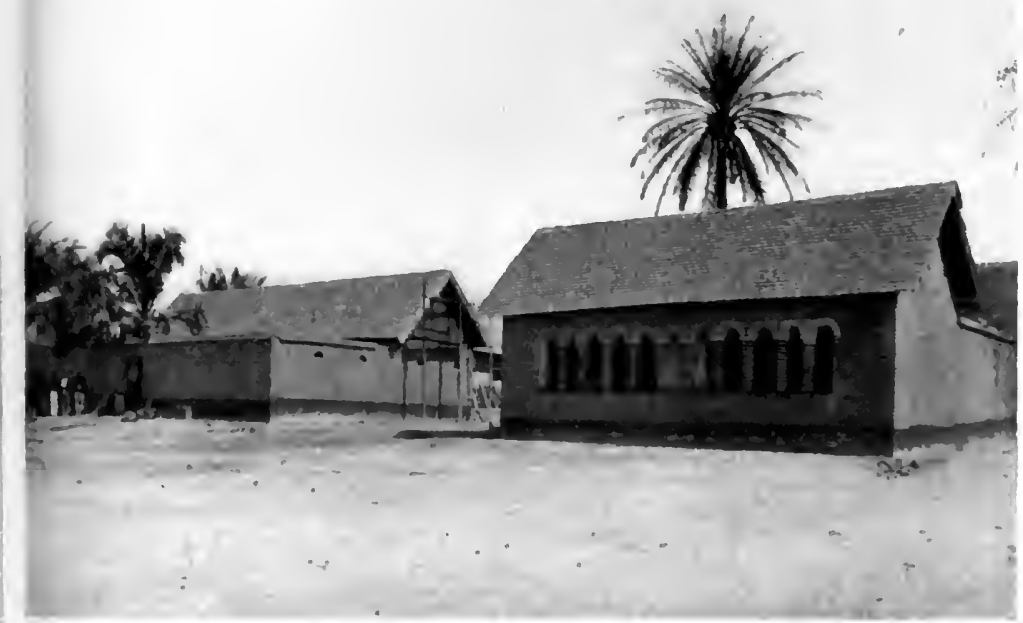

Prison, with Carpenter's Shop, at New Antwerp (Bangala). 

In I897, the services of Sir Charles Dilke were first enlisted against the Congo State. In that year it was evident to those who had previously erred in their estimate of the value of the Congo as a commercial and political asset, that the Free State would more than fulfil the early expectations of Leopold II. and Henry M. Stanley. The awakening to this fact is the genesis of the envy which enlivens Congolese history to-day. So long as Stanley sat in Parliament and avowed his confidence in the Belgians who are erecting a State upon the ruins of the slave trade, and so long as he reiterated to his colleagues on the benches there the truth of the practical difficulties in Central Africa, the campaign against the Congo State in England made little serious progress. When Stanley died, when his voice in defence of the great work which he had shared with the King of the Belgians could no longer expose the fallacies and the true motive of the despoiler, the Congophobe epidemic spread to America and became more virulent than ever.

Early in I903, a number of British merchants expressed their grievance against the French Congo in a volume by the author ${ }^{\mathrm{I}}$ whose active hostility against the Belgian Congo has given currency to many false statements and unjust beliefs. In the preface to the story of the British Case in the French Congo, this writer states that:

The British merchants in the French Congo have been sacrificed to save the face of certain French politicians-to stave off for a while the inevitable exposure of a deplorable error

E. D. Morel. 
of colonial policy. In the French Congo, rather than admit the overwhelming body of proof pointing to the Concessions Decree of 1899 being framed in ignorance, unworkable in practice, monstrously unjust in its effects upon the merchant and native alike, successive Colonial Ministers have endeavoured to square the circle, and, of course, they have lamentably failed. An existing trade has been destroyed, the colony is practically bankrupt, the revenue is steadily falling, the natives are either in open rebellion or thoroughly disaffected, the military expenditure has largely increased, and the Concessionaires will only last as long as they are allowed to maintain themselves by the ingenious system of fining the British firms - that is to say, until a way is graciously found for the latter to sell their factory depots and their merchandise (which, of course, is deteriorating steadily); or until, despairing finally of effectual home support, our merchants themselves destroy or embark all that remains of their actual possessions, and leave the country in a body.

The purely commercial considerations upon which this complaint against the French Congo is founded are quite apparent and need not form the subject of argument. It may be enlightening, however, to note the fact that since this impassioned book was hurled at the heads of Frenchmen across the English Channel, the Anglo-French rapprochement has been effected, and the entente cordiale of King Edward's visit to Paris has likewise intervened to divert the merchant wrath from the French Congo to the Congo Free State. French Deputies have visited London and enjoyed that bounteous hospitality which none can gainsay of a British household; members of Parliament have gone to Paris and dignified the gaiety of the quai d'Orsai. Not a vestige of the British complaint against the French 
Congo now freights the air. Instead, there prevails a friendly persiflage between those two great powers.

Inasmuch as the concessionaire system adopted in the French Congo gave new impetus to the British campaign against the Belgian Congo, it may be profitable to examine what precipitated matters.

The occasion was the organisation in the French Congo of the system known as the régime des concessions. A decree of the President of the French Republic, dated March 28, I899, divided the whole territory of the French Congo Colony between about forty concessionaire companies, which were to develop it under various conditions imposed upon them. The companies were granted all the rights of ownership over the ceded areas.

In I90I, several of these companies prohibited certain English merchants, who had been established in the country upwards of twenty-five years, from buying rubber direct from the natives, alleging that all natural produce belonged to the owner of the soil. Goods were even seized on their way to the English factories.

The injured traders complained that such action was not in accordance with the General Act of Berlin, the terms of which insure freedom of trade in the Congo Basin. They appealed to the French Congo courts, whose decision was in favour of the companies. Many judgments were pronounced, all of which held that the agricultural exploitation of the forests was an exclusive right of the concessionaire companies, and did not run counter to the provisions of the Berlin Act. 
These judgments were rendered by the Council of Appeal at Libreville, on November 27, I901, the petitioners being John Holt \& Company (Liverpool) and the defendants the Compagnie Française du Congo Occidental.

In spite of these judgments, British commercial circles persisted in the view that the concessions system was a violation of the free-trade clause of the Berlin Act. The Chamber of Commerce of Liverpool took the lead in a movement based upon this view. On September 30, 1901, a memorial was presented to the British Foreign Office protesting against the concessionaire régime in the French Congo, petitioning for an inquiry into its legality under the Berlin and Brussels Acts, and urging the British Government to insist on these Acts being respected by the French.

A similar memorial was presented on October 22, I90I, by the Manchester and Birmingham Chambers of Commerce, and in December of the same year delegates from ten British Chambers of Commerce were received in audience by Lord Lansdowne, who, according to the Paris Temps, acknowledged that their grievances were well founded and promised to do all in his power for those interested in the question.

At that time West Africa, the journal of the Liverpool Chamber of Commerce, renewed its campaign against the Congo Free State, accusing its administrators of being the principal sinners, inasmuch as the Free State's land system had been copied in the French Congo and German East Africa. 
In its issue of October 26, 190 I, West Africa called the Congo State fons et origo mali, and declared that it was the Belgian clique which had drawn France into the economic errors of its present system.

This campaign quickly assumed large proportions. West Africa continued to wage war against the French system of concessions and against the Congo Free State, the latter being bitterly denounced as the evil genius who conceived a land system which supported the State without the assistance of large revenue from the liquor trade or the presence of intriguing foreign merchants.

In the hope of putting an end to the Anglo-French difficulties in the Congo without raising questions of principle, the Temps of December 29, I90I, suggested that an amicable settlement be arranged between the French Government and the British traders affected by the concessionaire system in its West African Colony. By such arrangement, these traders would have received compensation for their loss. But, in a letter dated January 7, 1902, the Temps' special correspondent in Liverpool warned the French that such an expedient would not put a stop to the agitation. and endeavoured to show in its true light the campaign which was going on in England

Meantime the Aborigines' Protection Society pursued its old course of agitating something, anything, so long as its secretary, freedom of speech, and the attention of a Foreign Office combined to afford opportunity. The purely commercial grievances of British traders who had been made to conform to 
Congolese law required new elements of support. What could be of greater assistance to their commercial schemes than the tearful work of the Aborigines' Protection Society of England, the new Congo Reform Association of Liverpool, and their peculiar methods of playing upon the credulity, sentimentality, and the sympathies of susceptible and deluded persons whose leisure sought occupation and new interests? While the business brigade of the antiCongo campaign sought to enlist the aid of the German Chambers of Commerce, the humanitarian scouts developed the atrocity theme-not so much against the French Power as against the Belgian pigmy. Belgium and the Congo Free State cannot resort to the arbitrament of that force which as a last resort decides the contests of all nations.

The opportunity for attracting the co-operation of commercial factions in Germany was greatly propitiated by the unfortunate Stokes incident. Stokes, a British subject, once a missionary, had become an itinerant trader, and came into the Congo State from German East Africa, where he had established headquarters. His caravan was largely composed of natives from German territory, and the goods they carried for the purpose of barter were to a large extent of German manufacture. When Stokes was caught, red-handed, bartering guns and ammunition with the native enemies of the Free State for ivory which they had unlawfully acquired, he was tried and executed. This summary disposal of a trader who had been undermining Belgian and native security in the Congo met with vehement protests 
in Germany as well as in England. Other factors began to operate in favour of an Anglo-German alliance against the Free State, not the least of which was the apprehension felt in Hamburg, Bremen, and Berlin over the remarkable progress the Belgians were making with their transport facilities, whereby the trade of German East Africa was being diverted to the Free State. For a time, therefore, the German press joined the British in decrying the Belgian Government in Central Africa. German attacks upon the Congo State economic policy have, however, been largely confined to interested merchants or enlisted politicians. Herr von Bornhaupt, Prince F. d'Arenberg, and Consul Vohsen have been actively identified with German criticism of the Congo State's policy, notwithstanding that Germany, as shown in a previous chapter, has inaugurated a land policy founded upon precisely the same principles as those which prevail in the Belgian Congo. The statement of Consul Vohsen that "the Congo State's methods were diverting trade from the German East African colonies," betrays, perhaps, the only pretext upon which the criticism of German merchants may rest.

Until recently the political attitude of certain German statesmen toward the Belgian Congo has been to bring about a revision of the Berlin Act of I885. In announcing a desire to form an international league, Consul Vohsen said that its object should be to induce the Powers party "to revise the Berlin Act and to force the Congo State to respect its provisions." Europeans suggest that the 
gentleman probably means, by this contradiction in terms, that the real aim of England, Germany, and France, working in secret combination against the energetic little fellow with the biggest part of Central Africa, is to come to an understanding which will on the part of England realise the prophetic utterance of Mr. Cecil Rhodes' and the ambitions of Lord Cromer and Sir Reginald Wingate in the Cape to Cairo schemes; on the part of Germany, establish a new western frontier for German East Africa; and on the part of France, the final adoption of definite settlements in the Soudan and on the east and south banks of the Congo River. In short, the million square miles of immensely rich territory lying within the borders of the Congo Free State can, when rudely wrested from the heroic pioneers of little Belgium, be used by the three European Powers dominant in Africa to enlarge the gouty, the bilious, and the apoplectic tints of the African continent. That such views are abundant throughout Europe, and that the humanitarian pretext on the part of Congo enemies is regarded with derision, is all too evident from the columns of the leading continental journals. European editors have referred to the Congo debate in the British Parliament on May 20, I903, as a "Parliamentary raid," and likened it to the Jameson Raid in the Transvaal, which acted on the principle of violating first, negotiating afterwards, but in the end

In a speech delivered by Mr. Rhodes, in which he outlined his scheme for linking Egypt with the Cape, he said that his measures, if adopted, "will give to England Africa, the whole of it." (Boulger, p. 373.) 
bringing the whole subject within the pale of dispute, speculation, and bargain.

As long ago as $r 897$, Belgian statesmen were convinced that certain English statesmen, of whom Sir Charles Dilke was foremost, had espoused the cause of the commercial men of Liverpool and Manchester with intent to settle upon a purpose of hostility towards the Congo State. Whatever there may have been lacking to justify the Belgians in harbouring this belief at that time, intervening events have unfortunately confirmed them in their impression. Belgians connected with the Congo administration in Brussels still maintain what they said in 1897 , that "there was a set purpose to create for the Congo State difficulties both in Africa and in Europe, to discredit it by magnifying isolated facts, and by preparing, under the colour of philanthropy, the moment when there could be produced the territorial and financial designs concealed behind that campaign. The plan is clearly traced. At the commencement a feint is made that the sacrificed interests of the native populations of the whole of Africa is the cause they have at heart, and the idea of a new conference is put forward. As soon as this idea has appeared to germinate and public opinion has been baited, it becomes a question of the Congo State alone, and the division of its territories is boldly spoken of."

On March 2, 1903, Sir Charles Dilke asked the British Government in the House of Commons whether it intended taking steps to procure the co-operation of the principal signatories to the Berlin 
Act with a view to suppressing abuses in the Congo Free State. In reply the British Government stated that it did not then contemplate taking steps in that direction. On March 3rd, the Associated Chambers of Commerce of Great Britain met and resolved to press their grievances against the Congo State upon the British Government. On the irth of the same month Viscount Cranbourne declared that no action would be taken to interfere with the Congo State, as the British Government had no reason to believe that slavery was tolerated by that State. Then the Baptist Union threw in its weight on April 3 oth, and at a meeting held in London, denounced the concessionaire system of the Free State and attributed to that system all the cruelties alleged against the State. Meantime the British press, which reeked with stories of atrocities in the Belgian Congo, had not a word to say against the French Congo and that concessionaire system therein which was the Belgian system carried to extreme. At a meeting held in London on May 6, 1903, by the Aborigines' Protection Society, W. H. Morrison, an American Congo missionary, from Lexington, Virginia, having returned from a visit to Brussels, where he had asked for and been refused land concessions to which special advantages should attach, delivered a series of complaints against the administration of the Congo Free State, and caused his charges to be telegraphed to the press of Europe and America. While in Brussels seeking extraordinary land concessions, Mr. Morrison did not utter one word of complaint against the local administration 
of the Congo. On May 7 th, a member of the House of Commons again inquired whether a petition had been presented from British Chambers of Commerce or traders complaining that trading rights on the Congo under the Berlin Act were not respected, and what, if anything, the British Government intended doing in regard to the matter. Finally on May 2o, x 903 , the House of Commons, pressed by organised British commercial interests, passed the following resolution:

Resolved, That the Government of the Congo Free State having, at its inception, guaranteed to the Powers that its Native subjects should be governed with humanity, and that no trading monopoly or privilege should be permitted within its dominions, this House requests His Majesty's Government to confer with the other Powers, signatories of the Berlin General Act by virtue of which the Congo Free State exists, in order that measures may be adopted to abate the evils prevalent in that State.

On August 8, 1903, Lord Lansdowne addressed a dispatch ${ }^{\mathbf{T}}$ to the Powers signatory to the Berlin Act, setting forth the grievances which had been brought to the attention of his Government, and suggesting that:

In these circumstances, His Majesty's Government consider that the time has come when the Powers parties to the Berlin Act should consider whether the system of trade now prevailing in the Independent State is in harmony with the provisions of the Act; and, in particular, whether the system of making grants of vast areas of territory is permissible under the Act if the effect of such grants is in practice to create a monopoly of trade by excluding all persons other

$\checkmark$ See Appendix. 
than the concession-holder from trading with the natives in that area. Such a result is inevitable if the grants are made in favour of persons or Companies who cannot themselves use the land or collect its produce, but must depend for obtaining it upon the natives, who are allowed to deal only with the grantees.

His Majesty's Government will be glad to receive any suggestions which the Governments of the Signatory Powers may be disposed to make in reference to this important question, which might perhaps constitute, wholly or in part, the subject of a reference to the Tribunal at The Hague.

Three of the Powers, the United States, Italy, and Turkey, formally acknowledged receipt of the British dispatch; all maintained silence in respect of it.

On September I7, I903, the Government of the Congo Free State delivered its reply ${ }^{\mathbf{I}}$ and, pursuing the same course as the British Government had followed, sent it to all the interested Powers. The attitude of Europe concerning the issue thus joined may be gathered from the silence of the Powers signatory to the Berlin Act, and the press comment which the two dispatches evoked. The Morning Advertiser, London, a conservative organ, referring to the British dispatch, said:

A weaker official document we do not ever remember to have read. . . . The use of the word "alleged" in the title of the document gives the key to its whole tone. The note sets forth various "alleged" shortcomings of the Congo Government, and then says, lamely:

"His Majesty's Government do not know precisely to what extent these accusations may be true."

Surely this is a very serious matter-to accuse the Administration of a friendly State of inhumanity and "systematic

${ }^{1}$ See Appendix. 


\section{Attitude of Europe and United States}

oppression," and then to admit that we do not know whether the accusations are true.

The leading article in the Times (London) of the same day described the Congo State's reply as "weak, inconclusive, and confused." While Lord Lansdowne's note had been published in its entirety, the longer reply on behalf of the Congo Free State was accorded scant space in the British press.

From Black and White (London), November 2I, 1903:

To pile Pelion on Ossa in the way of accusation only to encounter a rebuff by being non-suited, scarcely recommends itself to the judgment as a course either dignified or statesmanlike. Yet in the present instance the fact that the English Note remains without a single answer from the twelve States to whom it was addressed three months after it was despatched, shows beyond question the trend of Continental opinion.

In the Standard (London) of October 24, I903, the following utterance would imply a threat:

The Belgian Administration objects to submitting questions of internal government to arbitration, but it would do well to remember that there is an alternative of a still more unpleasant character.

On September I gth the Morning Advertiser (London) has the following to say by way of insight into British desires in Congoland:

Nearly twenty years have passed since a great Englishman came through the Dark Continent and down the Congo, and it has always seemed a strange thing to other Englishmen that the great river of Central Africa should have remained ever since under the domination of the smallest country in Europe. 
The general tone of the British press was in support of Lord Lansdowne's Note, and intolerant of the Congo State's reply. On the Continent, the weight of opinion favourably acknowledged the force of the Congo State's reply. In France, Germany, Austria, and Italy certain British journals were severely criticised for suppressing the publication of all evidence favourable to Belgian rule in Congoland, for dignifying the fulminations of E. D. Morel, the penman of the merchants and shippers of Liverpool, the self-appointed coroner of the Congo, sitting in judgment upon the disjecta membra which he so luridly and so falsely portrays in the books which the anti-Congo campaign incidentally serves to advertise. Brief quotations from the arguments of M. Étienne, the French Deputy, have been set forth in a previous chapter. Criticising the London Times for its partisanship, the Dépêche Coloniale of October 16, I903. stated editorially:

- . We invite the great journal [London Times] of the city to cease this chicanery which might discourage men whose task in Africa demands the co-operation of every one. In this task, in its success, we are all interested, and the fact of having opened to commerce the immense territory of the Congo should of itself spare Belgium the bitterness of misdirected criticism.

In La Liberté (Paris) the editor, referring to the Congo State's reply, says:

Now that we have before us the reply of the King of the Belgians, we may say that we have reason from every point of view to defend the Congo Free State against accusations as 


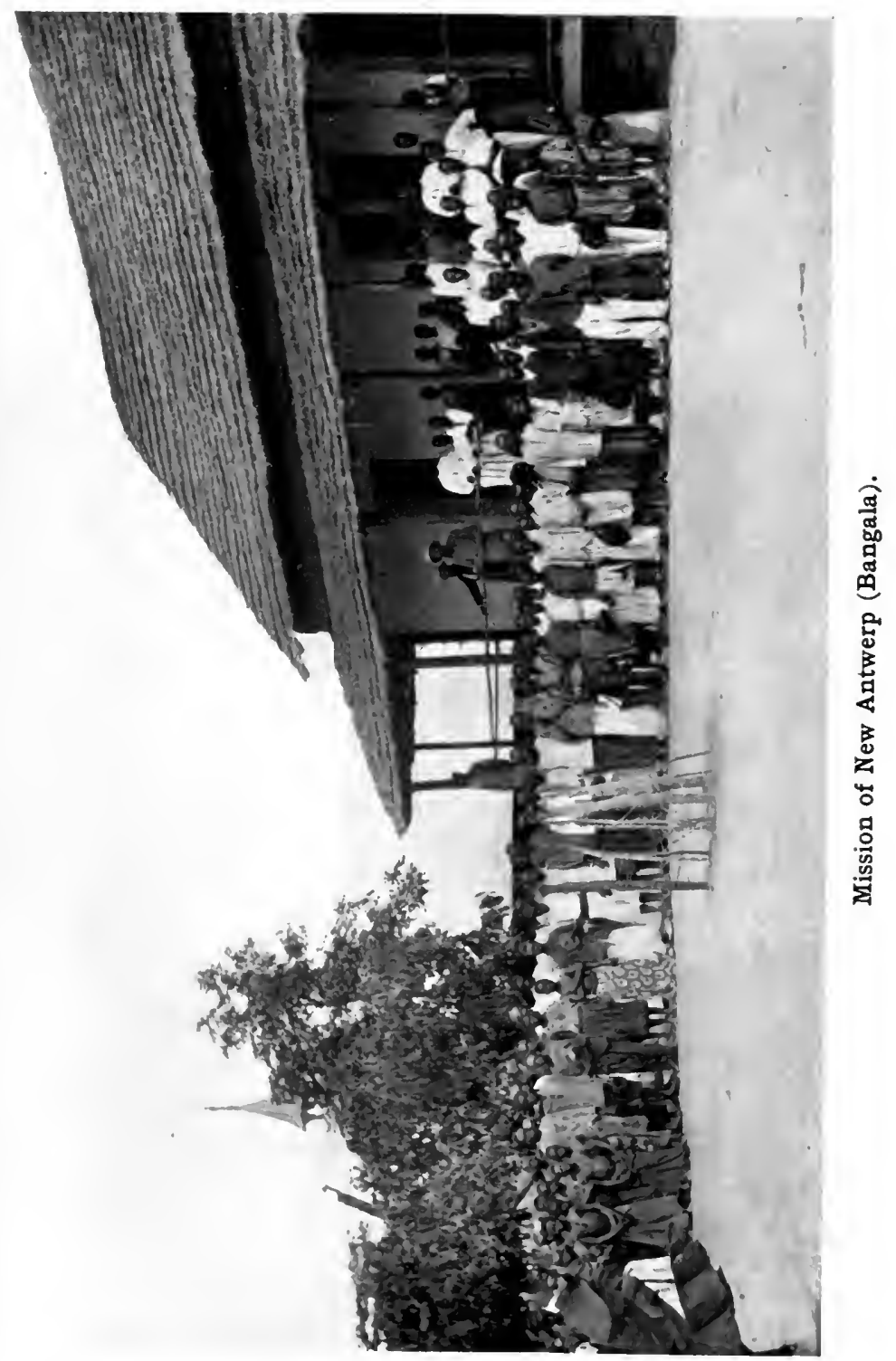





\section{Attitude of Europe and United States 461}

stupid as they are prejudiced. England may definitely renounce the hope that she had entertained of increasing her colonial empire by means of puerile calumnies.

\section{The Phare de la Loire:}

We should not forget that a similar quarrel has been sought for with us [the French]. French concessionaires have had much trouble with two English houses-Holt \& Company and Hatton \& Cookson [Liverpool]-whose agents had turned the natives away from French factories by offering them exorbitant wages.

The General Anzeiger, October 30, 1903, is merely quoted to indicate the violence to which criticism of the British dispatch attained, not as a specimen of sound Teutonic reasoning nor of temperate commentary:

Truly, when reading this one hardly credits one's eyes. Here is what the English Government, whose officials are almost without exception discredited by reason of their rude, brutal, and often inhuman attitude towards natives; here is what is written [sic] on the faith of pure colonial gossip, of unauthenticated rumour. It is not ashamed to act thusthis very Government whose cruelties in the last African war are still too fresh in the memory. . . . It is impossible to say whether this cynical fashion of acting is more striking than the hypocrisy which makes us indignant.

The Chronique (Belgium) of November 4, I903, contains an interview with M. Edmond Picard, advocate of the Belgian Court of Cassation, from which the following is quoted:

The reply to the English Note drafted by the Independent State of the Congo appears to me as nobly simple, and as 
proud in form as peremptory in substance. As for convincing the English ogre desirous of swallowing up the Bclgian Congo as it swallowed up the Transvaal and Orange Stateit would be ridiculous to hope for this. This people is as enthusiastic a brigand as a nation as it is honest and loyal in the individual.

\section{The Münster Westphal, November 3, I903:}

The insatiable English greed claims a new prey. The two Republics have been happily swallowed and digested. What is to be served up now? That fine phrase, "British Africa from the Cape to Cairo," has been recalled at the right moment, and it is remarked that the Congo State is still one of the obstacles to the realisation of that phrase freely quoted by our cousins. And hardly were the two Boer Republics given up to British domination than commenced, at first a little timidly, then with more effrontery and brutality, the chase of the Congo State. A mass of trifles were then put forward with incredible exaggeration; the pretext for the agitation against the Congo State was given: "British Africa from the Cape to Cairo," that is the objective of the antiCongolese. No one is deceived about it.

The Kleine Fournal (Berlin), October 21, r903, contains the following admonition from the wellknown explorer, Eugène Wolf:

"The Germans to the front!" such has always been the cry of the English when they have need of some one to take the chestnuts out of the fire for them.

"The Germans to the front!" has also been the cry of the English in the question of the Independent State of the Congo. And in this matter also the English have found among us a fool; for the aid which England has found in this Congolese question quite needlessly exaggerated cannot come from the heart of the German nation, but from the mouth of a member 
of the German Colonial Society, inhabiting Berlin, making himself of importance, and who, turning to account a residence many years ago on the east and west coasts of Africa, invoking his title as retired Consul, and his possession of a colonial library, gives himself out as the spokesman authorised by the nation in order to pass himself off on his own authority as infallible in colonial matters. With the war cry: "The trade of Germany is intercepted by the agents of the Independent State of the Congo, and we must settle it!" this gentleman, whose name is known to everybody, has made an attempt which has evidently remained unfruitful of stirring up Germany against Belgium and of disturbing the feelings of good neighbourship and the commercial relations existing between the two countries. The persons who have seriously at heart the interests of the German colonies do not allow themselves to be taken in by this trick. And if the Congo State is governed in a more profitable fashion than our own colonies, we must heed their example and imitate it. After all, it is not only with the object of realising permanent deficits that we have acquired our colonies.

\section{The Corriere Toscano (Italy), October 31, 1903:}

There is on the Congo as in every civilised country only one justice; blacks and whites are subject to the same laws, and the State's motto, Work and Progress, is adopted and followed by all with the greatest ardour.

Finally the views of some of the leading journals of the United States, manifestly free from bias, founded on self-interest, may be interesting.

The Evening Transcript (Boston).

The Congo Administration has not waited for any commission of inquiry to sit. It has already replied fully to the charges brought against it, but no reply will silence its accusers. They want thę Congo's riches, not its King's de- 


\section{Story of the Congo Free State}

fence, and will continue clamouring until the utter futility of their shouting threats at Leopold is brought home to them. Already they have prepared a map, a copy of which is before me as I write, of the Free State of the Congo partitioned out as they wish. The districts to be offered as bribes to France and Germany are duly marked on it, but they are small. The plotters do not hide their hands, they show clearly that England, and England's puppet Egypt, is to take the lion's share.

This, which I have related, accounts for the tumult of popular opinion in England, always easily stirred up by such tales. Multitudes, misled by the cheap, if genuine, sympathy felt with the oppressed, join unthinkingly in the cries against the Congo.

\section{From the New York Press:}

Those missionaries who are urging the United States Government to interfere in the quarrel between the British and the Congo Governments doubtless mean well, but they fail to offer any valid reason why this country should entangle itself in a matter in which it has no especial interest. The British Government has demanded, and the Belgian Government has conceded, all reasonable protection and privileges for the missionaries labouring in Congoland.

The other demands of the British with regard to the basin of the great African river are not entirely devoid of a tinge of self-interest, and it would be entirely improper for the United States to interfere at all in the matter. If an American missionary in the Congo is oppressed, or his treaty rights as an American citizen in any way violated, the State Department could and would interfere in that particular case, but further than that the missionaries ought not to expect this country to go. Missionaries, while most excellent and self-sacrificing people, are not perfect, and one of their imperfections is that in all parts of the world they are a little too anxious to bring about the interference of their home Power in the affairs of the Government in whose territory they are labouring. 


\section{Attitude of Europe and United States 465}

\section{The Public Ledger (Philadelphia), October 26,}

1903:

The acquisition by Great Britain of the Congo State would not only join her separate dominions, but would give her an immense territory of the most wonderful wealth. Not only so, but it would open to British Central Africa and Rhodesia an outlet to the sea down the Congo, and give even the Transvaal a chance of trading with England through a port on that great river, saving 2000 miles of the sea voyage to London.

English horror at Belgian mismanagement of Congoland is easily understood in the light of these facts. Does any one imagine that the British conscience would be so sensitive about cruelties alleged to have been committed in lands not contiguous to British territory, and not extremely desirable as annexations? The crime of King Leopold is that he has developed a colony which England wants.

Sufficient has been quoted to indicate that the silence of the Powers in regard to the British dispatch of August 8, I903, was fairly interpreted by the press of Europe. The meaning of that silence is unmistakable. British ministers having been misled to undertake a serious diplomatic act which was admittedly based on commercial grievance and unproved accusations, it now became necessary to back up the charges contained in Lord Lansdowne's dispatch by something seemingly more tangible than the complaints of persons peculiarly interested in doing mischief to the Government of the Congo Free State. It is the British view that the official report of Mr. Roger Casement, British Consul at Boma, in the Congo Free State, dated December I I, 1903, four months after the Powers had been appealed to, supplied the necessary confirmation of all that may 
have been lacking to justify the precipitate diplomatic act of August 8th which had met with rebuff.

The report ${ }^{2}$ and enclosures of Consul Casement would occupy approximately one hundred and eighty pages of this volume. It is an interesting account of a brief journey on the Upper Congo during a period of two and a half months, most of which was spent in the Equatorial district. The report contains many paragraphs in praise of the wonderful changes wrought by the Belgians in the Congo during the last twenty years. There are other passages in the report which condemn the land and concessionaire system of the State. Enclosed in the voluminous document are statements from Protestant missionaries and certain natives concerning alleged atrocities. As the official reply of the Government of the Congo Free State, brief as it is, deals fairly and fully with the essential allegations in Mr. Casement's report, it has been set out in full in the Appendix.

In To-Day (London), December 16, I903, Mr. John Henderson, an experienced traveller who had visited the Congo to ascertain for his journal the true state of affairs under Belgian rule in the Free State, wrote the following amongst other interesting comments on Consul Casement's Report:

I suggest that we should be careful in our condemnation of the methods of the Congo Government. The agents of the State are subject to perils and dangers unheard of, undreamed of by the people in comfortable Britain-the climate, the condition of living, and the natives combine to make life always

Africa, No. I, 1904. 
uncertain, and at times absolutely terrible. In Europe, or the West Indies, or Australia, or in any fairly salubrious country, the methods of Free State agents as pursued in Congoland might be judged barbarous, but it is impossible to judge the methods of the peoples of all countries and climates by one standard of ethics.

For my part, I shall hesitate to praise or blame the Congo State by this report alone. I have little doubt that some of the facts Mr. Casement will bring forward will be extremely shocking (while in the Congo I was several times shocked myself), but these reports of excesses will not prejudice me for or against the State. If Mr. Casement will furnish us with reports which will show us the exact conditions prevailing among the other West African districts-the French Congo, the Portuguese Congo, German West Africa, Nigeria, and the Gold Coast-then I shall hope to arrive at a more or less correct understanding of the matter. Cruelty and excess undoubtedly exist in the Congo Free State, but my experience in Congoland taught me that those guilty of any crime who come before the notice of State agents were severely punished.

To carry on the anti-Congo campaign in the United States, the Congo Reform Association of Liverpool has established headquarters at Boston. Its organisation includes a secretary. pamphleteers, press writers, and Protestant missionaries. It prints and sends broadcast to the press of America a weekly "News Letter," composed of articles designed to intensify agitation against the Belgians in the Congo. It is sagaciously understood by its supporters that one missionary with imagination and glib speech, turned loose on society in America or Europe, can make more noise, effect more mischief, do more to prostitute Christian work in foreign lands, than twenty earnest, patient, toiling, praying 
missionaries can accomplish for humanity by minding God's work in the dark heart of Africa. That concession-seeking, commercially-inclined Congo missionaries should be enabled to gratify their desire for notoriety after the fashion of the Congo coroner, Mr. Morel, and gain the slightest connection with American Missionary Societies, is only to be accounted for by the large financial support which, having prevailed in England, may be presumed to lie back of the campaign in America. There are certain phases of the Congolese question since 1897 by which even a disinterested observer is deeply impressed. The large financial support and the numerous agencies it employs is one of them.

So far the attitude of the American press has been eminently disinterested, Its leading journals have shown a keen insight into the motives which underlie a campaign that has been overdone to the disgust of all fair-minded observers. There is, in all colonies, whether under British, German, American, French, or Belgian rule, ample opportunity for criticism. There is, on the other hand, even greater opportunity for help and co-operation. The demoralising story of British Lagos is alone sufficient to make British criticism of every other nation's colonies pusillanimous. Acts of cruelty by natives, foreigners, or by State servants are in violation, not in consequence, of the Congo State's system of government. For such infractions of the law the individual, not the State, is responsible. But when the support of a British colony is derived from a debasing traffic in alcohol for whose existence the 


\section{Attitude of Europe and United States}

home Government is directly responsible, that Government should not assume the grotesque position of custos morum of Africa.

The Lagos Standard, reputed to be favourable to the British Government, referring to the Colony's revenue for $1901-1902$, says:

It would appear that the chief and ruling tendency of the successive administrations has been to draw from the Colony the fullest possible revenue, the greater part of which is spent in salaries of the officials. Every effort has been made in that direction, and no resource that ingenuity can appeal to was spared in order to reach that purpose.

The revenue derived from import duties on spirits, gin, rum, alcohol, whisky, reached $65.53 \%$ of the total revenue of the Colony. ${ }^{\mathrm{I}}$ To this add the licences for the sale of spirits, ${ }^{2}$ which brings up the contributive share of spirits in the budget's receipts to $67.53 \%$.

Alcohol is the great staple of trade. By visiting Lagos, one would be inclined to believe that it is practically the only commodity. Everywhere on the huge quay, extending several miles, where large business houses are established, on their wharfs, in their warehouses, are accumulated heaps of green cases and pyramids of demijohns of gin and rum. All the important stores have the same signboard, bearing in large letters the words, Wholesale Spirit Merchants, and from morning to night, every day of the week, there is on the lagoon a continual traffic of large steamers coming in to discharge their cargo and leaving empty. On the quay there is a continual movement of black porters carrying cases of spirits on their heads, which they either pile up by thousands in the warehouses, or remove them therefrom in order to load the boats, which are powerful launches of the native traders who spread the poison all over the markets of the villages alongside the lagoon and its affluents.

'Message of the Governor to the Legislative Council, February 26, 1903, p. 9.

2 Blue Book, 1902, p. 21. 
The quality of these horrible goods has been too often described to render it necessary to revert to the subject. Their price says sufficient: $4 \frac{1}{2} \mathrm{~d}$. per litre, bottle and packing included! The Government analyst found them to contain extremely strong poisons known under the name of fusel oils, in the enormous proportion of from $\mathrm{I} .46$ to $4.3 \mathrm{I} \%$ of the weight.' Is it to be wondered at that after absorbing several bottles of this poisonous liquor, the drinker should be overcome by a sort of madness? Is it to be wondered at that criminality is on the increase, that the birth rate is on the decrease, that this magnificent race of Yoruba agriculturists is speedily degenerating?

Where Europe, whose interests in Africa are material as well as moral, has not seen fit to join a British traders' campaign against a small neutralised State, it would seem that the United States Government could not be led into action on the pretext that its recognition of a friendly Government invested it with police powers over the internal affairs of the State so recognised. "Territory" and "commerce" are the tightly furled, secretly carried banners of the raid upon the Congo State. This exaggerated humanitarian solicitude for the African black is purely pretence. By its hypocrisy, falsehood, and disputative vulgarisation, the movement, instead of remedying what evils exist in all African colonies, is made utterly puerile. By such vituperative fanfaronade as the following, rational minds are made to turn from the subject in disgust: ${ }^{2}$

Of such is the kingdom of Congo.

The tale is told-the tale of " King Leopold's rule in Africa." $\checkmark$ Message of the Governer, p. 8. 2 E. D. Morel. 


\section{Attitude of Europe and United States}

A piratical expedition on a scale incredibly colossal. The perfection of its hypocrisy; the depth of its low cunning; its pitiable intrigues; the illimitableness of its egotism; its moral hideousness; the vastness and madness of its crimes-the heart sickens and the mind rebels at the thought of them. A perpetual nightmare reeking with vapours of vile ambitions-cynical, fantastic, appalling. A tragedy which appears unreal, so unutterably ghastly its concomitants, but the grimness of whose reality is incapable of superlative treatment. Destroying, decimating, degrading, its poisonous breath sweeps through the forests of the Congo. Men fall beneath it as grass beneath the scythe, by slaughter, famine, torture, sickness, and misery. Women and children flee from it, but not fast enough, though the mother destroy the. unborn life within her that her feet may drag less heavily through the bush.

There has been nothing quite comparable with it since the world was made. The world can never see its like again.

Sufficient that it exists, that each month, each year, the terror of this Oppression grows, immolating fresh victims, demanding new offerings to minister to its lusts, spreading in ever wider circles the area of its abominations.

After that, what can one say or do except to appreciate one's sense of humour, and the lack of it in a zealot? A tower of babel on a pile of words! 


\section{CHAPTER XXXVII}

SUMMARY, RETROSPECT, AND PROPHECY

\section{$\mathrm{T}$}

HE rise and progress of the Congo Free State marks a unique page in modern history. The boldness of the State's conception, the apparent hopelessness of its early conditions in a region unspeakably savage and barbarous, its gradual evolution under the magic touch of a master hand; the horrifying vicissitudes of its bloody redemption from the accursed slave-raider, and finally its admission into the society of independent nations, constitute a set of circumstances unparelleled in the history of the world. The span of its life from a wilderness to a self-supporting and prosperous State is about twenty-five years. Its rapid evolution was at first watched with sneers and derision. During the last ten years it has been the object of the hostile vigilance of those whose early regard had been scorn. Young as it is, a considerable literature already exists descriptive of the infant State. This literature, however, is very unsatisfactory, being for the most part bitterly partisan, either perceiving no good point at all in King Leopold's rule, or regarding that rule as a perfect thing in which no improvement is possible. Neither attitude is just. And this may be said not only of the Congo Free State and its ir- 


\section{Summary, Retrospect, and Prophecy 473}

resolute and disappointing African neighbours, but of States whose civilisation is the pride of our own times.

There have been error and crime on the Congo as there have been error and crime on the Thames and the Hudson. Savages left the banks of the Thames nearly eighteen hundred years ago. The white man came and refined their cruelties in a thousand ways now practised by civilisation behind the curtain and the padded door.

The aboriginal black cannibal still occupies the banks of the Congo. But his nature, so recently in its savage state, is manifesting great change. $\mathrm{He}$ is on his knees in the mission chapel; the song of the White Fathers and the Sisters of Mercy inspires in him the rude awakening of new emotions. His own voice abandons the war-cry and makes its fervid, untaught plea to the white man's God.

On the Congo, religion is perforce a plain, sincere, and a comforting thing. It is taught by a small, earnest band of men and women whom the epithets of the flaccid, arm-chair colonising hero will not disturb. These rugged Christian teachers pursue their lowly, patient work to please God-not Liverpool. On the Congo, the gospel knows nothing of the elaborations of insincerity, sophistry, and cant. It finds the soul of the black man in a patient and a practical way by instructing his body in the habits of honest toil, of cleanliness and decency, and by developing an intelligence to supersede his savage instinct.

The results of only twenty years' guidance in this 
direction are manifest to-day. They have placed the Negro in the midst of the uncovered wealth of a vast and fertile country; of waterways teeming with traffic; of a magnificent forest stored with rubber; timber of great variety, ivory, oil, and fruit; of promising fields of coffee, cotton, cocoa, tea, and sugar; deposits of gold, copper, coal, and iron. This short era of civilisation has created in the Congo over four hundred commercial houses doing a thriving business with Europe; built railways over mountain routes where only Belgian engineers and Belgian capital had the courage and the skill to venture. In the midst of it all the black man's hands and acquired energy have provided him with new value to himself and to the State. He is at the plough, on the cart and the railway, on the wharf and upon the road and the farm, in the shop and factory, learning the uses of the white man's implements of labour, and imitating his enlightened ways. Industry and order, Christianity, civilisation, and material progress have succeeded tribal wars, cannibalism, and the horrible atrocities of the slave chase. This has been achieved by the brawny men of Belgium in less than twenty years.

The smug men of the study, untravelled in regions wilder than Westminster, St. Albans, or Liverpool, are as incompetent to judge of civilisation in Congoland as are the Manyema of the lack of it on Park Lane, in London. Their beautiful theories of civilising the African Negro with illuminated manuscripts, florid dissertations on the Berlin Act, and freedom of (alcoholic) commerce, constitute a pyra- 


\section{Summary, Retrospect, and Prophecy}

mid of fustian with but a single thought starring its apex-Empire.

While the English campaign against the Congo Administration was confined to nebulous libels, proceeding for the greater part from wrangling missionaries and aggressive traders, it was the policy of that Administration, conscious of its own rectitude, to ignore the attacks made upon it. In light of subsequent events, the wisdom of that course appears open to question. Did not one of England's poets observe that a lie seven times repeated without being challenged acquires the force of truth? Some of the fiction concocted by enemies of the Congo Free State has been so industriously reiterated by so many different agents of English traders that, collectively, the British Government could no longer refuse to give ear to their vapourings. Whether the British Government did so willingly or unwillingly is another story. What has been the outcome of that Government's acquiescence in the demands of the slanderers of the Congo Free State the world now knows. Mr. Roger Casement was sent to the Free State, where he traversed ground carefully mapped out for him, and interviewed natives specially instructed in their parts by the persons whose agitation had occasioned his mission. The result was precisely what might have been expected, and that without impeachment of Mr. Casement's integrity - an inaccurate and partial report. That report, magnified, distorted, garbled, has afforded material for the enemies of the Congo Free State upon which they have not yet ceased to work. The refutation of all its more important pro- 
nouncements will probably not disconcert Mr. Casement's believers in the least, as they are immune to the logic of facts. Nevertheless, the Sovereign of the Congo Free State, in order that the world may not accept as a thing against which no defence can be made the judgment passed upon his rule by the cliques banded together to embarrass or overthrow it, in July, I904, resolved to send a special commission to the Congo to inquire into the atrocities alleged to have been committed.

The Committee of Inquiry appointed by King Leopold consists of the following members: (I) M. Janssens, Advocate-General of the Supreme Court of Belgium, president; (2) Baron Nisco, Judge of the Court of Appeal at Boma, and (3) Dr. De Schumacher. M. Janssens, who as Advocate-General holds the second highest judicial office in Belgium, is a Belgian; Baron Nisco is an Italian, and Dr. Schumacher is a Swiss. Assisting these three heads of the mission are MM. De Neyn and Grégoire and Professor Dupont, all of whom are Belgians. These gentlemen constitute a Court of Inquiry, and their instructions are to investigate closely every detail of Congo administration, and to examine on oath every person who may be able to give evidence of a nature valuable to the commission. The testimony of missionaries and traders is now being taken, and the committee will see to it that they obtain the evidence of the heads of British and American, as well as of Belgian, French, German, and Italian missions. The investigations are being held in many parts of the State. The committee is to travel 
throughout the country into all the districts covered by Mr. Casement in his recent tour of inspection, besides visiting many places $\mathrm{Mr}$. Casement never saw. In brief, the committee is to hold inquiry wherever evidence can be obtained. Where native witnesses give evidence of a nature prejudicial to white men, the committee will see that such witnesses are protected from the possibility of suffering at the hands of officials against whom they may bear witness. The Government of the Congo holds itself responsible for the safety and well-being of such witnesses. On this latter point King Leopold has expressed himself in the strongest possible terms. Inquiries are to be held publicly, open to all. The committee has the right to compel witnesses to appear before it. A general instruction to the committee asks for a report laying bare absolutely the condition of the rule in the Congo to-day, and enjoins it to devote all its efforts to a full and entire revelation of the truth. The duration of the stay of the Committee of Inquiry in Congoland is limited only by the exigencies of its task. The committee sailed from Southampton, in the Belgian SS. Philippeville, on September 16, 1904, and arrived at Boma early in October.

Such are the constitution, powers, and purpose of the Committee of Inquiry now at work in the Congo Free State. It is almost unnecessary to record that the committee has already been denounced by the enemies of the State on every conceivable ground. "A farcical commission" and "a bogus inquiry" are two of the descriptions which have been applied to 
it. That indefatigable meddler, Mr. H. R. Fox Bourne, who writes contemptuously of Stanley and his work, objected to Dr. Schumacher's presence on the committee on the ground that he is a brother of King Leopold's private secretary. On its being pointed out that Dr. Schumacher is nothing of the kind, Mr. Fox Bourne retracts his assertion, and substitutes another equally unfounded. Upon this second statement being questioned, Mr. Fox Bourne withdraws that also, and falls back upon his complaint that the members of the Committee of Inquiry will be paid for their labours. Such contentions are simply fatuous. Does not the Aborigines' Protection Society pay Mr. Fox Bourne for his labours?

During the few years in which the Belgians have been criticised for their progressive rule in the Congo, the Belgian people have heartily co-operated with their King in his long and arduous work. There has been, however, a small but active section in the Belgian Chamber spasmodically opposed to the Congo, and to any other expansion of territory, influence, or market, on the part of Belgium. This set of politicians, acting in suspicious harmony with the foreign enemies of the Congo State, have been exploited by the latter as representing the attitude of the Belgian people. To carry out this deception, certain foreign papers, peculiarly interested in the affairs of Liverpool merchants with African schemes, publish the speeches of this disloyal minority, and suppress the addresses of Baron de Favereau, Minister of Foreign Affairs, Count de Smet de Naeyer, 
Minister of Finance and Public Works, and other Belgian statesmen. In a masterly arraignment of those members of the Chamber who have been hostile to Belgium in this respect, these gentlemen, by their speeches in Parliament, inspired the organisation, in July, I903, of a federation composed of religious, commercial, industrial, social, and scientific societies throughout Belgium. This large and representative body is known as The Federation for the Defence of Belgian Interests Abroad. Its short address, presented to President Roosevelt in October, I904, has already been referred to. In a speech made at a meeting of the societies allied to the Federation, General Baron Wahis, President of the Brussels African Club, and Governor-General of the Congo Free State, eloquently contrasted the condition of the Central African tribes twenty years ago with their improved state to-day. Baron Wahis and Vice-Governor-General Fuchs are men on the spot. Their long experience on the Congo invests their statements with authority. In the address referred to, Baron Wahis narrated the following graphic picture of Congolese conditions two decades ago.

Let us see in what position these peoples were before the formation of the State, and what is their position now.

In the Lower Congo, close to the sea, there was one locality which already possessed some importance, viz., Boma. Before the first expedition of the State landed at Boma there were at that point some commercial houses. For a long period they derived their profits from the sale of slaves; later, they obtained their chief profits from the sale of alcohol, 
and, accessorily, of the products of the soil. The traders carried on a more or less prosperous business according to their strength and courage. They made expeditions into the interior, and frequently burnt native villages for not bringing in at fixed periods the expected quantities of palm nuts and other products. Their staff of labourers was composed of slaves upon whom they inflicted torments for the least infraction of their orders. These punishments had no limit. It is related, and the fact is not open to doubt, that during the time of which I am speaking there were once found in the waters of Boma the corpses of thirty blacks attached to one chain. The chain bore the name of "Olivarès," but it was alleged, and probably with good reason, that the perpetrator was not Olivarès, that the chain had been stolen from him. The name of the person really guilty of this horrible crime was mentioned, and it was represented as the consequence of a mutiny by the staff of a factory. That was the kind of administration to which the blacks were subjected, under the eyes of Europe it may be said, seeing that ships of war had easy access to Boma.

Higher up, in the present district of the Cataracts, the population was in part subject to the Negro king of San Salvador. Read the book of Mr. Bentley, an educated English missionary, who has been in Africa thirty years, and who saw the administration under which the natives lived when he arrived there. He expresses his admiration for the enormous progress which has been made, so far as the protection of the blacks goes, since they came under the government of the Congo State. Why are not the statements of this sterling man, so eminently competent in all questions relating to the protection of the blacks, quoted?

But whatever may be said to the contrary, the system adopted by the Government of the Independent State is more equitable than any other system whatever, and imposes upon the natives a minimum of taxes. Each man's tribute is very small. In certain regions where the rubber is abundant, he can gather in one day the tax that is required of him for a month. Besides the work thus performed by the natives 
being remunerated, their households find themselves in possession of some supplementary resources. The desire to add to their well-being increases each day.

Let us hope that the policy established by the Congo State in this respect will not be changed. The strong black races which cover many parts of its territory will acquire the habit of regular work, in place of their primitive idleness. There will result from this what has resulted in countries long civilised. The countries in which people know how to work are strong, and in the van of progress. Such a future seems to me reserved for the Congo State if it perseveres in its present course.

The story of the Congo Free State offers great opportunity for speculation and for prophecy. Taking a broad view of the opinion prevalent in Europe and the United States, the conclusion that Great Britain seeks to acquire important territory in Cen- tral Africa is inevitable. This theory of the antiCongo campaign is strenuously denied by all unofficial persons engaged in that campaign. And yet there are unmistakable signs that of the many theories so industriously exploited, British acquisition of the keystone of African territorial possession seems to be most in line with the history of British methods of expansion. The Free State is one-third the size of the United States. It lies squarely across the heart of Africa, with an outlet to the sea on the West Coast which brings it many miles and many days nearer European markets. It separates the British African Empire,- - the Soudan and the Nile country adjoining the Free State on the north, from the Cape and the Boer war territorial acquisitions on the south. It is as if the Louisiana Purchase, owned 
by a small country, say Portugal, divided the United States. One might dwell long and interestingly upon the political possibilities of such a rich country and its great waterways separating the energies of the east and the west in our country's social, political, and strategic solidarity. The British and the Germans appreciate the vast possibilities of the great African Continent. While the former expands its territory by costly wars, the latter, by adapting its methods to suit the native populations, encompasses the African market. While the former persists in imposing its ancient, crude, and ineffectual methods of colonial development, the latter, more modern, more direct, more flexible, is gaining trade and influence which might belong to intelligent British rule. The palsied arm and the obsolete method of regeneration, prevalent in the territories devastated by the Boer war, illustrate the incompetency of the present generation of British colonisers. Their failures are multiplying. It is the old story of worship of the Past, confusion in the Present, misconception of the Future.

The growth of the Congo Free State has from the first been skilfully directed by clever men of thought and action. Now that the transformation is complete, and what but three short decades ago was the very heart of savagery has become a valuable commercial and political asset, the forcible ejectment from the African Continent of the authors of all this good is openly discussed! Such is the reward which it is proposed should be meted out to the gallant, self-sacrificing little nation which has replaced the 


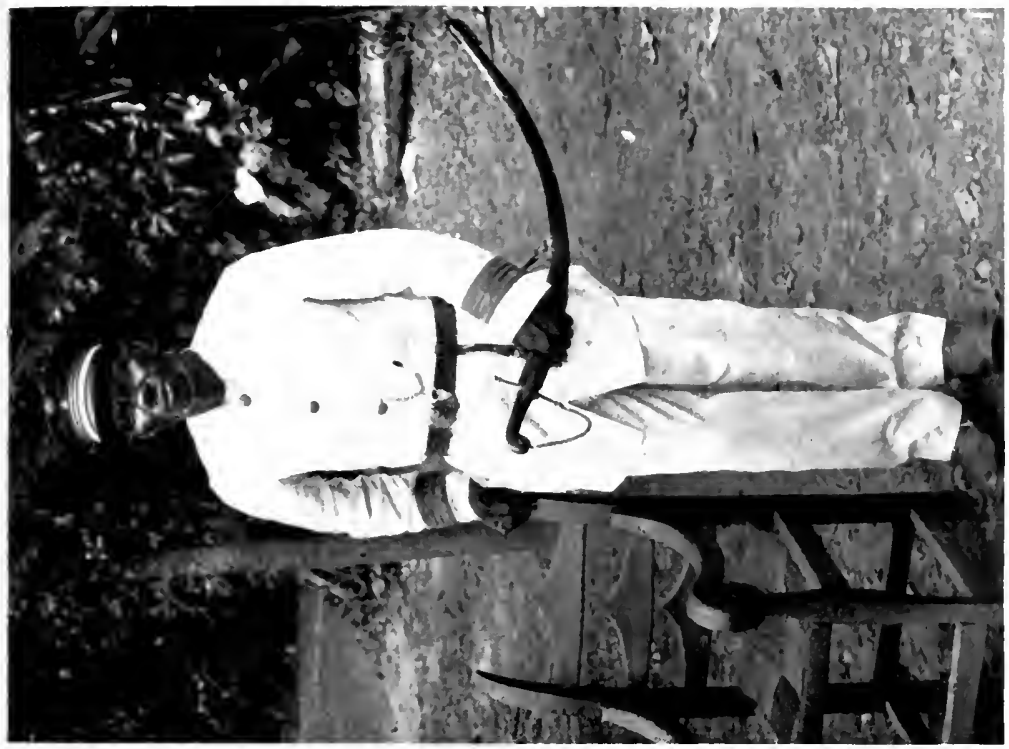

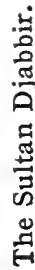

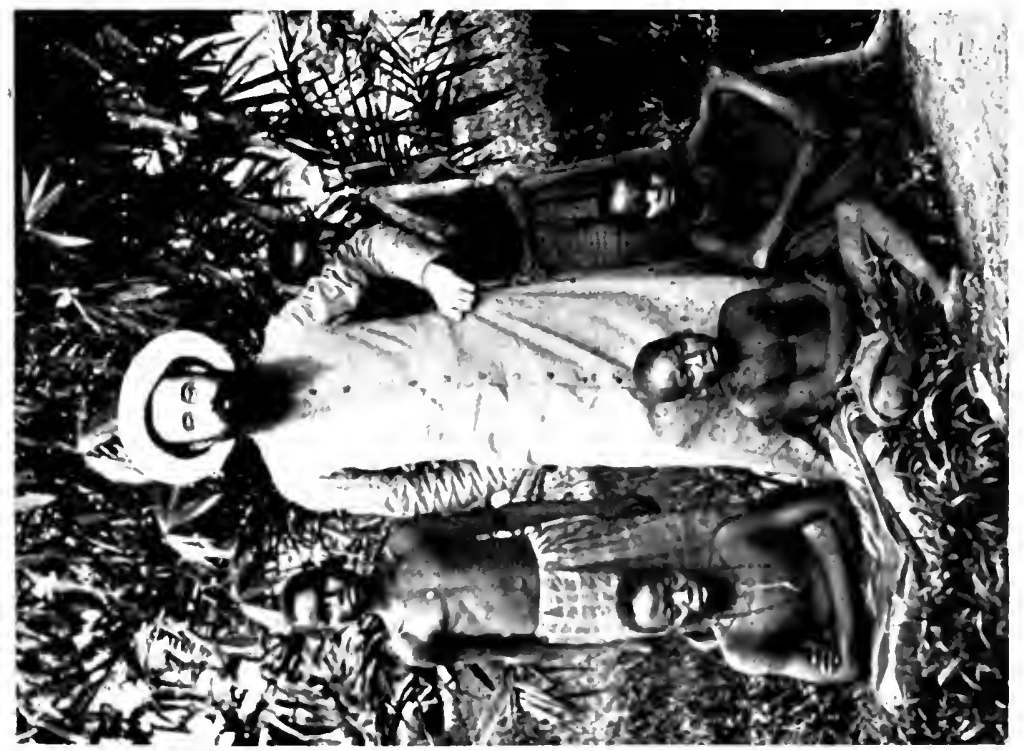

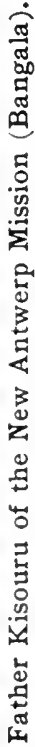





\section{Summary, Retrospect, and Prophecy 483}

horrors of barbarism by the blessings of civilisation, and incidentally discovered vast material wealth. After disposing of the Belgian African possession, that international pigmy, Portugal, occupying Delagoa Bay to the obvious chagrin of Britain, will be served with the long-expected writ of ejectment. These little fellows in Africa will have but one choice of leaving - by the door or by the window. Will the world tolerate such iniquity?-an iniquity of the baser sort, veiled with specious pretence. Much depends upon the attitude of the American peopleyoungest of the great nations, herself too recently emerged from the trials and tribulations which beset every newly created State not to discriminate between greed and hypocritical pretence on the one hand and conscientious well-doing on the other. 



\section{APPENDIX}

485 



\section{APPENDIX}

\section{TREATY OF VIVI}

M. August Sparhawk, agent of the International Expedition of the Upper Congo, acting in the name and for the account of the Comite d'Etudes, of the Lower Congo, and Vivi Mavungu, Vivi Mku, Ngusu Mpanda, Benzane Congo, Kapita, have come together the $1^{\text {th }}$ of June, 1880 , at the station Vivi, in order to discuss and to decide upon certain measures of common interest.

After full examination they have arrived at the dispositions and engagements which are embodied in the present treaty, to wit:

ARTICLE I.-The aforesaid chiefs of the district of Vivi recognise that it is highly desirable that the Comite. d'Études of the Congo should create and develop in their states establishments calculated to foster commerce and trade, and to assure to the country and its inhabitants the advantages which are the consequence thereof.

With this object they cede and abandon, in full property, to the Comité d'Etudes the territory comprised within the following limits: To the west and north and east the left banks of the river Lulu, and to the south the districts of Kolu and Congo.

ART. II.-The chiefs of the district of Vivi solemnly declare that these territories form an integral part of their states, and that they are able freely to dispose of them.

ART. III.- The cession of the territories specified in the last paragraph of Article $I$ is consented to in consideration of a present represented by the following articles and goods to each one: A uniform coat, a cap, a coral necklace, a knife; and a monthly gift to Vivi Mavungu of two pieces of cloth; to Vivi Mku of one piece of cloth: to Ngusu Mpanda, one piece of cloth; to Benzane Congo, one piece of cloth; to Kapita, one piece of cloth.

ART. IV.-The cession of the territory includes the abandonment by them and the transfer to the Comité d'Études of all sovereign rights.

Art. V.-The Comité d'Études engages itself expressly to leave to the natives the free enjoyment of the lands which they now cultivate to supply their needs. It promises to protect them and to defend their persons and their property against aggressions and encroachments, 
from whatsoever side. which shall attack their individual liberty or shall seek to take away from them the fruit of their labours.

ART. VI.-The chiefs of the district of Vivi grant, besides, to the Comité d'Études-

( 1 ) The cession of all the routes of communication now open or to be opened throughout the whole extent of their states. If the Comite deems it proper it shall have the right to establish and levy for its own profit tolls upon said routes, to defray the expenses incurred in their construction. The routes thus opened shall embrace, besides the routes properly so-called, a breadth of twenty metres right and left therefrom. This breadth constitutes part of the cession, and shall be, like the route itself, the property of the Comite d'Etudes.

(2) The right of trading freely with the natives who form part of their states.

(3) The right of cultivating unoccupied lands; to open up the forests; to cut trees; to gather india rubber, copal, wax, honey, and, generally, all the natural productions which are found there; to fish in the rivers and streams and water-courses, and to work the mines.

It is understood that the Comité can exercise the several rights mentioned in the third paragraph throughout the whole extent of the states of the chiefs of Vivi.

ART. VII.-The chiefs of the district of Vivi undertake to unite their forces to those of the Comite to repel attacks which may be made by intruders, no matter of what colour.

The chiefs, not knowing how to sign, have put their marks, in the presence of the witnesses hereafter designated and who have signed.

[Seal.]

[Seal.]

[Seal.]

[Seal.]
Aug. Spariawk.

JOHN KICKBRIGHT.

FraNK MAHONEY.

GeOFFREY.

\section{TREATY OF MANYANGA}

During the palabre held at Manyanga the I th of August, I882, it is agreed between the members hereinafter designated of the Expedition of the Upper Congo:

Dr. Edward Pechuel Loesche, chief of the Expedition;

Capt. Edmund Hanssens, chief of the division of Leopold-Manyanga;

Lieut. Arthur Niles, chief of Manyanga;

First Lieut. Orban, deputy chief of Manyanga;

Edward Ceris, assistant of Pechuel, representing the Comite of the Upper Congo;

and the chiefs hereafter named of Manyanga-

Makito, of Kintamba;

Nkosi, of Kintamba; 


\section{Appendix}

Filankuni, of Kintamba;

Maluka, of Kintamba;

Kuakala, of Kintamba;

Mankatula, of Kintamba-Kimbuku;

Luamba, of Kintamba;

In the name of their subjects.

ARTICLE I.-Hereafter the territory of Manyanga, heretofore belonging to the chiefs before cited, situated north and south of the river, and bounded on the west by the stream Luseto, and by the stream Msua Mungua on the east, shall be the sole property of the Comité d'Études of the Upper Congo.

ART. II.-The chiefs and their subjects, their villages, their plantations, their domestic animals, and fishing apparatus shall be placed under the protection of the Expedition.

ART. III.-In all political affairs of the populations of the district protected and acquired, their quarrels, differences, elections of chiefs, shall be submitted to the decision of the member of the Expedition who shall be present at the station.

If the people of Manyanga shall be attacked by neighbouring tribes, the Expedition shall defend their women and children and their property by all the means in their power. If the Expedition shall be attacked by another tribe, the men shall be bound to defend the station.

ART. IV.-In consequence of the rights acquired and protection afforded, no stranger whatsoever can build or open a road or carry on commerce in the territory of Manyanga.

ART. V.-At the request of the chief of the station, the chief of the district shall put at his disposition the necessary number of labourers, men or women, for the work of the station and the service of the caravans.

ART. VI.-Besides the sum stipulated, which has been remitted in goods to the assembled chiefs in payment for their territories, and for which they have given a receipt, the chiefs shall receive monthly presents on condition that they remain true friends and voluntarily perform the services asked of them.

ART. VII.-The first chief of Manyanga, Makito, residing at Kintamba, receives the flag of the Expedition, which he will raise in his village in sign of the protection exercised by the Expedition.

[Here follow the crosses and signatures.]

\section{TREATY OF LEOPOLDVILLE}

29 th of April, r883.

We, the undersigned, chiefs of the district of N'Kamo, of Kuiswangi, of Kimpe, and of all the districts extending from the river Congo to 
Leopoldville and to Ntamo, up to the river Lutess and the mountains of Sama Sankori, have resolved to put ourselves, as well as our heirs and descendants, under the protection and patronage of the Comite d'Études of the Upper Congo, and to give power to its representative at Miamo to regulate all disputes and conflicts that may arise between us and foreigners of whatsoever colour, residing out of the district or territory of N'Kamo, in order to prevent strangers, animated by wicked intentions or ignorant of our customs, from exciting embarrassments or endangering the peace and security and independence which we now enjoy.

By the present act we also resolve to adopt the flag of the Comitc d'Etudes of the Upper Congo, as a sign for each and all of us that we are under its sole protection.

We also solemnly and truly declare that this is the only contract we have ever made, and that we will never make any contract with any European or African without the concurrence and agreement of the Comité d'Études of the Upper Congo.

To the above resolution we freely put our marks.

Ngaliema, his $\times$ mark.

MARARI, his $\times$ mark.

NumBI, his $\times$ mark.

Manwale, his $\times$ mark.

NyasKo, his $\times$ mark.

\section{TREATY WITH THE KING OF NIADI}

\section{STEPHANIEVILLE}

Between, on the one side, Captain Johñ Grant Elliott, commissioner and representative of the Comité d'Etudes of the Upper Congo, and, on the other hand, M'Wuln M'Boomga, King of Niadi, in his own name, and in that of his heirs and successors, the following contract has been made and signed in the presence of the witnesses whose signatures are below given:

Article I.-The party first named engages himself to make to the second party named above an immediate payment of 60 yards of savelist, 20 pieces of superior stuffs, 8 pieces of ratteen stuff, and a keg of powder. He, moreover, engages to make to the above-named party of the second part, his heirs and successors, a monthly payment, which shall commence in four months, with arrears from the date of this contract, of four pieces of stuffs, and to continue always this payment, if, in compensation therefor, the party of the second part, in his name and in that of his heirs and successors, makes an absolute and immediate sale of a certain portion of territory sketched further on, de- 
scribed in Art. II., the territory selected by the first-named party, and over which the flag of the Comité d'Études of the Upper Congo, that is to say, a blue flag with a yellow star in the centre, has been raised.

ART. II.-The country ceded by the above-named article is described below, and accepted by the contracting parties, Captain John Grant Elliott and the King.

I. Six miles towards the west, from the junction of the Niadi and the Ludema, and following the banks of the Niadi (Niari).

2. Ten miles from the same confluence, towards the south, and following the banks of the Ludema.

3. Ten miles towards the east, from the confluence above named, and following the course of the Niadi (Niari).

4. Ten miles towards the south, from the same confluence, and following the Ludema.

5. Ten miles to the north of the Niadi (Niari), on each side from that point of the Niadi opposite the mouth of the Ludema, running back five miles towards the north.

Witnesses:

Grant Elliott, Wuln M'Boomga.

Von Shaumann,

LEGAT,

Destrain.

OTHER TREATIES, DISTRICTS CEDED, AND STATIONS CREATED BY THE INternational Association of the Congo, and which form the CHIEF PLACES OF THE STATES pOSSESSED By THIS AsSOCIATION ON the Congo and on the Niadi Kwilu in the Year i 883.

Stations: Vivi, Isanghila, Manyanga, Lutete, Leopoldville, Msuata, Bolobo, Rudolfstadt, Baudoinville, Franktown, Stanley Niadi, Stephanieville, Anvers, Gideemba, Lukolela, Equateur, Philippeville, Bulangungu, Mboka, Mkula, Grantville, Massabe.

Treaties and Districts ceded: Vivi, Yellala, Sala Kidougo, Ganghila, Sadika Banzi, Ingha, N'Sanda, Kionzo, N'Bambi M'bongo, Talaballa, Issanghila, Ndambi M'bongo, M'Kelo, Fua na Sondy, Konimovo M'Bongo, Yanga, Kamsalou, M'binda, Sakali Boadi, Tchouma Ranga, Tombukile, Ngoma, N'Zadi, Tchincala, Banza ngombi, Manyanga, Bandanga, Banza, M'bou, Sello, Loufountchou, Kimbanda, Ngombi, Leopoldville, Kimpoko, Kinshassa, Kintambou, Souvoulou, M'bala, Woutimi (south), Woutimi (north), Msuata, Bolobo, Matchibouga, Tchissanga, Kitabi, Zientu, Mengo, Franktown, Goudou, Ganda, Fouindoukifout, Makouba Banga, Sitambe, Bieba, Moyby, Matalila, N'Zombo, Ganda Kobombo, Mabuka, Chinnifor, Mudenda, Nyange, Lubu, Zoa, N'Gewlla Chunikonbo, M'Gwella, Sangha, Charli, Mikasse, Moulangas, Mackanga, Ludema, Ungoonga, Buconzo, Matenda, Tanga Dibiconga, Licarnga, Bumianga, Chibanda N'Kuni, Kingi, Anversland, Buda, Towha, Gideemba, Sushwangi. 


\title{
IN THE SENATE OF THE UNITED STATES
}

\author{
March 26, 1884.-Ordered to be printed \\ Mr. Morgan, from the Committee on Foreign Relations, submitted the \\ following
}

\section{REPORT}

(To accompany S. Res. 68 and Mis. Doc. 59)

The Committee on Foreign Relations, to whom were referred Senate Mis. Doc. No. 59 and Senate Joint Resolution 68, relating to the occupation of the Congo Country, in Africa, have had the same under consideration, and report a substitute for the same, and recommend its passage.

The President, in his annual message to this Congress, expresses the sentiment of the people of the United States on the subject of our future relations with the inhabitants of the valley of the Congo, in Africa.

Our attitude towards that country is exceptional, and our interest in its people is greatly enhanced by the fact that more than one-tenth of our population is descended from the negro races in Africa.

The people of the United States, with but little assistance from the Government, have established a free republic in Liberia, with a constitution modelled after our own, and under the control of the negro race. Its area is 14,300 square miles; its population is about $I, 200,000$ souls; its commerce is valuable: its government is successful, and its people are prosperous.

The necessity for a negro colony in Liberia was suggested by the fact that slaves found in vessels captured for violations of the slavetrade laws and treaties were required to be returned to Africa when that was practicable, and it was impossible, and it would have been useless and cruel, to send them back to the localities where they were first enslaved. Humanity prompted certain private citizens of the United States to organise the American Colonisation Society in aid of the return of captured slaves to Africa and to find a congenial asylum and home for negroes who were emancipated in the United States.

Henry Clay was, for many years, president of this association, and assisted it with the influence of his great name and broad philanthropy.

The success of the Liberian colony has demonstrated the usefulness of that system of dealing with a social question which is, to the people of the United States, of the highest importance. It has also established a recognised precedent in favour of the right of untitled individuals to found states in the interests of civilisation in barbarous countries, through the consent of the local authorities, and it has given 


\section{Appendix}

confidence to those who look to the justice of the nations for a restoration of the emancipated Africans to their own country, if they choose to return to it.

This great duty has, so far, been left entirely to the efforts of citizens of the United States, and it has been supported almost exclusively by their personal contributions. The governments of the world have been slow even to recognise the state thus founded by the courage and means of private citizens, but it is now firmly established in the family of nations and is everywhere recognised as a free and independent nation.

This pleasing history of progress, attended with peace and prosperity in Liberia, has given rise to a feeling of earnest interest amongst the people of the United States in the questions which arise from the recent discovery by their countryman, H. M. Stanley, of the great river which drains equatorial Africa. They rejoice in the revelation that this natural highway affords navigation for steamers extending more than half the distance across the continent, and opens to civilisation the valley of the Congo, with its 900,000 square miles of fertile territory and its 50,000,000 of people, who are soon to become most useful factors in the increase of the productions of the earth and in swelling the volume of commerce.

The movements of the International African Association which, with a statement of its purposes, are referred to in the letter of the Secretary of State, appended to this report, are in the direction of the civilisation of the negro population of Africa, by opening up their country to free commercial relations with foreign countries.

As a necessary incident of this praiseworthy work, which is intended, in the broadest sense, for the equal advantage of all foreign nations seeking trade and commerce in the Congo country, the African International Association has acquired, by purchase from the native chiefs, the right of occupancy of several places for their stations and depots. The property so acquired is claimed only for the association, which is composed of persons from various countries, and it could not, therefore, be placed under the shelter of any single foreign flag.

From the time when the people of Christian countries began to export slaves from Africa, the custom grew up of locating "barracoons" or slave depots along the African coasts and rivers, and they were each placed under the shelter of the flag of the country to which the slave merchants belonged. In this way certain settlements were made along the shores of the Congo River as far inland as Yellalla Falls, and were claimed and held under the protection of the respective flags of the countries from which thesc traders came.

This was, generally, a mere personal adventure, and had no relation to any governmental authority of those countries over the barracoons. When this traffic took the shape of legitimate commerce with the 
natives, these places were called factories, and they gradually assumed certain powers of self-government as their necessities required. Each factory was independent of the control of all others, and established for itself such regulations, having really the effect of laws, as were necessary to protect life and property. To this day those settlements are held in the same way, and while the governments, whose flags are thus displayed over them, claim no sovereignty there, they do not recognise the rights of their people at such places as entitling them to protection, and they require their flags to be respected.

In some instances the native chiefs sold the lands on which the factories were situated, with the privileges of trade to foreign companies, and these in turn sold them to persons of still other nationalities.

The African International Association established its stations, and opened roads leading from one to another around the falls of the Congo in the same way that the older factories had been established, with the additional fact in their favour that their settlements were always preceded by an open agreement with the local government in the form of a treaty. A flag was as necessary for the purposes of their settlement and as an indication of their right and to designate the places under their control, as it was to the slave-traders, whose only advantage is that they have been in possession a long time for the purposes of nefarious traffic in slaves, while the Association has been in possession only a short time for the benign purposes of introducing civilisation into that country.

Having no foreign flag that they could justly claim, they adopted a flag and displayed it, a golden star in a field of blue, the symbol of hope to a strong but ignorant people, and of prosperity through peace. The native people instinctively regarded that as the first banner they had seen that promised them goodwill and sccurity, and they readily yielded to it their confidence.

There is no historical record to be found of such a rapid and general assembling of separate and independent rulers under a banner that was raised by the hands of strangers, as that which took place amongst the chiefs and people of the Free States of the Congo. Within five years from the time the banner of this Association was first displayed on the Congo, its agents have made nearly one hundred treaties with the chiefs of the different tribes in the Congo country. In each of these treaties there are valuable commercial agreenents and regulations.touching law and order and certain delegations of limited powers, all of which are intended for the better government of the country.

The powers are not ceded to a new and usurping sovereignty seeking to destroy existing governments, but are delegated to a common agent for the common welfare. In the language of the first treaty, concluded at Vivi June 13, I880, and which is the plan after which nearly one hundred subsequent treaties have been modelled: 
"The aforesaid chiefs of the district of Vivi recognise that it is highly desirable that the Comite d'Etudes of the Congo should create and develop in their states establishments calculated to foster commerce and trade, and to assure to the country and its inhabitants the advantages which are the consequence thereof.

"With this object in view they cede and abandon, in full property (fee-simple) to the Comite d'Études, the territory comprised within the following limits," etc.

A copy of this treaty is appended to the report of the committee.

If these local governments had the right to make these concessions, so much sovereign power as they confer upon the African International Association is entitled to recognition by other nations as justifying its claim to existence as a government de jure. Or, if there is still a question as to its sovereignty, affecting either its territorial extent or the subjects as to which it may legislate, there is still enough of concert amongst the native tribes, in placing themselves in treaty relations with this Association, to warrant other nations in recognising its existence as a government de facto. In either case, it is our duty so to recognise it, because its purposes, as avowed in those treaties, are peaceful, and commend themselves strongly to the sympathies of our people.

The golden star of the banner of the International Association represents hospitality to the people and commerce of all nations in the Free States of the Congo; civilisation, order, peace, and security to the persons and property of those who visit the Congo country, as well as to its inhabitants; and if, in the promotion of these good purposes, it lawfully represents powers ceded or delegated to the Association by the local governments necessary to make them effectual, it does not thereby offend against humanity nor unlawfully usurp authority in derogation of the rights of any nation upon the earth.

Powers asserted in good faith, and with a reasonable show of ability to maintain them, even by rebels, within a state that denounces their assertion as treasonable, are often recognised as being lawful, as well in the interests of humanity, as to give to the alleged rebels an opportunity to make good their pretensions by arms.

The history of our recent civil war discloses the recognition of the belligerent rights of the Confederate States by all nations, including the United States, which wholly denied the lawfulness of the acts of secession which led to hostilities and denounced them as treasonable.

If the flag of the Confederate States could protect its armed citizens against the penalties of piracy while destroying the ships and commerce of the United States, it would be difficult to state a reason why the flag of the International African Association should not protect its ships from capture and condemnation while carrying on peaceful commerce on the Congo. It would be still more difficult for any 
Christian nation to assign a reason founded in the principles of international law why it should refuse to recognise this flag. The Congo River has been for centuries, and is now, the common resort of the ships and flags of all countries, and it requires a total change of the political conditions in that country to destroy this right, and either to declare the waters and shores of the Congo as being neutral territory or as being under the sovereignty of any one or more of the foreign nations.

These reasons, and others which appear in the papers appended to this report, are a just and sufficient foundation for the declaration by the United States which individualises the flag of the African International Association as a national flag, entitled to our recognition and respect.

The precedents in our own history to justify our recognition of states while in the process of early development are numerous and conclusive. They are cited in the papers appended to this report, and are sustained by many other references which show that in Europe, Asia, and Africa civil power, exerted by commercial associations, and by religious orders, and by propagandas of civilisation, and by groups of Hospitallers, has owned large war fleets and raised armies, fought great battles, levied taxes, and performed every function of government. They did all this without claiming to possess sovereign power as organised nations; and they submitted themselves to the authority of the state after they had prepared the country where they ruled for that final act of establishment of sovereign power, and then they ceased to exist.

It is not necessary to go further in order to find a justification of the action suggested in the message of the President, and of the resolution which the Committee on Foreign Relations recommend as a proper means of carrying into effect this policy concerning the Free States of the Congo.

It is, however, proper to make some examination of the alleged claim of Portugal to the sovereignty of the mouth of the Congo, and of the riparian country as far into the interior as the first falls of Yellalla.

Portugal's pretensions to this sovereignty are completely refuted by the fact that it has not been heretofore acknowledged by the five great powers whose flags have been flying for more than a century in the country now claimed by that Government. On the contrary, these powers have constantly refused to make any such concession on all occasions since $I 786$, and some of them previous to that time.

The claim of Portugal, based on discovery of the mouth of the Congo by Diego Cam in 1485 , and by his having erected a monument on the shore to testify to his landing there, only establishes its antiquity and not its rightfulness under modern interpretations of the laws of nations. 


\section{Appendix}

If the laws of Christian nations give any effect to the discovery by the subjects of a Christian power, of a country inhabited even by savages, they also require that discovery shall be followed by continuous subsequent occupation. If such occupation ceases, it is justly considered as being abandoned, since the only foundation of reason or of justice that can support the occupation of an inhabited country by a foreign power is, that it is better that the savages should have the advantages of Christian instruction and laws, than that they should continue in darkness to rule the country in their own way. If, therefore, the Christian ruler should cease to occupy the country, it must be considered that he abandons his duty, and, with it, the sovereignty of the country.

Portugal did not exert continuous or exclusive authority on the Congo for any great while; her possessions there, as well as those of the other Christian powers, fluctuated with the supply of slaves, the capture or purchase of which was the chief inducement to these settlements. They all followed up the supply of slaves from the interior of Africa, along the coast, according to its abundance, as the fishermen visit different localities in search of better fishing grounds.

In 1786 , disputes having arisen between France and Portugal, as to the sovereignty of the latter over the mouth of the Congo, under the mediation of the King of Spain, Portugal conceded the point that her rights in that country were not exclusive. Since that time England has repeatedly denied, in the most formal and solemn manner, that Portugal had any sovereignty or suzerainty over the Congo country. None of the great powers claimed such sovereignty for themselves, nor have they conceded it to Portugal; their occupancy has not been such as implied any right to rule the country, but only such as was necessary to carry on trade. That is equally free to all nations. In the papers appended to thisiseport, and especially in the valuable testimony of Earl Mayo, based upon his personal observations in the Congo country in 1882 , we find the most conclusive proof upon all the points above stated, and unquestionable evidence that Portugal's northernmost boundary on the West Coast of Africa, south of the Equator, for many years past, has been the river Loge.

The attitude of Great Britain towards the pretensions of Portugal to the sovereignty of the Lower Congo has been that of decided, frequent, and stern denial, accompanied with distinct orders to her fleets to repel any advance of Portugal to assert her authority north of Ambriz. This record, so repeatedly reaffirmed, is by no means changed by the fact that Great Britain may now be ready to admit Portugal, in alliance with her, to sovereign rights in the Lower Congo. Her change of policy cannot change the facts, especially when Great Britain obtains from Portugal the cession of Wydha in consideration that she will acknowledge the rights of Portugal to the sovereignty of the Lower 
Congo. Great Britain has also made treaties with fifteen tribes in the Lower Congo country, paying no attention to Portugal's claims of sovereignty there.

In like manner France has disregarded these pretensions, and has made treaties with tribes north of the Congo. De Brazza, an enterprising explorer, went into that region of Africa as an agent of the African International Association, and also as an agent of the French Government, and was supported with money from the French treasury. He made these treaties in the name of France, and the Chamber of Deputies has ratified them. In view of these facts it can scarcely be denied that the native chiefs have the right to make treaties. The able and exhaustive statements and arguments of Sir Travers Twiss, the eminent English jurist, and of Professor Arntz, the no less distinguished Belgian publicist, which are appended to this report, leave no doubt upon the question of the legal capacity of the African International Association, in view of the laws of nations, to accept any powers belonging to these native chiefs and governments which they may choose to delegate or cede to them.

The practical question to which they give an affirmative answer, for reasons which appear to be indisputable, is this: Can independent chiefs of savage tribes cede to private citizens (persons) the whole or part of their states, with the sovereign rights which pertain to them, conformably to the traditional customs of the country?

The doctrine advanced in this proposition, and so well sustained by these writers, accords with that held by the Government of the United States, that the occupants of a country at the time of its discovery by other and more powerful nations have the right to make the treaties for its disposal, and that private persons, when associated in such country, for self-protection or self-government, may treat with the inhabitants for any purpose that does not violate the laws of nations.

The following incidents, mentioned in Bancroft's History of the United States, show how much we owe, as a people, to the early recognition of these doctrines:

\section{"MASSACHUSETTS}

"One day in March, I621, Samoset, an Indian, who had learned a little English of the fishermen at Penobscot, entered the town, and, passing to the rendezvous, exclaimed in English, 'Welcome, Englishmen!' He was the envoy of Massasoit himself, the greatest commander of the country, sachem of the tribe possessing the land north of Narragansett Bay, and between the rivers of Providence and Taunton. After some little negotiation, in which an Indian who had been carried to England acted as interpreter, the chieftain came in person to visit the Pilgrims. With their wives and children they amounted to no more than fifty. He was received with due ceremonies, and a treaty 


\section{Appendix}

of friendship was completed in few and unequivocal terms. Both parties promised to abstain from mutual injuries, and to deliver up offenders; the colonists were to receive assistance, if attacked; to render it, if Massasoit should be attacked unjustly. The treaty included the confederates of the sachem; it is the oldest act of diplomacy recorded in New England; it was concluded in a day, and was sacredly kept for more than half a century. "-(Bancroft's History of the United States, p. 210.)

"The men of Plymouth exercised self-government without the sanction of a royal charter, which it was ever impossible for them to obtain."-(Ibid., p. 213.)

"The attempt to acquire the land on Narragansett Bay was less deserving of success. . . . In 1641 a minority of the inhabitants, wearied with harassing disputes, requested the interference of the magistrates of Massachusetts, and two sachems near Providence surrendered the soil to the jurisdiction of that State."-(Ibid., p. 287.)

\section{"PROVIDENCE PLANTATIONS AND RHODE ISLAND}

"In June ( $\left.16{ }_{3} 6\right)$ the law-giver of Rhode Island (Roger Williams), with five companies, embarked on the stream; a frail Indian canoe contained the founder of an independent State and its earliest citizens. Tradition has marked the spring of water near which they landed. To express unbroken confidence in the mercies of God, he called the place Providence. . . . The land which he occupied was within the territory of the Narragansetts. In March, 1636 , an Indian deed from Canonicus and Miantonomoh made him the undisputed possessor of an extensive domain; but he 'always stood for liberty and equality both in land and government.' The soil became his 'own as truly as any man's coat upon his back'; and he 'reserved to himself not one foot of land, not one tittle of political power, more than he granted to servants and strangers.' He gave away his lands and other estates to them that he thought most in want until he gave away all."-(Ibid., p. 254.)

"Before the month (March, 1638 ) was at an end, the influence of Roger Williams and the name of Henry Vane prevailed with Miantonomoh, the chief of the Narragansetts, to make them a gift of the beautiful island of Rhode Island. . . . A patent from England was necessary for their security; and in September they obtained it through the now powerful Henry Vane."-(Ibid., p. 263.)

\section{" CONNECTICUT}

"In equal independence a Puritan colony sprang up at New Haven, under the guidance of John Davenport as its pastor, and of his friend the excellent Theophilus Eaton. . . . In April, 1638 , the colonists 
held thcir first gathering under a branching oak. . . . A title to lands was obtained by a treaty with the natives whom they protected against the Mohawks."-(Ibid., p. 27I.)

\section{"NEW HAMPSHIRE}

"At the fall of the leaf in 1635 , a band of twelve families, toiling through thickets of ragged bushes and clambering over crossed trees, made their way along Indian paths to the green meadows of Concord. A tract of land six miles square was purchased for the planters of the squaw sachem and a chief, to whom, according to Indian laws of property, it belonged."-(Ibid., p. 27 I.)

\section{"NORTH CAROLINA}

"In $x 660$ or I66I New England men had found their way into the Cape Fear River, had purchased of the Indian chief a title to the soil, and had planted a little colony of herdsmen far to the south of any English settlement on the continent."-(Ibid., p. 409.)

"It is known that in 1662 the chief of a tribe of Indians granted to George Durant the neck of land which still bears his name."-(Ibid., p. 4 IO 0 .)

We owe it as a duty to our African population that we should endeavour to secure to them the right to freely return to their fatherland, and as freely to agree with their kindred people upon any concessions they may choose to make to them as individuals or as associated colonists, looking to their re-establishment in their own country. The deportation of their ancestors from Africa in slavery was contrary to the now accepted canons of the laws of nations, and now they may return under those laws to their natural inheritance. In exercising this right they should not be obstructed by a power that had more to do with their enslavement and expulsion, in bondage, from their own country than any other, and that never held a claim upon that country for any purpose of advantage to the people there, but held it chiefly, if not entirely, for the mere purpose of enslaving them.

It is stated, with the support of strong testimony, that Portugal is still protecting the slave trade on the West Coast of Africa under a thin guise of the voluntary emigration of the negroes to other countries.

Extracts appended to this report, from Earl Mayo's De Rebus Africanus, in which ne gives an account of his personal examination, in 1882 , of the Portuguese trading posts, supported by the report of M. du Verge, our United States consul at St. Paul de Loando, show that slavery still exists in the country claimed by Portugal on the Congo, and is fostered there and at St. Paul de Loando by the Portuguese residents.

This violation of the slave-trade treaties renders the occupancy by 


\section{Appendix}

Portugal of any African territory at the mouth of the Congo dangerous to all the tribes of the interior, and cannot be sanctioned by the treaty powers while it is attended with such incidents without an abandonment of all treaty obligations and duties relating to the slave trade.

The importance of the Congo River to the continent of Africa as a channel through which civilisation and all its attendant advantages will be introduced into a region inhabited by $50,000,000$ of people cannot be too highly estimated.

After Stanley had made his journey of exploration of nearly 7000 miles across the continent of Africa, and had revealed to the world the extent and importance of this great river Congo, all the great commercial nations at once began to look earnestly in that direction for a new and most inviting field of commerce, and with the high and noble purpose of opening it ireely to the equal enjoyment of all nations alike.

The merchants of Europe and America insist upon this equal and universal right of free trade with that country, and their Chambers of Commerce have earnestly pressed upon their respective Governments the duty and necessity of such international agreements as would secure these blessings to the people of Africa and of the entire commercial world.

The enlightened King of the Belgians has supplied the means from his private purse to inaugurate civilisation in the Congo country under the authority of its native rulers. He has no thought of extending the power of his realm over that country, but has engaged in this movement only as any citizen might.

Its progress is thus further described by an agent of the African International Association in a letter within the past month:

"Brussels, February 25.

"Our territories are extending now on a very rich coast south and north of the mouths of the Quillou, a distance of more than 350 kilometres (about 300 miles).

"That coast has given itself to us by unanimous acclamation of the natives, who hoisted our flag and refused our presents.

"Our territories are going to be divided into three provinces: ( $\mathrm{r}$ ) Coast and Quillou Madi; (2) Lower Congo, Vivi, Stanley Pool; (3) Upper Congo.

"Our governmental organisations will then be complete: in Africa, a head chief and governors administering the country and justice: in Europe, the association providing for the financial wants of the new State, and representing the new state and many native sovereigns who have confederated with us and hoisted our flag.

"This is the present situation and prospects of the enterprise."

It may be safely asserted that no barbarous people have ever so readily adopted the fostering care of benevolent enterprise as have the 
tribes of the Congo, and never was there a more honest and practical effort made to increase their knowledge and secure their welfare.

The people of the Congo country and their benefactors alike deserve the friendly recognition of the United States in their new national character.

Your committee, therefore, report a substitute for the resolutions referred to them by the Senate, and recommend its passage.

\section{(From the Revue de Droit International)}

\section{THE FREE NAVIGATION OF THE CONGO}

\section{BY SIR TRAVERS TWISS}

The Congress of Vienna inaugurated a new era in the reciprocal relations of European states, by laying down the principle that these relations should be subordinated to the interests of the European community in case of conflict between the individual interests of the states and that which is just in an international point of view. It is a fact, which is apparent to every attentive observer of the great political evolutions of our century, that it is more and more perceived that the community of nations create obligations towards it, and that the empire of this community over the states which form part of it has several times obtained formal sanction by means of conferences whose protocols point out to us the considerations which dominated their counsels. These protocols form declarations of whicl all the participants are the sureties. We are proud of modern civilisation. We congratulate ourselves upon the progress of international law among civilised nations. We are therefore justified, it seems to me, in asking of the states which participate in the European concert of public law, whether it would not be possible to assert this principle of duty towards the community of states as a means of solving the question of the Congo, without awaiting the stern necessity of intervening to put an end to war, or, at the least, the occasion of offering mediation to avert a recourse to the sad arbitrament of the sword. The Congo question is in the condition of a young tropical plant, whose germ has not yet commenced to develop, but which will perhaps assume suddenly unexpected proportions.

I have already treated of the free navigation of the Lower Congo, but I have omitted, or at least only glanced at the idea of an international protectorate, under the agis of which a modus vivendi could be established upon a solid basis of stipulated right, among the diverse nationalities whose flags float over the factories of Banana Creck, at the entrance of the Congo, and thus proclaim the cosmopolitan character of the settlement. Ascending the channel of the river, Punto da Lenha is reached, where a pentarchy, so to say, of European flags 


\section{Appendix}

equally affirms the cosmopolitan character of the port, and gives notification that the individual interests which prevail there rest under the protection of five states. Formerly, a common end, the slave trade, was the only bond which united those diverse nationalities in a kind of commercial fraternity. To-day there exists between them a law of usage, intended to regulate their common interests; but this usage leaves much to be desired, and it does not control the private life of the residents of each factory, who are free to regulate, according to their own pleasure, their relations with the natives. In fact, there does not exist social order, properly so called, among the factories; there is no collective will among their members, no authority which they are bound to obey, and one may say, "Ubi nulla societas, ibi nullum jus." The sad truth of this axiom is confirmed by the stories of frightful cruelties committed upon the natives in the year 1877 , an account of which can be found in the dispatches of the English consuls to their Government. (Parliamentary Papers, Africa, No. 2, 1883.)

M. Moynier, president of the International Committee of the Red Cross, at Geneva, called the attention of the Institute of International Law, during its last session at Munich, to the question of the Congo, and the readers of the Review will remember the proposition which M. Emile de Laveleye developed thereupon (pp. 254-262), asking, in the interests of humanity, that the waters of the Congo should be neutralised by European action. M. Moynier had already treated of this subject at the Institute in Paris, in September, 1878 ; but it was not expected at that time that the majestic course of waters explored by Stanley in 1877 would soon become the object of dangerous rivalries. The result has proved that the whites, who have formed many stations upon the Upper Congo and its affluents, have already run the risk of being engaged in competitions which may disturb the good feeling between the newcomers and the natives, to whom European civilisation should bring only benefits. The arrival at Stanley Pool of a French expedition which ascended the channel of the river Ogouve, from the affluents of the Congo, has introduced upon the banks of the Upper Congo the representative of a European Government, who has taken possession, in the name of France, of a territory ceded by the native chiefs of the country.

It is evident from the very nature of things that the question of the Congo may properly be divided into two parts, for the Lower Congo is already subjected to an order of things entirely exceptional, in which five European nations participate. This condition of affairs was based originally upon a common traffic in slaves, to which has succeeded a legitimate trade with the natives-a commerce in which the European nations take part in a perfectly independent manner, each for itself. In spite of that, there is on the Lower Congo, because of these na- 
tionalities, a certain solidarity of interest which counsels a common accord upon the subject of the navigation and the police of the river. But, as I have before said, as far as regards criminal jurisdiction, the whites of each factory regard themselves as independent, and not as responsible to any Government whatsoever.

The Upper Congo, on the contrary, bathes the territories of many native tribes. Their chiefs have granted stations to the agents of the International Association, which depend upon no European sovereign, but which are modelled upon certain institutions of the Middle Ages, to enable the population of barbarous Africa to participate in the advantages of European civilisation. All the stations which this Association possesses have been acquired peaceably by treaties with sovereign chiefs of the country. It governs them by intelligent men, belonging to all European nationalities. And, moreover, it has hoisted over these stations a flag which signifies that they belong to no especial nation, but that they form part of an International Association founded in the interests of the natives, and which represents all countries interested in the progress of humanity. A single European nation has entered this humanitarian arena, and that is the French Republic, which, in accepting, as a European State, the cession of territory made to M. Savorgnan de Brazza, has notified the civilised world that France has not sought to put private interests in opposition to the general interests of civilisation, represented in Africa by a flag, the principal merit of which is precisely that of not being the flag of any one power. (See Report presented by the Government of the Republic to the Chamber of Deputies, 2oth November, 1882.)

"Neither in the spirit of your Commission [it is there said] nor in the views of the Government, is there any purpose at this moment to go upon the banks of the Congo, or upon the neighbouring shores with military array, but simply to found scientific, hospitable, and commercial stations, without other military force than may be strictly necessary for the protection of the establishments successively created."

Unfortunately, the appearance of a European national flag upon the banks of Stanley Pool raised the question whether the agent of an association which had not the political character of a State, could, by a cession of the actual Sovereign of the country, acquire and exercise the sovereignty of a territory situated outside of Europe. I say outside of Europe, because we do not seek to find the solution of such a problem, as affecting Africa or Asia, in the existing political condition of affairs in Europe, nor in the fixed regulations of European society, upon which that condition of things rests, but in the unwritten law of nations, which should regulate the relations between free peoples, no matter to what family they belong, nor what religion they profess. Yet the practice of Europe, while Christianity was sceking to accomplish the high mission of civilising the barbarous races on the northern and 


\section{Appendix}

eastern frontiers, merits our attention, because of a certain analogy between the condition of those frontiers in the eleventh century, and the present condition of Equatorial Africa.

In order, therefore, to appreciate the action of the International African Association, and to fathom the question whether this action is without precedent in the action of European peoples, it will be profitable, in the first place, to study the archives of a period when Europe was not entirely Christian, and when Christianity made a propaganda among the native pagan tribes who at that time inhabited a part of the country which we now call Prussia. This study will bring to our knowledge the action of an international association which accomplished the civilisation of a country inhabited by people who might be called savages, and, at the same time, will furnish a refutation of the assertion put forth by certain publicists that States alone can exercise the rights of sovereignty.

M. de Laveleye, before cited, has made allusion to the Teutonic Order as an institution for the propagation of civilisation, which, in the Middle Ages, carried civilisation to the populations on the borders of the Baltic and cemented them to the rest of Europe. The action of this famous order in regard to the acquisition of the sovereignty of a barbarous country has an important analogy to the action of the International African Association.

Thus this order was originally a charitable association of Germans which the citizens of the free cities of Bremen and Lubeck instituted at the siege of St. Jean d'Acre, during the Fourth Crusade. Afterwards, this association constituted itself into an order of chivalry towards the end of the twelfth century, and, after the religious enthusiasm to which the Crusades had given birth had ceased to inflame the nations of Southern Europe, the order established itself at Culm, in the country which is now called Western Prussia, where Conrad, Duke of Massovie, of the Polish Dynasty of the Piasts, ceded to it a territory and assured to it the conquests it might make over the idolatrous Prussians. The order by gradual steps established its dominion with Christianity over the whole of Prussia. The city of Konigsberg, upon the Pregel, was built by it in 1255 , and the city of Marienbourg, upon the Nougat, which became afterwards the capital of the order, dates its foundation back to the year $1276 .^{x}$

Another order, that of the Chevalier's Sword-Bearers (Ensiferri), was established in Livonia, where, finding itself too weak to sustain the attacks of the pagans, it ended by uniting itself to the Teutonic Order. This union rendered the Teutonic Order so powerful it was able to

The Schloss Hauptmann of the Castle of Marienbourg, formerly the palace of the grand master of the order, is now appointed by the King of Prussia. 
establish its authority over the whole of Prussia, Courland, and Senegal, and from the annalists of that time we learn that in converting the people to Christianity the Teutonic Order subjected them to an exceedingly hard yoke. The Teutonic Order maintained itself in the sovereignty of this country until the middle of the fifteenth century, when it was subjected to great territorial losses in a war against Poland, and was compelled to become the vassal of the King of Poland for East Prussia. It is upon the embers of this order that the Prussian monarchy was established by the courage of the descendants of Duke Albert of Brandenbourg, grand master of the order, the first Duke of Prussia.

It is to be observed that, during all this time that this order was sovereign, it was not recognised as a State, and that the master of Livonia was not admitted to a sitting and vote among the States of the German Empire until after this order had ceased to be sovereign.

The City of Dantzic was, for two centuries, up to 1454 , the maritime capital of the order, and it may be said that the Teutonic Order was the supreme power during two centuries on the shores of the Eastern Baltic, without being organised as a State. ${ }^{\mathrm{s}}$

On the other hand, in the south of Europe, there was an order of chivalry whose services to civilisation in defending Christian countries against the invasions of the Arabs and the Turks are more famous even than those of the Teutonic Order. I refer to the sovereign Order of St. John of Jerusalem. This order, originally founded for the service of the hospital of St. John at Jerusalem, quitted the holy city at the commencement of the fourteenth century and established itself in the island of Rhodes to defend the frontiers of Christianity against the attacks of the Saracens. Then it had to give up the island of Rhodes to the Turks, and it established itself in the island of Malta, of which it obtained the territorial sovereignty as a gift from the Emperor, Charles V., in 1530. Even this order adopted a territorial title, that of the Order of Chevaliers of Malta, and maintained its sovereignty over this island until the year $\mathrm{r} 798$. The English having soon after become masters of the island by conquest from the French. it was proposed by the Congress of Amiens, the 27th March, 1802, to restore the fortress of Malta to the Order of St. John, and to put the independence of the island under the guarantee of the powers uniting in that congress. This project failed. At the Congress of Vienna, in 1815, the Order of Malta demanded to be provided with another

1 The old Teutonic Order was suppressed in the year 1809 at the peace of Luneville, when the grand master of the order was secularised for the archduke to be chosen by the emperor. It may be said of the Teutonic Order that it was renewed in 1824 and reorganised in 1840 and $\mathrm{r} 865$, but that it is the shadow of a great glory-magni stat nominis umbra. 


\section{Appendix}

sovereign establishment in the Mediterranean suitable for the institution of the order, and that its independence and neutrality should be guaranteed by all the powers. The congress would not listen to this demand.

I have cited these two examples to show that according to the law of usage of Europe, associations which are not organised as states can, nevertheless, exercise sovereign rights. But it may be said that these orders of chivalry were privileged orders, and that they belong to an epoch when Christian civilisation was propagated at the sword's point. Putting aside, then, the military epoch of the civilising propaganda, let us pass to the commercial era inaugurated by the discoveries of Christopher Columbus and Vasco de Gama. The theory of publicists which we have to examine is this, that a private association cannot exercise sovereign rights in a barbarous country. A learned collaborateur of the Revue de géographie, of Paris, has formulated it in these terms: "It is a principle of law that states alone can exercise sovereign rights; that no private company can have them." I It is evident that this proposition is affirmed by M. Delavand in too absolute a manner, for the facts of history contradict it. Among the members who formed the great Union of the United States of North America there were at least four which owed their origin to private associations, whose territorial sovereignty had been established before they received any charter of incorporation from the Crown of England. Everybody knows that a commercial company acquired by treaties with the natives the sovereignty of the English Indies. A similar Dutch company acquired and exercised sovereign rights in the island of Java and in the Malaccas. Should there be a different rule in Africa from that which has prevailed in America and Asia? Or should there be, for the young republics of the nineteenth century, a law of nations directly opposed to that which prevailed at the foundation of the independent States on the shores of North AmericaStates whose federation gave birth to the parent republic of our age? I do not think so. Doubtless the national law of a country may prohibit its citizens from accepting the sovereignty of a barbarous country, but the international question must not be confounded with the question of national law, in regard to which we may say, "Extra territorium jus dicenti impune non paretur."

Will it be said that these ideas are superannuated; that they do not belong to our age? I will reply by a very recent example, which has been the subject of discussion between the Governments of Spain, the Netherlands, and Great Britain. It is known that certain native chiefs on the northern coast of the island of Bornco delegated to a European, a private individual, rights implying the exercise of terri-

Vol. xii. of the Revue above cited, p. 224. 
torial sovereignty; that the person to whom the chiefs of the country had delegated supreme power, under the title of maharaja, ceded his rights to a private company, and that that company obtained from the English Crown a charter of incorporation. It may be said that the history of the propagation of civilisation in the seventeenth century in America is renewed in Asia and Africa in the nineteenth century. The English Government regarded this delegation of sovereign rights by native chiefs, in return for an annual subsidy, as a sufficient title to enable the company to exercise these powers, and sustained this proposition before the House of Commons. In reply to a question in regard to the granting of the charter of incorporation, Sir Henry James, Attorney General, said:

"The rights which have been accorded the company have become legally its property, and it would have been an act of confiscation if the Government of Her Majesty had attempted to deprive it of them."

And the prime minister, Mr. Gladstone, also affirmed that the charter had not granted to the company any power to exercise rights implying sovereignty which it had not already acquired by delegation from native chiefs. A correspondent of the Revue de géographie of Paris has specified these rights according to the contents of the act of delegation. ${ }^{1}$ It is not doubtful that in virtue of this act the company, without being a state, can exercise sovereign rights over a considerable territory in the northern part of the island of Borneo. M. E. de Laveleye, before cited, says that Germany, formally consulted by the British Government in 1882 , did not question the capacity of private individuals or of companies to obtain from non-civilised Sovereigns the concession of rights implying the exercise of rights of sovereignty. The Governments of the Netherlands and of Spain did not deny such power, but they claimed to have anterior rights over the northern portion of Borneo; and it was in virtue of those anterior rights that they protested against the rights claimed by the British North Borneo Company. It is, therefore, evident that the obstacles which the establishment of stations by the International Association upon the Upper Congo might meet with from European powers are not to be found in the fact that they are in contravention of any law of nations by virtue of which states alone can exercise sovereign rights, but solely in the fact that Portugal pretends, by reason of anterior rights, to deny the capacity of the native chiefs of the country to cede the sovereignty of a part of their territories without the consent of Portugal.

It appears, in the meantime, that the British Government did not

I Mr. A. J. Wauters, assistant secretary of the International Congress of Commercial Geography, 1879. First number of the Revue, July 1, 1883, p. 63 . 


\section{Appendix}

yield to the pretensions raised by Holland and Spain concerning the northern part of the island of Borneo, and that the Government of the French Republic, in spite of the pretensions of Portugal, has recognised the supremacy of a native king upon the Upper Congo, and has accepted the cession of his hereditary rights. This treaty, concluded by M. Savorgnan de Brazza, as the representative of France, at Neousa, the 30 th October, 1880 , ceded to France a territory which was in the possession of certain chiefs, vassals of the King Makoko; and said chiefs signed the treaty, whilst the King Makoko, in his capacity as suzerain of these chiefs, ceded to France, by an act invested with his mark, his rights of supremacy over this territory. It seems, therefore, that there is no place for a suzerainty of Portugal over the regions around Stanley Pool, according to the opinion of the Government of the French Republic, for the Senate and the Chamber of Deputies authorised the President of the Republic to ratify the treaty and act above mentioned, and the President has promulgated a law to give them full effect.

It might reasonably be asked, if there is any difference in principle between the right of African chiefs, admitting they are sovereigns of a territory, and the right of Asiatic chiefs to cede their territory to a private company. France, at least, has recognised the right of King Makoko, suzerain of the Batakes, to cede to a European State his rights of sovereignty, and the right of the chiefs subordinate to his authority to cede the possession of the parts of the territory they occupied. Why should it be forbidden to a native chief to cede his territory to an international European company, which, according to the law of nations, is perfectly capable of accepting and exercising such a sovereignty?

The Comite d'Etudes of the Upper Congo-for it is necessary to distinguish between the association which occupies the Lower Congo and the association which occupies the Upper Congo-has made, through Mr. Stanley, with the native chiefs, treaties, which in regard to their tenor resemble more closely the treaties concluded by the British Society with the Sultans of Brunei and Sooloo, in the island of Borneo, than the treaties concluded by the native chiefs of the Upper Congo with M. Savorgnan de Brazza. Take for example the treaty which Captain Eliot, agent of Mr. Stanley, concluded with the Chief Manipembo, the 2oth of May of this year. The first three articles declare that the Chief Manipembo cedes and abandons to the committee of the Upper Congo, in full property, certain territories in return for a present the receipt of which is acknowledged, and he solemnly declares that these territories form an integral part of his State, and that he can freely dispose of them. It is clearly evident from the tenor of these articles that the Chief Manipembo rccognises no superior chief Article IV. of the treaty states that the cession of territory carries with 
it the abandonment by the above-named chief, and the transfer to the committee of all his sovereign rights.

Was this transmission of sovereign rights to the committee of the Upper Congo illegal according to the law of nations? It is indisputable that the Chief Manipembo was legally capable of concluding treaties with European Powers, for the French Republic, through M. Cordier, on the 12 th of March of this year, concluded with him and with the King of Loango treaties by which all the left bank of the river Quillou, I which empties into the Bay of Loango, is placed under the protectorate of France.

Concerning the exercise of sovereign rights by the committec of the Upper Congo, acquired by treatics with native chiefs, if reliance can be placed upon an article in the Journal l'Export, which professes to have its facts from good authority, the committee has instructed its representatives, in case of expeditions from any nation seeking to establish themselves there, to give them gratuitously the necessary land. The committee wishes especially to create colonies at the stations of the Congo, and to see developed there a new kind of free cities. An idea which may throw some light on the future of the Upper Congo is this: An International Protectorate of the Lower Congo, under the presidency of Portugal, and a system of free cities for the Upper Congo.

History teaches us that the march of the caravans which traverse the sandy deserts of Northern Africa has been rendered possible by the existence of certain spots where nature has made provision of water and vegetation where travellers and camels can rest and refresh themselves. Why should not a philanthropic association be permitted to imitate this foresight of nature, and to establish, like these oases, free cities at certain distances upon the banks of the great river of Equatorial Africa, to facilitate the progress of a humane civilisation and the development of a beneficent commerce?

The institution of free cities in Germany greatly accelerated the progress of the arts and civilisation in Europe, and the rapid development of these cities in the fourteenth century teaches us that by means of such an organisation a nearly barbarous country can be erected into a civilised body upon an industrial and commercial basis. These cities, either through their origin or by virtue of the charters granted them by sovereign powers, secured to themselves a free government, which assured to their citizens personal liberty and the ownership of their property under the protection of their own magistrates.

The traveller in the free city of Bremen, on arriving at the marketplace, will see before him a great stone column which is called the Rolands Saule. This column supports the colossal figure of a man, holding in his right hand a sword, and crushing under his feet the head

I Niadi-Kwilu. 
and hand of a man. This is emblematical of the right of the city to dispose of the lives and labour of its inhabitants. The present column was erected in 1412 , but it replaced a wooden column which dated back to the period of the First Crusade, and whose origin is unknown. Other monuments of analogous character to this are found in many of the cities of Germany, and they are symbols of the right which the magistrates of these cities had to exercise both civil and criminal jurisdiction. They bear witness that these cities were sui juris in regard to the power to make and execute their laws. Should an institution which contributed so much to attach the North of Europe to the civilisation of the South, which rooted itself so firmly upon the shores of the North Sea and the Baltic that its vitality withstood the strain of wars and civil dissensions for six centuries, - should that be regarded as an innovation in the usages of nations when transplanted into Equatorial Africa?

When the Dutch Provinces of Spain revolted against the Spanish Crown, and the Prince of Orange granted letters of mark to individuals, to make reprisals against Spain, the Spanish Government refused to recognise the legality of these letters of mark, upon the pretext that a republic could not exercise rights of admiralty which belonged exclusively to crowned heads. This is the origin of the term of opprobrium, quex de mer, which the Spaniards employed to degrade the Dutch, but which the Dutch adopted as a title of honour. In the same way as now, it was then attempted to make it appear that under the law of nations states alone could exercise sovereign rights. But the facts contradicted this proposition. The suggestion recalls the fable of the hare and the tortoise. According to the principles of pure mathematics the tortoise should never be able to catch the hare, but the problem is simplified enormously when recourse is had to the proof of the facts. To use a scholastic expression, "Experience discovers the truth"-solvitur ambulando. For example, the right of the International African Association to hoist a flag upon its steamboats upon the Lower Congo cannot be denied, while the English society, in possession of the rights of the Sultans of Brunei and Sooloo, implying the exercise of rights of sovereignty, has raised its flag, and the British admiralty has been authorised to recognise it.

To return to the objection of certain publicists that a State alone can exercise sovereign rights. The free cities of ancient Rome and of the empire of Germany (to distinguish it from the present empire) were not subjects of the Emperor, but vassals of the empire, and when the free city of Strasbourg capitulated, in the year $168 \mathrm{I}$, the King of France received it under his royal protection, and it preserved all its privileges and its magistrates with civil and criminal jurisdiction, as a free republic, with a territorial zone, under the protection of France, until the French Revolution. 
What are the obstacles which delay the establishment of a system of free cities on the banks of the Upper Congo, and which prevent the powers whose subjects have establishments on the Lower Congo from coming to an agreement as to an international protectorate of the river? There is a European power which arrogates to itself, in virtue of a discovery of the mouth of the river Congo in the year 1484 , the sovereignty of all territory watered by this river and its affluents. I do not speak of the pretensions of this power over all the territory of the west coast of Africa, between $5^{\circ}, 12^{\prime}$, and $8^{\circ}$ south latitude-pretensions which have been contested by France, by Holland, and even by England since the slave trade was abolished by conventions between the British and Portuguese Governments. So long as the slave trade existed, everybody hunted Negroes in common in the regions of the Congo. Since the slave trade was abolished the maritime powers of Europe have treated the pretensions of Portugal with courtesy, but not one has admitted them.

I affirm, with all the respect due to the country of Prince Henry the Navigator, that this is the condition of things upon the Congo, although the Portuguese Government, in a circular dispatch, written in reply to a resolution of the Institute of International Law, has asserted that its rights are not disputed.

In support of this assertion of the Portuguese Government the author of the dispatch cites an incident of the last Franco-German war. During the war a French corvette captured a German merchant vessel, the Hero, lying at anchor in Banana Creek, inside the mouths of the Congo. The circular dispatch states that the German Government requested the Portuguese Government to demand the rendition of the prize, as captured in Portuguese waters; but it does not say that the Portuguese Government took any steps before the French prize courts, or that the French Government acceded thereto. The statement of facts stops there. Then, the dispatch says that "the news soon reached Europe that the French governor of Gaboon, the port into which the captor had carried his prize, had set at liberty the crew, and caused the German ship to be taken back to Banana Creek, where it remained at anchor till the close of the war."

The author of the dispatch appears to me the rictim of the paralogism described by the phrase post hoc, propter hoc, for he attempts to draw from these facts the "irresistible conclusion" that the Governor of Gaboon recognised the waters of Banana Creek as Portuguese waters. It appears, on the contrary, that the ship was set at liberty by the Governor of Gaboon, motu suo proprio, and in no manner on account of any demand of the Portuguese Government; and the only legitimate conclusion from the premises is this: The Governor of Gaboon recognised that the capture of the ship had been effected in territorial waters, where, whether they belonged to a native King or to 


\section{Appendix}

a European power, France had not the right as a belligerent power to capture the enemy's ships. ${ }^{x}$ The Governor of Gaboon conducted himself loyally without waiting special instructions from his Government. This fact, which the author of the dispatch cites as a proof of Portuguese sovereignty over the territories of the west coast of Africa, between $5^{\circ}, \mathrm{I} 2^{\prime}$, and $8^{\circ}$, south latitude, comprising the mouths of the Congo, has absolutely no significance as an argument.

Another event which the dispatch of the Portuguese Government recalls is that of the Ist of May, 1877 , which had previously acquired considerable notoriety by the publication of the correspondence between the Portuguese Government and the Government of her Britannic Majesty. Several old slave-traders, established at Punta da Lenha, were carrying on a regular and legal commerce with the natives, but, at the same time, were slave-owners. In consequence of an incendiary attempt upon a Dutch factory, the residents of Punta da Lenha made a "noyade" (drowning of several persons at the same time) of Negroes in the river opposite Boma. The British consul, who resides ordinarily at Saint Paul de Loando, which city is under the jurisdiction of the Portuguese crown, wished to make inquiries at the scene of the crime in regard to the summary execution of twenty-nine Negroes by order of their masters, but he did not dare to disembark at Punta da Lenha because of the threats of the inhabitants. Under these circumstances, the Portuguese Government conducted itself in a very proper manner. At the instance of Consul Hopkins, of Loando, the governor of the Portuguese province of Angola sent a gunboat to Punta da Lenha, and arrested a British subject named Scott, implicated in the noyade, and was perfectly willing to try the accused according to the laws of Portugal with the consent of the English consul; but the correspondence between the two governments shows that the English Government was unwilling to admit Portuguese sovereignty over the banks of the Congo. It is surprising that the author of the circular dispatch should have cited this incident as indicating the recognition of Portuguese sovereignty by the English Government, when the correspondence presented to the British Parliament in regard to the matter proves precisely the reverse. Here, for example, are the terms of a dispatch of Sir Julian Pauncefote, under secretary of state, to the English consul at Loando, which closes the correspondence:

"The territory in which these outrages have been committed has long been claimed by the Portuguese Government, and this claim is renewed in the correspondence with the Portuguese authorities in-

I The Times of the 5 th November, 1882 , in which an English translation of the circular dispatch of the Portuguese Government is published, says: "Unquestionably because the Government perceived that the capture had been made improperly." 
closed in your dispatches. Her Majesty's Government, however, as you are aware, have always contested and opposed that claim, and cannot, therefore, admit the jurisdiction of the Portuguese tribunals to deal with the case of Scott." I

No one accuses Portugal of wishing to impede the free navigation of the Congo, but it is to be regretted that, being powerless to insure that navigation to its own subjects, it is unwilling to consent to a friendly agreement with the powers whose subjects have factories upon the north bank, to put the navigation of the river beyond risk of danger. I have said advisedly that Portugal is powerless to insure the navigation of the river to its own subjects. I have already spoken of the tribes which inhabit the borders of Pirates' Bay, upon the north bank of the river, against whom the English commander, Hewitt, had to organise an expedition in 1875 , because they had plundered an English merchant ship and massacred the crew. But there is, on the south bank, a considerable tribe who practise piracy on a large scale, and do not even respect Portuguese vessels. The pirates especially infest San Antonio, at the southern extremity of the mouth, in the immediate neighbourhood of the column of Point del Padron. The author of a book entitled Four Years on the Congo, ${ }^{2}$ published in Paris, describes an attack by these pirates upon a Portuguese brig. The account is interesting, but I will not now go into details. What it imports is, the powerlessness of the Portuguese Government to suppress the piracy of this tribe and to punish the guilty ones. I cite an extract from this work which gives the history of the Portuguese expedition sent to punish the Mussorangos who had attacked the Portuguese brig:

"On the ${ }^{1} 5^{\text {th }}$ of November two corvettes and the frigate $\mathrm{La}$ Guadiana left Loando. The little fleet, commanded by M. Viegas de C-n headed for the Congo. The commander hoped to surprise the Negroes. Arrived at a place considered sacred, and which is called the "Stone of the Fetish," they anchored, and M. Viegas himself, with one company, ascended the creek in a steam gunboat and effected a landing, which the savages endeavoured at first to oppose; but soon afterwards, dislodged by the showers of grape shot from the frigate, moored a few cables' length only from the shore, they retired in good order. Meanwhile, the little band of whites, finding no serious resistance, advanced. The corvettes shelled the villages in sight. Some groups of Mussorangos, who had stood firm till then, feeling themselves vanquished fled in every direction, returning and stopping, from time to time, behind trees to discharge their guns at the whites. The commander burned all the villages he found. That was all that could be done. It would not have been prudent to march at a venture into an unknown country in search of an unapproachable enemy, always flee-

I Parliamentary Papers, Africa, No. 2, 1882, p. 86.

2 Paris, G. Charpentier \& Co., 1883. 


\section{Appendix}

ing. It was necessary to re-embark; the ships came back to Banana, where they remained some days, and then returned to Saint Paul."

This is a very recent occurrence, which does not very well bear out the assertions of the Portuguese Government relative to the efficacy of its jurisdiction as remedy for the disorders of the Congo.

"The Congo [says the author of the circular dispatch] and the territories bordering its mouth are already the seat of an important commerce, and of European establishments of diverse nationalities, but there is no security either for life or property, no police, no courts, nor any of the institutions so necessary to all civilised people, and which can only be established under a recognised and effective jurisdiction. And such jurisdiction can only be exercised by Portugal, because no other nation possesses or claims any rights of sovereignty over these territories." I

I repeat, the good intentions of Portugal are not in dispute. What is wanting is energy and material power; and it is necessary to have these in order to civilise the country discovered by the agents of the International Association. Four centuries have elapsed since Diego Cam, a Portuguese cavalier, erected a column upon the Point del Padron, the end of the south bank of the river's mouth, in commemoration of the fact that a subject of the crown of Portugal had discovered the great river Congo. This same point is to-day in the hands of a native tribe, which not only does not recognise the sovereignty of Portugal, but openly defies it. Nevertheless, the author of the circular finds much fault with the resolution of the Institute of International Law, because that resolution implies, according to him, forgetfulness of the rights of Portugal. What rights? There exist rights based upon the discovery of the country, but considering that the fleets of Pharaoh Neco, King of Egypt, made the circuit of Africa, we cannot admit that the legal discovery of the Congo was effected by Diego Cam. But rights founded upon the discovery of the country are only imperfect rights; occupation should follow, within a reasonable time, to render them perfect; otherwise the discovery becomes inoperative, like an abandoned title. Has Portugal occupied both banks of the Congo to acquire possession of its waters? Have we the proof of it? On the contrary, the very territory where Cam erected this column is to-day in the power of a native tribe, who have always resisted Portuguese sovereignty, and who openly claim to be (a thing almost incredible) the enemies of the human race (hostes humani generis). And, on the other hand, England, which pretends to no sovereignty over the waters of the Congo, has been obliged to land a force upon the north bank to chastise an act of piracy committed by the inhabitants of the creeks in the neighbourhood of Banana.

I I quote the text of the circular as published in the Independance Belge of the 7 th November, 1883 . 


\section{Story of the Congo Free State}

It is evident that very soon the problem of the free navigation of the Congo will assume such proportions that the solution cannot be longer deferred. Should this solution wait upon a state which up to now has only demonstrated its powerlessness to civilise the countries on the south bank of the Lower Congo, its sovereignty over which is not disputed by any European state?

LoNDON, November $21,1883$.

\section{ARGUMENT OF PROFESSOR ÉGIDE ARNTZ}

Can independent chiefs of savage tribes cede to private citizens the whole or part of their states, with the sovereign rights which pertain to them, conformably to the traditional customs of the country?

This question, as it is propounded, presents two aspects. It must be considered:

I. From the point of view of the right of the one who cedes.

II. From the point of view of the one to whom the cession is made.

\section{I}

In examining this question from the standpoint of international law, we must first ask if the chiefs of savage tribes can, generally, make treaties, conventions, cessions of territories; in other words, if the tribes which they represent are considered as states, having the capacity to make international treaties, which would be respected as such by all civilised or non-civilised nations.

From the fifteenth century till early in the nineteenth century, the rules of international law were regarded as being to some extent an exclusive privilege of Christian peoples, for the establishment of regular relations between them. With regard to pagan peoples, they were not considered as participating in the political community whlch international law established between Christians; and it was only by Article VII. of the treaty of Paris of the 3 oth of March, 1856 , that the Sublime Porte was admitted "to participate in the advantages of the European concert."

We can easily understand that Christian nations could not admit to participation in the advantages of international law the people of nations who did not recognise this law as binding upon themselves. and who did not practise its precepts. Publicists and moralists teach that in their relations with pagan and savage populations, Christian sovereigns should always conduct themselves honestly, and observe the rules of justice, equity, and Christian morality.

It would be too long to enter here into the details of the discussions which the authors of the sixteenth and seventeenth centuries had on the subject of the conduct of European nations in regard to the Indians. We shall limit ourselves to saying that the relations of the states of 


\section{Appendix}

Europe with other nations had no fixed rules, that they varied much, according to the power and importance of the foreign nations, according to the communications more or less numerous which Europeans had with them, and according to the manners and customs practised by them. ${ }^{\text {I }}$

Thanks to the progress of humanitarian ideas, of a better practice of Christian morality, and the greater influence of principles of international justice, feeble people, almost savage, although not possessed of the benefits of civilisation, are no longer considered in our days, as destined to serve as a mine for civilised nations to "work." All those having a human face, turned towards the heavens, are considered as members of the great human family, children of the common Father, animated by the same Divine breath, having the same destiny to accomplish, and meriting the respect due to human dignity.

These ideas have prevailed with jurisconsults and publicists, have permeated their doctrines, and happily have guided their practices. Savage tribes, although living in very imperfect communities, as well as their territories, are no longer regarded to-day as things without a master, and belonging to the first occupier, that is, to the first comer stronger than themselves. Want of civilisation can no longer serve as a pretext to civilised nations to put them under subjection, or to control them by violence.

The law of nations is a science still imperfectly moulded or stereotyped, and especially is it a science which ought not to be, and cannot be, formulated a priori. Its fundamental principle is, no doubt, philosophy, but it has its positive base in the facts of history and authoritative doctrine.

What are the conditions to enable a state to exist, as such, and to qualify it to treat?

"A certain number of men and families, who, being united, in a country, and having fixed their abode there, associate and submit themselves to a common chief, with the intention of providing for the safety of all, form a state," says Klüber, ${ }^{2}$ and to the same effect says G. F. Von Marten. 3

"Sovereignty [continues Klüber 4] in this extended sense consists in the ensemble of rights belonging to a state, independent as regards its

I Heffter, par. 7, p. I 4: “With respect to non-Christian states, which are not yet regularly admitted into the bosom of the European family, the application of the same law is entirely free, and founded upon a purely conventional reciprocity. Relations with them are formed according to the exigencies of policy and morality."

2 Droit de gens moderne, par. 20.

3 Einleitung in das positive europaïsche Völkerrecht, Gottingen, 1796, p. I.

4 Droit des gens moderne, par. 21. 


\section{${ }^{18}$ Story of the Congo Free State}

object. It comprises, first, the entire independence of the state in the face of foreign nations; second, legitimate power of the Government or of the authority which the purpose of the state demands."

The same author says ${ }^{1}$ :

"Sovereignty is acquired by a state either at its foundation or when it separates itself legitimately from the dependence under which it was. To be valid, it does not need to be recognised or guaranteed by any foreign power whatever, provided its possession is not faulty (vicieuse)."

It is useless to multiply extracts. The principles summarised by Klüber on the sovereignty, the independence, and the equality of states, from the legal point of view, are equally professed by all authors. We will limit ourselves to the following: Heffter, par. 15, 16, pp. 32-34; par. 23, pp. 42, 43; par. 26, 27, pp. 47-49. Wheaton, vol. i., pp. 32, 43. Vattel, lib. i., chap. i., sec. 4. W. E. Hall, International Law, par. 2, 4, pp. 16-20; par. 6-8, pp. 34-37; par. 9, 10, pp. 39-42. Calvo, Droit international, par. 39-41, pp. 1 43-147.

Tribes inhabiting determined territory, represented by their chiefs, form, therefore, independent states.

From this the first consequence is that the territories which they occupy are not things without masters (res nullius), and cannot be occupied by other states. It is only territories without master, that is to say, upon which no sovereign power is yet established, that can be the object of occupation.

As regards the right of occupation, see the following authors:

"Christian people cannot rightfully take possession of lands which savages already really occupy," says George Frederick von Marten. ${ }^{2}$

Klüber 3 says: "A state can acquire things which belong to no one (res nullius) by occupation (original), and the goods of others by means of conventions (derivative occupation) . . . In order that the occupation may be legitimate, the thing itself should be susceptible of exclusive property and belong to no one. (A) The state should have the intention of acquiring the property thereof.'

In the note (A) the author says: "Property thus is acquired rightfully by an occupation without flaw; it is preserved by continuous possession. In consequence no nation is authorised, no matter what its pretensions, especially if of a higher degree of culture, to seize upon the property of another nation. It cannot even take it from savages or nomads."

The author cites in support of this, Gunther, Volkerrecht, vol. ii., p. ro et seq. See also the beautiful and energetic passage from Heffter, Le droit international public, vol. i., par. 70, pp. I4I, I42: "Droit d'Occupation."

Droit des gens moderne, par. 23.

2 Einleitung in das positive europaische Volkerrecht, par. $3 \mathrm{I}$.

3 Droit des gens moderne de l'Europe, par. 25. 


\section{Appendix}

To give validity of occupation it is necessary that the property should be without master, and that the intention to acquire the domain should be joined to the fact of an effective taking possession. Let us examine each of the three conditions:

r. Occupation is only to be applied to property which, although susceptible of being possessed, has no master. It does not extend to persons, who can only be the object of a submission, whether voluntary or forced. Occupation is to be applied notably to countries and islands uninhabited or not entirely occupied; but no power on earth has the right to impose its laws upon wandering or even savage peoples. Its subjects can seek to establish commercial relations with these latter, can remain among them, in case of necessity can demand of them indispensable articles of provisions, and even negotiate with them the voluntary cession of a portion of the territory, with the object of colonising it. Nature, it is true, does not forbid nations to extend their empire upon the earth; but it does not give the right to a single one among them to establish its dominion anywhere wherever it chooses to do it. The propaganda of civilisation, the development of commercial and industrial interests, the putting into activity of unproductive values, do not justify it either. All that can be accorded on the subject is, that in the interest of the preservation of the human kind, it may be permitted to nations to unite in order to open by common accord the ports of a country hermetically sealed to their commerce.

See, to the same effect, Bluntschli, Droits des gens, codifié, par. 20 , p. 63 .

Similar citations could be multiplied.

Communities of non-civilised tribes, forming according to the law of nations, as to-day admitted, independent states, the first logical consequence which follows is that these states cannot be acquired by reason of occupation by other states. A second consequence which necessarily follows from the same premises is, that these states, or their chiefs, can make international treaties of every kind-treaties which have obligatory force for the contracting parties, and which should be respected by all other states, if they do not interfere with existing rights.

We would remark here, with Calvo, ${ }^{\mathrm{x}}$ that "international treaties may be concluded, even with nomadic peoples, having no territory of their own nor fixed domicile, when they have an expressed political organisation and a common council by the intermediary of their chiefs or their assemblies." "In this category [adds the same author] may be classed the Bedouins, scattered over the deserts of Arabia, Syria,

I See Charles Calvo, Manuel du droit international publuc et prive, par. 49, p. 85; also his Droit international theorique et pratique, vol. i., p. 320 . 
Egypt, and barbarous Africa, and the Turcomans, who wander over the plains of Central Asia."

"There are conglomerated populations which do not compose a state. . . But the nomads and the savages have, either among themselves or with civilised peoplc, an international law which is observed equally with the international law of civilised nations," say Funck, Brentano, and Sorel. ${ }^{\mathrm{r}}$

By still stronger reasoning the tribes composing states dwelling in determined territory can make international treaties. Savage African tribes, possessing determined territories, can make all kinds of treaties. Their chiefs can therefore cede territory, in whole or in part, to whom, we will see under No. 2. This rule, or rather this consequence, cannot be impeached in theory.

"Sovereignty of a state, in the sense of international law [says Klüber, Droits des gens moderne de l'Europe, p. 22], consists essentially in independence of all foreign control in relation to the exercise of rights of sovereignty; it ought by its nature even to be exercised independently of the antiquity of the state, or the form of its constitution of government, or the order established for the succession to the throne, or the rank, title, or state of its sovereign; of the extent of its territory; of its population, political importance, manners, religion, state of culture in general, the commerce of its inhabitants," etc.

And the same author, par. 127, says:

"In regard to public domain, the state has, over the things which form part thereof, all rights of property, not only of exclusive possession and the right to enjoy it as owner, but also that of disposing freely thereof. The conventions or arrangements which it may make in this respect, whether with its subjects or with foreigners, are absolutely independent of other Governments. Nothing forbids it alienating its property, its putting it in pledge, or abandoning it. It has the capacity to acquire by accession." 2

Without going back to antiquity, modern history, since the seventeenth century up to our own days, furnishes us numerous examples of treaties, of cessions of territories, etc., concluded between civilised states on the one hand and savage tribes on the other. It is sufficient to recall the most noted cases:

In r620 the English Puritans embarked on board the Mayflower, after establishing themselves in the northern part of Virginia, concluded with the chief or sachem of the Indians, Massasoit, a treaty of friendship, the most ancient treaty concluded by New England. 3

In 1639 the founders of the colony of New Hampshire concluded

'Précis du droit des gens, Paris, 1877 , No. X., p. 23.

${ }^{2}$ See on this point, International Law, by Edward W. Hall, M.A., barrister-at-law, Oxford, 1880 , par. 35 , p. roo.

3 Bancroft's History of the United States, vol. i., pp. 342-350. 


\section{Appendix}

with the Indians conventions for the purchase of land situated between the Piscataqua and the Merrimac, and there established the town of Exeter. ${ }^{\mathbf{I}}$

Later, William Penn made treaties with chiefs of Indians. It is useless to cite here the numerous treaties between the different States of New England and the chiefs of Indian tribes.

Wheaton ${ }^{2}$ recounts that some of these Indian tribes have recognised by conventions that they held their existence entirely at the will of the State within the limits of which they resided, and that others preserved a limited sovereignty and the absolute dominion of the territory inhabited by them; and he adds that by two decisions of the Supreme Court of the United States, in $183_{1}$ and $183_{2}$, the Cherokee Nation, residing within the limits of the State of Georgia, are held to constitute a distinct political society; that numerous treaties made by this nation with the United States recognise it as a people capable of maintaining relations of peace and war; that the English Government, having preceded the United States, bought their lands by contracts of sale, freely assented to, and never forced them to make sale against their will.

Let us pass from America to Africa and Asia. In the course of the last fifty years England has concluded with the chiefs of countries adjacent to the Congo thirteen treaties, of which we mention specially two, one concluded the Irth of February, 1853 , with the King and chiefs of Cabinda, the other concluded the 20 th June, 1854 , with divers chiefs of the river Congo.

The treaty concluded by M. Savorgnan de Brazza with the King Makoko is of public notoriety.

To terminate the series of historical documents in support of the theory that chiefs of savage tribes can validly make treaties and cessions of territories in full sovereignty, let us recall further the recent treaties of the 29 th of December, 1877 , and the 22 nd of January, 1878 , by which the Sultans of Brunei and of Sulu, in the island of Borneo, ceded a part of their territory to Mr. Alfred Dent and Baron Overbeck.

If, from the point of view of international law, it is indisputable that no state, civilised or not, has the right to arbitrarily trouble the chiefs of savage tribes in the possession of their sovereignty, the same prohibition applies to those to whom they have conceded, whoever they may be.

The cessionnaires have the same rights as the ceders. Under what pretext could another state trouble them? Their cession is valid, and thus all motive, or even all pretext for trouble is wanting; or, the cession is null, according to the law of nations, and then the sovereign who made the cession has, in right, preserved all his sovereignty, and

x Carlier, History of the American People, vol i., p. 300.

- Elements of International Law (Fr. tr.), vol. i., p. 50. 
no other state has the right to trouble it, or even to intervene to make good the nullity of the cession.

Let us take the second question. Can a cession be made to a private citizen?

We are happy to be able to abridge this part of our work by referring to the article, "The Free Navigation of the Congo," published by our eminent colleague of the Institute. Sir Travers Twiss, in the sixth number of the Revue du droit international for 1883 .

It is true that Sir Travers Twiss occupies himself with the question whether those associations which are not organised as States can exercise sovereign rights, rather than whether these rights of sovereignty can be conceded to private individuals; but the argument which he invokes in support of his thesis applies in great part to cessions made to individuals.

When writers establish their point of departure to arrive at a demonstration they commence often by saying:

"It is an established principle," etc. Or, "It is a principle of law," etc. And they employ this form when their principles are the most contestable. In the article we have just citcd, Sir Travers Twiss mentions an article in the Revue de géographie of Paris, ${ }^{1}$ in which Mr. Delavand says: "It is a principle of law that states alonc can exercise sovereign rights, and that no private company can have them." $\mathrm{He}$ (Sir Travers Twiss) adds, with reason, that this proposition is affirmed in too absolute a manner, and he proves conclusively by historical facts that his criticism is just.

Doubtless an individual, as such, and a private society, in that capacity, are not sovereigns, and exercise no act of sovereignty. This needs no demonstration. But, in virtue of what principle of international law is it sought to be shown that one who is a private citizen to-day cannot become a sovereign to-morrow, and be in possession of the plenitude of sovereignty? Such a principle does not exist. No author of international law has ever sustained it, and all the history of humanity, from the earliest down to modern times, denies it.

Individuals can become sovereigns, and exercise the rights of sovereigns, in two ways:

First. By creating themselves into a state-that is to say, by establishing themselves upon a territory which belongs to them, and forming themselves into a community with a regular government, and legal organs of public power-in a word, with all the constituent elements of a state.

Most of the states of antiquity, according to legends and tradiIVol. xii., p. 12. 


\section{Appendix}

tions, or positive historical information, have been created in no other way.

The states of the Middle Ages had the same origin. The Franks, the Visigoths, the Ostrogoths, the Burgundians, and others, were only nomadic peoples, composed of chiefs who, in the eyes of international law, were only individuals, but who founded states.

The Italian republics of the Middle Ages were only municipalities without international sovereignty, and they have become sovereign states. Simple individuals, poor fishermen, caused the republic of Venice to rise from the waves of the Adriatic and to become its queen.

Almost all the States of New England, in America, have been founded by individuals. ${ }^{\mathrm{I}}$

States, to exist, have no need to be recognised by other states. Those who have founded them are the sovereigns, and therefore have the right to exercise the rights of sovereignty in so far as this exercise has not been delegated to an authority instituted under the constitution of the state.

And a revolution which has for result the detaching from a state of one of its parts, is it not at the commencement the work of individuals? And those individuals, if they unite themselves in their enterprise, can erect a simple province or provinces into a new and sovereign state, and exercise then sovereign rights.

And if to-day, simple individuals should establish themselves on a desert island, or on territory unoccupied by another state, they can establish a new state, with all the rights of sovereignty. We have seen Texas thus formed.

Second. An individual can become sovereign by succeeding to another sovereign in the exercise of the sovereignty of a state. From a private individual he becomes a sovereign.

The question whether a private individual can accept a sovereignty when the interior laws of his state forbid him is outside of our subject, and we do not treat of it.

Philip, Duke of Anjou, great-grandson of Louis XIV., was, from the point of view of international law, a simple individual. After the death of Charles II., by the treaty of Utrecht the states belonging to the Crown of Spain were dismembered, and Philip V. was recognised as the King of Spain, and acquired part of the states of the Spanish monarchy. Other examples might be cited.

When a prince was elected King of Germany he became a sovereign from a private individual that he was.

Or, again, when a chief of an African tribe, forming a sovereign state, cedes to an individual in full sovereignty a part of his state, does he do other than to call another person to the exercise of rights of

see the histories of Bancroft and Carlier. 
sovereignty over one part of his state, erected into a new state? What difference is there between the case of a European prince who is called as sovereign to a state, or part of a state, and that where an African chief calls upon an individual to exercise sovereign powers over part of his state? In the fact undoubtedly there is much difference, but in law there is none; and that is the question. It is a question of law (droit) we have to study here.

It is even possible that an individual may remain a subject of the state to which he belongs, and may be the sovereign of another country. The sovereign, therefore, can have a double personality. Thus, Ernest Augustus, and George V., Dukes of Cumberland, were subjects of Queen Victoria and peers of England and at the same time Kings of Hanover. In ${ }_{1} 787$ the sovereign bishop of the principality of Osnabruck, the Duke of York, sat as a peer of England in the House of Lords. ${ }^{\mathrm{t}}$

The question which has been laid down at the head of this opinion is a novel one. It has not been foreseen or treated in works of international law. Many authors treat a question which touches upon this one, but which differs from it a good deal. They ask if an individual can make in his own name an act of occupation of a territory newly discovered without a master. They reply negatively to this question, and, in their line of ideas, they are right; for those who discover new territories are almost always navigators, travelling in a public ship, of ten public officers or individuals commissioned by their governments-agents of the government-and they cannot occupy in their own name.

A recent event furnishes a powerful support to the theory that rights of sovereignty can be ceded to individuals, namely, the treaty between the Sultans of Borneo and Sulu and Mr. Dent and Baron Overbeck, who, in their turn, have ceded their rights to a private British company, the "British North Borneo Company." This fact has importance in itself, as a new event which enlarges juridical science; but what especially gives strong support to our thesis is the manner in which this event has been appreciated, be it inferentially or explicitly, by several governments, by jurisconsults, and by eminent statesmen whose opinions can be invoked as having authority.

The opinions of jurisconsults and publicists are ranged among the sources of international law. ${ }^{2}$

In the first place, the Governments of Holland and of Spain, who believed themselves most directly affected by the concessions, accorded by the two Sultans of Borneo, did not deny the principle of the capacity of individuals or of associations to have ceded to them rights

Ieffter, Le droit international publique, par. 52, p. I0.4.

2 Wheaton, vol. i., par. 12, p. 25; Heffter, par. 8, p. 16. 


\section{Appendix}

of sovereignty, but they raised reclamations against these treaties by invoking rights previously acquired.

Let us reproduce here the passage written by $\mathrm{M}$. de Laveleye upon the discussion to which the giving of a charter of incorporation to the British North Borneo Company gave rise in the English Parliament ${ }^{\prime}$ :

"Certain members of the left, adversaries of what is called in England the imperial policy, that is to say of the policy which seeks extension of territory and of influence, criticised the measure because it created a new responsibility for the country; but no one contested the right of individuals or of the company-rights resulting from treaties concluded with indigenous chiefs. In the reply made in the House of Commons by the attorney-general, Sir Henry James, we read:

"'These rights were conceded to the company and became legally its property. The Government of Her Majesty had no power to enter into a general examination of the propriety of the occupation of Borneo by a commercial company. It would have been an act of confiscation if, after what had happened, the Government had interfered, and had endeavoured to take from it the rights which it had acquired. . . . The only thing the Government had to decide was whether or not it was necessary to leave the company to act without impediment and entirely without control.'

"Mr. Gladstone was not less affirmative. Said he, at the same sitting:

"' The charter has not conferred upon the company a single privilege above and beyond what it had already acquired by virtue of a title sufficient to enable it to exercise all these powers.'

"From the explanations given by Lord Granville in the House of Lords, the $13^{\text {th }}$ March, 1882 , it appears that if Holland and Spain have protested against the rights invoked by the Overbeck-Dent Company, it was because of anterior rights which these states pretend to have over the northern part of Borneo; but, no more than Germany, formally consulted in the matter by the British Government, have they raised any doubt as to the capacity of individuals and companies to obtain from non-civilised sovereigns the cession of rights implying the exercise of sovereignty. This capacity also was not denied by the members on the opposition side of the House of Commons."

Thus, the opinion of four Governments, the opinion of two English ministers, Lord Granville and Mr. Gladstone, and of the attorneygeneral, Sir Henry James, that of Sir Travers Twiss, and of $M$. de Laveleye, to which we would add the considerations developed in the

x Revue de droit international, vol. xi., pp. 258, 259. 
open letter addressed, the ${ }_{3} 3 \mathrm{~d}$ April, $188_{3}$, by a member of the African International Association to the Courrier des Etats-Unis, form an assemblage of authorities of a nature to fortify us in our conviction if we had any doubts.

We conclude with these observations:

1. It is evident that if some powers have raised against similar concessions, made by chiefs of savage tribes to individuals and associations, reclamations founded upon rights previously acquired, there would be ground to submit these pretensions to serious examination, or perhaps they might be submitted to arbitration, as Great Britain and Portugal, in 1875 , submitted to the arbitration of the President of the French Republic, M. MacMahon, the contest in regard to certain lands situated on the bay of Delagoa.

2. New sovereignties, at the head of which are individuals or associations, the concessionaries of the chiefs of savage tribes, exist of themselves, of their own right and their own strength, without having need of the recognition of other States. (See Klüber, par. 24; Heffter, par. 23, p. 42 , and par. 51, p. ro4; Bluntschli, pars. 28 and 38 ; and all the authors.)

It depends upon the convenance of other States to recognise or not to recognise these new sovereignties. But whatever may be their determination in this respect, the want of recognition does not give them the right to act as if these sovereignties did not exist, and to consider their territories susceptible of occupation.

3. According to the practice of international law, at this day, the recognition of one to whom sovereignty has been conceded, as a sovereign, can even follow of itself, in certain cases. Almost all governments, especially Great Britain and the United States of America I have adopted the rule of considering de facto governments as legitimate, as far as they themselves are concerned. (See Heffter, pars. 51, 53, pp. 101-105.)

Let us suppose a European nation had concluded a treaty of friendship or commerce with the chief of a savage tribe, inhabiting a fixed territory. This treaty is supposed to be concluded, and is effectively concluded with the State which the chief represents. The chief had ceded his rights of sovereignty to a European individual or a European association, who are put in real possession of the sovereignty. Could the European nation deny the legitimacy of this new Government if it was a government de facto, according to international usages? No. At least, Great Britain and the United States would recognise it, and probably other States also. And if the preceding chief had been displaced by internal revolution-which can break out among blacks as among whites-and if the black chicf had ceded his sovereignty to another Negro, a relation or even a stranger to his family, would that

1 See manifesto of President Monroe, of December 2, 1823. 
be a reason for refusing recognition to the new sovereign? And if the chief of the tribe had ceded his sovereignty to a white man, in place of choosing for his successor a black man, or an association composed of whites, certainly the difference of colour could not be a reason for refusing recognition to the new sovereign.

Thus it is seen that in wandering away from true and simple principles difficulties of every kind are encountered.

Therefore I am of opinion that independent chiefs of savage tribes can validly cede to a private individual the whole or part of their State, with the sovereign rights which belong to them, and conformably to the traditional customs of the country.

Brussels, December 15,1883 .

\section{OTHER AUTHORITIES CITED}

(Extract from the Droit international codifie, by M. Bluntschli.)

(Page 68, paragraph 35): A new State has the right to enter into the international association of States, and to be recognised by other powers when its existence cannot be put in doubt and is assured. It has the right because it exists, because international law unites existing States by common laws and principles based upon justice and humanity.

Recognition by other sovereign States is a voluntary act on a part of these latter. It is not, nevertheless, an absolutely arbitrary act, because international law unites, even against their will, diverse existing States, and makes of them a kind of political association.

The opinion is frequently advanced by the older publicists that it depends upon the good pleasure of each State to recognise or not to recognise another, outside of the necessary and absolute line of international law. If this law rested solely upon the atbitrary will of States, it would not be just that it should be simply a conventional law.

(Page I64): A State has evidently the right to constitute itself without the ratification of another State. This would be the case when emigrants, for example, found a State upon an uninhabited island, as did the Norwegians in Iceland in the middle ages. A number of new States of North America were founded by individuals; it was only later that they were recognised by England, and to this day they proceed in the same manner in the United States. If new states can in this way constitute themselves, by still stronger reasoning analogous extensions of territory already existing should be recognised.

\section{ANOTHER MANNER OF ACQUIRING THE SOVEREIGNTY OF A FREE COUNT⿱RY}

(From Vattel, Le droit des gens, vol. i,, page 489 , par. 206.)

If free families, scattered over an independent country, unite to form themselves into a nation or a State, they acquire the sovereignty 
over the whole State which they inhabit, for they possess already the domain; and since they wish to form a political society and to establish a public authority to which all will owe obedience, it is quite manifest that their intention is to confer upon this public authority the right of sovereignty of the whole country.

\section{(From Heffter, Le droit international publique de l'Europe.)}

(Pages 32 and 33): The existence of a state supposes the following conditions, to wit:

I. A society capable of existing by itself and independently.

II. A collective will regularly organised, or a public authority charged with the direction of society for the end which we have just indicated.

III. A permanent status of society, the natural base of a free and permanent development, and which depends essentially on the fixity of the tenure of real estate and the intellectual and moral tendencies of its members.

We regard as idle the questions discussed by the schools, such as, What is the number of persons necessary to form a state? or, If one or three persons are sufficient? The distinctive characteristics of a state which we have just indicated sufficiently answer these questions.

(Page 42): A state exists de facto so soon as it unites the necessary elements indicated above; that is to say, will, united to the indispensable means and strength to defend its independence.

(Page 43): The entry of a new state upon the political scene depends in no wise upon an express preliminary recognition by foreign powers. It is fully accomplished the day when it commences to exist. On the other hand, political reasons alone may decide foreign powers to recognise or enter into direct relations with it. Recognition only confirms what legally exists by admitting the new member into the grand European family.

(From the Commentary upon the Elements of International Law, and History of the Progress of International Law, by William Beach Lawrence.)

(Page 162): It is not necessary that there should be a determined number of persons to form a state.

(Page 197): Texas was recognised by England in 1839 , when its population was not more than 60,000 souls. Lord Palmerston said on that occasion to Mr. O'Connell that "the principle of the Government was to recognise every state which had a de facto independence."

(Chamber of Commerce of the State of New York. Founded A.D. I 768.)

At an adjourned meeting of the Chamber of Commerce, held January 10, 1884 , the following resolutions, presented by Mr. A. A. Low, were adopted: 


\section{Appendix}

Whereas, the President of the United States has, in his recent message, called attention to the fact that the rich and populous valley of the Congo is now being opened to commerce by the International African Association, and has especially dwelt upon the interest, for the purposes of trade and commerce, that we have, as a people, in the neutrality of that valley, free from the interference or political control of any one nation: Therefore,

$B e$ it resolved, As the opinion of this Chamber that it is incumbent upon the Government of the United States, through its accredited representative, to apprise the Portuguese Government that it will not recognise, but denies the right of the latter to interfere with the free navigation of the Congo; that the discovery of this great waterway into the interior of Central Africa is not due to Portugal, but was the discovery of an explorer in the interest of no one nationality; and that the entry, 400 years ago, into the mouth of the Congo, by the Portuguese, not having been followed up by actual and continued occupation, can give that nation no territorial right to the river, or to the countries upon its banks.

Resolved, That the recognition by the Government of the United States of the flag of the International African Association, now extending over twenty-two settlements, in the heart of Africa, will be but an acknowledgment of the fact that that organisation, under rights ceded to it by African chiefs of independent territories, is exercising rule and authority over a large part of Africa in the protection of life and property, the extinguishment of the slave trade, the facilitating of commercial intercourse, and other attributes of sovereignty; and that it be recommended to the President to send an accredited agent of the Government to the Congo, to confer with that association in the adopting of such measures as may secure to American citizens free commercial intercourse along the course of that river, and through the various settlements or stations established by the association.

A true copy.

JAS. M. BRown,

George WiLson,

President.

Secretary.

(From copy of correspondence of the Manchester Chamber of Commerce and the Secretary of State for Foreign Affairs.)

His Majesty the King of the Belgians has, during the last two years, incurred considerable expense in an expedition to the Upper Congo for the purposes of opening roads, establishing stations for trade, and for communication with the vast tribes inhabiting the interior of Africa. For the result of this expedition merchants are watching with 
interest, believing that this river whll ultimately become one of the great highways for trade in the heart of Africa.

. . . It is, therefore, both manifest and notorious that the African tribes who inhabit the coast-line claimed by Portugal, between $5^{\circ}$ I $2^{\prime}$, and 8 th degree south latitude, are in reality independent, and that the right acquired by Portugal from priority of discovery at the end of the fifteenth century has for a long time been suffered to lapse, owing to the Portuguese Government not having occupied the country so discovered. In the presence of these facts the undersigned must repeat the declaration of Her Majesty's Government that the interests of commerce imperatively required it to maintain the right of unrestricted intercourse with that part of the coast of Western Africa extending between $5^{\circ}, 12^{\prime}$, and the 8 th degree of south latitude.

I have the honour to be, my lord, your lordship's obedient, very humble servant,

John SLAgG,

President.

(From Earl Granville's reply to Lord Mount Temple in the House of Lords, March 9, 1883.)

- . The labours of men like Livingstone, Stanley, and others have given us a knowledge of the physical character of Central Africa, and of the populations which inhabit it, showing that there are great capabilities for the development of trade, and of the civilising effects which are the result of commerce. The work of the philanthropic International Association, in which the King of the Belgians takes a great interest, the mission of M. de Brazza, the increasing trade in different degrees, of the English, the Portuguese, the French, the Germans, the Dutch, and the Belgians, on the Congo and its banks, are acting as a stimulus and afford grounds why no reasonable endeavours should be neglected to insure freedom of commerce and navigation, and to anticipate possible jealousies, which so easily check trade, and which, under the pretence of securing peculiar advantages to some, are really injurious to all.

\section{GENERAL ACT OF THE BERLIN CONFERENCE}

In the name of Almighty God,-

His Majesty the German Emperor, King of Prussia; His Majesty the Emperor of Austria, King of Bohemia, etc., and Apostolic King of Hungary; His Majesty the King of the Belgians; His Majesty the King of Denmark; His Majesty the King of Spain; the President of the United States of America; the President of the French Republic; Her Majesty the Queen of the United Kingdom of Great Britain and 
Ireland, Empress of India; His Majesty the King of Italy; His Majesty the King of the Netherlands, Grand Duke of Luxembourg, etc.; His Majesty the King of Portugal and the Algarves, etc.; His Majesty the Emperor of All the Russias; His Majesty the King of Sweden and Norway, etc.; and His Majesty the Emperor of the Ottomans,

Wishing, in a spirit of good and mutual accord, to regulate the conditions most favourable to the development of trade and civilisation in certain regions of Africa, and to assure to all nations the advantages of free navigation on the two chief rivers of Africa flowing into the Atlantic Ocean; being desirous, on the other hand, to obviate the misunderstandings and disputes which might in future arise from new acts of occupation (prises de possession) on the coast of Africa; and concerned, at the same time, as to the means of furthering the moral and material well-being of the native populations: Have resolved, on the invitation addressed to them by the Imperial Government of Germany, in agreement with the Government of the French Republic, to meet for those purposes in Conference at Berlin, and have appointed as their Plenipotentiaries, to wit:-

His Majesty the German Emperor, King of Prussia, Otho, Prince von Bismarck, his President of the Prussian Council of Ministers, Chancellor of the Empire; Paul, Count von Hatzfeldt, his Minister of State and Secretary of State for Foreign Affairs; Auguste Busch, his Acting Privy Councillor of Legation and Under-Secretary of State for Foreign Affairs; and Henri von Kusserow, Privy Councillor of Legation in the Department for Foreign Affairs;

His Majesty the Emperor of Austria, King of Bohemia, etc., and Apostolic King of Hungary, Emeric, Count Széchényi de Sárvári Felsö-Vidék, Chamberlain and Acting Privy Councillor, his Ambassador Extraordinary and Plenipotentiary at the Court of His Majesty the German Emperor, King of Prussia;

His Majesty the King of the Belgians, Gabriel Auguste Count Van der Straten Ponthoz, Envoy Extraordinary and Minister Plenipotentiary at the Court of His Majesty the German Emperor, King of Prussia; and Auguste, Baron Lambermont, Minister of State, Envoy Extraordinary and Minister Plenipotentiary;

His Majesty the King of Denmark, Emile de Vind, Chamberlain, his Envoy Extraordinary and Minister Plenipotentiary at the Court of His Majesty the German Emperor, King of Prussia;

His Majesty the King of Spain, Don Francisco Merry y Colom, Count Benomar, his Envoy Extraordinary and Minister Plenipotentiary at the Court of His Majesty the German Emperor, King of Prussia;

The President of the United States of America, John A. Kasson, Envoy Extraordinary and Minister Plenipotentiary of the United States of America at the Court of His Majesty the German Emperor, King of Prussia; and Henry S. Sanford, ex-Minister; 
The President of the French Republic, Alphonse, Baron de Courcel, Ambassador Extraordinary and Plenipotentiary of France at the Court of His Majesty the German Emperor, King of Prussia;

Her Majesty the Queen of the United Kingdom of Great Britain and Ireland, Empress of India, Sir Edward Baldwin Malet, her Ambassador Extraordinary and Plenipotentiary at the Court of His Majesty the German Emperor, King of Prussia;

His Majesty the King of Italy, Edward, Count de Launay, his Ambassador Extraordinary and Plenipotentiary at the Court of His Majesty the German Emperor, King of Prussia;

His Majesty the King of the Netherlands, Grand Duke of Luxembourg, Frederic Philippe, Jonkheer Van der Hoeven, his Envoy Extraordinary and Minister Plenipotentiary at the Court of His Majesty the German Emperor, King of Prussia;

His Majesty the King of Portugal and the Algarves, etc., Da Serra Gomes, Marquis de Penafiel, Peer of the Realm, his Envoy Extraordinary and Minister Plenipotentiary at the Court of His Majesty the German Emperor, King of Prussia; and Antoine de Serpa Pimentel, Councillor of State and Peer of the Realm;

His Majesty the Emperor of all the Russias, Pierre, Count Kapnist, Privy Councillor, his Envoy Extraordinary and Minister Plenipotentiary at the Court of His Majesty the King of the Netherlands;

His Majesty the King of Sweden and Norway, etc., Gillis, Baron Bildt, Lieutenant-General, his Envoy Extraordinary and Minister Plenipotentiary at the Court of His Majesty the German Emperor, King of Prussia;

His Majesty the Emperor of the Ottomans, Méhemed Said Pasha, Vézir and High Dignitary, his Envoy Extraordinary and Plenipotentiary at the Court of His Majesty the German Emperor, King of Prussia;

Who, being provided with full powers, which have been found in good and due form, have successively discussed and adopted:-

I. A Declaration relative to freedom of trade in the basin of the Congo, its embouchures and circumjacent regions, with other provisions connected therewith.

2. A Declaration relative to the Slave Trade, and the operations by sea or land which furnish slaves to that trade.

3. A Declaration relative to the neutrality of the territorics comprised in the Conventional Basin of the Congo.

4. An Act of Navigation for the Congo, which, while having regard to local circumstances, extends to this river, its affluents, and the waters in its system (eaux qui leur sont assimilées), the general principles enunciated in Articles CVIII. and CXVI. of the Final Act of the Congress of Vienna, and intended to regulate, as between the Signatory Powers of that $\Lambda$ ct, the free navigation of the waterways separating or 


\section{Appendix}

traversing several States - these said principles having since then been applied by agreement to certain rivers of Europe and America, but especially to the Danube, with the modifications stipulated by the Treaties of Paris ( $185^{6}$ ), of Berlin ( 1878 ), and of London (of 1871 and 1883).

5. An Act of Navigation for the Niger, which, while likewise having regard to local circumstances, extends to this river and its affluents the same principles as set forth in Articles CVIII. and CXVI. of the Final Act of the Congress of Vienna.

6. A Declaration introducing into international relations certain uniform rules with reference to future occupations on the coasts of the African Continent.

And deeming it expedient that all these several documents should be combined into one single instrument, they (the Signatory Powers) have collected them into one General Act, composed of the following Articles:

Chapter I.-Declaration relative to Freedom of Trade in the Basin of the Congo, its Mouths, and circumjacent Regions, with other Provisions connected therewith.

ARticle I. The trade of all nations shall enjoy complete freedom-

I. In all the regions forming the basin of the Congo and its outlets. This basin is bounded by the watersheds (or mountain ridges) of the adjacent basins, namely, in particular, those of the Niara, the Ogowe, the Schari, and the Nile, on the north; by the eastern watershed line of the affluents of Lake Tanganyika, on the east; and by the watersheds of the basins of the Zambesi and the Logé, on the south. It therefore comprises all the regions watered by the Congo and its affluents, including Tanganyika, with its eastern tributaries.

2. In the maritime zone extending along the $\Lambda$ tlantic Ocean from the parallel situated in $2^{\circ} 30^{\prime}$ of south latitude to the mouth of the Logé.

The northern boundary will follow the parallel situated in $2^{\circ} 30^{\prime}$ from the coast to the point where it meets the geographical basin of the Congo, avoiding the basin of the Ogowé, to which the provisions of the present Act do not apply.

The southern boundary will follow the course of the Loge to its source, and thence pass eastwards till it joins the geographical basin of the Congo.

3. In the zone stretching eastwards from the Congo Basin, as above defined, to the Indian Ocean from the $5^{\circ}$ of north latitude to the mouth of the Zambesi in the south, from which point the line of demarcation will ascend the Zambesi to five miles above its confluence with the Shire, and then follow the watershed between the affluents of Lake Nyassa and those of the Zambesi, till at last it reaches the watershed between the waters of the Zambesi and the Congo. 


\section{4 Story of thc Congo Free State}

It is expressly recognised that in extending the principle of free trade to this eastern zone the Conference Powers only undertake engagements for themselves, and that in the territories belonging to an independent Sovereign State this principle shall only be applicable in so far as it is approved by such State. But the Powers agree to use their good offices with the Governments established on the African shore of the Indian Ocean for the purpose of obtaining such approval, and in any case of securing the most favourable conditions to the transit (traffic) of all nations.

ARTICLE 2. All flags, without distinction of nationality, shall have free access to the whole of the coast-line of the territories above enumerated, to the rivers there running into the sea, to all the waters of the Congo and its affluents, including the lakes, and to all the ports situate on the banks of these waters, as well as to all canals which may in future be constructed with intent to unite the watercourses or lakes within the entire area of the territories described in Article I. Those trading under such flags may engage in all sorts of transport, and carry on the coasting trade by sea and river, as well as boat traffic, on the same footing as if they were subjects.

ARTICLE 3. Wares, of whatever origin, imported into those regions, under whatsoever flag, by sea or river, or overland, shall be subject to no other taxes than such as may be levied as fair compensation for expenditure in the interest of trade, and which for this reason must bc equally borne by the subjects themselves and by foreigners of all nationalities. All differential dues on vessels, as well as on merchandise, are forbidden.

ARTICLE 4. Merchandise imported into those regions shall remain free from import and transit dues.

The Powers reserve to themselves to determine after the lapse of twenty years whether this freedom of import shall be retained or not.

Article 5. No Power which exercises or shall exercise sovereign rights in the above-mentioned regions shall be allowed to grant therein a monopoly or favour of any kind in matters of trade.

Foreigners, without distinction, shall enjoy protection of their persons and property, as well as the right of acquiring and transferring movable and immovable possessions; and national rights and treatment in the exercise of their professions.

Article 6. Provisions relative to Protection of the Natives, of Missionaries and Travellers, as well as relative to Religious Liberty.-All the Powers exercising sovereign rights or influence in the aforesaid territories bind themselves to watch over the preservation of the native tribes, and to care for the improvement of the conditions of their moral and material well-being, and to help in suppressing slavery, and especially the Slave Tradc. They shall, without distinction of creed 


\section{Appendix :}

or nation, protect and favour all religious, scientific, or charitable institutions, and undertakings created and organised for the above ends, or which aim at instructing the natives and bringing home to them the blessings of civilisation.

Christian missionaries, scientists, and explorers, with their followers, property, and collections, shall likewise be the objects of especial protection.

Freedom of conscience and religious toleration are expressly guaranteed to the natives, no less than to subjects and to foreigners. The free and public exercise of all forms of Divine worship, and the right to build edifices for religious purposes, and to organise religious missions belonging to all creeds, shall not be limited or fettered in any way whatsoever.

Article 7. Posial Régime.-The Convention of the Universal Postal Union, as revised at Paris the Ist June, 1878 , shall be applied to the Conventional Basin of the Congo.

The Powers who therein do or shall exercise rights of sovereignty or protectorate engage, as soon as circumstances permit them, to take the measures necessary for the carrying out of the preceding provision.

ARTICLE 8. Right of Surveillance vested in the International Navigation Commission of the Congo.-In all parts of the territory had in view by the present Declaration, where no Power shall exercise rights of sovereignty or protectorate, the International Navigation Commission of the Congo, instituted in virtue of Article I7, shall be charged with supervising the application of the principles proclaimed and perpetuated (consacrés) by this Declaration.

In all cases of difference arising relative to the application of the principles established by the present Declaration, the Governments concerned may agree to appeal to the good offices of the International Commission, by submitting to it an examination of the facts which shall have occasioned these differences.

\section{Chapter II.-Declaration relative to the Slave Trade}

ARTICLE 9. Seeing that trading in slaves is forbidden in conformity with the principles of international law as recognised by the Signatory Powers, and seeing also that the operations which by sea or land furnish slaves to trade ought likewise to be regarded as forbidden, the Powers which do or shall exercise sovereign rights or influence in the territories forming the Conventional Basin of the Congo declare that these territories may not serve as a market or means of transit for the trade in slaves, of whatever race they may be. Each of the Powers binds itself to employ all the means at its disposal for putting an end to this trade and for punishing those who engage in it. 


\section{Story of the Congo Free State}

\section{ChAPTER III.-Declaration relative to the Neutrality of the Territories comprised in the Conventional Basin of the Congo}

ARTiCle Io. In order to give a new guarantee of security to trade and industry, and to encourage, by the maintenance of peace, the development of civilisation mentioned in Article $\mathrm{I}$, and placed under the free trade system, the High Signatory Parties to the present Act, and those who shall hereafter adopt it, bind themselves to respect the neutrality of the territories, or portions of territories, belonging to the said countries, comprising therein the territorial waters, so long as the Powers which exercise or shall exercise the rights of sovereignty or protectorate over those territories, using their option of proclaiming themselves neutral, shall fulfil the duties which neutrality requires.

Article 11. In case a Power exercising rights of sovereignty or protectorate in the countries mentioned in Article $\mathbf{r}$, and placed under the free trade system, shall be involved in a war, then the High Signatory Parties to the present Act, and those who shall hereafter adopt it, bind themselves to lend their good offices in order that the territories belonging to this Power and comprised in the Conventional free trade zone shall, by the common consent of this Power and of the other belligerent or belligerents, be placed during the war under the rule of neutrality, and considered as belonging to a non-belligerent State, the belligerents thenceforth abstaining from extending hostilities to the territories thus neutralised, and from using them as a base for warlike operations.

ART1Cle I 2. In case a serious disagreement originating on the subject of, or in the limits of, the territories mentioned in Article I and placed under the free trade system, shall arise between any Signatory Powers of the present Act, or the Powers which may become parties to it, these Powers bind themselves, before appealing to arms, to have recourse to the mediation of one or more of the friendly Powers.

In a similar case the same Powers reserve to themselves the option of having recourse to arbitration.

\section{Chapter IV.-Act of Navigation for the Congo}

Article I3. The navigation of the Congo, without excepting any of its branches or outlets, is, and shall remain, free for the merchant ships of all nations equally, whether carrying cargo or ballast, for the transport of goods or passengers. It shall be regulated by the provisions of this Act of Navigation, and by the rules to be made in pursuance thereof.

In the exercise of this navigation the subjects and flags of all nations shall in all respects be treated on a footing of perfect equality, not only for the direct navigation from the open sea to the inland ports of 


\section{Appendix}

the Congo and vice versa, but also for the great and small coasting trade, and for boat traffic on the course of the river.

Consequently, on all the course and mouths of the Congo there will be no distinction made between the subjects of Riverain States and those of non-Riverain States, and no exclusive privilege of navigation will be conceded to companies, corporations, or private persons whatsoever.

These provisions are recognised by the Signatory Powers as becoming henceforth a part of international law.

ARTICle 14. The navigation of the Congo shall not be subject to any restriction or obligation which is not expressly stipulated by the present Act. It shall not be exposed to any landing dues, to any station or depôt tax, or to any charge for breaking bulk, or for compulsory entry into port.

In all the extent of the Congo the ships and goods in process of transit on the river shall be submitted to no transit dues, whatever their starting-place or destination.

There shall be levied no maritime or river toll based on the mere fact of navigation, nor any tax on goods aboard of ships. There shall only be levied taxes or duties having the character of an equivalent for services rendered to navigation itself, to wit:

I. Harbour dues on certain local establishments, such as wharves, warehouses, etc., if actually used.

The tariff of such dues shall be framed according to the cost of constructing and maintaining the said local establishments; and it will be applied without regard to whence vessels come or what they are loaded with.

2. Pilot dues for those stretches of the river where it may be necessary to establish properly qualified pilots.

The tariff of these dues shall be fixed and calculated in proportion to the service rendered.

3. Charges raised to cover technical and administrative expenses incurred in the general interest of navigation, including lighthouse, beacon, and buoy duties.

The last-mentioned dues shall be based on the tonnage of vessels as shown by the ship's papers, and in accordance with the rules adopted on the Lower Danube.

The tariffs by which the various dues and taxes enumerated in the three preceding paragraphs shall be levied shall not involve any differcntial treatment, and shall be officially published at each port.

The Powers reserve to themselves to consider, after the lapse of five years, whether it may be necessary to revise, by common accord, the above-mentioned tariffs.

ARTICLE I 5. The affluents of the Congo shall in all respects be subject to the same rules as the river of which they are tributaries. 


\section{$538 \quad$ Story of the Congo Free State}

And the same rules shall apply to the streams and river as well as the 'lakes and canals in the territories defined in paragraphs 2 and 3 of Article I.

At the same time the powers of the International Commission of the Congo will not extend to the said rivers, streams, lakes, and canals unless with the assent of the States under whose sovereignty they are placed. It is well understood, also, that with regard to the territories mentioned in paragraph 3 of Article 1 , the consent of the Sovereign States owning these territories is reserved.

ARTICle I 6. The roads, railways, or lateral canals which may be constructed with the special object of obviating the innavigability or correcting the imperfection of the river route on certain sections of the course of the Congo, its affluents, and other waterways placed under a similar system, as laid down in Article I 5, shall be considered, in their quality of means of communication, as dependencies of this river, and as equally open to the traffic of all nations.

And as on the river itself, so there shall be collected on these roads, railways, and canals only tolls calculated on the cost of construction, maintenance, and management, and on the profits due to the promoters.

As regards the tariff of these tolls, strangers and the natives of the respective territories shall be treated on a footing of perfect equality.

ARTiCle I7. There is instituted an International Commission, charged with the execution of the provisions of the present Act of Navigation.

The Signatory Powers of this Act, as well as those who may subsequently adhere to it, may always be represented on the said Commission, each by one Delegate. But no Delegate shall have more than one vote at his disposal, even in the case of his representing several Governments.

This Delegate will be directly paid by his Government. As for the various agents and employees of the International Commission, their remuneration shall be charged to the amount of the dues collected in conformity with paragraphs 2 and 3 of Article I 4.

The particulars of the said remuneration, as well as the number, grade, and powers of the agents and employees, shall be entered in the Returns to be sent yearly to the Governments represented on the International Commission.

ARTICLE I 8. The members of the International Commission, as well as its appointed agents, are invested with the privileges of inviolability in the exercise of their functions. The same guarantee shall apply to the offices and archives of the Commission.

ARTICle 19. The International Commission for the Navigation of the Congo shall be constituted as soon as five of the Signatory Powers of the present General Act shall have appointed their Delegates. And pending the constitution of the Commission the nomination of these 


\section{Appendix}

Delegates shall be notified to the Imperial Government of Germany, which will see to it that the necessary steps are taken to summon the meeting of the Commission.

The Commission will at once draw up Navigation, River Police, Pilot, and Quarantine Rules.

These Rules, as well as the tariffs to be framed by the Commission, shall, before coming into force, be submitted for approval to the Powers represented on the Commission. The Powers interested will have to communicate their views with as little delay as possible.

Any infringements of these Rules will be ehecked by the agents of the International Commission wherever it exercises direct authority, and elsewhere by the Riverain Power.

In the case of an abuse of power, or an act of injustice, on the part of any agent or employee of the International Commission, the individual who considers himself to be aggrieved in his person or rights may apply to the Consular Agent of his country. The latter will examine his complaint, and if he finds it prima facie reasonable, he will then be entitled to bring it before the Commission. At his instance then, the Commission, represented by at least three of its members, shall in conjunction with him inquire into the conduct of its agent or employee. Should the Consular Agent look upon the decision of the Commission as raising questions of law (objections de droit), he will report on the subject to his Government, which may then have recourse to the Powers represented on the Commission, and invite them to agree as to the instructions to be given to the Commission.

ARticle 20. The International Commission of the Congo, charged in terms of Article 17 with the execution of the present Act of Navigation, shall in particular have power-

I. To decide what works are necessary to assure the navigability of the Congo in accordance with the needs of international trade.

On those sections of the river where no Power exercises sovereign rights, the International Commission will itself take the necessary measures for assuring the navigability of the river.

On those sections of the river held by a Sovereign Power, the International Commission will concert its action (s'entendra) with the riparian authorities.

2. To fix the pilot tariff and that of the general navigation dues as provided for by paragraphs 2 and 3 of Article 14 .

The tariffs mentioned in the first paragraph of Article ${ }_{4} 4$ shall be framed by the territorial authorities within the limits prescribed in the said Article.

The levying of the various dues shall be seen to by the international or territorial authorities on whose behalf they are established.

3. To administer the revenue arising from the application of the preceding paragraph (2). 
4. To superintend the quarantine establishment created in virtue of Article 24.

5. To appoint officials for the general service of navigation, and also its own proper employees.

It will be for the territorial authorities to appoint Sub-Inspectors on sections of the river occupied by a Power, and for the International Commission to do so on the other sections.

The Riverain Power will notify to the International Commission the appointment of Sub-Inspectors, and this Power will undertake the payment of their salaries.

In the exercise of its functions as above defined and limited. the International Commission will be independent of the territorial authorities.

ARTICLE 2r. In the accomplishment of its task the International Commission may, if need be, have recourse to the war-vessels of the Signatory Powers of this Act, and of those who may in future accede to it, under reserve, however, of the instructions which may be given to the Commanders of their vessels by their respective Governments.

ARTICle 22. The war vessels of the Signatory Powers of this Act that may enter the Congo are exempt from payment of the navigation dues provided for in paragraph 3 of Article 14 ; but unless their intervention has been called for by the International Commission or its agents, in terms of the preceding Article, they shall be liable to the payment of the pilot or harbour dues which may eventually be established.

Article 23. With the view of providing for the technical and administrative expenses which it may incur, the International Commission created by Article I 7 may, in its own name, negotiate loans to be exclusively guaranteed by the revenues raised by the said Commission.

The decisions of the Commission dealing with the conclusion of a loan must be come to by a majority of two thirds. It is understood that the Governments represented on the Commission shall not in any case be held as assuming any guarantee, or as contracting any engagement or joint liability (solidarité) with respect to the said loans, unless under special Conventions concluded by them to this effect.

The revenue yielded by the dues specified in paragraph 3 of Article I 4 shall bear, as a first charge, the payment of the interest and sinking fund of the said loans, according to agreement with the lenders.

Article 24. At the mouth of the Congo there shall be founded, either on the initiative of the Riverain Powers, or by the intervention of the International Commission, a quarantine establishment for the control of vessels passing out of as well as into the river.

Later on, the Powers will decide whether and on what conditions a 


\section{Appendix}

sanitary control shall be exercised over vessels engaged in the navigation of the river itself.

ARTICLE 25. The provisions of the present Act of Navigation shall remain in force in time of war. Consequently all nations, whether neutral or belligerent, shall always be free, for the purposes of trade, to navigate the Congo, its branches, affluents, and mouths, as well as the territorial waters fronting the embouchure of the river.

Traffic will similarly remain free, despite a state of war, on the roads, railways, lakes, and canals mentioned in Articles 15 and 16.

There will be no exception to this principle except in so far as concerns the transport of articles intended for a belligerent and, in virtue of the law of nations, regarded as contraband of war.

All the works and establishments created in pursuance of the present Act, especially the tax-collecting offices and their treasuries, as well as the permanent service staff of these establishments, shall enjoy the benefits of neutrality (places sous le régime de la neutralité), and shall therefore be respected and protected by belligerents.

\section{Chapter V.-Act of Navigation for the Niger}

ArTICLE 26. The navigation of the Niger, without excepting any of its branches and outlets, is and shall remain entirely free for the merchant-ships of all nations equally, whether with cargo or ballast, for the transportation of goods and passengers. It shall be regulated by the provisions of this Act of Navigation, and by the rules to be made in pursuance of this Act.

In the exercise of this navigation the subjects and flags of all nations shall be treated, in all circumstances, on a footing of perfect equality, not only for the direct navigation from the open sea to the inland ports of the Niger and vice versâ, but for the great and small coasting trade, and for boat trade on the course of the river.

Consequently, on all the course and mouths of the Niger there will be no distinction made between the subjects of the Riverain States and those of non-Riverain States; and no exclusive privilege of navigation will be conceded to companies, corporations, or private persons.

These provisions are recognised by the Signatory Powers as forming henceforth a part of international law.

ArTicle 27. The navigation of the Niger shall not be subject to any restriction or obligation based merely on the fact of navigation.

It shall not be exposed to any obligation in regard to landing, station, or depôt, or for breaking bulk, or for compulsory entry into port.

In all the extent of the Niger the ships and goods in process of transit on the river shall be submitted to no transit dues, whatever their starting-place or destination.

No maritime or river toll shall be levied based on the sole fact of 
navigation, nor any tax on goods on board of ships. There shall only be collected taxes or duties which shall be an equivalent for services rendered to navigation itself. The tariff of these taxes or duties shall not warrant any differential treatment.

Article 28. The affluents of the Niger shall be in all respects subject to the same rules as the river of which they are tributaries.

ARticle 29. The roads, railways, or lateral canals which may be constructed with the special object of obviating the innavigability or correcting the imperfections of the river route on certain sections of the course of the Niger, its affluents, branches, and outlets, shall be considered, in their quality of means of communication, as dependencies of this river and as equally open to the traffic of all nations.

And as on the river itself, so there shall be collected on these roads, railways, and canals only tolls calculated on the cost of construction, maintenance, and management, and on the profits due to the promoters.

As regards the tariff of these tolls, strangers and the natives of the respective territories shall be treated on a footing of perfect equality.

Article 30. Great Britain undertakes to apply the principles of freedom of navigation enunciated in Articles 26, 27, 28, and 29, on so much of the waters of the Niger, its affluents, branches, and outlets, as are or may be under her sovereignty or protection.

The rules which she may establish for the safety and control of navigation shall be drawn up in a way to facilitate, as far as possible, the circulation of merchant-ships.

It is understood that nothing in these obligations shall be interpreted as hindering Great Britain from making any rules of navigation whatever which shall not be contrary to the spirit of these engagements.

Great Britain undertakes to protect foreign merchants and all the trading nationalities on all those portions of the Niger which are or may be under her sovereignty or protection as if they were her own subjects, provided always that such merchants conform to the rules which are or shall be made in virtue of the foregoing.

Article 31. France accepts, under the same reservations, and in identical terms, the obligations undertaken in the preceding Articles in respect of so much of the waters of the Niger, its affluents, branches, and outlets, as are or may be under her sovereignty or protection.

Article 32. Each of the other Signatory Powers binds itself in the same way, in case it should ever exercise in the future rights of sovereignty or protection over any portion of the waters of the Niger, its affluents, branches, or outlets.

Article 33. The arrangements of the present Act of Navigation will remain in force in time of war. Consequently, the navigation of all neutral or belligerent nations will be in all times free for the usages of commerce on the Niger, its branches, its affluents, its mouths, and 


\section{Appendix}

outlets, as well as on the territorial waters opposite the mouths and outlets of that river.

The traffic will remain equally free in spite of a state of war on the roads, railways, and canals mentioned in Article 29.

There will be an exception to this principle only in that which relates to the transport of articles destined for a belligerent and considered, in virtue of the law of nations, as articles of contraband of war.

Chapter VI.-Declaration relative to the essential Conditions to be observed in order that new Occupations on the Coasts of the

African Continent may be held to be effective

Article 34. Any Power which henceforth takes possession of a tract of land on the coasts of the African Continent outside of its present possessions, or which, being hitherto without such possessions, shall acquire them, as well as the Power which assumes a protectorate there, shall accompany the respective act with a notification thereof, addressed to the other Signatory Powers of the present Act, in order to enable them, if need be, to make good any claims of their own.

ARTICLE 35. The Signatory Powers of the present Act recognise the obligation to ensure the establishment of authority in the regions occupied by them on the coasts of the African Continent sufficient to protect existing rights, and, as the case may be, freedom of trade and of transit under the conditions agreed upon.

\section{Chapter VII.-General Dispositions}

Article 36. The Signatory Powers of the present General Act reserve to themselves to introduce into it subsequently, and by common accord, such modifications and improvements as experience may show to be expedient.

Article 37. The Powers who have not signed the present General Act shall be free to adhere to its provisions by a separate instrument.

The adhesion of each Power shall be notified in diplomatic form to the Government of the German Empire, and by it in turn to all the other Signatory or adhering Powers.

Such adhesion shall carry with it full acceptance of all the obligations as well as admission to all the advantages stipulated by the present General Act.

Article 38. The present General Act shall be ratified with as little delay as possible, the same in no case to exceed a year.

It will come into force for each Power from the date of its ratification by that Power. 


\section{Story of the Congo Free State}

Meanwhile, the Signatory Powers of the present General Act bind themselves not to take any steps contrary to its provisions.

Each Power will address its ratification to the Government of the German Empire, by which notice of the fact will be given to all the other Signatory Powers of the present Act.

The ratifieations of all the Powers will be deposited in the archives of the Government of the German Empire. When all the ratifications shall have been sent in, there will be drawn up a Deposit Act, in the shape of a Protocol, to be signed by the Representatives of all the Powers which have taken part in the Conference of Berlin, and of which a certified copy will be sent to each of those Powers.

In testimony whereof the several Plenipotentiaries have signed the present General Act and have affixed there to their seals.

Done at Berlin the 26 th day of February, 1885 .

(Here follow the signatures of the Plenipotentiaries in the order of their names in the preamble.)

THE TEXT OF THE DECLARATIONS AND TREATIES BETWEEN THE INTERNATIONAL ASSOCIATION OF THE CONGO AND ITS NEIGHBOURS, GERMANY, GREAT BRITAIN, FRANCE, AND PORTUGAL. ALSO ITS DECLARATION EXCHANGED WITH BELGIUM.

On 8th November, $\mathrm{r} 884$, a convention was concluded between the German Empire and the Association. The following are its terms:

Article 1." The International Association of the Congo engages not to levy any duty on articles or merchandise imported directly or in transit into its present or future possessions in the basins of the Congo and the Niadi-Kwilu, or into its possessions situated on the Atlantic Ocean. This exemption from duties especially applies to merchandise and articles of commerce which are carried by the roads made round the eataracts of the Congo

Article z. The subjects of the German Empire shall have the right of sojourning and of establishing themselves on the territories of the Association. They shall be treated on the same footing as the subjects of the most favoured nation, including the inhabitants of the country, so far as concerns the protection of their persons and possessions, the free exercise of their religion, the recognition and defence of their rights, as well as in matters of navigation, trade, or manufactures. 


\section{Appendix}

Especially, they shall have the right of buying, selling, and leasing lands and buildings situated in the territories of the Association, of establishing commercial houses, and carrying on trade or the coasting trade under the German flag.

ARTICLE 3. The Association engages never to grant any privileges whatsoever to the subjects of any other nation without their being immediately extended to German subjects.

Article 4. In the event of the cession of the present or future territory of the Association, or of any part of it, the obligations contracted by the Association towards the German Empire shall be transferred to the occupier. These obligations and the rights granted by the Association to the German Empire and its subjects shall remain in force after every cession as far as regards each new occupier.

Article 5. The German Empire recognises the flag of the Association-a blue flag with a golden star in the centre-as that of a friendly State.

Article 6. The German Empire is ready on its part to recognise the frontiers of the territory of the Association and of the new State which is to be created, as they are shown in the annexed Map.

ARTICLE 7. This Convention shall be ratified and the ratifications shall be exchanged with the least possible delay.

This Convention shall come into force immediately after the exchange of the ratifications.

Done at Berlin the 8 th November, 1884 .

(Signed) Count v. Brandenbourg.

STRAUCh.

On I6th December, I884, Great Britain and the International Association of the Congo exchanged declarations and concluded a Convention. The following is the declaration of the Association:

The International Association of the Congo, founded by His Majesty the King of the Belgians for the purpose of promoting the civilisation and commerce of Africa, and for other humane and benevolent purposes, hereby declares as follows:-

ARTICLE I. That by Treaties with the legitimate Sovereigns in the basins of the Congo and of the Niadi-Kivilu, and in adjacent territories upon the Atlantic, there has been ceded to it territory for the use and benefit of Free States established, and being established, in the said basins and adjacent territories.

ARTICLE 2. That by virtue of the said Treaties, the administration of the interests of the said Free States is vested in the Association. 


\section{Story of the Congo Free State}

Article 3. That the Association has adopted as its standard, and that of the said Free States, a blue flag with a golden star in the centre.

ARTICLE 4. That with a view of enabling commerce to penetrate into Equatorial Africa, the Association and the said Free States have resolved to levy no customs duties upon goods or articles of merchandise imported directly into their territories or brought by the route which has been constructed around the cataracts of the Congo.

Article 5. That the Association and the said Free States guarantee to foreigners established in their territories the free exercise of their religion, the rights of navigation, commerce, and industry, and the right of buying, selling, letting, and hiring lands, buildings, mines, and forests, on the sole condition that they shall obey the laws.

ARTicle 6. That the Association and the said free States will do all in their power to prevent the Slave Trade and to suppress slavery.

Done at Berlin, the 16 th December, $188_{4}$.

(On behalf of the Association), (Signed) Strauch.

\section{The declaration of the British Government was as} follows:

The Government of Her Britannic Majesty declare their sympathy with, and approval of, the humane and benevolent purposes of the Association, and hereby recognise the flag of the Association, and of the Free States under its administration, as the flag of a friendly Government.

(On behalf of Her Majesty's Government),

Edward B. Malet.

\section{The Convention itself was couched in the following} terms:

Whereas the Government of Her Britannic Majesty have recognised the flag of the International Association of the Congo, and of the Free States under its administration, as the flag of a friendly Government;

And whereas it is expedient to regulate and define the rights of British subjects in the territories of the said Free States, and to provide for the exercise of civil and criminal jurisdiction over them, in manner hereinafter mentioned, until sufficient provision shall have been made by the Association for the administration of justice among foreigners;

It is hereby agreed as follows:-

ArTiCle I The International Association of the Congo undertakes not to levy any duty, import or transit, on articles or merchandise 
imported by British subjects into the said territories, or into any territory which may hereafter come under its government. This freedom from custom-house duties shall extend to merchandise and articles of commerce which shall be transported along the roads or canals constructed, or to be constructed, around the cataracts of the Congo.

Article 2. British subjects shall have at all times the right of sojourning and of establishing themselves within the territories which are or shall be under the Government of the said Association. They shall enjoy the same protection which is accorded to the subjects or citizens of the most favoured nation in all matters which regard their persons, their property, the free exercise of their religion, and the rights of navigation, commerce, and industry. Especially they shall have the right of buying, of selling, of letting, and of hiring lands and buildings, mines, and forests, situated within the said territories, and of founding houses of commerce, and of carrying on commerce and a coasting trade under the British flag.

ARTICLE 3. The Association engages itself not to accord any advantages whatsoever to the subjects of any other nation without the same advantages being extended to British subjects.

ARTICle 4. Her Majesty the Queen of Great Britain and Ireland may appoint Consuls or other Consular Officers to reside at ports or stations within the said territories, and the Association engages itself to protect them.

Article 5. Every British Consul or Consular Officer within the said territories, who shall be thereunto duly authorised by Her Britannic Majesty's Government, may hold a Consular Court for the district assigned to him, and shall exercise sole and exclusive jurisdiction, both civil and criminal, over the persons and property of British subjects within the same, in accordance with British law.

Article 6. Nothing in the last preceding Article contained shall be deemed to relieve any British subject from the obligation to observe the laws of the said Free States applicable to foreigners, but any infraction thereof by a British subject shall be justiciable only by a British Consular Court.

ARTICLE 7. Inhabitants of the said territories who are subject to the Government of the Association, if they shall commit any wrong against the person or property of a British subject, shall be arrested and punished by the authorities of the Association according to the laws of the said Free States.

Justice shall be equitably and impartially administered on both sides.

Article 8. A British subject, having reason to complain against an inhabitant of the said territories, who is subject to the Government of the Association, must proceed to the British Consulate, and there 


\section{Story of the Congo Free State}

state his grievance. The Consul shall inquire into the merits of the case, and do his utmost to arrange it amicably. In like manner, if any such inhabitant of the said territories shall have reason to complain against a British subject, the British Consul shall no less listen to his complaint and endeavour to settle it in a friendly manner. If disputes take place of such a nature that the Consul cannot arrange them amicably, then he shall request the assistance of the authorities of the Association to examine into the merits of the case and decide it equitably.

ARTICLE 9. Should any inhabitant of the said territories, who is subject to the Government of the Association, fail to discharge any debt incurred to a British subject, the authorities of the Association will do their utmost to bring him to justice, and to enforce recovery of the said debt; and should any British subject fail to discharge a debt incurred by him to any such inhabitant, the British authorities will in like manner do their utmost to bring him to justice, and to enforce recovery of the debt. No British Consul nor any authority of the Association is to be held responsible for the payment of any debt contracted either by a British subject or, by any inhabitant of the said territories, who is subject to the Government of the Association.

Article io. In case of the Association being desirous to cede any portion of the territory now or hereafter under its Government, it shall not cede it otherwise than as subject to all the engagements contracted by the Association under this Convention. Those engagements, and the rights thereby accorded to British subjects, shall continue to be in vigour after every cession made to any new occupant of any portion of the said territory.

This Convention shall be ratified, and the ratifications shall be exchanged with the least possible delay. It shall come into operation immediately upon the exchange of ratifications.

Done at Berlin the $\mathrm{I} 6$ th December, $\mathrm{I} 884$.

(Signed) EDWard B. MaLet. StRaUCh.

\section{On 5th February, I885, was concluded a Conven- tion with the French Republic.}

Article 1. The International Association of the Congo hereby declares that it extends to France the privileges it has conceded to the United States of America, the German Empire, England, Italy, Austria-Hungary, the Netherlands, and Spain, in virtue of the Conventions which it concluded with those Powers respectively on the 2nd April, 8th November, r6th, 19th, 24th, and 29th December, 


\section{Appendix}

1884, and 7 th January, 1885 , the text of which is annexed to the present Convention.

Article 2. The Association engages moreover never to grant any privileges whatever to the subjects of any other nation without their being immediately extended to French citizens.

ArTicle 3. The Government of the French Republic and the Association adopt as frontiers between their possessions:-

The River Chiloango from the ocean to its northernmost source;

The water-parting of the waters of the Niadi Quilloo and the Congo as far as beyond the meridian of Manyanga;

A line to be settled, which, following as far as possible some natural division of the land, shall end between the station of Manyanga and the cataract of the Ntombo Mataka, at a point situated on the navigable portion of the river;

The Congo up to Stanley Pool;

The centre of Stanley Pool;

The Congo up to a point to be settled above the River LiconaNkundja;

A line to be settled from that point to the $I 7$ th degree of longitude east of Greenwich, following, as closely as possible, the water-parting of the basin of the Licona-Nkundja, which is part of the French possessions;

The ${ }_{1}{ }^{\text {th }}$ degree of longitude east of Greenwich.

Article 4. A Commission, composed of an equal number on each side of Representatives of the two parties, shall be intrusted with the duty of marking out on the spot a frontier-line in conformity with the preceding stipulations. In case of a difference of opinion, the question shall be settled by Delegates, who shall be named by the International Commission of the Congo.

ArTiCle 5. Subject to the arrangements to be made between the International Association of the Congo and Portugal as to the territories situated to the south of the Chiloango, the Government of the French Republic is disposed to recognise the neutrality of the possessions of the International Association comprised within the frontiers marked on the annexed Map, conditionally upon discussing and regulating the conditions of such neutrality in common with the other Powers represented at the Berlin Conference.

Article 6. The Government of the French Republic recognises the flag of the International Association of the Congo-a blue flag with a golden star in the centre-as the flag of a friendly Government.

In testimony whereof the respective Plenipotentiaries have signed the present Convention and have affixed thereunto their seals.

Done at Paris the 5 th February, 1885 .

(L. S.) (Signed) Jules FERRY.

(L. S.) (Signed) Comte Paul de Borchgrave d'Altena. 


\section{The Convention concluded with Portugal is dated} I4th February, 1885 .

Article 1. The International Association of the Congo hereby declares that it extends to Portugal the privileges it has conceded to the United States of America, the German Empire, England, Italy, Austria-Hungary, the Netherlands, Spain, France, and the United Kingdoms of Sweden and Norway, in virtue of the Conventions which it concluded with the Powers respectively on the 2 nd April, 8th November, 16 th, I 9 th, $24^{\text {th }}$, and 29 th December, 1884,7 th January and $5^{\text {th }}$ and roth February, 1885 , certified copies of which the Association engages to transmit to the Government of His Most Faithful Majesty.

Article 2. The International Association of the Congo engages moreover never to grant any privileges whatsoever to the subjects of any other nation without their being immediately extended to the subjects of His Most Faithful Majesty.

Article 3. The International Association of the Congo and His Most Faithful Majesty the King of Portugal and the Algarves adopt the following frontiers between their possessions in West Africa, namely:-

To the north of the River Congo (Zaire) the right frontier joining the mouth of the river which empties itself into the Atlantic Ocean, to the south of the Bay of Kabinda, near Ponta Vermelha, at CaboLombo;

The parallel of this latter point prolonged till it intersects the meridian of the junction of the Culacalla with the Luculla;

The meridian thus fixed until it meets the River Luculla;

The course of the Luculla to its junction with the Chiloango (Luango Luce);

The course of the Congo (Zaire) from its mouth to its junction with the little River Uango-Uango;

The meridian which passes by the mouth of the little River UangoUango between the Duteh and Portuguese factories, so as to leave the latter in Portuguese territory, till this meridian touches the parallel of Nokki;

The parallel of Nokki till the point where it intersects the River Kuango (Cuango);

From this point, in a southerly direction, the course of the Kuango (Cuango).

Article 4. A Commission, composed of an equal number on each side of Representatives of the two sides, shall be intrusted with the duty of marking out on the spot a frontier-line in conformity with the preceding stipulations. In case of a difference of opinion, the question shall be settled by Delegates who shall be named by the International Commission of the Congo. 


\section{Appendix}

Article 5. His Most Faithful Majesty the King of Portugal and the Algarves is inclined to recognise the neutrality of the possessions of the International Association of the Congo, conditionally upon discussing and regulating the conditions of such neutrality in common with the other Powers represented at the Berlin Conference.

Article 6. His Most Faithful Majesty the King of Portugal and the Algarves recognises the flag of the International Association of the Congo-a blue flag with a golden star in the centre-as the flag of a friendly Government.

Article 7. The present Convention shall be ratified, and the ratifications shall be exchanged at Paris within three months, or a shorter time if possible.

In testimony of which the Plenipotentiaries of the two Contracting Parties, as well as his Excellency Baron de Courcel, Ambassador Extraordinary and Plenipotentiary of France at Berlin, as representing the mediatory Power, have. signed and affixed their seal to the present Convention.

Done in triplicate at Berlin this $14^{\text {th }}$ day of the month of February, 1885 .

(Signed) STrauch.

Marquis de Pénafiel.

Alph. de Courcel.

\section{Declarations were exchanged between the Belgian Government and the Association on 25th February, I 885 .}

The International Association of the Congo declares by these presents that, by Treaties concluded with the legitimate Sovereigns in the basin of the Congo and its tributaries, vast territories have been ceded to it with all the rights of sovereignty, with a view to the creation of a free and independent State; that Conventions mark off the frontiers of the territories of the Association from those of France and Portugal, and that the frontiers of the Association are shown on the annexed Map;

That the said Association has adopted as the flag of the State administered by it a blue flag with a golden star in the centre;

That the said Association has resolved not to levy any customs duties on goods or products imported into its territories or carried by the road which has been made round the cataracts of the Congo; this resolution has been adopted to assist commerce to penetrate into Equatorial Africa;

That it insures foreigners who may establish themselves in its terri- 
tories the right of buying, selling, or leasing lands and buildings therein situated, of establishing commercial houses, and carrying on trade under the sole condition of obeying the law. It engages, moreover, never to grant the citizens of one nation any privilege whatever without immediately extending it to the citizens of all other nations, and to do all in its power to prevent the Slave Trade.

In testimony of which the President of the Association, acting in its behalf, has hereunto affixed his seal and signature.

Berlin, the 23 rd day of February, 1885 .

(Signed) Stravch.

The Belgian Government takes note of the declarations of the International Association of the Congo, and by these presents recognises the Association within the limits indicated by it, and recognises its flag as on an equality with that of a friendly State.

In testimony of which the Undersigned, being duly authorised thereto, have hereunto affixed their scal and signature.

Berlin, the 23 rd day of February, 1885 .

(Signed) Comte Auguste van der Straten-Ponthoz. BaTON LAMBERMONT.

\section{DECLARATION OF THE GENERAL ACT OF THE BRUSSELS CONFERENCE, JULY 2, $189^{\circ}$}

The Powers assembled in Conference at Brussels, who have ratified the General Act of Berlin of the 26 th February, 1885 , or who have acceded thercto,

After having drawn up and signed in concert, in the General Act of this day, a collection of measures intended to put an end to the Negro Slave Trade by land as well as by sea, and to improve the moral and material conditions of existence of the native races;

Taking into consideration that the execution of the provisions which they have adopted with this object imposes on some of them who have possessions or Protectorates in the conventional basin of the Congo obligations which absolutely demand new resources to meet them;

Have agreed to make the following Declaration:-

The Signatory or adhering Powers who have possessions or Protectorates in the said conventional basin of the Congo are authorised, so far as they require any authority for the purpose, to establish therein duties upon imported goods, the scale of which shall not exceed a rate equivalent to ro per cent. "ad valorem" at the port of entry, always excepting spirituous liquors, which are regulated by the provisions of Chapter VI. of the General Act of this day. 


\section{Appendix}

After the signature of the said General Act, negotiations shall be opened betweer the Powers who have ratified the General Act of Berlin or who have adhered to it, in order to draw up, within the maximum limit of ro per cent. "ad valorem" the conditions of the Customs system to be established in the conventional basin of the Congo.

Nevertheless, it is understood:-

I. That no differential treatment or transit duty shall be established;

2. That in applying the Customs system which may be agreed upon, each Power will undertake to simplify formalities as much as possible, and to facilitate trade operations;

3. That the arrangement resulting from the proposed negotiations shall remain in force for fifteen years from the signature of the present Declaration.

At the expiration of this period, and failing a fresh Agreement, the Contracting Powers shall return to the conditions provided for by Article IV. of the General Act of Berlin, retaining the power of imposing duties up to a maximum of 10 per cent. upon goods imported into the conventional basin of the Congo.

The ratifications of the present Declaration shall be exchanged at the same time as those of the General Act of this day.

In witness whereof the undersigned Plenipotentiaries have drawn up the present Declaration, and have affixed thereto their seals.

Done at Brussels, the and day of the month of July, r89o.

[L. S.] Vivian, John Kirk, Alvensleben, Göhring, R. Khevenhüller, Lambermont, E. Banning, Schack de Brockdorff, J. G. de Aguera, Edm. van Eetvelde, A. van Malgeghem, A. Bouree, G. Cogordan, F. de Renzis, T. Catalani, L. Gericke, Henrique de Macedo, Pereiro Coutinho, L. Ouroussoff, Martens, Burenstam, Et Caratheodory.

\section{TREATY OF AMITY, COMMERCE, AND NAVIGATION}

His Majesty Leopold II., King of the Belgians, Sovereign of the Independent State of the Congo, and

The United States of America,

desiring to perpetuate, confirm and encourage the relations of commerce and of good understanding existing already between the two respective countries, by the conclusion of a treaty of amity, commerce, navigation and extradition, have for this purpose named as their respective Plenipotentiaries, viz.:

His Majesty Leopold II., King of the Belgians, Sovereign of the Independent State of the Congo,

Edm. van Ectvelde, Administrator General of the Department of Foreign Affairs, Officer of His Order of Leopold, and 


\section{Story of the Congo Free State}

\section{His Excellency the President of the United States op AMERICA,}

Edwin H. Terrell, Envoy Extraordinary and Minister Plenipotentiary of the United States of America near His Majesty the King of the Belgians, who, after having communicated to each other their full powers, found in good and due form, have agreed upon the following articles:

ARTICLE I.-There shall be full, entire and reciprocal liberty of commerce, establishment and navigation between the citizens and inhabitants of the two High contracting Parties.

The citizens and inhabitants of the Independent State of the Congo in the United States of America and those of the United States of America in the independent State of the Congo shall have reciprocally the right, on conforming to the laws of the country, to enter, travel and reside in all parts of their respective territories; to carry on business there; and they shall enjoy in this respect for the protection of their persons and their property the same treatment and the same rights as the natives, or the citizens and inhabitants of the most favoured nation.

They can freely exercise their industry or their business, as well wholesale as retail, in the whole extent of the territories, without being subjected as to their persons or their property, or by reason of their business, to any taxes, general or local, imposts or conditions whatsoever other or more onerous than those which are imposed or may be imposed upon the natives other than non-civilised aborigines, or upon the citizens and inhabitants of the most favoured nation.

In like manner, they will enjoy reciprocally the treatment of the most favoured nation in all that relates to rights, privileges, exemptions and immunities whatsoever concerning their persons or their property and in the matter of commerce, industry and navigation.

ARTICLE II.-In all that concerns the acquisition, succession, possession and alienation of property, real and personal, the citizens and inhabitants of each of the High contracting Parties shall enjoy in the territories of the other all the rights which the respective laws accord or shall accord in those territories to the citizens and inhabitants of the most favoured nation.

Article III.-The citizens and inhabitants of each of the High contracting Parties shall be exempt in the territories of the other from all personal service in the army, navy, or militia, and from all pecuniary contributions in lieu of such, as well as from all obligatory official functions whatever, except the obligation of sitting, within a radius of one hundred kilometres from the place of their residence, as a juror in judicial proceedings; furthermore, their property shall not be taken for the public service without an ample and sufficient compensation. 


\section{Appendix}

They shall have free access to the courts of the other, on conforming to the laws regulating the matter, as well for the prosecution as for the defence of their rights, in all the degrees of jurisdiction established by law. They can be represented by lawyers, and they shall enjoy, in this respect, and in what concerns domiciliary visits to their houses, manufactories, stores, warehouses, etc., the same rights and the same advantages which are or shall be granted to the citizens and inhabitants of the most favoured nation, or to natives.

Article IV.- The citizens and inhabitants of the two countries shall enjoy, in the territory of the other, a full and entire liberty of conscience. They shall be protected in the free exercise of their worship; they shall have the right to erect religious edifices and to organise and maintain missions.

Article V.-It will be lawful for the two High contracting Parties to appoint and establish consuls, vice consuls, deputy consuls, consular agents and commercial agents in the territories of the other; but none of these agents can exercise his functions before having received the necessary exequatur from the Government to which he is delegated.

The said agents of each of the two High contracting Parties shall enjoy, in the territories of the other, upon the footing of a complete reciprocity, all the privileges, immunities and rights which are actually granted to those of the most favoured nation or which may be accorded to them hereafter.

The said agents, citizens or inhabitants of the State by which they are appointed shall not be subject to preliminary arrest, except in the case of acts qualified as crimes by the local legislation and punished as such. They shall be exempt from military billeting and from service in the army, navy, or militia, as well as from all direct taxes, unless these should be due on account of real estate, or, unless the said agents should exercise a profession or business of any kind.

The said agents can raise their national flag over their offices.

The consular offices shall be at all times inviolable. The local authorities can not invade them under any pretext. They can not in any case examine or seize the papers which shall be there deposited. The consular offices can not, on the other hand, serve as place of asylum, and if an agent of the consular service is engaged in business, commercial or other, the papers relating to the consulate shall be kept separate.

The said agents shall have the right to exercise all the functions generally appertaining to consuls, especially in what concerns the legalisation of private and public documents, of invoices and commercial contracts, the taking of depositions and the right of authenticating legal acts and documents.

The said agents shall have the right to address the administrative and judicial authorities of the country in which they exercise their 


\section{$55^{6} \quad$ Story of the Congo Free State}

functions in order to complain of any infraction of the treaties or conventions existing between the two Governments, and for the purpose of protecting the rights and interests of the citizens and inhabitants of their country. They shall have also the right to settle all differences arising between the captains or the officers and the sailors of the seavessels of their nation. The local authorities shall abstain from interfering in these cases unless the maintenance of the public tranquillity requires it, or, unless their assistance should be asked by the consular authority in order to assure the execution of its decisions.

The local authorities will give to the said agents and, on their default, to the captains or their casual representatives, all aid for the search and arrest of sailor deserters, who shall be kept and guarded in the prisons of the State upon the requisition and at the expense of the consuls or of the captains, during a maximum delay of two months.

Article VI.-The citizens and inhabitants of each of the High contracting Parties shall have reciprocally, according to the same rights and conditions and with the same privileges as those of the most favoured nation, the right to enter with their vessels and cargoes into all the ports and to navigate upon all the rivers and interior waters of the other State.

The vessels of each of the contracting Parties and of its citizens or inhabitants can freely navigate upon the waters of the territory of the other, without being subject to any other tolls, charges or obligations than those which the vessels belonging to the citizens or inhabitants of the most favoured nation would have to bear.

There will not be imposed by either of the contracting Parties upon the vessels belonging to the other or to the citizens or inhabitants of the other, in the matter of tonnage, port charges, pilotage, lighthouse and quarantine dues, salvage of vessels and other administrative expenses whatsoever concerning navigation, any taxes or charges whatever, other or higher than those which are or shall be imposed upon the public or private vessels of the most favoured nation.

It is agreed that every vessel belonging to one of the High contracting Parties or to a citizen or inhabitant of one of them, having the right to bear the flag of that country and having the right to its protection, both according to the laws of that country, shall be considered as a vessel of that nationality.

ArTICLE VII.-In what concerns the freight and facilities of transportation, and tolls, the merchandise belonging to the citizens or inhabitants of one of the contracting States transported over the roads, railroads and waterways of the other State, shall be treated on the same footing as the merchandise belonging to the citizens or inhabitants of the most favoured nation.

Article VIII.-In the territories of neither of the High contract- 
ing Parties shall there be established or enforced a prohibition against the importation, exportation or transit of any article of legal commerce, produced or manufactured in the territories of the other, unless this prohibition shall equally and at once be extended to all other nations.

ARTICLE IX.-Relating to extraction was stricken out by the Senate.

ARTiCle X.-The Republic of the United States of America, recognising that it is just and necessary to facilitate to the Independent State of the Congo the accomplishment of the obligations which it has contracted by virtue of the General Act of Brussels of July 2nd, I 890 , admits, so far as it is concerned, that import duties may be collected upon merchandise imported into the said State.

The tariff of these duties cannot go beyond ro per cent. of the value of the merchandise at the port of importation, during fifteen years to date from July 2 nd, 1890 , except for spirits, which are regulated by the provisions of Chapter VI. of the General Act of Brussels.

At the expiration of this term of fifteen years, and in default of a new accord, the Independent State of the Congo will be placed as to the United States of America in the situation which existed prior to July 2nd, I890; the right to impose import duties to a maximum of Io per cent. upon merchandise imported into the said State remaining acquired to it, on the conditions and within the limitations determined in Articles XI. and XII. of this treaty.

ARTICLE XI.-The United States shall enjoy in the Independent State of the Congo, as to the import duties, all the advantages accorded to the most favoured nation.

It has been agreed besides:

I. That no differential treatment nor transitduty can be established;

2. That in the application of the tariff régime which will be introduced, the Congo State will apply itself to simplify, as far as possible, the formalities and to facilitate the operations of commerce.

ArTicle XII.-Considering the fact that in Article X. of the present treaty, the United States of America have given their assent to the establishment of import duties in the Independent State of the Congo under certain conditions, it is well understood that the said Independent State of the Congo assures to the flag, to the vessels, to the commerce and to the citizens and inhabitants of the United States of America, in all parts of the territories of that State, all the rights, privileges and immunities concerning import and export duties, tariff régime, interior taxes and charges and, in a general manner, all commercial interests, which are or shall be accorded to the Signatory Powers of the Act of Berlin, or to the most favoured nation. 
Article XIII.-In case a difference should arise between the two High contracting Parties as to the validity, interpretation, application or enforcement of any of the provisions contained in the present treaty, and it could not be arranged amicably by diplomatic correspondence between the two Governments, these last agree to submit it to the judgment of an arbitration tribunal, the decision of which they bind themselves to respect and execute loyally.

The tribunal will be composed of three members. Each of the two High contracting Parties will designate one of them, selected outside of the citizens and the inhabitants of either of the contracting States and of Belgium. The High contracting Parties will ask, by common accord, a friendly Government to appoint the third arbitrator, to be selected equally outside of the two contracting States and of Belgium.

If an arbitrator should be unable to sit by reason of death, resignation, or for any other cause, he shall be replaced by a new arbitrator whose appointment shall be made in the same manner as that of the arbitrator whose place he takes.

The majority of arbitrators can act in case of the intentional absence or formal withdrawal of the minority. The decision of the majority of the arbitrators will be conclusive upon all questions to be determined.

The general expenses of the arbitration procedure will be borne, in equal parts, by the two High contracting Parties; but the expenses made by either of the parties for preparing and setting forth its case will be at the cost of that party.

ArTicle XIV.-It is well understood that if the declaration on the subject of the import duties, signed July 2 nd, 1890 , by the Signatory Powers of the Act of Berlin, should not enter into force, in that case, the present treaty would be absolutely null and without effect.

Article XV.-The present treaty shall be subject to the approval and the ratification, on the one hand, of His Majesty the King of the Belgians, Sovereign of the Independent State of the Congo, and on the other hand, of His Excellency the President of the United States, acting by the advice and with the consent of the Senate.

The ratifications of the present treaty shall be exchanged at the same time as those of the General Act of Brussels of July 2nd, 1890, and it will enter into force at the same date as the latter.

In faith of which the respective Plenipotentiaries of the High contracting Parties have signed the present treaty, in duplicate, in French and in English, and have attached thereto their seals.

Done at Brussels, the twenty-fourth day of the month of January of the year eighteen hundred and ninety-one.
Edm. van Eetvelde.
[S.] EDwiN
H. Terrell. 


\section{Appendix}

\section{RATIFICATION BY THE UNITED STATES}

And whereas the said Treaty has been duly ratified on both parts, and the ratifications of the two Governments were exchanged in the city of Brussels, on the 2 nd day of February, 1892,

Now, therefore, be it known that I, Benjamin Harrison, President of the United States of America, have caused the said Treaty to be made public as amended, to the end that the same and every article and clause thereof may be observed and fulfilled with good faith by the United States and the citizens thereof.

In witness whereof, I have hereunto set my hand and caused the seal of the United States to be affixed.

Done at the city of Washington this second day of April in the year of our Lord one thcusand eight hundred and ninety-two, and of the Independence of the United States the one hundred and sixteenth.

[SEAL]

BENJ. Harrison.

By the President.

James G. Blaine,

Secretary of State.

\section{PROTOCOL RECORDING THE RATIFICATION BY THE UNITED STATES OF AMERICA OF THE GENERAL ACT OF BRUSSELS OF JULY 2, 1890-SIGNED AT BRUSSELS, FEBRUARY 2, 1892}

On the 2nd February, 1892 , in conformity with Article XCIX. of the General Act of the 2nd July, 1890 , and with the unanimous decision of the Signatory Powers prolonging till the 2nd February, 1892, in favour of the United States, the period fixed by the said Article XCIX., the Undersigned, Envoy Extraordinary and Minister Plenipotentiary of the United States of America, deposited in the hands of the Belgian Minister for Foreign Affairs the Ratification by the President of the United States of the said General Act.

At His Excellency's request the following Resolution whereby the Senate of the United States consented to the Ratification of the President, was inserted in the present Protocol:-

"Resolved (two-thirds of the Senators present concurring therein),

"That the Senate advise and consent to the ratification of the General Act signed at Brussels on the 2 nd July, r $89 \circ$, by the Plenipotentiaries of the United States and other Powers, for the suppression of the African Slave Trade, and for other purposes.

"Resolved further: That the Senate advise and consent to the acceptance of the partial ratification of the said General Act on the part 
of the French Republic, and to the stipulations relative thereto, as set forth in the Protocol signed at Brussels on the and February, 1892 .

"Resolved further, as a part of this act of ratification, That the United States of America, having neither Possessions nor Protectorates in Africa, hereby disclaims any intention, in ratifying this Treaty, to indicate any interest whatsoever in the Possessions or Protectorates established or claimed on that Continent by the other Powers, or any approval of the wisdom, expediency, or lawfulness thereof, and does not join in any expressions in the said General Act which might be construed as such a declaration or acknowledgment; and, for this reason, that it is desirable that a copy of this Resolution be inserted in the Protocol to be drawn up at the time of the exchange of the ratifications of this Treaty on the part of the United States."

The above Resolution of the Senate of the United States having been textually communicated in advance by the Government of Belgium to all the Signatory Powers of the General Act, the latter have assented to its insertion in the present Protocol which shall remain annexed to the Protocol of the 2 nd February, 1892.

An official notification to this effect was made to the United States Minister.

The Ratification of the President of the United States having been found in good and due form, notification of its deposit was made to his Excellency Mr. Edwin $H$. Terrell. It will be retained in the archives of the Belgian Foreign Office.

On proceeding to the signature of the present Protocol the Minister for Foreign Affairs of His Majesty the King of the Belgians announced that the Representative of Russia, in his note expressing the assent of his Government, expressed the opinion that it was desirable that, in the Protocol, a French translation should accompany the English text of the Resolution of the Senate of the United States of America, and that, in any case, the absence of such translation should not form a precedent.

A certified copy of the present Protocol will be sent by the Belgian Government to the Signatory Powers of the General Act.

Done at Brussels the end February, 1892.

The Minister for Foreign Affairs,

(Signed) Prince de Chimay.

The Envoy Extraordinary and Minister Plenipotentiary of the United States of America,

(Signed) Edwin H. Terrell. 
DISPATCH FROM HIS MAJESTY'S MINISTER AT BRUSSELS RESPECTING THE COMMISSION FOR THE PROTECTION OF THE NATIVES, INSTITUTED BY THE GOVERNMENT OF THE INDEPENDENT CONGO STATE UNDER THE DECREE OF SEPTEMBER 18,1896

Sir C. Phipps to the Marquess of Lansdowne.-(Received May 19.)

(Extract.)

Brussels, May 18, 1903 .

M. De Cuvelier handed to me this morning the documents herewith inclosed on the subject of the working of the Commission for the Protection of the Natives, instituted by the Congo State Government under the Decree of the 18 th September, 1896 , which had been collected and prepared for me in consequence of my request made to that effect the day before yesterday.

Your Lordship will observe that the Congo Government places at my disposal, without concealment, the whole correspondence which has passed in regard to the Commission under discussion, including dispatches not intended for publication. It undoubtedly leads to the conclusion that, if the operation of the Commission has not been so effective as might have been anticipated, the fault has rather been due to the great extent of territory which it had the duty to watch, and to the considerable distances by which its members were separated, and not to any deficiency of conception or absence of energy on the part of the Central Government.

\section{SETTLEMENTS FOR NATIVE CHILDREN}

LEOPOLD II., King of the Belgians; Sovereign of the Independent State of the Congo,

To all present and to come, greeting:

Whereas it is expedient to make provision for the protection of those children who have been victims of the Slave Trade; and

Whereas it is the general duty of the State to assume the guardianship of abandoned children, or of those whose parents do not fulfil their duties;

Now, therefore, on the proposal of our Administrator-General of the Foreign Department, we have decreed and do hereby decree:-

ARTICLE r. The State shall assume the guardianship of children liberated in consequence of the arrest and dispersal of a convoy of slaves; of fugitive slaves who demand such protection, of children forsaken, abandoned, or orphans, and of those whose parents do not fulfil their duty with regard to maintaining and educating them. 
They shall be provided with the means of livelihood and a practical education, and established in life.

ART. 2. With this object agricultural and professional settlements shall be established, which shall admit not only such children as come under the definitions of Article r, but, as far as may be, those children who shall ask to be admitted.

ART. 3. From the day of their admission the children shall be placed exclusively under the guardianship of the State, to which they shall remain subject, and shall be liable to work, at the discretion of the Governor-General, up to the expiration of their twenty-fifth year in return for maintenance, food, lodging, and free medical attendance.

ART. 4. Rules of administration prescribed by our GovernorGeneral shall decide the mode and conditions of admission to the settlements, the composition of the directing staff, the programme of manual and intellectual work, the details of supervision, disciplinary penalties and their application, and the public services to which the children shall be attached.

ART. 5. The administration of the guardianship of the children admitted to the settlements shall, as far as their personal rights and property are concerned, be regulated by the Civil Code.

Art. 6. Our Administrators-General of the Foreign and Home Departments are charged, each in so far as it concerns him, with the execution of this Decree.

Done at Brussels this 12 th day of July, 1890.

By the King-Sovereign:

LEOPOLD.

The Administrator-General of the Foreign

Department,

(Signed) Edm. van Eetvelde.

\section{INSTITUTION OF A COMMISSION FOR THE PRO- TECTION OF NATIVES}

Leopold II., King of the Belgians, Sovereign of the Independent State of the Congo, to all present and to come, greeting:

On the motion of our Secretary of State,

We have decreed and do hereby decree:

A permanent Commission is instituted to watch over the protection of the natives throughout the territories of the State.

The members of this Commission are nominated by the KingSovereign for a period of two years from among the representatives of philanthropic and religious Associations.

Are named in the first instance:

Mgr. van Ronslé, Bishop of Thymbrium, Vicar Apostolic of the Congo Independent State, President; 


\section{Appendix}

Father van Hencxthoven, J., Superior of the Jesuit Mission at Leopoldville;

Father de Cleene, of the Congregation of Scheut;

William Holman Bentley, of the Baptist Missionary Society Corporation;

Dr. A. Sims, of the American Baptist Missionary Union;

George Grenfell, of the Baptist Missionary Society Corporation, Secretary.

The members of the Commission are to inform the Judicial authorities of any acts of violence of which the natives may be the victims.

Each of the members, individually, may exercise this right of protection, and communicate directly with the Governor-General.

The Commission shall further indicate to the Government the measures to be taken to prevent slave-trading, to render more effective the prohibition or restriction of the trade in spirituous liquors, and gradually to bring about the abolition of barbarous customs, such as cannibalism, human sacrifices, ordeal by poison, etc.

Our Secretary of State is charged with the execution of the present Decree.

Done at Brussels, the 18 th September, 1896 .

By the King-Sovereign:

(Signed) LEOPOLD.

The Secretary of State,

(Signed) Edm. van Eetvelde.

\section{LETTER OF INSTRUCTION FROM THE SECRETARY OF STATE TO THE GOVERNOR-GENERAL AT BOMA IN RE PROTECTION OF NATIVES}

SIR,

$$
\text { Brussels, October I, } 1896 \text {. }
$$

I have the honour to transmit to you herewith a certified copy of a Decree, dated the 18 th September, appointing a Commission for the protection of natives.

It has seemed advisable that selected and impartial men, without official or administrative connection, should be placed in a position to form a perfectly independent opinion in regard to any acts of violence of which the natives may have to complain. Such is the object of the new Commission which has been appointed to watch over the protection of natives throughout the country.

Its nembers are nominated by the King-Sovereign, for a period of two years, from among the representatives of philanthropic and religious Associations.

By this expression the Decree pointed specially to the missionaries, 


\section{$564 \quad$ Story of the Congo Free State}

who were, indced, marked out for nomination in virtue of their office.

The first members nominated are: Mgr. van Ronslé, Fathers van Hencxthoven and De Cleene, the Protestant missionaries William Holman Bentley, Dr. A. Sims, and G. Grenfell. The last mentioned is appointed Secretary; Mgr. van Ronslé is nominated President.

I have to request you to inform them individually of their selection by the King-Sovereign; the Government are confident that they will not be appealing in vain to the devotion of these gentlemen in requesting the assistance of their services in a work of humanity and protection. One of the authenticated copies of the Decree hereto annexed is intended for each, and will serve as a letter of appointment.

The Decree specifies the duty intrusted to them as being that of notifying to the judicial authorities acts of violence of which the natives may be the victims. This right of initiative belongs to each member individually, that is to say, that he can act separately without any co-operation on the part of the other members of the Commission. Each member may of his own accord address direct communications to the Governor-General with regard to any matters which come within the scope of his mission.

It is the express desire of the Government that the authorities should act upon the information thus given by the members of the Commission, and open an inquiry and institute proceedings either administrative or, in cases of infractions of the law, judicial, in accordance with the general instructions given to the Department of Criminal Justice (le Parquet).

It will hardly be necessary to call the attention of the members of the Commission to the fact that, by reason of the great attention which will be paid to any complaint which they may make, it will behove them to act with circumspection, and to give the authority of their support only to those facts of which they may liave personal knowledge, and which are based on trustworthy evidence.

The Decree lastly provides that the Commission may, through the medium of its Secretary, indicate to the Government the measures to be taken to prevent slave-trading, to render more effective the prohibition or restriction of the trade in spirituous liquors, and gradually to bring about the disappearance of inhuman practices. The simplest mode of procedure will be for the Secretary of the Commission-and I am sure that Mr. G. Grenfell will be willing to accept the duty-to forward to the Governor-General a half-yearly report on these questions, containing the observations and proposals of the members of the Commission on the subject. This half-yearly report would also deal with the working of the Commission, the acts of violence definitely cstablished by the members, the complaints made, and the results achieved. 


\section{Appendix}

I have to request you to keep me informed of the manner in which the new Decree is carried out, and to acquaint me with the definite constitution of the Commission.

The terms of the Decree seem calculated to afford the natives a real guarantee. In order to strengthen this still more, the Government have decided that all offences against the persons of natives, and all attempts against their liberties committed by Europeans, shall be remitted exclusively to the Court of First Instance at Boma, that is to say, before a Court sitting under the fullest conditions of publicity and control. I therefore request that you will instruct the Public Prosecutors (Parquet) to bring offences of the kind before that Court, instead of sending them to the territorial Courts, reserving of course the special jurisdiction which the law gives to military Courts (Conseils de Guerre) in the case of soldiers.

Believe, etc.,

The Secretary of State,

(Signed) Edm. van Eetvelde.

\section{Reverend Sir,}

BoLobo, December 26, I 896 .

I have the honour to transmit to you herewith a certified copy of the Decree of the 18 th December last appointing a Commission for the protection of natives, and nominating you to fulfil the duties of Secretary to the said Commission. This authenticated copy will serve you as your letter of appointment to the important functions for the performance of which the King-Sovereign has selected you. The Government are confident that their appeal for your assistance in a work of humanity and protection will not be in vain.

Owing to the powers devolving upon you as a member of the Commission, you will be in a position to form a perfectly independent opinion in regard to any acts of violence of which the natives may have to complain, and it will be your duty to notify to the judicial authorities any improper proceedings of which the natives in question may be the victims. This right of initiative belongs to you individually, that is to say, you may act separately, without any co-operation on the part of the other members of the Commission. On your information the authorities will open an inquiry, and will institute proceedings, either administrative or, in cases of infractions of the law, judicial.

In view of the action which will be taken on any complaint emanating from you or from the Commission, it is scarcely necessary to remind you that circumspection is called for, and that you should give the authority of your support only to those facts of which you may have a personal knowledge, and which are based on trustworthy evidence. 
The Commission will also have the duty of drawing the attention of the Government to the measures to be taken to prevent slavetrading, to render more effective the prohibition or restriction of the trade in spirituous liquors, and gradually to bring about the disappearance of inhuman practices. The simplest mode of procedure in this matter would be, in the opinion of the Government, that you, in your capacity as Secretary-and the Government is convinced that you will be willing to accept this duty-should send in a half-yearly report on these questions, containing the observations and proposals of the members of the Commission on the subject. This half-yearly report might also deal with the working of the Commission, the acts of violence definitely established by its members, the complaints made, and the results achieved.

But in this matter, as in everything which relates to the working of the Commission, the Government give it full discretion.

In forwarding to each of the members a copy of the new Decree, and in announcing his nomination to each individually, I am informing them of your appointment as Secretary. You will be good enough to place yourself in communication with them in order, if possible, in spite of distance, to arrange, at Leopoldville, for instance, a meeting of all the members of the Commission, or of a certain number of them, or definitely to constitute the Commission by correspondence, and to settle such measures as should be taken for the execution of the Decree.

Believe, etc.,

The Governor-General,

To (Signed)

WAHIS.

The Reverend George Grenfell, Baptist Missionary Society, Bolobo.

\section{CIRCULAR TO ALL THE DISTRICT COMMISSIONERS, HEADS OF ZONES AND OF POSTS, WITH REGARD TO BARBAROUS CUSTOMS PREVAILING AMONG THE NATIVE TRIBES.}

Gentlemen,

Brussels, February 27, 1897 .

As you are aware, the Government have had constantly under their consideration the barbarous practices, such as cannibalism, ordeal by poison, and human sacrifices, which prevail among the native tribes, and the best means of bringing about their disappearance.

In this matter, as in all questions in which allowance must to some extent be made for long-established custom and social conditions which it would be impolitic to attack too directly, the Government 


\section{Appendix}

have thought it advisable to act at first with prudence and circumspection, without, however, remaining inactive.

For this reason the first instruction issued to officers did not, in all cases, prescribe repression by force; they enjoined the exercise of their influence and authority with a view to deterring the natives by persuasion from indulging in these inhuman practices. A further advance has been made: the moment the authority of the State was sufficiently established in the neighbourhood of its posts and stations, the toleration of such customs was formally prohibited within a certain distance round the State stations or European establishments, and the Penal Law made their repression in these places possible by its provisions respecting acts of violence against the person. Outside this limit it lay with the officers of the Department of Criminal Justice (Ministere Public) to prosecute or not, according as the situation of the district and the forces at the disposal of the authorities permitted.

These measures have not been without result. Not only have cases of cannibalism become less frequent in the centres occupied by the officers of the State, but the native himself has learnt, and now knows, the horror felt by Europeans for cannibalism, and is no longer ignorant of the fact that by giving way to it he renders himself liable to punishment. As a general rule, indeed, it is only in secret, and out of sight of Europeans, that he still indulges in the odious custom, for he has become convinced that, save in exceptional cases in which the white man is powerless to do otherwise, he will not let him go unpunished.

The Government considers that an even more decisive step should be taken in the direction of repression. As the State's occupation of these districts becomes more and more complete, as its posts are multiplied all along the Upper Congo, and as regular Courts are gaining a footing in the interior, the moment seems to have come to endeavour to reach the evil once for all, and to seek to extirpate it everywhere where our authority is sufficiently established to enable us to enforce absolute respect for the Penal Law.

It was with this view that the Decree of the 18 th December, 1896 , was drawn up, by which more particularly cases of cannibalism and ordeal by poison were made special offences. It is the Government's intention that these provisions shall be strictly enforced, and it is the aim of the present Circular to direct all our officers to bring to justice any offences of this kind which may cone to their knowledge. It will be the duty of the officers of the Department of Criminal Justice (Ministere Public) to institute proceedings against the delinquents, and in these special cases they will not be at liberty to apply Article 84 of the Decree of the 27 th April, 1889 , and to hand them over to the jurisdiction of the local Chief to be dealt with by native custom. It is, indeed, evident that such a course is out of the question in dealing 
with a class of offences which are contrary to the principles of our civilisation, and which are the outcome of customs which we are seeking to abolish.

The Government count on general assistance, with a view to insuring the prompt and certain repression of these offences, and they believe that a few severe examples will have a powerful effect in inducing the native to put an end to these reprehensible practices. The District Commissioners and Heads of Stations are in this connection expected to police the territories under their administration, and to take the necessary measures to obtain exact information.

The Director of Justice will forward to the Government every quarter a Report on the practice of cannibalism, on the cases prosecuted, and, if necessary, on the new measures which should be taken in order to check and extirpate this custom.

\title{
MISSIONARY GRENFELL ON ADMINISTRATION OF JUSTICE
}

Sir,

\author{
Baptist Missionary Society, Bolobo, July 13, 1897.
}

I have the honour to acknowledge the receipt of your letter dated the 17 th May, together with the enclosure, relative to cannibalism, proof by poison, and human sacrifices, dated Brussels, the $27^{\text {th }}$ February, 1897 .

I need hardly say, M. le Gouverneur, that I sympathise most sincerely with the Government in its desire to eradicate the evils referred to; and you may rely upon my best efforts in the long and arduous struggle involved in combating them.

I am glad to recognise the gradual extension of the zone where justice is administered by regularly constituted Judges, for there is no doubt that where the administration of the State has been sufficiently advanced to allow of this, the evils referred to are very markedly on the decrease. It is not possible, of course, to complete at a stroke the organisation of distant territory, or at once to appoint Judges in new districts, but the fact that the State is persistently pushing the regular administration of justice towards the interior encourages one in confidently looking forward to the reducing of the cases of cannibalism, proof by poison, and human sacrifices in those parts of the Colony that as yet have not benefited by the ameliorating influences that have done so much for its western section.

M. le Gouverneur-Général, I have, etc.,

(Signed) George Grenfell. Boma. 


\section{Appendix}

\section{CO-ORDINATED TEXT OF VARIOUS INSTRUCTIONS RESPECTING RELATIONS BETWEEN CONGO STATE OFFICIALS AND NATIVES}

It will be the especial care of Heads of Expeditions and of District Commissioners to see that their subordinates, of whatever degree, act, in their dealings with the natives, with the tact which is necessary to avoid such conflict as might arise from misunderstandings or from proceedings which run too sharply counter to native habits and customs.

They will recommend their officers to proceed slowly in reforming the native, and will draw their serious attention to the danger of trying to obtain too rapid results. Before using force, they will try to enter into negotiations with the natives, and they must remember that it is better to obtain redress for harm done to the State by pacific means rather than by force of arms.

The Government are aware that energetic measures of repression are sometimes necessary, but they consider that such measures should be used only in exceptional cases, and after every means of conciliation has been exhausted.

In many cases negotiations skilfully conducted and prolonged will avoid direct hostilities.

It is, for instance, obviously advisable, with a view to avoid bloodshed, to make use of such Chiefs as are at once devoted to the State and in friendly relations with the tribes in conflict with the authorities.

In this way the natives, and especially those who are not in continuous relations with Europeans, will not misunderstand the intentions and sentiments of the State towards them, a misunderstanding which would certainly arise from a too hasty recourse to extreme measures.

In any case, whenever resort to force has become inevitable, the Government must receive exact and complete information in regard to the motives which have led to its employment, and operations must, as far as possible, be so carried out that only the guilty suffer.

No officer is to engage in hostilities with the natives, unless in selfdefence, or duly authorised by the Commissioner of his district or the Head of his expedition.

Moreover, the regular and auxiliary troops engaged in warlike operations must always be commanded by a European. No exception to this rule will be admitted, and officers who transgress it will render themselves liable to dismissal as well as to any judicial proceedings it may be thought advisable to institute against them.

In case of hostilities, the property of natives is not to be destroyed, and under no pretext may villages be burnt as a means of repression. The European commissioned and non-commissioned officers will take 
especial care that the operations shall be conducted in such a manner as to avoid all cruelty. Wounded rebels are to receive careful attention, and the bodies of the dead must be respected. The barbarous mutilation of dead bodies, as often practised by the natives among themselves, is to be absolutely forbidden by the Europeans.

All Europeans at the head of troops engaged in warfare will be held personally responsible for all such cruelties as they may tolerate; all guilty persons will be brought before a military Court and dealt with according to law.

Prisoners of war and hostages are to be treated humanely, and their ill-usage is strictly forbidden.

Any women and children found among them shall be placed under the immediate protection of the officer in command of the operations.

Officers of the State must remember that the disciplinary penalties provided by the Military Regulations are only applicable to such as are military recruits, and then only for offences against discipline and in accordance with the special provisions of the said Regulations.

The said penalties can, under no pretence, be put into force against non-military servants of the State or against the natives, whether rebels or not.

Those among them who are accused of offences or crimes must be remitted to the competent Tribunals and tried according to law.

Should officers of the State infringe the Rules laid down respecting the relations which they are to have with the natives, or tolerate mutilations and cruelties on the part of their soldiers, they will, in case of a specified offence, be remitted to a Court of Justice. They would, in any case, be subjected to disciplinary punishment. Moreover, the guilty officers, if already decorated with the Service Star, will lose their right to wear it.

It is equally indispensable that officers should act justly, and in accordance with the instructions in force, in their dealings with the servants of the State. They are forbidden to act illegally, $i . e$., to inflict punishments other than those provided for breaches of discipline or to disregard legal forms for the purpose of repressing offences of which the servants of the State, and notably soldiers, may be guilty. When sentences have been passed, they must be undergone in accordance with the specified legal conditions.

Any officer departing from these Rules would be guilty of abuse of authority, and render himself liable to dismissal.

District Commissioners and Heads of expeditions must exercise the most vigilant control over such detachments of black soldiers as they may be obliged to place among the natives. These detachments must on no account be provided with improved fire-arms. Their task is exclusively one of protection and supervision.

They are never to intervene in quarrels between natives. They 


\section{Appendix}

must confine themselves to informing the nearest station commanded by an European.

It is the duty of the European officers to make frequent inspections of such detachments, and to see that they do not in any way transgress the limits imposed upon them by their orders. They are to summon the neighbouring native Chiefs on the occasion of these inspections, and will receive their complaints, should they have any to make.

The Negro officers of the stations are strictly forbidden themselves to take any measures of repression against the natives; the duty of taking measures, when occasion arises, devolves upon the European officers alone.

The arrangements to be made with the villages must be concluded by a European.

Any Chief of a Negro station levying exactions on the natives, or ill-treating them, or in any way abusing his authority over them, mustbe prosecuted according to law, and immediately suspended from his duties.

The Heads of expeditions and Commissioners of Districts are personally responsible for the conduct of any Negro posts under their orders. They would be guilty of a very serious offence if they gave these detachments any duties other than those defined above, and if they did not constantly supervise them and immediately repress all abuses coming under their notice.

\section{REPORT OF THE FIRST MEETING OF THE COM- MISSION FOR THE PROTECTION OF NATIVES, HELD AT LEOPOLDVILLE ON MAY I7, I897. PRESENT, THE REVEREND FATHER VAN HENCXTHOVEN, DR. SIMS, AND THE SECRE- TARY, MR. GRENFELL}

In the absence of Mgr. van Ronsle, the Rev. Father van Hencxthoven was elected President for the sitting.

Seeing that the members of the Commission live far apart, and in view of the difficulty of all the members meeting, it was decided that three members should form a quorum.

The members of the Commission found that from the date of the constitution of the Commission, so far as their personal experience went, the laws of the State had been duly administered with a view to the protection of life and property, as well as to the well-being of the community. They found, further, that every case of injustice brought to the notice of the authorities had been immediately followed by measures of the most energetic description.

In the absence of Mr. Bentley, his Report was communicated to the Secretary. He writes that the Judge of the district where he re- 
sides, had, in each case notified to him, at once taken measures to punish the guilty, some cases having been settled satisfactorily, and the others being before the Court. The Judge informed Mr. Bentley that he would always be ready, on receiving a week's notice, to go to Lutété, and try any case.

The members of the Commission, recalling the days of native rule, take this opportunity of recording their sincere appreciation of, and their gratitude for, the law and order introduced by the Independent State into the districts where they reside.

The members of the Commission also record with the deepest satisfaction their opinion that, as far as they know, the laws forbidding the introduction of alcoholic liquor for natives to the east of the River N'Kissi have been satisfactorily enforced. They consider the restriction of the zone up to the west of the River $K$ wilu as a really judicious and beneficent measure, and they trust that the Government will be as successful within the new limit as heretofore within the old.

The members of the Commission deeply regret that ordeal by poison is still practised over so great an extent of the country, and that its suppression is so difficult In those districts which are more completely administered, ordeal by poison is practised in secret, owing to the penalties of the law, and the members hope that the same measures of repression will be taken in the interior districts as soon as the organisation of the Government allows of it.

The Commission desire to call the attention of the Government to the fact that all its members are chosen from the Stanley Pool district and below, and that no one has been chosen from the immense districts which are supposed to furnish the reason for the existence of the Commission for the protection of the natives.

The members of the Commission, also, seeing that it is only possible for them to act within the very narrow scope of their personal experience, venture to hope that the Inspector specially nominated by His Majesty the King-Sovereign, will soon arrive, seeing that his powers of observation would be infinitely greater than our own.

(Signed) George Grenfell, Secretary.

LEOPOLDVILLE, May I 7,1897 .

\section{PROTECTION OF NATIVES-COMMISSION}

Leopold II., King of the Belgians, Sovereign of the Independent State of the Congo, to all present and to come, greeting:

On reconsideration of our Decree of the 18 th September, 1896 , appointing a Commission for the protection of natives:

On the suggestion of our Secretary of State,

We have decreed and do hereby decree: 


\section{Appendix}

Article r. The following are appointed members of this Commission, for the period of two years mentioned by the said Decree:

Mgr. van Ronsle, Bishop of Thymbrium, Vicar Apostolic of the Vicariat of Belgian Congo, President.

The Reverend Father van Hencxthoven, J., of the Society of Jesus.

The Reverend Father Cambier, of the Congregation of Scheut.

Mr. William Holman Bentley, of the Baptist Missionary Society Corporation.

Dr. A. Sims, of the American Baptist Missionary Union.

Mr. George Grenfell, of the Baptist Missionary Society Corporation, Secretary.

Art. 2. The members of the Commission shall carry out their mandate in accordance with the terms of the above-mentioned Decree of the 18 th September, 1896 .

Art. 3. Our Secretary of State is intrusted with the execution of the present Decree.

Done at Brussels, March 23, 1901 .

By the King-Sovereign:

(Signed)

LEOPOLD.

In the name of the Secretary of State,

The Secretaries-General,

(Signed)

Chevalier de Cuvelier,

H. Droogmans,

LIEBRECHTS.

DISPATCH TO CERTAIN OF HIS MAJESTY'S REPRESENTATIVES ABROAD IN REGARD TO ALLEGED CASES OF ILL-TREATMENT OF NATIVES AND TO THE EXISTENCE OF TRADE MONOPOLIES IN THE INDEPENDENT STATE OF THE CONGO

The Marquess of Lansdowne to His Majesty's Representatives at Paris, Berlin, Rome, St. Petersburg, Vienna, Madrid, Constantinople, Brussels, Lisbon, the Hague, Copenhagen, and Stockholm.

SiR,

Foreign Office, August 8,1903 .

The attention of His Majesty's Government has during recent years been repeatedly called to alleged cases of ill-treatment of natives and to the existence of trade monopolies in the Independent State of the Congo. Representations to this effect are to be found in memorials from philanthropic socicties, in communications from commercial bodies, in the public press, and in dispatches from His Majesty's Consuls. 
The same matters formed the subject of a debate in the House of Commons on the 2oth ultimo, when the House passed the Resolution, a copy of which is inclosed.

In the course of the debate, the official record of which is also inclosed, it was alleged that the object of the Administration was not so much the care and government of the natives as the collection of revenue; that this object was pursued by means of a system of forced labour, differing only in name from slavery; that the demands upon each village were exacted with a strictness which constantly degenerated into great cruelty; and that the men composing the armed force of the State were in many cases recruited from the most warlike and savage tribes, who not infrequently terrorised over their own officers and maltreated the natives without regard to discipline or fear of punishment.

As regards the ill-treatment of natives, a distinction may be drawn between isolated acts of cruelty committed by individuals, whether in the service of the State or not, and a system of administration involving and accompanied by systematic cruelty or oppression.

The fact that many individual instances of cruelty have taken place in the Congo State is proved beyond possibility of contradiction by the occurrence of cases in which white officials have been convicted of outrages on natives. These white officials must, however, in view of the vast extent of the territory under their administration, in most cases be of necessity isolated the one from the other, with the result that detection becomes additionally difficult. It is therefore not unfair to assume that the number of convictions falls considerably short of the number of actual offences committed.

It is, however, with regard to the system of administration that the most serious allegations are brought against the Independent State.

It is reported that no efforts are made to fit the native by training for industrial pursuits; that the method of obtaining men for labour or for military service is often but little different from that formerly employed to obtain slaves; and that force is now as much required to take the native to the place of service as it used to be to convey the captured slave. It is also reported that constant compulsion has to be exercised in order to exact the collection of the amount of forest produce allotted to each village as the equivalent of the number of days' labour due from the inhabitants, and that this compulsion is of ten exercised by irresponsible native soldiers uncontrolled by any European officer.

His Majesty's Government do not know precisely to what extent these accusations may be true; but they have been so repeatedly made, and have received such wide credence, that it is no longer possible to ignore them, and the question has now arisen whether the Congo State can be considered to have fulfilled the special pledges, given 


\section{Appendix}

under the Berlin Act, to watch over the preservation of the native tribes, and to care for their moral and material advancement.

The graver charges against the State relate almost exclusively to the upper valleys of the Congo and of its affluents. The lands forming these vast territories are held either by the State itself or by Companies closely connected with the State, under a system which, whatever its object, has effectually kept out the independent trader, as opposed to the owner or to the occupier of the soil, and has consequently made it difficult to obtain independent testimony.

His Majesty's Government have further laboured under the disadvantage that British interests have not justified the maintenance of a large Consular staff in the Congo territories. It is true that in Igor His Majesty's Government decided to appoint a Consul of wide African experience to reside permanently in the State, but his time has been principally occupied in the investigation of complaints preferred by British subjects, and he has as yet been unable to travel into the interior and to acquire, by personal inspection, knowledge of the condition of the enormous territory forming his district.

His reports on the cases of British subjects, which have formed the basis of representations to the Government of the Independent State, afford, however, examples of grave maladministration and ill-treatment. These cases do not concern natives of the Congo State, and are therefore in themselves alien to the subject of this dispatch; but as they occurred in the immediate vicinity of Boma, the seat of the central staff, and in regard to British subjects, most of whom were under formal engagements, they undoubtedly lead to the belief that the natives, who have no one in the position of a Consul to whom they can appeal and have no formal engagements, receive even less consideration at the hands of the officers of the Government.

Moreover, information which has reached His Majesty's Government from British officers in territory adjacent to that of the State tends to show that, notwithstanding the obligations accepted under Article VI. of the Berlin Act, no attempt at any administration of the natives is made, and that the officers of the Government do not apparently concern themselves with such work, but devote all their energy to the collection of revenue. The natives are left entirely to themselves, so far as any assistance in their government or in their affairs is concerned. The Congo stations are shunned, the only natives seen being soldiers, prisoners, and men who are brought in to work. The neighbourhood of stations which are known to have been populous a few years ago is now uninhabited, and emigration on a large scale takes place to the territory of neighbouring States, the natives usually averring that they are driven away from their homes by the tyranny and exaction of the soldiers.

The sentiments which undoubtedly animated the founders of the 
Congo State and the representatives of the Powers at Berlin were such as to deserve the cordial sympathy of the British Government, who have been loath to believe either that the beneficent intentions with which the Congo State was constituted, and of which it gave so solemn a pledge at Berlin, have in any way been abandoned, or that cvery effort has not been made to realise them.

But the fact remains that there is a feeling of grave suspicion, widely prevalent among the people of this country, in regard to the condition of affairs in the Congo State, and there is a deep conviction that the many charges brought against the State's administration must be founded on a basis of truth.

In these circumstances, His Majesty's Government are of opinion that it is incumbent upon the Powers parties to the Berlin Act to confer together and to consider whether the obligations undertaken by the Congo State in regard to the natives have been fulfilled; and, if not, whether the Signatory Powers are not bound to make such representations as may secure the due observance of the provisions contained in the Act.

As indicated at the beginning of this dispatch, His Majesty's Government also wish to bring to the notice of the Powers the question which has arisen in regard to rights of trade in the basin of the Congo.

Article I. of the Berlin Act provides that the trade of all nations shall enjoy complete freedom in the basin of the Congo; and Article V. provides that no Power which exercises sovereign rights in the basin shall be allowed to"grant therein a monopoly or favour of any kind in matters of trade.

In the opinion of His Majesty's Government, the system of trade now existing in the Independent State of the Congo is not in harmony with these provisions.

With the exception of a relatively small area on the Lower Congo, and with the further exception of the small plots actually occupied by the huts and cultivation patches of the natives, the whole territory is claimed as the private property either of the State or of holders of land concessions. Within these regions the State or, as the case may be, the concession-holder alone may trade in the natural produce of the soil. The fruits gathered by the natives are accounted the property of the State, or of the concession-holder, and may not be acquired by others. In such circumstances, His Majesty's Government are unable to see that there exists the complete freedom of trade or absence of monopoly in trade which is required by the Berlin Act. On the contrary, no one other than the agents of the State or of the concession-holder has the opportunity to enter into trade relations with the natives; or, if he does succeed in reaching the natives, he finds that the only material which the natives can give in exchange for his trade goods or his money is claimed as having been the prop- 


\section{Appendix}

erty of the State or of the concession-holder from the moment it was gathered by the native.

His Majesty's Government in no way deny either that the State has the right to partition the State lands among bona-fide occupants, or that the natives will, as the land is so divided out among bona-fide occupiers, lose their right of roaming over it and collecting the natural fruits which it produces. But His Majesty's Government maintain that until unoccupied land is reduced into individual occupation, and so long as the produce can only be collected by the native, the native should be free to dispose of that produce as he pleases.

In these circumstances, His Majesty's Government consider that the time has come when the Powers parties to the Berlin Act should consider whether the system of trade now prevailing in the Independent State is in harmony with the provisions of the Act; and, in particular, whether the system of making grants of vast areas of territory is permissible under the Act if the effect of such grants is in practice to create a monopoly of trade by excluding all persons other than the concession-holder from trading with the natives in that area. Such a result is inevitable if the grants are made in favour of persons or Companies who cannot themselves use the land or collect its produce, but must depend for obtaining it upon the natives, who are allowed to deal only with the grantees.

His Majesty's Government will be glad to receive any suggestions which the Governments of the Signatory Powers may be disposed to make in reference to this important question, which might perhaps constitute, wholly or in part, the subject of a reference to the Tribunal at the Hague.

I request that you will read this dispatch to the Minister for Foreign Affairs, and leave a copy of it with his Excellency.

I am, etc.,

(Signed) LANsDowne.

\section{REPLY OF THE CONGO STATE GOVERNMENT TO THE BRITISH DISPATCH OF AUGUST 8TH, TO THE POWERS SIGNATORY TO THE BERLIN ACT}

Brussels, September 17, 1903.

The Government of the Independent State of the Congo have examined the dispatch from the Foreign Office, dated the 8th August last, which was communicated to the Signatory Powers of the Berlin Act, and declare themselves in agreement with His Majesty's Government on two fundamental points, viz., that natives ought to be treated with humanity and gradually led into the paths of civilisation, and that freedom of commerce in the Conventional Basin of the Congo ought to be entire and complete. 


\section{$578 \quad$ Story of the Congo Free State}

They deny, however, that the manner in which the State is administered involves a systematic régime "of cruelty or oppression," and that the principle of commercial freedom would introduce modifications in the rights of property as universally understood, seeing that there is not a word to this effect in the Berlin Act. The Congo State observes that there is in that Act no provision which would sanction restrictions of any kind on the exercise of the rights of property, or give to one Signatory Power the right of intervention in the interior administration of another. It desires faithfully to observe the Berlin Act, that great International Act which binds all Signatory or Adhering Powers, according to the clear grammatical sense of the text, which none has power either to take from or add to.

The English note observes that it is within the last few years that a definite shape has been assumed by the campaign conducted in England against the Congo State, on the two-fold pretext of the ill-treatment of natives and the existence of commercial monopolies.

It is indeed worthy of remark that this campaign dates from the time when the prosperity of the State became assured. The State had been founded for years, and administered in the same way as it is now; its principles in regard to the State-ownership of vacant lands, and the manner in which its armed forces were organised and recruited, were known to the public, without any interest in the matter being shown by the philanthropists and traders to whose opinion the note begins by referring. This was the period during which the State Budget could only be balanced by means of the King-Sovereign's subsidies and Belgian loans, and when the commerce of the Congo did not attract attention. The term "Congo atrocities" was at that time only used in connection with "the alleged ill-treatment of African natives by English and other adventurers in the Congo Free State." I After 1895 the trade of the Congo State developed remarkably, and the amount of its exports shows a progressive increase from ten millions in 1895 to fifty millions in 1902 . It is also about this time that the antiCongo movement took shape. As the State gave increased proof of vitality and progress, the campaign became more active, reliance being placed on a few individual and isolated cases with a view to using the interests of humanity as a pretext and concealing the real object of a covetousness which, in its impatience, has betrayed itself in the writings of pamphleteers and in the speeches of members of the House of Commons, in which the abolition and partition of the Congo State has been clearly put forward.

Such being the object in view, it became necessary to bring a whole series of charges against the State. So far as the humanitarian side of the question is concerned, the alleged cases of violence offered to natives have once more been brought forward and re-edited ad infini-

${ }^{1}$ Transactions of the Aborigines Protection Society, I890-1896, p. 155. 


\section{Appendix}

tum. For in all the meetings, writings, and speeches which have latterly been directed against the State, it is always the same facts which are brought up, and the same evidence which is produced. With regard to the economic side of the question, the State has been accused of having violated the Act of Berlin, notwithstanding the legal opinions of such lawyers as are most qualified to speak to the point, which afford ample legal justification both for its commercial and for its land system. With regard to the political side, a heresy in international law has been imagined, viz., that a State, the independence and sovereignty of which are absolute, should, at the same time, owe its position to the intervention of Foreign Powers.

With regard to the cases of ill-treatment of natives, we attach special importance to those which, according to the note, have been reported in the dispatches of His Majesty's Consular Agents. At the sitting of the House of Commons on the I Ith March, I903, Lord Cranborne referred to these official documents, and we have requested through his Excellency Sir C. Phipps that the British Government will make known to us the facts alluded to. We repeat the request.

The Government of the State have, however, never denied that crimes and offences are committed in the Congo, as in every other country or colony. The note itself recognises that these offences have been brought before the Tribunals; and that the criminals have been punished. The conclusion to be drawn from this is that the State fulfils its mission; the conclusion actually drawn is that "many individual instances of cruelty have taken place in the Congo State," and that "the number of convictions falls considerably short of the number of offences actually committed." This deduction does not appear necessarily to follow. It would seem more logical to say that the severe sentences inflicted will serve as a wholesome example, and that a decrease of crime may on that account be looked for. If some offences have indeed, in the extensive territories of the State, escaped the vigilance of the judicial authorities, this is a circumstance which is not peculiar to the Congo State.

The English note proceeds chiefly on hypotheses and suppositions: "It was alleged . . . It is reported . . . It is also reported . . ." and it even says that "His Majesty's Government do not know precisely to what extent these accusations may be true." This is an acknowledgment that, in the eyes of the British Government themselves, the accusations in question are neither established nor proved. And, incleed, the violence, the passion, and the improbability of many of these accusations must raise doubt in an impartial mind as to their genuineness. To give but one example:- a great deal has been made of the statement that, in a train coming down from Leopoldville to Matadi, three carriages were full of slaves, a dozen of whom were in chains and guarded by soldiers. The Governor-General was asked 
for a report on the case. He replied: "The individuals represented as composing a convoy of slaves were, the great majority of them (125), levies proceeding from the district of Lualaba-Kassai, Lake Leopold II., and the Bangalas to the camp in the Lower Congo. Annexed you will find lists of these persons. As regards the men in chains, they were certain individuals on whom sentence had been passed by the territorial Tribunal at Basoko, and who were on their way to undergo their sentence at the central prison at Boma. They are Nos. $3^{642}$ to 3649 on the prison register at Boma."

In the same way, quite a recent "interview," in which the usual accusations of cruelty were reproduced, is due to a person formerly in the employ of the State, who was "declared unfit for service," and who has failed to persuade the State to accept his proposal to write for the press articles favourable to the Administration.

The note ignores the replies, contradictions, and corrections which the attacks on the agents of the State have occasioned at the various times when they have taken place. It ignores the official declarations publicly made by the Government of the State in June last, after the debate in the House of Commons on the 2oth May, the report of which is annexed to the note. We also annex the text of these declarations which dealt, by anticipation, with the considerations set forth in the dispatch of the 8th August.

The only fresh cause of complaint which the note brings forwarddoubtless with the object of explaining the not unimportant fact that the English Consul, who has resided in the Congo since r9or, does not appear to support, by his personal authority, the accusations of private individuals-is that this agent has been "principally occupied in the investigation of complaints preferred by British subjects." The impression which one would derive from this is that such complaints have been exceptionally numerous. No doubt the Consul has, on different occasions, communicated with the Administration at Boma in the interests of his countrymen, but the subjects of his representations, if one may judge by such of their number as the English Legation has had to bring to the notice of the Central Government at Brussels, do not appear, either in number or importance, to have been more than matters of everyday administrative routine: some cases in particular concerned the regulation of the succession to property in the Congo left by deceased English subjects; the object in others was to repair errors of judicial procedure, such as occur elsewhere, and it is not even alleged that the proper action has not been taken upon these representations. The same Consul, who was appointed in 1898 , wrote to the Governor-General on the 2 nd July, r901, as follows:

"I pray believe me when I express now, not only for myself, but for my fellow-countrymen in this part of Africa, our very sincere ap- 


\section{Appendix}

preciation of your efforts on behalf of the general community-efforts to promote goodwill among all and to bring together the various elements of our local life."

Nor do the predecessors of Mr. R. Casement-for English Consuls with jurisdiction in the Congo were appointed by His Majesty's Government as long ago as 1888-appear to have been absorbed in the examination of innumerable complaints; at all events, that is not the view taken in the Report (the only one published) by Consul Pickersgill, who, by the mere fact of giving an account of his journey into the interior of the Congo as far as Stanley Falls, disproves the alleged impossibility for the English consular agents to form an opinion de visy in regard to every part of their district.

With regard to the charges against the administrative system of the State, the note deals with taxes, public armed forces, and what is termed forced labour.

It is, at bottom, the contributions made by the Congo natives to the public charges which are criticised, as if there existed a single country or colony in which the inhabitants do not, under one form or another, bear a part in such charges. A State without resources is inconceivable. On what legitimate grounds could the exemption of natives from all taxes be based, seeing that they are the first to benefit by the material and moral advantages introduced into Africa? As they have no money, a contribution in the shape of labour is required from them. It has been said that, if Africa is ever to be redeemed from barbarism, it must be by getting the Negro to understand the meaning of work by the obligation of paying taxes.

"It is a question [of native labour] which has engaged my most careful attention in connection with West Africa and other Colonies. To listen to the right honourable gentlemen, you would almost think that it would be a good thing for the native to be idle. I think it is a good thing for him to be industrious; and by every means in our power we must teach him to work. . . . No people ever have lived in the world's history who would not work. In the interests of the natives all over Africa, we have to teach them to work."

Such was the language used by Mr. Chamberlain in the House of Commons on the 6th August, I90I; and still more recently he expressed himself as follows:

"We are all of us taxed, and taxed heavily. Is that a system of forced labour? . . . To say that because we put a tax on the native therefore he is reduced to a condition of servitude and of forced labour is, to my mind, absolutely ridiculous. . . . It is perfectly fair to my mind that the native should contribute something towards the cost of administering the country." -(House of Commons, 9th March, 1903.) 
"If that really is the last word of civilisation, if we are to proceed on the assumption that the nearer the native or any human being comes to a pig the more desirable is his condition, of course I have nothing to say. . . . I must continue to believe that, at all cvents, the progress of the native in civilisation will not be secured until he has been convinced of the necessity and the dignity of labour. Therefore, I think that anything we reasonably can do to induce the native to labour is a desirable thing."

And he defended the principle of taxing the native on the ground that "the existence of the tax is an inducement to him to work." (House of Commons, 24th March, I903.)

Moreover, it is to be observed that in nearly every part of Africa the natives are taxed. In the Transvaal every native pays a "head tax" of $£^{2}$; in the Orange River Colony he is subject to a "poll tax"; in Southern Rhodesia, Bechuanaland, Basutoland, Uganda, and Natal a "hut-tax" is levied; in Cape Colony we find a "hut-tax" and a "labour tax"; in German East Africa also a tax is levied on huts, payable either in money, in kind, or in labour. This species of tax has also been applied in the Sierra Leone Protectorate, where payment could be made "in kind by rice or palm nuts," and it has been suggested that work on roads and useful works should be accepted in lieu of payment in money or produce.

The legality of a tax is, therefore, not affected by the mode of its payment, whether in money or in kind, so long as the amount is not excessive. It is certainly not so in the Congo, where the work done by the native does not represent more than forty hours' work a month. Such work, moreover, is paid for, and the tax in kind thus gives the native as it were some return for his labour.

Payment of taxes is obligatory everywhere; and non-payment involves measures of compulsion. The regulations under which the hut-tax is levied impose on the native, for non-payment, such penalties as imprisonment and forced labour. Nor in the Congo is payment of taxes optional. Repressive measures have occasionally been rendered necessary elsewhere by the refusal of natives to conform to the law, e. g., the disturbances at Sierra Leone, in connection with which an English publicist, speaking of the police force, states:

"Between July, I 894 , and February, 1 896, no fewer than sixty-two convictions, admittedly representing a small proportion of offences actually committed, were recorded against them for flogging, plundering, and generally maltreating the natives."

Further instances might be recalled of the opposition encountered among native populations to the institution of governmental regulations. Civilisation necessarily comes into collision with their savage instincts and barbarous customs and habits; and it can be understood that they submit but impatiently to, and even try to escape from, a 


\section{Appendix}

state of society which seems to them to be restrictive of their licence and excesses. It frequently happens in Africa that an exodus of natives takes place from one territory to another, in the hope of finding beyond the frontier a government less well established or less strong, and of thus freeing themselves from all obligations and restraints. Natives of the State may quite well, under the influence of considerations of this kind, have crossed into neighbouring territories, although no kind of emigration on a large scale, such as is referred to in the English note, has ever been reported by the commandants of the frontier provinces. On the contrary, it is a fact that natives in the Upper Nile region who had settled in British territory have returned to the left bank in consequence of the imposition of new taxes by the English authorities. Besides, if it is these territories which are alluded to, the information contained in the note would seem to be in contradiction with other particulars furnished, for instance, by Sir Harry Johnston.

"This much I can speak of with certainty and emphasis, that from the British frontier near Fort George to the limit of my journeys into the Mbuba country of the Congo Free State, up and down the Semliki, the natives appear to be prosperous and happy. . . . The extent to which they were building their villages and cultivating their plantations within the precincts of Fort Mbeni showed that they had no fear of the Belgians."

Major H. H. Gibbons, who was for several months on the Upper Nile, writes:

"Having had occasion to know many officers, and to visit their stations in the Congo State, I am convinced that their behaviour has been much misunderstood by the press. I have quoted as a proof my experience, which is at variance with an article recently published in the English press, in which they are accused of great cruelties."

The declaration of last June, of which a copy is enclosed, has disposed of the criticisms directed against the public forces of the Statc, by pointing out that recruitment for them is regulated by law, and that it is only one man in every ro,ooo who is affected. To say that "the method of obtaining men for military service is often but little different from that formerly employed to obtain slaves" is to misunderstand the carefully drawn regulations which have, on the contrary, been issued to check abuses. Levies take place in each district; the District Commissioners settle the mode of conscription in agreement with the native chiefs. Voluntary enlistment, and numerous re-enlistments, easily fill up the ranks, which only reach, all told, the moderate total of $\mathrm{r} 5,000$ men.

Those who allege, as the note says, that "the men composing the armed force of the State were in many cases recruited from the most warlike and savage tribes" must be unaware that the public forces 


\section{$584 \quad$ Story of the Congo Free State}

are recruited from every province, and from the whole population. It is inconceivable that the authorities of a State, with due regard to its interests, should form an army out of undisciplined and savage elements, and instances are to be found-such as the excesses said to have been perpetrated by irregular levies in Uganda, and the revolts which formerly occurred in the Congo-which, on the contrary, render it necessary that special care should be exercised in raising armed forces. The European establishment, consisting of Belgian, Italian, Swedish, Norwegian, and Danish officers, maintains strict discipline, and it would be vain to seek the actual facts alluded to in the assertion that the soldiers "not infrequently terrorised over their own officers." Such an assertion is as unfounded as the one "that compulsion is often exercised by irresponsible native soldiers uncontrolled by any European officer." For a long time past the authorities have been alive to the danger arising from the existence of stations of Negro soldiers, who inevitably abuse their authority, as recognised in the Report of Sir D. Chalmers on the insurrection in Sierra Leone. In the Congo such stations have been gradually abolished.

Those who do not refuse to accept patent facts will recognise that, of the reproaches levelled at the State, the most unjust is the statement "that no attempt at any administration for the natives is made, and that the officers of the Government do not apparently concern themselves with such work." "

It is astonishing to come across such an assertion in a dispatch from a government, one of whose members, Lord Cranborne, UnderSecretary of State for Foreign Affairs, stated on the 2oth May last:

"There was no doubt that the administration of the Congo Government had been marked by a very high degree of a certain kind of administrative development. There were railways, there were steamers upon the river, hospitals had been established, and all the machinery of elaborate judicial and police systems had been set up."

Another member of the House of Commons acknowledged:

"That the Congo State had done good work in excluding alcoholic liquor from the greater part of their domain; that they had established a certain number of hospitals, had diminished smallpox by means of vaccination, and had suppressed the Arab Slave Trade."

However limited these admissions, still they contradict the assertion now made that "the natives are left entirely to themselves, so far as any assistance in their government or in their affairs is concerned."

Such does not seem to have been the conclusion at which Mr. Pickersgill, the English Consul, had arrived as long ago as 1898 .

"Has the welfare of the African," he asks, "been duly cared for in the Congo State?" He answers: "The State has restricted the liquor trade. . . . It is scarcely possible to overestimate the 


\section{Appendix}

service which is being rendered by the Congo Government to its subjects in this matter. . . . Intertribal wars have been suppressed over a wide area, and the imposition of European authority being steadily pursued, the boundaries of peace are constantly extending.

The State must be congratulated upon the sccurity it has created for all who live within the shelter of its flag and abide by its laws and regulations. . . . Credit is also due to the Congo Government in respect of the diminution of cannibalism. . . . The yoke of the notorious Arab slave-traders has been broken, and traffic in human beings amongst the natives themselves has been diminished to a considerable degree."

This Report also showed that the labour of the native was remunerated, and gave due credit to the State for its efforts to instruct the young natives, and to open schools.

Since 1898 the general condition of the native has been still further improved. The system of carriers (le portage d dos d'homme), the hardships of which, so far as the native was concerned, were specially pointed out by Mr. Pickersgill, has disappeared from those parts of the country where it was most practised, in consequence of the opening of railways. Elsewhere motor cars are used as means of transport. The "sentry," the station of Negro soldiers which the Consul criticised, not without reason, no longer exists. Cattle have been introduced into every district. Sanitary commissions have been instituted. Schools and workshops have multiplied.

"The native," says the enclosed document, ${ }^{x}$ "is better housed, better clad, and better fed; he is replacing his huts by better built and healthier dwelling-places; thanks to existing transport facilities, he is able to obtain the produce necessary to satisfy his new wants; workshops have been opened for him, where he learns handicrafts, such as those of the blacksmith, carpenter, mechanic, and mason; he extends his plantations and, taking example by the white man, learns rational modes of agriculture; he is always able to obtain medical assistance; he sends his children to the State school-colonies and to the missionary schools."

As stated in the House of Commons, it is only right to recognise that the material and moral regeneration of Central Africa cannot be the work of a day. The results so far obtained have been considerable, and these we shall try to consolidate and develop, in spite of the way in which an effort is being made to hamper the action of the State, which in the real interests of civilisation should rather be promoted.

The English note does not show that the economic system of the State is in opposition to the Berlin Act. It does not meet the points of law and fact by means of which the State has demonstrated the conformity of its system of land tenure and concessions with the pro-

'See Annex No. I. 
visions of that Act. It does not explain either how or why freedom of trade-a term used at the Conference of Berlin in its usual, grammatical, and economic sense-is incomplete in the Congo State because there are landowners there.

The note confuses the utilisation of his property by the owner with trade. The native who collects on behalf of the owner does not become the owner of what is so collected, and naturally cannot dispose of it to a third party, any more than a miner can rob the proprietor of the produce of the mine and dispose of it himself. These rules are in accordance with the principles of justice and are explained in numerous documents, such as legal opinions and judicial decisions, some of which are annexed. His Majesty's Government do not deny that the State is justified in allotting domain lands to bona-fide occupants, or that the native has no longer any right to the produce of the soil as soon as the "land is reduced into individual occupation." The distinction is without legal foundation. If the State can part with land, it is because the native is not the owner; by what title could he then retain a right to the produce of property which has been lawfully acquired by others? Could it be contended, for instance, that the Lower Congo Railway Company, or the South Cameroons Company, or the Italian Colonial Trading Company are, on the ground that they are not at present in occupation, bound to allow the native to plunder the territories allotted to them? As a matter of fact, moreover, in the Congo State the appropriation of lands worked on Government account or by the Concessionary companies is an accomplished fact. The State and the companies have devoted large sums, amounting to many millions of francs, to the development of the lands in question, and more especially to that of the forests. There can, therefore, be no doubt that throughout the territories of the Congo the State really and completely works its property, just as the companies really and completely work their concessions.

The state of affairs then which actually exists, and is established in the Independent State, is such that there is really no need, as far as the State itself is concerned, to dwell longer on the theory set forth in the note which deals in turn with the rights of the State, with those of bona-fide occupiers, and those of the natives.

Still this theory calls for the attention of the Powers in view of the serious difficulties which would arise were it to be implicitly accepted.

The note lays down the three following propositions:

"The State has the right to partition the State lands among bonafide occupants."

"The natives will, as the land is so divided out amongst bona-fide occupiers, lose their right of roaming over it and collecting the natural fruits which it produces."

"Until unoccupied land is reduced into individual occupation, and 


\section{Appendix}

so long as the produce can only be collected by the native, the native should be free to dispose of that produce as he pleases."

There is no single one of these propositions but apparently excludes the other two, and, as a matter of fact, such contradictions amount to a denial of the right to grant concessions.

If bona-fide occupiers ever existed they have become proprietors; occupation, where it can be exercised is, under all legislative codes, one of the methods by which property can be acquired, and in the Congo State titles of ownership deriving from it have been legally registered. If the land has never been legally occupied, it is without an owner, or, rather the State is the owner; the State can allot it to a third party, for whom such allotment is a complete and absolute title. In either case it is hard to see how the fruits of the soil can be reserved for any but the owner on the pretext that the latter is not able to collect the produce of his property.

By a curious contradiction it is observed in the note that, as a consequence of the allotment of lands by the State, the natives "lose their right of collecting the natural fruits," and, on the other hand, that they retain the right of disposing of these fruits "until unoccupied land is reduced into [sic] individual occupation." It is difficult to understand what is meant by a right which belongs to the natives or not according to the action of a third party. Either they lost their rights on the lands being allotted, and in that case they have lost them entirely and completely, or else they have retained them, and are entitled to retain them, although the "land is reduced into [sic] individual occupation."

Again, what are we to understand by the expressions "bona-fude" occupiers and "individual occupation?" Who is to determine whether the occupier has brought his lands into a state of individual occupation, whether he is able to collect their produce, or whether it is still for the native to do so? In any case, such a question is essentially one to be settled by municipal law.

The note is, moreover, incomplete in another respect. It states that where the land has not yet been worked by those who have a right to it, the option of working should belong to the native. Rights would thus be given to the natives to the prejudice of the Government or of white concessionaires, but the note does not explain how nor by whom the wrong thus caused would be repaired or made good. Though the system thus advocated cannot be applied in the Congo State, as there are no longer any unappropriated lands there, attention should be called to the statement in the interest of white men established in the Conventional Basin. If it is right to treat the Negro well, it is none the less just not to despoil the white man, who, in the interest of all, must remain the dominant race.

From an economic point of viow, it would be very regrettable if, in 
spite of the rights regularly acquired by white men, the domain lands were, even temporarily, handed over to the natives. Such a course would involve a return to their former condition of abandonment, when the natives left them unproductive; for the collection of rubber, the plantation of coffee, cocoa, tobacco, etc., date from the day when the State itself took the initiative: the export trade was insignificant before the impetus it received from Government enterprise. Such a course would furthermore certainly involve the neglect of rational methods of work, of planting and of replanting-measures which the State and the Concessionary companies have assumed as an obligation with a view to securing the preservation of the natural riches of the country.

Never in the Congo, so far as we know, have requests to buy natural produce been addressed to the rightful owners. Up to now the only attempts made have been to buy the produce which has been stolen, and the State, as was its duty, has had those guilty of these unlawful attempts prosecuted.

It is not true, as has been asserted, that the policy of the State has killed trade; it has, on the contrary, created the materials which trade deals in and keeps up the supply; it is thanks to the State that, on the Antwerp market-and soon even in the Congo where the possibility of establishing trade depots is being considered-5000 tons of rubber collected in the Congo can be annually put on sale to all and sundry without privilege or monopoly, while formerly, in 1887 , for instance, the rubber export amounted to hardly 30 tons. It is the State which, after having created, at its own expense, the material of trade, carefully preserves the source of it by means of planting and replanting.

It must not be forgotten either that the Congo State has been obliged to rely on its own resources. It was forced to utilise its domain in the public interest. All the receipts of the domain go into the Treasury, as also the dividends of the shares which the State holds in exchange for concessions granted. It has only been by utilising its domain lands, and pledging the greater part of their revenues, that it has been able to raise loans, and encourage the construction of railways by guarantees of interest, thus realising one of the means most advocated by the Brussels Conference for promoting civilisation in Central Africa. Nor has it hesitated to mortgage its domain lands with this object.

The Berlin Act is not opposed to such a course, for it never prescribed the rights of property as there is now an ex post facto attempt to make out, an attempt tending, consciously or not, to the ruin of the whole Conventional Basin of the Congo.

It will not escape the notice of the Powers that the English note, by suggesting a reference to the Court at the Hague, tends to bring 


\section{Appendix}

into consideration as cases for arbitration questions of sovereignty and internal administration as questions for arbitration which, according to prevailing doctrines, are excluded from arbitral decisions. As far as the present case is concerned, it must be assumed that the suggestion of referring the matter to the Court at the Hague has a general meaning, if it is true that, in the opinion of the English Chambers of Commerce, "the principles and practice introduced into the administration of the affairs of the French Congo, the Congo Free State, and other areas in the Conventional Basin of the Congo being [sic] in direct opposition to the Articles of the Act of Berlin, 1885." The Government of the Congo State have never ceased advocating arbitration as a mode of settling questions which are of an international nature, and can thus be suitably treated, as, for instance, the divergencies of opirion which have arisen in connection with the lease of the territories of the Bahr-el-Ghazal.

The Government of the Congo State, after careful examination of the English note, remain convinced that, in view of its vagueness, and the complete lack of evidence, which is implicitly admitted, there is no tribunal in the world, supposing there were one possessing competent jurisdiction, which could, far from pronouncing a condemnation, take any decision other than to refuse action on mere supposition.

If the Congo State is attacked, England may admit that she, more than any other nation, has been the object of attacks and accusations of every kind, and the list would be long of the campaigns which have at various times, and even quite recently, been directed against her colonial administration. She has certainly not escaped criticism in regard to her numerous and bloody wars against native populations, nor the reproach of oppressing natives and invading their liberty. Has she not been blamed in regard to the long insurrections in Sierra Leone; to the disturbed state of Nigeria, where quite recently, according to the English newspapers, military measures of repression cost, on one single occasion, the lives of 700 natives, of most of their Chiefs, and of the Sultan; and to the conflict in Somaliland, which is being carried on at the cost of many lives, without, however, exciting expressions of regret in the House of Commons, except on the score of the heavy expense?

Seeing that these attacks have left England indifferent, it is some what surprising to find her now attaching such importance to those made on the Congo State.

There is, however, reason to think that the natives of the Congo State prefer the Government of a small and pacific nation, whose aims remain as peaceful as its creation, which was founded on treaties concluded with the natives.

(Signed) Chr. de Cuvelier. 


\section{AnneXes I}

I. Bulletin Officiel de l'État Indépendant du Congo, Juin, 1903.

II. Judgments delivered by the Tribunals of French Congo.

III. Opinions of Messrs. van Maldeghem and de Paepe, Van Berchem, Barboux, and Nys.

\section{OFFICIAL CORRESPONDENCE BETWEEN THE CONGO FREE STATE AND GREAT BRITAIN}

\section{The Congo Rejoinder to Charges Contained in the Report of Consul Casement}

The Appendices on pages $59 \mathrm{r}$ to $6 \mathrm{Ir}$ are taken from the official correspondence ${ }^{2}$ sent by Sir Constantine Phipps, his Britannic Majesty's Minister at Brussels, to the Marquess of Lansdowne, His Britannic Majesty's Foreign Secretary, enclosing the reply of the Government of the Congo Free State to the Report of Mr. Roger Casement, British Consul at Boma. Having regard to the voluminous nature of Consul Casement's report, and the fact that the Congo State's Note (reply) cites its principal charges against that Government, it is not printed herewith, to expand a volume already extended beyond practical dimensions.

No. I

Sir C. Phipps to the Marquess of Lansdowne.-(Received March 17)

MY LORD,

Brussels, March I 3,1904 .

I have the honour to enclose the rejoinder on the part of the Congo Government to the Report of His Majesty's Consul at Boma on the condition of the Congo.

In handing these "Notes" to me this afternoon M. de Cuvelier was instructed to call my attention to the passage where his Government expresses a desire to be placed in possession of the full Report, including names, dates, and places referred to. The "Notes" will be communicated to-morrow to the Representatives of the other Powers.

I have, etc.,

(Signed) Constantine Phipps.

${ }^{1}$ Copies have been sent to the Library of each House of Parliament.

${ }^{2}$ Soe Africa, No. 7, 1904, presented to both Houses of Parliament, June, 1904 . 


\section{Appendix}

ENCLOSURE IN No. I

NOTES BY THE GOVERNMENT OF THE CONGO FREE STATE ON THE REPORT OF MR. CASEMENT, CONSUL OF HIS BRITANNIC MAJESTY, OF THE IITH DECEMBER, I903.

\section{(Translation)}

During the sitting of the House of Commons of the I Ith March, I903, Lord Cranborne observed:

"We have no reason to think that slavery is recognised by the authorities of the Congo Free State, but reports of acts of cruelty and oppression have reached us. Such reports have been received from our Consular Officers."

The Government of the Congo State addressed a letter on the $14^{\text {th }}$ March, I903, to Sir C. Phipps, requesting him to be good enough to communicate the facts which had formed the subject of any reports from British Consuls.

No reply was received to this application.

Lord Lansdowne's dispatch of the 8th August, 1903, contained the following passage:

"Representations to this effect [alleged cases of ill-treatment of natives and existence of trade monopolies] are to be found . . . in dispatches from His Majesty's Consuls."

The impression was thus created that at that date His Majesty's Government were in possession of conclusive evidence furnished by their Consuls; but none the less it seemed clearly necessary that Consul Casement should undertake a journey in the Upper Congo. It would appear, therefore, as if the conclusions contained in the note of the 8th August were at least premature; it equally follows that, contrary to what was said in that note, the British Consul was at liberty to undertake any journey in the interior that he thought fit. In any case it is to be observed that, in spite of the repeated applications of the Congo State, the White Paper [Africa, No. I (1904)] recently presented to Parliament does not contain any of these former Consular Reports, which nevertheless would have been the more interesting as dating from a time when the present campaign had not yet been initiated.

The present Report draws attention to the fact that in certain places visited by the Consul the population is decreasing. Mr. Casement does not give the facts on which he bases his comparative figures for 1887 and 1903 . The question arises how, during the course of his rapid and hasty visits, he was able to get his figures for this latter year. On what facts, for instance, does he found his assertion that the riverain 
population of Lake Mantumba seems to have diminished from 60 to 70 per cent. in the course of the last ten years? He states that at a certain place designated as $\mathrm{F}$ - the population of all the villages together does not at present amount to more than 500 souls; a few lines farther on these same villages are spoken of as only containing 240 inhabitants altogether. These are only details, but they show at once what a lack of precision there is in certain of the deductions made by the Consul. It is, no doubt, unfortunately only too true that the population has diminished; but the diminution is due to other causes than to the exercise on the native population of a too exacting or oppressive Administration. It is owing chiefly to the sleeping-sickness, which is decimating the population throughout Equatorial Africa. The Report itself observes that "a prominent place must be assigned to this malady," I and that this malady is "probably one of the principal factors" in the diminution of the population. ${ }^{2}$ It is only necessary to read the Rev. John Whitehead's letter, quoted by the Consul (Annex II. to the Report), to obtain an idea of the ravages of the malady, to which this missionary attributes half of the deaths which take place in the riverain parts of the district. In a recent interview Mgr. Van Ronsle, Vicar Apostolic of the Belgian Congo, who speaks with the authority of one who has had a large experience of African matters, and has resided for long periods in many different localities in the Congo, explained the development of this scourge and the inevitable decay of the population it attacks, whatever the conditions of their social existence; mentioning among other cases the terrible loss of life caused by this disease in Uganda. If to this principal cause of the depopulation of the Congo are added smallpox epidemics, the inability of the tribes at the present moment to keep up their numbers by the purchase of slaves, and the ease with which the natives can migrate, it can be explained how the Consul and the missionaries may have been struck with the diminution of the number of inhabitants in certain centres without that diminution necessarily being the result of a system of oppression. Annex I. contains the declarations on the subject made by Mgr. Van Ronslé. His remarks as to the effect of the suppression of slavery on the numbers of the population are printed elsewhere:

"The people [slave] are for the most part originally" prisoners of war. Since the Decree of emancipation they have simply returned to their own distant homes, knowing their owners have no power to recapture them. This is one reason why some think the population is decreasing, and another reason is the vast exodus up and down river." 3

"So long as the Slave Trade flourished the Bobangi flourished, but

1 Report, p. 2 I.

2 Idem, p. 26.

3 M. Boudot, missionary of the Congo Balolo Mission. Regions Beyond, December, 1901, p. 337 . 


\section{Appendix}

with its abolition they are tending to disappear, for their towns were replenished by slaves." I

The Consul mentions cases, the causes of which, however, are unknown to him, of an exodus of natives of the Congo to the French bank. It is not quite clear on what grounds he attaches blame to the State on their account, to judge at least from the motives by which some of them have been determined-for instance, the examples of such emigration which are given and explained by the Rev. W. H. Bentley, an English missionary. One relates to the station at Lukolela:

"The main difficulty has been the shifting of the population. It appears that the population, when the station was founded in 1886 , was between 5,000 and 6,000 in the riverain colonies. About two years later the Chief Mpuki did not agree with his neighbours or they with him. When the tension became acute, Mpuki crossed over with his people to the opposite [French] side of the river. This exodus took away a large number of people. In 1890 or 1891 a chief from one of the lower towns was compelled by the majority of his people to leave the State side, and several went with him. About 1893 the rest of the people at the lower towns either went across to the same place as the deposed chief or took up their residence inland. Towards the end of 1894 a soldier, who had been sent to cut firewood for the State steamers on an island off the towns, left his work to make an evil request in one of the towns. He shot the man who refused him. The rascal of a soldier was properly dealt with by the State officer in charge; but this outrage combined with other smaller difficulties to produce a panic, and nearly all the people left for the French side, or hid away inland. So the fine township has broken up." 2

The other refers to the station at Bolobo:

"It is rare indeed for Bolobo, with its 30,000 or 40,000 people, divided into some dozen clans, to be at peace for any length of time together. The loss of life from these petty wars, the number of those killed for witchcraft, and of those who are buried alive with the dead, involve, even within our narrow limits here at Bolobo, an almost daily drain upon the vitality of the country, and an incalculable amount of sorrow and suffering. . . . The Government was not indifferent to these murderous ways. . . . In 1890 , the District Commissioner called the people together, and warned them against the burying of slaves alive in the graves of free people, and the reckless killing of slaves which then obtained. The natives did not like the rising power of the State. . . . Our own settlement among them was not unattended with difficulty. . . There was a fceling against white men generally, and especially so against the State. The people

' W. H. Bentley, Pioneering on the Congo, ii., p. 229.

2 Idem, p. 243. 
became insolent and haughty. . . . Just at this time . . . as a force of soldiers steamed past the Moye towns, the steamers werc fired upon. The soldiers landed and burnt and looted the towns. The natives ran away into the grass, and great numbers crossed to the French side of the river. They awoke to the fact that Bula Matadi, the State, was not the helpless thing they had so long thought. This happened early in $1891 . " 1$

It will be seen that these examples do not attribute the emigration of the natives to any such causes as

"The methods employed to obtain labour from them by local officials and the exactions levied on them." 2

The Report dwells at length on the existence of native taxes. It shows how the natives are subject to forced labour of various kinds, in one district having to furnish the Government posts with "chikwangues," or fresh provisions, in another being obliged to assist in works of public utility, such as the construction of a jetty at Balolo, or the upkeep of the telegraph line at F-_; elsewhere being obliged to collect the produce of the domain lands. We maintain that such imposts on the natives are legitimate, in agreement on this point with His Majesty's Government, who, in the Memorandum of the i 1 th February last, declare that the industry and development of the British Colonies and Protectorates in Africa show that His Majesty's Government have always admitted the necessity of making the natives contribute to the public charges and of inducing them to work. We also agree with His Majesty's Government that, if abuses occur in this connection-and undoubtedly some have occurred in all colonies -such abuses call for reform, and that it is the duty of the authorities to put an end to them, and to reconcile as far as may be the requirements of the Government with the real interests of the natives.

But in this matter the Congo State intends to exercise freely its rights of sovereignty-as, for instance, His Majesty's Government explain in their last Memorandum that they themselves did at Sierra Leone-without regard to external pressure or foreign interference, which would be an encroachment upon its essential rights.

The Consul, in his Report, obviously endeavours to create the impression that taxes in the Congo are collected in a violent, inhuman, and cruel manner, and we are anxious before all to rebut the accusation, which has so often been brought against the State, that such collection gives rise to odious acts of mutilation. On this point a superficial perusal of the Report is calculated to impress by its easy accumulation not of facts, simple, precise, and verified, but of the declarations and affirmations of natives.

I Pioneering on the Congo, by the Rev. W. Holman Bentley, ii. pp. $235^{-2} 36$.

2 Report, p. 29. 


\section{Appendix}

There is a preliminary remark to be made in regard to the conditions in which the Consul made his journey.

Whether such was his intention or not, the British Consul appeared to the inhabitants as the redresser of the wrongs, real or imaginary, of the natives, and his presence at La Lulonga, coinciding with the campaign which was being directed against the Congo State, in a region where the influence of the Protestant missionaries has long been exercised, necessarily had for the natives a significance which did not escape them. The Consul made his investigations quite independently of the Government officials, quite independently of any action and of any co-operation on the part of the regular authorities; he was assisted in his proceedings by English Protestant missionaries; he made his inspection on a steamer belonging to a Protestant Mission; he was entertained for the most part in the Protestant Missions; and, in these circumstances, it was inevitable that he should be considered by the native as the antagonist of the established authorities.

Other proof is not required than the characteristic fact that while the Consul was at Bonginda, the natives crowded down to the bank, as some agents of the La Lulonga Company were going by in a canoe, and cried out: "Your violence is over, it is passing away; only the English remain; may you others die!" There is also this significant admission on the part of a Protestant missionary, who, in alluding to this incident, remarked:

"The Consul was here at the time, and the people were much excited and evidently thought themselves on top. . . . The people have got this idea [that the rubber work was finished] into their heads of themselves, consequent, I suppose, upon the Consul's visit."

In these circumstances, in view of the state of mind which they show to exist among the natives, in view of their impressionable character and of their natural desire to escape taxation, it could not be doubted that the conclusions at which the Consul would arrive would not be other than those set forth in his Report.

To bring out this point, and to show how little value is to be attached to his investigations, it will be sufficient to examine one case, that on which Mr. Casement principally relies; we allude to the Epondo case. It is that of the child II., mentioned on pp. 56,58 , and 78 of the Report.

It is indispensable to enter somewhat at length into the details of this case, which are significant.

On the $4^{\text {th }}$ September, 1903 , the Consul was at the Bonginda station of the Congo Balolo Mission, having returned from a journey on the Lopori, during the course of which he had not come across any of those acts of mutilation which it is the custom to attribute to officials in the Congo.

At Bonginda, the natives of a neighbouring village (Bossunguma) 
came to him and informed him, amongst other things, that a "sentry" of the La Lulonga Company, named Kalengo, ' had, at Bossunguma, cut off the hand of a native called Epondo, whose wounds were still scarcely healed. The Consul proceeded to Bossunguma, accompanied by the Rev. W. D. Armstrong and the Rev. D. J. Danielson, and had the mutilated native brought before him, who, "in answer to the Consul's question, charged a sentry named 'Kalengo' (placed in the town by the local agent of the La Lulonga Society to see that the people work rubber)" with having done it. Such are the Consul's own words: it was necessary to establish a relation of cause and effect between the collection of india-rubber and this alleged case of cruelty.

The Consul proceeded to question the chief and some of the natives of the village. They replied by accusing Kalengo; most of them asserted that they were eye-witnesses of the deed. The Consul inquired through his interpreters if there were other witnesses who saw the crime committed and accused Kalengo of it. "Nearly all those present, about forty persons, shouted out with one voice that it was 'Kalengo' who did it."

In order to understand the violence with which the natives accused Kalengo, and the unanimous manner in which the denials of the accused were rejected by his accusers, it is necessary to read the whole of the report of this inquiry, as drawn up by the Consul himself in a kind of process-verbaux, dated the 7 th, 8 th, and 9 th September (Annex II.). From all quarters accusers appeared, and the excited crowd gave vent to all sorts of accusations: he had cut off Epondo's hand, chained up women, stolen ducks and a dog! The Consul did not allow his suspicions to be aroused by the passionate character of these accusations; without any further guarantee of their sincerity or further examination into their truth, he looked upon his inquiry as conclusive, and as he had taken upon himself the duties of the Public Prosecutor in making preliminary inquiries into the matter, so he anticipated the decision of the responsible authorities by declaring to the assembled people that "Kalengo deserved severe punishment for his illegal and cruel acts." He proceeded to dramatise the incident by carrying off the pretended victim, and exhibiting him on the roth September to the official in command of the station at Coquilhatville, to whom he handed a copy of the record of his inquiry, and on the 12 th September he addressed a letter to the Governor-General which he marked as "personal and private," and in which he makes the incident in question among others a text for an attack on "the system of general exploitation of an entire population which can only be rendered successful by the employment of arbitrary and illegal force." His inquiry terminated, he immediately started on his return journey to the Lower Congo.

$$
\text { I K. K. in Africa, No. I (1904). }
$$




\section{Appendix}

Even if the circumstances had been correctly reported, the disproportion would still have been striking between them and the conclusions which the Consul draws when emphasising his general criticisms of the Congo State. But the facts themselves are incorrectly represented.

As a matter of fact, no sooner did the Consul's denunciation reach the Public Prosecutor's Department than M. Gennaro Bosco, Acting Public Prosecutor, proceeded to the spot and held a judicial inquiry under the usual conditions, free from all outside influences. This inquiry showed that His Britannic Majesty's Consul had been the object of a plot contrived by the natives, who, in the hope of no longer being obliged to work, had agreed among themselves to represent Epondo as the victim of the inhuman conduct of one of the capitas of a commercial company. In reality, Epondo had been the victim of an accident while out hunting, and had been bitten in the hand by a wild boar; gangrene had set in and caused the loss of the member, and this fact had been cleverly turned to account by the natives when before the Consul. We append (Annex No. III.) extracts from the inquiry conducted by the Acting Public Prosecutor into the Epondo case. The evidence is typical, uniform, and without discrepancies. It leaves no doubt as to the cause of the accident, makes it clear that the natives lied to the Consul, and reveals the object which actuated them, namely, the hope that the Consul's intervention would relieve them from the necessity of paying taxes. The inquiry shows how Epondo, at last brought to account, retracted what he had in the first instance said to the Consul, and confessed that he had been influenced by the people of his village. He was questioned as follows:

$Q$. "Do you persist in accusing Kalengo of having cut off your left hand?"

A. "No. I told a lie."

$Q$. "State, then, how and when you lost your hand."

A. "I was a slave of Monkekola's at Malele, in the Bangala district. One day I went out boar-hunting with him. He wounded one with a spear, and thereupon the animal, cnraged, turned on me. I tried to run off with the others, but falling down, the boar was on me in a moment and tore off my left hand and [wounded me] in the stomach and left thigh."

[The witness exhibits the scars he carries at the places mentioned, and lying down of his own accord shows the position he was in when the boar attacked and wounded him.]

$Q$. "How long ago did this accident happen?"

$A$. "I don't remember. It was a long time ago."

$Q$. "Why did you accuse Kalengo?"

A. "Because Momaketa, one of the Bossunguma Chiefs, told me to, and afterwards all the inhabitants of my village did so too." 


\section{$598 \quad$ Story of the Congo Free State}

Q. "Did the English photograph you?"

$A$. "Yes, at Bonginda and Lulonga. They told me to put the stump well forward. There were Nenele, Mongongolo, Torongo, and other whites whose names I don't know. They were whites from Lulonga. Mongongolo took away six photographs." I

Epondo of his own accord repeated his declarations and retractions to a Protestant missionary, Mr. Faris, who lives at Bolengi. This gentleman has sent the Conmissary-General at Coquilhatville the following written declaration:

"I, E. E. Faris, missionary, residing at Bolengi, Upper Congo, declare that I questioned the boy Epondo, of the village of Bosongoma, who was at my house on the roth September, 1903, with Mr. Casement, the British Consul, and whom, in accordance with the request made to me by Commandant Stevens, of Coquilhatville, I took to the mission station at Bolengi on the 16 th October, 1903 ; and that the said boy has this day, the 17 th October, 1903 , told me that he lost his hand through the bite of a wild boar.

"He told me at the same time that he informed Mr. Casement that lis hand was cut off either by a soldier or, perhaps, by one of those working for the white men (travailleurs de blanc), who have been making war in his village with a view to the collection of rubber, but he asserts that the account which he has given me to-day is the truth.

"Bolengi, October 17, I 903."

$$
\text { “(Signed) E. E. FARIs. }
$$

The inquiry resulted in the discharge of the prisoner, which, so far as it concerned the Epondo question, was in the following terms:

"Wc, Acting Public Prosecutor of the Court of Coquilhatville:

" Having regard to the notes made by His Britannic Majesty's Consul, on the occasion of his visit to the villages of Ikandja and Bossunguma in the territory of the Ngombe, from which it would appear that a certain Kalengo, a forest guard in the service of the La Lulonga Company,

"(a) Cut off the left hand of a certain Epondo;

“(b) . . . .;

" $(c)$. . . . . ;

"Having regard to the inquiry instituted by Licutenant Bracckman, which partly confirms the result of the inquiry instituted by His Britannic Majesty's Consul, but also partly contradicts it, and to the charges already brought against Kalengo adds that of having killed a native of the name of Baluwa;

"Having regard to the conclusions arrived at by the police employee in question, which tend to raise grave doubts as to the truth of all these charges; 


\section{Appendix}

"In view of the fact that all the natives who brought these charges against Kalengo, whether before His Britannic Majesty's Consul or Lieutenant Braeckman, on being summoned by us, the Acting Public Prosecutor, took to flight, and all efforts to find them have been fruitless; that this flight obviously throws doubt on the truth of their allegations;

"That all the witnesses whom we have questioned during the course of our inquiry declare . . . that Epondo lost his left hand from the bite of a wild boar;

"That Epondo confirms these statements, and admits that he told a lie at the instigation of the natives of Bossunguma and Ikondja who hoped to escape collecting rubber through the intervention of His Britannic Majesty's Consul, whom they considered to be very powerful;

"That the witnesses, almost all inhabitants of the accusing villages, admit that such was the object of their lic;

"That this version, apart from the unanimous declaration of the witnesses and the injured parties, is also the most plausible, seeing that cvery one knows that the natives dislike work in general and having to collect rubber, and are, moreover, ready to lie and accuse people falsely;

"That it is confirmed by the clearly statcd opinion of the English missionary Armstrong, who considers the natives to be "capable of any plot to escape work, and especially the labour of collecting rubber";

"That the innocence of Kalengo having been thoroughly established, there is no reason for proceeding against him;

"On the above-mentioned grounds, we, the Acting Public Prosecutor, declare that there are no grounds for proceeding against Kalengo, a forest guard in the service of the La Lulonga Company, for the offences mentioned in Articles 2, 5, I I, and 19 of the Penal Code.

\section{" (Signed) Bosco, " Acting Public Prosecutor.}

"Mамроко, October 9, I903."

We have dealt at length with the above case because it is considered by the Consul himself as being onc of the utmost importance, and because he relies upon this single case for accepting as accurate all the other declarations made to him by natives.

"In the one case I could alone personally investigate," he says," "that of the boy II., I found this accusation proved on the spot without seemingly a shadow of doubt existing as to the guilt of the accused sentry."

And further on:

"I had not time to do more than visit the one village of $\mathrm{R}-$, and

$$
\text { I Report, p. } 5^{8 .}
$$


in that village I had only time to investigate the charge brought by II." I

And elsewhere:

"It was obviously impossible that I should . . . verify on the spot, as in the case of the boy, the statements they made. In that one case the truth of the charges preferred was amply demonstrated." 2

It is also to this case that he alludes in his letter of the 12 th September, 1903 , to the Governor-General, where he says:

"When speaking to M. le Commandant Stevens at Coquilhatvilie on the loth instant, when the mutilated boy Epondo stood before us as an evidence of the deplorable state of affairs I reprobated, I said, 'I do not accuse an individual, I accuse a system.",

It is only natural to conclude that if the rest of the evidence in the Consul's Report is of the same value as that furnished to him in this particular, it cannot possibly be regarded as conclusive. And it is obvious that in those cases in which the Consul, as he himself admits, did not attempt to verify the assertions of the natives, these assertions are worth, if possible, still less.

It is doubtless true that the Consul deliberately incurred the certain risk of being misled owing to the manner in which he interrogated the natives, which he did, as a matter of fact, through two interpreters"through Vinda, speaking in Bobangi, and Bateko, repeating his utterances . . . in the local dialect 3 ; so that the Consul was at the mercy not only of the truthfulness of the native who was being questioned, but depended also on the correctness of the translations of two other natives, one of whom was a servant of his own, and the other apparently the missionaries' interpreter.4 But any one who has ever been in contact with the native knows how much he is given to lying; the Rev. C. H. Harvey 5 states that:

"The natives of the Congo who surrounded us were contemptible, perfidious, and cruel, impudent liars, dishonest, and vile."

It is also important, if one wishes to get a correct idea of the valuc of this evidence, to note that while Mr. Casement was questioning the natives, he was accompanied by two local Protestant English missionaries, whose presence must alone have necessarily affected the evidence. ${ }^{6}$

I Report, p. 58.

3 See Annex No. II. (enclosure No. 6 in III.).

${ }^{2}$ Idem, p. $5^{6}$.

4 Regions Beyond, 1900, p. 198.

5 Idem., January-February, I 9o3, p. 53.

6 Sec Annex No. II. "Present: Rev. W. D. Armstrong and Rev. D. J. Danielson of the Congo Balolo Mission of Bonginda, Vinda Bidilou (Consul's head man) and Bateko as interpreters, and His Britannic Majesty's Consul." This passage is omitted in Annex No. 6 of the Consul's Report (p. 78). 


\section{Appendix}

We should ourselves be going too far if from all this we were to conclude that the whole of the native statements reported by the Consul ought to be rejected. But it is clearly shown that his proofs are insufficient as a basis for a deliberate judgment, and that the particulars in question require to be carefully and impartially tested.

On examining the Consul's voluminous Report for other cases which he has seen, and which he sets down as cases of mutilation, it will be observed that he mentions two as having occurred on Lake Mantumba I "some years ago." 2 He mentions several others, in regard to the number of which the particulars given in the Report do not seem to agree, 3 as having taken place in the neighbourhood of Bonginda, ${ }^{4}$ precisely in the country of the Epondo inquiry, where, as has been seen, the general feeling was excited and prejudiced. It is these cases which, he says, he had not time to inquire into fully, 5 and which, according to the natives, were due to agents of the La Lulonga Company. Were these instances of victims of the practice of native customs which the natives would have been careful not to admit? Were the injuries which the Consul saw due to some conflict between neighbouring villages or tribes? Or were they really due to the black subordinates of the Company? This cannot be determined by a perusal of the Report, as the natives in this instance, as in every other, were the sole source of the Consul's information, and he, for his part, confined himself to taking rapid notes of their numerous statements for a few hours in the morning of the $5^{\text {th }}$ September, being pressed for time, in order to reach $\mathrm{K}$ - (Bossunguma) at a reasonable hour. ${ }^{6}$

Notwithstanding the weight which he attached to the "air of frankness" and the "air of conviction and sincerity" 7 on the part of the natives, his own experience shows clearly the necessity for caution, and renders rash his assertion "that it was clear that these men were stating either what they had actually seen with their eyes or firmly believed in their hearts." 8

Now, however, that the Consul has drawn attention to these few cases-whether cases of cruelty or not, and they are all that, as a matter of fact, he has inquired into personally, and even so without being able to prove sufficiently their real cause-the authorities will of course look into the matter and cause inquiries to be made. It is to be regretted that, this being so, all mention of date, place, and name has been systematically omitted in the copy of the Report communicated to. the Government of the Independent State of the Congo. It is impossible not to see that these suppressions will place great difficulties in the way of the magistrates who will have to

1 Report, p. 34.

${ }^{2}$ Idem, pp. 76 and 77 .

3 Cf. Idem, pp. 54 and 55 and p. 58.

4 Idem, pp. 54, 55.

5 Idem, p. 56.

${ }^{6}$ Idem, p. $5^{6}$.

7 Idem, p. 62.

8 Idem, p. 57. 
inquire into the facts, and the Government of the Congo trust that, in the interests of truth, they may be placed in possession of the complete text of the Consul's Report.

It is not to be wondered at if the Government of the Congo State take this opportunity of protesting against the proceedings of their detractors who have thought fit to submit to the public reproductions of photographs of mutilated natives, and have started the odious story of hands being cut off with the knowledge and even at the instigation of Belgians in Africa. The photograph of Epondo, for instance, mutilated in the manner shown, and who has "twice been photographed," is probably one of those which the English pamphlets are circulating as proof of the execrable administration of the Belgians in Africa. One English review reproduced the photograph of a "cannibal surrounded with the skulls of his victims," and underneath was written: "In the original photograph the cannibal was naked. The artist has made him decent by . . . covering his breast with the star of the Congo State. It is now a suggestive emblem of the Christian-veneered cannibalism on the Congo." I At this rate it would suffice to throw discredit on the Uganda Administration if the plates were published illustrating the mutilations which, in a letter dated Uganda, I6th December, I902, Dr. Castellani says he saw in the neighbourhood of Entebbe itself: "It is not difficult to find there natives without noses or ears, etc." 2

The truth is, that in Uganda, as in the Congo, the natives still give way to their savage instincts. This objection has been anticipated by Mr. Casement, who remarks:

"It was not a native custom prior to the coming of the white man: it was not the outcome of the primitive instincts of savages in their fights between village and village; it was the deliberate act of the soldiers of a European Administration, and these men themselves never made any concealment that in committing these acts they were but obeying the positive orders of their superiors." 3

That Mr. Casement should formulate so serious a charge without at the same time supporting it by absolute proof would seem to justify those who consider that his previous employment has not altogether been such as to qualify him for the duties of a Consul. Mr. Casement remained seventeen days on Lake Mantumba, a lake said to be 25 to 30 miles long and I 2 to 15 broad, surrounded by a dense forest. $4 \mathrm{Hc}$ scarcely left its shores at all. In these circumstances it is difficult to see how he could have made any useful researches into the former habits and customs of the inhabitants. On the contrary, from the fact that the tribes in question are still very savage, and addicted to

I Review of Reviews, February 14, 1903.

2 The Tribuna of Rome.

3 Report, Annex No. IV., p. 77.

4 Idem, p. 30. 
cannibalism, ${ }^{1}$ it would seem that they have not abandoned the practice of those cruelties which throughout Africa were the usual accompaniments of barbarous habits and anthropophagy. In one portion of the districts which the Consul visited, the evidence of the English missionaries on this point is most instructive. The Rev. McKittrick, in describing the sanguinary contests between the natives, mentions the efforts to pacify the country which he formerly made through the chiefs: ". . . . We told them that for the future we should not let any man carrying spears or knives pass through our station. Our God was a God of peace, and we, His children, could not bear to see our black brothers cutting and stabbing each other." 2 "While I was going up and down the river," says another missionary, "they pointed out to me the King's beaches, whence they used to despatch their fighting men to capture canoes and men. It was heartrending to hear them describe the awful massacres that used to take place at a great chief's death. A deep hole was dug in the ground, into which scores of slaves were thrown after having their heads cut off; and upon that horrible pile they laid the chief's dead body to crown the indescribable human carnage." 3 And the missionaries speak of the facility with which even nowadays the natives return to their old customs. It would seem, too, the statement made in the Report, 4 that the natives now fly on the approach of a steamer as they never used to do, is hardly in accordance with the reports of travellers and explorers.

Be this as it may, it is to be observed that nowhere in the territory which is the scene of the operations of the A. B. I. R. Company did the Consul discover any evidence of acts of cruelty for which the commercial agents might have been considered responsible. The coincidence is remarkable, since it so happens that the A. B. I. R. Company is a concessionary company, and that it is the system of concessions to which are constantly attributed the most disastrous consequences for the natives.

What it is important to discover from the immense number of questions touched on by the Consul, and the multiplicity of minor facts which he has collected, is whether the sort of picture he has drawn of the wretched existence led by the natives corresponds to the actual state of affairs. We will take, for instance, the district of the Lulonga and the Lopori, as the head-stations of the missions of the Congo Balolo Mission have been established there for years past. These missions are established in the most distant places

report, Annex No. IV., p. 30.

2 "Ten Years at Bonginda." D. McKittrick, Regions Beyond, 1900, p. $2 \mathrm{I}$.

3 "Congo Contrasts." M. Boudot, Regions Beyond, 1900, p. 197.

4 Report, p. 34. 
in the interior, at Lulonga, Bonginda, Ikau, Bongandanga, and Baringa, all of which are situated in the scene of operations of the La Lulonga and A. B. I. R. Companies. They are in constant communication with the native populations, and a special monthly review, called Regions Beyond, regularly publishes their letters, notes, and reports. An cxamination of a set of these publications reveals no trace, at any time previous to April, 1903-by that date, it is true, Mr. Herbert Samuel's motion had been brought before Parliamentof anything either to point out or to reveal that the general situation of the native populations was such as ought to be denounced to the civilised world. The missionaries congratulate themselves on the active sympathy shown them by the various official and commercial agents, ${ }^{1}$ on the progress of their work of evangelisation, ${ }^{2}$ on the facilities afforded them by the construction of roads, ${ }^{3}$ on the manner in which the natives are becoming civilised, "owing to the mere presence of white men in their midst, both missionaries and traders," 4 on the disappearance of slavery, 5 on the density of the population, ${ }^{6}$ on the growing number of their pupils, "especially since the State has issued orders for all children within reach to attend the mission schools," 7 on the gradual disappearance of the primitive customs of the natives, ${ }^{8}$ and lastly, on the contrast between the present and the past. 9 Will it be admitted that these Christian English missionaries, who, during their journeys, visited the various factories, and witnessed markets of rubber being held, would, by keeping silence, make themselves the accomplices of an inhuman or wrongful system of government? Among the conclusions of one of the Annual Reports of the Congo Balolo, Mission is to be found the following: "On the whole, the retrospect is encouraging. If there has been no great advance, there has been no heavy falling off, and no definite opposition to the work.

There has been much famine and sickness among the natives, especially at Bonginda. . . . Apart from this, there has been no scrious hindrance to progress. . . ." to And speaking incidentally of the beneficial effect produced by work on the social condtion of the natives, a missionary writes: "The greatest obstacle to conversion is polygamy. Many evils have been put down, e. g., idleness, thanks to the State having compelled the men to work; and fighting, through their not having time enough to fight." I1 These opinions of missionaries appear to us to be more precise than those expressed in a Report on every page of which it may be said one finds such expressions as: "I was told," "it was said," "I was informed,"

I Regions Beyond, 1900, p. 150; 1902, p. 209.
2 Idem, passim.
3 Idem, r 900, p. 150
4 Idem, 1901, p. 27.
5 Idem, 1900, p. 199.
6 Idem, 1900, pp. 243, 297, 306.
7 Idem, 1901, p. 40: 1902, p. 315.
8 Idem, I $90 \mathrm{I}, \mathrm{p} .40$.
9 Idem, 1900, p. 196. 1०Idem, 1901, p. 43.
II Idem, 1901, p. 60. 
"I was assured," "they said," "it was alleged," "I had no means of verifying," "it was impossible for me to verify," "I have no means of ascertaining," etc. Within a space of ten lines, indeed, occur four times the expressions, "appears," "would seem," "do not seem." r

The Consul does not appear to have realised that native taxes in the Congo are levied in the shape of labour, and that this form of tax is justified as much by the moral effect which it produces, as by the impossibility of taxing the native in any other way, sceing that, as the Consul admits, the native has no money. It is to this consideration that is due the fact, to give another example, that out of 56,700 huts which are taxed in North-Eastern Rhodesia 19,653 pay that tax "in labour," while 4938 pay it "in produce." 2 Whether such labour is furnished direct to the State or to some private undertaking, and whether it is given in aid of this or that work as local necessities may dictate, one ground of justification is always to be found in what the Memorandum of the $\mathrm{I} r$ th February last recognises is the "necessity of the natives being induced to work." The Consul shows much anxiety as to how this forced labour should be described; he is surprised that if it be a tax it is sometimes paid and recovered by commercial agents. Strictly speaking, of course, it cannot be denied that the idea of remunerating a person for paying his taxes is contrary to the ordinary notions of finance; but the difficulty disappears if it is considered that the object in view has been to get the natives to acquire the habit of labour, for which they have always shown a great aversion. And if this notion of work can more easily be inculcated on the natives under the form of commercial transactions between them and private persons, is it necessary to condemn such a mode of procedure, especially in those parts where the organisation of the Administration is not yet complete? But it is essential that in the relations of this nature which they have with the natives, commercial agents, no less than those of the State, should be kind and humane. In so far as it bears on this point the Consul's Report will receive the most careful consideration, and if the result of investigation he to show that there are real abuses and that reforms are called for, the heads of the Administration will act as the circumstances may require.

But no one has ever imagined that the fiscal system in the Congo attained perfection at once, especially in regard to such matters as the assessment of taxes and the means for recovering them. The system of "chieftaincies," which is recommended by the fact that it enables the authorities and the native to communicate through the latter's natural chief, was based on an idea carried into practice elsewhere:

"The more important Chiefs who helped the Administration have

Report, p. 28.

2Reports on the Administration of Rhodesia, 1900-1902, p. 408. 
been paid a certain percentage of the taxes collected in their districts, and $I$ think that if this policy is adhered to each year, the results will continue to be satisfactory and will encourage the Chiefs to work in harmony with the Administration." :

The Decree on the subject of these Chieftaincies ${ }^{2}$ laid down the principle of a tax, and its levy in accordance with "a table of contributions to be made every year by each village in produce, forced labour, labourers, or soldiers." The application of this Decree has been provided for by deeds of investiture, tables of statistics, and particulars of contributions, forms of which will be found in Annex IV. In spite of what is stated in the Report, this Decree has been carried out so far as has been found compatible with the social condition of the various tribes; numerous deeds of investiture have been drawn up, and efforts have been made to draw up an equitable assessment of the contributions. The Consul might have found this out at the Commissioners' offices, especially in the Stanley Pool and Equator districts which he passed through; but he neglected as a rule all official sources of information. No doubt the application of the Decree was at first necessarily limited, and it is possible that the result has been that for a certain time only such villages as were within a short distance from stations have been required to pay taxes; but this state of things has little by little altered for the better in proportion as the more distant regions have become included in the areas of influence of the Government posts, the number of villages subject to taxation has gradually increased, and it has been found possible to levy taxes on a greater number of persons. The Government aim at making progress in this direction continuous, that is to say, that taxation should be more equitably distributed, and should as much as possible be personal; it was with this object that the Decree of "the i 8 th November, $190_{3}$, provided for drawing up "lists of native contributions" in such a way that the obligations of every native should be strictly defined.

"Article 28 of this Decree lays down that within the limits of Article 2 of the present regulations (that is to say, within the limit of forty hours' work per month per native) the District Commissioners shall draw up annual lists of the taxes to be paid, in kind or duration of labour, by each of the natives resident in the territories of their respective districts. And Article 55 punishes 'whoever, being charged with the levy of taxes, shall have required of the natives, whether in kind or labour, contributions which shall exceed in value those prescribed in the tables of taxes.",

It is matter of common notoriety that the collection of taxes is occasionally met by opposition, and even refusal to pay. The proofs

Reports on the Administration of Rhodesia, 1900-1902, p. 408.

2 Decree of the 6th October, 1891 (Bulletin Officiel, 1891, p. 259). 


\section{Appendix}

of this, which are to be found in the Report of the Consul for the Congo, are borne out by what has happened, for instance, in Rhodesia:

"The Ba-Unga (Awemba district), inhabitants of the swamps in the Zambesi delta, gave some trouble on being summoned to pay taxes." I

"Although in many cases whole villages retired into the swamps on being called upon for the hut-tax, the general result was satisfactory for the first year (Luapula district)." 2

"Milala's people have succeeded in evading taxes." 3

"A few natives bordering on the Portuguese territory, who, owing to the great distance they reside from the native Commissioners' Stations, are not under the direct supervision of the Native Commissioners, have so far evaded paying hut-tax, and refused to submit themselves to the authority of the Government. The rebel Chief, Mapondera, has upon three occasions successfully eluded punitive expeditions sent against him. Captain Gilson, of the British South Africa Police, was successful in coming upon him and a large following of natives, and inflicting heavy losses upon them. His kraal and all his crops were destroyed. He is now reported to be in Portuguese territory. Siji M'Kota, another powerful Chief, living in the northern parts of the M'toko district, bordering on Portuguese territory, has also been successful in evading the payment of hut-tax, and generally pursuing the adoption of an attitude which is not acceptable to the Government. I am pleased to report that a patrol is at present on 'its way to these parts to deal with this Chief, and to endeavour to obtain his submission. It will be noted that the above remarks relate solely to those natives who reside along the borders of our territories, and whose defiant attitude is materially assisted by reason of this proximity to the Portuguese border, across which they are well able to proceed whenever they consider that any meeting or contact with the Native Commissioner will interfere in any way with their indolent and lazy life. They possess no movable property which might be attached with a view of the recovery of hut-tax unpaid for many years, and travel backwards and forwards with considerable freedom, always placing themselves totally beyond the reach of the Native Commissioner." 4

The above is an instance of those "punitive expeditions" to which the authorities are occasionally obliged to resort, as also of the native custom, which is not peculiar to the natives of the Congo, of moving into a neighbouring territory when they are secking to evade the operation of the law. Whether in the process of collecting native taxes there have been cases in the Congo, amongst those mentioned by the

I Reports on the Administration of Rhodesia, r900-1902, p. 409.

2 Idem, p. 4 10. 3 Idem, p. 4 I 0.

4 Idem, 1900-1902, pp. 145, 146. 
Consul, in which the limits of a just and reasonable severity have been overstepped is a question of fact which investigation on the spot can alone ascertain, and instructions to this effect will be given to the authorities at Boma.

We are also unable to accept, on the information at present before us, the conclusions of the Report in regard to the conduct of the forest guards in the employ of the A. B. I. R. and La Lulonga Companies. These subordinate officers are represented by the Consul as being exclusively employed in "compelling by force the collection of india-rubber or the supplies which each factory needed." I It is true that another explanation has been given-though not, indeed, by a native-according to which the business of these same forest guards is to see that the india-rubber is harvested after a reasonable fashion, and especially to prevent the natives from cutting the plants. ${ }^{2}$ It is, indeed, well known that the law has made rigorous provision for preserving the rubber zones, has regulated the manner in which they are to be worked, and has made planting and replanting obligatory, with a view to avoiding the complete exhaustion of the rubber plant, which has occurred, for instance, in North-Eastern and Western Rhodesia. 3 A heavy responsibility in this direction lies on the companies and private persons engaged in developing the country, and it is obvious that they are bound to exercise the most careful superintendence over the way in which the harvest is collected. The object for which these forest guards are employed, therefore, may well be quite different from that alleged by the Consul; in any case, the complaints which have been made on this head will form a subject for inquiry in the Congo, as also the other remark of the Report that the manner in which these forest guards are armed is excessive, and liable to abuse. It is here to be observed that in calculating the number of these forest guards the Consul is obliged to rely on hypothesis, ${ }^{4}$ and that he himself admits "I have no means of ascertaining the number of this class of armed men employed by the A. B. I. R. Company." $5 \mathrm{He}$ mentions that the gun of one of these men was marked on the butt "Depôt 22 ro." But it is evident that such a mark can only have the significance which the Consul would like to see in it in so far as it can be proved that it refers to the numbering of the arms used in the Concession, and such is not the case, since this particular mark "Depôt" is not used either by the officials of the State or those of the Company. and it would seem that it is an old manufactory or store mark. In regard to the manner of arming the capitas, the Consul can hardly be ignorant that the higher authorities have always given great attention to the matter, which is, indeed, one surrounded with difficulties,

Report, p. 44.

2 Annex III., p. 26.

3 Reports on the Administration of Rhodesia, 1900-1902, pp. 397, etc.

4 Report, p. 57.

5 Idem, p. $4^{2}$. 


\section{Appendix}

seeing that while on the one hand it is necessary to consider the question of the personal protection of the capita, on the other the possibility of the arms in question being used for improper purposes must not be lost sight of. It is not only in the Circular of the 2oth October, 1900, which the Consul has reprinted, that this question is dealt with; there is a whole collection of Circulars on the subject, among which may be mentioned those of the I 2 th March, 1897, 3ist May and 28th November, 1900, and 30th April, 1901. Copies of them are annexed as proof of the fixed determination of the Government to see that the law relating to this question is strictly enforced (Annex V.). Yet, in spite of all these precautions, the Consul has ascertained that several capitas were not provided with permits (perhaps they might have been found at the head office), and that two of them were furnished with arms of precision. ${ }^{x}$ But these few infractions of the rule are obviously not enough to prove the existence of a sort of vast armed organisation destined to strike terror into the natives. On the contrary, the Circular of the 7 th September, r 903 , printed in Annex VII. of the Consul's Report, is a proof of the care taken by the Government that the regular black troops should always be under the control of European officers. ${ }^{2}$

Such are the preliminary remarks suggested by Mr. Casement's Report, and we reserve to ourselves the right of dealing with it more in detail as soon as the Government shall be in possession of the results of the inquiry which the local authorities are about to make. It will be observed that the Government, in its desire not to seem to wish to avoid the discussion, has not raised a question in regard to the manner, surely unusual, in which His Britannic Majesty's Consul has acted in a foreign country. It is obviously altogether outside the duties of a Consul to take upon himself, as Mr. Casement has done, to institute inquiries, to summon natives, to submit them to interrogatories as if duly authorised thereto, and to deliver what may be styled judgments in regard to the guilt of the accused. The reservations called for by this mode of procedure must be all the more formal, as the Consul was thus intervening in matters which only concerned subjects of the Congo State, and which were within the exclusive jurisdiction of the territorial authorities. Mr. Casement, indeed, made it his business himself to point out how little authorised he was to interfere when on the 4 th September, 1903, he wrote to the Governor-General: "I have no right of representation to your Excellency

I Report, p. 43.

${ }^{2}$ The Circular of the 7 th September, 1903 , has reference to the "prohibition" to despatch armed soldiers in charge of black non-commissioned officers, and not, as would appear from the incorrect copy produced by the Consul, to the "instruction."-(Annex VII. of the Report, p. 80.) 
save where the persons or interests of British subjects dwelling in this country are affected." It is thus obvious that he was aware that he was exceeding his duties by investigating facts which concerned only the internal administration, and so, contrary to all laws of Consular jurisdiction, encroaching on the province of the territorial authorities.

"The grievances of the natives have been made known in this country by - who brought over a petition addressed to the King, praying for relief from the excessive taxation and oppressive legislation of which they complain."

These lines are extracted from the Report for 1903 of the British and Foreign Anti-Slavery Society, and the natives referred to are the natives of the Fiji Isles. The Report goes on:

"The case has been brought before the House of Commons. The grievances include forced labour on the roads, and restrictions which practically amount to slavery; natives have been flogged without trial by magistrate's orders, and are constantly subject to imprisonment for frivolous causes. Petitions lodged with the local Colonial Secretary have been disregarded. Mr. Chamberlain, in reply to the questions asked in Parliament, threw doubt upon the information received, but stated that the recently appointed Governor is conducting an inquiry into the whole situation in the Fiji Islands, in the course of which the matter will be fully investigated."

Such are also our conclusions in regard to Mr. Casement's Report.

Brussels, March I 2, 1904 .

Chr. de Cuvelier.

\section{Memorandum}

Lorci Lansdowne's dispatch of the 19th April, I904, a copy of which was handed to the Congo Government on the $27^{\text {th }}$ April by his Excellency Sir Constantine Phipps, calls for certain remarks.

With regard to the opinion to which this dispatch takes exception, "that the interests of humanity have been used in this country as a pretext to conceal designs for the abolition of the Congo State." it will be well to remember that a Member of the House of Commons declared that he would prefer "to see the Valley of the Congo pass into the hands of a foreign Power," and that some pamphlets described the "disruption of the Congo Free State," the "partition of the Congo Free State among the Powers," as absolute and immediate necessities, and even went so far as to suggest the bases of such a partition; while the organs of the English press contemplated one of two alternatives, either that "advocated by the more thorough-going critics of the present Administration, namely, the disruption of the Congo Free State," or "the partition of the Congo territory among the great Powers whose possessions in Africa border those of the Congo Free State," or declared that "what Europe ought to do, under 
the leadership of Great Britain, is summarily to sweep the Congo Free State out of existence." The Congo State Note of the I 7 th September has called attention to these suggestions, of which we merely point out the tenor in this instance, and which all aimed at despoiling the Sovereign-King, and at dispossessing him of the State which was his own creation-suggestions which are entirely incompatible with respect for rights and treaties, and with the motives of a purely humanitarian and philanthropic nature by which the enemies of the State allege themselves to be exclusively animated in the passionate campaign which they are conducting against it.

In reply to the objections raised by His Majesty's Government against the communication of the entire text of Mr. Casement's Report, the Government of the Congo State points out that it has asked for the complete Report precisely with a view to transmitting it to the competent judicial and administrative authorities, without which this communication would be purportless. The anxiety to obtain an impartial inquiry and the rights of the defence render it an imperative necessity that the men accused should be informed, in a precise and fully detailed manner, of the acts laid to their charge; the fear that the persons accused might be able, by means of the knowledge they would have of the details, to influence or suppress evidence, does not appear to be justified by the mere fact that the natives, who, in the Epondo case, had given mendacious information to the Consul, subsequently avoided presenting themselves before the Magistrate presiding over the inquiry; the flight of these witnesses is explained more naturally by the fact that they were conscious of the grave fault they had committed in wittingly deceiving the English Consul. If the Congo Government be permitted to give an assurance, which it does willingly, that any case of suborning witnesses, or any attempt to do so, would form the subject of a prosecution, it is evidently not within its power to prejudice or quash such legal measures as persons who might find themselves wrongfully accused might consider it necessary to take, either in the interests of their honour or their dignity.

The Government of the Congo State regrets that His Majesty's Government does not deem it necessary to communicate to it the other previous Consular Reports to which Lord Lansdowne's dispatch of the 8th August, 1903, alluded. As was stated in the notes of the I 2 th March last, these reports possessed the interest of having been written at a date anterior to the inception of the present discussion.

A copy of this Memorandum will be addressed to the Powers to whom copies of Lord Lansdowne's dispatch of the rgth April last was transmitted.

Administration, Congo Free State, Brussels, May $14,1904$. 


\section{Story of the Congo Free State}

\section{FEATURES OF THE LAND SYSTEM IN THE AFRI- CAN COLONIES OF GERMANY, GREAT BRITAIN, FRANCE, AND PORTUGAL}

The following notes are taken from the Bulletin Officiel of June, 1903, reporting to the Sovereign the accounts of the Congo Free State for the nineteenth year of its existence. The apt comparisons and pointed remarks upon the land system of the State are the work of M. le Chevalier de Cuvelier, Secretary of State for the Congo Free State, an official of great executive ability, to whose tremendous energy is due much of the later prosperity and progress which the Congo State enjoys to the chagrin of its detractors. Chevalier de Cuvelier has been engaged twenty years in the work of creating and developing the State. His official utterances have the quality of long experience behind them.

"During the twenty years that the rule of the State possession of vacant lands has been inscribed in the laws of the Congo State, not one of the Powers Signatory of the Berlin Act has pointed it out as being contrary to that International Act, either at the time of the publication in the Official Bulletin of the regulation of ${ }_{1} 88_{5}$, or on the occasion of any of the public applications made by the State on successive occasions either in exploiting en régie certain lands of the Domain with the object of assuring to the Treasury indispensable resources, or in granting concessions to certain societies for the purpose of carrying out works of general utility and contributing towards the public expenses.

"It can be said on the contrary that the Powers which, together with the Congo State, are in possession of territory in the zone of commercial liberty-France, Germany, Great Britain, Portugal-have followed the same principles, and considered, like it, that the Berlin Act no more excluded the right of property on the part of the State than it excluded that of private individuals.

"In German East Africa the regulation of ist September, 1891, says:

" 'ArTicle 1.-The Government alone has the right to take possession of vacant lands in the limits of the German sphere of influence in East Africa fixed by the Anglo-German Convention of rst July, I 890 , excepting for the length of the coast strip which was formerly part of the Zanzibar sultanate, and in the provinces of Usambara, Nguru, Usegua, Ukami, and the island of Mafia.'

"By the prior arrangement of 20 th November, i 890 , between the Imperial Government and the Deutsch Ostafrikanische Gesellschaft, the vacant lands of these latter regions were already found to be assigned 


\section{Appendix}

to that Company. The produce of the exploitation of the forests throughout these territories, in the terms of Article 4 of the contract of 5 th February, 1894 , was to be shared in equal halves between the [German] Government and the Company.

"The [German] regulation of the 26 th November, 1895, readmits the principle:

" ARTICLE 1.-Under reserve of the rights of property, or of other real rights that individuals or judicial persons, native chiefs or villages, may advance, as well as rights of occupation by third parties resulting from contracts effected with the Imperial Government, all vacant land in German East Africa belongs to the Crown.'

"The circular of the Imperial Governor von Liebert, dated 29 th April, r900, explains that:

" "By the transference to the Empire of the sovereignty, all pretensions to landed property derived from the sovereign rights, real or apparent, of chiefs, sultans, etc., have passed to the Empire. All land which has not been proved to be the private property of an individual, or of a community, is to be considered as the property of the Crown.'

"Under the powers of the regulations of 1895 , concessions have been granted in the terms taken, for example, from the acts of the concession for the Urangi Society $(1896)$ and the Gold Syndicate of Usinja ( 1899 ):

"“The Society receives the right to acquire under the prescriptions of the land regulation of 26 th November, 1895 , a superficies of 100 square kilometres, either by contract with the natives, or by taking provisional possession of vacant lands.'

"In the Cameroons, the south-east portion of which forms part of the zone of liberty of commerce, there exists a regulation of the German Emperor of 15 th June, 1896 , the first article of which is identical with the first article of the regulation of $26 \mathrm{th}$ November, 1895 , for German East Africa.

"The Society of the South Cameroons has obtained there, 16th January, 1899, a charter of concession which grants it the property of the domain lands situated between the I 2 th degree of West longitude, the $4^{\text {th }}$ degree of North latitude, and the political frontiers of the Cameroons to the South and to the East.

"In the French Congo, Article 19 of the order of the Government Commissioner General of 26th September, 189I, decrees:

"'Waste lands and abandoned lands, to the ownership of which no one can legitimately lay claim, will be considered as belonging to the State and will form part of the colonial domain. They can under that head be alienated or conceded in the terms of the $5^{\text {th }}$ and following articles. Lands considered waste are those which are neither legally occupied nor utilised in reality by any one.' 
"Decrees passed in 1899 granted a totality of some forty concessions embracing almost the whole of the French territory.

"In British East Africa, the powers given by the Royal Charter, 3d September, 1888 , to the Imperial British East Africa Company, whilst Article $\mathrm{r} 6$ forbids it to grant any commercial monopoly, confer upon it the right to 'concede all lands for a period or in perpetuity, by right of pledging them or otherwise.'

"After the British Protectorate was substituted for the Company, the question of vacant lands was regulated in the following manner, in accordance with the terms of the report of Mr. (now Sir) H. H. Johnston, Her Britannic Majesty's Special Commissioner, dated $27^{\text {th }}$ April, r 900:

". The land question may now be considered as partially solved over the greater part of the Uganda Protectorate. Over all the more thickly-inhabited countries the waste or unoccupied lands belong to Her Majesty the Queen, having been transferred to the Crown, in most cases by agreement with the chiefs, after payment of indemnities; in some other cases, as in Unyoro, as the result of conquest. . . . By Proclamation it has been forbidden to any foreigner to acquire land from the natives in any part of the Uganda Protectorate without the prior assent of the Uganda Administration. . . . A large area of the Kingdom of Uganda is guaranteed to the possession of its native occupants. The rest of the land, including the forests, has now been transferred by agreement to the Crown on behalf of, and in trust for, the administration of the Uganda Protectorate.'

"Finally the land régime in the Portuguese Colonies, especially in Angola, is regulated by the decree of 9 th May, I 901 , the first article of which stipulates:

"'The State domain in the countries beyond the sea are all lands which at the date of the publication of this law do not constitute a private property, acquired according to the terms of Portuguese legislation.'

"The Congolese law protects the natives in the enjoyment of the lands that they occupy, and in fact not only are they not disturbed in that enjoyment, but it even extends their cultivation and their plantations in proportion with their necessities. Manifold are the measures taken by the Congo State in order to safeguard the natives against all spoliation:

“" No one has the right to dispossess the natives of the lands which they occupy.' (Order of ist July, $188_{5}$, Article 2.)

"'The lands occupied by native populations under the authority of their chiefs shall continue to be governed by local customs and uses.' (Decree of 14 th September, 1886 , Article 2.)

"All acts or conventions which would tend to expel the natives from the lands that they occupy, or to deprive them, directly or 


\section{Appendix}

indirectly, of their liberty, or of their means of existence are forbidden.' (Decree of 14 th September, 1886, Article 2.)

"'When native villages are surrounded by alienated or leased lands, the natives shall be able, as soon as the official measurement has been effected, to extend their cultivation without the consent of the proprietor, or the lessee, over the vacant lands which surround their villages.' (Decree of 9 th April, I 893, Article 6.)

"'The members of the Commission of Lands will specially examine whether the lands àsked for should not be reserved either for requirements of public utility, or in view of permitting the development of native cultivation.' (Decree of and February, r898, Article 2.)

"The other Powers have not understood otherwise than the Congo State the obligations which are imposed upon them in this require in favour of the natives. So the decrees of concessions in the French Congo contain in the roth Article the clause that:

"'The Society having the concession cannot exercise the rights of enjoyment and exploitation which are accorded to it except outside villages occupied by natives, and the lands reserved to them for purposes of cultivation, pasturage, or as forest. The surroundings of these lands shall be fixed by the decisions of the Governor of the Colony, which shall equally determine the lands over which the natives shall preserve the rights of hunting and fishing.'

"In German East Africa, the regulation of the 27th November, 1895, Article 2, stipulates:

"'ARTICLE 2.- If on fixed lands, chiefs, villages, or other native communities assert rights based upon a pretended sovereignty, or if these rights belong to them, it will be necessary to take them into account so far as possible, and to endeavour before anything to arrive at a friendly arrangement in virtue of which the territory necessary for the existence of the community shall be reserved, and the remainder placed at the disposal of the Government.

"'If this arrangement is not brought about, the Governor decides.'

"Commenting upon this arrangement, the circular of 29th April, 1900, of the Imperial Governor von Liebert [Germany] gives the following instructions:

"“In principle there should only be left to the natives the lands of which they have absolute need for their system of exchange, and for the existence of their village communities. Nevertheless, in order not to give rise to political complications, care will be taken provisionally, in the practical execution of this rule, not to show too much rigour, and especially is it recommended not to extend the taking possession of property without an owner except in regions which are under a strong administration.'

"The Portuguese decree of gth May, 1901, says:

"“ARTICLE 2.- The right of natives to lands habitually cultivated by 
them, which are comprised in the sphere of the concessions, is recognised; a certain extent of land shall be reserved for the habitation and the agricultural work of those residing there." "

\section{CONCESSIONAIRES, PRIVATE FIRMS, AND COMMER- CIAL TRADING COMPANIES IN THE CONGO FREE STATE}

There are at present over four hundred commercial establishments carrying on trade in the Belgian Congo, among which are the following:

Société Anonyme Belge pour le Commerce du Haut-Congo, 3i establishments; Abir, 28; Nieuwe Afrikaansche Handels Vennootschap, 28; Société Anversoise du Commerce au Congo, 22; Comité Spécial du Katanga, 21; Hatton \& Cookson [Liverpool], r6; Comptoir Commercial Congolais, I3; Valle \& Azevedo, I2; Magasins Généraux, 12 ; Compagnie du Congo Portugais, 10; Compagnie du Lomami, 9; Freitas \& Barreira, 9; Produits Végétaux du Haut-Kasai, 8; Plantations de la Lukula, 7; Crédit Commercial Congolais, 7; L'Enterprise Africaine, 7; Société Isangi, 7; La Helgika, 6; Shanu, 6; L'Equatoriale Congolaise, 5; La Congolia, 4; La Loanje, 4; Produits du Mayumbe, 4; La Lulonga, 4; Comptoirs Congolais Velde, 4; Les Produits du Congo, 4; Samuel, 4; Shanusi Agbabiaka, 4; Les Plantations Lacourt, 3; Société Forestière et Commerciale du Haut-Congo, 3; Plantations du Lubefu, 3; Ferreira Viegas, 3; La Djuma, 3; Syndicat Commercial et Agricole du Mayumbe, 3; Mouture et Panification, 2; Ikelemba, 2; Société d'Agriculture et de Plantations au Congo, 2; Compagnie Agricole du Mayumbe, 2; Ferreira Frères, 2; Traffic Congolais, 2; Société Africa, 2; Société 1'est du Kwango, 2; Dana Bernabe, 2; Carrico Frères, 2; Ribiero, 2; Ferreira \& Figueiredo, 2; Vicoso \& Martins, 2; A. N. Figueiredo, 2; Plantations Coloniales la Luki, I; Compagnie Sucrière Européene et Coloniale, I; La Mayumbienne, I ; L’Urselia, I; La Kassaienne, I; Citas, I ; Compagnie Française du Haut-Congo, r; Compagnie Bruxelloise pour le Commerce du Haut-Congo, r; La Centrale Africaine, r; Harms \& Marcus, r; D'Heygere, I; Lemos et Irmôo, I; Compagnie Franco-Belge, I; Rocha Santos et Cie., I; Agme, r ; Docteur Villa, I; Messageries Fluviales, I; Folgosa, I; Joao da Fonseca, I; Rebello Luiz, r; Felgueiras, I; Branca da Giovanni, I; Gomez, r; Nogueira, x; Shanu, I; Sabaī Smith, I; Thomas, I; Disu Aremu, I; Smithe, I; Adiolo Balawao, r; John Andrew, r; Mana, r; Somano Fayamo, r; Radji Ibadan, r; Davidson Williams, I; Macole, I; Georges Southey, I; Lania, I; Abondu Ramano, I; Mamadu Adejene, I; Moses Williams, I; John 


\section{Appendix}

Sani, I; J. W. Davis, I; John David, I; John Uriah, I; Toki, I; Adekule, I; Mabadu Vango, I; N'chiama Lello, I; Choko Malo, I; Mafonda N'Baka, I; Simpson, I; Sacra Mancoga, I; Latete Bako, I; Peto N'Foa, I; Malenda Longo, I ; Chioma Moundoungou, I; Sacra Shimbanda, I; Hall Chamberlain, I.

\section{PRINCIPAL CONGO OFFICIALS IN BRUSSELS, CENTRAL ADMINISTRATION}

Ministers of State: Baron van Eetvelde, Chevalier Descamps. Treasurer-General: M. H. Pochez.

Secretaries-General: M. le Chevalier A. DE Cuvelier, Department of Foreign Affairs and Justice; M. H. Droogmans, Department of Finances; Commandant C. $\mathrm{H}$. Liebrechts, Department of the Interior.

Directors: $\quad$ M. A. BAERTS, Chef de Cabinet; M. N. ARNold, Auditor; M. ED. KERVYN, Director of the Department of Foreign Affairs; M. DE KEUZER, Director of the Department of Finances; Le Major LombarD, and Commandant F. LEBRUN, Directors of the Department of the Interior.

Chief of Division: M. G. OlyfF, Chief of Division of the Department of Foreign Affairs.

\section{OFFICIALS OF THE LOCAL ADMINISTRATION OF} THE CONGO FREE STATE

Governor-General: Général Baron WaHis.

Vice-Governors-General: Fuchs, Wangermee, Costermans.

Secretary-General: VAN Damme.

Directors:

Of Justicc: A. Gohr.

Of Finance: Delhaye.

Of Agriculture: BroHé.

Of Public Works: ItTeN.

Court of Appeal: $\quad$ President, Interior Administration: Baron G. Nisco.

Judges: Horstmans, A. Golir.

Court of First Instance: Judge: T. BEECKMAN.

Prosecuting Attorney: F. WALEFF.

Magistrates (Territorial Judges and Substitutes): Sec Chapter XXII. 


\begin{tabular}{|c|c|c|}
\hline Public Force: & Commander-in- $\mathrm{Cl}$ & hief: Major WARNANT. \\
\hline Chief of the District of & Boma, & COSTERMANS. \\
\hline & Banana, & Dr. CASSÉ. \\
\hline & Matadi, & DERACHE. \\
\hline & The Cataracts, & Delhaye. \\
\hline & Stanley Pool, & MaHiEU. \\
\hline & Lake Leopold II., & STORMS. \\
\hline & The Equateur, & Stevens. \\
\hline & The Bangalas, & GÉ RARD. \\
\hline & The Ubanghi, & BERTRAND. \\
\hline & The Uelle, & WACQUEZ. \\
\hline Chief of the Zone: & Rubi Uelle, & Pourbaix. \\
\hline & Uere Bomu, & HolM. \\
\hline & Bomokandi, & SAROLÉa. \\
\hline & Gurba Dungu, & SAMAES. \\
\hline & Enclave of Lado, & SERESCHE. \\
\hline hief of the District o & the Aruwimi, & Pimpurniaux. \\
\hline & Lualaba, & Chenot. \\
\hline & Kwango, & DUvivier. \\
\hline & Oriental Prov., & De Meulemeester. \\
\hline Chief of the Zone of & Haut-Ituri, & ENGH. \\
\hline & Ponthierville, & Cordella. \\
\hline & Manyema, & VERDICK. \\
\hline & Stanley Falls, & FEDERSPIEL. \\
\hline & zizi-Kivu, & TOMBEUR. \\
\hline
\end{tabular}

\section{THE BELGIAN MINISTER TO THE UNITED STATES}

Baron Ludovic MoncheuR, Belgian Legation, Washington, D. C.

Baron Moncheur graduated at the University of Louvain (Belgium) in philosophy, letters, and law, with the highest honours. He entered the diplomatic service of Belgium at the age of twenty-five, and was successively Attaché to the Belgian Legation at The Hague in $188_{3}$; Second Secretary, Belgian Legation at Vienna, $188_{5}$; First Secretary, Belgian Legation at Berlin, 1887 ; Counsellor of the Belgian Legation at Rome, I892; Chargé d'Affaires at Luxembourg, I897; Minister Resident of Belgium to Mexico, r 898; Envoy Extraordinary and Minister Plenipotentiary of Belgium to the United States, r 901. $\mathrm{He}$ is a member of the Geographical Society of Antwerp, and author of La Terre chaude Mexicaine and From Tampico to the Pacific.

The Baroness Moncheur is a daughter of the Hon. Powell Clayton, United States Minister to Mexico. 


\section{INDEX}

A

A. B. I. R., 608

Aborigines' Protection Society, 369,374 ; damaging estimate of its work and methods, note, 376 et seq., 451 et seq., 456, 478

Africa, formerly called the "Dark Continent," 2 ; its value unrecognised, ibid.; diamonds in, ibid.; its climate once thought to be fatal to Europeans, ibid.; portioned by Europe in eighteenth century to facilitate slave trade, 129

Africa, Central, slavery in, 5; creation of International Association for its exploration and civilisation, 12 ; its healthfulness insisted upon by $\mathrm{Liv}$ ingstone and Stanley, 17; large sections claimed by England, France, Portugal, and Germany, ibid.; review of, 64 et seq.; nomadic habits of its people, 223 ; their superstition, ibid.; its consequences, 224 ; the iron horse in, 252 ; its real curse, 289

African Exploration Fund, 29; London Geographical Society contributes $£ 250$, ibid.; Belgian Committee collects 500,000 francs, $i b i d$.

African explorers, Gladstone's opinion of, 4

Albert Edward, Lake, 56, 208

Albert Nyanza, Lake, 52, 56

Albertville, 58

Alcohol, in Congo Free State, 138 ; its prohibition, 273 ; in Lagos, note, $289,3 \mathrm{II}$

Alvensleben, Count Von, 136; speech at second Brussels Conference, 143
American Baptist Missionary Union, 299, 300; fifteen grants of land to, 387

American Congo Mission, two grants of land to, 387

American Indians, Wheaton on their political status, $7 \mathrm{I}$

American Secretary of State (Mr. Fish) on political status of savages, 72

Amity, Commerce, and Navigation, treaty of, 553 et seq.; its ratification by United States, 559

Anglo-Portuguese Convention, 21 ; it is quashed, ibid.

Anti-slavery meeting at Cologne, I 3 I

Anti-Slavery Society, of Belgium, founded by Cardinal Lavigerie, 9I

Arab slave-traders, 5

Armstrong, Rev. 'W. D. See Epondo.

Arnot, Mr. Frederick Stanley, on native punishments, 426

Arntz, Prof. Égide, 105 ; argument by, 5 I 6

Aruwimi, 52, 179

Ascenso, Signor, Italian physician, remarks on Congo Free State, 428 et seq.

Askaris, a Congolese tribe employed by Stanley as carriers, 39

Atrocities, Congo, 578, 595 et seq.

Austria-Hungary, 68

Avakubi, 219, 220, 22 I

Azandés, 158

\section{B}

Bacon on progress of States, 18

Bacteriological Institute, 268

Bahr-Djur, 213 
Bahr-el-Ghazal, France objects to Great Britain leasing it to Congo Free State, 208, 210; British scheme to break lease, 2ro, 211, 213; vast mineral wealth discovered there, 2 I 4

Baker, Sir Samuel, employed by Khedive of Egypt, 4; discovers Lake Albert, ibid.

Bakumu, cannibal tribe, 46; Stanley's encounters with, ibid.

Balolo, the "men of iron," 46

Bangala, 74

Bankes, Mr. J. Eldon, K. C., 34 I

Banning, M. Emile, ${ }_{3} 6$

Bantu race, 309

Banzyville, 53

Baoilis, 153

Baptist Missionary Society of London, 299, 300

Baraka, 59

Barbour, Rev. Thomas S., presents memorial to Congress, 387 et seq., 396

Baron A. Descamps. See Descamps, Baron A.

Baron de Courcel. See Courcel.

Baron Dhanis. See Dhanis.

Baron Gericke d'Herwijen. See D'Herwijen.

Baron Lambermont. See Lambermont, Baron.

Baron Nisco. See Nisco, Baron.

Baron Van Eetvelde. See Eetvelde, Baron Van.

Batetelas, 52; their grievance, $216,218,220,221,222$; their revolt crushed, 222

Baudouinville, 58,59

Beernaert, M., Belgian Minister of Finance, speech by, 97

Belgian and French boundary, $+6$

Belgian Anti-Slavery Society, raises volunteer corps to protect individual liberty, 200; despatches three missionary expeditions to Congo, ibid.

Belgian Society of the Upper Congo, 78

Belgique, La, twin-screw steamer employed by Stanley, 39

Bena Kalunga, 194

Benedetti, M. Antoine, 373; appointed chief commissary of
Congo State, 376; pretends he is opposed to Congo Government, 377

Bergamoyo, 33

Berlin Conference, $23,26,24,308$, 309 ; the General Act of, its full text, 530 et seq.

Bernard, Montague, on de jure and de facto governments, 69

Besche, De, 2 I 8

Bia, Lieutenant, 47

Bigwood, Mr., 353

Bird, Strode \& Bird, Messrs., solicitors, $34 \mathrm{I}$

Bishop Taylor Self-Supporting Mission, 300; seven grants of land to, 387

Bismarck, Prince, convenes International Conference at Berlin to regulate "African Ques. tion," 23 ; speech, ibid.; speech, 26; speech at close of Berlin Conference, $9+$

Black and White comments upon Lord Lansdowne's dispatch of August 8, 1903, 459

Blood-brotherhood, I 60

Blue Mountains, 52, 53

Bluntschli, M., on the rights of new States, 527

Bokala, 50

Boma, a native fort, 187, I 88 , note; description of, by Dr. Hinde, ror

Bosco, M. Gennaro, public prosecutor. See Epondo.

Bosoko, 179

Boston Peace Conference, 389

Boula Matari, native name for Stanley, 235

Boulger, Mr. Demetrius C., I65, note, I 88

Bourée, M., I 36

Bourne, Mr. Fox, Secretary Aborigines' Protection Society, 372 , 373,386

Bowara, 54

Brabant, Duke of (see Leopold II.), 4,65

Brassem, Lieut , 47

Brazza, De, 262

Britain, Great, recognises Portugal's claims to Congo River, 20 ; declines to aid Stanley, 65; appeals to King Leopold to call conference at Brussels to 


\section{Britain-Continued}

concert measures for suppression of slavery on East Coast of Africa, $\mathrm{r} 32$; land system of its African colonies, 612 et seq.

British and Foreign Anti-Slavery Society, 6ro

British Baptist Society Corporation, fifteen grants of land to, 387

British colonies, crown lands in, 329 ; system of government attacked, 589

British expedition to Congo, 43

Brussels, International Conference of Geographers ( 876 ) at, 7 , r 34; Brusseis Second Conference $(1889-90)$, declaration of General Act of, 552 et seq.; ratification by United States, 559 et seq.

Bruyn, De, $181, x 83$

Bryon, M., 34

Bull, John, paints the map red, 19; some of his traits, 366 et seq.; his missionaries at work for his merchants, 388

Burdo, M., 36

Burrows, Captain Guy, is charged by Belgian officers with libel, 340 et seq.; claims to have silenced Captain Salusbury, 348; is announced to contribute series of articles on Congo Free State to Wide World Magazine, 35I; agrees with R. A. Everett \& Co. as to publication of book about Congo, ibid.; his agreement with Mr. John George Leigh, 353

Burton, Sir Richard, discovers Lake Tanganyika, $4,5^{8}$

Busira-Momboya River, 335

C

Cambier, Lieut., 32; assumes command of Belgian expedition, 33; reaches Mirambo's territory, ibid.; becomes "blood-brother" of Mirambo, ibid.; founds station on Lake Tanganyika, 34; learns of death of Wautier, ibid.; hands over command to Captain Ramaeckers, 36, 253, 256

Cameron, Commander Lovett, on native punishments, 425

Campbell, Mr. John, M.P., derides anti-Congo agitation, 370

Canada, British, concessions in, 328

Canisius, M., 349

Cannibalism, I6I; State circular on repression of, 566 et seq.

Caoutchouc. See Rubber.

Cape-to-Cairo Railway, 208

Cardinal Lavigerie, 90

Carlyle, Thomas, his philosophy, 63

Carriers, their insubordination, 34

Casement, Mr. Roger, his Britannic Majesty's consul, I 75, 234; Congo Government's reply to his report refused publication by London editors, 369 ; suppression of parts of his report favourable to Congo Free State, 37 I, 465, 475 et seq., 477; notes by Congo Administration on his report, 59r et seq.

Cassart, Lieut., 185

Cataracts of Mokoangi, 54

Cataracts Railway, 252 ; cost of travelling upon, 255

Cataracts of Zongo, 54

Catholic Herald, $37 \mathrm{I}$ et seq.

Cattle, 269

Central Africa. See Africa, Central.

Chaltin, Commandant, 190; strikes severe blow at Dervishes, 201, 219; his action for libel against Captain Guy Burrows, 340 et seq.

Charing Cross Hospital, London, 267

Chieftaincies, native, 239

Chige, battle at, 182,183

Chimay, Prince de, 135

Christian and Missionary Alliance, 300

Christy, Dr., English physician, remarks on Congo Free State, 430 et seq.

Chronique, $46 \mathrm{I}$

Cicatrisation, 156

Cinnamon, 268

Clarke, Sir Edward, K. C., 34x; his speech in case against Cap- 
Clarke, Sir Edward-Continued tain Guy Burrows and Messrs. R. A. Everett \& Co., 342 et seq., 363,364

Cloves, 269

Coal, discovery of, $29 \mathrm{I}$

Cocoa, 268 ; State reward for native cultivation of, 269

Coffee, 53, 268; Statc reward for native cultivation of, 269

Cologne, anti-slavery mecting at, I3 I

Colonel Strauch. See Strauch.

Comite d' Études du Haut-Congo formed at Brussels, 29; its name changed to International Association of the Congo, 39; Stanley enters its scrvice, ibid.

Commerce, Chamber of, of Manchester (England), correspondence with British Secretary for Foreign Affairs re Upper Congo,

529 et seq.
Commerce, Chamber of, of 'State of New York, resolution of, 528 et seq.

Concessionary companies, I 6 ; their contracts with the State and their operations, 322 et seq.

Congo Bololo Mission, 299; seven grants of land to, 387

Congo, Conventional Basin of the, its limits, 206

Congo Free State, its evolution, 2 ; conceived by King of the Belgians and Stanley, 22; its flag, 26 ; extent, 44 ; boundary with North-eastern Rhodesia, 47 ; its natural wealth, $5 \mathrm{I}$; early legislation in, 66 ; a properly organised government previous to General Act of Berlin Congress, 67; recognised as such by Powers previous to that Act, ibid.; declaration concerning, by General Sanford, 79 ; recognised as a friendly government by American Secretary of State Frelinghuysen, 80 ; makes treaties with United States in 1884 and 1885,92 ; freedom of trade established in, by General Act of Berlin Conference, ibid.; treaties with various powers, 93; attacked by Sir Charles Dilke in British Parliament, 96; develops land, I15; concessionaire companies in, i 16 ; alcohol in, 138; import duties, I 40; cost of founding the State, I45; bequeathed by Sovereign to Belgium, 149; population, 15I; origin of races, $\mathrm{I}^{2} 2$ et seq.; Public Force, 164 ; prohibits trade in firearms, gun powder, and other explosives, 200; regulates contracts of service, ibid.; creates volunteer corps to protect individual liberty, ibid.; delimitation of its territory, 206; its enemies, 223; displacement of population, 225 ; internal administration, 228; nationality of its servants, 230; Department of Justice, 23 I, intrigues against, 235 ; its means of communication with Europe, 249 ; scientific stations in, 264 ; climate, 265 ; influx of Europeans and Americans, ibid.; trade and revenue, 277 ; receives from King Leopold annual subsidy of $\mathrm{r}, 000,000$ francs, 278; exports and imports, 280-286; Herr Eberhard Von Schkopp on trade of, 287 ; declining trade with England, 290 ; discoveries of gold, coal, and copper in, 291; revenue, 292 ; expenditure, 294 et seq.; monetary system, ibid.; missions in, 299; schools, 301 ; origin of land system, 3 3 ; unappropriated lands declared property of, 314 ; dealings with foreign squatters upon lands in Congo Basin, 316; adopts Torrens Act system of transferring land titles, 3 I 7 ; a ppoints Land Commission, 318; authorises natives to work mines on own account, 319; recognises certain local customs as valid, 320 ; its various land tenures, 322 ; traders' alleged grievances against, 330 et seq.; domain of the crown, its extent, 335 et seq.; its forests finest in the world, $33^{6}$; its mining laws, ibid. et seq.; campaign against, begun in America, 387 ; its 
Congo Free State-Continued value generally recognised, 447 ; replies to Lord Lansdowne's dispatch of August 8, I903, $45^{8}$; reception of reply by British press, 460 ; instructions respecting officials and natives, 569 ; text of reply to British dispatch of August 8, I 903,577 et seq.; official correspondence with Great Britain, 590; notes on Mr. Casement's report, 591 et seq.; concessionaires, private firms, and trading companies therein, 6 i6 et seq.; principal officials in Brussels, $6 \mathrm{I}_{7}$; principal local officials, ibid.

Congo, Lower, 20I; charted by buoys, 250, 252

Congo, Middle, 46, 201

Congo Question, 3

Congo Reform Association (of Liverpool), its specious arguments, 3I5; letter to, from editor of Catholic Herald, note, $37 \mathrm{I}, 374,45^{2}$; establishes its American headquarters at Boston, 467

Congo Reform Association, Secretary of, 372 ; enters into correspondence with Mr. Benedetti, and requests interview with him, 378, 379; introduces Mr. Benedetti to Mr. John Holt, 380; his agreement with Mr. Benedetti, 38r et seq.; receives letter from $\mathrm{Mr}$. Benedetti, $383,384,386$; presents memorial to President Roosevelt, asking for American intervention in affairs of Congo Free State, 388 ; abuses King Leopold at Boston Peace Congress, 395 ; is estimated by Major James Harrison, 409 et seq.; publishes book attacking government of French Congo, 447 et seq.; ceases hostility to French Congo, ibid.; the Congo coroner, 468; specimen of his vituperative fanfaronade, 470 et seq.

Congo River, its source, 45 ; discovered by Livingstone, ibid.; its harbours and shipping, 250; Sir Travers Twiss on free navi- gation of, 502; navigation of, as provided for in General Act of Berlin Conference, 536 et seq.

Congo, Upper, 44, I87; slavery finally extinguished on, $20 \mathrm{r}$, 252

Copal, 272

Copper, discovery of, 291

Coquilhat, Captain, 165

Corriere Toscano, 463

Count Van der Straeten Ponthoz. See Ponthoz.

Courcel, Baron de, speech at International Conference, Berlin, 27

Cranborne, Viscount. See Salisbury, Marquess of.

Crespel, Captain, commands first Belgian expedition, 32; arrives at Zanzibar, ibid.; his death, ibid.

Crispe, Mr., K. C., 341, 357

Cromer, Lord, reports upon migratory habit of Soudan population, 226; 454

Crystal Mountains, 47

Curse of Central Africa, The, title of book by Captain Guy Burrows, 353

Curzon, Viscount, Viceroy and Governor-General of India, his opinion of the Congo Free State Government, 422

Cuvelier, Chevalier de. Secretary of State of Congo Free State, 293

D

Daily Chronicle, letter to, from Sir Harry Johnston, 40 i et seq. Daily News, 369, 371, 372, 373,

Daily Telegraph (London), Stanley's letters to, 38

D'Arenberg, Prince F., 453

Davis, Mr. Alexander, his opinion of the Congo Free State Government, extracted from his book, The Native Problem in South Africa, 4 r 8 et seq.

Defence of Congo Free State, 577 et seq.

Dekere, 54 
De Keyser, Captain Henri Joseph Leon, his action for libel against Captain Guy Burrows, 340 et seq.; is awarded $£ 500$ damages and costs, $36_{3}$

Delcommune, Lieut., 47, 55, 184, 185

Delecourt, Lieut., 220

Derscheid, Lieut., 47

Descamps, Baron A., his work entitled New Africa, 74 ; exposition of international law, $8 \mathrm{I}$; on Government Civilisation in New Countries, 110; 257, 293; exposition of early Congolese policy, 309; analysis of theory of State ownership of vacant lands, 3 I 5

Dhanis, Lieut. (afterwards Baron), I 79, 180, 181, 182, 183 , $184,185,186,187$, note 188 , I89, I90, I9I, 192, 193, 194; his final report on Arab campaign, 195; 219, 220, $221 ; 222$

D'Herwijnen, Baron Gericke, I 4 I

Diego Cam, discoverer of the Congo, 42

Dilke, Sir Charles, attacks Congo Free State in British Parliament, 96, 370, 447, 455

Dirfi, 220

Doorme, Lieut., 187

Doumergue, M. Gaston (French Colonial Minister), decree consolidating legislation for French West Africa, 338 et seq.

Droeven, 2 I 8

Dubreucq, Commandant, his action for libel against Captain Guy Burrows, 340 et seq.

Duchesne, Lieut., I 82

Dufile, railroad to Redjaf, 256

Dufourny, A., President of the Federation for the Defence of Belgian Interests Abroad, 395

Dupont, Professor, assistant at Court of Inquiry, 476

Dutalis, Lieut., 35

Dutrieux, Dr., 33

\section{$\mathrm{E}$}

Edward, King of England, visits Paris, 448

Eetvelde, Baron Van, I36; report on conscription, 168 ; report on civilisation of native races, 202 ; reviews complete work of Congo Free State, 203

Egypt, Khedive of, employs Sir Samuel Baker, 4; is coerced by Europe to suppress slavetrading on the Upper Nile, 6; employs Sir Samuel Baker and General Gordon to govern the Soudan, ibid.

Ekongo, King of, 42 ; his conversion to Christianity, ibid.; old kingdom of, 43

Elephants, Indian, experiment with, 35 ; abundant in Kivu forest, 57,272

Emin Pasha, 53, 60, 188

Employees, dismissed, misrepresentations by, 580

En Avant, steamer employed by Stanley, 39

England, claims large sections of Africa, I7; decreasing trade with Congo Free State, 290; its cause, ibid.

Epondo case, 595 et seq.

Equateurville, 46,50

Etienne, M. Eugène, dissertation on the French Congo and Congo Free State, 324 et seq.

Etoile Belge, 346, 355

Evening Transcript, $46_{3}$ et seq.

Everett, Messrs. R. A. \& Co., London publishers, legal action against for libel, $34^{\circ}$ et seq.; letter from, to Secretary of State of Congo Free State, 35 I et seq.

Expedition, British, to Congo, 43

Exports from Congo Free State, I 903 (statistics of), 280 ; value of, ibid.; comparison with previous years, $28 \mathrm{I}$

\section{$\mathrm{F}$}

Fashoda, 21 2, 2 I 3

Favereau, Baron de, 478

Federation for the Defence of Belgian Interests Abroad, 389; address to President Roosevelt, 390,479

Fetish doctor, 223, 224, 225

Fiji Islands, 6ro

Force Publique, 216

Foreign Christian Missionary Society, 300 
Forfeit, Mr. William, remarks on Congo Free State, 427 et seq.

Flanders, Count of, becomes President of National Committee of International Association for the Exploration and Civilisation of Central Africa, I3

France, war with Germany, 4; claims large sections of Africa, I 7 ; sets up her flag at Brazzaville, I9; denounces AngloPortuguese Convention, 2I; recognises International Association as a friendly Government, 22; land system of its African colonies, 6r 2 et seq.

Franciscans, 301

Francqui, Lieut., 47, 59, I 84

Fraud, A gross, I 57

Frelinghuysen, F. F., American Secretary of State, recognises Congo Free State as a friendly Government, 80

French and Belgian boundary, 46

French Sheldon, Mrs., on atrocities in Congo Free State, 445

Frere, Sir Bartle, becomes Governor of the Cape, I 2; letter to, from Mr. H. Nixon, on baneful influence of Aborigines' Protection Society, 377

Fuchs, M., reports on Public Force, I70; suggests (in his capacity of Vice-GovernorGeneral) plan to control migration of natives, 226 ; report of July, 1904, 229; report on routes for motor cars, 263

\section{G}

Gandu, 181, 21 7, 218

Garenganze Evangelical Mission, 300

General Anzeiger, $46 \mathrm{I}$

Germaine, Mr., K. C., 34 I

Germany, war with France, 4; claims large sections of Africa, 1 7; wants part of East Africa, 19; denounces Anglo-Portuguese Convention, 2I; recognises International Association as a friendly Government, 22 ; invites Powers to confer in Berlin, ibid.; land system of its African colonies, 6 2 et seq.
Ghent, Sisters of Charity, 301

Gibbons, Cardinal, 438; letter to Secretary Congo Reform Association, 439 et seq.

Gibbons, Major H. H., opinion of Congo State, $5^{8} 3$

Gillain, Commandant, 187,194 , 217,218

Ginger, 268

Gladstone, his opinion of African explorers, 4

Globe, The, letter from Lord Mountmorres to, 44I et seq.

Gois Kapopa, I 84

Gold, discovery of, 291

Goldsmid, Sir Frederic, his report on Portuguese claims, 2 I

Gongo Lutete. See Lutete.

Gongo Machoffe, 2 I 9

Goodwill, English Baptist mission steamer, 300

Gordon, General, is employed by Khedive of Egypt to govern Soudan, 6; appointed by King Leopold to chief command on the Congo, 4I ; British Government claim his services, $i b i d$.

Gortchakoff, Prince, 68

Grant discovers sources of the Nile and Lake Victoria, 4

Granville, Lord, 20; on development of trade in Central Africa, $53^{\circ}$

Great Britain. See Britain, Great. Grégoire, M., assistant at Court of Inquiry, 476

Grenfell, Mr. George, English missionary, remarks on Congo Free State, 427 ; on administration of justice in, 568 et seq.

Grey, Mr., English civil engineer, remarks on Congo Free State, 435 et seq.

Grison, Rev. Father, missionary in charge of St. Gabriel's, Stanley Falls, 301 ; extracts from his diary, $30^{\circ}$; his strenuous life, 306, 307

Guinness, Dr. H. Grattan, lectures in Scotland on atrocities in Congo Free State, 424 et seq.; 427

Guinness, Mrs. H. Grattan, her testimony different from that of her husband, 425 


\section{$\mathrm{H}$}

Hamburgische Borsen Halle, Neue, its estimate of British opinion of Congo Free State, 333 et seq.

Hamed-ben-Mohamed, note, 179

Hanssens, Captain, 40

Harbey, Rev. C. H., testifies as to lying proclivities of natives, 600. See Epondo.

Harrison, Major James, 369, 374; letter to London Times, 404 et seq.; remarks upon side issue raised by Secretary of Congo Reform Association, 409 et seq.

Head, Mr. George, M.A., demolishes arguments of Secretary of Congo Reform Associa-

tion at Boston Peace Congress, 396

Head tax, in British colonies, 582

Health committees, 268

Heffter, his theory of the existence of a State, 528

Henderson, Mr. John, his comments on Consul Casement's report, 466 et seq.

Henry, Commandant, 220, 221 , 222

Heusch, De, Lieut., I94; is killed in battle, ibid.

Heuval, Dr. Van den, 35

Heymans, Captain, 54

Hinde, Dr. Sidney, I 79, I83, note, 188 ; his description of a boma, note, I9I

Hodister, I 78

Holland, Queen of, I 43

Holt, Mr. John, Liverpool merchant, 373 ; pays Mr. Benedetti $f_{40}, 383,384$; his trading company loses its case against the Compagnie Française du Congo Occidental before the Council of Appeal at Libreville, $45^{\circ}$

Horses, 269

Hospital for Natives, Boma, 268

Humanitarianism, pretext of, 578

Hut tax, in British colonies, $5^{82}$, 605

Hygienic Commission, Boma, 265 I

Import duties, $14^{\circ}$

Imports into Congo Free State, $1903,282,283,284,286$; com- pared with imports of previous years, 286

Independance Belge, 352, 353; 374

Influenza, I87

International Association for the Exploration and Civilisation of Central Africa, creation of, I 2; General Sanford (United States Minister at Brussels) becomes member, 13 ; receives influential support, ibid.; receives report of Commission of Eight, 25; founds station on Lake Tanganyika, 34; stations created by, 49I; its recognition by United States as a friendly Government recommended by Senator Morgan, 492; treaties with Germany, Great Britain, France, and Portugal, 544 et seq.; declaration exchanged with Belgium, ibid.

International Missionary Alliance, 300 ; eleven grants of land to, 387

Irebu, 56

Itembo, 52

Itimbiri, 25 I

Ituri, forest of, 52

Ivory, $\operatorname{tax}$ on, 178, 272; export duty on, 278

\section{$\mathrm{J}$}

Janssen, M. Camille, I 65

Janssens, M., president of Committee of Inquiry, 476

Japan, domainal system of, 334

Jesuits, 301

Johnston, Sir Harry, G. C. M. G., 152; quotation from his book, The Uganda Protectorate, $400 \mathrm{et}$ seq.

Juan II., King of Portugal, 42

Junker, Dr., German explorer, 53; on native punishments, 425

Jürgens, 2 I 8

\section{$\mathrm{K}$}

Kabambari, r 9 r

Kabinda, 43 ; attacked by Batetelas, 2 I 7,2 I 8

Kabindas, a Congolese tribe employed by Stanley as carriers, 39 
Kakongos, I 53

Kalengo. See Epondo.

Karema, 34

Kassai, 50.

Kassali, Lake, 48

Kasson, Mr., United States Plenipotentiary, 107

Kassongo, 47, 181, 182, 187, 188, I89, 191, 193, 221

Katanga, 48; copper deposits in, ibid.; soon to be reached by railroad, $48 ; 184$

Katué, 22 I

Khartoum, 214

Khedive of Egypt employs Sir Samuel Baker, 4

Kibala Mountains, the African Switzerland, 48

Kiranga-cha-gungo, largest inland volcano in world, 57

Kirk, Sir John, I36, 426

Kipango, 186

Kivu, Lake of, 57

Kleine Journal, 462

Konings, 218

Kwango, $5^{\circ}$

\section{L}

La Liberté, 460

La Lulonga Society. See Epondo; 608

Labour, question of native, $5^{8 \mathrm{I}}$

Labudi, 47

Lado, Enclave of, 210

Lado territory, 2 I 9

Laeken, Brussels, King Leopold's palace, 248

Lagos, British colony of, its revenue, 1898-rgor, note, 289 ; sixty-five per cent. of revenue derived from alcoholic liquor, $31 \mathrm{I}$; wasteful methods of dealing with rubber and timber, 323 ; decline of prosperity in, ibid., 374,468 ; its revenue reviewed by the Lagos Standard, 469 et seq.

Lake Albert Edward, 56

Lake Albert Nyanza, 52, 56

Lake Kassali, 48

Lake Kivu, 57

Lake Leopold II., discovered by Stanley, 56

Lake Matumba, 46, 53

Lake Moero, 49
Lake Tanganyika. See Tanganyika.

Lambermont, Baron, attends Brussels Conference ( 1876$), 8$; reports upon safeguards for native races, 26; drafts final act of International Conference, ibid.; on slavery, 89 ; his definition of free trade, III; presides over Second Brussels Conference, 136

Land system, features of the, in the African colonies of Germany, Great Britain, France, and Portugal, 612 et seq. (See Congo Free State; 586 )

Lange, De, Belgian officer, 192

Lansdowne, Marquess of, 450 ; his dispatch to the Powers Signatory to the Berlin Act, 457 et seq.; its reception by British press, 460,465 ; dispatch to the Powers Signatory of the General Act of Berlin respecting alleged cases of ill-treatment of natives and the existence of trade monopolies in Congo State, 573 et seq.

Launay, Count de, 298

Laveleye, M. Emile, 105

Lavigerie, Cardinal, 9o; founds Belgian Anti-Slavery Society, 9I ; visits Belgium, I34, 426

Lawrence, William Beach, on what constitutes a State, 528

Le Marinel, Lieut., I 78, I 79

Leigh, Mr. John George, his agreement with Captain Guy Burrows, 353

Leopold II. (King of the Belgians and Sovercign of the Congo Free State), his accession to Belgian throne, 2; believes Africa promising outlet for surplus European population, 3 ; his magnificent physique and personal accomplishments, ibid.; perceives opportunity to civilise Central Africans and found Belgian colony, ibid.; his scheme disregarded, ibid.; speech before Belgian Scnate in 1860,4 ; his philanthropy, 6 ; considers how the slave trade in Africa can be abolished, ibid.; convenes an international confer- 


\section{Leopold II.-Continued} ence of geographers in Brussels $(1876)$ to discuss the subject, 7 ; his eircular letter, ibid.; his speech, 8 ; becomes President of International Association for the Exploration and Civilisation of Central Africa, x 2; speech before National Committee, I4; his desire for new markets for Belgian manufactures, I7; his prescience, ibid.; spends largely of his private fortune to suppress slavery, 18 ; a ppeal to British Government, 21; recognised by Powers as Sovereign ruler of Congo Free State, 28 ; becomes honorary President of the Comité d'Études du Haut-Congo, 29 ; invites Stanley to Brussels, 39 ; induces him to enter service of International Association of the Congo (new name of the Comité d'Études du HautCongo), ibid.; plans campaign of exploration, $60 ; a$ true friend to Stanley, 65; his early declaration, ibid.; letter to his ministers, 99; authorised by Belgian Chamber to assume sovereignty of Congo Free State, 10I; his acknowledgment, ibid.; receives congratulations and is visited by Lord Mayor of London, IOI, 102 ; is appealed to by British Government to call conference at Brussels to concert measures for suppression of slavery on East Coast of Africa, I32; letter to M. Beernaert, I 47 ; bequeaths sovereignty of Congo Free State to Belgium, 149; note, r79; confers title of Baron on Captain Dhanis, I 95; his plans to suppress slavery excite little interest, I97; depletes his fortune to achieve his object, 198; receives scant support outside Belgium, ibid.; his Majesty's mandate, ibid.; his first object realised, 205; his political foresight, $210 ;$ his energy and industry, 248;
Laeken, his palace at Brussels, ibid.; his châlet at Ostend, ibid.; his immense expenditure on Congo State, 276 ; impossible to recover, 277 ; grants annual subsidy of $1,000,000$ francs to Congo State, 278; his early declarations consistently carried out, 320; Captain Guy Burrows dedicates book to, 347 ; is abused by Secretary of Congo Reform Association at Boston Peace Congress, 395; Congo Frec State likcly to fulfil his expectations, 447

Leopoldville, 46 ; fortnightly communication with Stanley Falls, 251 ; treaty of, 489

Leroi, Captain, 2 1 9, 220

Leslie, Rev. IV. H., of American Baptist Missionary Union, 4I I; contributes article on Congo to Missionary Review of the IVorld, 414

Liebrechts, Mr., Secretary-General of Congo Free State, letters to from Captain Burrows, 347 et seq.

Lindi, 22 I

Lindt, Van, Lieut., I 89

Lippens, I 81, I 83

Livingstone, Dr., enters Congo region, 1860 , and discovers lakes Moero and Bangwcolo, 4; found by Stanley in 1871 , ibid.; says white man can live in Central Africa, I 7, I 97

Livingstone Inland Mission, 290

Lomami, 49, 50, 5 I, I 8 I, I 82,183 , 217,2 1 8

Lopori, 49

Lothaire, Commandant, 194,217 , 218,219

Lua, 54

Luahilimta, 57

Lualaba, 47, I 77, I 86, 25 I

Lualaba-Kassai, 201

Luapula, 47

Lubefu, 50, 335

Lubuga, 57

Lubukine, 194

Lufila, 47

Lufupa, 47

Lukenie River, 335

Lulongo, 49,50

Luluabourg, 74, 201; outbreak of Batetelas at, 2 I 6,2 I 8 
Lumber, 272

Lunda country, 74

Lusambo, 179, 201,217

Lusana, 183

Lutete, Gongo, I79; his personality, $180,181,182,184$; is court-martialled and shot, I 90 ; disastrous consequences of that event, 191, 216

\section{M}

Mabode, 52

Maes, Dr., 32; his death, ibid.

Maguire, Dr., English missionary, remarks on Congo Free State, 429 et seq.

Mahagi, 2 I 2

Malet, Sir Edward, attends International Conference at Berlin, $24 ;$ speech, 27

Maloney, Mr. J. A., on native punishments, 426

Malumba, Batetela mutineer, murdered by one of his followers, 221

Manning, Cardinal, 13 1

Manyema, collectors of ivory, 59, I 82; country of, $191,218,221$

Marès, M. Roland de, 384

Marno, M., 32

Marriage, Christian, among natives, 273

Martens, Prof., I 36

Martin of Bohemia, cosmographer 42

Matadi, 47, 252, 253; trains from, 255

Matumba, Lake, 46, 53, 56

Mayombés, I 53

Mayumbe Railway, 256

Mbomu, 54, 208, 209, 2 10

Meshra-er-Rek, 2 I 3

Mfini, 56

Mgonda-Mkali, 33

Michaux, Captain, 182, 183, 184, 218

Middle Congo, 46,48

Mirambo, 33; his conflict with Simba, 36

Missionaries, 299, 300, 30 I, 385 , $387,411,424,425,427,429$; deccived by native witncsses, 233

Missions, Protestant, 299

Modes et Robes à la Congo, 154
Moero, Lake, 49; south-eastern boundary between British territory and Congo Free State, 59

Moharra, Munie, I8I, 184, I85, I 86

Mohun, Mr., formerly United States Consul at Boma, 4II; his opinion of Congo Free State Government, 415 et seq.

Mokoangi, Cataracts of, 54

Molieka, 52

Moltke, Von, i 80

Moncheur, Baron, Belgian Minister to United States, 389; career, 618

Mongalla, 52

Moore, English naturalist, 57; discovers zoölogical remains of a dead sea, 59

Morgan, Senator, of Alabama, presents memorial to Congress, 388 ; submits Report from Committee on Foreign Relations recommending United States to recognise International African Association as friendly government, 492

Morning Advertiser, comments upon Lord Lansdowne's dispatch of August 8, 1903, 458 et seq.; betrays some British desires, 459

Morning Post, 369; letter to from Major James Harrison, 409; from Mr. Grey, 435 et seq.

Morrison, Rev. Mr. W. M., of Lexington, Va., 385; fails to obtain land concessions and special privileges, 386 ; his statements compared with facts, $387,388,396,456$

Mountains, Blue, 52,53

Mountains, Crystal, 47

Mountains, Kibala, 48

Mountains, Pallaballa, 252, 253

Mountmorres, Lord, 374; starts on journey through Congo Free State, 440 ; letter from, to London Globe, 44I et seq.

Mpala, 37

Msiri, 48

Münster Westphal, 462

Musserongés, 153

Mwadi, 184 
Mwana Mkwanga, Arab camp at, 19I

$$
\mathrm{N}
$$

Natives, Commission for Protection of, report of first meeting, 572 et seq.; alleged to be illtreated, 573 et seq.

Nerincx, Professor A., coadjutor of Baron Moncheur, 389

Netherlands, Prince Henry of, becomes President of the National Committee of the International Association for the Exploration and Civilisation of Central Africa, I 3

New York Herald, Stanley's letters to, 38

New York Press, 464

Neyn, M. De, assistant at Court of Inquiry, 476

Niadi $\mathrm{K}$ wilu Basin explored, 73

Niadi, treaty with King of, 490

Niam-Niam, tribe inhabiting Bahr-el-Ghazal country, 214

Niangara, 53

Niger, navigation of the, as provided for in General Act of Berlin Conference, 54 $\mathrm{r}$ et seq.

Nisco, Baron, President of Court of Appeal, 232; member of Court of Inquiry, 476

Nôtre Dame, Sisters of, 301

Nutmegs, 269

Nyangwe, 45, 52, 59, 181, 182, $186,187,188,217,221$

Nys, M. Ernest, 77

Nzilo, 47

Obi, 220

Omdurman, battle of, 2 I 3

Ordeal by poison, 159; State Circular on repression of, $566 \mathrm{et}$ seq.

Ostend, King Leopold's châlet at, 248

Our Lady of Perpetual Help, Roman Catholic Mission steamer, 300

Ourroussof, Prince, ${ }_{136}$

\section{$\mathrm{P}$}

Padrão Foreland, 42

Pallaballa Mountains, 252, 253
Palmerston, Lord, on recognition of States by British Government, 528

Panga Falls, 53

Parliament, British, debate in, 580

Partition of Congo State, 578 et seq.; 6 10

Peace, English Baptist Mission steamer, 300

Pepper, 268.

Petit Bleu, interview with Stanley published in, 397

Phare de la Loire, 46I

Philippeville, SS., 477

Phipps, Sir Constantine, his Britannic Majesty's minister at Brussels, dispatch on protection of natives, 56r et seq.

Photographs, faking of, 37 I et seq.; 602 et seq.

Pigmies, 156

Poison, ordeal by, 159

Polidori, Signor, Italian physician, remarks on Congo Free State, 428 et seq.

Poll tax, in British colonies, 582

Polygamy, 163,273

Ponthier, Captain, 190, 19 1, I 93

Ponthoz, Count Van der Straeten, on safeguarding native races, 26

Pope Leo XIII., encyclical on abolition of slavery in Brazil, 9०; receives Central African Christian Negroes, ibid.; his speech, ibid.

Popelin, Captain, commands second Belgian expedition, 35 ; death of, 37

Population, displacement of, 225 ; diminution of, $591 \mathrm{et} \mathrm{seq}$.

Portugal, claims large sections of Africa, 17 ; claims Congo River, 19; land system of its African colonies, 61 2 et seq.

Postal Service, 244

Prémontré Fathers, $30 \mathrm{I}$

Prestation, natives' contribution of labour towards support of State, 294

Public Force, 164

Public Ledger, 465

Puttkamer, Herr Von, Governor of the Cameroons, his opinion of the navigation of the Congo River, 252 
Q

Queen of Holland, r 43

$\mathbf{R}$

Ramaeckers, Captain, commands fourth Belgian expedition, 36; joins his colleagues at Tanganyika, ibid.; takes over command from Cambier, ibid.; death of, 37

Rashid, I79, I89, 190, 194

Redemptionists, 301

Redjaf, 20I; railroad to Dufile, 256

Reed, Henri, American Baptist Mission steamer, 300

Rejoinder of Congo State to charges in Consul Casement's Report, 590 et seq.

Reply of Congo State to British Dispatch, Aug. 8, 1903, denying that Administration involves systematic cruelty to natives, 577 et seq.

Revenue, various sources of, 279

Rhodes, Cecil, 208; prophetic utterance by, 454

Rhodesia, North-eastern, and Congo Free State boundary, 47 ; taxes in, 605 et seq.

Riba Riba, 178

Ridley, Mr. Justice, tries suit for libel brought by Belgian officers against Messrs. R. A. Everett \& Co. and Captain Guy Burrows, in London, 340 et seq.; his charge to jury, 358

Roger, M., 36

Roman Catholic Mission, fortyfour grants of land to, 387

Roosevelt, President, 388, 389

Royal, steamer employed by Stanley, 39

Rubber (caoutchouc), its cultivation and collection, 270; its varieties, 272 ; export duty on, 278; decrease in export of, from eight British colonies, 324 et seq.

Rubi, 52

Rudolph, Archduke, of Austria, becomes President of National Committee of International Association for the Exploration and Civilisation of Central Africa, 13

Ruki, 50

Rumeliza, chief of Ujiji, I9r, I93, I94

Rusisi, 57

\section{S}

Sacred Heart of Mary, Sisters of the, $30 \mathrm{r}$

Sacred Heart, Priests of the, zor

Salisbury, Marquess of, his opinion of the Congo Free State Government, 423, 456, 584

Salisbury, Marquess of (the late), his opinion of the Congo Free State Government, 423

Salusbury, Captain, his allegations against Congo Free State denied by Captain Guy Burrows, 346

Sambas Plateau, $5 \circ$

Sanford, General (United States Minister at Brussels), becomes member of International Society for the Exploration and Civilisation of Central Africa, r 3 ; declaration by, 79; founds, with M. Georges Brugmann, Exploring Expedition, 276

Sankuru, 50, I 79, 336

Sannaes, Lieut., 221

San Salvador, 43

Scherlink, Lieut., I 83

Scheut Fathers, 301

Schkopp, Herr Ebcrhard Von, his remarks upon Congolese trade, 287

School of Tropical Medicine, Liverpool, 267

Schumacher, Dr. De, member of Court of Inquiry, 476,478

Scott, Mr. G. A., 34I

Sefu, I 79, I $81,183,184,185,186$, 187, I89, 190

Semlika, boundary between British and Belgian possessions, 56

Semliki, 22 I

Seyyid Burghash, Sultan, 32

Shanu, British subject of Lagos, tries to induce Mr. Benedetti to join anti-Congo campaign, 377 et seq.

Sierra Leone, convictions for maltreatment of natives in, $5^{82}$ 
Simba, his conflict with Mirambo, 36

Sir Bartle Frere. See Frere, Sir Bartle.

Sir Charles Dilke. See Dilke, Sir Charles.

Sir Frederic Goldsmid. See Goldsmid, Sir Frederic.

Sir Harry Johnston. See Johnston, Sir Harry.

Sir John Kirk. See Kirk, Sir John.

Sir Travers Twiss. See Twiss, Sir Travers.

Slavery in Central Africa, 5; slavery defined, 83 ; antiquity of, ibid.; Christ the first liberationist, 84 ; first awakening to infamy of slavery, ibid.; England's traffic in slaves, ibid.; her retribution, 85 ; America's civil war to abolish, ibid.; still extant in some countries, ibid.; England's efforts to suppress, 86 ; horrors of, 87 ; Baron Lambermont on, 89; Pope Leo XIII.'s encyclical on, 90; its strange uses before the founding of Congo Free State, 274; Congo State accused of, 294; declaration concerning, in General Act of Berlin Conference, 535 et seq.

Sleeping sickness, 225; no known cure for, 266

Smallpox, 187, 221, 225, 266

Smet de Naeyer, Count de, 478

Soudan, migratory habit of its population, 226

South Africa, British punitive expeditions in, for collection of taxes from natives, 607

Spain, King of, becomes President of National Committee of International Association for the Exploration and Civilisation of Central Africa, I 3

Speke, Captain, discovers Lake Tanganyika, and sources of the Nile and Lake Victoria, 4, 58

St. Paul de Loanda, 43

Standard, The, comments upon Lord Lansdowne's dispatch of August 8, 1903, 459
Stanley Falls, 46, 52, 179, 181, I $94,220,22 \mathrm{I}$; fortnightly communication with Leopoldville, 251

Stanley, Henry Morton, Sir, discovers Dr. Livingstone, 4 ; says white man can live in Central Africa, 17 ; visits Congo in interest of King Leopold, 20; demonstrates importance of Congo River in letters to New York Herald and London Daily Telegraph, 39 ; founds and fortifies station at Vivi, 40; constructs road from Vivi to Isanghila, ibid.; founds a station at Manyanga, ibid.; learns of French founding Brazzaville, and replies by founding Leopoldville, ibid.; goes to Brussels to report progress, ibid.; returns to Central Africa, February, $x 883$; his achievements impossible without King Leopold's aid, 65 , I 97 ; Boula Matari, native name for, note, 235 ; insists upon necessity of railroad round the thirty-two cataracts, $253,262,274,275$; on a common measure of civilisation, 277; writes introduction to book by Captain Guy Burrows, 347 ; the true motive of the anti-Congo campaign, 370; his opinion of Congo Free State Government, 397 et seq.; Congo Free State likely to fulfil his expectations, 447

Stanley Pool, 50, 252

Stanleyville, railroad from, to Great Lakes, 256

Stephanieville, treaty of, 490

Stokes, executed for selling arms to State's enemies in time of war, originally Protestant missionary, $307,373,45^{2}$

Storm, Lieut., founds station at Mpala, 37

Strauch, Colonel, President of the Comité d'Études du Haut-Congo, 29,67

Sugar, 53,272

Svensson, 2 I 8

Swanton, Mr., 34r

Swedish Missionary Society, 300 ; nine grants of land to, $3^{87}$ 


\section{T}

Tanganyika, Lake, effort to found station at, 34; the first station of the International Association for the Exploration and Civilisation of Central Africa, ibid.; partitioned equally between Congo Free State and German East Africa, 58; discovered in 1858 by Burton and Speke, ibid.; first circumnavigated by Stanley, ibid.; I9I, I 94, 200, 208

Taxation, Mr. Joseph Chamberlain ridicules native exoneration from, 58 i et seq.; defends theory of, 582

Taxation of natives, I I4; their migration to avoid, 224 ; personal, the bases of, 293 ; reduction of direct, ibid.

Telegraph, 59

Telegraph service, 245

Telephone, 59

Telephone service, 245

Terrell, Mr., I 36

Tervueren, Brussels, Museum, containing objects illustrating Central African life, 265

Thomas, Mr. Lewis, 341

Thys, Lieut., 256

Times, The, 373, 384 ; letter from Major James Harrison, 404 et seq.; 459; French criticism of, 460

Tippo Tip, 59, note, 179, ×80, 181, I $83,189,194$

Tobacco, 53, 272

Tobback, M., resident for Congo Free State at Stanley Falls, 189

To-Day, 466

Trappistines, $30 \mathrm{I}$

Trappists, 301

Tuckey, James Kingston, British explorer, 43

Twiss, Sir Travers, I05; on free navigation of the Congo, 502

\section{$\mathrm{U}$}

Ubanghi, 53, 208, $25 \mathrm{I}$

Uelle, 53, I 77, 201, 208, 209

Uelle Railway, proposed extension, 54

Uganda Protectorate. See Harrison, Major.
Ujiji, I9I

United States, particulars of their origin recorded, I; recognises International Association as a friendly Government, 22 ; makes treaties with Congo Free State in 1884 and $1885,92,199$ Upper Congo, 44; Belgian Society of the, I 78

Uranga, 49

Usamba Plateau, 49

\section{V}

Van Dorpe, Captain, 165

Van Gele, 53

Vanilla, 269

Vattel on manner of acquiring sovereignty of free country, 527

Vivi, first station founded by Stanley, 40; road from, to Isanghila made by Stanley, ibid.; treaty of, 487

Vivian, Lord, I 36 ; speech at Second Brussels Conference, ${ }^{4} 42$

Vohsen, Consul, 453

Von Bornhaupt, Herr, 453

Von Gotzen, Count, discoverer of volcano Kiranga-cha-gungo, 57

Von Moltke. See Moltke, Von.

\section{W}

Waddas, 53

Wagenia, a riverain tribe, 186 , 187

Wahis, Colonel (afterwards General Baron Wahis), 253 ; speech deseribing Congolese conditions twenty years ago, 479 et seq.

Washington, Mr. Booker, 424

Wauters, A. J., note, 188

Wautier, Lieut., 33 ; his death, 34

West Africa, journal of the Liverpool Chamber of Commerce, 450 et seq.

Wheaton, on recognition of States, 69; on political status of American Indians, $7 \mathrm{I}$

White Fathers, 301

Whiteley, Mr. James Gustavus, of Baltimore, his opinion of the Congo Free State Government, 4 I I et seq.

Widows, strangling, 158

Wingate, Sir Reginald, 454 
Winton, Sir Francis de (GovernorGencral of Congo during absence of Stanley), formulates land system, 313

Wissmann, 262

Wissmann Falls, 50

Wolf, Eugenc, admonition from, 462

Wouters, De, Lieut., I 85 , I 88 , r 93 , r 94 ; his death, 195

Wulfers, Rev. Father, of the Romee Mission, Yanonghi, 302; extracts from his diary, $3^{\circ} 3^{-}$ 305

\section{$\mathrm{Y}$}

Yambuya, 52

Young Africa, onc-screw barge employed by Stanley, 39

$Z$

Zanzibar, Englishmen murdered by brigands at, 35

Zongo, Cataracts of, 54 





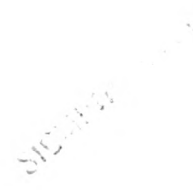




\section{||||||||||||||||||||||||||| 007503612006}

PLEASE DO NOT REMOVE CARDS OR SLIPS FROM THIS POCKET

\section{UNIVERSITY OF TORONTO LIBRARY}

DT

652

W2 cop. 2

Wack, Henry Wellington

The story of the Congo Free State 


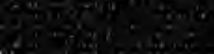

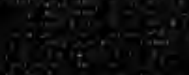
.

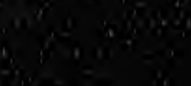

